
of Engineers ${ }_{\circledast}$

Engineer Research and

Development Center

\title{
Character-Defining Features of Contributing Buildings and Structures in the United States Merchant Marine Academy Historic District
}
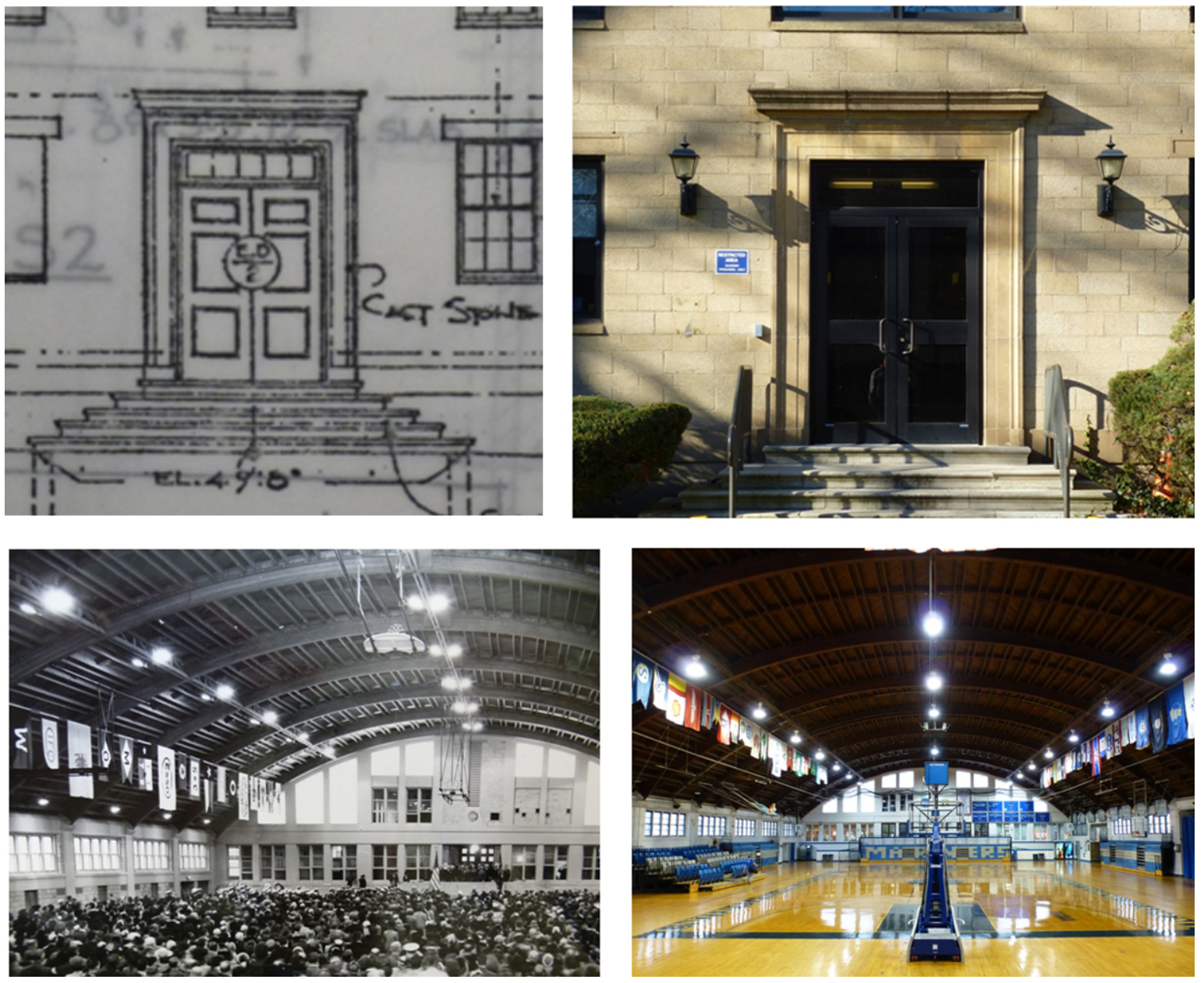
The US Army Engineer Research and Development Center (ERDC) solves the nation's toughest engineering and environmental challenges. ERDC develops innovative solutions in civil and military engineering, geospatial sciences, water resources, and environmental sciences for the Army, the Department of Defense, civilian agencies, and our nation's public good. Find out more at www.erdc.usace.army.mil.

To search for other technical reports published by ERDC, visit the ERDC online library at http://acwc.sdp.sirsi.net/client/default. 


\section{Character-Defining Features of Contributing Buildings and Structures in the United States Merchant Marine Academy Historic District}

Adam D. Smith, Susan I. Enscore, and Sunny E. Adams

Construction Engineering Research Laboratory

U.S. Army Engineer Research and Development Center

2902 Newmark Drive

PO Box 9005

Champaign, IL 61826-9005

Final report

Approved for public release; distribution is unlimited.

Prepared for U.S. Department of Transportation

Maritime Administration

MAR-612-W23-495

1200 New Jersey Ave SE

Washington, DC 20590

Under Project \#400142, "Historic Preservation Plan for U.S. Merchant Marine Academy" 


\section{Abstract}

This document is an architectural survey of character-defining features for the contributing features of the United States Merchant Marine Academy Historic District. This survey satisfies Section 110 of the National Historic Preservation Act of 1966 as amended, and it was used to determine which elements of the buildings and structures of the historic district are character-defining features for the elements that are eligible for the National Register of Historic Places. 


\section{Contents}

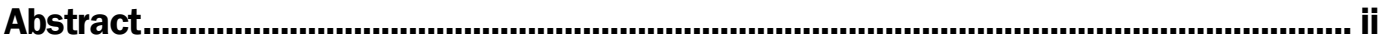

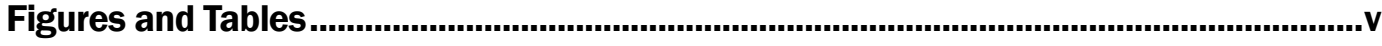

Preface

Unit Conversion Factors...................................................................................................

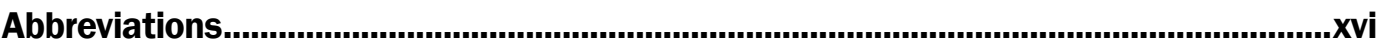

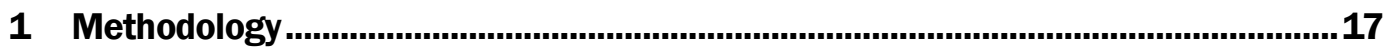

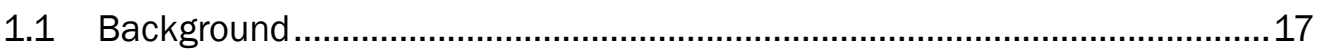

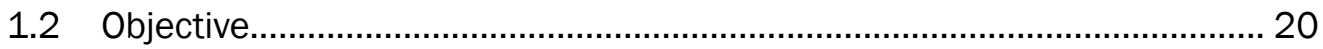

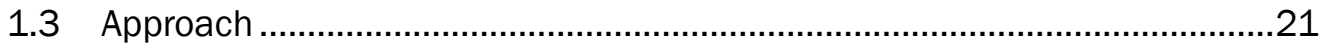

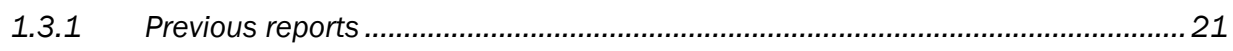

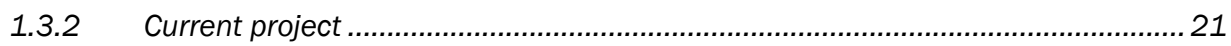

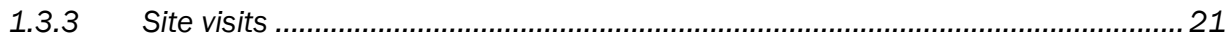

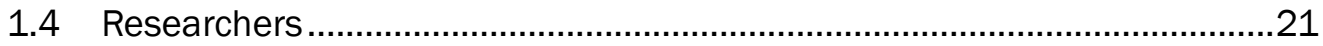

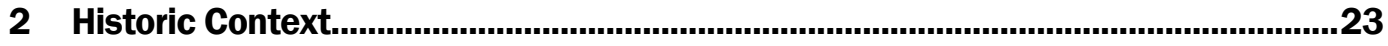

2.1 Introduction to the U.S. Merchant Marine Academy ................................. 23

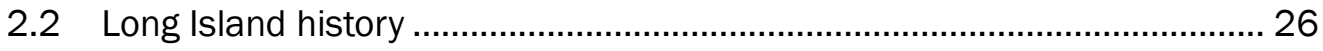

2.3 Kings Point Estates on the future grounds of the U.S. Merchant

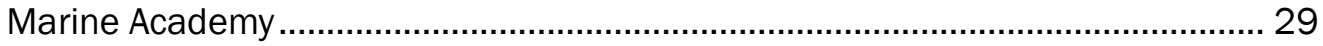

2.3.1 The Henri W. Bendel/Walter P. Chrysler Estate (Wiley Hall) (\#10 on

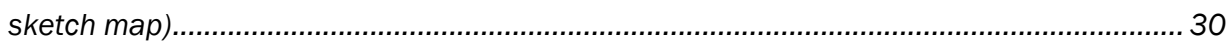

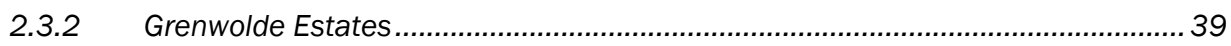

2.3.3 W.S. Houston Estate (not extant) (not on sketch map)....................................... 41

2.3.4 Nicholas M. Schenck Estate (Land Hall) (\#7 on sketch map)...............................42

2.3.5 Thomas Meighan (Melville Hall) (\#5 on sketch map) ...........................................45

2.3.6 Charles Neiley (Quarters A) (\#3 on sketch map)..................................................49

2.3.7 Dan A. Japhet (Quarters D) (\#2 on sketch map) ................................................ 51

2.3.8 James C. Marchant (not extant) (not on sketch map).........................................52

2.3.9 Beth S. Colen (Quarters B) (\#8 on sketch map) ................................................... 53

2.3.10 Walter J. Vreeland/Underwriters Trust Company (Quarters C) (\#9 on

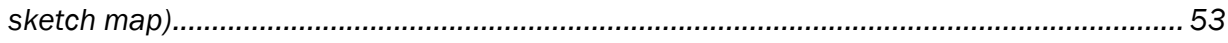

2.4 Merchant Marine Academy ............................................................ 54

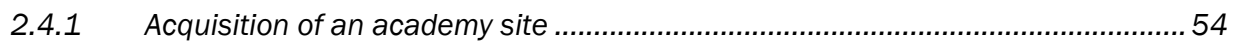

2.4.2 Acquisition of other properties .......................................................................... 56

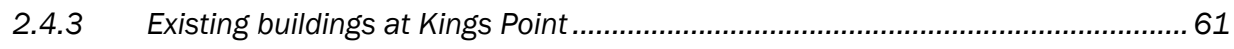

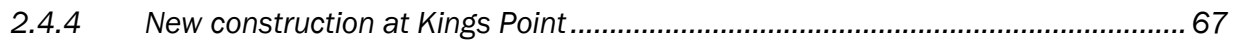

2.4.5 Training program and academy administration ................................................. 76

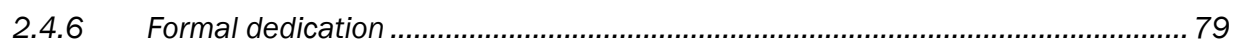




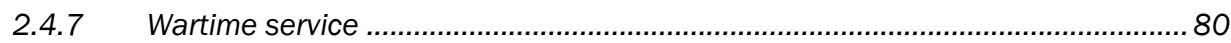

2.4.8 The Academy after World War II...................................................................... 81

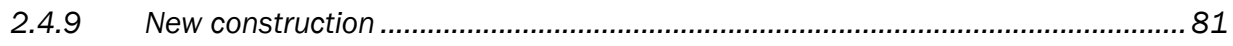

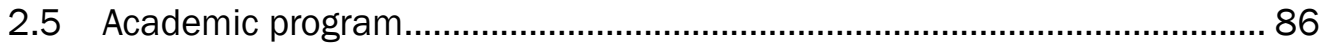

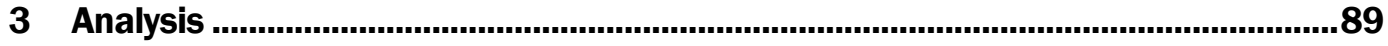

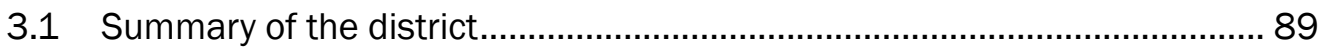

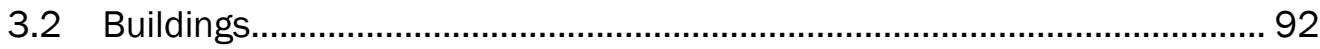

3.2.1 Quarters D (Grenwolde Casino)..................................................................... 92

3.2.2 Quarters A (Neiley Estate - main house)......................................................... 94

3.2.3 Quarters J (Neiley Estate - garage) ................................................................96

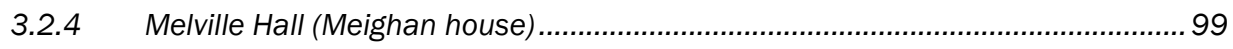

3.2.5 Quarters K (Meighan Estate - garage) ........................................................... 102

3.2.6 Land Hall (Schenck house)........................................................................... 104

3.2.7 Quarters B (a Grenwolde house)................................................................ 106

3.2.8 Quarters C (Vreeland house) ......................................................................... 108

3.2.9 Wiley Hall (Bendel/Chrysler Mansion) ................................................................111

3.2.10 Barracks (Palmer, Murphy, Cleveland, and Rogers Halls)....................................124

3.2.11 Barracks (Barry and Jones Halls) and the Truxton Arcade .................................132

3.2.12 Furuseth Hall ..................................................................................................... 140

3.2.13 Classrooms (Fulton Hall and Bowditch Hall) .......................................................145

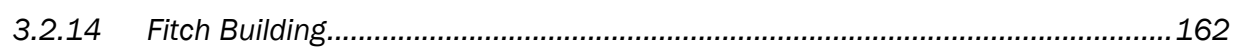

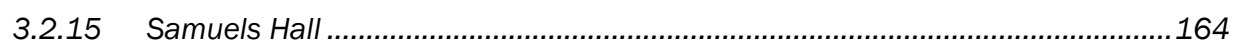

3.2.16 Delano Hall ........................................................................................ 167

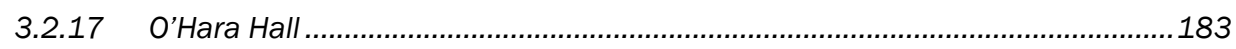

3.2.18 Admissions Center ......................................................................................... 194

3.2.19 Patten Medical Clinic ...................................................................................... 197

3.2.20 U.S. Merchant Marine Memorial Chapel ..............................................................200

3.2.21 Crowninshield Pier and Boat House....................................................................208

3.2.22 Men's shower, women's shower, and paint locker ..............................................209

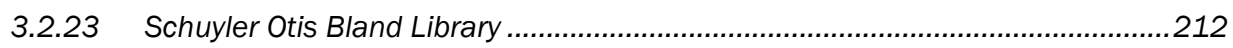

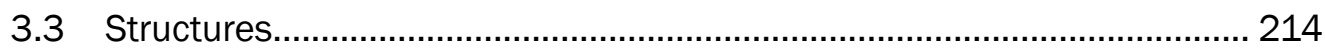

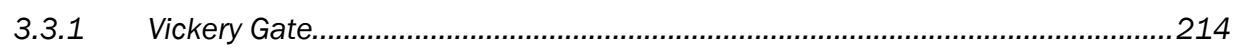

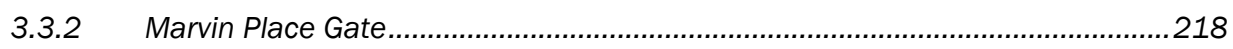

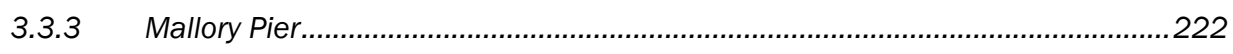

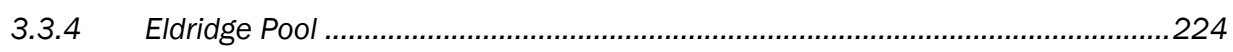

References....................................................................................................... 225

\section{Report Documentation Page}




\section{Figures and Tables}

\section{Figures}

Figure 1. Location and boundary for the USMMA historic district (USGS)..........................20

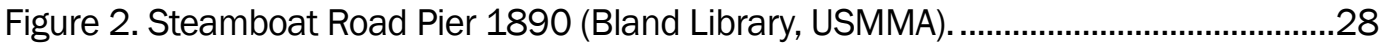

Figure 3. Sketch map of USMMA historic district, with numbered properties shown within bold outline of the district. (USMMA DPW with modifications by

ERDC-CERL). 29

Figure 4. 1914 map of Elm Point (Hyde).

Figure 5. Bendel/Chrysler mansion (Wiley Hall) and grounds, west façade, 1941

(Previews Incorporated).

Figure 6. Components of the Chrysler Estate in 1941 (Previews Incorporated). 36

Figure 7. Interior of Chrysler mansion, 1941 (Previews Incorporated).

Figure 8. Gardens and landscaped grounds, Chrysler mansion, 1941 (Previews Incorporated).

Figure 9. Rose garden south of Chrysler mansion, undated (American Merchant Marine Museum).

Figure 10. Amphitrite Fountain at the Chrysler estate, undated (Bland Library, USMMA).

Figure 11. View of Chrysler estate (center front) and Grenwolde lots (toward upper right near circular road), 1932 (Bland Library, USMMA).

Figure 12. Houston house (center) and garden (left), with Chrysler rose garden at lower right, undated; all were later demolished (MacKay et al. 1997).

Figure 13. Schenck house (Land Hall), north façade, 1942 (National Archives

and Records Administration [NARA] RG 178).

Figure 14. Schenck swimming pool (Prosser Boat House), 1942 (NARA RG 178).

Figure 15. Map of Schenck estate, 1942 (NARA RG 178)

Figure 16. Satirical map of Great Neck by John Held, Jr., 1927 (American

Merchant Marine Museum). (Note: locations and scale are not entirely accurate.).

Figure 17. Thomas Meighan's house (Melville Hall) as depicted in New Movie Magazine in 1931 (Browning).

Figure 18. New Movie Magazine article on Thomas Meighan's estate (Melville Hall), 1931 (Browning). 49

Figure 19. Smithers' House (Neiley/Quarters A) in 1915 (Architecture).

Figure 20. Smithers' garage (Neiley Garage/Quarters J) in Dutch Colonial Style, 1919 (Arts and Decoration).

Figure 21. 1943 aerial showing the new Patten Hospital with the Neiley garden in the lower center, the expanded Neiley garage (Quarters $J$ ) in the lower right, and the Meighan garage (Quarters K) in the upper right (Bland Library, USMMA). 
Figure 22. The Grenwolde Casino (Quarters D) in 1912, later to become the Japhet property (The Sun).

Figure 23. Panoramic View of the Marchant house and garage (both demolished), 1942 (NARA RG 178).

Figure 24. Vreeland (Friedman) house (Quarters C) in 1914 (Architectural

Record).

Figure 25. Map of Property in Kings Point showing lot owners, July 1942 (U. S. Coast Guard, from Berger 2005:19).

Figure 26. Using a photo taken prior to 1932, the names of property owners prior to January 1942 were handwritten by Capt. McCready in May 1954, to show USMMA acquisitions (Bland Library, USMMA). Bathing beach is in lower left. 59

Figure 27. Preliminary plan for use of Chrysler Mansion, first floor, 1942 (NARA RG 178).

Figure 28. Preliminary plan for use of Chrysler Mansion, second floor, 1942 (NARA RG 178)...

Figure 29. Former west-side loggia, newly enclosed on Wiley Hall, 1942 (Bland Library, USMMA).

Figure 30. Path from Wiley Hall to waterfront with new walkway and War Memorial, 1943 (Bland Library, USMMA). 65

Figure 31, Expanded waterfront facilities, 1943 (Mitchell). .66

Figure 32. Schenck pool (Prosser Boat House) enclosed with Chrysler greenhouse glass, 1943 (Bland Library, USMMA).

Figure 33. Plan for USMMA, showing existing buildings and CCC structures, August 1942 (Bland Library, USMMA).

Figure 34. Plan for USMMA, showing new construction overlaid on existing buildings, 1942 (Bland Library, USMMA).

Figure 35. Construction materials for permanent buildings, 1942 (Bland Library, USMMA). 71

Figure 36. Barry and Jones Halls (barracks), April 1943 (Bland Library, USMMA). ...........72

Figure 37. Fulton Hall, academic building, ca. 1960s (Bland Library, USMMA)..................73

Figure 38. O'Hara Hall, drill hall/gymnasium, 1944 (Bland Library, USMMA)....................73

Figure 39. Delano Hall and Parade Ground, 1943 (Bland Library, USMMA). 74

Figure 40. Dedication Day for USMMA at O'Hara Hall, 30 September 1943 (Bland Library, USMMA). 80

Figure 41. Memorial Chapel, with Kings Point Light navigational beacon visible in the steeple, 1960 (Bland Library, USMMA).

Figure 42. Newly finished Schuyler Otis Bland Library, 1969 (Bland Library, USMMA).

Figure 43. USMMA as it appeared in 1969 (Bland Library, USMMA).

Figure 44. Sketch map of USMMA historic district, with numbered properties shown within bold outline of the district. (USMMA DPW with modifications by ERDC-CERL).

Figure 45. West façade of Quarters D (Grenwolde Casino) in 1912 (The Sun)..................92

Figure 46. West façade of Quarters D (Grenwolde Casino) (USMMA, 2013).....................93 
Figure 47. South façade of Quarters A (Neiley house) in 1915 (Architecture)...................94

Figure 48. South façade of Quarters A (Neiley house) (ERDC-CERL, 2013). .....................95

Figure 49. North façade of Quarters A (Neiley house) (ERDC-CERL, 2013).......................95

Figure 50. Southwest oblique of Quarters J (Neiley garage), 1919 (Arts and Decoration).

Figure 51. South façade of Quarters J (Neiley garage) (ERDC-CERL, 2013). (NOTE: large, beige building on left is not part of the quarters.) ....................................................97

Figure 52. Southwest oblique of Quarters J (Neiley garage) (ERDC-CERL, 2013)..............98

Figure 53. East façade of Melville Hall (Meighan house) as depicted in New Movie Magazine in 1931 (Browning).

Figure 54. East façade of Melville Hall (ERDC-CERL, 2013)............................................. 100

Figure 55. Detail of the east entrance to Melville Hall (ERDC-CERL, 2013)....................... 101

Figure 56. Southwest portions of the ballroom addition to Melville Hall (ERDC-

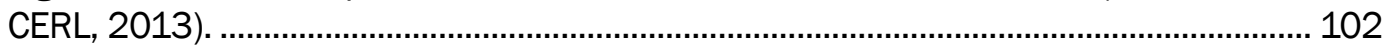

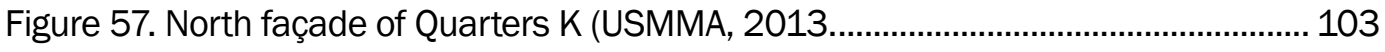

Figure 58. North façade of Land Hall (Schenck house), 1942 (NARA RG 178). ............. 104

Figure 59. South façade of Land Hall (Schenck house), no date (Great Neck

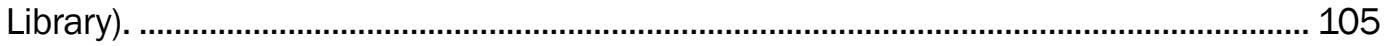

Figure 60. Southwest oblique of Land Hall (Schenck house) (ERDC-CERL, 2013)......... 105

Figure 61. South façade of Quarters B (USMMA, 2013 ................................................. 107

Figure 62. North façade of Quarters B (ERDC-CERL, 2013). .......................................... 107

Figure 63. South façade of Quarters C (Vreeland house) in 1914 (Architectural

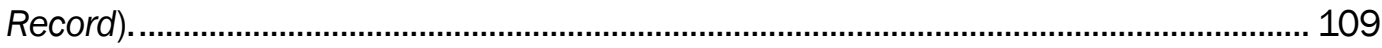

Figure 64.South façade of Quarters C (Vreeland house) (USMMA, 2013)....................... 109

Figure 65. Northwest oblique of Quarters C (Vreeland house) (ERDC-CERL, 2013)

Figure 66. West façade of Wiley Hall (Bendel/Chrysler Mansion), showing the then-newly enclosed west-side loggia, 1942 (Bland Library, USMMA)............................ 112

Figure 67. East façade of Wiley Hall (ERDC-CERL, 2013)................................................. 112

Figure 68. South façade of Wiley Hall (ERDC-CERL, 2013) ............................................... 113

Figure 69. North façade of Wiley Hall (ERDC-CERL, 2013) ............................................ 113

Figure 70. West façade of Wiley Hall (ERDC-CERL, 2013)............................................... 114

Figure 71. Porte cochere on the east façade of Wiley Hall (ERDC-CERL, 2013). ............. 115

Figure 72. Balustrade beneath window on the east façade of Wiley Hall (ERDC-

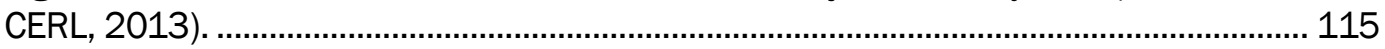

Figure 73. Round window on the east façade of Wiley Hall (ERDC-CERL, 2013)............ 116

Figure 74. Light fixture underneath porte cochere on the east façade of Wiley Hall

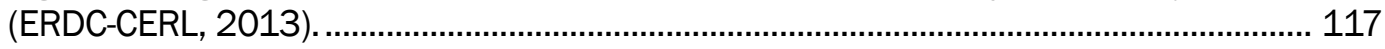

Figure 75. Corbels and egg-and-dart detail on the soffit on the west façade of Wiley Hall (ERDC-CERL, 2013).................................................................................... 118

Figure 76. Terrace on the south side of Wiley Hall (ERDC-CERL, 2013).......................... 118

Figure 77. Main entrance hall in Wiley Hall (ERDC-CERL, 2013)..................................... 119 
Figure 78. Main staircase in Wiley Hall (ERDC-CERL, 2013).

Figure 79. Former Bendel/Chrysler living room, now a lounge in Wiley Hall (ERDC-CERL, 2013). 120

Figure 80. Painted ceiling in Wiley Hall (ERDC-CERL, 2013)......................................... 120

Figure 81. Tile floor in Wiley Hall (ERDC-CERL, 2013).................................................... 121

Figure 82. Door and door surround in Wiley Hall (ERDC-CERL, 2013)............................. 122

Figure 83. Fireplace in Wiley Hall (ERDC-CERL, 2013)................................................... 123

Figure 84. One of the original Bendel/Chrysler bathrooms (with a replacement sink) in Wiley Hall (ERDC-CERL, 2013).

Figure 85. West façades of Rogers Hall [left] and Cleveland Hall [right] (ERDC-

CERL, 2013). 125

Figure 86. North façade of Murphy Hall [left] and east façade of Palmer Hall [right] (ERDC-CERL, 2013).

Figure 87. Close-up of the entry (center) on east façade of Palmer Hall, with entrance to Murphy Hall shown on the left (ERDC-CERL, 2013). 126

Figure 88. West entrance to Palmer Hall (ERDC-CERL, 2013).......................................... 126

Figure 89. Cast-stone door surround and replacement light fixture on the west entrance to Palmer Hall (ERDC-CERL, 2013).

Figure 90. Detail of original architectural drawings for the barracks (USMMA, DPW).

Figure 91. South façade of arcade that connects Rogers Hall to Cleveland Hall (ERDC-CERL, 2013)

Figure 92. Detail of concrete block walls, showing distinctive stone-like pattern on these barracks (ERDC-CERL, 2013)...

Figure 93. Detail of cornice and parapet on Cleveland Hall (ERDC-CERL, 2013).

Figure 94. Original light schedule drawing for barracks entrance light fixtures (USMMA DPW).

Figure 95. Typical replacement light fixture at entrance to one of the barracks (ERDC-CERL, 2013).

Figure 96. West façade of the Truxton Arcade that connects Barry and Jones Halls (barracks), April 1943 (Bland Library, USMMA).

Figure 97. West façades of Jones Hall [left], Truxton Arcade [center], and Barry Hall [right] (ERDC-CERL, 2013).

Figure 98. East façade of the Truxton Arcade (ERDC-CERL, 2013).................................. 134

Figure 99. East façade of Barry Hall (ERDC-CERL, 2013).................................................. 134

Figure 100. North façade of Jones Hall (ERDC-CERL, 2013)........................................ 135

Figure 101. Detail of doorway on east façade of Barry Hall with nonhistoric doors (with original cast-stone surround), light fixtures, and railings (ERDC-CERL, 2013)....... 136

Figure 102. Detail of cast-stone door surround and nonhistoric light fixture on the east façade of Barry Hall (ERDC-CERL, 2013)..

Figure 103. Detail of a cast-stone bas-relief on the east façade of the Truxton Arcade (ERDC-CERL, 2013). 
Figure 104. Detail of cast-stone elements on the arches of the Truxton Arcade (ERDC-CERL, 2013)

Figure 105. Detail of replacement parapet and original cast-stone quoins and cornice on the east façade of Barry Hall (ERDC-CERL, 2013)

Figure 106. Original light schedule drawing for barracks entrance light fixtures (USMMA).

Figure 107. West façade of Furuseth Hall (ERDC-CERL, 2013).

Figure 108. Beltcourse, replacement windows, cornice, inscription, and parapet on Furuseth Hall (ERDC-CERL, 2013).

Figure 109. Detail of original architectural drawing showing cast-stone door surround, windows, and concrete block walls (USMMA)

Figure 110. Windows, entrance doors, cast-stone surrounds, and exterior light fixtures on Furuseth Hall (ERDC-CERL, 2013).

Figure 111. Original light schedule drawing for barracks entrance light fixtures (USMMA)

Figure 112. Replacement light fixture at entrance (ERDC-CERL, 2013).

Figure 113. Southeast oblique of the east entrance to Fulton Hall (classroom building), ca. 1960s (Bland Library, USMMA).

Figure 114. Southeast oblique of the east entrance to Fulton Hall (classroom building) (ERDC-CERL, 2013).

Figure 115. East entrance to Fulton Hall (ERDC-CERL, 2013).

Figure 116. Mechanical room and base of chimney at the northeast corner of Fulton Hall (ERDC-CERL, 2013).

Figure 117. South façade of Gibbs Hall [left] and Fulton Hall [right], showing the transition between the two buildings (ERDC-CERL, 2013).

Figure 118. East façade of Bowditch Hall (ERDC-CERL, 2013).

Figure 119. North façade of Bowditch Hall (ERDC-CERL, 2013). 151

Figure 120. Auditorium vestibule in Bowditch Hall (ERDC-CERL, 2013). 152

Figure 121. Detail of southwest corner of portico entrance to Fulton Hall showing cast-stone architectural elements (ERDC-CERL, 2013).

Figure 122. East entrance to Fulton Hall (ERDC-CERL, 2013).

Figure 123. Replacement light fixture at east entrance to Fulton Hall (ERDC-

CERL, 2013).

Figure 124. Inscription on cast-stone lintel at portico entrance to Fulton Hall (ERDC-CERL, 2013).

Figure 125. Bas-relief over portico entrance doors to Fulton Hall (ERDC-CERL, 2013)

Figure 126. Original light fixture at portico entrance to Fulton Hall (ERDC-CERL, 2013).

Figure 127. Replacement windows in original openings on Bowditch Hall (ERDCCERL, 2013).

Figure 128. Original light schedule drawing for auditorium light fixtures (USMMA) 157

Figure 129. Original light fixture in auditorium vestibule in Bowditch Hall (ERDCCERL, 2013). 
Figure 130. Original light schedule drawing for corridor ceiling light fixtures (USMMA).

Figure 131. Original light fixture in lobby of auditorium in Bowditch Hall (ERDCCERL, 2013).

Figure 132. Original stairwell railings in auditorium vestibule in Bowditch Hall (ERDC-CERL, 2013).

Figure 133. Northwest oblique of the Fitch Building (ERDC-CERL, 2013).

Figure 134. East façade of the Fitch Building [lens distortion caused by panorama] (ERDC-CERL, 2013).

Figure 135. Entrance to the Fitch Building on the east façade (ERDC-CERL, 2013).

Figure 136. South façade of Samuels Hall, with the 1975 addition on the left (ERDC-CERL, 2013).

Figure 137. South façade of Samuels Hall with the 1975 addition on the left (ERDC-CERL, 2013).

Figure 138. South entrance to Samuels Hall with cast-stone door surround, caststone with inscription, and replacement light fixtures (ERDC-CERL, 2013).

Figure 139. Replacement awning (tilt) window on Samuels Hall (ERDC-CERL, 2013).

Figure 140. North façade of Delano Hall (mess hall) and Parade Ground, 1943

(Bland Library, USMMA).

Figure 141. North façade of Delano Hall with Blarney Square in the foreground (ERDC-CERL, 2013).

Figure 142. North façade of the Delano Hall entrance portico (ERDC-CERL, 2013)

Figure 143. Southeast oblique of Delano Hall, showing the kitchen wing on the left and the dining hall on the right (ERDC-CERL, 2013).

Figure 144.. Original railing on the portico on Delano Hall (ERDC-CERL, 2013). 170

Figure 145. Original light fixture, ceiling, and cast-stone elements on the portico of Delano Hall (ERDC-CERL, 2013).

Figure 146. Original light schedule drawing for portico ceiling light fixture on Delano Hall (USMMA, DPW).

Figure 147. Detail of original light fixture on the portico (ERDC-CERL, 2013).

Figure 148. Original light schedule drawing for "zodiac" vestibule ceiling light fixture (USMMA, DPW).

Figure 149. Looking up at the original "zodiac" light fixture in a dining hall vestibule in Delano Hall (ERDC-CERL, 2013).

Figure 150. Main entrance from the north into the dining hall (ERDC-CERL, 2013).

Figure 151. Cast-stone clock above doorway from dining hall to the vestibule (ERDC-CERL, 2013).

Figure 152. Interior of dining hall (ERDC-CERL, 2013).

Figure 153. Original light schedule drawing for dining hall ceiling light fixtures (USMMA). 
Figure 154. One of the original dining hall light fixtures in Delano Hall (ERDCCERL, 2013).

Figure 155. Mural in Delano Hall dining hall (ERDC-CERL, 2013).

Figure 156. Replacement interior doors in Delano Hall (ERDC-CERL, 2013).

Figure 157. Detail of paint on cast-stone quoins and on concrete block wall as well as one of the replacement exterior light fixtures on Delano Hall (ERDC-CERL, 2013).

Figure 158. Non-character-defining stair railing on the portico steps (ERDC-CERL, 2013)

Figure 159. Northwest oblique of O'Hara Hall (drill hall/gymnasium), 1944 (Bland Library, USMMA)

Figure 160. Northeast oblique of O'Hara Hall (ERDC-CERL, 2013).

Figure 161. Interior of O'Hara Hall (drill hall/gymnasium), no date (Bland Library, USMMA).

Figure 162. West façade of O'Hara Hall (ERDC-CERL, 2013).

Figure 163. East façade of O'Hara Hall (ERDC-CERL, 2013). 186

Figure 164. South side of O'Hara Hall, showing buttresses (ERDC-CERL, 2013). ........... 186

Figure 165. Interior of O'Hara Hall (ERDC-CERL, 2013).

Figure 166. Replacement doors on the west façade entrance of O'Hara Hall (ERDC-CERL, 2013).

Figure 167. Detail of cast-stone elements on the portico at the west entrance of O'Hara Hall (ERDC-CERL, 2013).

Figure 168. An eagle from the demolished New York Pennsylvania Station placed in front of the west façade of O'Hara Hall (ERDC-CERL, 2013).

Figure 169. Original interior windows and doors between east vestibule and the drill hall at O'Hara Hall (ERDC-CERL, 2013).

Figure 170. Original light schedule drawing for portico ceiling light fixture, O'Hara Hall (USMMA, DPW).

Figure 171. Original ceiling fixture on portico of O'Hara Hall (ERDC-CERL, 2013).......... 191

Figure 172. Replacement exterior light fixture on O'Hara Hall (ERDC-CERL, 2013)....... 192

Figure 173. Hyphen (connection) between O'Hara Hall [right] and the Natatorium [left] (ERDC-CERL, 2013).

Figure 174. The east façade of the Admissions Center with addition to the right (ERDC-CERL, 2013).

Figure 175. South façade of the Admission Center with Vickery Gate connected on the right (ERDC-CERL, 2013).

Figure 176. Northeast oblique of the Admissions Center, showing addition (ERDC-CERL, 2013).

Figure 177. Detail of concrete block pattern and a cast-stone surround on Admissions Center (ERDC-CERL, 2013).

Figure 178. Replacement window with cast-stone belt course above and cast-

stone lintel below at Admissions Center (ERDC-CERL, 2013).

Figure 179. North façade of Patten Clinic (ERDC-CERL, 2013). 
Figure 180. South façade of Patten Clinic (ERDC-CERL, 2013)....................................... 198

Figure 181. West façade detail of Patten Medical Clinic, showing concrete block pattern and cast-stone surrounds (ERDC-CERL, 2013).

Figure 182. Detail of the south façade of Patten Medical Clinic, showing three-

part window, parapet, and cast-stone belt courses (ERDC-CERL, 2013).

Figure 183. North façade of Memorial Chapel, with Kings Point Light navigational beacon visible in steeple, 1960 (Bland Library, USMMA).

Figure 184. Rotating altar inside the Memorial Chapel, showing two of its three sides, no date (Bland Library, USMMA).

Figure 185. Northwest oblique of the chapel (ERDC-CERL, 2013). .................................. 203

Figure 186. Chapel nave (ERDC-CERL, 2013)................................................................. 203

Figure 187. Altar inside the nave of the chapel, showing one side of the three-

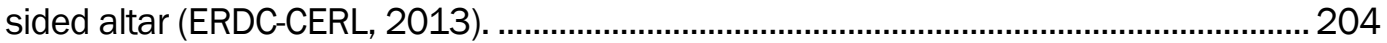

Figure 188. South side of the Memorial Chapel steeple (ERDC-CERL, 2013).................. 205

Figure 189. Weathervane detail of the Memorial Chapel steeple (ERDC-CERL, 2013) 205

Figure 190. Wood cornice detail and downspout on Memorial Chapel (ERDCCERL, 2013). 206

Figure 191. Detail of interior staircase, terrazzo flooring, metal railing, and wood banister in Memorial Chapel (ERDC-CERL, 2013).

Figure 192. Looking southwest towards Crowninshield Pier and Boat House (ERDC-CERL, 2013). 208

Figure 193. The replacement door into the men's shower at Crowninshield Pier and Boat House (ERDC-CERL, 2013)... 209

Figure 194. The replacement door into the women's shower near Eldridge Pool, shown flanked by wrapped training boats in foreground (ERDC-CERL, 2013).

Figure 195. Noncontributing shower interior (ERDC-CERL, 2013).

Figure 196. The paint locker north of Eldridge Pool (ERDC-CERL, 2013)..

Figure 197. The interior of the paint locker (ERDC-CERL, 2013).

Figure 198. South façade of the newly finished Schuyler Otis Bland Library, 1969 (Bland Library, USMMA).

Figure 199. South façade (front) of Bland Library (ERDC-CERL, 2013)

Figure 200. North façade (rear) of Bland Library (ERDC-CERL, 2013). 213

Figure 201. Original architectural drawing for the east façade of the Vickery Gate guard room on the north side of Steamboat Road (USMMA). 215

Figure 202. Original architectural drawing for the east façade of Vickery Gate guard room on the south side of Steamboat Road (USMMA). 215

Figure 203. East façade of the Vickery Gate guard room on the north side of Steamboat Road (ERDC-CERL, 2013). Note the added top layer of wall extending from guard room that is not part of original plans.

Figure 204. West façade of the Vickery Gate guard room on the south side of Steamboat Road (ERDC-CERL, 2013). (Note that this gate's wall does not have the upper layer of stone.) 
Figure 205. Globe and dolphin detail on top of Vickery Gate guardroom on the north side of Steamboat Road; the same detail is also on top of the south side guard room. (ERDC-CERL, 2013).

Figure 206. Northeast oblique of the Marvin Place Gate guard house on the south side of Steamboat Road (ERDC-CERL, 2013)...

Figure 207. Southeast oblique of the Marvin Place Gate guard house on the north side of Steamboat Road (ERDC-CERL, 2013).

Figure 208. Cast-stone eagle on the northeast corner of the Marvin Place Gate guard house on the south side of Steamboat Road (ERDC-CERL, 2013). 220

Figure 209. East façade of the Marvin Place Gate guard house on the north side of Steamboat Road, showing replacement door (ERDC-CERL, 2013). 221

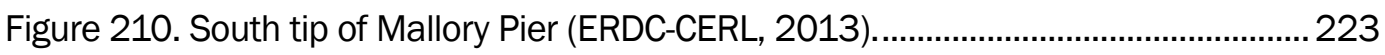

Figure 211. Looking to the north over Eldridge Pool (ERDC-CERL, 2013)....................... 224

\section{Tables}

Table 1. Superintendents of the U.S. Merchant Marine Academy. 77

Table 2. List of contributing and noncontributing features. Numbers in first column refer to site sketch map locations (see Figure 44). .90 


\section{Preface}

This study was conducted for the U.S. Department of Transportation Maritime Administration under Project Number 400142, "Historic Preservation Plan for U.S. Merchant Marine Academy.” The technical monitor was Barbara Voulgaris, Federal Preservation Officer, U.S. Department of Transportation, Maritime Administration (MARAD).

The work was performed by the Land and Heritage Conservation Branch (CN-C) of the Installations Division (CN), U.S. Army Engineer Research and Development Center - Construction Engineering Research Laboratory (ERDC-CERL). At the time of publication, Dr. Michael L. Hargrave was Chief, CEERD-CN-C; and Ms. Michelle Hanson was Chief, CEERD-CN. The Deputy Director of ERDC-CERL was Dr. Kirankumar Topudurti, and the Director was Dr. Ilker Adiguzel.

Colonel Jeffrey R. Eckstein was the Commander of ERDC, and Dr. Jeffery P. Holland was the Director. 


\section{Unit Conversion Factors}

\begin{tabular}{|l|c|l|}
\hline Multiply & By & To Obtain \\
\hline acres & $4,046.873$ & square meters \\
\hline degrees Fahrenheit & $(\mathrm{F}-32) / 1.8$ & degrees Celsius \\
\hline feet & 0.3048 & meters \\
\hline gallons (U.S. liquid) & $3.785412 \mathrm{E}-03$ & cubic meters \\
\hline hectares & $1.0 \mathrm{E}+04$ & square meters \\
\hline inches & 0.0254 & meters \\
\hline miles (U.S. statute) & $1,609.347$ & meters \\
\hline miles per hour & 0.44704 & meters per second \\
\hline square feet & 0.09290304 & square meters \\
\hline square inches & $6.4516 \mathrm{E}-04$ & square meters \\
\hline square miles & $2.589998 \mathrm{E}+06$ & square meters \\
\hline square yards & 0.8361274 & square meters \\
\hline yards & 0.9144 & meters \\
\hline
\end{tabular}




\section{Abbreviations}

$\begin{array}{ll}\text { Term } & \text { Spell-out } \\ \text { ADA } & \text { Americans with Disabilities Act } \\ \text { ALCO } & \text { American Locomotive Company } \\ \text { CAORF } & \text { Computer Aided Operations Research Facility } \\ \text { CCC } & \text { Civilian Conservation Corps } \\ \text { CO } & \text { Commanding Officer } \\ \text { ERDC-CERL } & \text { Engineer Research and Development Center - Construction } \\ & \text { Engineering Research Laboratory } \\ \text { LILRC } & \text { Long Island Library Resources } \\ \text { LIRR } & \text { Long Island Rail Road } \\ \text { MARAD } & \text { Maritime Administration (US Department of Transportation) } \\ \text { NARA } & \text { National Archives and Records Administration } \\ \text { NHPA } & \text { National Historic Preservation Act of 1966 } \\ \text { NRHP } & \text { National Register of Historic Places } \\ \text { NY SHPO } & \text { New York State Historic Preservation Office } \\ \text { SUNY } & \text { State University of New York } \\ \text { USNR } & \text { US Navy Reserve } \\ \text { USMMA } & \text { United States Merchant Marine Academy } \\ \text { USMMAHD } & \text { United States Merchant Marine Academy Historic District } \\ \text { VADM } & \text { Vice Admiral }\end{array}$




\section{Methodology}

\subsection{Background}

Congress codified the National Historic Preservation Act of 1966 (NHPA), the nation's most effective cultural resources legislation to date, in order to provide guidelines and requirements for preserving tangible elements of our past. This was done primarily through the creation of the National Register of Historic Places (NRHP). Contained within this piece of legislation (Sections 110 and 106) are requirements for federal agencies to address their cultural resources, which are defined as any prehistoric or historic district, site, building, structure, or object. Section 110 requires federal agencies to inventory and evaluate their cultural resources. Section 106 requires the determination of effect of federal undertakings on properties deemed eligible or potentially eligible for the NRHP.

The United States Merchant Marine Academy (USMMA) Historic District (see Figure 1 for location and boundary) encompasses a group of buildings of various property types (administrative, academic, residential, religious, and athletic/recreational; see site map-Figure 3 in Chapter 2) that form a defined space in which the individual elements are similar in materials, architectural details, and physical proportions, and that collectively exhibit a unity of exterior design that creates a cohesive visual environment. The Classical Revival-style buildings of the academy were designed with an emphasis on balance and symmetry. This cohesion and repetition of architectural elements was a conscious decision on the part of Alfred Hopkins \& Associates, who designed the buildings and gave the space a campus-like feeling. The centerpiece of the district is Wiley Hall, the former BendelChrysler mansion designed by architect Henry Otis Chapman, Sr., which was located on the property when the government purchased it in 1942. The clockwise completion of residence halls and academic buildings around Wiley Hall created a quadrangle that became the heart of the new academy. The new buildings, all of which were completed between 1942 and 1943, were designed in a Classical Revival inspired vocabulary that echoed the Beaux Arts Classical Style of Wiley Hall, thus creating a unified architectural complex. The USMMA incorporated a series of preexisting Gold Coast-era mansions, houses, and support buildings to the south of the original Bendel/Chrysler estate. Their construction dates range from 1912 to the 1920s. A chapel, which was designed by Eggers \& Higgins, was 
added on the waterfront of the USMMA in 1961, and a library (also designed by Eggers \& Higgins) was added to the center of campus in 1969.

As the former site of a mansion and estate belonging first to Henri W. Bendel and then to Walter P. and Della Chrysler, as well as the site of former estates belonging to other prominent wealthy Americans, the USMMA Historic District (USMMAHD) is nationally significant as a reminder of the "Golden Age" of the late nineteenth and early twentieth centuries. This was a period when financial, industrial, and entertainment leaders were nationally known and the recipients of vast amounts of wealth, either earned or inherited. In and around the New York City area, this affluent cohort sought the "country life" in Long Island for their second (or third, or fourth) homes. Like those of Newport, Rhode Island, these estates were often called "cottages" or given other diminutive terms that belied their often palatial dimensions and decorations. The owners of these estates were at the pinnacle of the New York social scene, and their entertainments and other extravagances during the "Jazz Age" were fodder to the news outlets of the time, with magazines and newspapers recounting every party, event, real estate transaction, new construction, and civic institution with which these "celebrities" were involved. With a period of significance from 1915-1941, the USMMAHD retains its integrity and meets National Register Criteria A and $\mathrm{C}$ at a national level. Criterion A is met through the association of the remaining structures from this period with the history of the Long Island "Gold Coast" estates. Criterion C is met through the design of the estate buildings surviving on USMMAHD grounds.

The USMMAHD is also significant nationally as the nation's only federally-owned educational facility for the advanced training of merchant mariners, and is one of five federal service academies (others are: U.S. Military Academy, U.S. Naval Academy, U.S. Air Force Academy, and U.S. Coast Guard Academy). The merchant marine officers serve the U.S. merchant fleet, including commercial and military transport. The USMMA was established in 1942, with the acquisition of the Walter P. Chrysler estate at King's Point, New York, followed quickly by adding other estates and grounds.

The USMMAHD has a period of significance from its beginning in 1942 through 1969, when the last remaining building in the central campus plan was constructed. USMMAHD retains its integrity and meets, at a national level, National Register Criteria A and C, and Criteria Consideration G. 
Criterion A is met through the association of the campus buildings with the historical trends of merchant marine training and the development of a professional merchant marine for the nation; Criterion $\mathrm{A}$ is also met for buildings associated with the development of Kings Point as a summer resort for Manhattanites in the early twentieth century. Criterion $\mathrm{C}$ is met through the design of the campus buildings, both those remaining from the previous estates and those constructed specifically for the USMMA. Criteria Consideration $\mathrm{G}$ is met through the inclusion of one building that is less than 50 years old as an integral part of the historic district.

The architectural resources included in the USMMAHD were constructed specifically for or were converted for use by USMMA during its initial establishment in 1942 and $1943 .{ }^{1}$ These buildings represent the academic, administrative, and residential support provided to cadet-midshipmen during their ashore training at USMMA. The USMMAHD, consisting of 49 contributing resources and 10 noncontributing resources, meets National Register Criterion $\mathrm{C}$ as an excellent example of a significant concentration of buildings that are linked historically and that are physically and spatially interrelated. The centerpiece of the district is Wiley Hall, which was a preexisting mansion on the property when the government purchased it. The clockwise completion of Fulton, Bowditch, Barry, Jones, Cleveland, Rogers, Delano, Murphy, and Palmer Halls around Wiley Hall created a quadrangle that became the heart of the new academy. The new buildings, all of which were completed between 1942 and 1944, were designed in a classically inspired vocabulary that echoed the Beaux Arts classicism of Wiley Hall, thus creating a unified architectural complex. With the exception of Wiley Hall, which is masonry and stucco, all buildings are of buffcolored concrete masonry units with cast stone (concrete) accents, and the buildings display a generally consistent cornice line, which adds to the visual cohesiveness of the area. The Classical Revival-style buildings are designed with an emphasis on balance and symmetry. The choice of architectural style likely was influenced by the architecture of the Bendel-Chrysler house. This cohesion and repetition of architectural elements was a conscious decision on the part of the architects who designed the buildings and give the space a campus-like feeling.

\footnotetext{
1 This paragraph is extracted from The Louis Berger Group, Inc., Cultural Resources Survey Report, U.S. Merchant Marine Academy, Kings Point, New York, (Lester, PA: Naval Facilities Engineering Command, 2005).
} 
For all areas of significance claimed for USMMAHD under Criteria A and C, USMMAHD is significant at a national level. The USMMAHD contains all features that contribute to these areas of significance, and conveys a sense of historic and architectural cohesiveness through its location, design, setting, materials, workmanship, feeling, and association.

\subsection{Objective}

The objective of this effort was to inventory and assess all features of the buildings and structures within the USMMAHD with boundaries shown in Figure 1.

Figure 1. Location and boundary for the USMMA historic district (USGS).

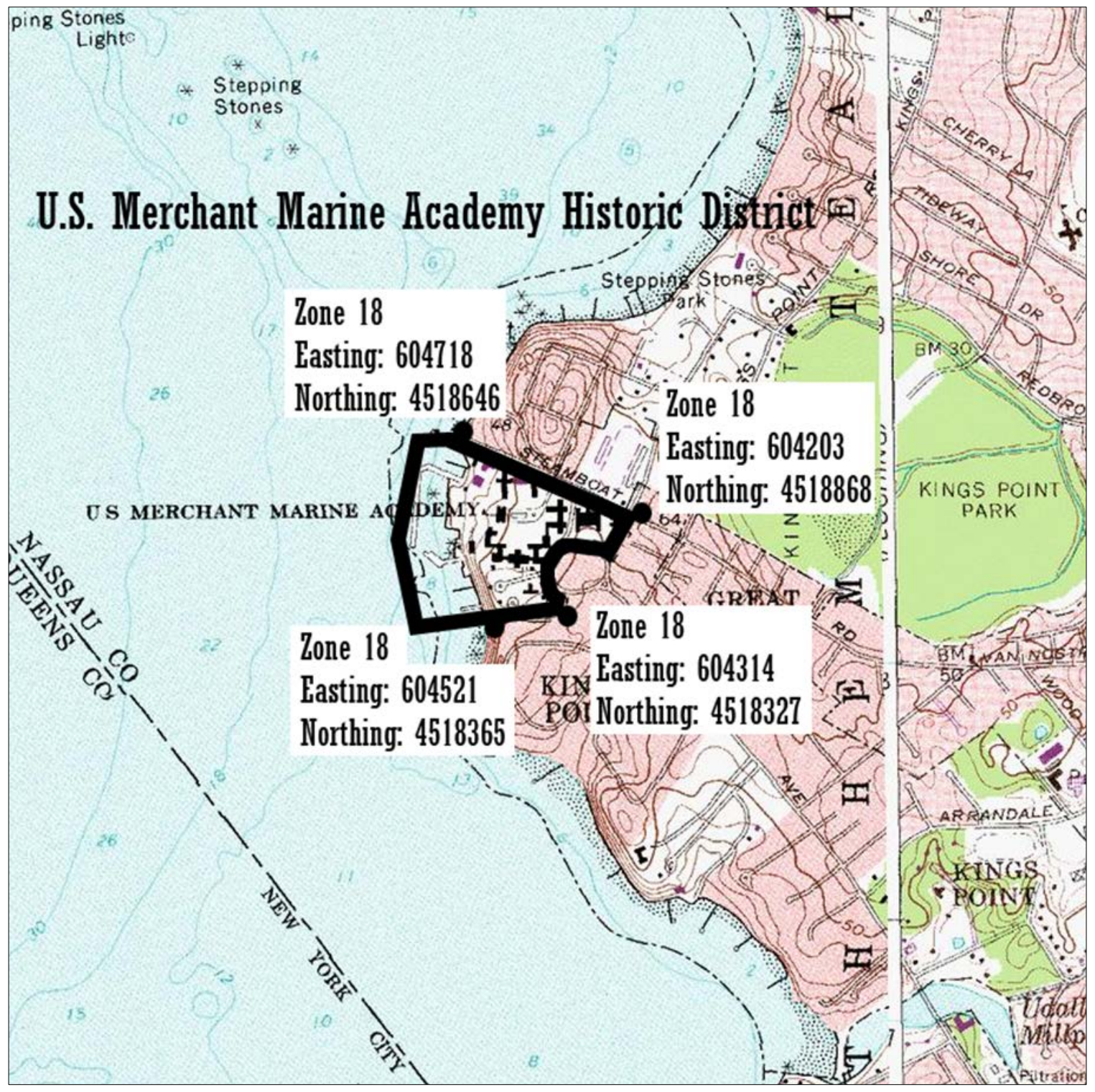




\subsection{Approach}

\subsubsection{Previous reports}

The USMMA has performed two previous architectural inventories and evaluations of building at the USMMA per Section 110 of the NHPA. In 2005, the Louis Berger Group wrote Cultural Resources Survey Report, U.S. Merchant Marine Academy, Kings Point, New York. The second report from 2013 is a nomination to the NRHP for the campus of the USMMA written by the U.S. Army Corps of Engineers, Engineer Research Development Center-Construction and Engineering Research Laboratory (ERDC-CERL), and it expanded the historic context and historic district contained in the Louis Berger report. While not a part of the USMMAHD, the William Barstow Mansion on the USMMA grounds (now serving as the American Merchant Marine Academy Museum) was the subject of a third report and a second nomination to the NRHP prepared by ERDC-CERL.

\subsubsection{Current project}

Under a Military Interdepartmental Purchase Request (MIPR), ERDCCERL was retained by USMMA to complete an inventory and assessment of character-defining features of all buildings and structures within the USMMAHD.

\subsubsection{Site visits}

The researchers conducted two site visits to inventory and assess the buildings and structures at the USMMAHD. The site visits occurred in December 2012 and January 2013.

\subsection{Researchers}

This project was conducted by ERDC-CERL in Champaign, Illinois. The researchers were Adam Smith (M.Arch), with 15 years experience in military architectural history; Susan Enscore (PhD.), with over 20 years experience in military history; and Sunny Adams (M.Arch), with 10 years experience in military architectural history. 
(This page intentionally left blank.) 


\section{Historic Context}

\subsection{Introduction to the U.S. Merchant Marine Academy²}

The direct federal program to train merchant mariners is a relatively recent development in U.S. maritime history. Prior to the 1938 establishment of the U.S. Maritime Service training program under the provisions of the Merchant Marine Act of 1936, the federal government provided support and assistance to city (later state) nautical schools and mandated a privately-run cadet program on ships receiving mail subsidies (USMM 2002b). Established under the 1891 Postal Aid Law (and later the 1928 Jones-White Act), private ships that received federal mail subsidies were required to embark young men as cadets and to teach those cadets the duties of seamanship (USMM 2002b). The graduates of these programs generally had no financial tie or duty to serve in the merchant marine, and no obligation to the federal government for its contribution to the cost of their education. These systems, when combined with the state schools, were generally adequate to meet the demand for merchant marine personnel before World War I. The USMMA was the final step in an evolutionary process of formal merchant mariner training that developed beginning in the mid-180os and reached maturity following World War II.

For much of recorded history, the art of seafaring was learned and practiced aboard ship and in shipyards. Ship's officers were groomed as cadets (midshipmen in naval service) from a young age and "graduated" as they demonstrated proficiency in navigation and shiphandling. In the sailing ship era, this apprenticeship method of training kept pace as ships slowly grew in size and complexity. The industrial revolution saw the advent of steam propulsion, the introduction of first composite and then all-iron and steel construction methods, and the general application of the scientific method to all aspects of ship design, construction, and operation. This rapid technological transformation of the maritime industry necessitated fundamental change in the methods and practices of seafaring, including the eventual abandonment of the apprenticeship method in favor of formalized education. However, change was slow and often lagged substantially

\footnotetext{
2 This section was authored by Erhard Koehler and Barbara Voulgaris of the United States Maritime Administration for the USMMA nomination to the NRHP.
} 
behind the technology as evidenced by major accidents and disasters that usually featured human error as a primary cause (Voulgaris 2009).

In 1838 , the U.S. Congress passed the first federal legislation requiring some degree of inspection for steamboats. In 1852, legislation reformed the inspection system, and for the first time, it included requirements for the licensing of officers and certification of crews. Succeeding legislation continued to strengthen these requirements, leading incrementally to the consolidation of marine inspection and merchant mariner licensing and credentialing programs in 1940 (Voulgaris 2009).

As officer licensing requirements gradually increased throughout the latter part of the 1800s, the systems of formal education followed. In 1850, the U.S. Navy established the U.S. Naval Academy in Annapolis, Maryland, and in 1884 the Naval War College in Newport, Rhode Island. The 1874 Nautical School Ship Act allowed coastal cities to apply for the assignment of naval vessels and personnel to train young men for the merchant marine (Independence Seaport Museum 2012). The first school established under the Act was the New York Nautical School, which survives today as the State University of New York (SUNY) Maritime College at Fort Schuyler (USMM 2002b). The SUNY Maritime campus is at the confluence of the East River and the Long Island Sound, immediately across from the campus of the USMMA. Other schools followed in Philadelphia (1889) and Boston (1891).

In the period prior to World War I, these schools were transferred to their respective states. The program was transferred from the U.S. Navy to the Maritime Commission in 1940 and is administered today by the Maritime Administration, with six state academies receiving support (Maine, Massachusetts, New York, Texas, California, and Michigan. The state schools were initially vocational schools with programs running from 1824 months. The Boston school was the first to offer marine engineering on its steam-propelled school ship. Academic programs gradually increased in scope and length, moving first to three-year programs and eventually to full four-year undergraduate degree programs coupled with the Coast Guard license. Most of the schools either adopted or planned to adopt four-year programs prior to World War II, but the need to dramatically increase the number of officers led to curtailed wartime programs of as little as 15 months. 
Federal oversight and involvement in maritime affairs ebbed and flowed in the two decades after World War I. Maritime revitalization became a focus of the Roosevelt Administration, leading to the landmark Merchant Marine Act of 1936. Among the objectives of the Act was the establishment of a federal program for the training of merchant marine officers; this objective was identified in the policy statement of the Act. To carry out this objective, the Maritime Commission created the United States Maritime Service as the training organization, to be administered by the Coast Guard (U.S. Coast Guard 2012).

In the pre-war period, two training ships were converted for use by the USMS, and training centers were established in New London (Fort Trumbull), Connecticut, and Alameda (Government Island), California (U.S. Coast Guard 2012). Under the Act, the old mail subsidy program was replaced by a more comprehensive operating differential subsidy. The mail cadet program was abolished and replaced by the U.S. Merchant Marine Cadet Corps, whose personnel were assigned to commercial vessels receiving operating subsidies (USMM 2002b). A formal training program for the cadets was established and administered by the USMS, with training officers stationed in various port cities. Cadets would report to the training officers for vessel assignments, and to review completed training and study packages. This program was the direct antecedent of the USMMA.

As the cadet corps program grew, it became apparent that a permanent, centralized shore establishment was necessary to effectively carry out the program. That shore establishment became the USMMA (USMM 2002b). The federal training program expanded considerably during World War II to meet the massive demand for officers and seamen to crew the nearly 6,000 merchant ships built for war service. In the postwar period, the training program retrenched and eventually, all direct federal activities were consolidated at Kings Point, which operates today alongside the six state maritime academies and several training centers operated by maritime unions and private concerns to serve the personnel needs of the merchant marine.

Today's merchant marine consists of privately-owned, U.S.-registered merchant ships and a variety of towing, offshore supply, and passenger vessels operated by merchant mariners to provide waterborne transportation for passengers and cargoes moving in domestic and international commerce. 


\subsection{Long Island history ${ }^{3}$}

English settlement of Long Island began in the 1640s, although Manhattan, then known as New Amsterdam, was still controlled by the Dutch. The English established the town of Hempstead near Manhasset Bay, and in 1683 , nearly twenty years after the British had gained control of the New York colony, Long Island was divided into three counties: Kings, Suffolk, and Queens. Queens encompassed land along western Long Island, including nearly all of present-day Nassau County (Nassau County Board of Supervisors 1989:3-4). A 1936 map recreating the historical land ownership of Kings Point in the 1700 s described the area now occupied by USMMA as part of "John's Division, Lot No. 24," which encompassed over 116 acres (Whittle 1936). The same map depicted George Hewlett's stone house, constructed in 1660, towards the east side of Elm Point. A clay pit, in operation during the mid-1700s, was located on the southwest side of the neck. This map indicated that by the mid-seventeenth century, Great Neck was occupied by Euro-American settlers and enterprises, such as the clay pit, were underway by the mid-eighteenth century. Grist mills were also established in the area by the late seventeenth century. Land was cleared for farms on which sheep and cattle were raised (Whittle 1940).

On January 1, 1898, western Queens became part of metropolitan New York. The towns of Hempstead, North Hempstead, and Oyster Bay, however, were not part of this incorporation. In April 1898, New York Governor Frank S. Black signed the law creating Nassau County, which included the three towns formerly included in Queens County. Garden City, located within one mile of the Mineola railroad station, was selected as the county seat (Nassau County Board of Supervisors 1989:6).

Agriculture and fisheries were among the earliest economic endeavors in Nassau County. These would later be supplemented with the presence of manufacturing industries, such as aviation production plants, and summer resort and tourist-oriented enterprises. During the late nineteenth century, agricultural production in Nassau County increased to support the burgeoning population of New York City (Nassau County Planning Commission 1997: III-1). Associated industries, such as milling, continued to develop throughout the county.

\footnotetext{
3 Paragraphs in the Long Island History section are extracted verbatim from Berger, Cultural Resources Survey Report.
} 
Beginning in the last quarter of the nineteenth century, Nassau County was part of what became known as Long Island's "Gold Coast," where many wealthy New Yorkers established elaborate estates within easy commuting distance to downtown Manhattan. Between the Civil War and World War II, over 900 estates were developed between Queens and Montauk (MacKay 1994:169). Most of these estates were summer retreats from which the residents returned to their city dwellings during the winter (Schisgall 1951:24). Long Island possessed several advantages that led to the development of estates, including easy access by rail, road, or water to the social, economic, and media center of New York City; the availability of recreational pursuits; and the founding of sporting and other clubs (MacKay 1994:170). Great Neck and Kings Point were part of this development, and many of these early twentieth-century estates survive today.

The railroad was a dominant factor in the evolution of Long Island from a largely rural farming area into a thriving residential area. By 1865 , railroads were constructed across the center of Long Island and along the north and south shores. By the turn of the twentieth century, the Long Island Rail Road (LIRR), which began construction in 1834, was the dominant means of transportation to New York City, and in 1911, the railroad completed direct rail service to Pennsylvania Station in the heart of Manhattan. The decision of the LIRR to build stations and spur lines throughout Long Island "sparked the summer colony movement" (MacKay 1994:170). The population of Nassau's small villages along the railroad lines swelled with commuters, leaping from 55,448 in 1900 to 303,053 in 1930 (Nassau County, Long Island, New York 2002).

Although rail was the preferred method of commuters, many of Kings Point's residents traveled to their city jobs by steamboat since the landing off Elm Point proved to be more conveniently located than the rail station. As early as 1859, a steamboat landing was located at the end of presentday Steamboat Road, which runs through the USMMA campus (Walling 1859). Boats left the landing at 8:00 a.m. and returned at 6:00 p.m. The boats, however, were subject to seasonal weather delays. Steamboats such as the Sewanhaka and the Idlewild continued their daily commutes until the 1930s (Schisgall 1951:24). The landing and an adjacent park remained public until the establishment of USMMA in 1942 (Figure 2). Some of the area's wealthier residents even invested in their own "business boats," which were private yachts that ferried them back and forth between their Long Island homes and the city (MacKay 1994:171). 
Figure 2. Steamboat Road Pier 1890 (Bland Library, USMMA).

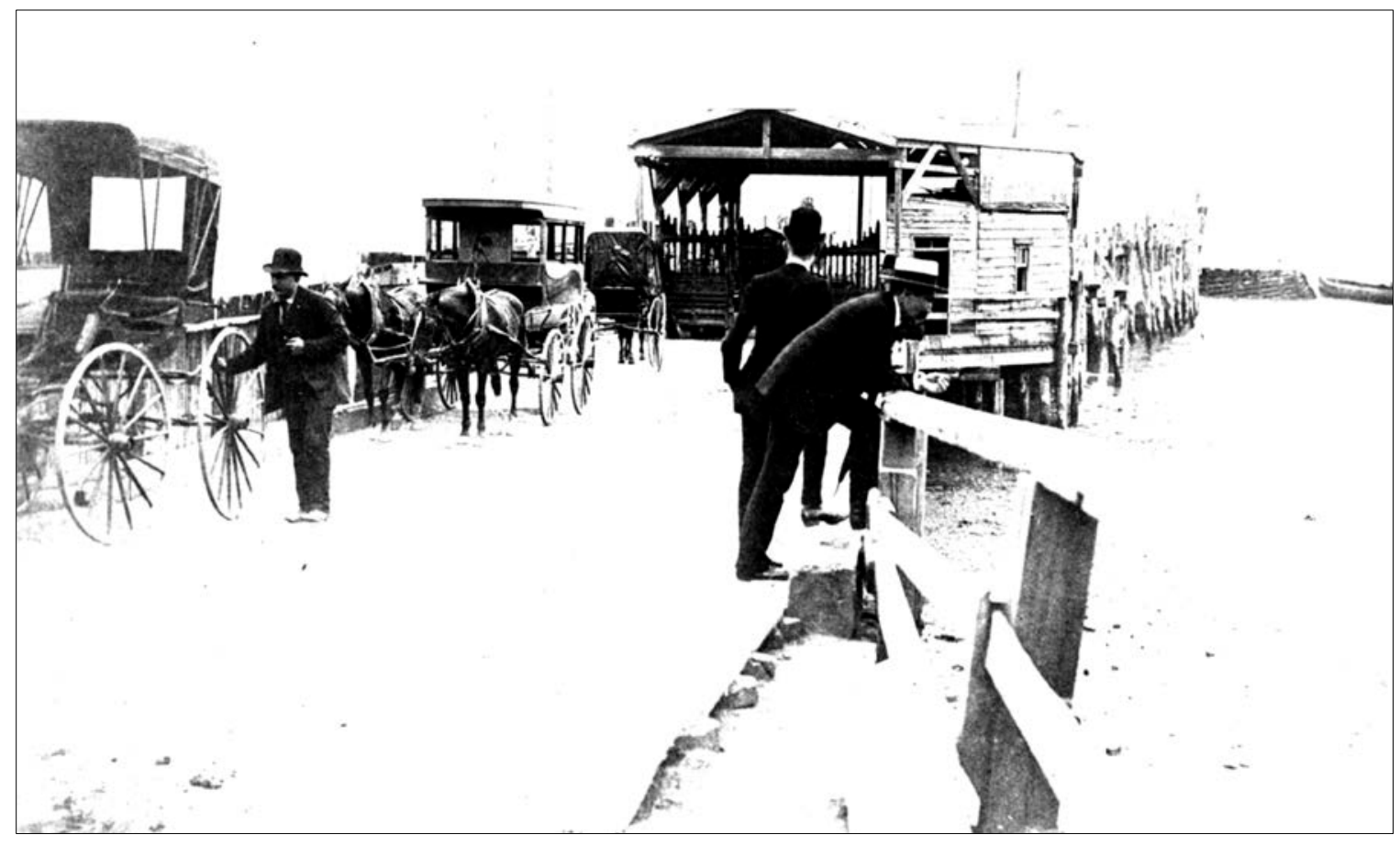

By the mid-twentieth century, major redevelopment of the east/west parkway systems, which were created just before World War II, was supplemented by the creation of additional north/south parkways and the Long Island Expressway (Nassau County, Long Island, New York 2002). Automobile travel was bolstered by the construction of bridges over the East River as well. Increased access was a stimulus for additional residential construction. After World War II, with increased industrial opportunities and such mass housing developments as Levittown, which held over 10,000 new homes, Nassau County's population continued to grow throughout the 1940 . What had at first been a retreat for wealthy city dwellers soon became accessible to the middle class. Between 1950 and 1960, Nassau County experienced its greatest population growth with an increase of 93.3 percent (from 672,765 to 1,300,171) (Long Island Power Authority 2001: iv). Prior to and immediately after World War II, new county residents were mostly middle-class families settling in the more affordable communities located along the LIRR. After World War II, the construction of new roads and parkways and the subsequent growth in the use of automobiles made Nassau County even more accessible to suburbanization (Nassau County Planning Commission 1997: III-2). Combined with the increase in Suffolk County's population, the population on Long Island for the period 1950-1960 increased by over a million people. Population in Nassau County continued to increase into the 1970 s when the 
county's population peaked at 1,428,000; during the 1980s and 1990s, however, the county experienced a slight loss of population.

\subsection{Kings Point Estates on the future grounds of the U.S. Merchant Marine Academy4}

The properties acquired for the USMMA are discussed below in spatial order along the shore from the Chrysler Estate south to the Grenwolde Casino property, then around the curve of the Grenwolde development moving to the north and east, then finally northeast to the edge of the USMMA grounds (please refer to numbered properties shown in Figure 3).

Figure 3. Sketch map of USMMA historic district, with numbered properties shown within bold outline of the district. (USMMA DPW with modifications by ERDC-CERL).

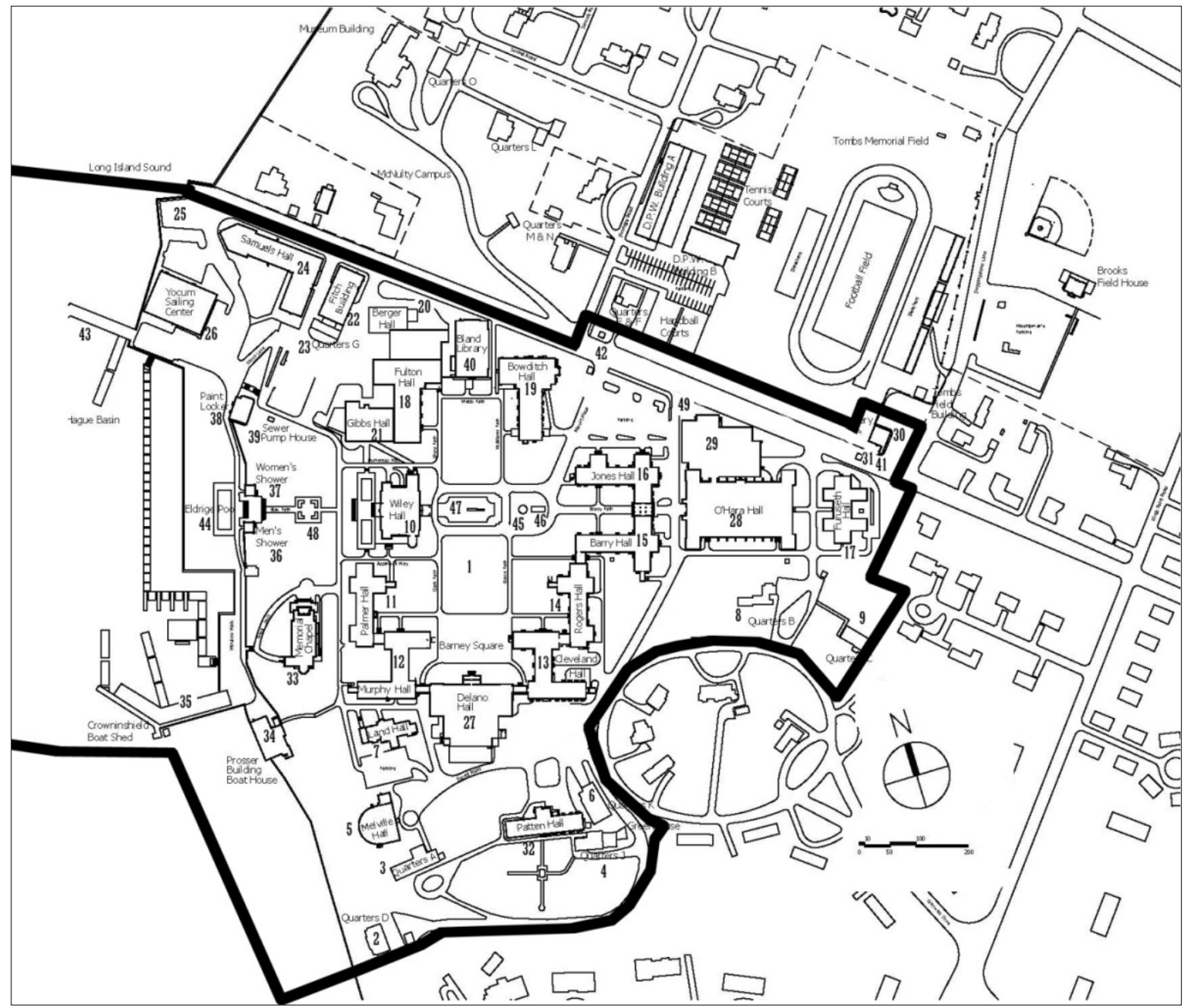

4 The Kings Point Estates section was researched and written by ERDC-CERL authors. 


\subsubsection{The Henri W. Bendel/Walter P. Chrysler Estate (Wiley Hall) (\#10 on sketch map)}

The main house (named the Forker House by the Chryslers) was originally built for, and owned by, retail magnate Henri Willis Bendel. The couturier made his fortune in women's clothing in the first several decades of the twentieth century and established a retail store in New York City bearing his name that remains in business to the current day, although it is no longer family owned. During the 1910s and 1920s, Bendel was the foremost fashion designer in America, and was also primary in introducing European designers, including Coco Chanel, to American society. Bendel is also credited with staging New York City's first fashion show (Holub 2008). Henri Bendel maintained a Manhattan residence on Park Avenue as his primary abode until his death in 1936. After selling the Kings Point property in 1923, Bendel purchased and helped design a large mansion and country estate in Stamford, Connecticut, and acquired another large estate near his hometown of Lafayette, Louisiana (Stamford Museum 2013; Arsht 2006:11).

Bendel purchased the Kings Point property in 1915, and the house was built in 1916 (New York Times 1916). Prior to Bendel's purchase, the property went through a series of owners, with records of Skidmore (unknown-1912), Howell (1912-unknown), and Busch (unknown-1915) as previous owners (The Sun 1917). An insurance map from 1914 shows the property as owned by C.N. Busch, with a two story house (Figure 4), and a 1915 New York Times article about the sale mentioned an existing large brick and stone dwelling, with a purchase price for the property of \$150,000 (Hyde 1914; New York Times 1915b). 
Figure 4. 1914 map of Elm Point (Hyde).

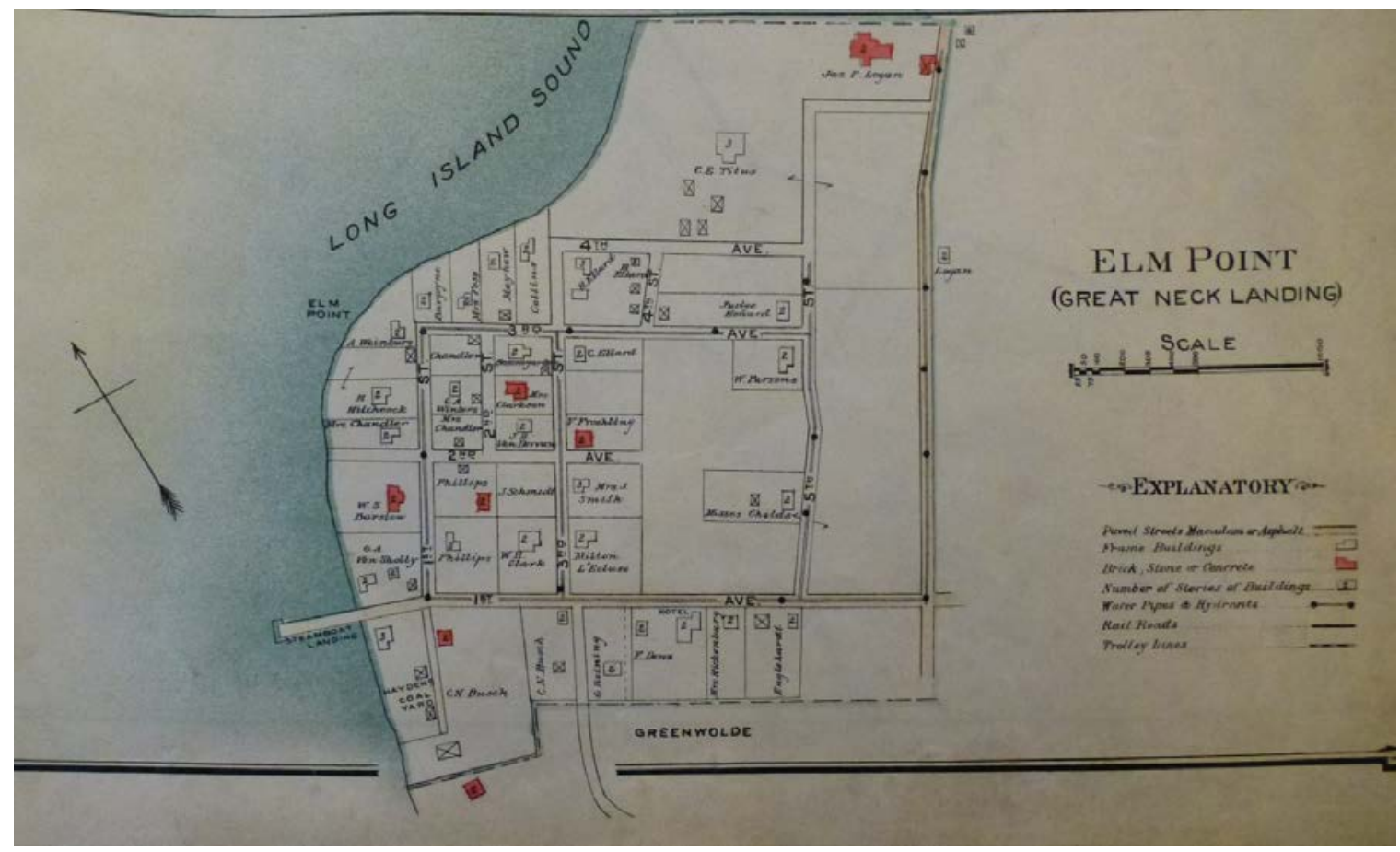

The architect was Henry Otis Chapman, who in 1913 had designed Bendel's eight-story $57^{\text {th }}$ Street store in Manhattan. Chapman graduated from Cornell University in 1890 and began an architectural practice in New York City. By 1900 he was a partner in the firm of Barney \& Chapman, along with John Stewart Barney. During the eight years of the partnership, the firm was primarily noted for designing churches, hotels, and commercial structures, but they also designed four "country-house" estates on Long Island ca. 1900, primarily in the Tudor Style (MacKay et. al. 1997:62). One of the houses, in Woodmere, was a home for Chapman. After the partnership dissolved in 1908, both former partners had residential commissions on Long Island, with Barney designing one home and Chapman credited with three. The final one of the three was the house for Henri Bendel, and it is unique among Chapman's projects for the use of French Renaissance design elements (MacKay et. al. 1997:66).

Walter Percy Chrysler and Della V. Forker Chrysler, his wife, purchased the property, with both receiving the premises by deed dated 16 February 1923 ( $77^{\text {th }}$ Congress 1942a:3). Walter Percy Chrysler (1875-1940) was not born to a life of estates and mansions. His childhood was spent in Kansas, where his father worked as an engineer for the Union Pacific Railroad. He acquired a love of engines from his father and from early jobs for the Union Pacific as a janitor and mechanic's apprentice (Kansas Historical Soci- 
ety 2013). After absorbing all he could from the Union Pacific shops, he left home in 1897 for a series of railroad mechanic jobs that carried him through the next decade. These jobs provided steady increases in responsibility, and he felt secure enough to marry Della Forker in 1901 (Walter P. Chrysler Museum 2009a:I:4). By 1905 the Chryslers were in Oelwein, Iowa, where Walter was working for the Chicago Great Western Railroad as master mechanic of the repair shops. By 1907 he was the superintendent of motive power for the entire system, including all locomotives and supervising 1,000 men (Walter P. Chrysler Museum 2009a:I:5). Becoming more financially secure, Chrysler bought his first car the following year, a 1908 Locomobile. The car was produced by the American Locomotive Company (ALCO), the second largest manufacturer of locomotives in the United States, which had recently branched out into automobile production. Chrysler immediately spent three months taking the car apart and putting it back together to understand how it worked before he drove it (Walter P. Chrysler Museum 2009a:I:6). Still ambitious, Chrysler left the Chicago Great Western Railroad in 1909, and managed to get hired by ALCO in Pittsburgh, Pennsylvania. Within two years, he was the works manager of the Allegheny shops in Pittsburgh, where the locomotives were manufactured, and he had made the business profitable. Even so, when an offer to work in the automotive industry arose, he never looked back. First, he worked as the works manager for the Buick plant in Flint, Michigan, transforming it in four years from an inefficient operation with skilled craftsmen hand-assembling cars one at a time to one with a basic assembly-line structure, augmented by increased productivity through an open factory floor, simplifying production. Between 1912 and 1916, production at the plant increased from 19,812 to 124,834 , with a greatly improved product (Walter P. Chrysler Museum 2009a:I:7-9). Chrysler had become a valuable property to Buick's parent company, General Motors. After a corporate shake-up in 1916, Chrysler was offered the position of president of Buick at a salary of $\$ 500,000$ a year - he accepted (Walter P. Chrysler Museum 2009a:I:10). By 1918 he had risen to become General Motors' vice president with responsibilities across the corporation, but conflicts with Billy Durant, the head of General Motors resulted in Chrysler leaving the company in 1919; his General Motors stock was purchased by Durant in 1920 for $\$ 10$ million (Walter P. Chrysler Museum 2009a:I:10-12). That same year, he was asked to take over management of the Willys-Overland Company to save the automobile company from going out of business. Chrysler agreed, dependent on being able to live in New York City (a Park Avenue apartment), make any changes he saw as necessary to the firm, 
and receiving a salary of $\$ 1$ million a year (Walter P. Chrysler Museum 2009a:I:13). Walter Chrysler entered the Roaring Twenties as a very wealthy man and began making his own cars in 1924. The new Chrysler car was an immediate hit, and 32,000 were sold the first year, enabling Chrysler to form the Chrysler Corporation in 1925 and selling over 100,000 cars that year with profits of $\$ 17$ million; two years later, nearly 200,000 Chryslers were sold (Walter P. Chrysler Museum 2009b:III: $5,8,10)$. The Chrysler Corporation soon rivaled Ford and General Motors as one of the "big three" American automobile companies. Walter Chrysler ran the company on a day-to-day basis until 1935, when he retired as president and became chairman of the board. Three years later, he retired completely after a stroke. His wife, Della, with whom he had four children, died in 1938, and Chrysler followed her in 1940, dying at home in the Forker House (Kansas Historical Society 2013).

The building most closely associated with Walter Chryslers' life is undoubtedly the world-renowned 1930 Art Deco masterpiece that is the Chrysler Building in Manhattan. It served as Chrysler Company's New York headquarters for decades and was owned entirely by the Chrysler family until 1953 (Pierpont 2002). The King's Point property purchase in 1923 was, however, Walter Chrysler's first big real estate purchase (Curcio 2001:307). The grounds were landscaped by the landscape architecture firm of Charles W. Leavitt \& Sons. (Old Long Island 2009). Leavitt began his career as an engineer, and had opened an office in New York City for civil and landscape engineering and city planning by 1897 . Leavitt's combination of skills ensured a steady stream of diverse work, including city parks, college campuses (Universities of Georgia and South Carolina), race tracks (Saratoga), city planning (Garden City, Long Island and West Palm Beach, FL), and dozens of grounds and gardens for private estates in New York and New Jersey, including Long Island (Hamersly 1918:654). Among his estate clients were William C. Whitney, Chester A. Congdon, George Foster Peabody, Charles M. Schwab, Carlton Macy, and Harry K. Knapp (Hamersly 1918:654; MacKay et. al. 1997:253). The work he did at Kings Point for Chrysler was probably circa 1929 (Sclare 1975:244). Leavitt's firm provided flower gardens along the drive and south of the mansion, along with broad terraces to the waterfront with geometric patterns, and grassy lawns with scattered trees. He also provided Chrysler with an elaborate sea wall, pergolas, a boathouse, and a jetty (MacKay et.al. 1997:253) (Figure 5). 
Figure 5. Bendel/Chrysler mansion (Wiley Hall) and grounds, west façade, 1941

(Previews Incorporated).

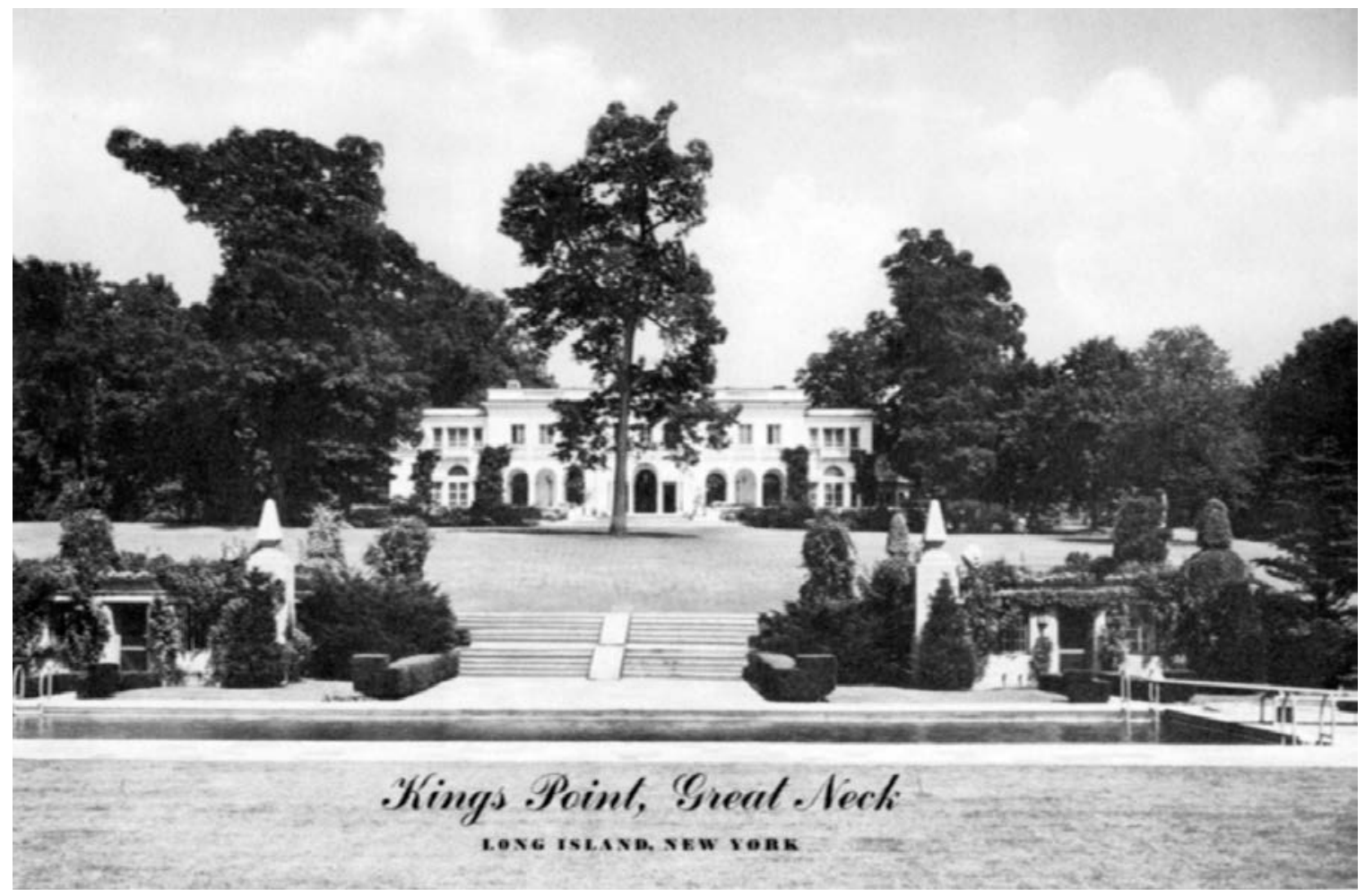

During the 1920 and 1930s, after a day in his Manhattan skyscraper office, Walter Chrysler often came home to the elegant, shore-lined Kings Point estate. Chrysler was quoted in a 1936 promotional publication for the area as saying, "I have always found Great Neck a most delightful place in which to live. Its distinct advantages attracted me a good many years ago and I have come to have an increasing appreciation of the beauty, convenience and climate of this pleasant section of Long Island. As a suburban community, it is ideally located, combining natural country surroundings with proximity to the city" (Spear 1936:84). Ownership of an elegant mansion in the most sought-after part of New York placed the Chryslers in the midst of the Gold Coast heyday. As a biographer of Chrysler described the era, there were "diaphanous summer evenings on sweeping lawns, mad parties in impossibly big waterfront mansions, and over it all the smell and feel of fresh money, crackling and new, pervaded the whole atmosphere" (Curcio 2001:309). The Chrysler family entertained guests and relaxed in their Long Island home, while in good weather, Walter commuted to work on one of his several private yachts (Curcio 2001:308). Daughter Thelma married Byron Foy at the estate on 3 December 1923. On 12 May 1932, Walter deeded the property solely to Della ( $77^{\text {th }}$ Congress 1942a:5,8; U.S. Coast Guard 1942). 
Immediately before the government acquisition, the property was inspected, and the 12-acre estate was described as containing a garage (three apartments on the second floor), a Superintendent's house, a greenhouse, and the main house at the center of the estate (Figure 6). The main house was large and equipped with a variety of rooms necessary for entertaining guests, providing spacious comfort for the family, and work spaces for the running of the house. On the first floor, the main house contained a large main hall, a dressing room, and office, a dining room, breakfast room, living room, music room, enclosed veranda, card room, kitchen, butler's pantry, servants' dining room, and store room. Up the grand staircase, the second floor housed six bedrooms, six baths, two sitting rooms, and a library. The northeast wing of the second floor had four bedrooms and three baths for servants. On the third floor were three bedrooms (one for guests), one bath, and one sitting room. The house had a large basement for recreation and housekeeping, with an indoor swimming pool, shower room, massage room, enclosed veranda, four storage rooms, billiard room, furnace room, laundry room, and pressing room. A 1941 sales brochure for the property gives a sense of the splendor contained within the walls (Figure 7):

The entrance hall runs through the width of the house, is two and a half stories high with a balcony around it on the second floor. To the left of the entrance is an impressive Gothic music room, also two stories high, with grey stone walls, vaulted ceiling and stained glass windows. The organ in this room is so constructed that through a remote control system it may be heard in any part of the house. Opening off the music room is a large living room and off this a small card room with walls and vaulted ceiling painted on canvas. On the right hand side of the entrance is a powder room and coat room, a wide stairway, and a large and spacious dining room with a small breakfast room, decorated with original Della Robbias, at one side. All of the rooms have large and imposing fireplaces and the ceilings are beyond descriptions; beamed, carved or decorated with the most delicate and exquisite paintings (Previews Incorporated 1941). 
Figure 6. Components of the Chrysler Estate in 1941 (Previews Incorporated).
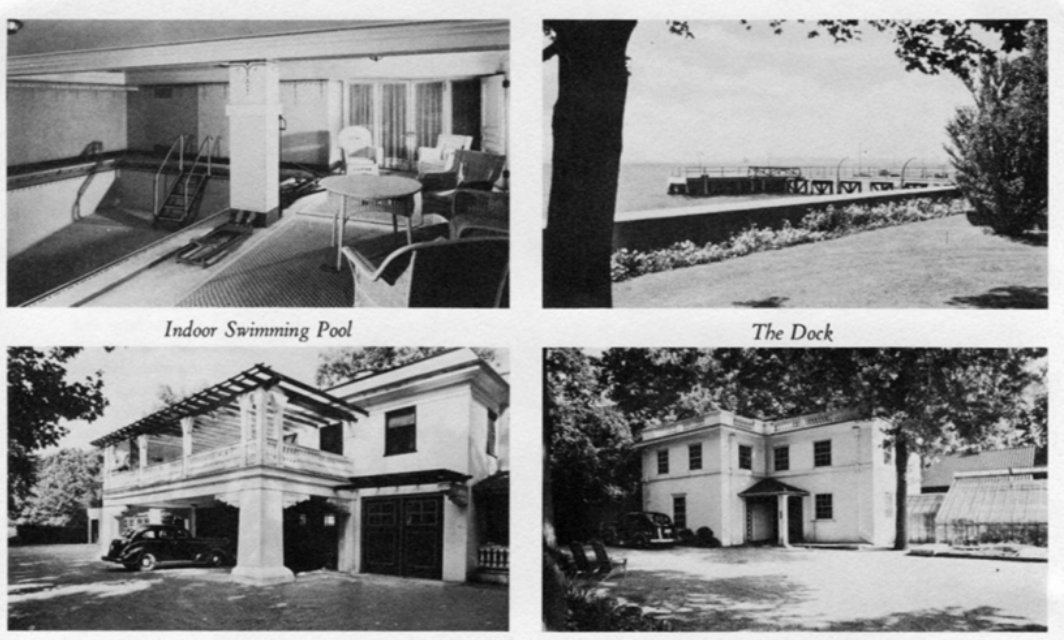

Garage

Superintendent's Cottage and Greenhouse

12 Acres $\quad$ Concrete and Timber Pier

Residence: $23 r, 106$

$(7 \mathrm{mbr}, 7 b ; 6 \mathrm{sbr}, 36$ )

Outdoor Swimming Pool

$(82.6 \times 30$ feet $)$

(ISO Feet Long)
Boat House

Superintenden's House

9 rooms, bath

Men's and Women's

Greenbouse

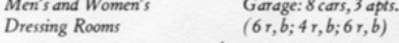

OFFERED FOR SALE

$$
\underset{\$ 175,000}{\mathrm{AT}}
$$

Previews Incorporated has made every

effort to provide accurate information,

but offering is subject to errors and

omissions as well as prior sale, change

or withdrawal without notice and ap-

proval of purchaser by owner.

WEEKES \& WEEKS

53 EAST MAIN STREET

OYSTER BAY, LONG ISLAND, N. Y.

Tel. Oyster Bay 737

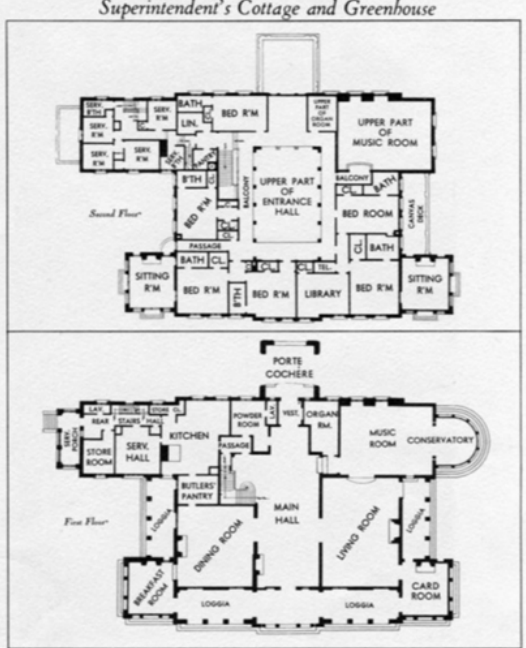


Figure 7. Interior of Chrysler mansion, 1941 (Previews Incorporated).
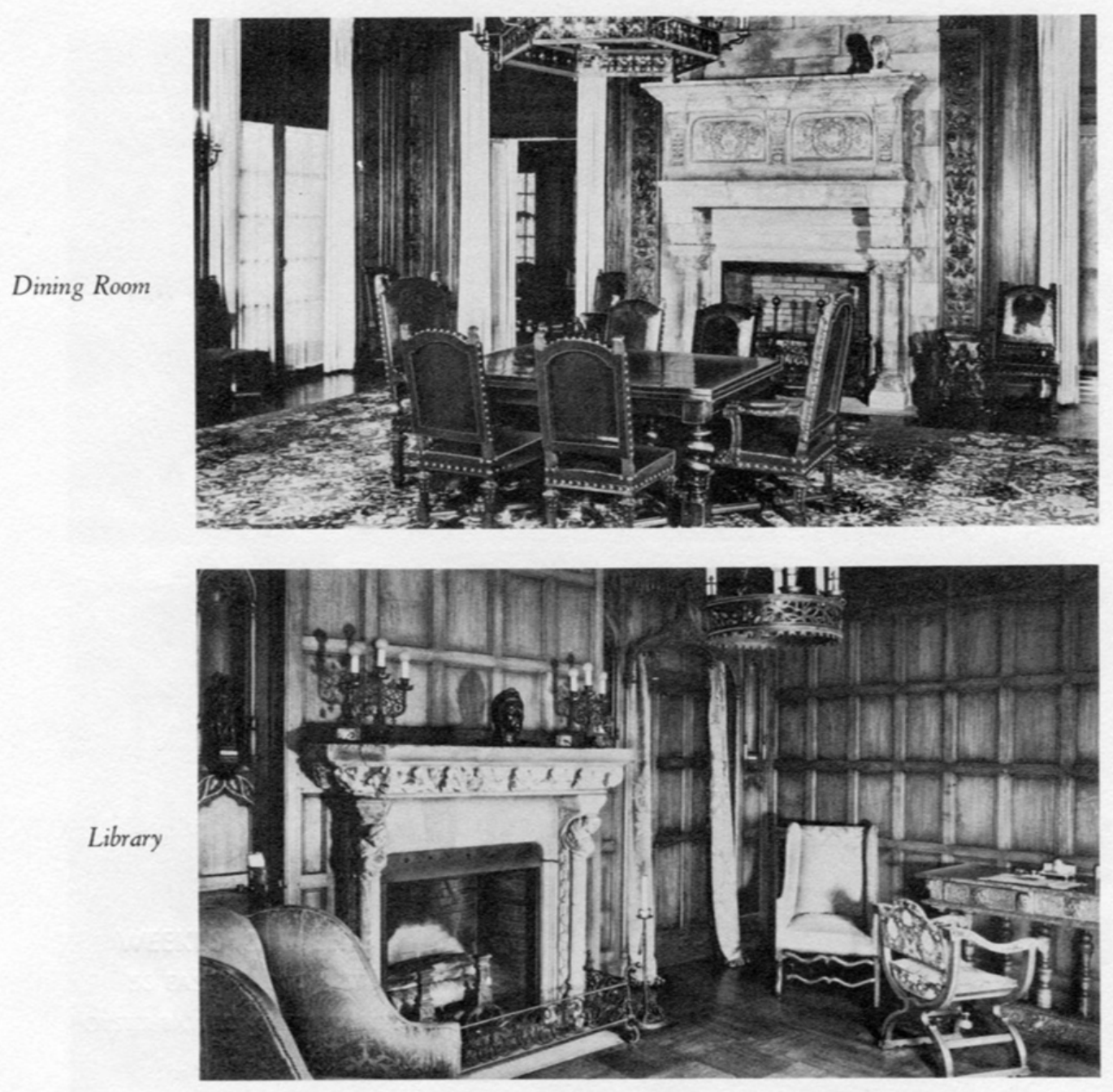

Toward the waterfront, there was a separate recreation building near the pier, a large salt water outdoor pool, a boat house, and 2 bath houses. The grounds contained several large areas of lawn with paved terraces (Wilson 1941:1-4; Previews Incorporated 1941). A formal sunken garden with lawn and ornamental plantings located at the main entry east of the house had steps at its eastern end leading up to a fountain or statuary (Figure 8). There was also a formal rose garden to the south of the house, with an exedra at the southern end (Figure 9). The Amphitrite Fountain currently located at the eastern end of the formal lawn to the east of the house has been in that position since before government acquisition. There is an extant photograph of Walter Chrysler in the 1930s that shows him beside a car and in front of the fountain, at the end of the eastern garden (Curcio 2001:609), was likely originally set at the end of the exedra, but moved when the academy construction began (Berger 2005: Appendix B). The 
fountain is cruciform in shape and contains a female statue representing the mythological goddess Amphitrite, "queen of the sea" and Poseidon's wife (Berger 2005: Appendix B) (Figure 10). The three acres across the road from the estate's Main Gate (also owned by the Chryslers) were being used for a greenhouse and vegetable garden (Wilson 1941:1).

Figure 8. Gardens and landscaped grounds, Chrysler mansion, 1941 (Previews Incorporated).
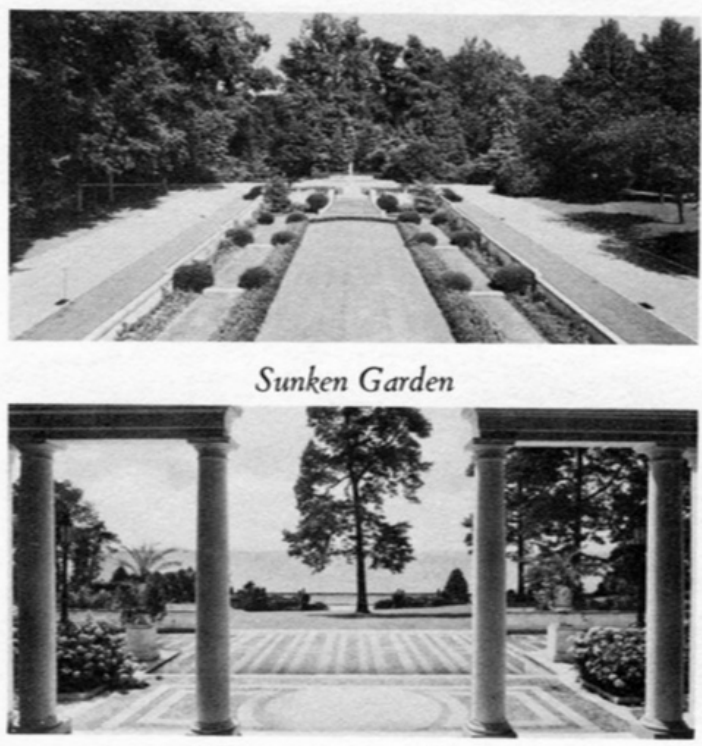

Sound View from Terrace

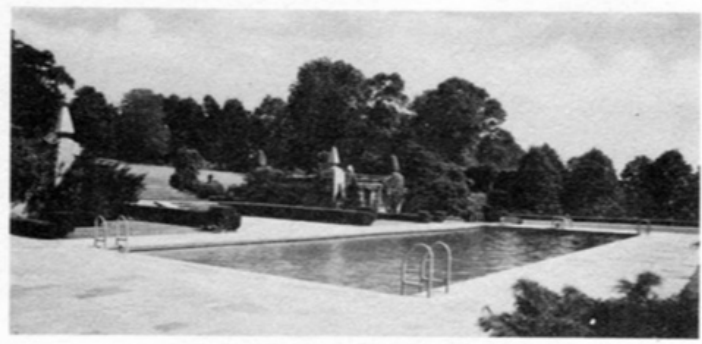

Swimming Pool

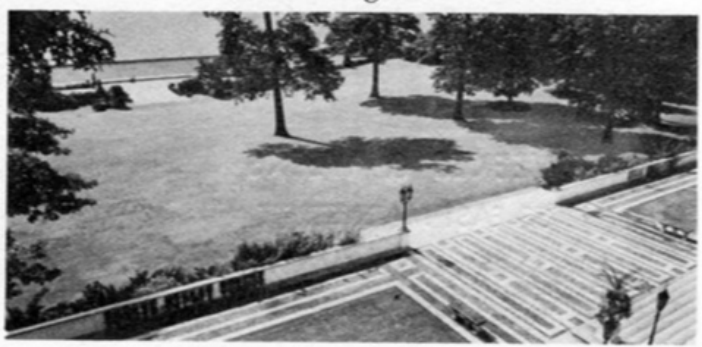

Terrace -

Figure 9. Rose garden south of Chrysler mansion, undated (American Merchant Marine Museum).

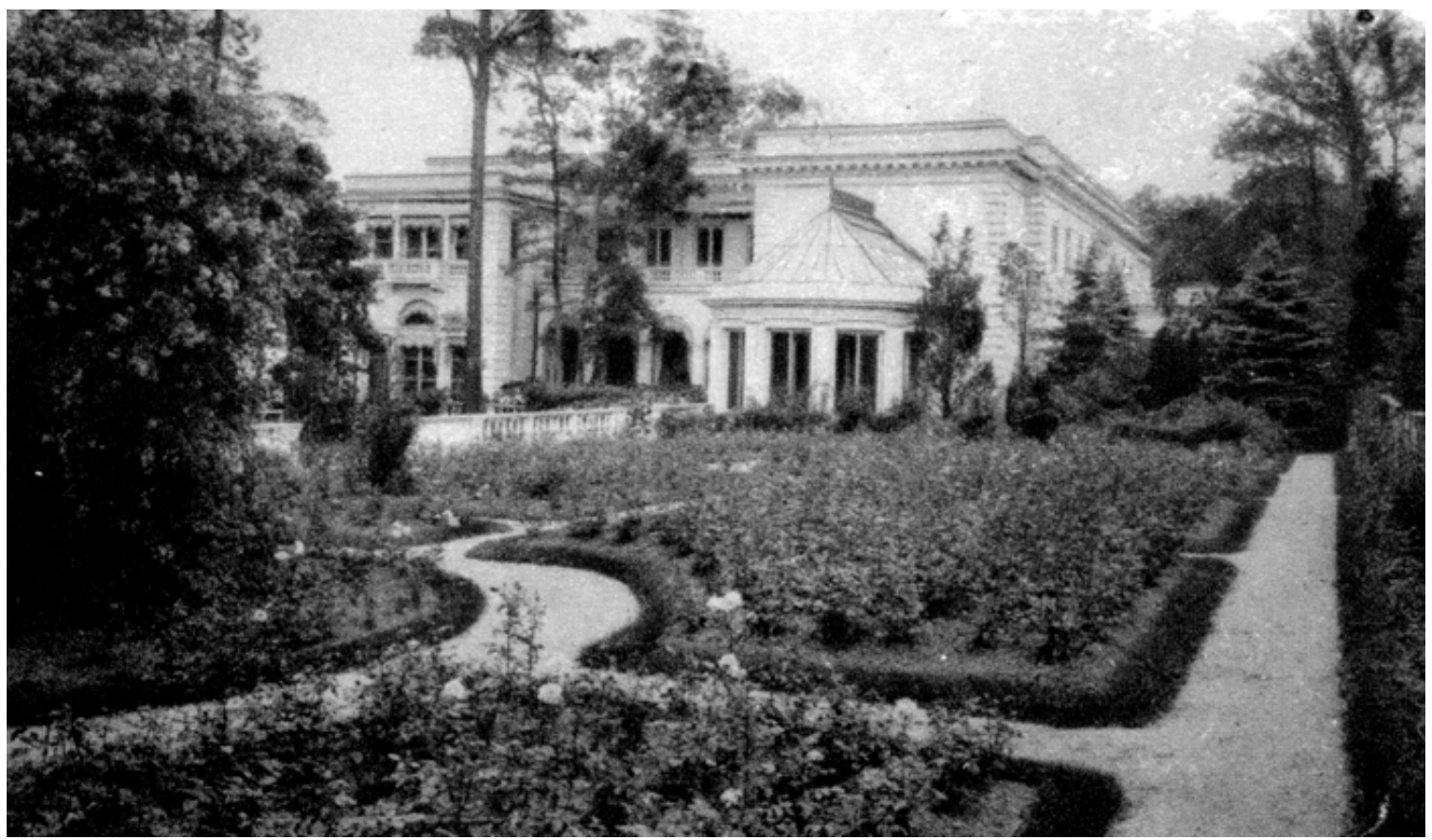


Figure 10. Amphitrite Fountain at the Chrysler estate, undated (Bland Library, USMMA).

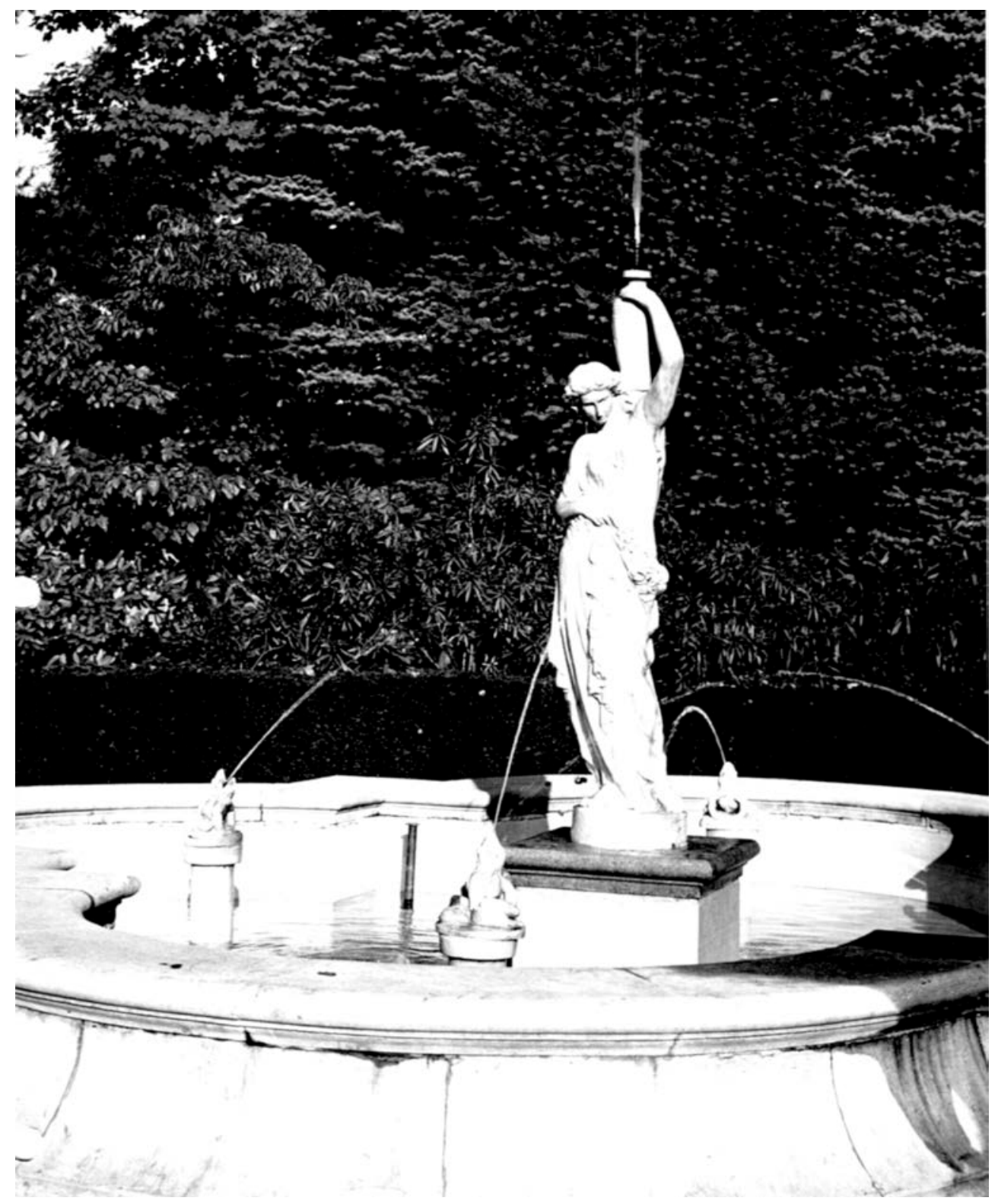

\subsubsection{Grenwolde Estates}

The Grenwolde development plot map was filed with Nassau County on 10 October 1913 (U.S. Coast Guard 1942). Grenwolde was part of a boom in Great Neck land sales for country estates during the 1910s. In 1915 alone, over \$1,500,000 in real estate sales occurred in Great Neck (New York Times 1916). The development was controlled by the Great Neck Shores Corporation, with Walter J. Vreeland, President (New York Times 1915a). Planning and construction was underway before that time, as a series of advertisements for the development had appeared in House and Garden 
magazine that Spring. The ads were geared towards the New York City resident that desired a country haven but could not afford a large estate. The romantic notion of English country houses was invoked in the ads, with phrases such as "the fascination that impels the tourist to linger amid the hedgerows and by-ways of the English countryside finds its counterpart at Grenwolde, Great Neck, Long Island" (House and Garden 1913a:82). The lots were described as "generous in size, unique in shape and outlook and lend themselves readily to individual treatment in landscaping and architecture" (House and Garden, 1913b:160). The revival styles of the homes reflected the "old world" charm the developers sought to present. Grenwolde was an exclusive community, with property restrictions and purchase conditions, as well as an owners association. Several of the Grenwolde homes were designed by Frank J. Forster under the firm name of Caretto \& Forster. Based in New York City, Forster became well known as a designer of domestic architecture, building estate houses on Long Island's North Shore, along the Hudson River, and in Fairfield County (Fisher 2012). He was an advocate for traditional French, Tudor, and Gothic architecture, often utilizing elements of these styles in his commissions (MacKay et. al. 1997:170). The Grenwolde property stretched south from the Chrysler estate to include four more estates, and then encompassed a circle to the east, and a line of properties north of the circle (Figure 11) which are described below. 
Figure 11. View of Chrysler estate (center front) and Grenwolde lots (toward upper right near circular road), 1932 (Bland Library, USMMA).

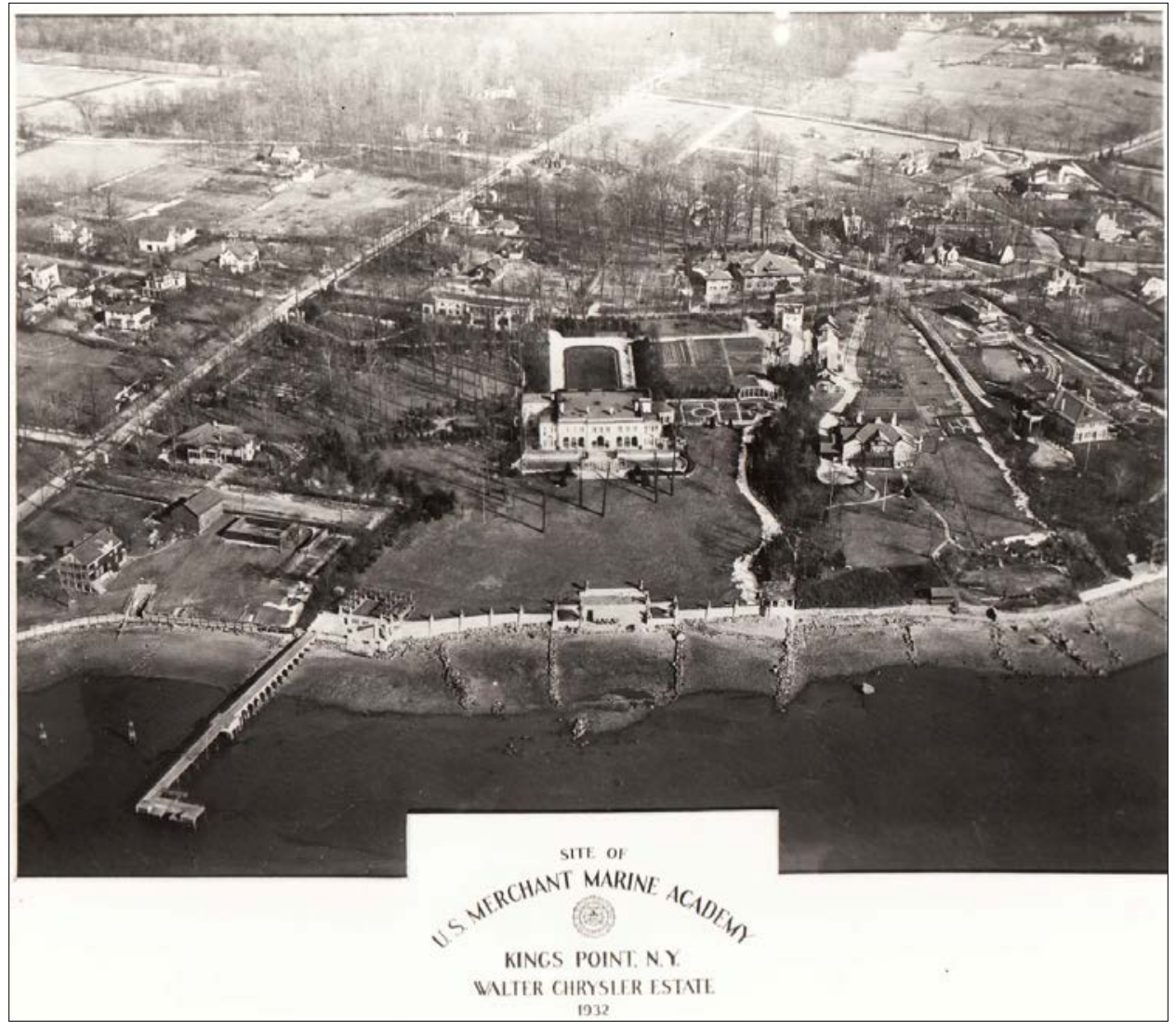

\subsubsection{W.S. Houston Estate (not extant) (not on sketch map)}

Located next to the Chrysler estate, this property (Grenwolde Plot 1 and part of Plot 2), fronted on the shore and was owned in the first years of the 1920 s by H.O. Lisser, or Lesser, or Losser (Great Neck Public Library ca.1922). It was owned by W. S. Houston in 1923, when a large Tudor Revival house was constructed (Spinzia 2006:385). The architect is not known. Houston was listed as a "ship owner" in the 1929 phone directory for Great Neck (Great Neck Directory 1929). The Houstons remained in the house until at least 1932, but by 1936 the property was owned by someone named Band or Dand (Hagstrom 1932; Pincus 1983: Appendix; Sanborn 1937). By the time of the land's acquisition by the government in 1942, the property was owned by the next door neighbor, Nicholas Schenck (listed as Schenck building \# 2 in government acquisition documents); by 22 May 1942, the house had been demolished for the expansion of USMMA, but the garage and greenhouses that abutted those of Walter Chrysler remained for a brief time (Tomb 1942a; USMMA 1942a; USMMA $1942 b)$. There was a small, square, formal garden located to the south of 
the house with four quadrants and a central feature, and a long driveway to the north side of the house (Figure 12).

Figure 12. Houston house (center) and garden (left), with Chrysler rose garden at lower right, undated; all were later demolished (MacKay et al. 1997).

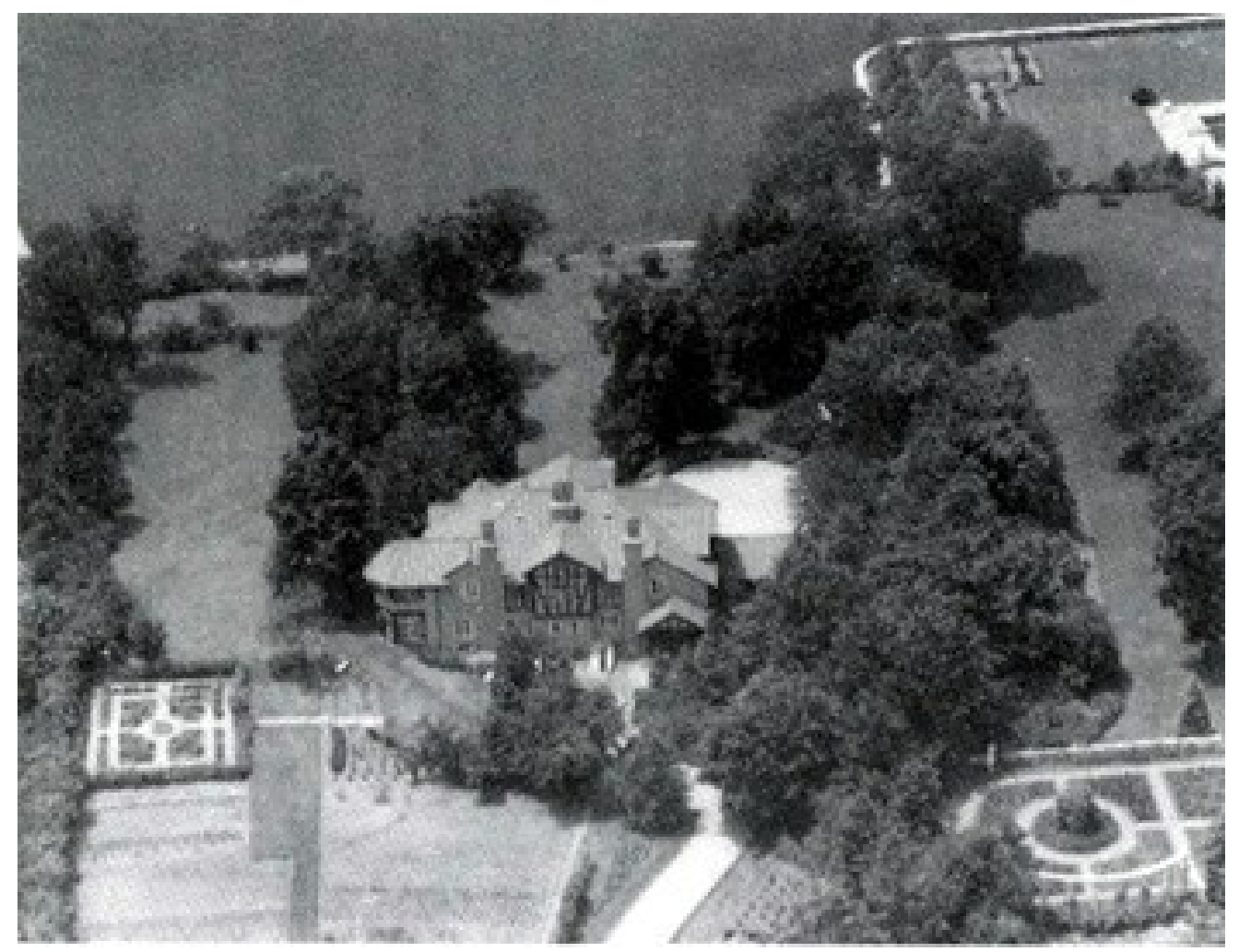

\subsubsection{Nicholas M. Schenck Estate (Land Hall) (\#7 on sketch map)}

This property (Grenwolde Plot 3 and part of Plot 2) was owned by Sidney H. March, and a house erected on the property ca. 1920 (MacKay 1997:522; LILRC 2013). The architect is unknown, but the house was known early as "Claralea." A few years later, it was owned by Max Horowitz (LILRC 2013). In 1925, the famous Vaudeville comedian Ed Wynn purchased the property for $\$ 250,000$, gaining a four-acre estate, a house with 24 rooms and nine baths, a five-car garage with two apartments, and greenhouses (New York Times 1925) (Figure 13). Mr. Wynn only owned the home for a few years, as by 1927, the property had passed to Ellsworth M. Statler, president of the Statler Hotels (New York Times 1927). He was the most successful hotelier of the era, pioneering establishments that were clean, comfortable, and moderately priced. Statler remodeled the house, but did not enjoy his home for long, as he died in 1928; his widow continued to live in the house until she sold it in 
1929 (New York Times 1929). The purchaser was Nicholas M. Schenck, president of Loew's Incorporated.

Figure 13. Schenck house (Land Hall), north façade, 1942 (National Archives and Records Administration [NARA] RG 178).

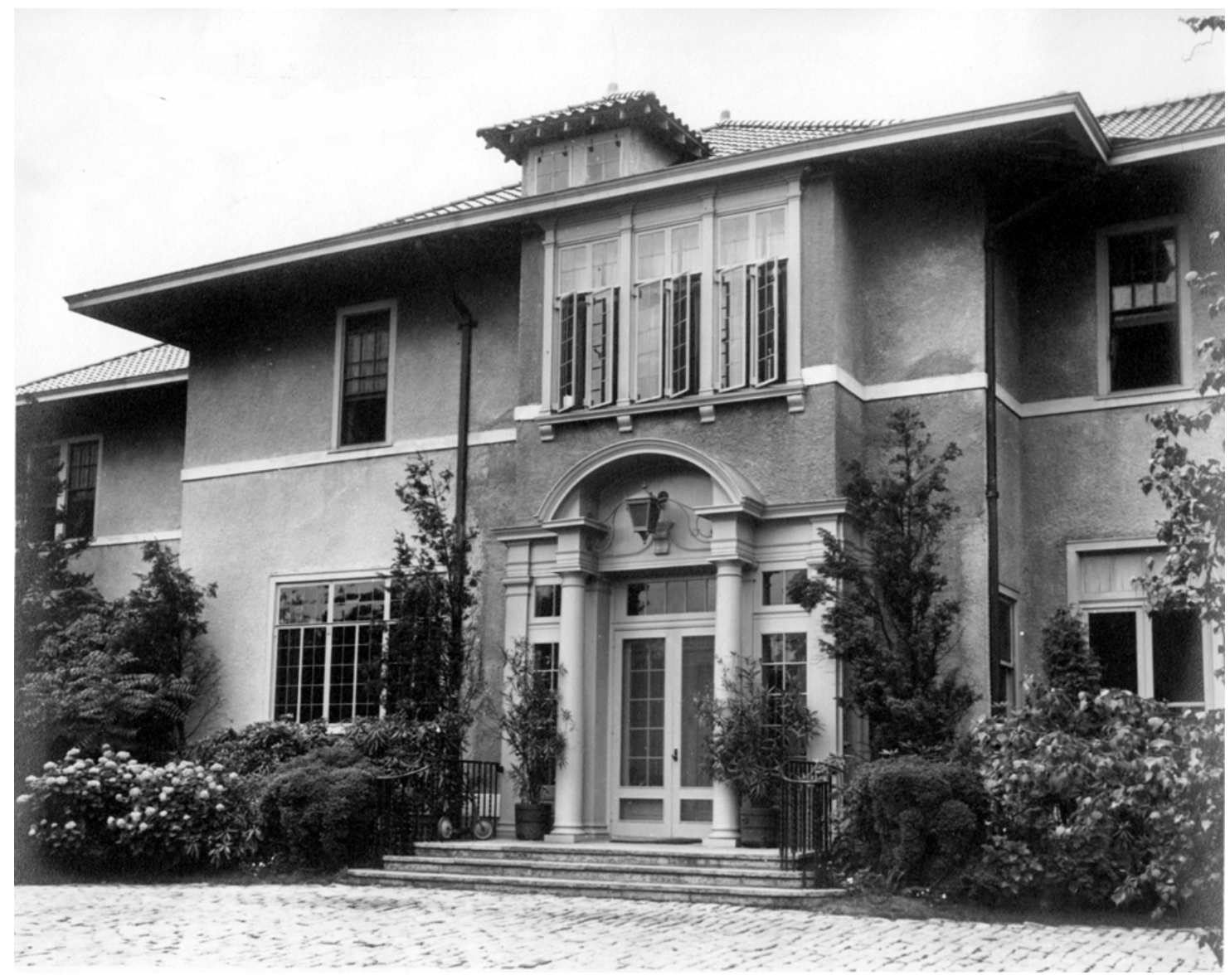

Schenck had started in the motion picture business by becoming Marcus Loew's right-hand man for managing his extensive chain of movie theaters and becoming president of the company in 1927, three years after the firm had put together Metro-Goldwyn-Meyer studios (Gomery1991:146). As one of the most powerful movie moguls (his brother Joseph ran $20^{\text {th }}$ Century Fox), Schenck ran Loew's as an integrated empire with a movie studio, an international film distribution network, and a profitable chain of theaters (Gomery 1991:146). As a result, Schenck was a very wealthy man, and he invested some of his wealth in his King's Point home. Among his improvements to the property was the construction of a separate building to serve as a private theater sometime after 1932, and in 1934 he had an 80-foot swimming pool installed against the seawall (Plattsburgh Daily Press 1934) (Figure 14). 
Figure 14. Schenck swimming pool (Prosser Boat House), 1942 (NARA RG 178).

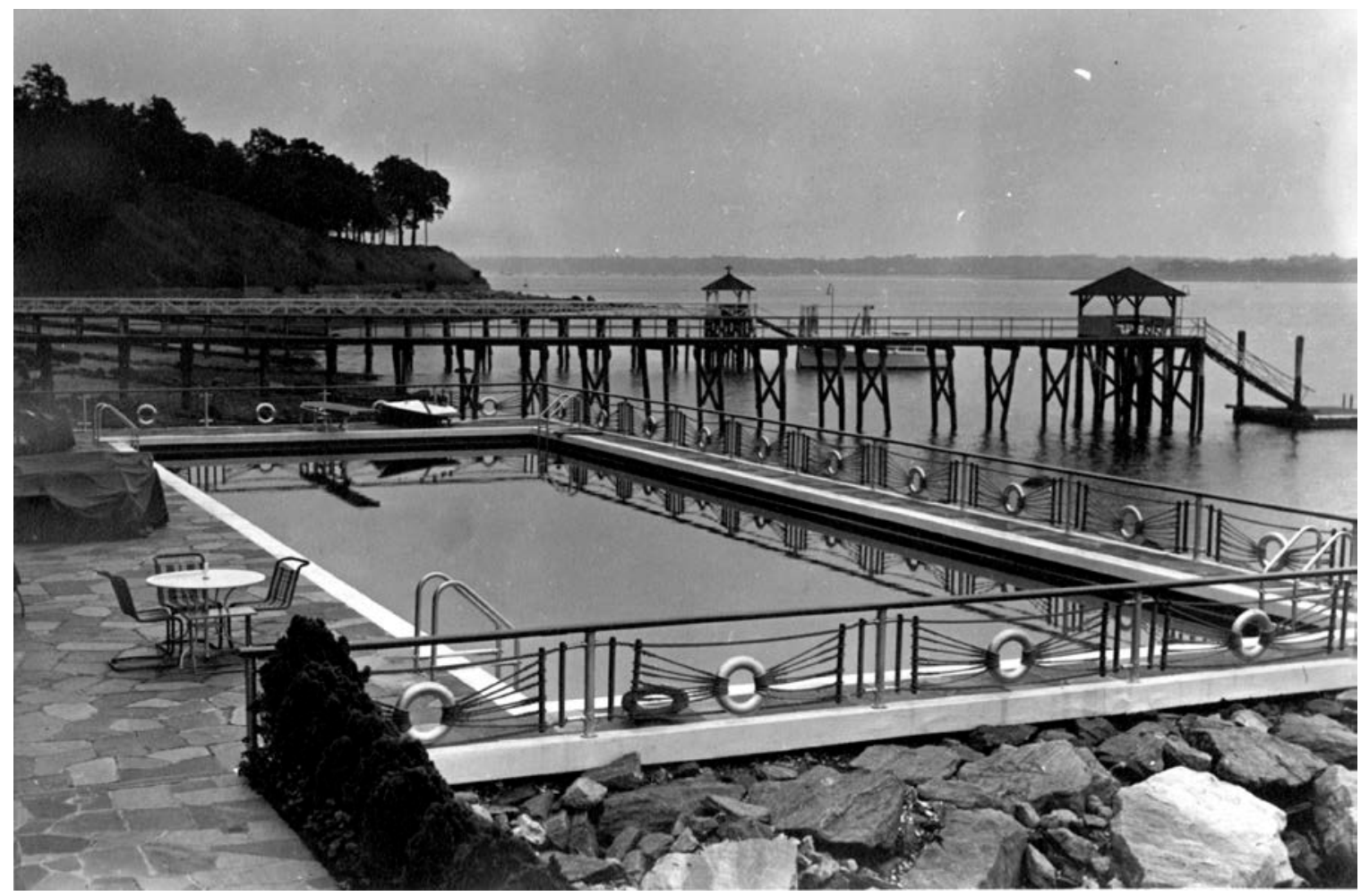

With the presence of many other entertainers in the Great Neck area and Schenck's powerful position in the movie business, the house was the scene of many illustrious parties. In a letter sent to an cadet journalist in 1946, Schenck included a list of guests to the estate, recalling dozens of nationally known figures including "Thomas Meighan, Mary Pickford and Douglas Fairbanks, Clark Gable, Spencer Tracy, Greer Garson, Lana Turner, Judy Garland, Ed Wynn, Mickey Rooney, David Warfield, Charlie Chaplin, Grace Moore, Irving Thalberg, Norma Shearer, and Irving Berlin” (Schenck 1946). At some point in the late 1930s or early 1940s, the Schencks had acquired the property between his estate and Walter Chrysler's, and both were sold to the government in 1942. In early 1942, there were six buildings located on the Schenck property-two houses (Schenck's and Houston's), theater, garage/quarters with connected greenhouse, a small cottage, and another garage/quarters with connected greenhouse. The latter two buildings were from the Houston estate (USMMA 1942a) (Figure 15). There was a small designed garden to the south of the house with a circular feature, and a large circular parking area on the north side just past the porte cochere (see Figure 11 aerial). The original Schenck garage was used as Quarters I until 2001 (Berger 2005:9). 
Figure 15. Map of Schenck estate, 1942 (NARA RG 178).

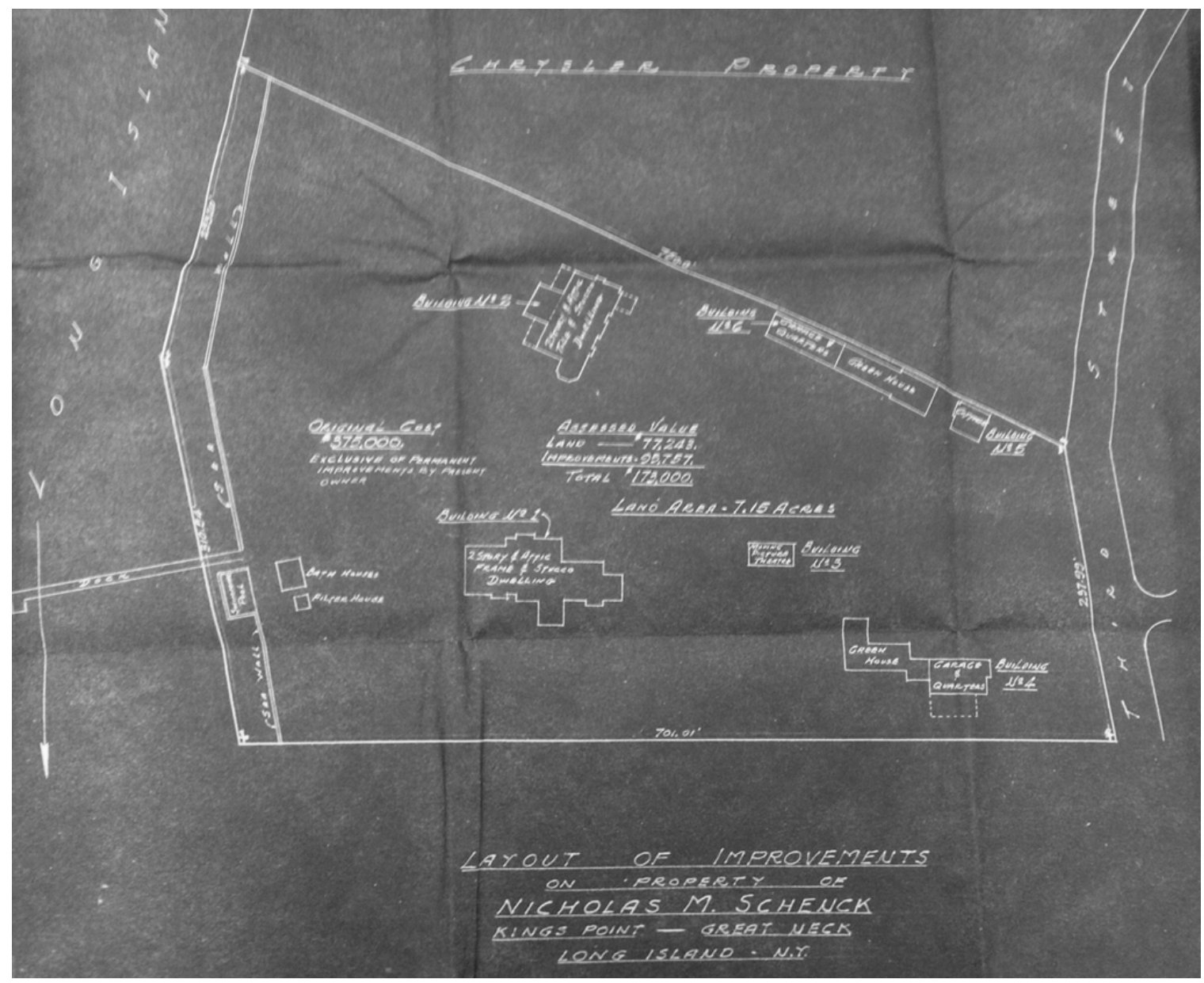

\subsubsection{Thomas Meighan (Melville Hall) (\#5 on sketch map)}

It is not known when the residence known today as Melville Hall was constructed. The name of the original owner is not known; by the early $1920 \mathrm{~s}$ the property was owned by Mr. and Mrs. Trabue Pittman (Pittman 1923). The Pittmans were from St. Louis, and summered on Long Island. On 26 November 1923, the property was sold to Thomas Meighan, including a house and garage (with boat), along with a mortgage for \$50,000 (Pittman 1923).

Born in 1879, Thomas Meighan was a very famous silent film star in the 1920s and 1930s. Originally from Pittsburgh, Pennsylvania, he worked on the stage before his film career began in 1916. His screen portrayals of heroic protagonists brought him great fame and great wealth. In 1925, he was reputed to be making $\$ 10,000$ a week, one of the highest salaries of the day for actors. His career largely did not survive the industry's move into sound pictures, but he worked off and on until 1934. He died at his 
home in Great Neck in 1936 (Los Angeles Times 1936). As the center of the film industry at this time was still New York, particularly for the business aspects, many studio heads, producers, actors, directors, writers, and composers lived in Manhattan and summered on Long Island. The Great Neck area attracted the largest number of this group, and a specialized society soon developed, including such luminaries such as Groucho Marx, Fannie Bryce, Charlie Chaplin, and literary authors such as Ring Lardner, and F. Scott Fitzgerald, author of The Great Gatsby (USMMA 2013). There were many parties with impromptu performances by stage and screen icons reported in the local papers, while the movie moguls made the rounds as well. The Meighans were socially active in this group and hosted their share of parties. Writer Ring Lardner wrote to F. Scott Fitzgerald recounting such an event, "On the Fourth of July, Ed Wynn gave a fireworks party at his new estate in the Grenwolde division....all the Great Neck professionals did their stuff, the former chorus girls danced...the party lasted through the next day and wound up next evening at Tom Meighan's" (Goldstein 2006:35). A satirical map drawn by John Held, Jr., a social cartographer for the New Yorker, depicts a 1927 snapshot of some of the famous names that Great Neck and the larger Gold Coast populace had as neighbors (Goldstein 2006:14-15; Held 1927) (Figure 16). 
Figure 16. Satirical map of Great Neck by John Held, Jr., 1927 (American Merchant Marine Museum). (Note: locations and scale are not entirely accurate.)

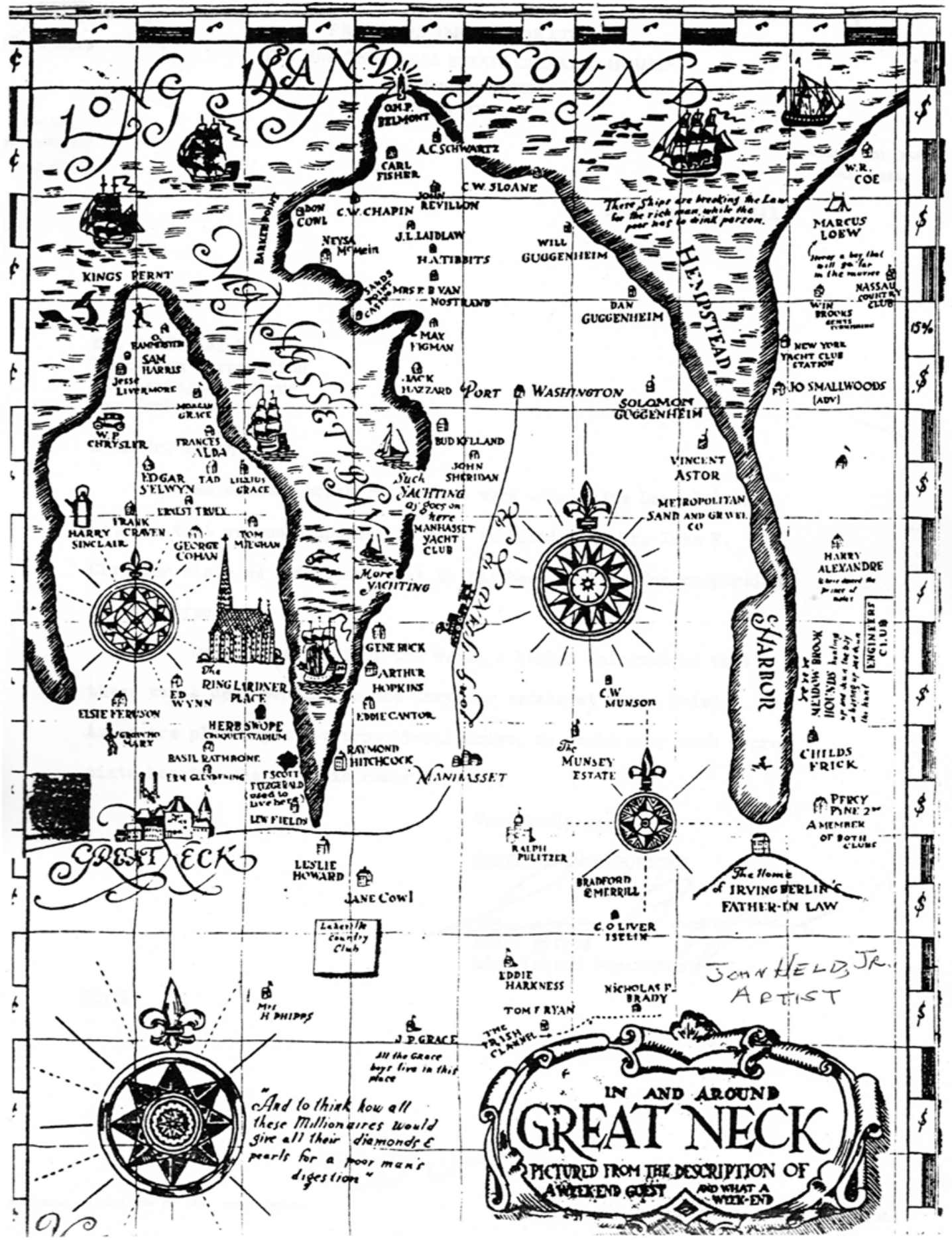


It is likely that the Pittman house was removed and a new house was built by Meighan, as it was reported by a representative for the owner in 1942 that the house "was originally built by Thomas Meighan" (McNulty 1942g) (Figure 17). The house was featured in the December 1931 issue of New Movie Magazine (Browning 1931:44-45) (Figure 18). In addition to the main house, there was a garage, servant's quarters, and a greenhouse (Edwards 1942). (The garage/quarters is now Quarters $K$, \#6 on the sketch map.) Sometime after Meighan's death on 8 July 1936, the home was sold (Miller 2013). At the time of the government's acquisition in 1942, the property was owned by Ernest T. Laubscher or Julius Mueller-Mueller is the name used in acquisition documents, but the property maps use Laubscher (U.S. Coast Guard 1942; Edwards 1942). The lot was wooded and there was a significant slope down to the waterfront. A small formal garden was located south of the main house, and there was also an English-style garden. The entrance and front of the house had foundation plantings (Figure 18).

Figure 17. Thomas Meighan's house (Melville Hall) as depicted in New Movie Magazine in 1931 (Browning).

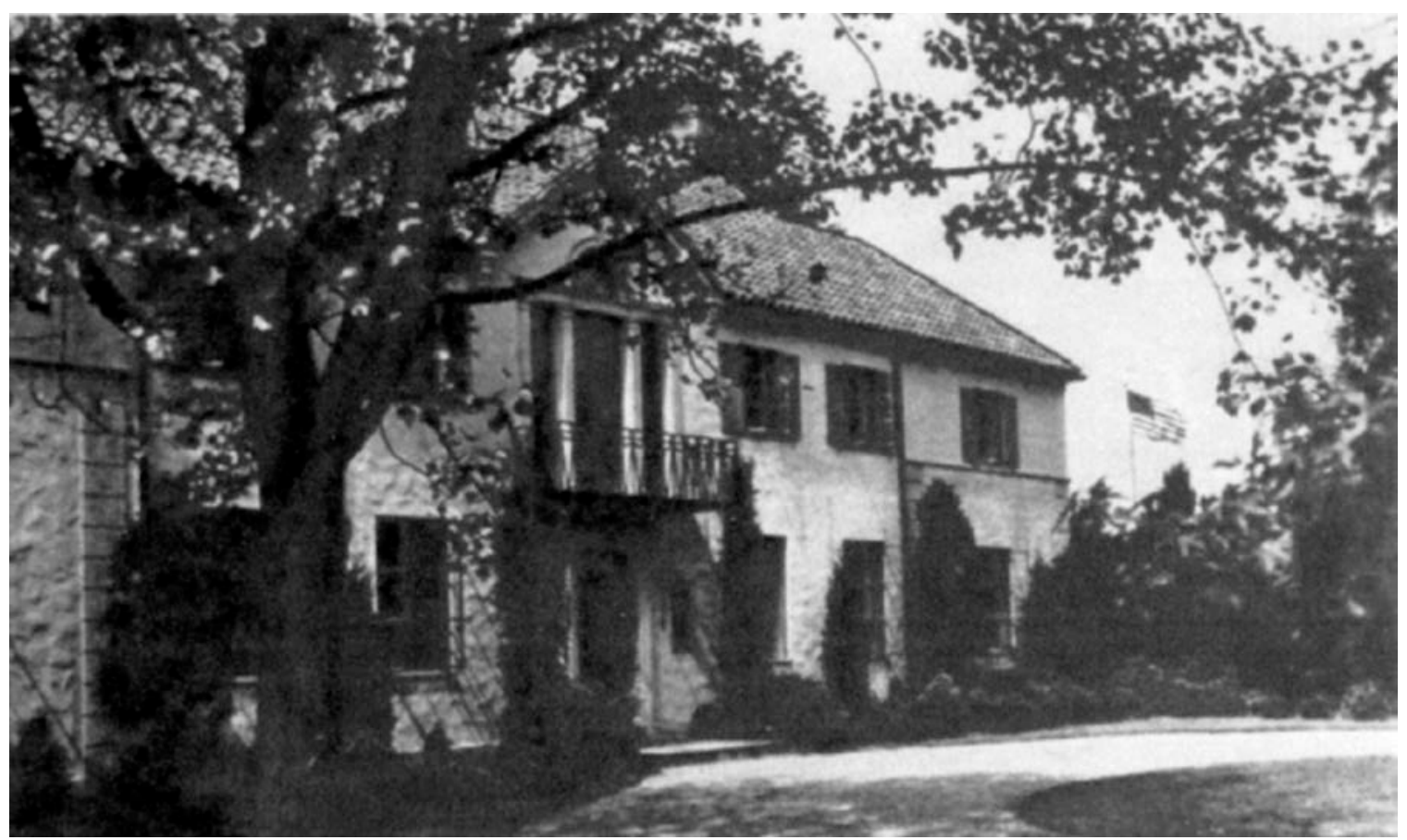


Figure 18. New Movie Magazine article on Thomas Meighan's estate (Melville Hall), 1931 (Browning).

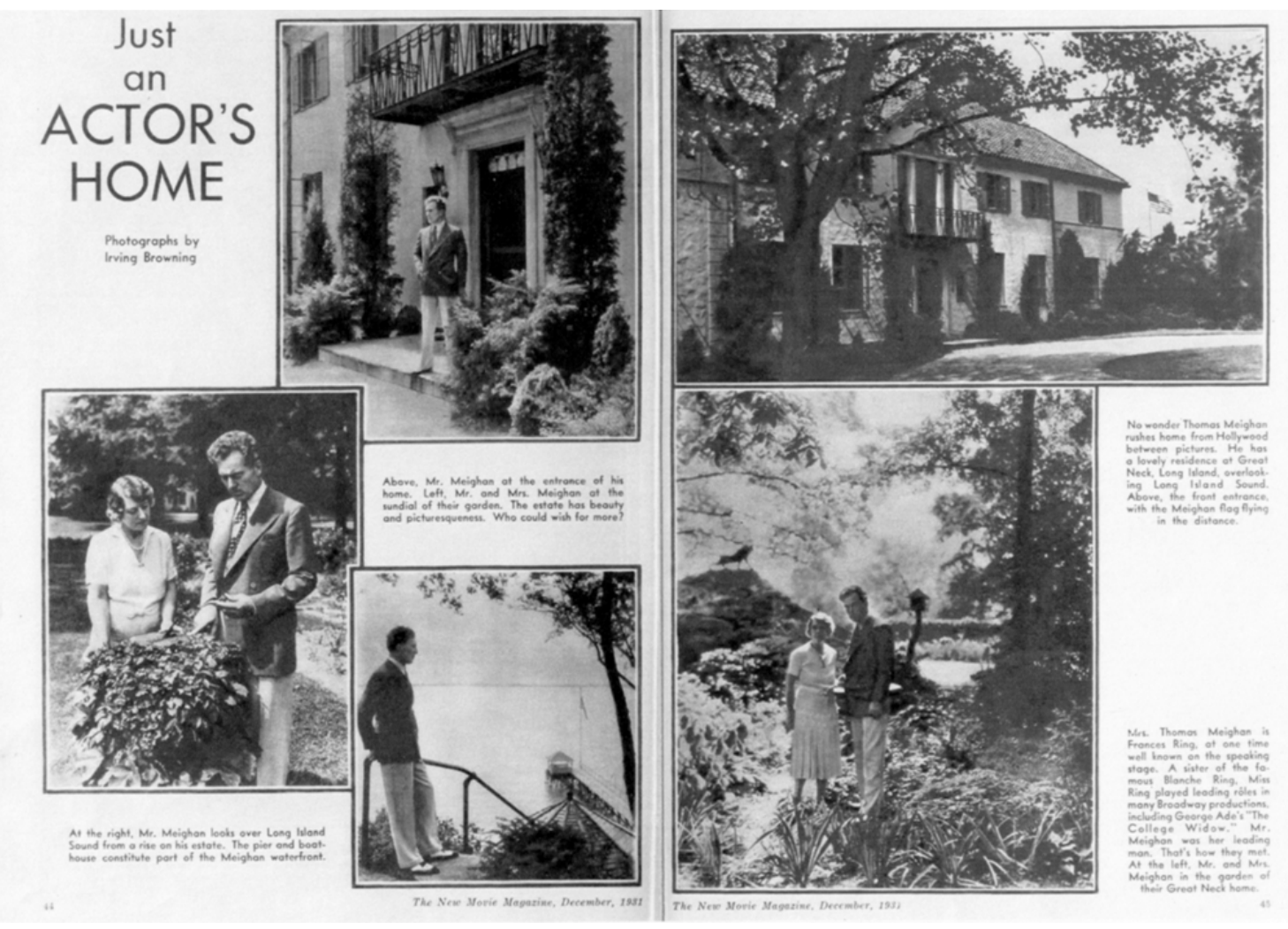

\subsubsection{Charles Neiley (Quarters A) (\#3 on sketch map)}

The estate, consisting of Grenwolde plots 5, 5A, and 6, was originally owned and developed by Mrs. C.H. Smithers. The house was featured in the June 1915 Architecture magazine, and the architect was Frank J. Forster of Caretto \& Forster, New York (Architecture 1915) (Figure 19). The estate was also featured in a February 1919 issue of Arts and Decoration (1919: 213). The property was owned by Joseph Bryan in the 1920s, a successful financier (Renick 2001). Mary C. Bryan was the owner by 1926 (Houston et.al. 1926). By late 1932 or 1933, the property was purchased by Charles F. Neiley (Bland Library 1932). Neiley was an executive of the American Tobacco Company during the 1920 s and 1930 s. The property contained the main house, garage with servant's quarters (now Quarters J, \#4 on sketch map) (Figure 20), and a greenhouse attached to the garage sometime after 1919 (Edwards 1942). The garage was greatly expanded sometime between 1919 and 1943 (Figure 21). A circular, paved driveway with center plantings was constructed for the house. There was a large formal garden south of the house (Figure 21). The property was acquired by the government in 1943 from Charles Neiley. 
Figure 19. Smithers' House (Neiley/Quarters A) in 1915 (Architecture).

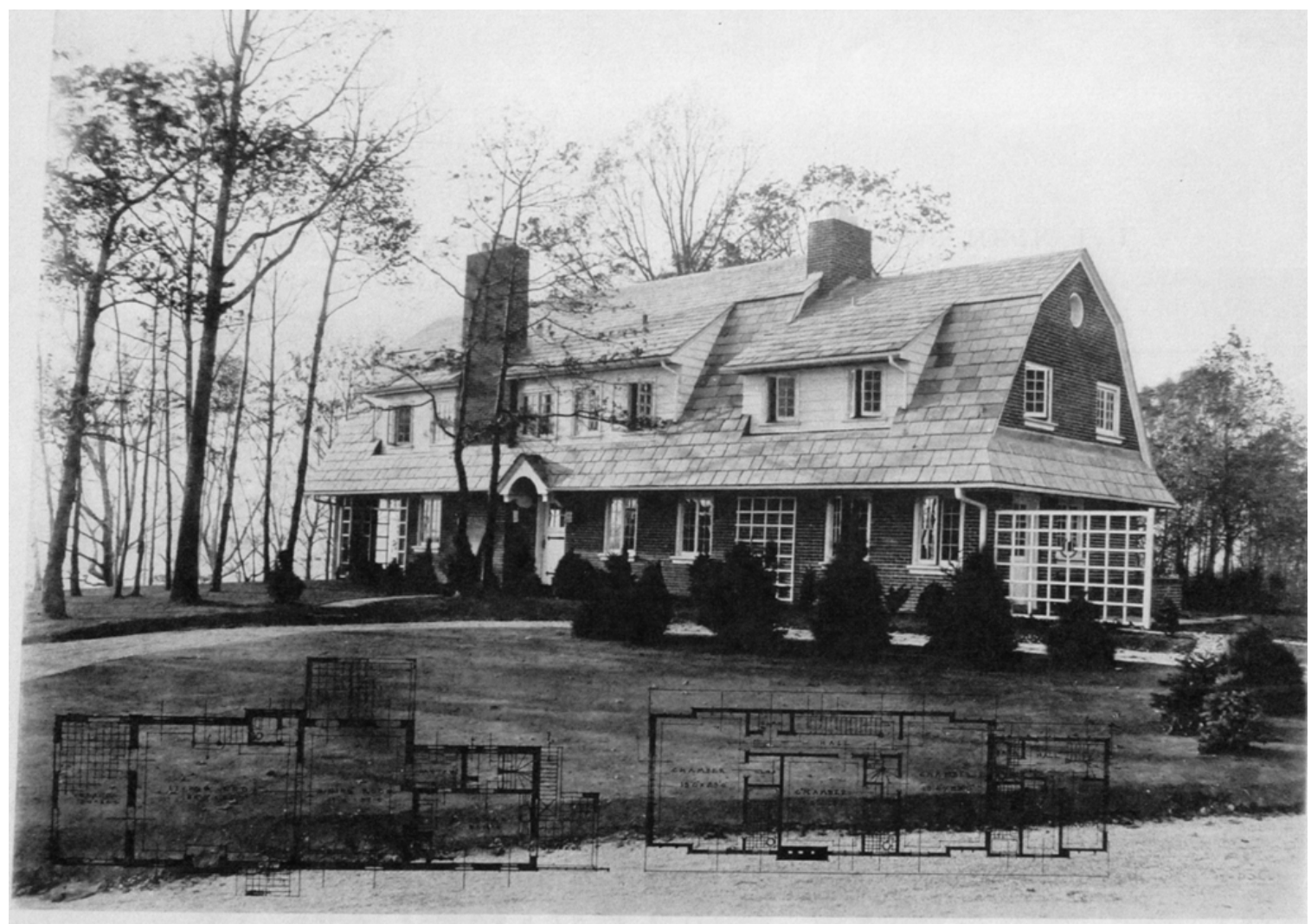

Figure 20. Smithers' garage (Neiley Garage/Quarters J) in Dutch Colonial Style, 1919 (Arts and Decoration).

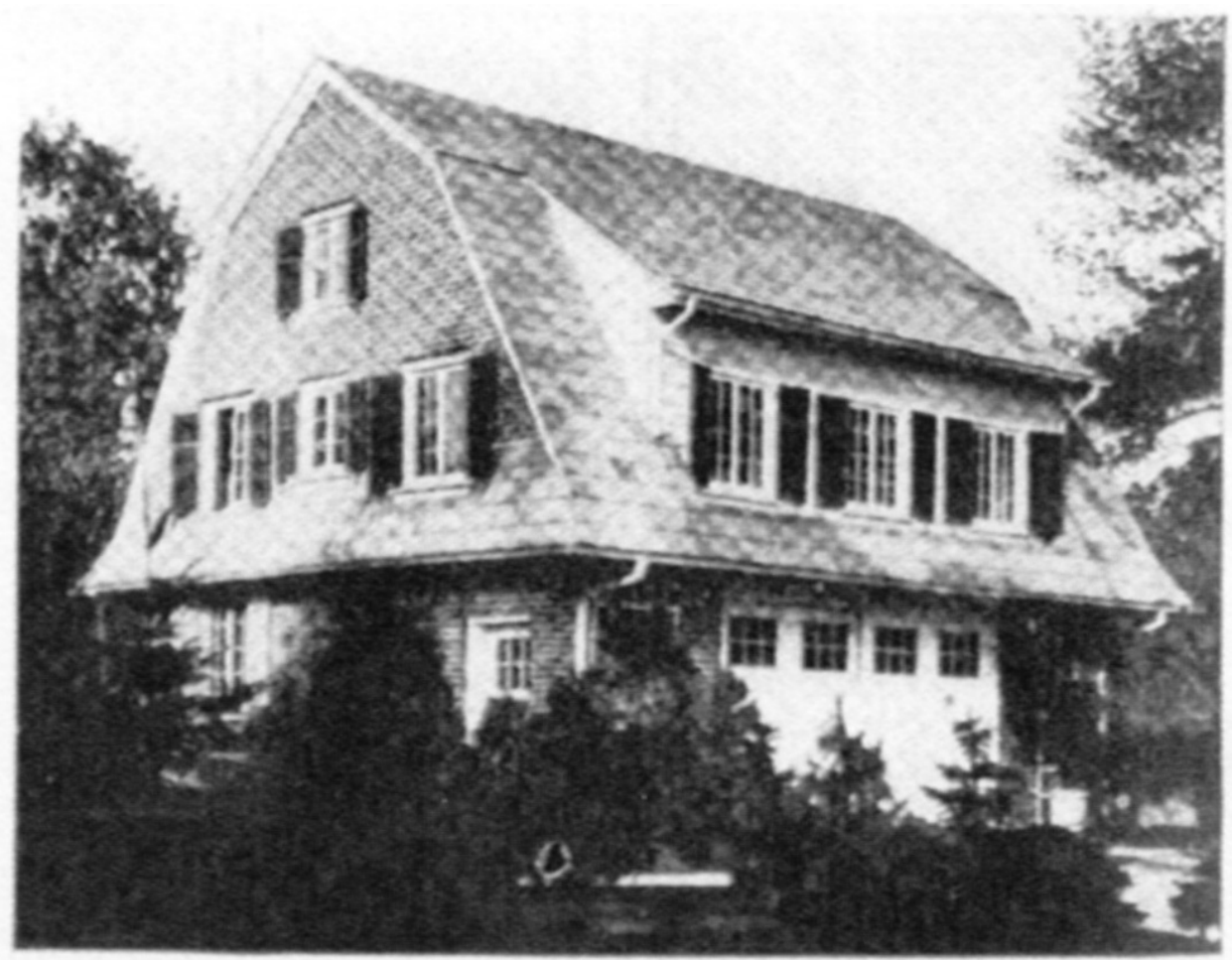


Figure 21. 1943 aerial showing the new Patten Hospital with the Neiley garden in the lower center, the expanded Neiley garage (Quarters $\mathrm{J}$ ) in the lower right, and the Meighan garage (Quarters $K$ ) in the upper right (Bland Library, USMMA).

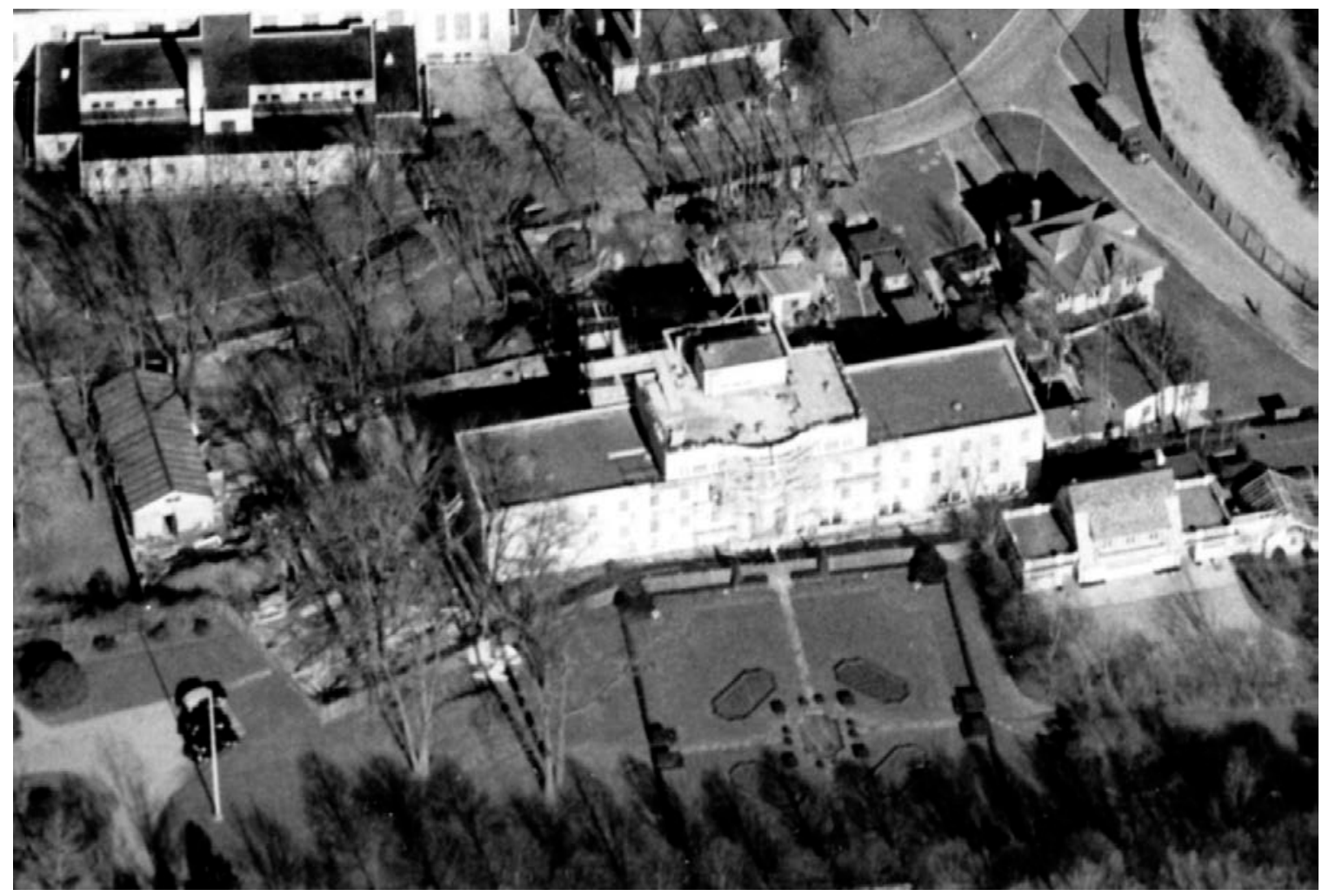

\subsubsection{Dan A. Japhet (Quarters D) (\#2 on sketch map)}

The property farthest to the south to be acquired by USMMA belonged initially to the Grenwolde developers (known as the "casino plot") who first utilized it as an access point to the beach for Grenwolde homeowners. By 1912, a building was constructed on the plot to serve as a "casino," a term used at that time for recreational buildings associated with the waterfront (Figure 22). The Grenwolde Casino had bathing facilities and a dancing hall; a seawall had been built on the property, and a pier for yachts was planned (New York Times 1915a). By 1926, the building had ceased its function as a casino and had been purchased by Dan A. Japhet for use as a residence (Houston et. al. 1926). The casino/house was constructed on a sloping lot with lower-story access directly to the beach. The government acquired the property from Mr. Japhet in 1943. 
Figure 22. The Grenwolde Casino (Quarters D) in 1912, later to become the Japhet property (The Sun).

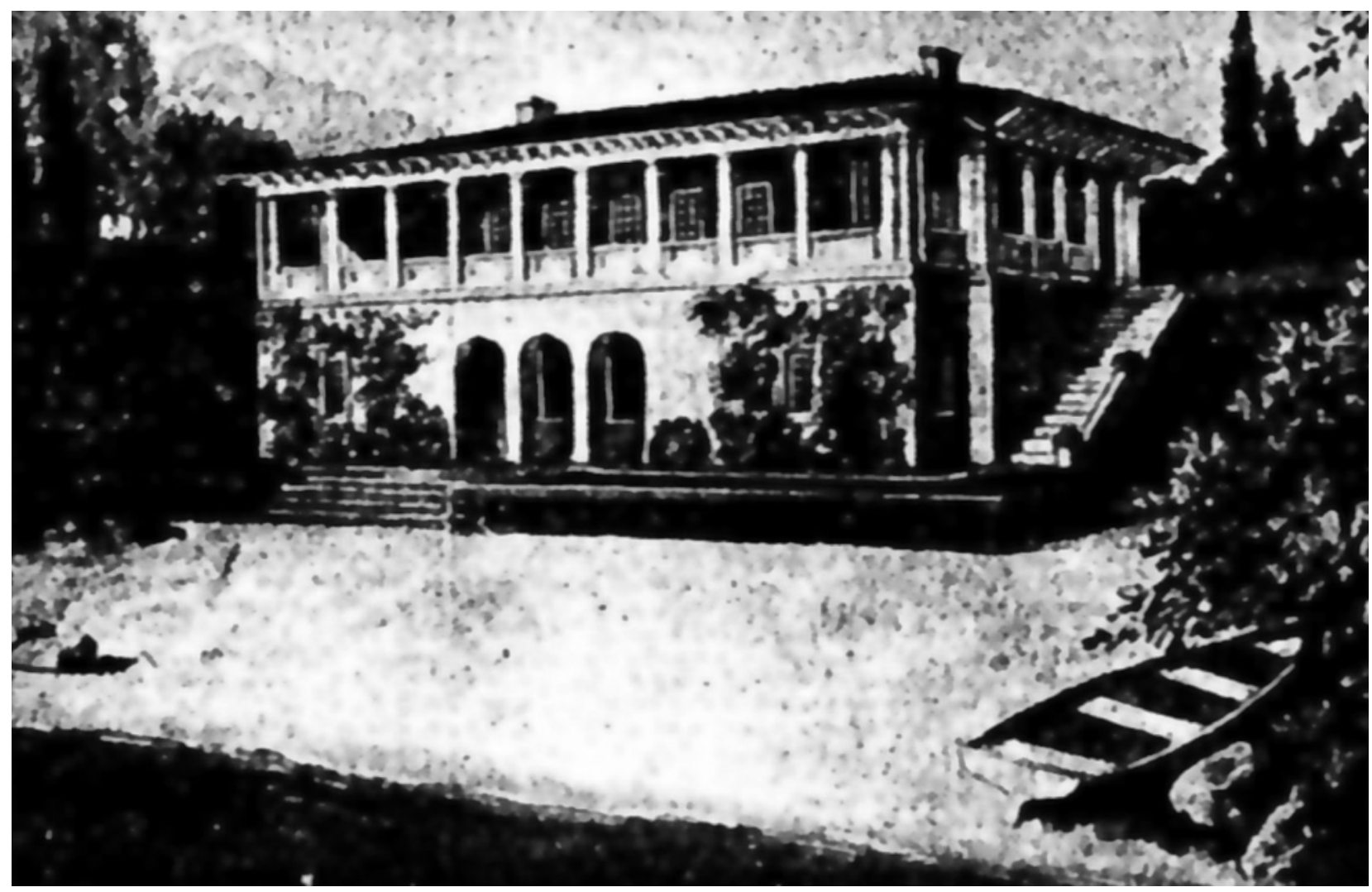

\subsubsection{James C. Marchant (not extant) (not on sketch map)}

The James Marchant property was located southeast of the Chrysler property on approximately 3 acres (Grenwolde lots 18 and 19). Henri Bendel first acquired the property in 1919 (Houston et.al. 1926). It is likely the house was constructed around the same time, and that it was constructed for Mr. Bendel (Wilson 1942). A map compiled between 1930 and 1932 also shows Bendel as the property owner (Pincus 1983: Appendix). The property contained a large, stuccoed concrete house with design similarities to the interior of the Chrysler house (Figure 23). A covered passageway led to a large garage with caretaker's house to the north of the main house (Wilson 1942; U.S. Coast Guard 1942). It is not known when the property was sold, but it was likely in 1936 or 1937 after Bendel's death. When acquired by the government in 1942, the estate was owned by James C. Marchant (Wilson 1942). The property was utilized for a few years after acquisition, but the buildings were gone by the late 1940s. The property was open on the north, with the remainder covered by lawns and shade trees, and had a large driveway to the main house. 
Figure 23. Panoramic View of the Marchant house and garage (both demolished), 1942 (NARA RG 178).

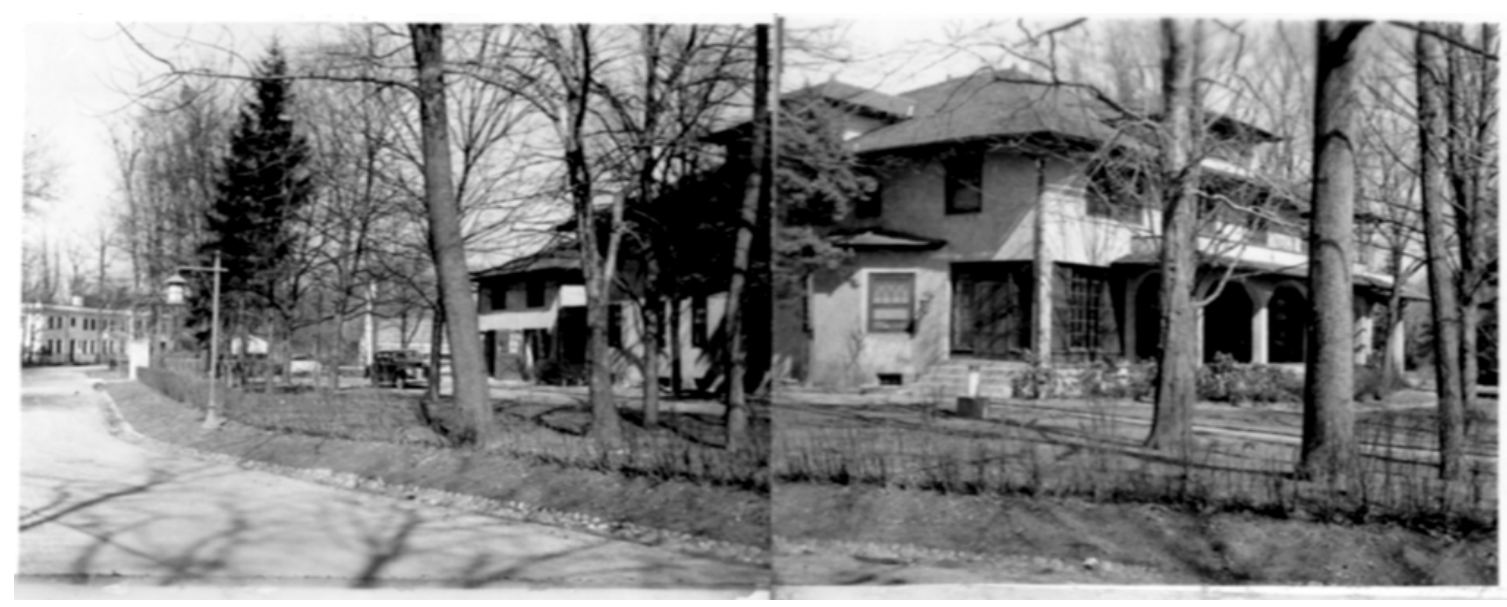

\subsubsection{Beth S. Colen (Quarters B) (\#8 on sketch map)}

Little is known about this Grenwolde property. Beth S. Colen is listed as the owner on a July 1942 map prepared for the government acquisition that year, with the properties directly adjacent to the west and to the north owned by Bernard D. Colen (U.S. Coast Guard 1942). The house is a 1.5story Dutch Colonial. The house was likely designed by Caretto and Forster as it is similar to the Neiley house (Quarters A) and another Dutch Colonial house in the Grenwolde development attributed to Frank J. Forster. There was a garage in addition to the main house. For approximately the first year of Academy operation, this house was used as the Superintendent's Quarters.

\subsubsection{Walter J. Vreeland/Underwriters Trust Company (Quarters C) (\#9 on sketch map)}

This property was owned in 1914 by Walter J. Vreeland, who was likely the developer of Grenwolde, and the house was designed by Caretto \& Forster (Architectural Record 1914). As Mr. Vreeland had a home at the intersection of King's Point Road and Steamboat Road, it is probable that this was a model house for the development and not his personal house (Great Neck Public Library ca.1922; Pincus 1983: Appendix). A 1913 advertisement for the Grenwolde development uses illustrations of similar houses, and the thatched roof fits in with the overall marketing scheme for the development as similar to rural England (House and Garden 1913a). The property was featured in the November 1914 issue of Architectural Record (Figure 24). By the late 1930s, the property was owned by Judith Friedman, but at the time of acquisition in 1942, the owner was the 
Underwriters Trust Company, and the property contained a main house and a garage (Pincus 1983: Appendix; U.S. Coast Guard 1942).

Figure 24. Vreeland (Friedman) house (Quarters C) in 1914 (Architectural Record).

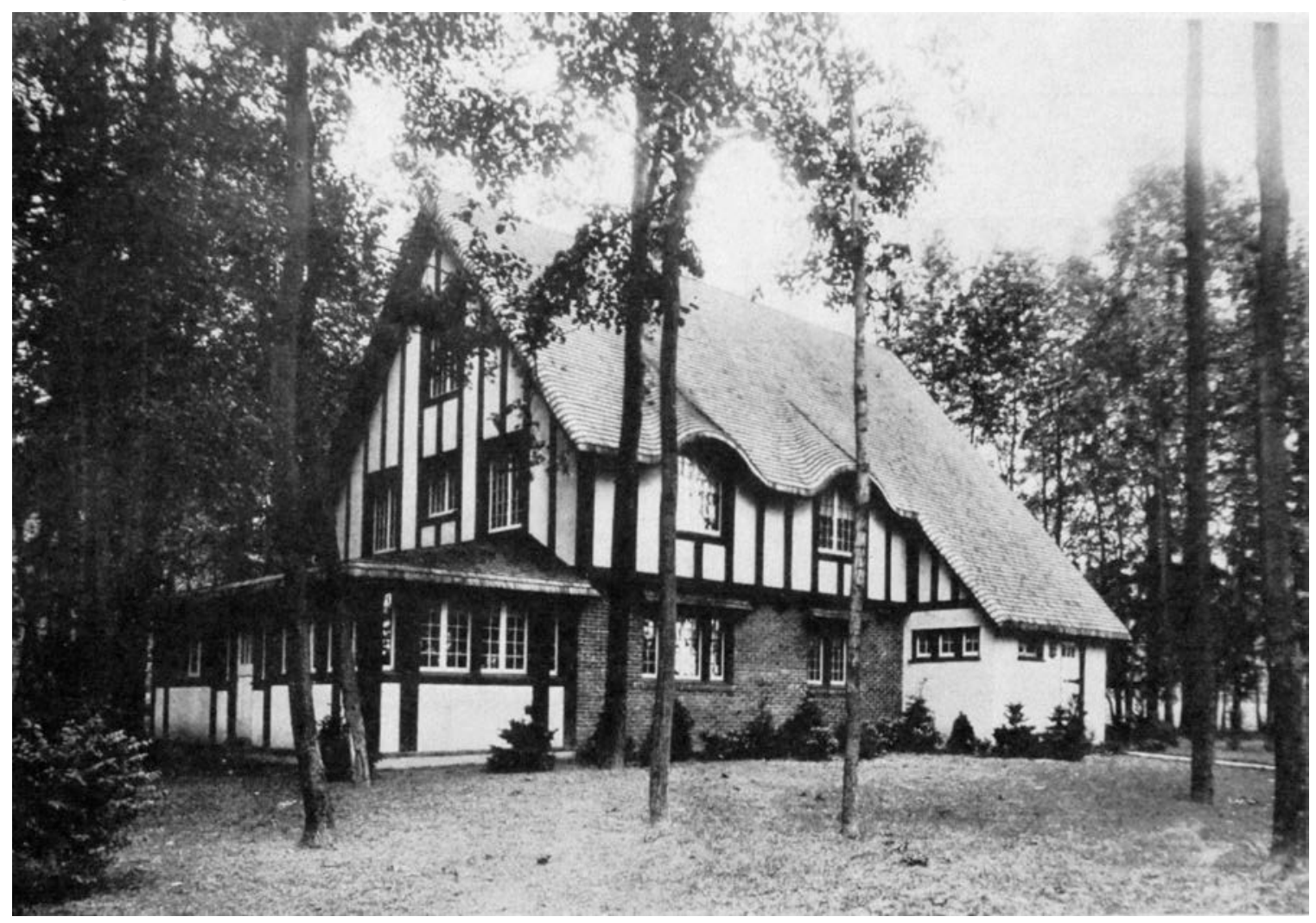

\subsection{Merchant Marine Academy}

\subsubsection{Acquisition of an academy site5}

By late November 1941, the Chrysler Estate was becoming the choice of the United States Maritime Commission and the Cadet School for the new Merchant Marine Academy. A 29 November 1941 Commission report provides the major reasons for selection of the Chrysler property: the Chrysler heirs were willing to consider government acquisition; existing facilities could be utilized without delay for approximately 100 cadets; sufficient space was available for additional construction and cadet drill; it was a desirable location protected from heavy winds; and there was an existing wooden and concrete pier (Nerney 1941:1-2).

5 This section researched and written by ERDC-CERL authors. 
With the sudden U.S. involvement in World War II on 7 December 1941, the United States Maritime Commission was placed on a war footing, and quick expansion of facilities for officer and cadet training was essential. Telfair Knight, Director of Training for the Commission, reported on the expanded program on 19 December 1941, particularly the need for training officers and securing the Chrysler Estate. Knight stated that "since 1,200 new ships to be placed into service in those two years [1942 and 1943] require 10,000 officers, and since it is daily becoming more apparent that we cannot rely on securing many experienced officers who now have shore jobs, it is apparent that this expansion is absolutely necessary" (Knight 1941).

The King's Point estate was held by Walter's wife, Della V. Chrysler, then by their four children after her death in 1938 . The heirs put the property on the market in 1941, at an asking price of $\$ 175,000$ (Cruikshank and Kline 2008:78). On 15 January 1942, Della Chrysler's Executors (Byron C. Foy and Dick R. McLain) and her heirs "granted to the United States of America, represented by the United States Maritime Commission, the exclusive option to purchase prior to July 15,1942 , the estate of the late Della V. Chrysler located in the Village of Kings Point, Town of North Hempstead, Nassau County, New York. The agreement provides for a purchase price of \$100,000" (Farbach 1942). On 4 March 1942, President Franklin D. Roosevelt signed Public Law 472, $77^{\text {th }}$ Congress, a Joint Resolution authorizing the United States Maritime Commission to acquire the Chrysler Estate on behalf of the United States (Farbach 1942). The government formally elected to exercise the purchase option on 19 March 1942. The purchase option included the property itself (all buildings and improvements) as well as the implements and tools used for the property's upkeep (Land 1942).

The 15 January 1942 option to purchase agreement granted the United States Maritime Commission the right to begin using the property upon execution of the agreement, which occurred the following day. This occupancy was at no cost if the option to purchase was exercised; if not, the government agreed to pay the sellers $\$ 25,000$ in rent for the 15 January15 July period (Farbach 1942). Included with the immediate possession of the Chrysler Estate was permission to "make alterations, attach fixtures, and erect buildings and other structures" on the property, with the stipulations that the government's changes would remain government property 
and in the event the government did not acquire the estate, the additions would be removed at government expense (Farbach 1942:3).

News of the proposed acquisition broke before the formal offer was even in place. On 11 January 1942, the New York papers carried articles proclaiming the Chrysler mansion to be the home of the new maritime training academy. The articles discussed the potential new use of the property, the erection of temporary buildings, details of the property itself, and the imminent completion of negotiations (New York Times 1942a and 1942b; New York Herald Tribune 1942).

The Chrysler Estate was formally acquired through condemnation proceedings with a Declaration of Taking to pass the property's title to the government. The declaration was filed in New York on Monday, 29 June 1942. At the same time, the estate's executors received a government check for $\$ 100,000$. In a letter to Mr. McLain on 27 June, Telfair Knight, Assistant to the Commandant of the Coast Guard, informed him that "the Chrysler heirs may rest assured that the sale of this property for the site of the United States Merchant Marine Academy represents a real contribution both to national defense and to the merchant marine of the United States" (Knight 1942c). It was estimated in a Congressional report on the Joint Resolution that the former owners had invested approximately $\$ 2,000,000$ in the property ( $77^{\text {th }}$ Congress $1942 \mathrm{~b}: 3$ ).

\subsubsection{Acquisition of other properties}

Shortly after plans to acquire the Chrysler property were initiated in 1942, several surrounding properties also were sought for the new Academy. This turned out to be an iterative process, with several different acquisition efforts put in place over the ensuing year. The U.S. Coast Guard received \$3,350,000 on 8 April 1942 for the acquisition of property for the USMMA and for the new construction required for the Academy (McNulty 1942a). Besides the Chrysler estate (including the three acres directly east of the main estate and an unimproved property north of the Friedman lot belonging to Walter P. Chrysler Jr.), the first group of properties marked for acquisition consisted of the Schenck, Marchant, Colen, and Friedman lots in Grenwolde, and a series of lots east of the Chrysler estate and adjoining Grenwolde, not all of which were improved (Figure 25 and Figure 26). Owners of the lots included the Grenwolde Association Inc. (property containing a sewage station for the development), the Kings Point Village (Police Station property with station/jail and garages), Elizabeth and 
Thomas Keegan, Thomas Bogart and Eleanor Copeland, Dora Rickenburg, and another lot owned by Bernard Colen (US Coast Guard 1942). With the exception of the Schenck estate which was appraised between $\$ 140,000$ and $\$ 145,000$, the individual properties came in at less than $\$ 35,000$ each, with the total for the eight properties of \$250,000 (McNulty 1942a). The Lands Division, Department of Justice, instituted a condemnation proceeding on 25 April 1942 to acquire these properties, in combination with a Declaration of Taking filed by the U.S. Navy on the same day. Funds representing "fair value and just compensation" were deposited with the court (Dolan 1942). Marchant was paid \$32,500 for his property and Schenck received $\$ 142,500$ (Dolan 1942; McNulty 1942g). The Village of Kings Point was paid $\$ 18,500$ for the Police Station property, and the buildings were moved to the Kings Point park not far away (Village of Kings Point 1942). Third Street, between Steamboat Road and Grenwolde Drive, was acquired from Marchant and Schenck in September 1942 (Nerney 1942). 
Figure 25. Map of Property in Kings Point showing lot owners, July 1942

(U. S. Coast Guard, from Berger 2005:19).

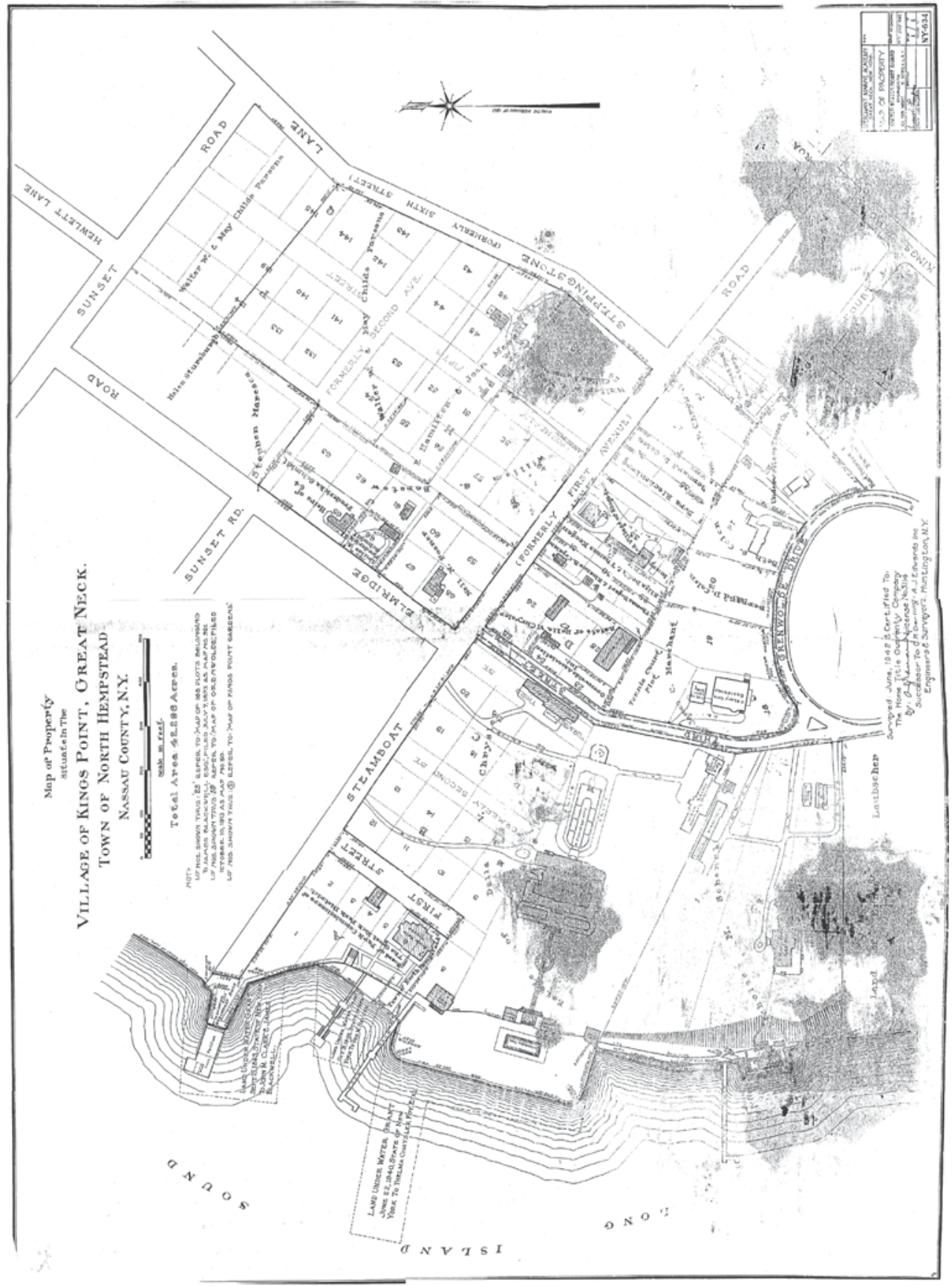


Figure 26. Using a photo taken prior to 1932 , the names of property owners prior to January 1942 were handwritten by Capt. McCready in May 1954, to show USMMA acquisitions (Bland Library, USMMA). Bathing beach is in lower left.

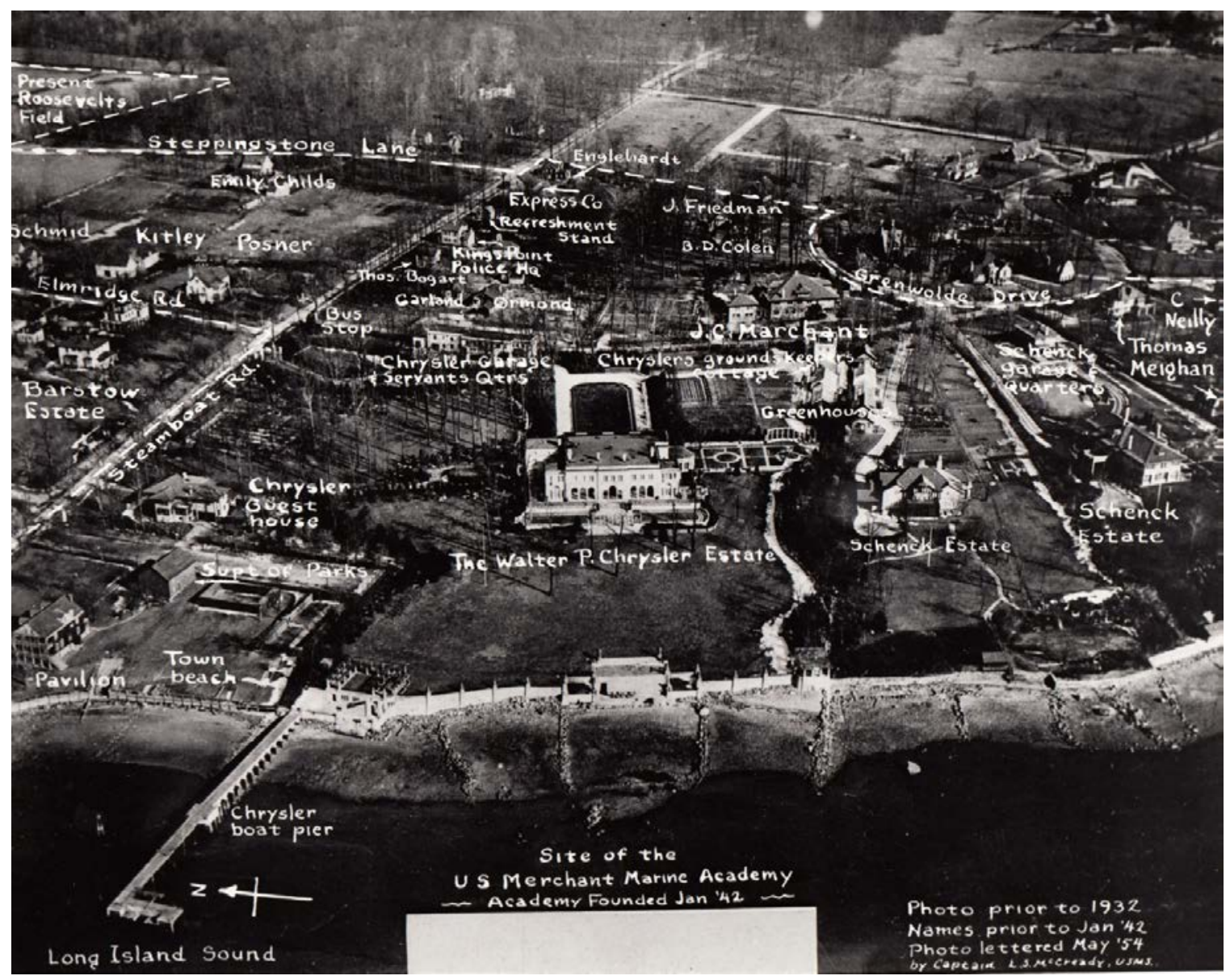

Efforts to acquire a drill and athletic field for the USMMA also began in early April 1942. A 13 April memorandum from Commander McNulty presented the desired location and property acquisition needed (McNulty 1942b). A 10-acre field existed across Steamboat Road from the proposed location of the drill hall and gymnasium; the property contained two houses, a garage, and a barn. Property owners were William S. Barstow, Walter and May Childs Parsons, and Hamilton and Jean Merrill (Figure 25). An area adjacent to the field to the west was selected for potential to house the Superintendent, the Commandant, and the Department Heads, which contained eight houses owned by Nell Posner, Louise and Frederick Schmidt (and heirs), Helen Stursburgh, Carla Garabelli/Stephen Maresca, and May Bertrand. Commander McNulty recommended the immediate acquisition of these properties, and that a contract be to prepared for the athletic field with baseball and softball diamonds and tennis courts, as well as wooden bleachers and a fence around the field with gates on four sides (McNulty 
1942b). As of 10 May, acquisition of the relevant properties was in progress, including the Parsons, Merrill, Posner, Barstow, Schmidt, Garabelli, Stursburgh, and Bertrand holdings (McNulty 1942c). By 18 May 1942, houses on the Elmridge Road block had not yet been acquired, but were expected to be in hand by the end of that month (McNulty 1942d). In actuality, it was September before the last of these properties was acquired (Swann 1942). The appraised value of the athletic field and adjacent properties was $\$ 130,000$ (McNulty 1942a).

There was also property just north of the Chrysler waterfront owned by the Town of North Hempstead and the Board of Park Commissioners of the Great Neck Park District (MacRoberts 1942; Berger 2005:16). This area included the old wooden steamboat pier at the end of Steamboat Road, which had a small wooden pavilion (Figure 26). The property also included a public bathing beach for Great Neck residents, and there was a threestory frame building and a bathhouse on the lot as well as a pier (Spear 1936:39). The government purchased this property in September 1942 for $\$ 90,000$ (Pincus 1983:82). The former bathhouse on the park property, constructed around 1920, was utilized by the USMMA until it was demolished in 2001 (Berger 2005:9).

The Mueller/Laubscher (Meighan), Neiley, and Japhet properties were appraised for the Department of Justice on 20 August 1942. At the time, it was determined by the USMMA to take action to acquire the Mueller property, and wait on the others. The Mueller property was acquired by the USMMA on 2 October 1942, at a negotiated price of $\$ 60,000$ (Page 1942). The property consisted of 3.65 acres with 139 feet of waterfront, a pier, bath house, 15-room mansion of hollow-tile construction and tile roof, and a large three-car garage and separate servants' quarters (McNulty 1942g). The buildings were needed to house the Educational Unit.

The Neiley and Japhet properties were acquired after the others, in 1943. The land was needed for the construction of a permanent medical clinic, and the Japhet house was planned for immediate use as a dispensary. An inquiry conducted in July 1942 listed assessed values for the Neiley property at $\$ 74,150$ and $\$ 20,800$ for the Japhet property (Tomb 1942b). 


\subsubsection{Existing buildings at Kings Point6}

As soon as was possible, cadets began to arrive on the new campus. According to the USMMA Cultural Resources Report, "on January 21, 1942, 103 midshipmen from Fort Schuyler crossed Long Island Sound and arrived at Kings Point" (Berger 2005:16). Wartime exigencies resulted in a rapidly increasing number of cadets, and "by March, there were over 220 midshipmen on campus; in April there were 500; and by October 1942, there were approximately 1,00o midshipmen at Kings Point" (Berger 2005:16). By June, equipment for the full complement of 2,400 students and 300 enlisted men expected by the end of 1942 had been determined at a cost of $\$ 319,800$ (McNulty 1942e). This cost included berthing, messing, and instructional items necessary for operation of the USMMA. Plans were immediately drawn up for utilizing the Chrysler mansion (Wiley Hall) for barracks, messing, and classrooms (Figure 27 and Figure 28).

Figure 27. Preliminary plan for use of Chrysler Mansion, first floor, 1942 (NARA RG 178).

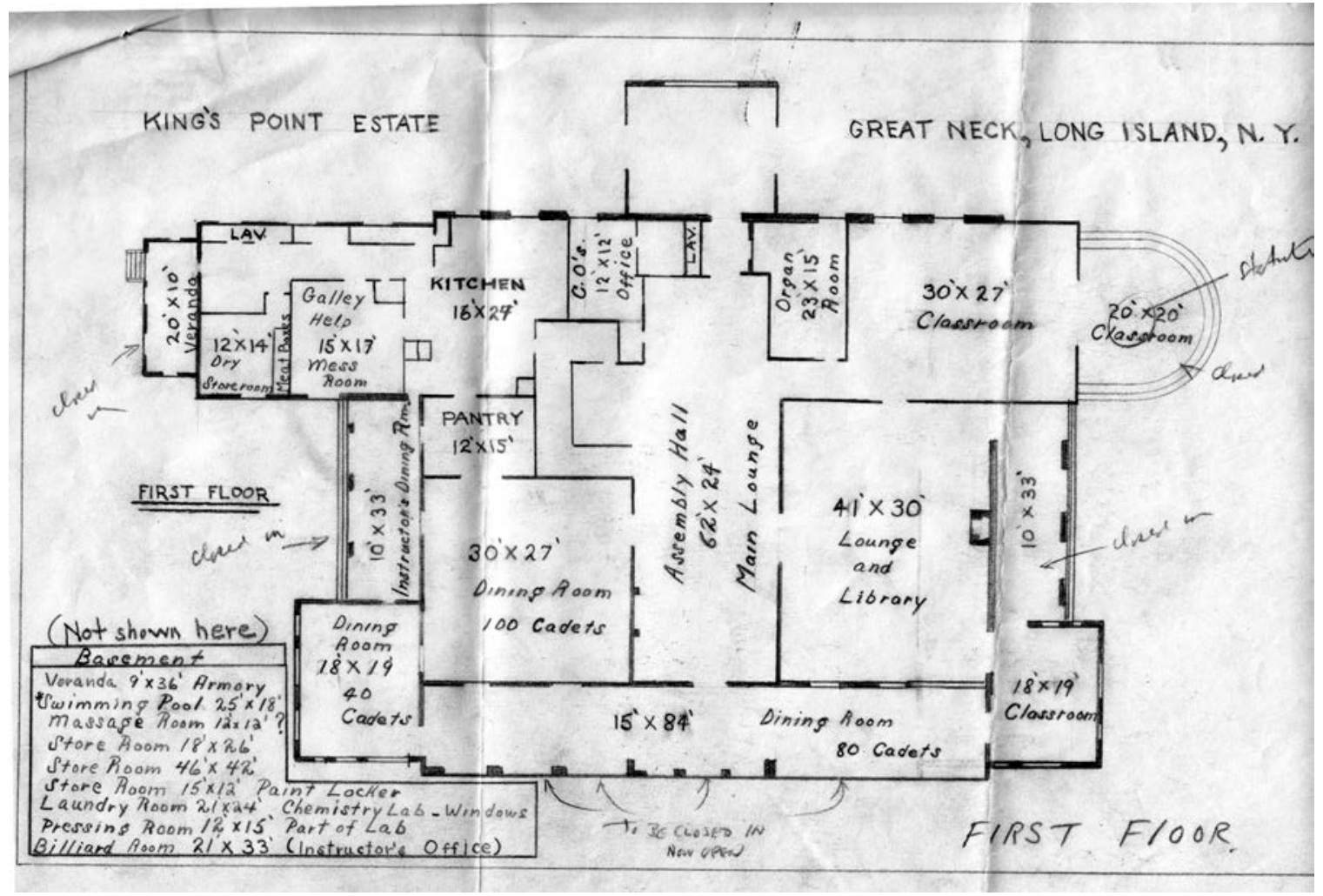

6 This section researched and written by ERDC-CERL authors. 
Figure 28. Preliminary plan for use of Chrysler Mansion, second floor, 1942 (NARA RG 178).

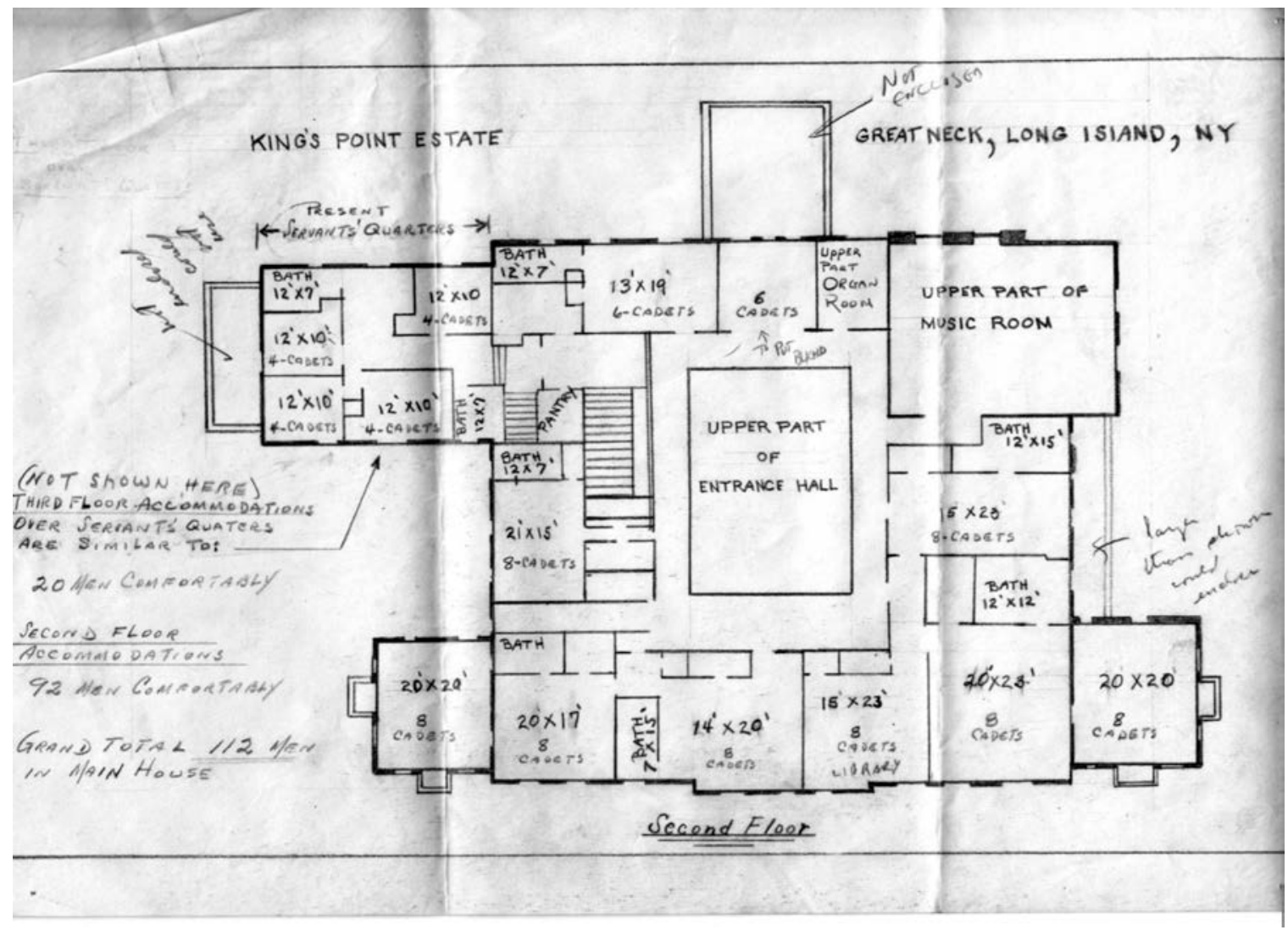

By mid-May 1942, USMMA had developed capacity for 758 students, utilizing a combination of existing buildings and temporary Civilian Conservation Corp (CCC) structures scattered around the central area of the Academy. Cadets were berthed in six CCC barracks and also in the Chrysler mansion (only briefly), the Chrysler superintendent's house, the Chrysler garage, the Schenck main house and garage, and the Marchant house and garage (McNulty 1942c). Cadet mess halls were placed in a CCC building and on the lower floor of the Schenck house, while the upper floor housed approximately 100 cadets (Bosler 1942). Classes were taught in four CCC buildings, and the Chrysler garage, greenhouses, playhouse, and billiard room (McNulty 1942c). Enlisted staff was housed in two CCC buildings and in the servants' wings of the Chrysler and Schenck houses (McNulty 1942c). Uses were still being determined for the garage, greenhouses, and cottage from the Houston property that Schenck acquired, as well as the Schenck movie theater and nearby greenhouses (McNulty 1942c). The Friedman property was to be used as headquarters for the Educational Unit, pay and supply personnel, and storage, while the Grenwolde Association, Keegan, and Kings Point Village properties had 
uncertain usage plans (McNulty 1942c). The Colen house became quarters for Superintendent Tomb (Quarters B) (McNulty 1942c). In 1943, the Neiley house became home to the Superintendent (Quarters A), first inhabited by Rear Admiral (RADM) Giles Stedman, U.S. Navy Reserve (USNR) (Renick 2001). The Bogart house was used as staff barracks, and the Chrysler bathhouses were converted to classrooms (Bosler 1942). The barracks facilities in existing buildings were gradually moved into the CCC structures as the interiors of existing buildings were converted into classrooms. The Chrysler garage became the location for seamanship classes, and engineering courses were taught in the Marchant house, with the garage becoming the armory (Mitchell 1977:51). In later years, the Friedman property became Quarters C, the Meighan house became Melville Hall (reconfigured for the Officers Club in the 1950s) and the Meighan garage became Quarters K (USMMA 2013). The Schenck house became Land Hall. The Neiley garage became Quarters J, and the Japhet property became Quarters D.

This use of facilities required alterations of the structures and grounds to varying degrees. For the Chrysler mansion (first named McKay Hall and renamed Wiley Hall in 1943), the largest change was the enclosure of the loggia on the west façade to provide a cadet entrance to the building. The construction firm of Vermilya-Brown Company Inc. was contracted for this work, and the task was completed by 10 July 1942 (McLaren 1942) (Figure 29). Light blue awnings were put up at the same time. By midsummer, the mansion was primarily used for administrative purposes. Vermilya-Brown was also tasked to convert the two existing Chrysler greenhouses into machine shops (McLaren 1942). 
Figure 29. Former west-side loggia, newly enclosed on Wiley Hall, 1942 (Bland Library, USMMA).

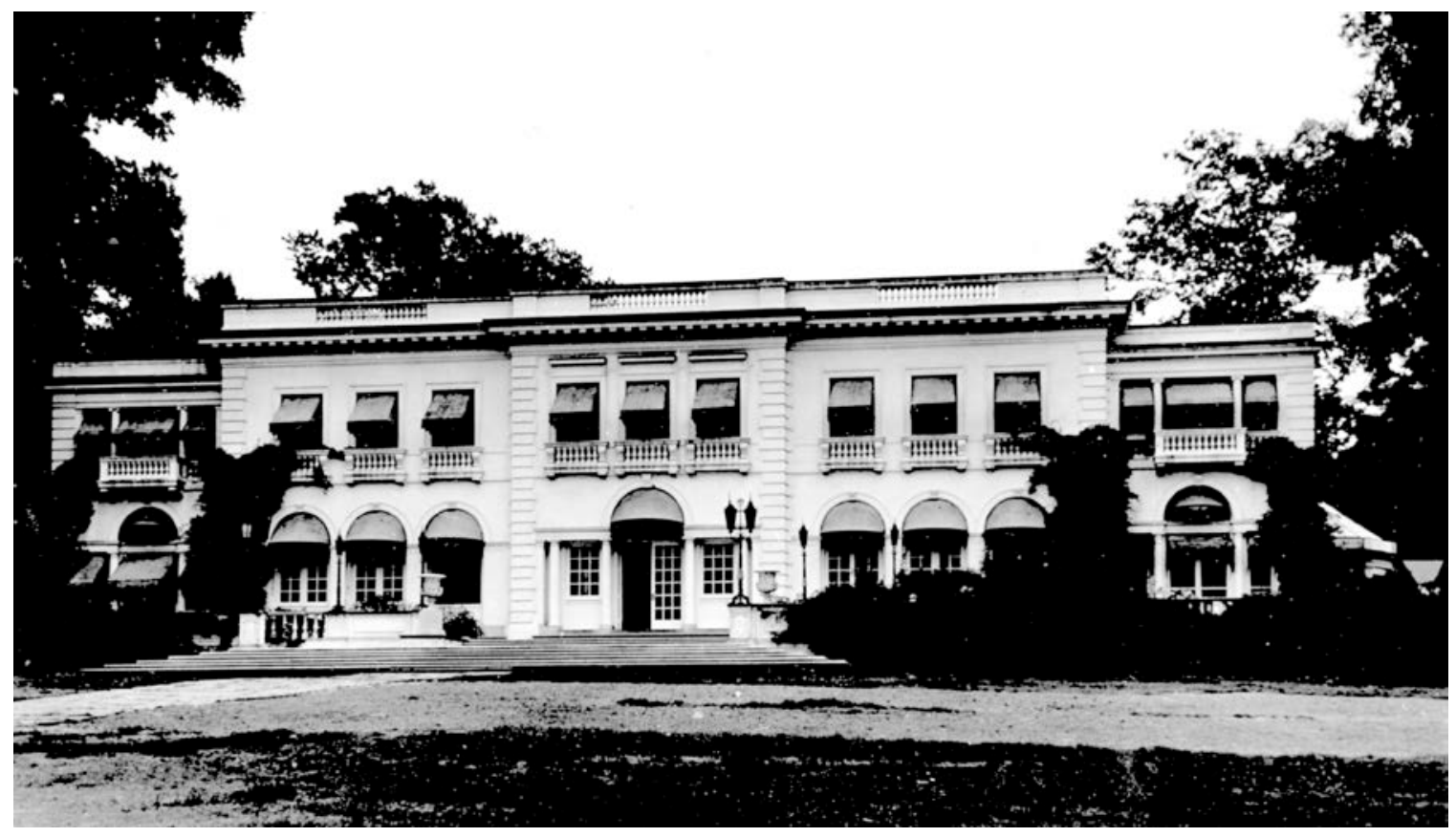

The Chrysler grounds were altered by the removal of the south garden for CCC structures; CCC structures were also placed on the open lawn areas around the mansion for midshipman barracks and mess facilities. The eastern part of the sunken garden was paved for a gun emplacement in July 1942, and a tall flagpole was added east of the gun. A new entrance road to the mansion was also completed in 1942. On the waterfront side, a new flagstone walkway between the mansion and the pool was in place by early July 1942. The path split around a large tree in the center of the lawn (Figure 30). A memorial was constructed in the oval area created by the split path to commemorate all Kings Pointers who had died in WWII. The memorial was completed in 1946 with a gift from Bethlehem Steel and is composed of a commemorative shaft with a bell and poised eagle (Mitchell 1977:149-150). 
Figure 30. Path from Wiley Hall to waterfront with new walkway and War Memorial, 1943 (Bland Library, USMMA).

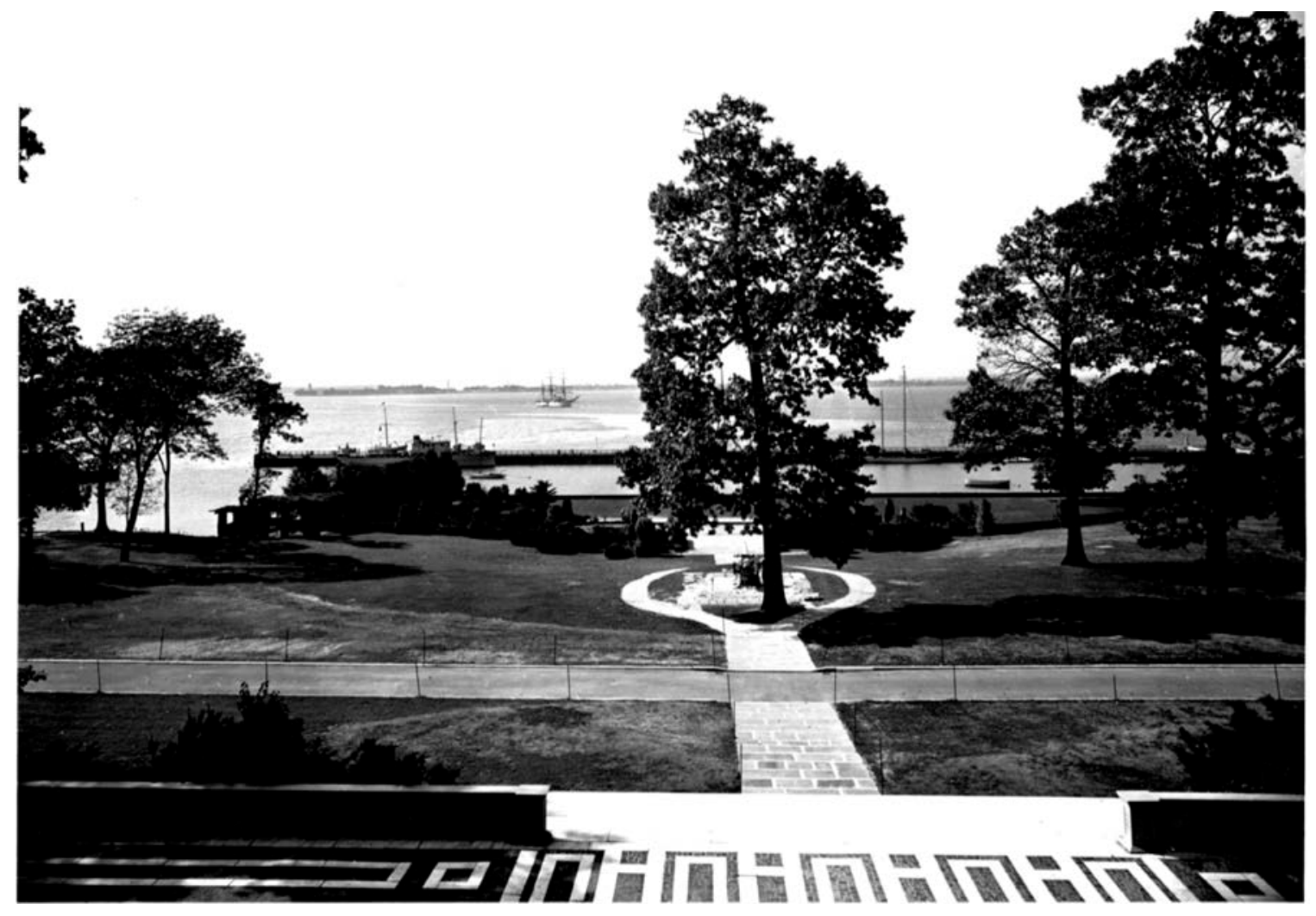

The waterfront facilities were greatly expanded, with the existing Chrysler pier (Mallory Pier) enlarged to form the semi-enclosed Hague Basin, and a new pier was constructed on the south end of Chrysler estate waterfront (Crowninshield Pier) with a covered pavilion (Knight 1942a) (Figure 31). The Schenck pool (Marshall Pool/Prosser Boat House) was used in the early years of the USMMA for swimming instruction in cold weather, after the dismantled Chrysler greenhouse glass had been used to enclose the pool in early 1943 (Otto 1942, 1943) (Figure 32). 
Figure 31, Expanded waterfront facilities, 1943 (Mitchell).

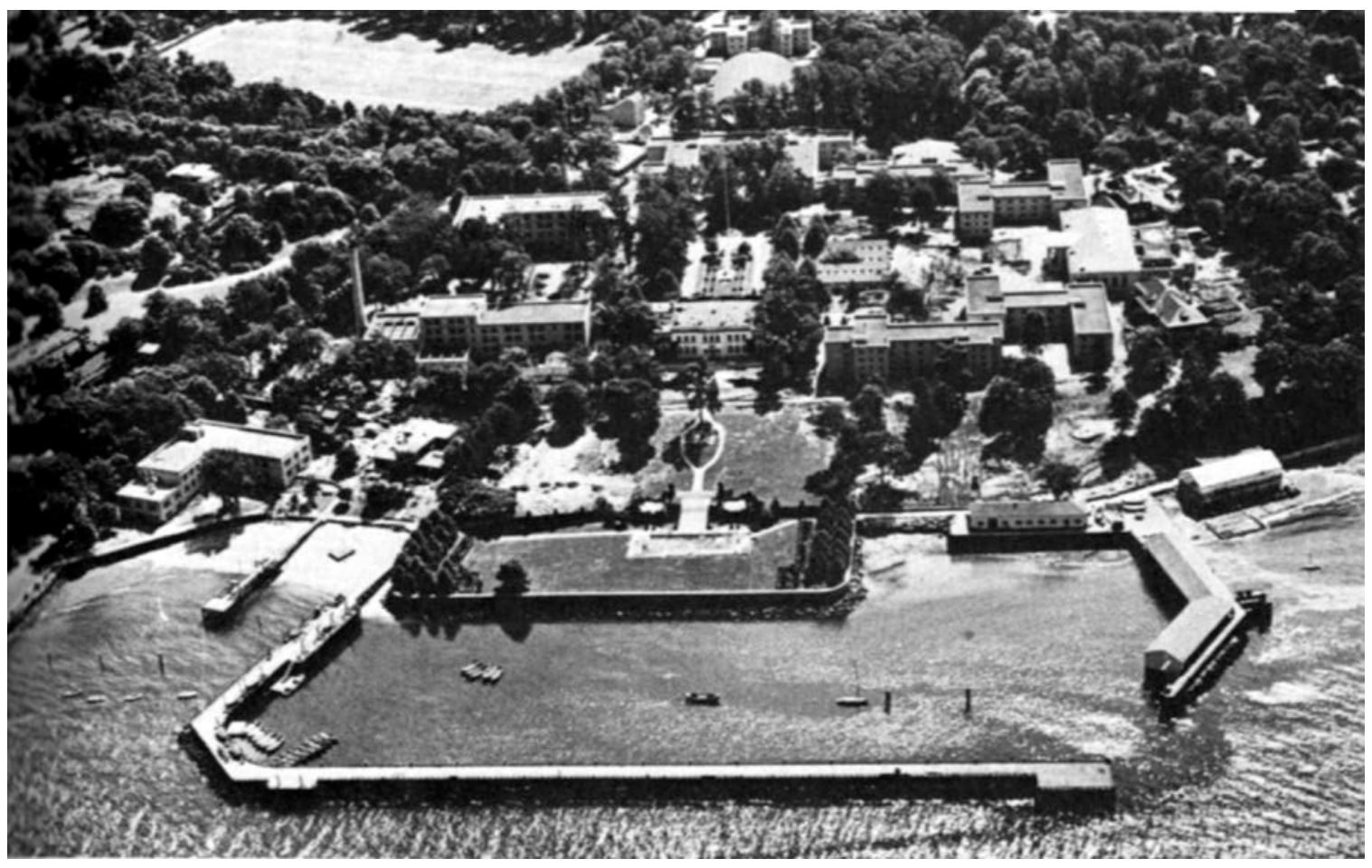

Figure 32. Schenck pool (Prosser Boat House) enclosed with Chrysler greenhouse glass, 1943 (Bland Library, USMMA).

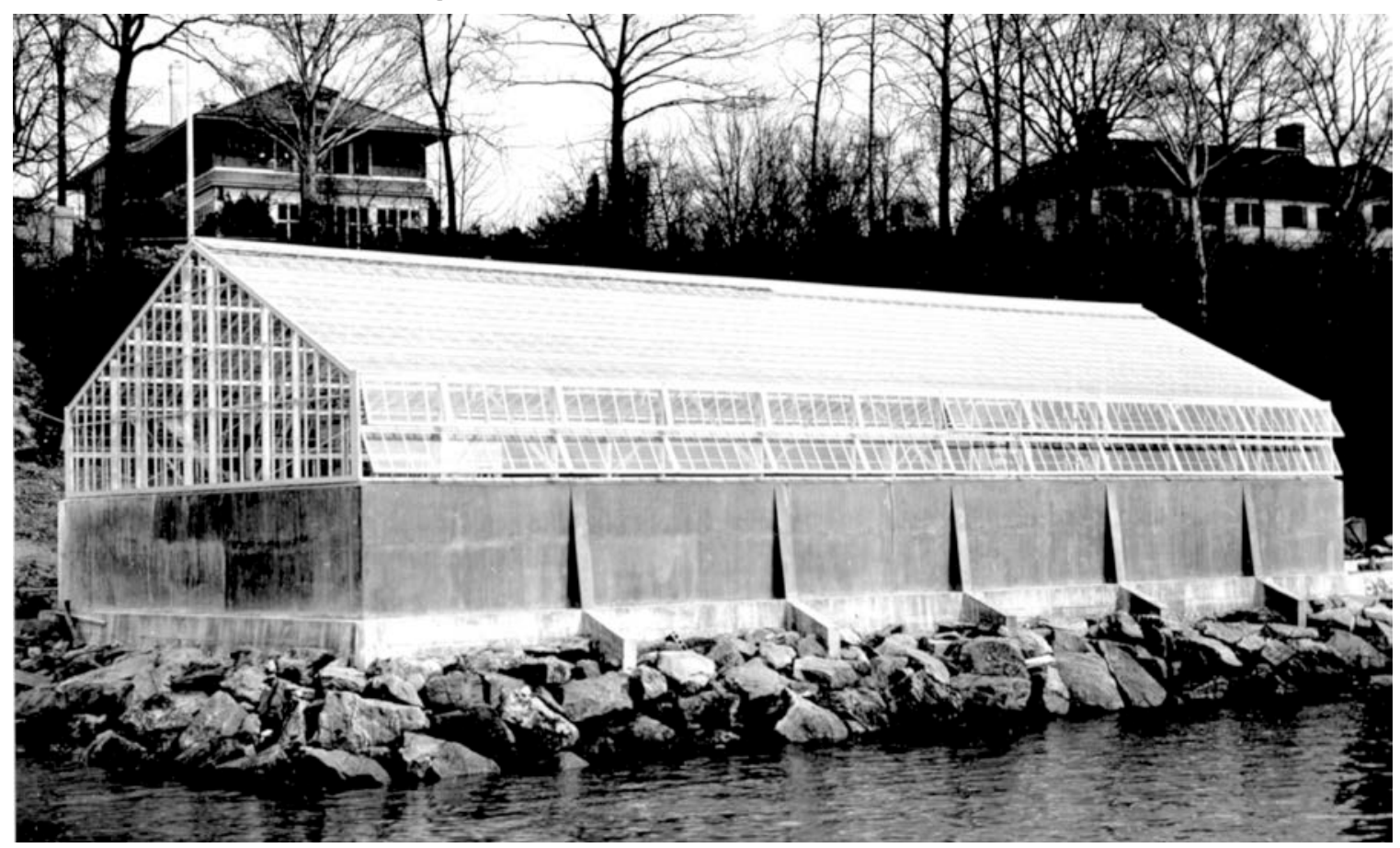


By the end of May 1942, plans were made for enclosing USMMA within a wooden stockade type of fencing, which necessitated removing existing iron fencing around parts of the Chrysler property and moving vegetative barriers to areas where new construction was not planned. VermilyaBrown received a request for an estimate on this task 11 July 1942 for a $6 \mathrm{ft}$ 6 in.-high reed fence to enclose the campus beginning at the southern beach terminus of the Schenck property, around the Academy, down Steamboat Road, and across the entrance to the dock, complete with eleven gates (Vermilya-Brown 1942). There was a separate task to enclose the Drill and Athletic Field with the same type fencing with four gates. The project was authorized by Commander McNulty on 17 July 1942 (McNulty 1942f).

\subsubsection{New construction at Kings Point 7}

In February 1942, contracts were signed with the architectural and construction firms that would design and build the new academy (Mitchell 1977:52; Polaris 1946b:9). Alfred Hopkins \& Associates of New York City completed detailed plans and specifications for the new buildings, which were designed to accommodate 1,200 cadets during peacetime. The firm was selected, as they had served as architects for Coast Guard projects at Avery Point and New London, Connecticut, as well as other large-scale government projects including two penitentiaries (Knight 1942b). Hopkins received his architectural training at the École des Beaux-arts in Paris and was best known as an architect of state and federal correctional facilities; he also designed several groups of farm buildings for numerous Long Island estates (MacKay et al. 1997:215). In so doing, he worked with some of the leading architects of the day including Bertram G. Goodhue, John Russell Pope, and Charles A. Platt. Hopkins, however, died in 1941, before the commission for USMMA was received by the firm, which at the time of his death was located at 415 Lexington Avenue, New York, New York. The design that the office produced nonetheless exhibits elements of Beaux Arts design, including strong axial arrangements and balance, which were ideas that Hopkins might well have endorsed.

Construction of new buildings was completed by the Vermilya-Brown Company of New York City (Mitchell 1977:51-52). They were first contracted to provide temporary CCC buildings for living and working facilities

\footnotetext{
7 This section is a combination of text extracted from Berger, Cultural Resources Survey Report, and content added by ERDC-CERL authors.
} 
while the campus was constructed, and to construct two cadet quarters buildings, one mess hall and galley, one central power plant, utilities, and miscellaneous alterations to the existing buildings (McLaren 1942).

Of the $\$ 3,350,000$ received in April 1942 for creating the USMMA, $\$ 2,950,000$ was earmarked for new construction. The initial list of needed construction included a mess hall and galley, engineering building, docks and dredging, utilities, roads, walks and yards, CCC buildings, grading, fire alarm system, and cadet barracks (McNulty 1942a). The most expensive item was the cadet barracks, budgeted at $\$ 1,052,500$, and the architects and contractor's fees came to $\$ 340,175$ (McNulty 1942a). It soon became apparent that the appropriated funds would not be sufficient for the additional construction required, and additional funds were requested for fiscal year 1943 in the amount of $\$ 3,516,000$ (McNulty 1942a). These funds were needed for alterations to the "taken over" buildings to alter them for USMMA purposes, completion of the mess hall and barracks, an academic building, a staff barracks building, a drill hall, armory and gymnasium, carpenter shops, boat sheds, sail loft, marine railways and dock, completion of utilities, fencing, athletic field, and equipment (McNulty 1942a). Plans from August 1942 show the existing buildings acquired up to that time and the temporary $\mathrm{CCC}$ buildings in place during construction (Figure 33), while a similar plan from later in the year depicts the placement and design of the new buildings, with the use of Wiley Hall as the USMMA focal point made clear (Figure 34). 
Figure 33. Plan for USMMA, showing existing buildings and CCC structures, August 1942

(Bland Library, USMMA).

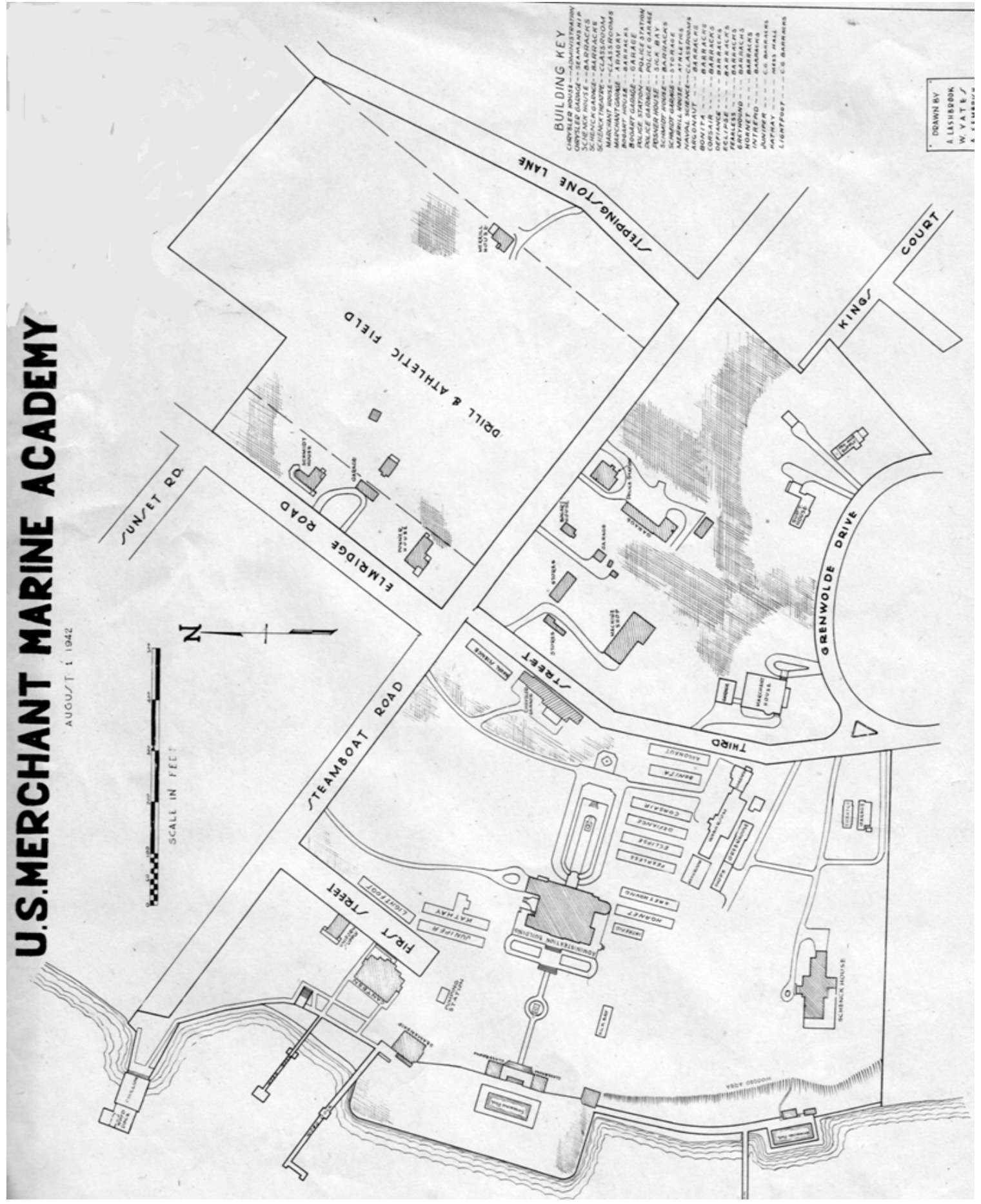


Figure 34. Plan for USMMA, showing new construction overlaid on existing buildings, 1942 (Bland Library, USMMA).

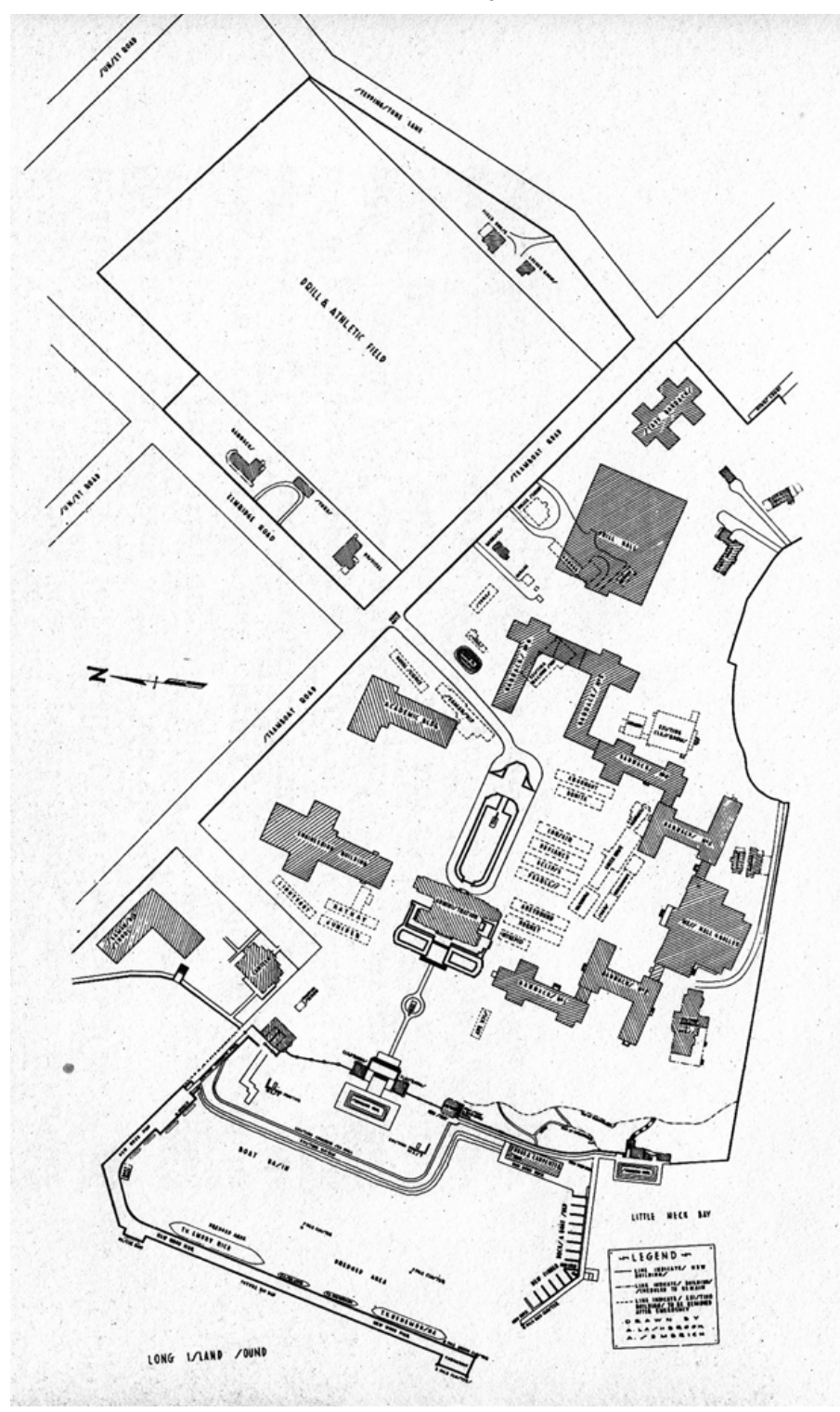

Alfred Hopkins \& Associates designed the new buildings with a frame of reinforced concrete columns and concrete block exterior walls with cast stone trimming (Figure 35). Interior walls were also of concrete block, floors were concrete, and windows were wood double-hung (Litchfield 1942). According to Litchfield, the architects had to work within wartime constraints when determining the building materials:

Since construction was carried on during the war, it was necessary to curtail the use of critical materials and at the same time provide structures as permanent as possible. The solution which Alfred Hopkins \& Associates evolved was a concrete frame-posts, girders, piers and grade 
beams-with enclosing walls of concrete blocks. A finished exterior surface of great interest was obtained by using an irregular surface texture and several color tone variations in the blocks, and laying them in 4,6 , and 8 inch courses with random vertical joints. In this way a permanent wall surface was obtained, which has an interesting character, is inexpensive, and does not use scarce materials, or crucial transportation facilities (Alfred Hopkins \& Associates undated).

Figure 35. Construction materials for permanent buildings, 1942 (Bland Library, USMMA).

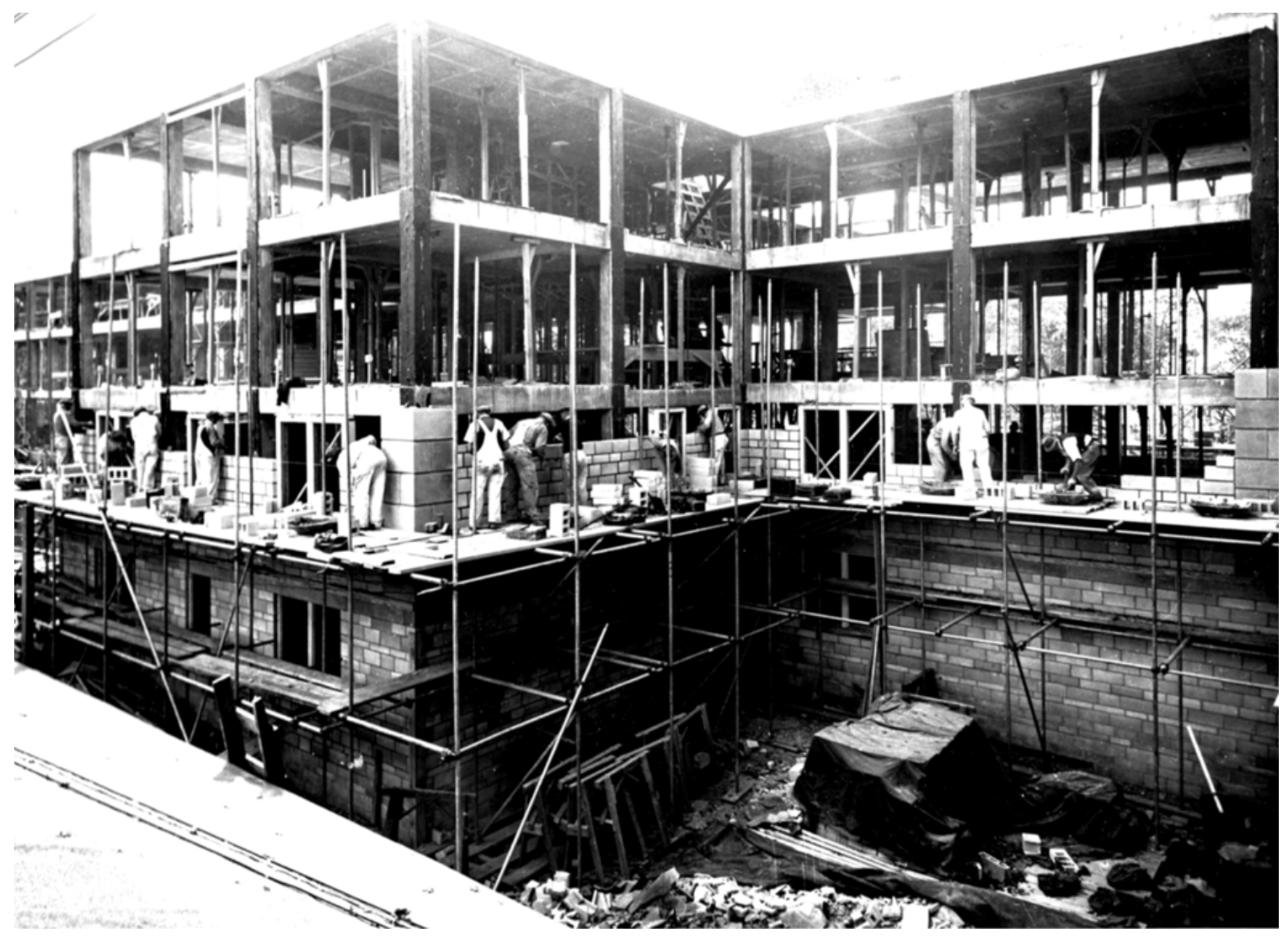

On 11 June 1942, concrete was poured for the first new permanent building, Palmer Hall, a dormitory located south of the Chrysler mansion. However, progress was halted nearly as soon as it was started. An Executive Order, issued on 1 March 1942, had transferred all maritime training responsibilities from the Maritime Commission to the Coast Guard. In the Coast Guard's view, the establishment of the school at Kings Point was a wartime emergency effort and was, therefore, temporary. Construction of "permanent" facilities, that is, concrete structures, was halted and orders were given to construct the academy buildings of wood (Merrill 1977:53). It seems that the administrative and philosophical battle for the academy 
occurred mostly in Washington offices and that the cadets continued about their training, while surrounded by half-completed buildings. The situation was resolved by an Executive Order issued on 15 July 1942 that transferred training responsibilities to the newly-established War Shipping Administration (Mitchell 1977:39-42). The War Shipping Administration held the view that Kings Point was to be a permanent service academy, an idea that was echoed in a letter sent by President Franklin D.

Roosevelt to the Maritime Commission on the occasion of the school's official dedication. In his letter, Roosevelt stated, "This Academy serves the Merchant Marine as West Point serves the Army and Annapolis serves the Navy" (Mitchell 1977:102). This declaration seemed to put the issue to rest.

Of the 14 new buildings constructed at the academy, six were dormitories (Barry, Jones, Cleveland, Rogers, Palmer, and Murphy Halls), one was a large dining facility (Delano Hall), one was a medical facility (Patten Clinic), one was a drill hall and gymnasium (O’Hara Hall), and five were academic and administrative buildings (Bowditch, Fulton, and Samuels Halls and Fitch and Furuseth buildings) (Figure 36 to Figure 39).

Figure 36. Barry and Jones Halls (barracks), April 1943 (Bland Library, USMMA).

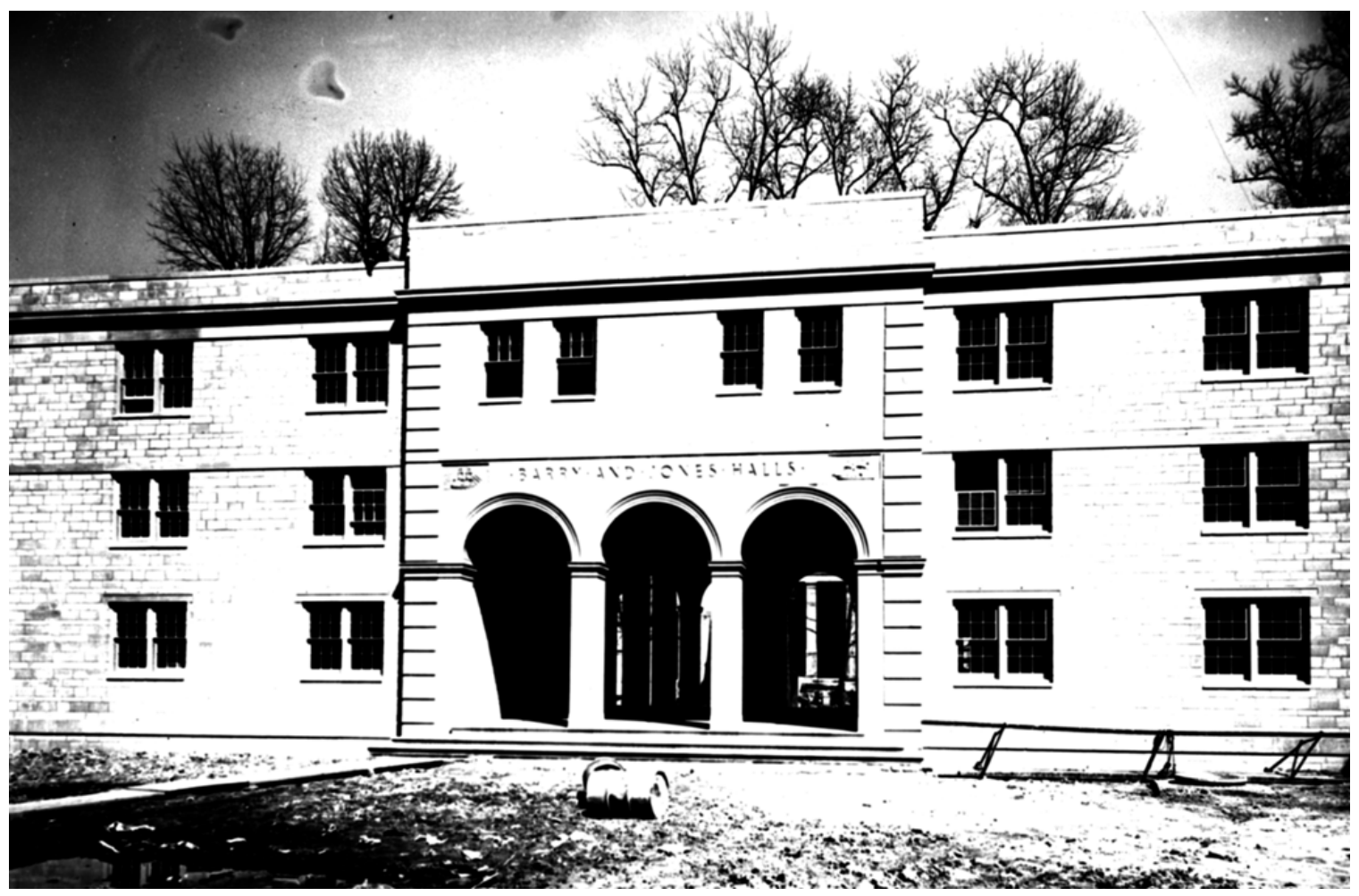


Figure 37. Fulton Hall, academic building, ca. 1960s (Bland Library, USMMA).

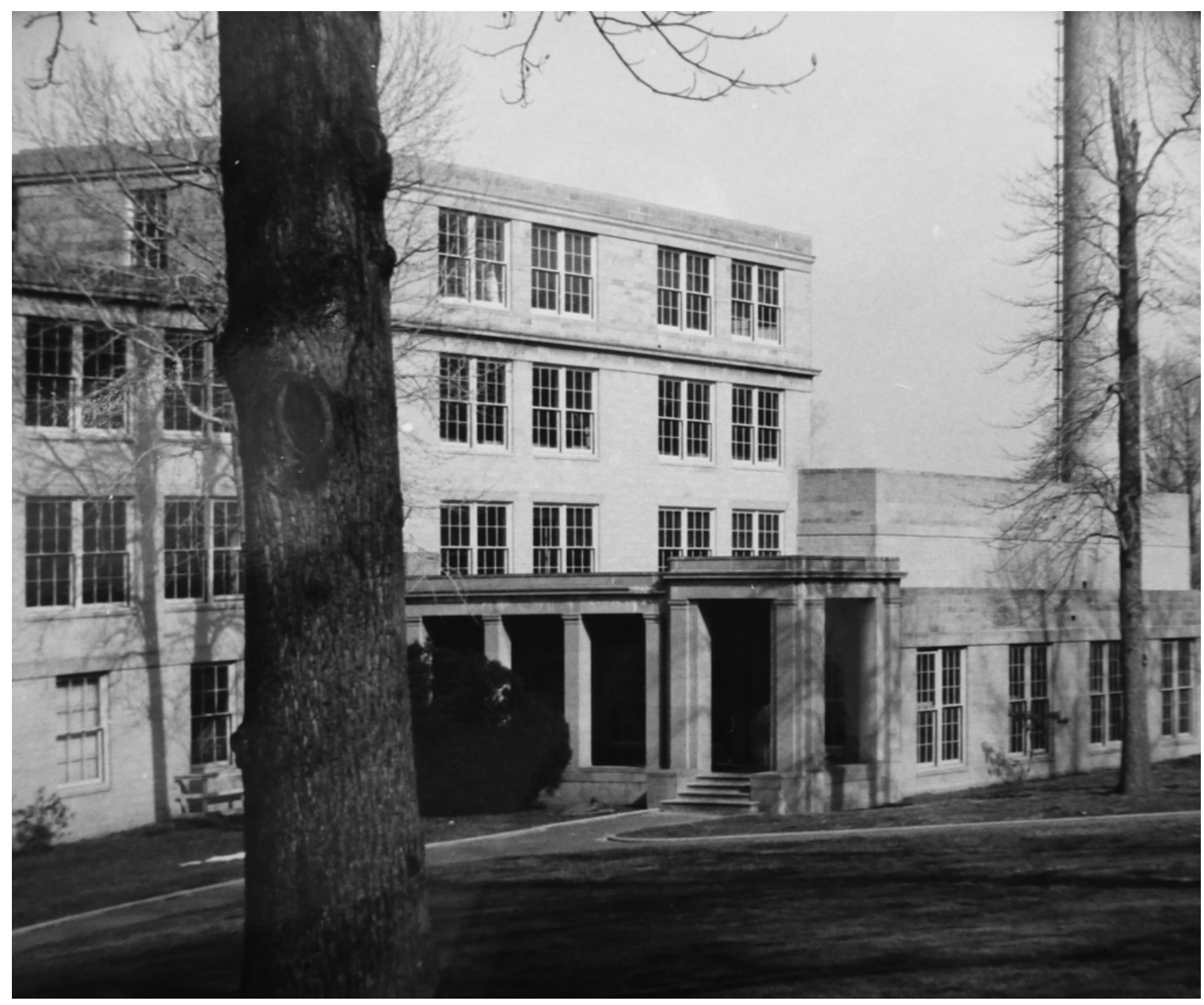

Figure 38. O’Hara Hall, drill hall/gymnasium, 1944 (Bland Library, USMMA).

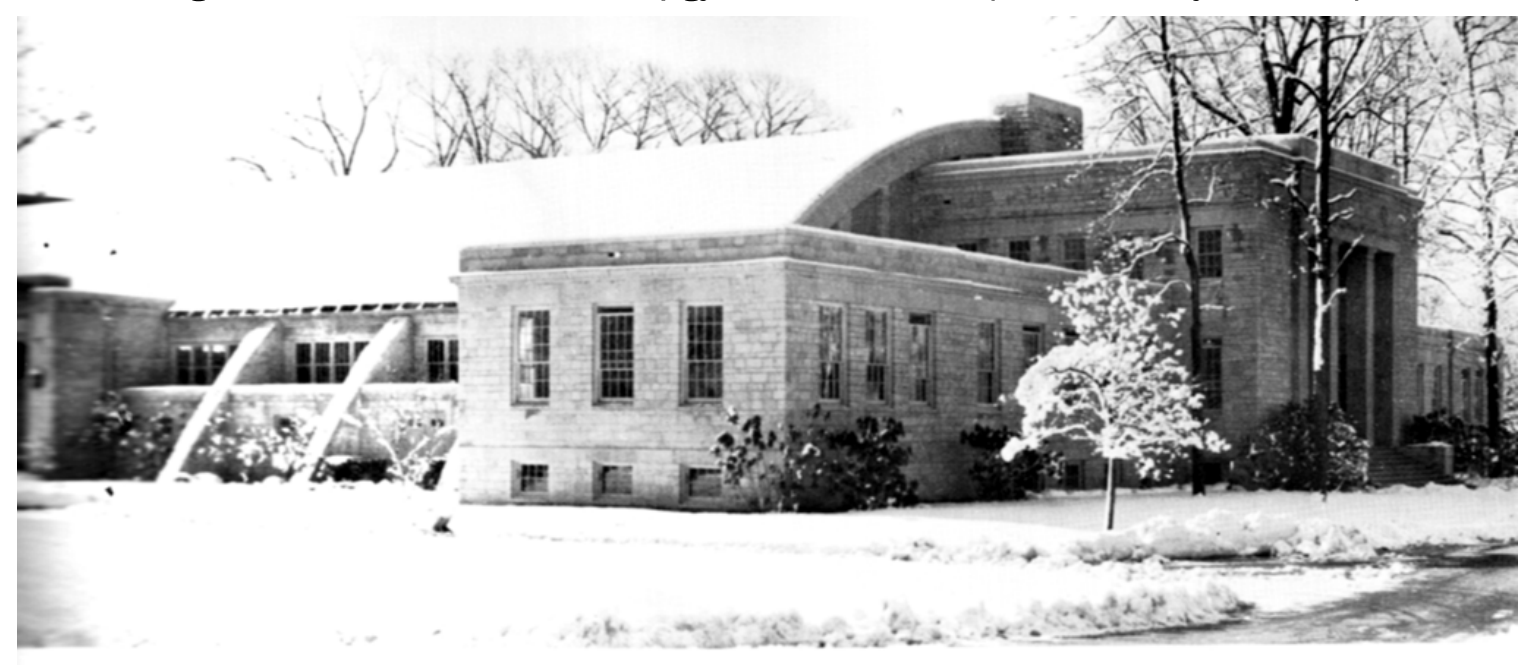


Figure 39. Delano Hall and Parade Ground, 1943 (Bland Library, USMMA).

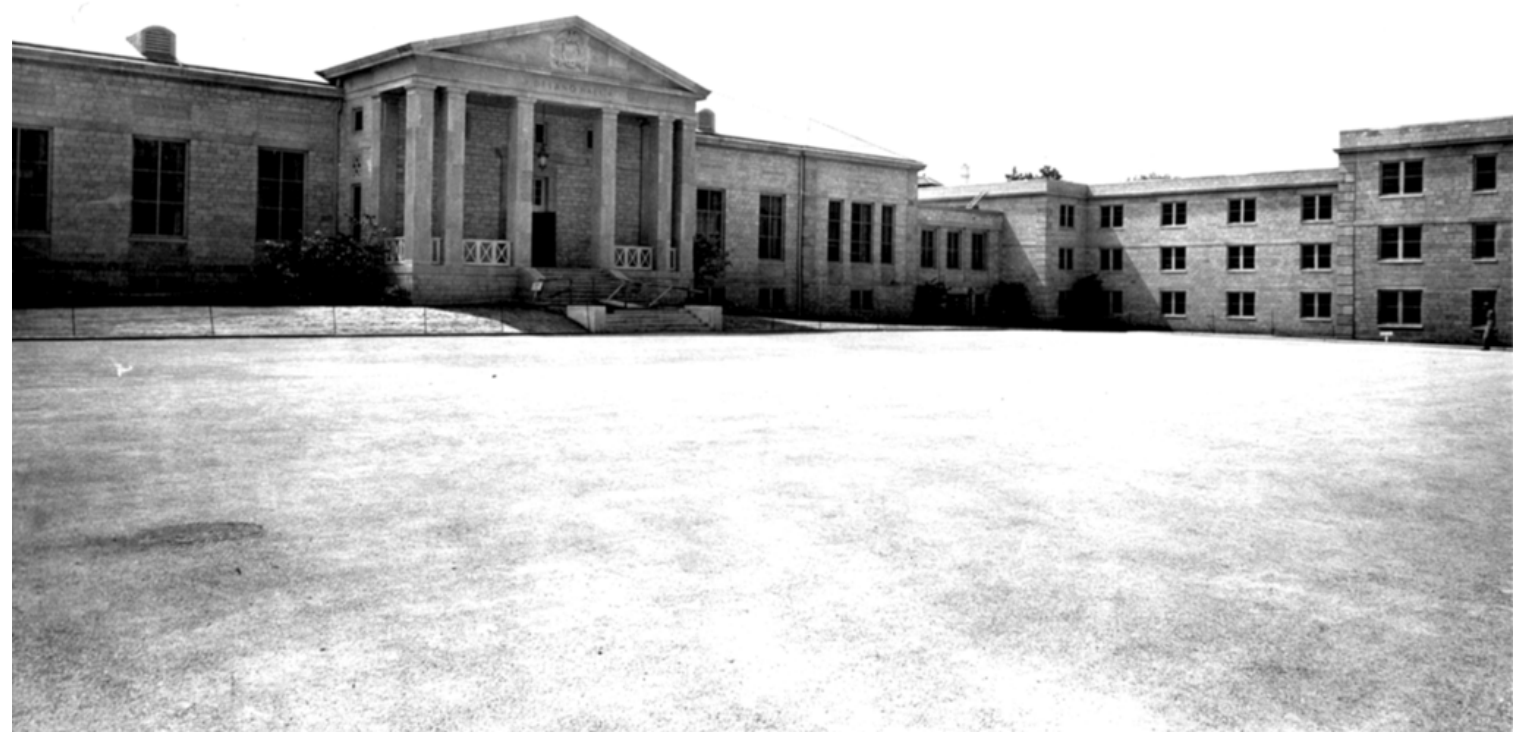

A series of Polaris articles in early 1943 described some of the features of the new academic buildings as the buildings were completed and put into use. Bowditch Hall, located northeast of Wiley Hall, held the chart and navigation lab, the radio code room, and also housed the navigating bridge that was equipped with a Mark XV Sperry gyroscope repeater and Pelorus stand on both port and starboard sides. Bowditch Hall also played an important part in the social lives of the midshipmen. A 900-seat auditorium and stage, since dedicated as the Ackerman Auditorium, was used to show movies and the library was housed on the first floor. The Merchant Marine Band had offices in the basement, along with the visual education department (Polaris 1943a:11). Today, the Department of Marine Transportation is located in Bowditch Hall.

In 1943, one of the engine labs at Fulton Hall (Figure 37), located north of Wiley Hall, held a scale model of an engine room from a Liberty Ship, complete with valves, ladders, generators, and a miniature machine shop. The basement level held a steam engine laboratory and full-sized Liberty Ship boilers. The second floor held conventional classrooms and an electronics laboratory, while the third floor held more classrooms and a chemistry laboratory. The fourth floor (the penthouse), housed the mechanical 
drawing department (Polaris 1943b:9). Today, Fulton Hall is known as the marine engineering and science building.

Samuels Hall, located on the south side of Steamboat Road near the former landing, housed the seamanship and visual signaling school. Sailmaking and canvas work, such as making seabags, was conducted on a wooden-decked sail loft at the south end of the first floor. Classrooms were located on the second floor where blinker, code flag, and semaphore (mirror) signaling training was held (Polaris 1943c:13). Today, the humanities department is housed in Samuels Hall, which had a large addition constructed to it in 1974 for the Computer Aided Operations Research Facility (CAORF). A ship's bridge simulator, located in this addition and under the Department of Marine Transportation, offers midshipmen the opportunity to practice team management and vessel maneuvering under realistic conditions (USMMA 2001:59).

O'Hara Hall, the drill hall and gymnasium, held the Department of Naval Science, the Department of Ship's Medicine, and the Department of Physical Training. Located near the east end of the campus, O'Hara Hall provided basketball and volleyball courts, punching bags, wrestling mats, and a trampoline. Tennis courts and handball courts were located outside, north across Steamboat Road. The Marshall Pool, as well as the Eldridge Pool, provided outdoor swimming facilities. Each midshipman was required to pass a swimming test before they departed for their Third Class training at sea (Polaris 195ob:18).

As mentioned, the six new three-story barracks, or dormitories, formed two sides of the central quadrangle, of which the Administration Building, Wiley Hall, was the focal point. Billeting was two to four midshipmen per room, 75 midshipmen per floor, for a total of about 225 midshipmen per dormitory. Barracks No.1, later designated as Palmer Hall, was completed around November 1942; Barracks No.2, Murphy Hall, was completed about two weeks later (Polaris 1942a:5; 1942b:2). The buildings featured a wide central hallway with rooms to either side, and large entrances planned to avoid congestion at doorways. Each floor had two lavatories, one at each end, with six tiled showers. The average room measured 16' by 16 ' and was furnished with two double-tiered metal bunks, a wooden table, chairs, built-in lockers, and two washstands. A duty officer's office was located on the first floor. Each barracks was considered to be a selfcontained unit (Polaris 1942b:2). 
The need for a permanent medical clinic was growing along with the cadet population, and the Posner House (Quarters E and F) on Elmridge Road was no longer adequate to the task. In an 8 March 1943 memorandum from Superintendent Tomb, the need for a new medical facility was spelled out, primarily overcrowding and unsanitary conditions. By that time, the Schmidt House (Facilities Management Building A), adjacent to the Posner House was also being utilized for health care, and was unsuitable for the task. Superintendent Tomb recommended steps be taken to construct a new hospital of up to 100 beds on the Neiley property (Tomb 1943). The new Patten Hospital was constructed in 1943-44, and was placed between the Neiley house (Quarters A) and garage (Quarters J) (Mitchell 1977:96). Neiley's formal garden survived the construction and became a park-like area directly south of the hospital.

The original gate to the USMMA was at the Third Street entrance off of Steamboat Road (now Marvin Place), but in 1943 a new entrance was created at the intersection of Steamboat Road and Steppingstone Lane, at the far eastern edge of the USMMA. In 1946, the main gate to the campus was designated Vickery Gate in honor of Vice Admiral (VADM) Howard L. Vickery, Vice Chairman of the Maritime Commission (Polaris 1946a). Barney Square, located on the north side of Delano Hall, is a paved area that has served as a parade and formation area since 1944 (Polaris 1944:45).

\subsubsection{Training program and academy administration}

On January 28, 1942, one week after the first midshipmen arrived, Kings Point held classes in visual signaling (Mitchell 1977:49). Days later, seamanship classes were held, followed by the start of engineering courses. Throughout the first year of the academy's existence, there was a shortage of laboratory and shop equipment. Instructors often salvaged used items from naval yards and port docks, or improvised with hastily assembled equipment. Instructors were also at a premium since many served in the naval reserves and throughout the war were often called to active duty. The first instructors to arrive at Kings Point arrived from state-operated naval schools, such as the New York Merchant Marine Academy at Fort Schuyler and the Pennsylvania Maritime Academy (Mitchell 1977:49, 55)

For the first two months of 1942, John F. Wilson served as the academy's Commanding Officer (CO). On 9 March 1942, Wilson was called to active naval duty and was succeeded as CO by John D. Bosler. On 11 April 1942, 
Capt. James Tomb was appointed as the first Superintendent of USMMA (Polaris 1946b:9-10). Tomb served as Superintendent until 1943 when he was succeeded by RADM Giles C. Stedman. At present, RADM James A. Helis serves as USMMA's twelfth Superintendent (Table 1).

Table 1. Superintendents of the U.S. Merchant Marine Academy.

\section{Superintendent}

Capt. J. Harvey Tomb

RADM Giles C. Stedman

RADM Richard R.

McNulty

VADM Gordon McLintock

RADM Arthur B. Engel

RADM Thomas A. King

RADM Paul L. Krinsky

RADM Thomas T.

Matteson

VADM Joseph D. Stewart

RADM Allen B. Worley $\quad$ 2009-2010

RADM Phillip H. Greene, 2010-2011 Jr.

RADM James A. Helis

\section{Dates of Service}

1942-1943

1943-1946

1946-1948

1948-1970

1970-1979

1980-1987

1987-1993

1993-1998

1998-2008

2010-2011

2012-present 
In May 1942, the Educational Unit of the War Shipping Administration's Division of Training moved its offices from Washington, D.C., to Kings Point in order to more efficiently develop accelerated courses and provide training to instructors (Polaris 1946b:10; Mitchell 1977:67). The department, however, retained its countrywide jurisdiction, providing guidance for the training programs at the Pacific and Gulf coast schools as well.

Prior to the war, a midshipman's training consisted of three years at sea and one year ashore. Beginning in April 1942, the training program was cut to 16 months, which included 6 months at sea, 2 weeks preliminary training, 8 weeks of basic training, and 30 weeks of advanced training (Mitchell 1977:63). On 8 December 1942, the War Shipping Administration issued emergency regulations that limited Fourth Class (freshman) instruction to 12 weeks, while Third Classmen (sophomores) spent at least 6 months at sea aboard a merchant vessel; Second and First Classmen (juniors and seniors) returned to the academy for 36 weeks of advanced training at USMMA (Polaris 1946b:42). This shortened training program continued in operation until July 1, 1944.

The academy had three academic departments: Naval Science, Engineering, and Seamanship and Navigation (Nautical Science). Two weeks of indoctrination and orientation were followed by academic training consisting of classroom work and drills. In eight weeks, midshipmen who had selected either "deck section" or "engine section" carried eight class periods and three periods of study every day (Mitchell 1977:69). With the initial 10 weeks completed, the midshipmen then took a "year at sea," which was to last at least six months. While aboard, midshipmen served as a fulltime member of the ship's company, while also pursuing studies assigned to be completed upon his return to the academy (Mitchell 1977:69-70).

While the Maritime Service was not officially a branch of the military, its officers and midshipmen could be called to active duty at any time. Since 5 October 1940, midshipmen had been enrolled as "Cadets, Merchant Marine Reserve." Accordingly, the midshipman corps standards, as far as physical health and educational qualifications, had to conform to Naval Reserve standards (Mitchell 1977:35, 72). On August 8, 1942, the Chief of Naval Personnel announced that all enrolled midshipmen were appointed as Midshipmen, U.S. Naval Reserve, resulting in an official designation of "Cadet-Midshipman" (Polaris 1946b:42). Those seeking acceptance as a cadet had to be American citizens, between the ages of 18 and 23 years, 
and 5'6" to 6'4" in height. Midshipmen had to have good eyesight and hearing and could not be color blind. A cadet also had to have completed at least 15 high school credits (USMM 2002b; Mitchell 1977:72). During the war, some waivers were allowed concerning the age and education requirements, but no waivers were granted on the color-perception, vision, or hearing requirements-senses that were essential in performing the duties of a mariner.

\subsubsection{Formal dedication}

In July 1942, there were 739 midshipmen at the academy; one year later, July 1943 , there were nearly 2,500 midshipmen at USMMA (Polaris 1946b:42; 1958a:7). On 30 September 1943, "Dedication Day," official dedication services for the new academy were held in O'Hara Hall and were broadcast over national radio (Polaris 1958a:9) (Figure 40). By this time, most buildings, streets, and other structures of consequence had been christened with names of naval heroes, sea captains, naval designers, authors, scientists, inventors, ship owners, legislative supporters, and maritime labor leaders. The academy's third Superintendent, Admiral Richard McNulty, endorsed the program of naming the buildings in honor of historic persons, ships, or events associated with the nation's maritime history as a way to give the new academy "roots" and a sense of its heritage (Mitchell 1977:91). It was ADM McNulty's wife who also coined the motto for the academy and corps: Acta Non Verba (deeds not words). 
Figure 40. Dedication Day for USMMA at O'Hara Hall, 30 September 1943 (Bland Library, USMMA).

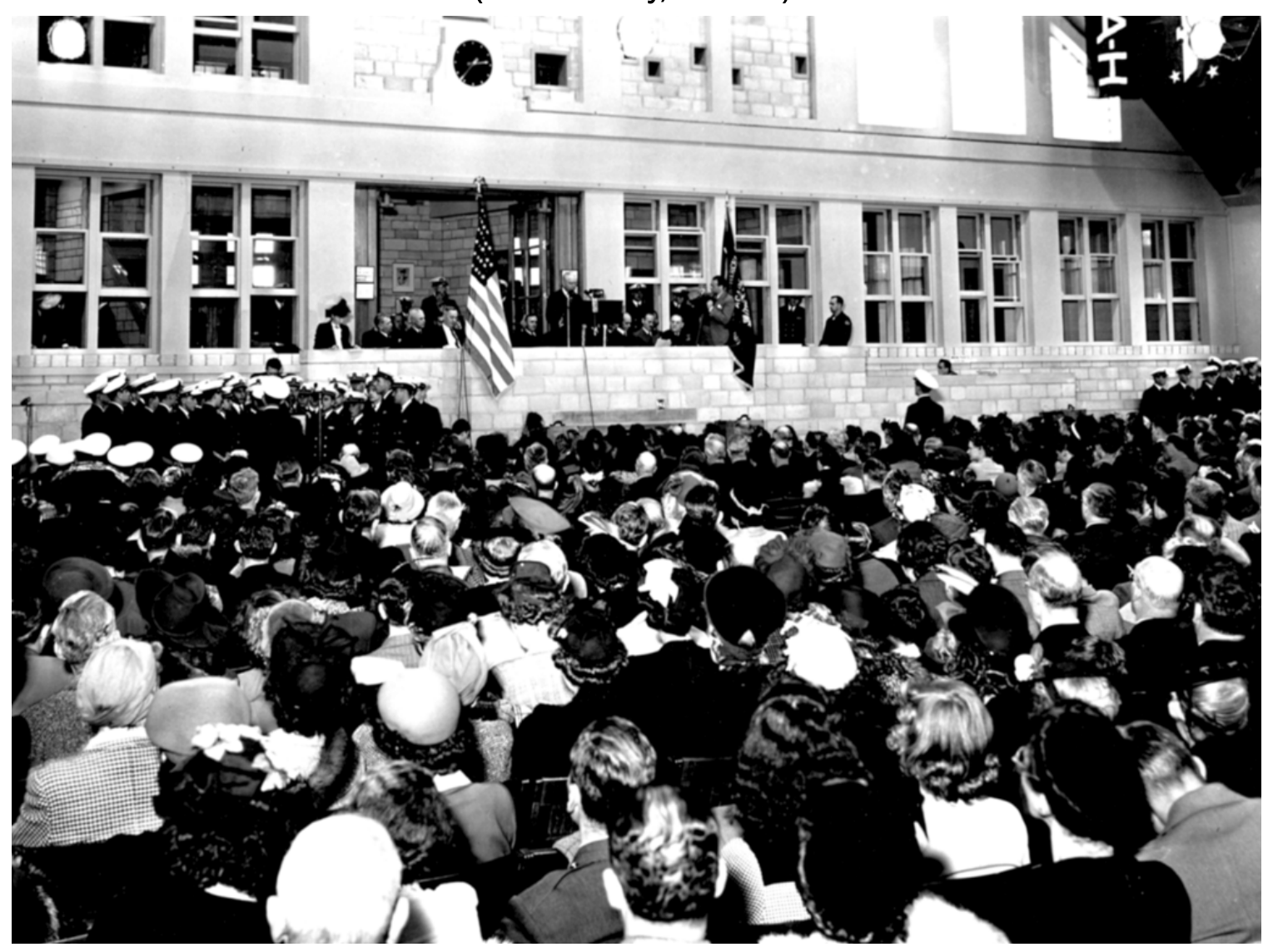

\subsubsection{Wartime service}

As mentioned, during World War II, the United States' merchant fleet of ships was in effect "nationalized" by the federal government. The government controlled the cargo and its destination and contracted with private companies to operate the ships. Cargo included gasoline, food, vehicles, medicine, war supplies, and even the mail. The government also placed Navy personnel and guns on the vessels. With the establishment of USMMA, the government also trained the men who would operate the ships and would provide military defense of the ships at sea (USMM 2002a).

Since the Merchant Marine was not an official military branch during World War II and official records were not kept, estimates vary as to the number of mariners who served during combat. A 1946 press release from the War Shipping Administration stated that 243,000 mariners had served, while some estimates go as high as 285,000. The total number of Merchant Marine casualties is estimated at 9,349 (USMM 2002a). Com- 
pared with the other branches of service (Marines, Army, Navy, Coast Guard), the Merchant Marine had the highest percentage of personnel loss during the war (3.85 percent). Despite their contribution, members of the Merchant Marine do not receive veteran status for their service, although some World War II mariners and others have successfully sought veteran status and benefits (USMM 2002a).

\subsubsection{The Academy after World War II}

After World War II, the mission of USMMA remained the same as it had been during the war-the academy was there to educate and train Merchant Marine officers. The Merchant Marine training program was once again extended from its condensed 16-month program back to a fouryear program, one year of which was spent at sea. As discussed above, the basic cadet schools at San Mateo and Pass Christian were closed in 1947 and 1950, respectively, leaving Kings Point as the sole federal maritime training school. In 1949, Congress approved the granting of Bachelor of Science degrees to USMMA graduates. In 1956, after some campaigning to close Kings Point, President Dwight Eisenhower signed a Congressional Bill making Kings Point a permanent federal facility (Polaris 1958a:9). Although it had received permanent status, tight budgets meant that little physical change occurred at Kings Point during the 1950s. It would be in the next decade that significant additions were made to the campus facilities.

\subsubsection{New construction}

While chapel services had long been held in the music room of the former Chrysler house (Wiley Hall), which was equipped with a pipe organ, members of the Merchant Marine were eager to provide a suitable place of worship on the Kings Point campus. Plans for construction of a chapel had been discussed as early as 1942-43, but funding was not available. The Academy plan for new 1945 construction contained a request for a new chapel and provided a sketch showing a Gothic Revival Style structure, but it was not built (USMMA 1944). In the early 1950s, the Merchant Marine Memorial Chapel Fund was begun to provide for the design and construction of a non-sectarian chapel that was intended to serve as a memorial to merchant seaman who were killed during the World Wars (Polaris 1950a:12). Initially, the drive sought $\$ 500$, o0o for the building program; in 1959, it was reported that the total cost for construction and furnishing was estimated at $\$ 720,000$, of which $\$ 620,000$ had been raised (Polaris 
1959a:19). Donations, however, kept pace with the increase, and construction began that year. By 1961, the chapel was completed (Figure 41).

Figure 41. Memorial Chapel, with Kings Point Light navigational beacon visible in the steeple, 1960 (Bland Library, USMMA).

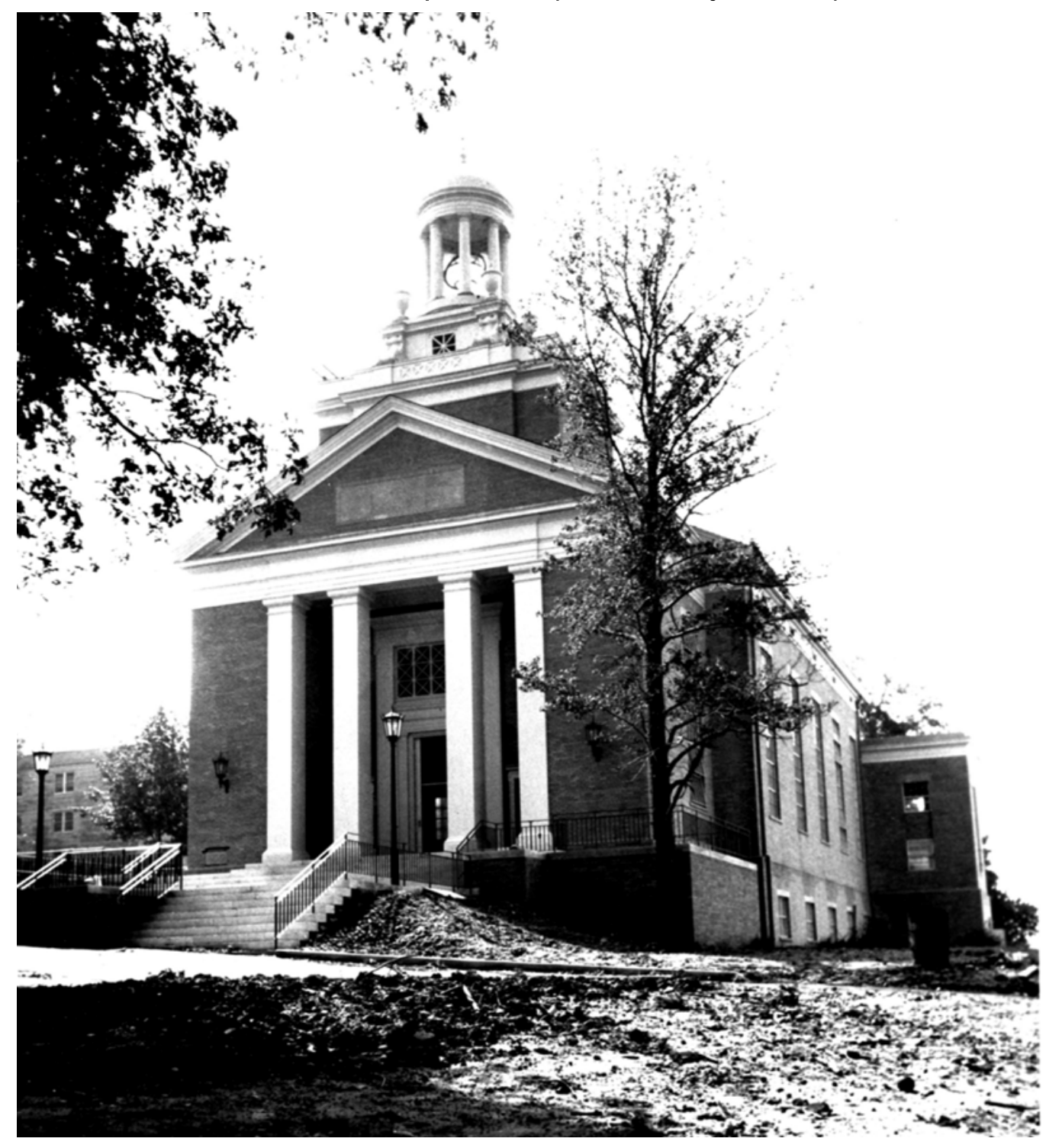

The chapel was designed by the architectural firm of Eggers \& Higgins of New York and constructed by the Fisher-Malik Company of Long Island. Sited northwest of the Land Building (Activities Building) and southwest of Wiley Hall (Administration Building), the chapel faces north on a bluff overlooking Long Island Sound. The chapel contains a sanctuary and chaplain offices. Conceived as a "national memorial to the members of the American merchant service," the chapel contains a "Roll of Honor Book," which lists the name, rank or rating, and ship and date of sinking of over 
7,000 officers and seamen who lost their lives on merchant ships during both World Wars (Polaris 1951:6; USMMA 2002b). An engraved panel above the chapel's portico states:

This Chapel is built to the glory of God and to commemorate the sacrifices of the officers and men of the United States Merchant Marine who gave their lives at sea, in enemy action, in World Wars I and II and whose names are recorded in its Roll of Honor.

Donated by the Class of 1954 and erected in 1960, the classical steeple designed for the chapel, known as "Kings Point Light," serves as a navigational beacon. The Coast Guard approved the establishment of the light which is located 102 feet above water with 1,200 candlepower and a 1.0second flash (Polaris 1960:28; 1961:14). The chapel underwent exterior renovation and provision of handicap access in 2005.

Improvements were also made during the 1960 s to the academy's waterfront facilities. The existing Chrysler dock had been extended and enlarged during the 1940s, and additional buildings had been constructed along the shoreline; however, twenty years later, much needed renovations were taking place to the outmoded facilities (Polaris 1963:27). The multi-step program of improvement included the construction of three floating finger piers along the east side of the main Academy docking facility, Mallory Pier; dredging of Hague Basin; construction of a two-story building on land reclaimed by the deposition of dredge materials; and the construction of an observation platform on top of the Crowninshield boat shed (Polaris 1963:27). While the latter two projects were not realized, dredging of the basin, reclamation of about three acres, and construction of a new sea wall was completed. Additional rip rap breakfront was also added to the shoreline.

A 1944 plan also contained a request for a new academic library, stating that adequate space, accessibility, collections, and professional staff were essential in reaching a high academic standard for the Academy (USMMA 1944). ${ }^{8}$ A proposed building was designed in the Classical Revival Style, but this design was never constructed. Beginning in mid-1942, the academy library had consisted of a random collection of reading material, largely provided by community donation, which was housed in areas of the

8 This paragraph and the one that follows are a combination of text extracted from Berger, Cultural Resources Survey Report, and content added by ERDCCERL authors. 
Chrysler and Schenck houses. By August 1943, the library had secured space in Bowditch Hall, where it remained for the next 25 years. The overcrowded conditions, and the need to provide a research and study facility for the midshipmen, resulted in the construction of the Brutalist three-story Schuyler Otis Bland Memorial Library (at the north end of the central core of buildings between Fulton and Bowditch Halls [Figure 42]). The new library building was designed by the chapel's architectural firm of Eggers \& Higgins, and it was the culmination of over 25 years of urging by the Board of Visitors for a permanent library. Constructed by the Frank L. Marino Corporation, the library was dedicated on 12 December 1968. The completion of this building formally closed the quadrangle of buildings making up the core of the USMMA campus, finalizing in concrete the original design intent for the campus. The campus has largely retained this configuration and appearance to the present (Figure 43).

Figure 42. Newly finished Schuyler Otis Bland Library, 1969 (Bland Library, USMMA).

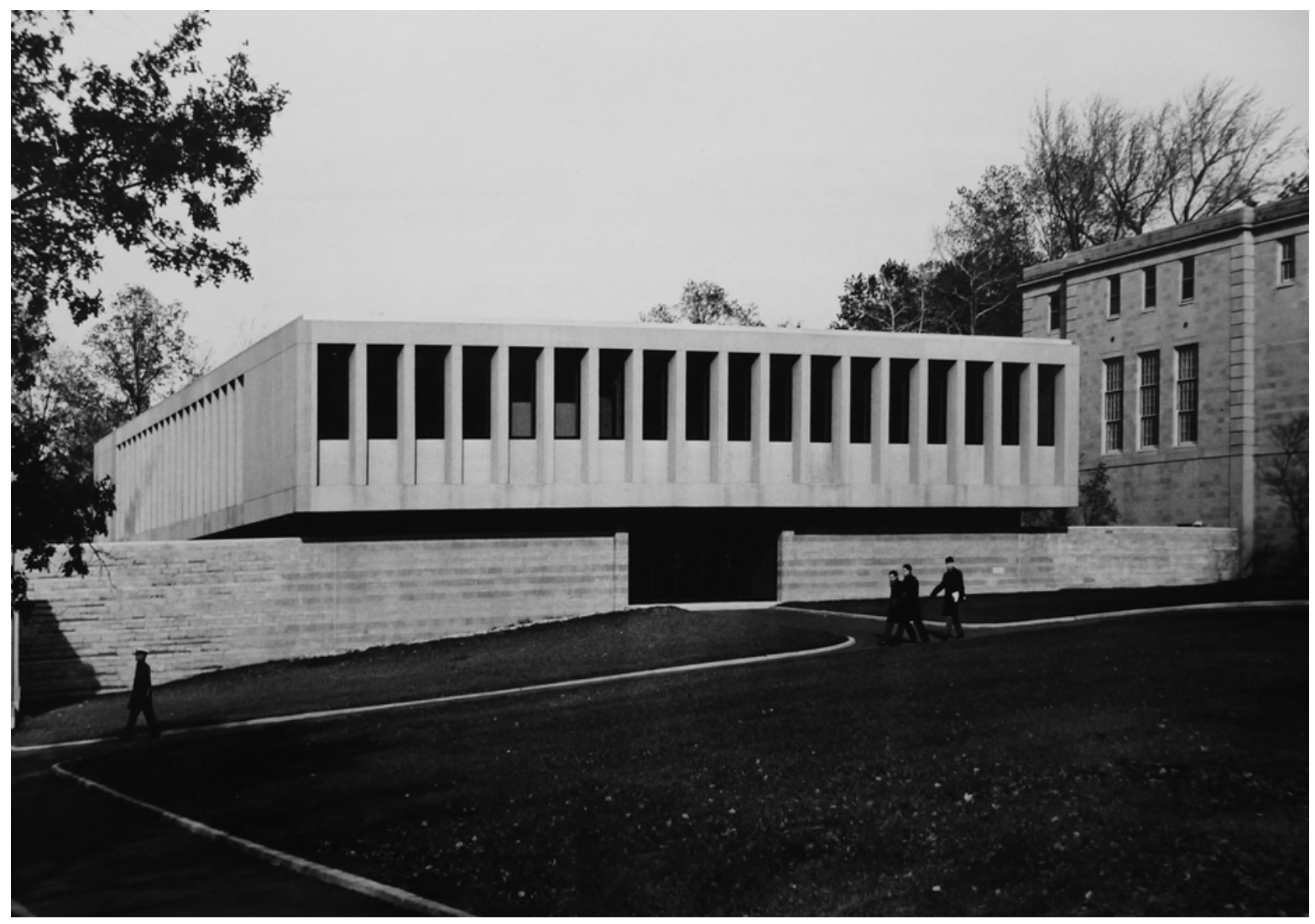


Figure 43. USMMA as it appeared in 1969 (Bland Library, USMMA).

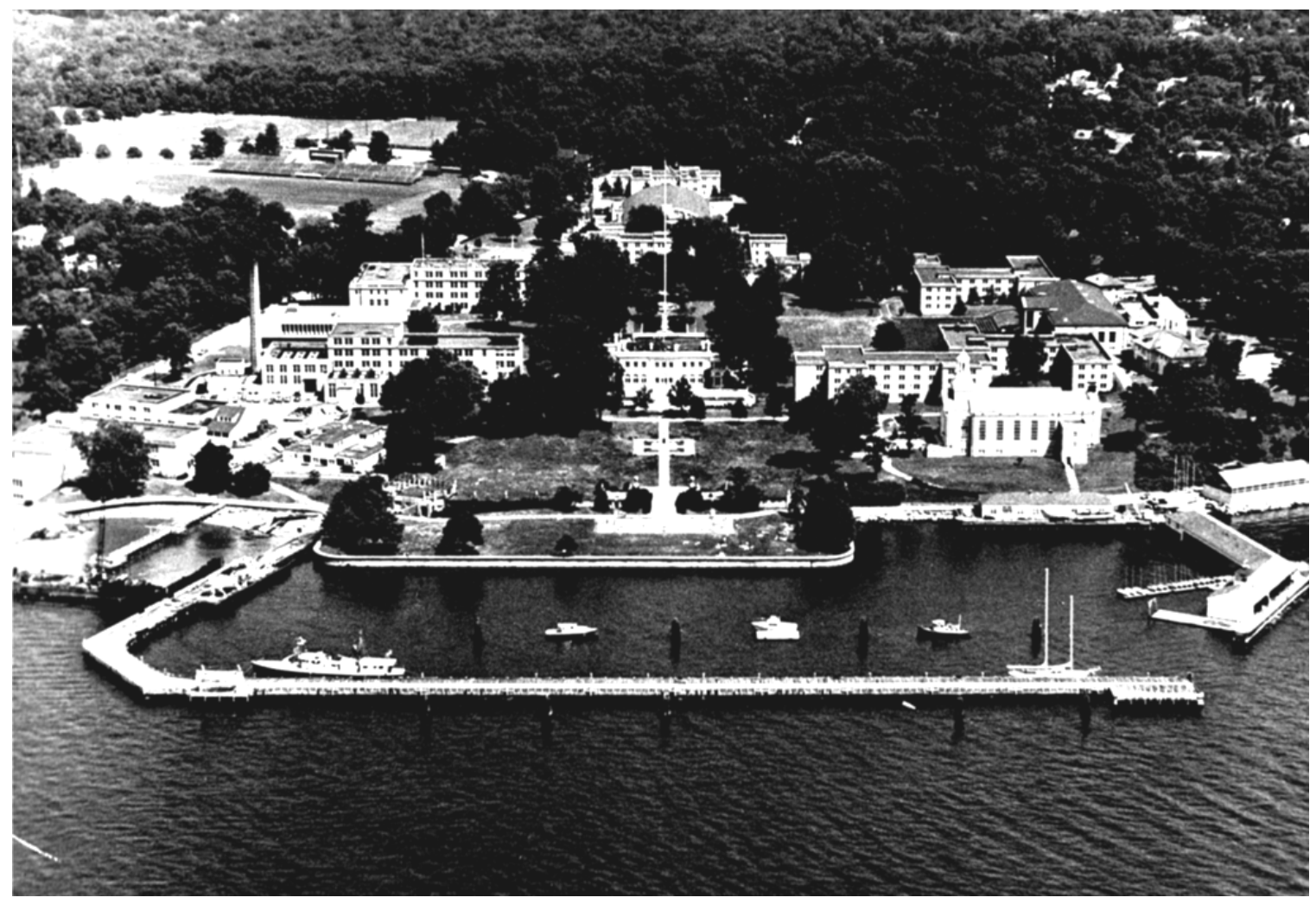

A number of projects were part of a $\$ 1.8$ million renewal program in 1974-75 which upgraded facilities at USMMA. In 1974, a complex of floating piers was added to the Academy's waterfront, along with a renovation of Mallory Pier, and the addition of a 50-ton walking lift for fleet maintenance. At some point after 1969, the bathing beach was filled in to a line that extended farther into the sea than the Chrysler seawall, and the fill became the site of new construction; this work may have been part of the larger renewal program. All 452 midshipman rooms were refurbished with painting, new closets and desks, and carpeting. The athletic field received an all-weather track, classroom buildings were enlarged and modernized, and Samuels Hall received a new wing in 1974. That same year, the Alumni Association raised $\$ 300,000$ to add a large dining and meeting area to Melville Hall (King's Point Newsletter 1975:4).

In 1975, the USMMA Alumni Association purchased the eight-acre Barstow estate, ${ }^{9}$ which lay adjacent to the USMMA campus on the north side of Steamboat Road, through its Kings Point Fund, Inc. The park-like estate consisted of the fully furnished 20-room main dwelling on the 
waterfront, terraced gardens, a four-car garage with apartment above, a guest house, a superintendent's house, a tea house, and a greenhouse (Morgan Guaranty Trust Company 1975). The purchase of the estate, designated as "McNulty Campus," ensured that "the last sizeable tract available in the immediate vicinity [of the campus] was secured to allow space for future growth and development of the Academy" (Kings Point Newsletter 1975:1). The Barstow mansion is now used as the American Merchant Marine Museum and provides space for special events. The secondary residences on the estate are now used as staff quarters.

The Alumni Association, which has played a major role in the late twentieth-century development of the campus, also helped to raise funds for the construction of a grandstand at Tombs Field in 1977 and the natatorium addition to O'Hara Hall in 1978. Berger Hall was constructed in 1985 as an administrative facility, as were Buildings $\mathrm{A}$ and $\mathrm{B}$ of the Department of Facilities Management (western edge of Athletic Field). In 1988, Fulton Hall received a new wing (Gibbs Hall) for academic use. The Yocum Sailing Center, constructed in 1994 and also funded by alumni, is the most recent addition to USMMA's waterfront facilities. The center provides storage, maintenance, and class space for the academy's sailing teams and clubs and other waterborne extracurricular activities.

\subsection{Academic program}

While the curriculum of the academy has changed significantly over the years, the mission of USMMA today remains essentially the same as it was in 1942:

\footnotetext{
To educate and graduate professional officers and leaders of honor and integrity who are dedicated to serving the economic and defense interests of the United States in our Armed Forces and Merchant Marine, and who will contribute to an intermodal transportation system that effectively ties America together [USMMA 2002a].
}

The academic program at the academy has changed over the years as new technology has been introduced and as the world moved into the atomic age. Accelerated classes were once again offered during the Korean and Vietnam war eras. Midshipmen at USMMA were the first to train as officers aboard the first U.S. nuclear-powered merchant ship, the Savannah (Polaris 1958b:8-9; USMMA 2001:7). Since USMMA is a fully accredited four-year degree-granting institution, beginning in 1968, the academic ad- 
visory committee instituted a new program with an increase in hours spent in general education, including English, history, and other liberal arts disciplines, to provide midshipmen with a more well-rounded education $(\mathrm{Po}-$ laris 1965:15). Social sciences, communications, and other courses are also offered.

In 1974, the Academy became the first federal service school to enroll women students (USMMA 2001:7). Each year approximately 260 "plebes" (new students) enter the academy. Total annual enrollment at USMMA is about 950 midshipmen. Qualifications for admission include meeting specified age and physical requirements as well as educational requirements. In addition, each candidate must be nominated by his or her Congressional member. Graduating midshipmen receive a B.S. in their chosen field of discipline, and are awarded a merchant marine license as third mate or third assistant engineer and a reserve or active duty appointment as a commissioned officer in the U.S. Armed Forces (USMMA 2001:97). Pursuant to the Maritime Education and Training Act of 1980, USMMA receives financial assistance from the Department of Transportation's Maritime Administration (MARAD) in training merchant marine officers. MARAD also supports six other state maritime academies.

Academic departments at USMMA include engineering, humanities, marine transportation, mathematics and science, naval science, and physical education and athletics. Midshipmen select their major course of study from USMMA's seven programs, which determines the type of license they receive upon graduation. The programs offered include: marine transportation, maritime operations and technology, logistics and intermodal transportation, marine engineering, marine engineering systems, marine engineering and shipyard management, or a dual license combining marine engineering and marine transportation studies. Regardless of the major field of study, all midshipmen will spend approximately one year at sea (USMMA 2001:25-26). 
(This page intentionally left blank.) 
3 Analysis

\subsection{Summary of the district}

The USMMAHD is a compact district whose boundary encompasses the heart of the USMMA campus plus the Gold Coast mansions to the south of the main academic buildings (sketch map reproduced again here as Figure 44). From a total of 49 features located within the district, there are 39 contributing and 10 noncontributing features (Table 2).

Figure 44. Sketch map of USMMA historic district, with numbered properties shown within bold outline of the district. (USMMA DPW with modifications by ERDC-CERL).

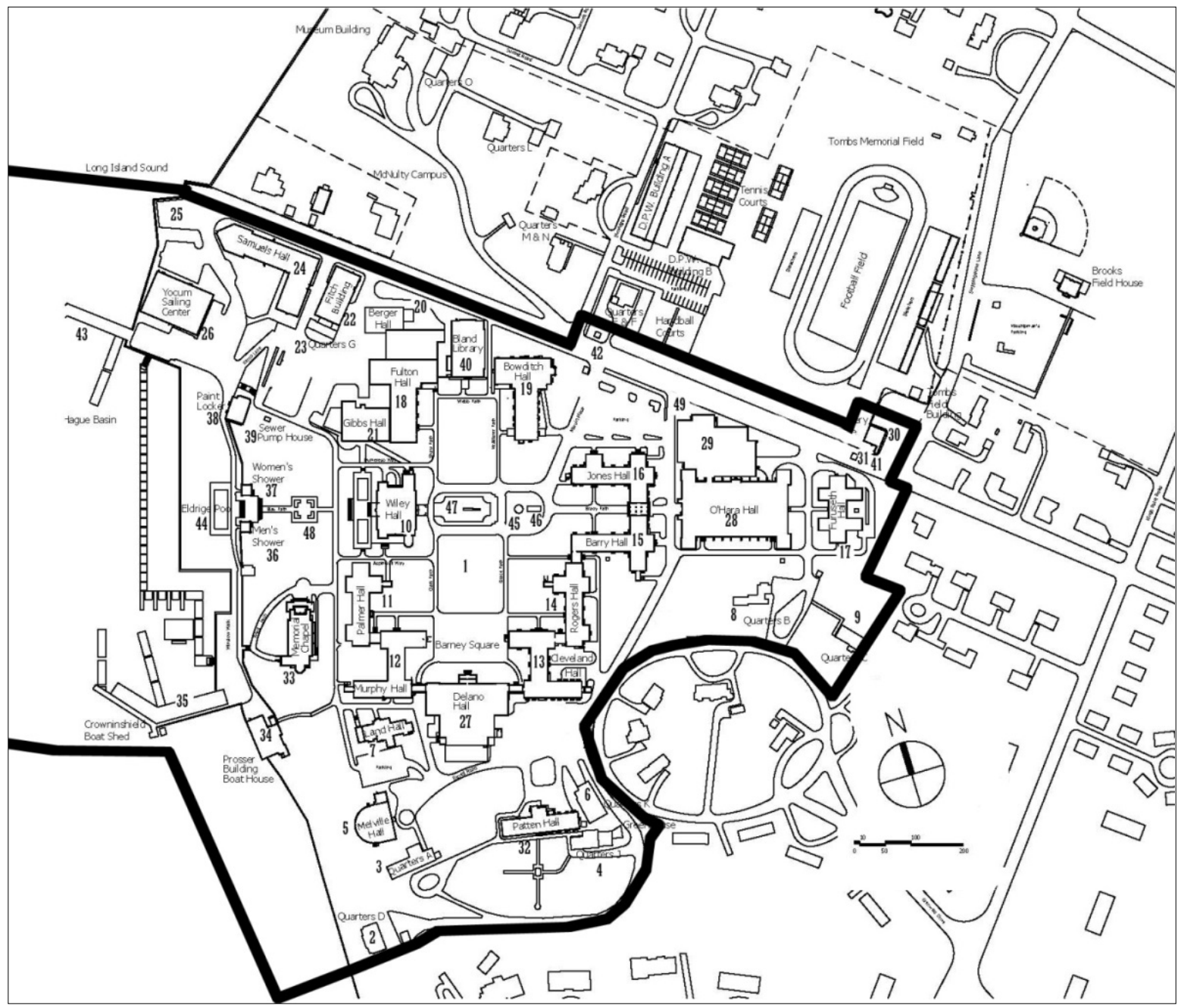


Table 2. List of contributing and noncontributing features.

Numbers in first column refer to site sketch map locations (see Figure 44).

\begin{tabular}{|c|c|c|}
\hline $\begin{array}{l}\text { Feature Type } \\
\text { and Site Map } \\
\text { Number }\end{array}$ & Description of Feature & $\begin{array}{l}\text { Contributing or } \\
\text { Noncontributing } \\
\text { Status }\end{array}$ \\
\hline \multicolumn{3}{|c|}{ Site (1 contributing) } \\
\hline 1 & $\begin{array}{l}\text { Topography, landscape, viewsheds, layout, and } \\
\text { circulation }\end{array}$ & Contributing \\
\hline \multicolumn{3}{|c|}{ Buildings (30 contributing, 9 noncontributing) } \\
\hline 2 & Quarters D (Grenwolde Casino) & Contributing \\
\hline 3 & Quarters A (Neiley Estate - Main House) & Contributing \\
\hline 4 & Quarters J (Neiley Estate - Garage) & Contributing \\
\hline 5 & Melville Hall (Meighan Estate) & Contributing \\
\hline 6 & Quarters K (Meighan Estate - Garage) & Contributing \\
\hline 7 & Land Hall (Schenck Estate) & Contributing \\
\hline 8 & Quarters B (a Grenwolde house) & Contributing \\
\hline 9 & Quarters C (Vreeland house) & Contributing \\
\hline 10 & Wiley Hall (Bendel/Chrysler Mansion) & Contributing \\
\hline 11 & Palmer Hall & Contributing \\
\hline 12 & Murphy Hall & Contributing \\
\hline 13 & Cleveland Hall & Contributing \\
\hline 14 & Rogers Hall & Contributing \\
\hline 15 & Barry Hall & Contributing \\
\hline 16 & Jones Hall & Contributing \\
\hline 17 & Furuseth Hall & Contributing \\
\hline 18 & Fulton Hall & Contributing \\
\hline 19 & Bowditch Hall & Contributing \\
\hline 20 & Berger Hall & Noncontributing \\
\hline 21 & Gibbs Hall & Noncontributing \\
\hline 22 & Fitch Building & Contributing \\
\hline 23 & Quarters G & Noncontributing \\
\hline 24 & Samuels Hall & Contributing \\
\hline 25 & Coast Guard Station & Noncontributing \\
\hline 26 & Yocum Sailing Center & Noncontributing \\
\hline
\end{tabular}




\begin{tabular}{|c|c|c|}
\hline $\begin{array}{l}\text { Feature Type } \\
\text { and Site Map } \\
\text { Number }\end{array}$ & Description of Feature & $\begin{array}{l}\text { Contributing or } \\
\text { Noncontributing } \\
\text { Status }\end{array}$ \\
\hline 27 & Delano Hall & Contributing \\
\hline 28 & O’Hara Hall & Contributing \\
\hline 29 & Natatorium & Noncontributing \\
\hline 30 & Admissions Center & Contributing \\
\hline 31 & Guard Shack & Noncontributing \\
\hline 32 & Patten Medical Clinic & Contributing \\
\hline 33 & U.S. Merchant Marine Memorial Chapel & Contributing \\
\hline 34 & Boat House (Schenck Estate swimming pool) & Noncontributing \\
\hline 35 & Crowninshield Pier and Boat House & Contributing \\
\hline 36 & Men's Shower & Contributing \\
\hline 37 & Women's Shower & Contributing \\
\hline 38 & Paint Locker & Contributing \\
\hline 39 & Sewer Pump House & Noncontributing \\
\hline 40 & Bland Library & Contributing \\
\hline \multicolumn{3}{|c|}{ Structures (4 contributing) } \\
\hline 41 & Vickery Gate & Contributing \\
\hline 42 & Marvin Place Gate & Contributing \\
\hline 43 & Mallory Pier & Contributing \\
\hline 44 & Eldridge Pool & Contributing \\
\hline \multicolumn{3}{|c|}{ Objects ( 4 contributing, 1 noncontributing) } \\
\hline & Flagpole & Contributing \\
\hline & Amphitrite Pool & Contributing \\
\hline & Gun (5-inch deck gun) & Contributing \\
\hline & War Memorial & Contributing \\
\hline & Mariner Monument & Noncontributing \\
\hline
\end{tabular}

The remainder of this chapter describes the contributing buildings and structures of USMMAHD by listing the character-defining features that remain, the character-defining features that have been removed (if any), 
and the nonhistoric features (if any). ${ }^{10}$ Various photos that highlight these features are included with each subsection (Figure 45 - Figure 211).

\subsection{Buildings}

\subsubsection{Quarters D (Grenwolde Casino)}

Quarters D is a contributing feature of the USMMAHD. The interior is noncontributing. It was constructed in 1912 for use by the Grenwolde Association as a bathhouse and recreation building (then called Grenwolde Casino), and it is the oldest building on the USMMA campus. It is a rectangular two-story house. The east side of the house is built into the side of the bluff, so the entrance to the house is on the second floor. The west side faces out to Long Island Sound and is a full two stories in height. The west side has an open loggia (a remnant of a wraparound veranda) on the top floor and a three-arched arcade on the ground floor. The walls are covered in stucco, and it has a hipped roof covered in asphalt shingles. The original style of the building was Italian Renaissance Revival.

Figure 45. West façade of Quarters D (Grenwolde Casino) in 1912 (The Sun).

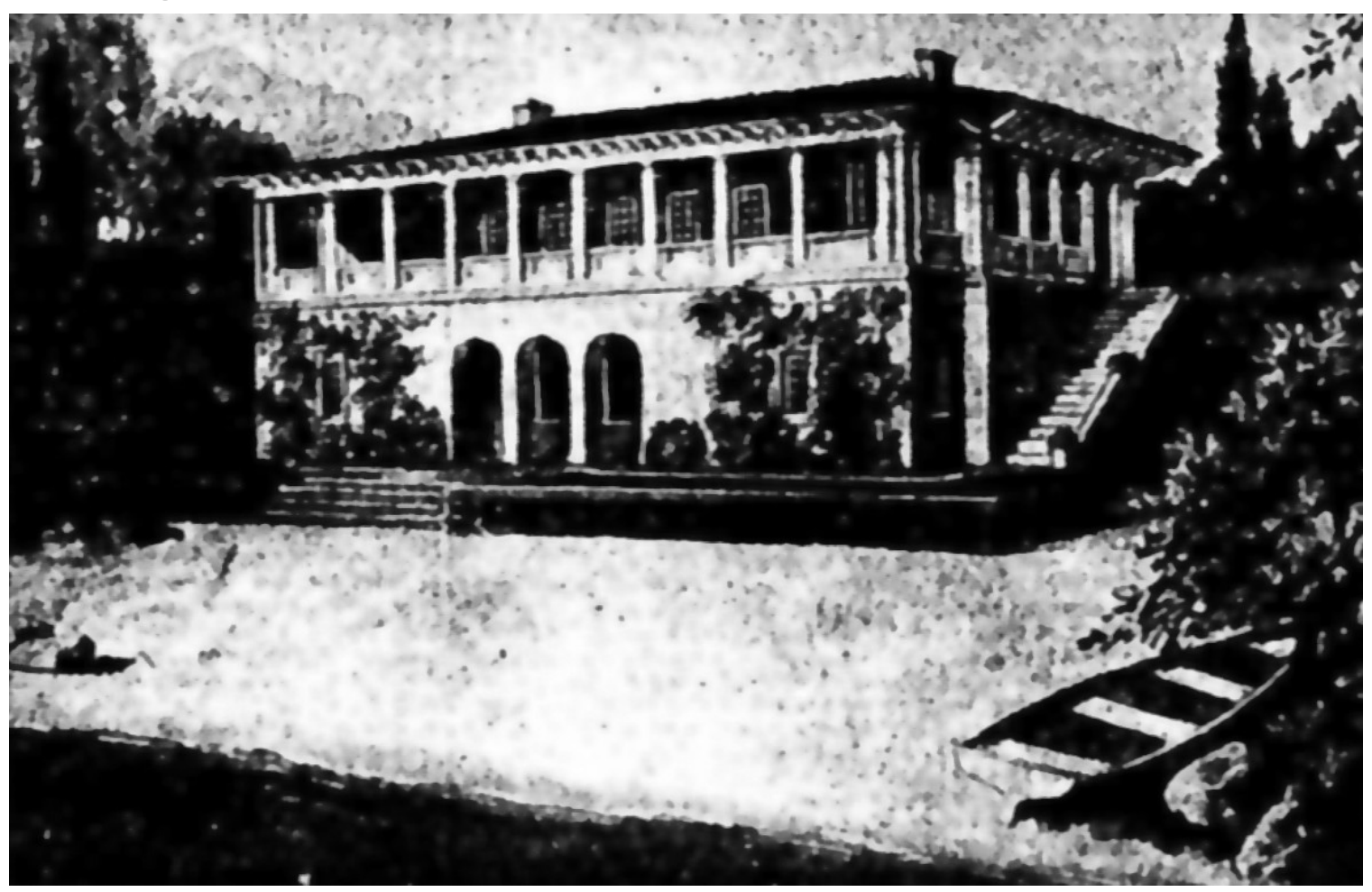

10 Features of the character-defining objects are not discussed in the subsections because the entire object itself is character-defining. 
Figure 46. West façade of Quarters D (Grenwolde Casino) (USMMA, 2013).

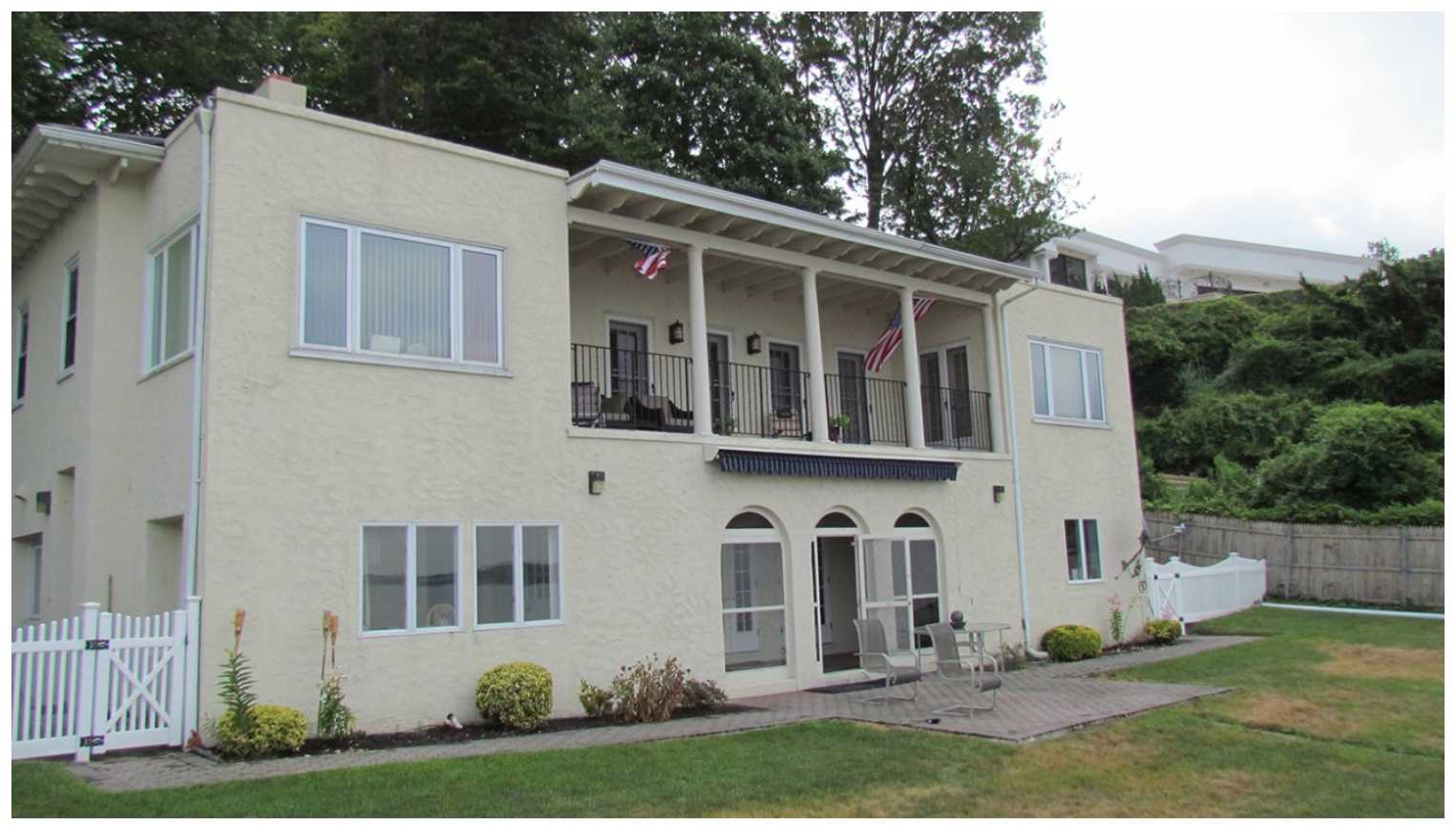

\subsubsection{Character-defining features}

Repair, renovation, and replacement of the following character-defining features of Quarters D must be coordinated with the New York State Historic Preservation Office (NY SHPO).

- Overall massing

- Footprint

- Roof shape

- Rafter tails

- Stucco

- Three arched openings on the ground level of the west façade

- Partial veranda on the first level of the west façade

\subsubsection{Character-defining features that have been removed}

Listed below are character-defining features of Quarters D that have been removed or replaced over the years; as future renovations occur, these need to be replaced with elements that replicate the original characterdefining features of the building. The historic photograph will guide this process in coordination with the NY SHPO.

- Windows

- Doors 


\subsubsection{Nonhistoric features}

- Enclosed portions of the veranda on the first floor

\subsubsection{Quarters A (Neiley Estate - main house)}

Quarters A (Neiley house) is a contributing feature of the historic district, although the interior is noncontributing. The building was designed by Caretto \& Forster and completed at the latest by 1915. It was part of the Grenwolde development. It is a large Dutch Colonial revival house with a large ell to the north. It is one-and-one-half stories tall, and the half story has almost full-width shed dormers. The house is brick that is painted white, and the roof is covered in slate. At some point the house was extended seamlessly to the west.

Figure 47. South façade of Quarters A (Neiley house) in 1915 (Architecture).

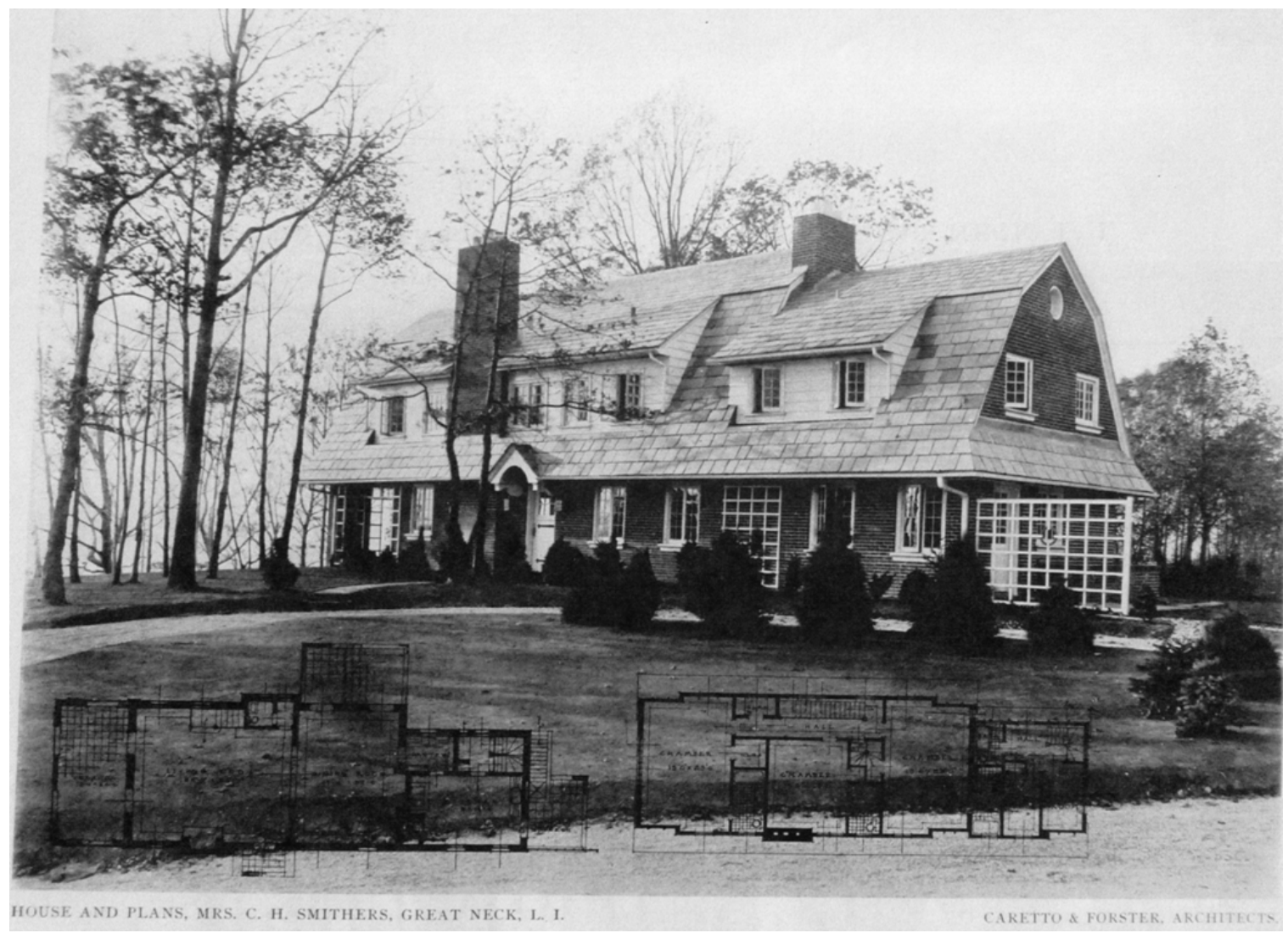


Figure 48. South façade of Quarters A (Neiley house) (ERDC-CERL, 2013).

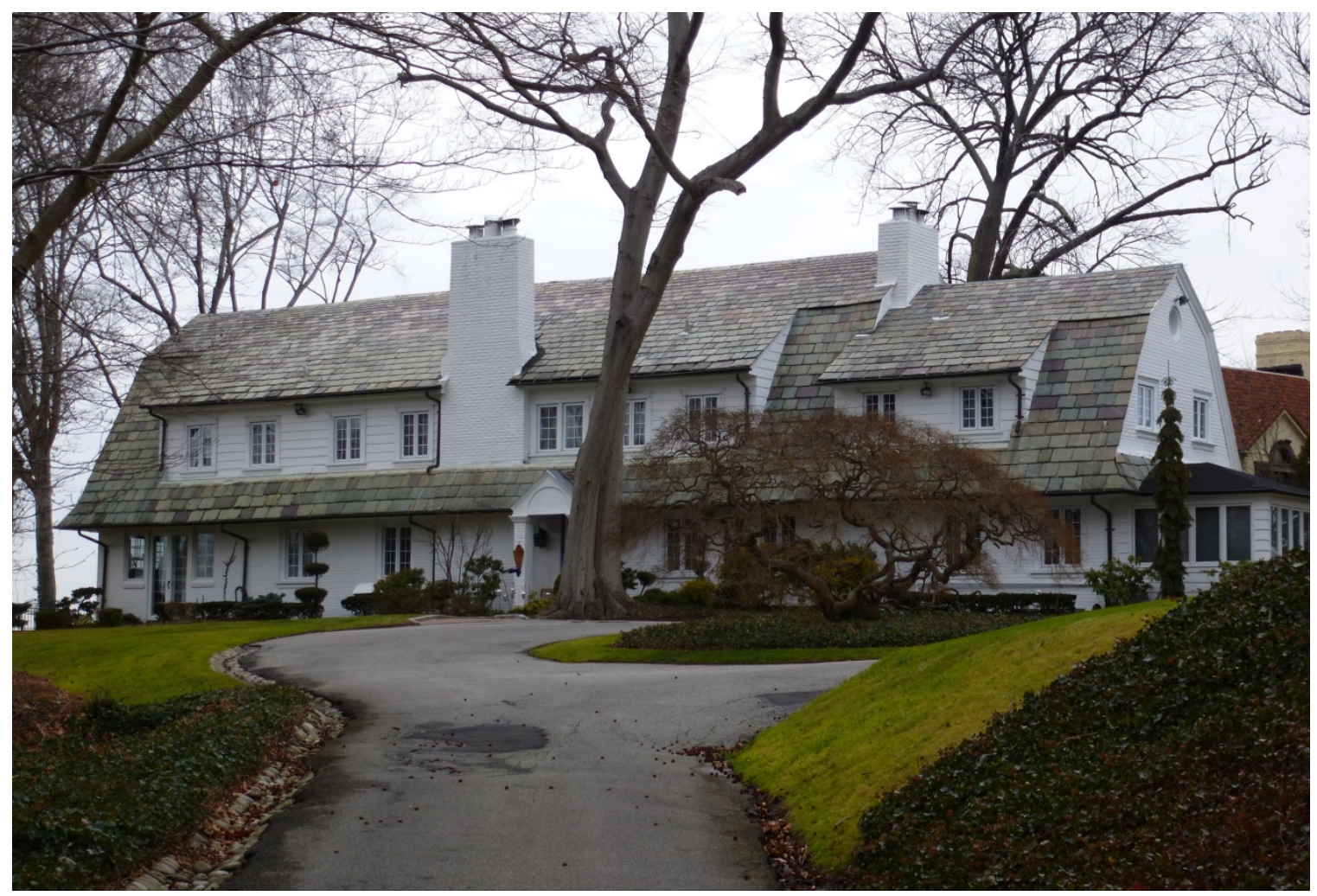

Figure 49. North façade of Quarters A (Neiley house) (ERDC-CERL, 2013).

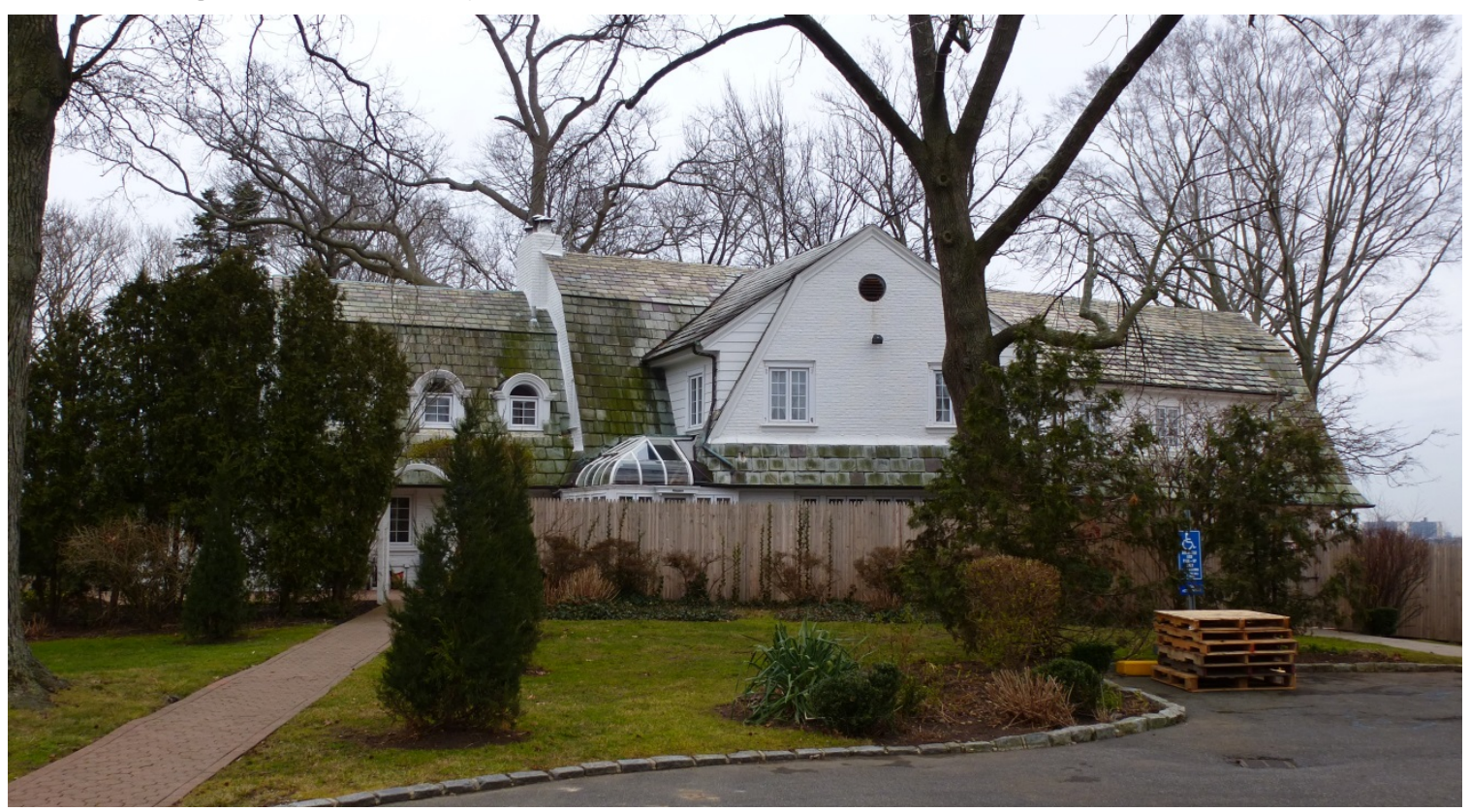




\subsubsection{Character-defining features}

Repair, renovation, and replacement of the following character-defining features of Quarters A must be coordinated with the NY SHPO.

- Overall massing

- Footprint

- Roof shape

- Roof material

- Brick

- Window placement

- Door placement

- Chimneys

- Addition to the west

\subsubsection{Character-defining features that have been removed}

Listed below are character-defining features of Quarters A that have been removed or replaced over the years; as future renovations occur, these need to be replaced with elements that replicate the original characterdefining features of the building. The historic photograph will guide this process in coordination with the NY SHPO.

- Windows

- Doors

- White paint (it could not be determined when Quarters A was painted white)

\subsubsection{Quarters J (Neiley Estate - garage)}

Quarters $\mathrm{J}$ is a contributing part of the USMMA historic district, but its interior is noncontributing. Quarters $\mathrm{J}$ was originally the garage and chauffeur apartment for Quarters A. It is not known when Quarters J was constructed, but it was probably at the same time as Quarters A. The building is in the Dutch Colonial Revival Style and is one-and-one-half stories with large shed dormers on the north and south sides of the roof. There are one-story additions to the building on the east, west, and north sides. The building is constructed of brick, and the gambrel roof is covered with asphalt shingles. There is a large greenhouse attached to the quarters on the east side. The original garage is still a garage, but the additions to either side afford entrance to the newer house portions of the building. 
Figure 50. Southwest oblique of Quarters J (Neiley garage), 1919

(Arts and Decoration).

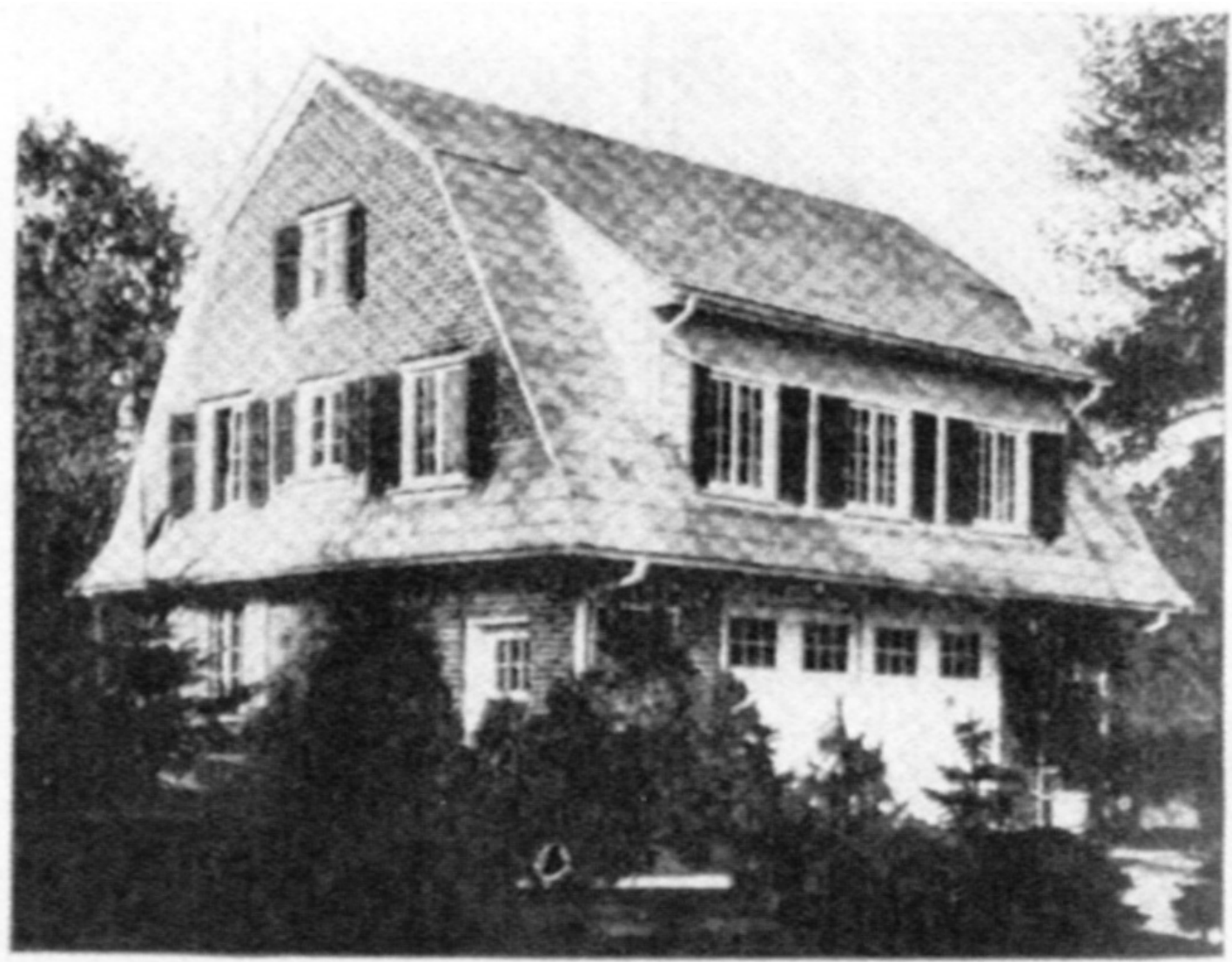

Figure 51. South façade of Quarters J (Neiley garage) (ERDC-CERL, 2013). (NOTE: large, beige building on left is not part of the quarters.)

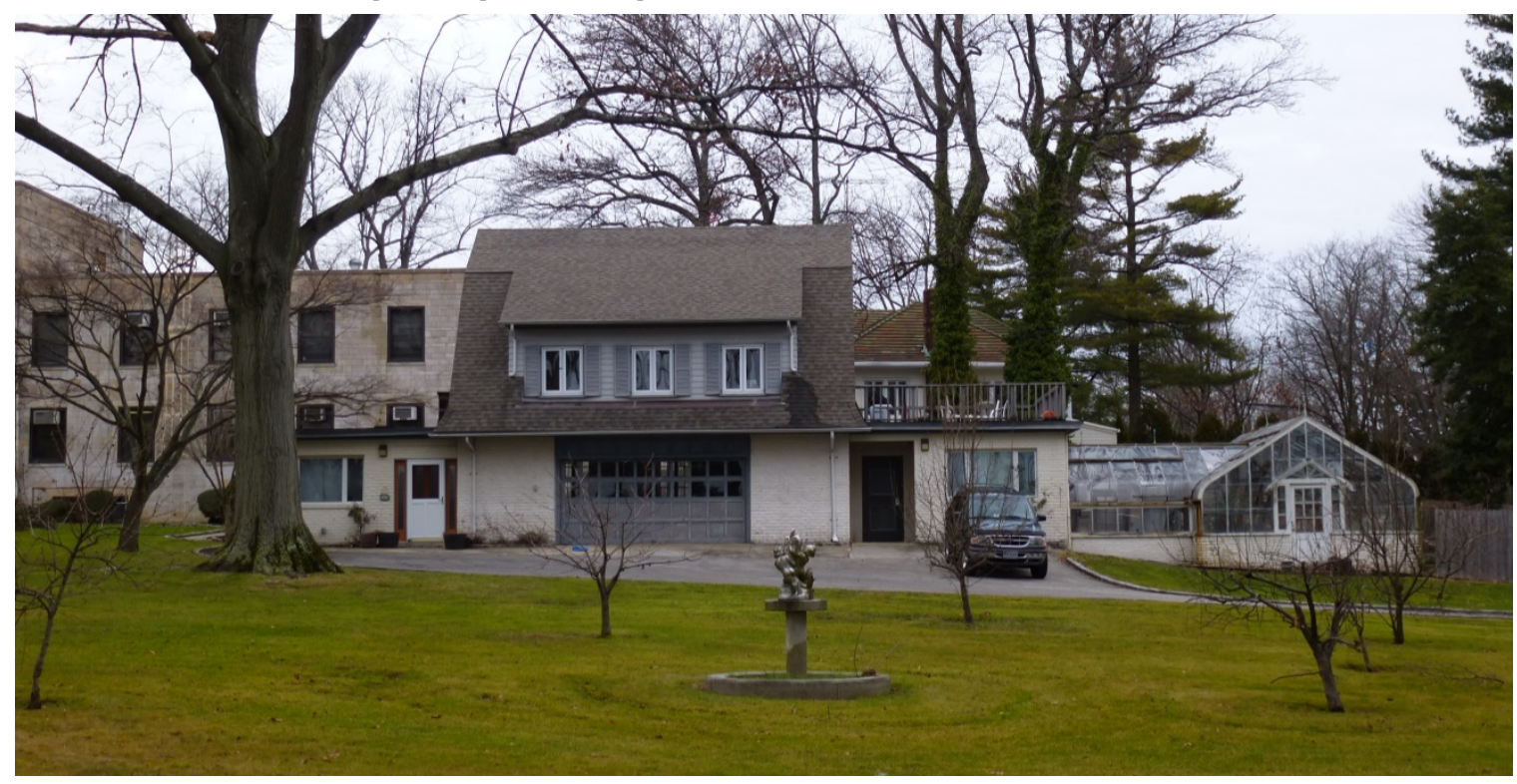


Figure 52. Southwest oblique of Quarters J (Neiley garage) (ERDC-CERL, 2013).

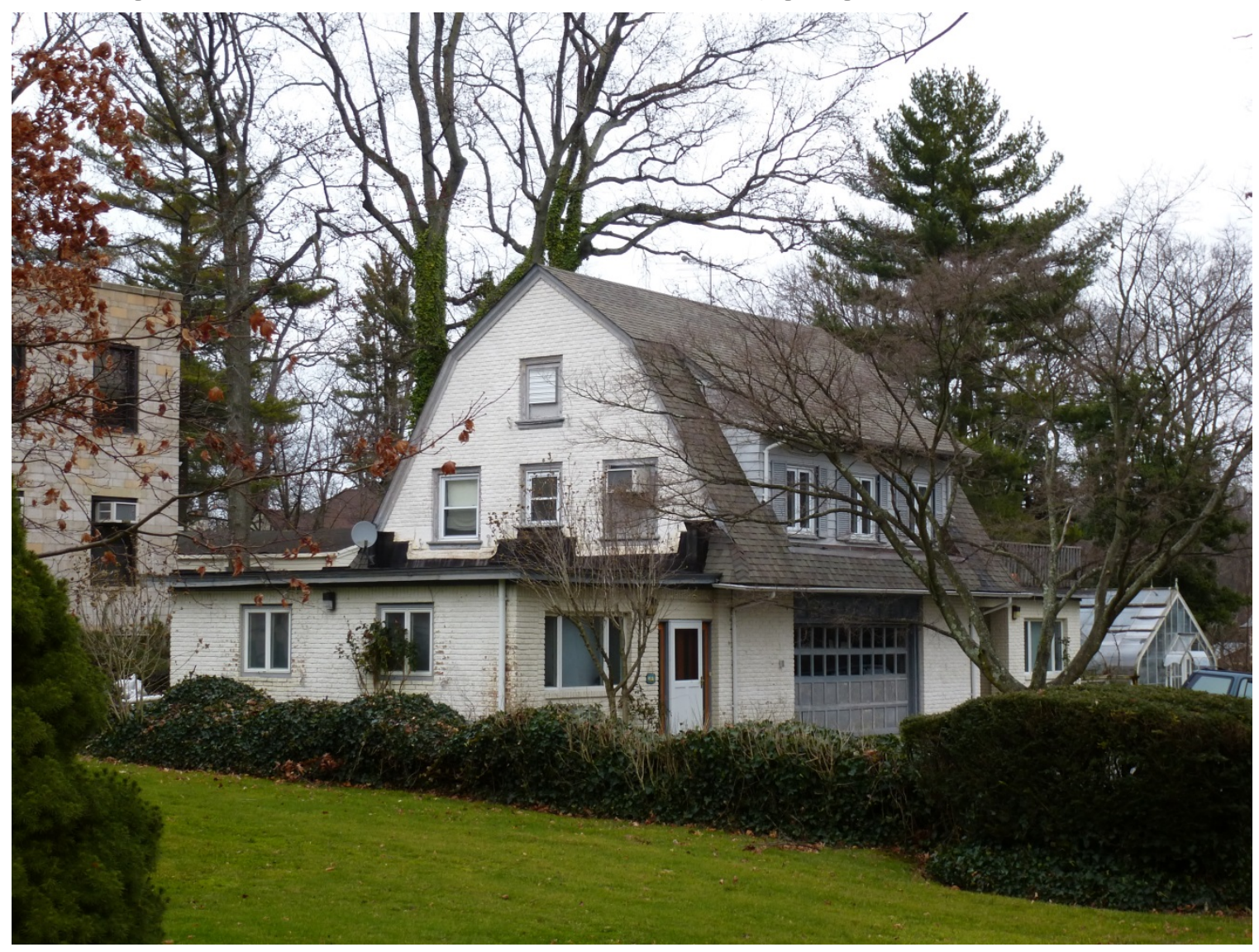

\subsubsection{Character-defining features}

Repair, renovation, and replacement of the following character-defining features of Quarters J must be coordinated with the NY SHPO.

- Massing of the central one-and-one-half-story section

- Roof shape of the central one-and-one-half-section

- Roof material

- Brick

- Window placement of the central one-and-one-half-story section

- Door placement of the central two-and-one-half-story section

\subsubsection{Character-defining features that have been removed}

Listed below are character-defining features of Quarters $J$ that have been removed or replaced over the years; as future renovations occur, these need to be replaced with elements that replicate the original characterdefining features of the building. The historic photograph will guide this process in coordination with the NY SHPO. 
- Windows

- Doors

\subsubsection{Nonhistoric features}

- East addition

- West addition

- North addition

\subsubsection{Melville Hall (Meighan house)}

Melville Hall is a contributing feature of the historic district, but the interior is noncontributing. It is not known when Melville Hall (Meighan house) was constructed. It is part of the Grenwolde development, but it does not follow the design aesthetic of Grenwolde since it is in the Mediterranean Style. It is a large two-story house covered with stucco. The former house faces east and has a central entrance. The hipped roof is covered in original variegated Spanish clay tile. The building is now utilized as a meeting and conference facility, and a large one-story addition was constructed on the west to house a ballroom. The ballroom has a window-wall of smoked glass.

Figure 53. East façade of Melville Hall (Meighan house) as depicted in New Movie Magazine in 1931 (Browning).

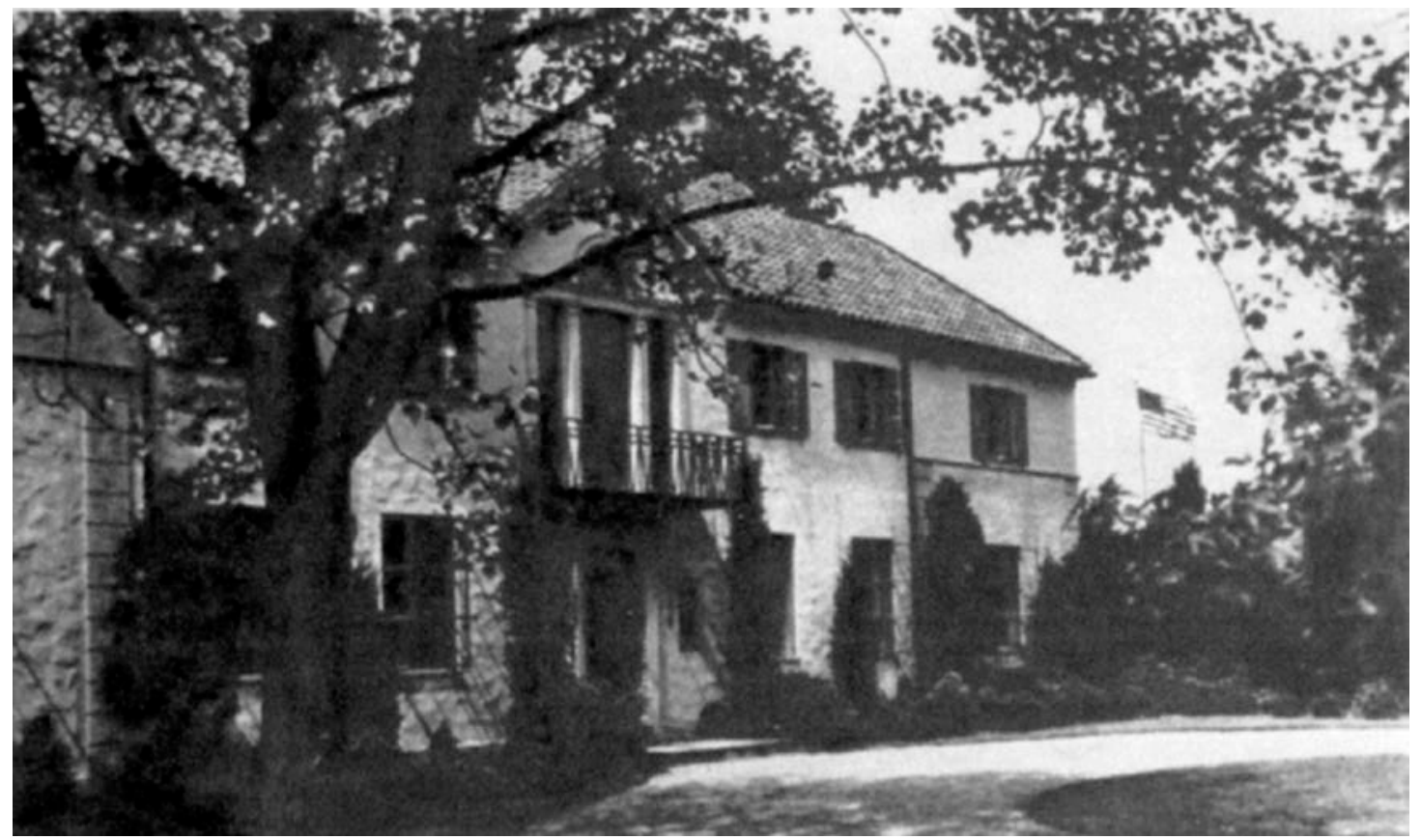


Figure 54. East façade of Melville Hall (ERDC-CERL, 2013).

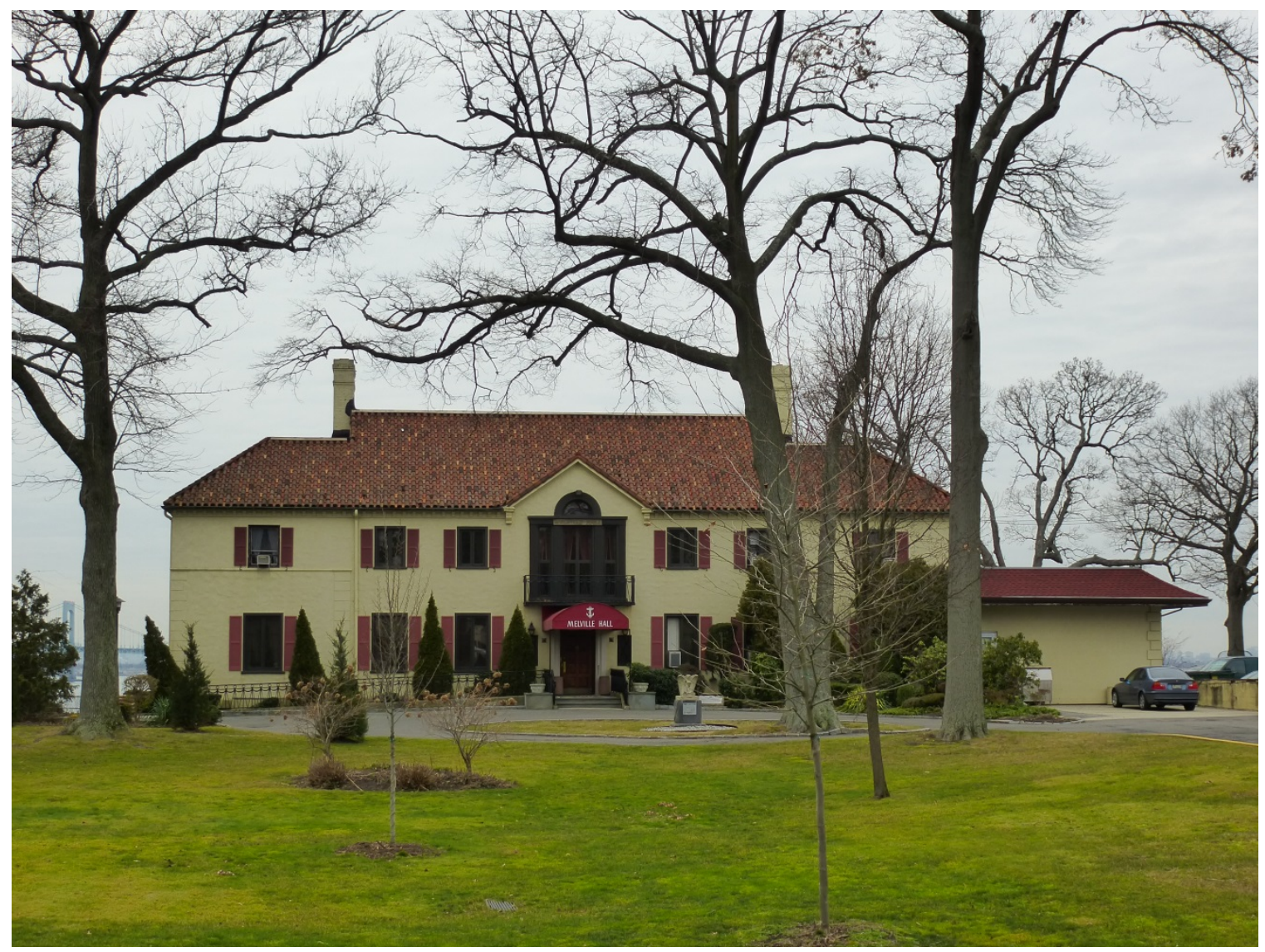

\subsubsection{Character-defining features}

Repair, renovation, and replacement of the following character-defining features of Melville Hall must be coordinated with the NY SHPO.

- Massing of the eastern original portion of the house

- Roof shape of the eastern original portion of the house

- Roof material

- Stucco

- Window placement of the eastern original portion of the house

- Door placement of the eastern original portion of the house

- Iron balcony on eastern façade

\subsubsection{Character-defining features that have been removed}

Listed below are character-defining features of Melville Hall that have been removed or replaced over the years; as future renovations occur, these need to be replaced with elements that replicate the original character- 
defining features of the building. The historic photographs will guide this process in coordination with the NY SHPO.

- Windows

- Doors

- Shutters

3.2.4.3 Nonhistoric features

- West addition (ballroom)

- North addition (kitchen)

Figure 55. Detail of the east entrance to Melville Hall (ERDC-CERL, 2013).

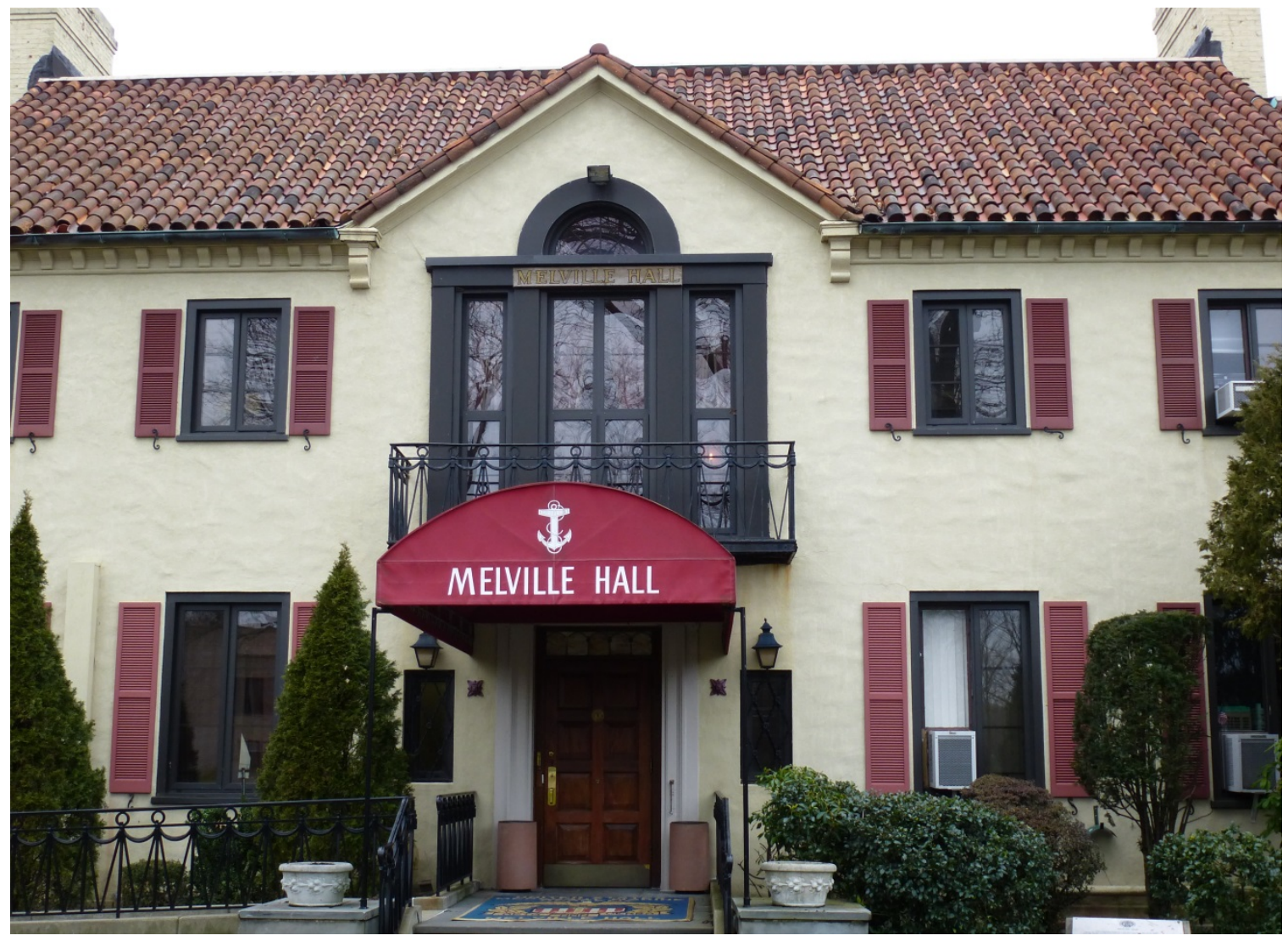


Figure 56. Southwest portions of the ballroom addition to Melville Hall (ERDC-CERL, 2013).

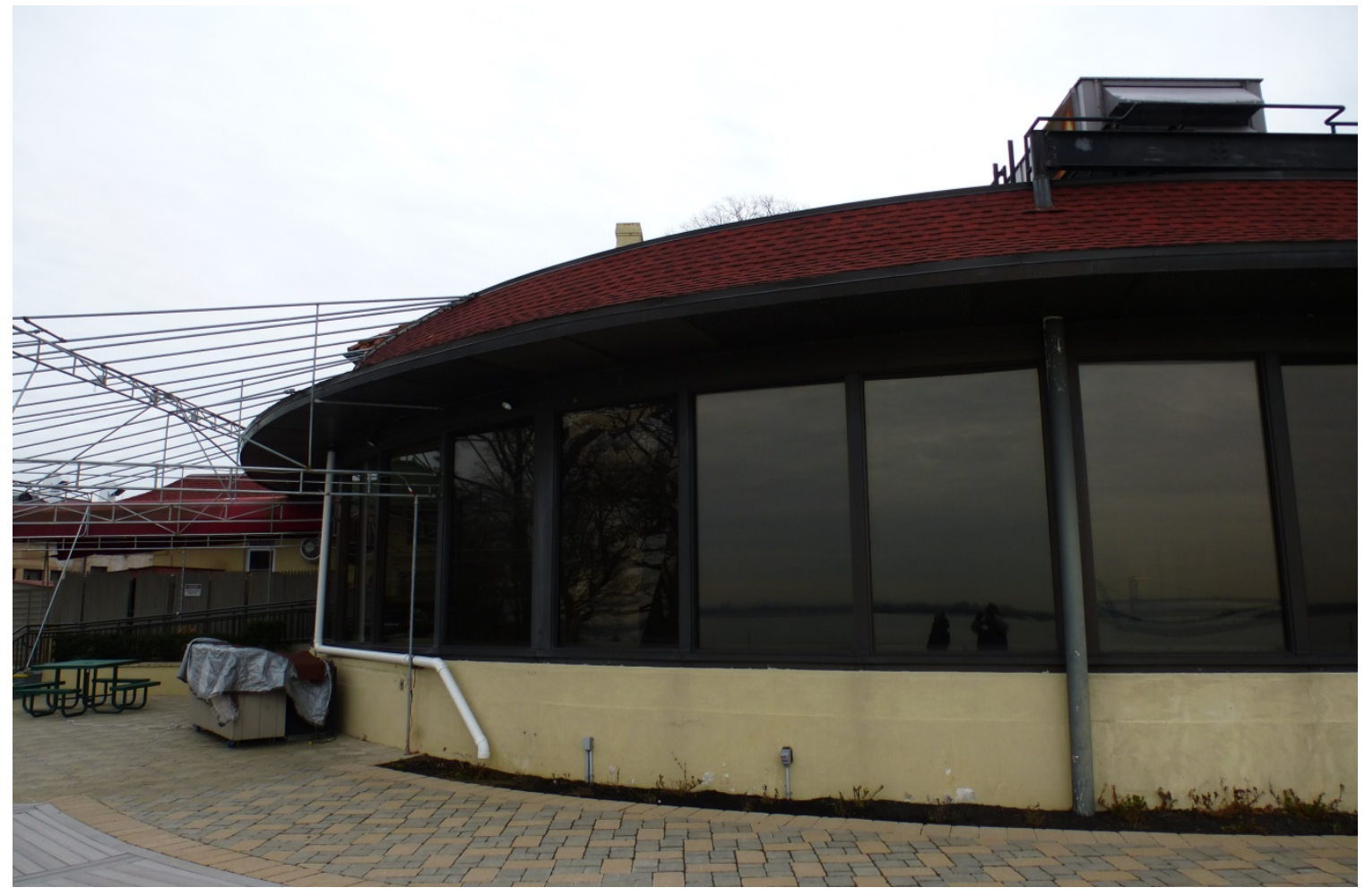

\subsubsection{Quarters K (Meighan Estate - garage)}

Quarters K is a contributing feature of the USMMA historic district, but the interior of the quarters is not contributing. It is not known when Quarters $\mathrm{K}$ was constructed, but it was constructed as the garage and chauffeur apartment for the Meighan Estate. It is a two-story building with another half-story in the attic under the roof. The garage portion was converted to living quarters at some point, and a large addition was constructed on the eastern portion of the building (not visible in photo). The house is covered in stucco, and the hipped roof is covered with flat clay tiles. 
Figure 57. North façade of Quarters K (USMMA, 2013.

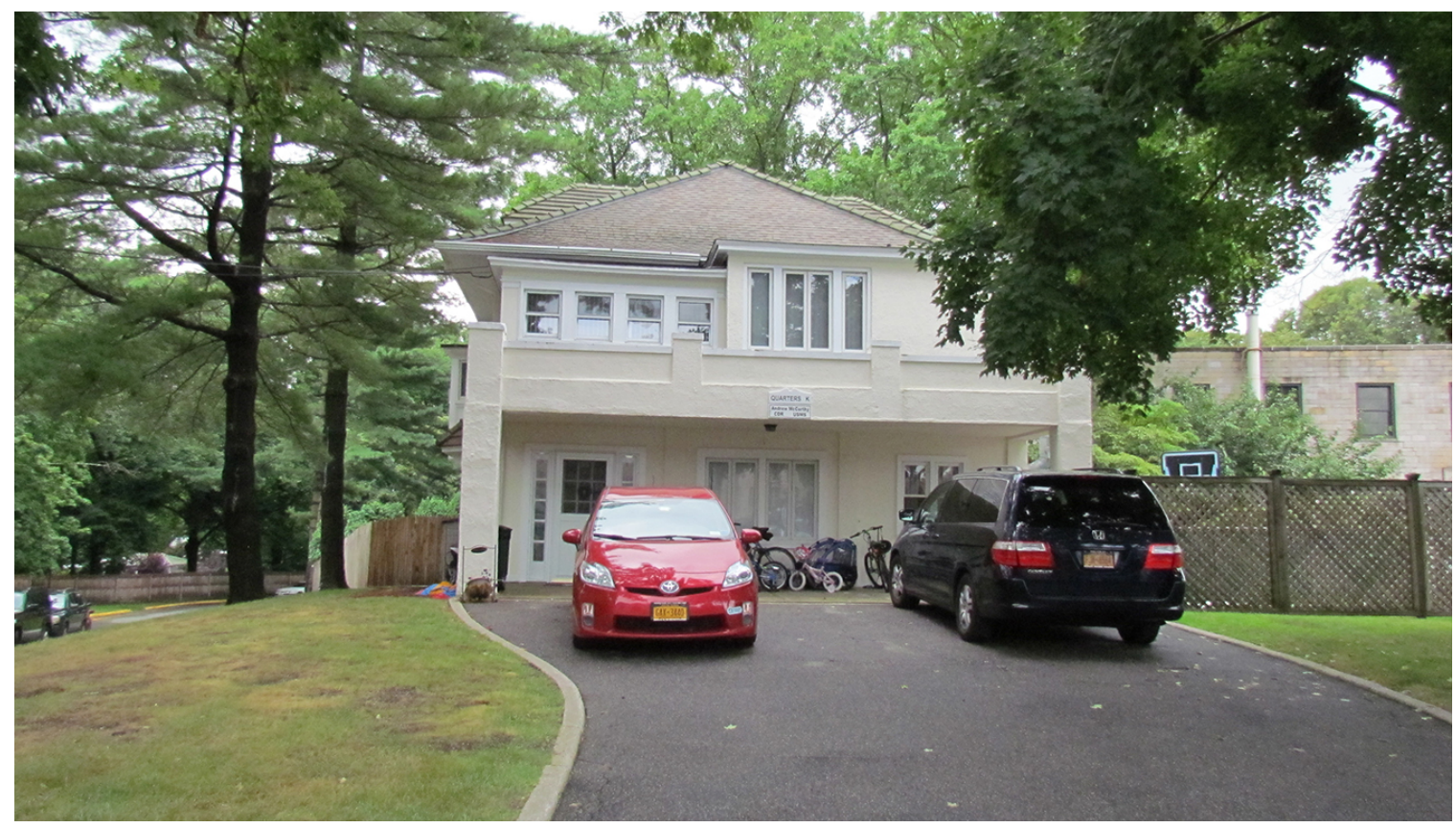

\subsubsection{Character-defining features}

Repair, renovation, and replacement of the following character-defining features of Quarters K must be coordinated with the NY SHPO.

- Massing

- Roof shape

- Roof material

- Stucco

- Window placement

- Door placement

\subsubsection{Character-defining features that have been removed}

Listed below are character-defining features of Quarters K that have been removed or replaced over the years; as future renovations occur, these need to be replaced with elements that replicate the original characterdefining features of the building.

- Windows

- Doors 


\subsubsection{Land Hall (Schenck house)}

Land Hall (Schenck house) is a contributing feature of the USMMA historic district, but the interior is noncontributing. Land Hall was constructed circa 1920, but the architect is not known. The house was originally named "Claralea" and was part of the Grenwolde development, although its design did not follow the Grenwolde aesthetic. It is a large, two-story, Italian Renaissance revival house covered in yellow-painted stucco with a large, hipped roof covered with green clay tile. The building is now utilized for cadet recreation services.

Figure 58. North façade of Land Hall (Schenck house), 1942 (NARA RG 178).

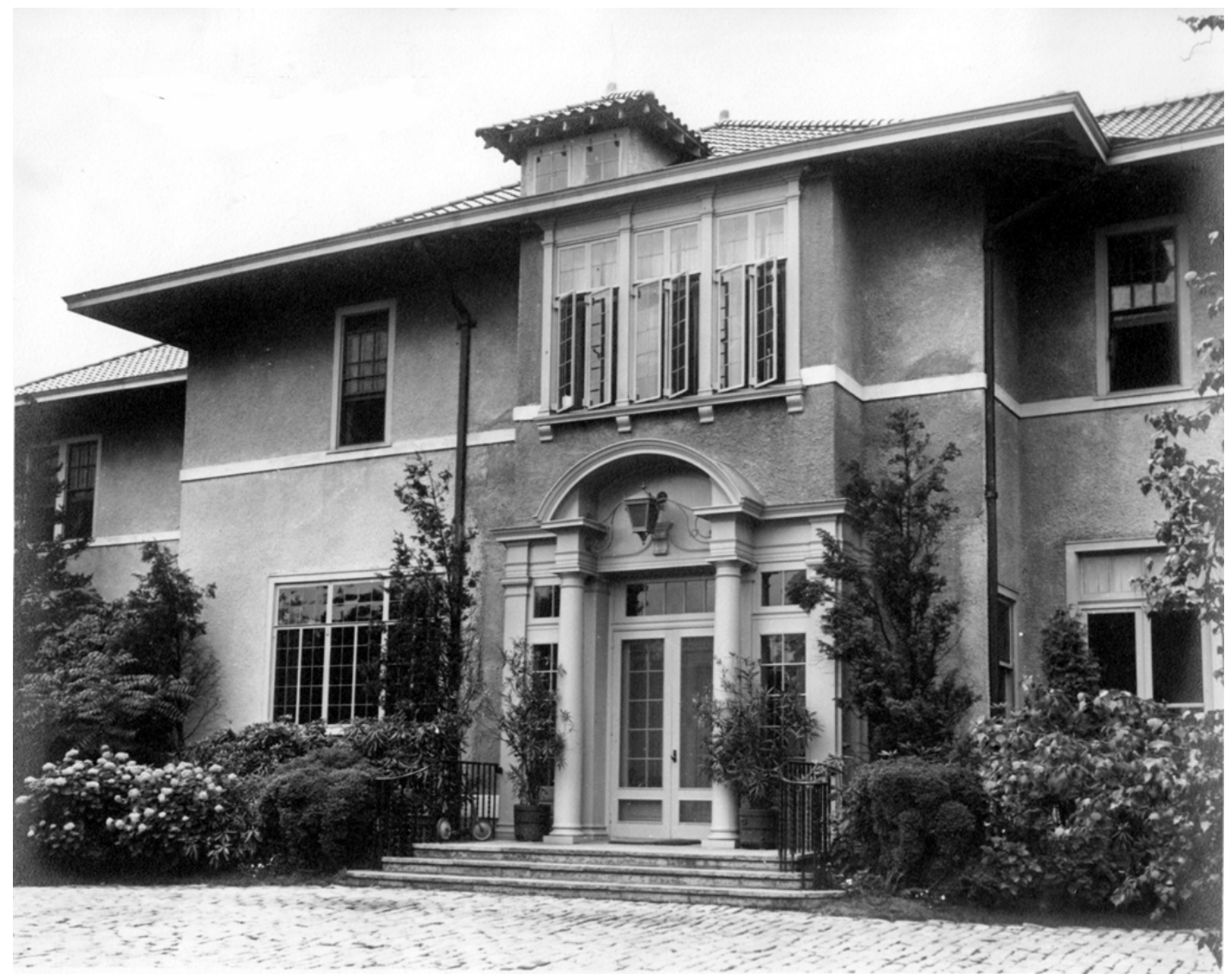


Figure 59. South façade of Land Hall (Schenck house), no date (Great Neck Library).

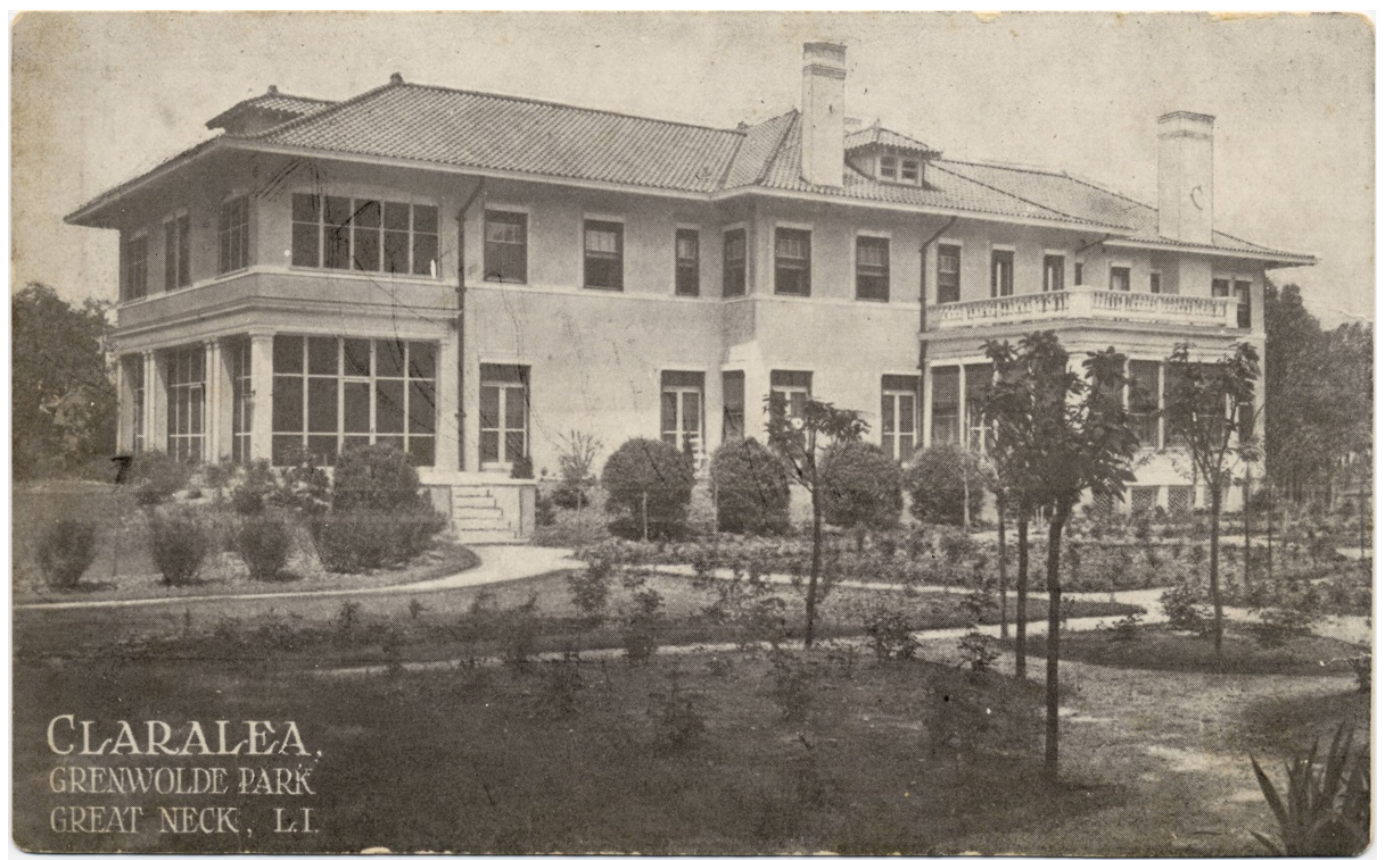

Figure 60. Southwest oblique of Land Hall (Schenck house) (ERDC-CERL, 2013).

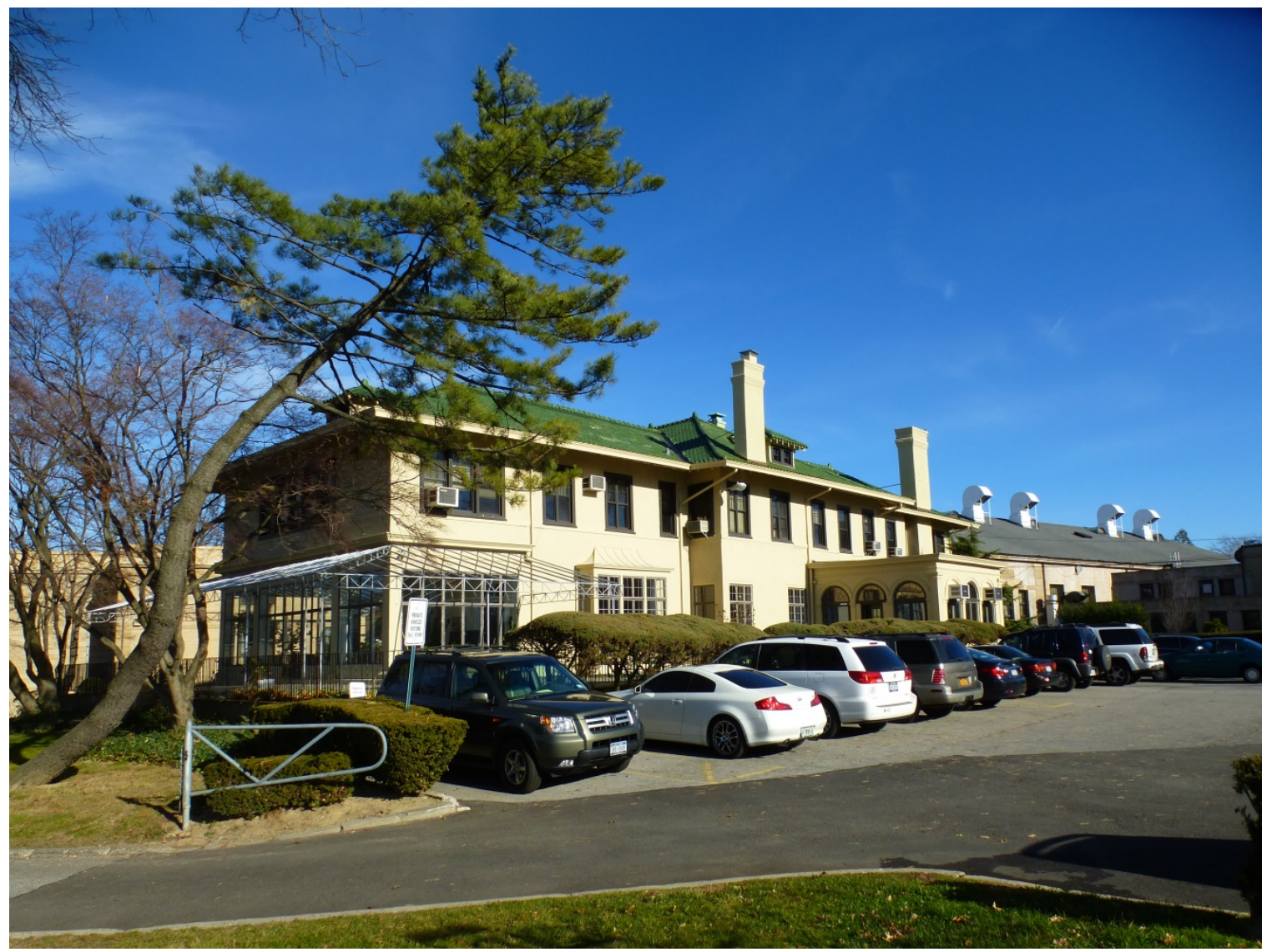




\subsubsection{Character-defining features}

Repair, renovation, and replacement of the following character-defining features of Land Hall must be coordinated with the NY SHPO.

- Massing

- Footprint

- Roof shape

- Roof material

- Stucco

- Window placement

- Door placement

\subsubsection{Character-defining features that have been removed}

Listed below are character-defining features of Land Hall that have been removed or replaced over the years; as future renovations occur, these need to be replaced with elements that replicate the original characterdefining features of the building. The historic photographs will guide this process in coordination with the NY SHPO.

- Windows

- Doors

\subsubsection{Quarters B (a Grenwolde house)}

Quarters B (a Grenwolde house) is a contributing feature to the historic district, but the interior is noncontributing. It was completed at the latest by 1915 as part of the Grenwolde development. The house was more than likely designed by Caretto \& Forster, since it is very similar to Quarters A and other Grenwolde houses in the Dutch Colonial Revival Style. It is oneand-one-half stories tall, and the half story has almost full-width shed dormers. The house is brick painted blue, and the roof is covered in brown asphalt shingles. 
Figure 61. South façade of Quarters B (USMMA, 2013.

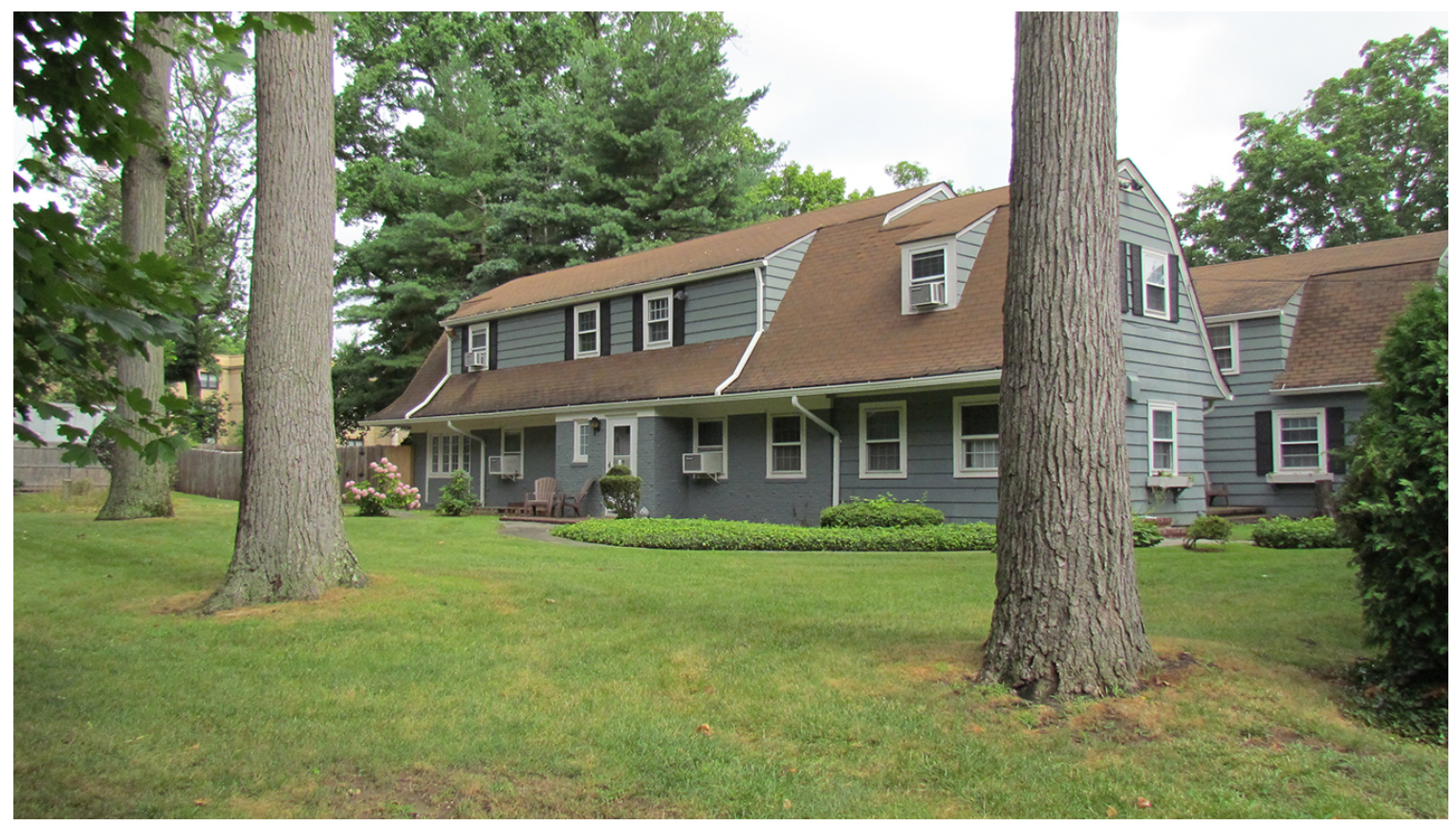

Figure 62. North façade of Quarters B (ERDC-CERL, 2013).

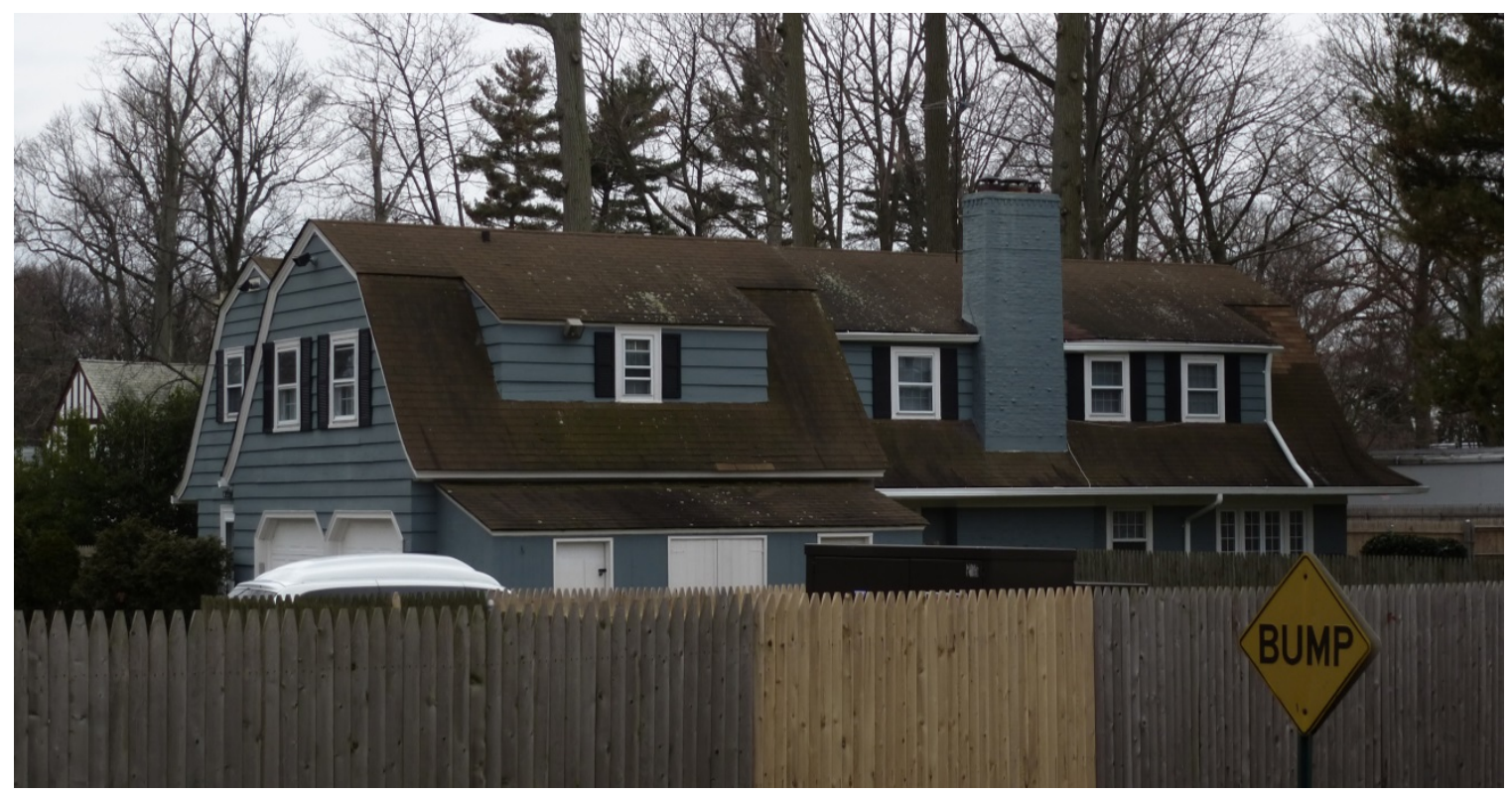

3.2.7.1 Character-defining features

Repair, renovation, and replacement of the following character-defining features of Quarters B must be coordinated with the NY SHPO.

- Overall massing

- Footprint 
- Roof shape

- Roof material

- Siding

- Window placement

- Door placement

- Chimney

\subsubsection{Character-defining features that have been removed}

Listed below are character-defining features of Quarters B that have been removed or replaced over the years; as future renovations occur, these need to be replaced with elements that replicate the original characterdefining features of the building.

- Windows

- Doors

\subsubsection{Quarters C (Vreeland house)}

Quarters C (Vreeland house is a contributing feature of the historic district, but its interior is noncontributing. It was designed by Caretto \& Forster and was completed at the latest by 1915 as part of the Grenwolde development. It is two and one-half stories tall. The house has white painted brick on the first story, and half-timbering with stucco on the second and half stories. The roof mimics English thatching and rolls around on the rakes. The roof is covered with green asphalt shingles. 
Figure 63. South façade of Quarters C (Vreeland house) in 1914 (Architectural Record).

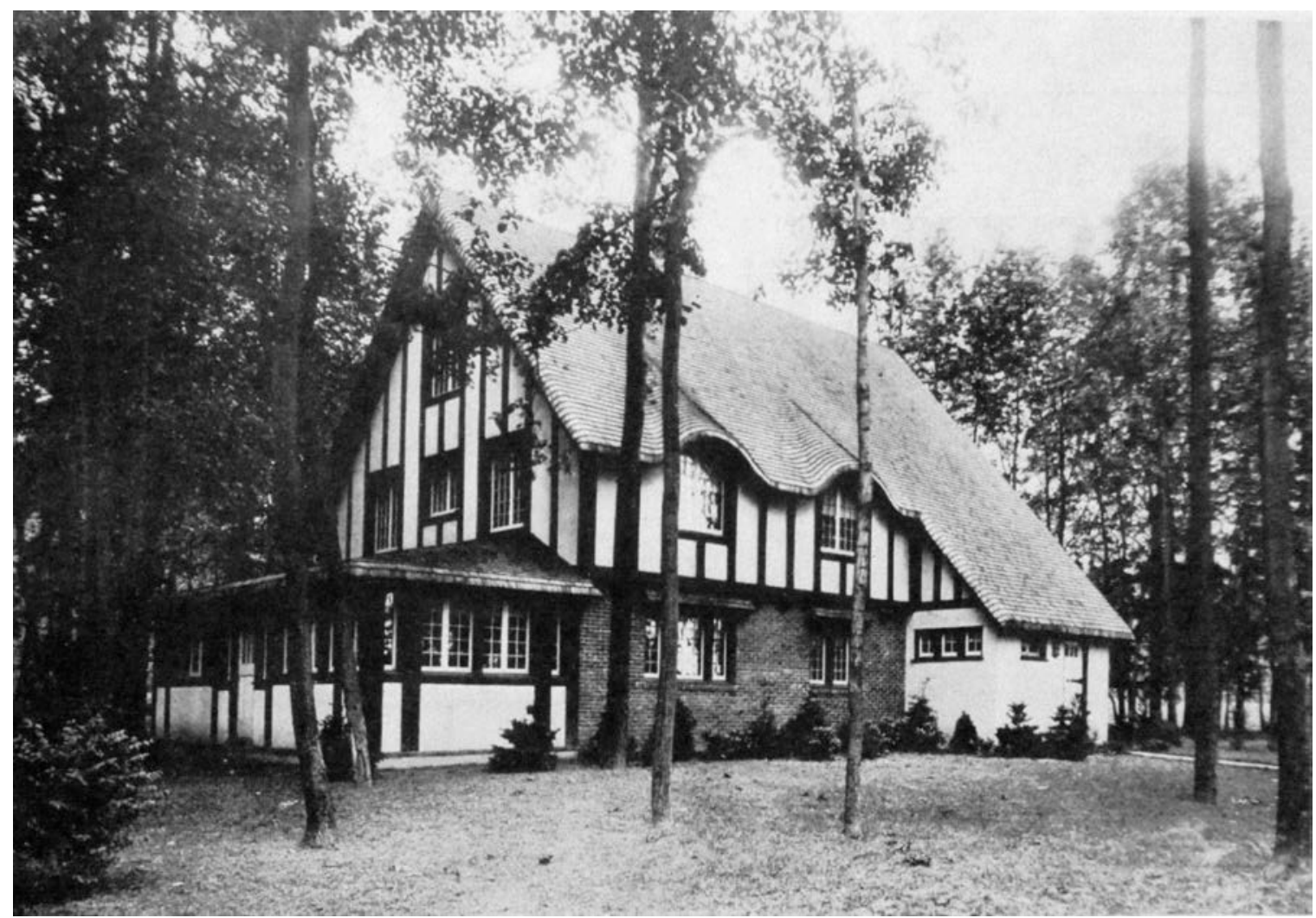

Figure 64.South façade of Quarters C (Vreeland house) (USMMA, 2013).

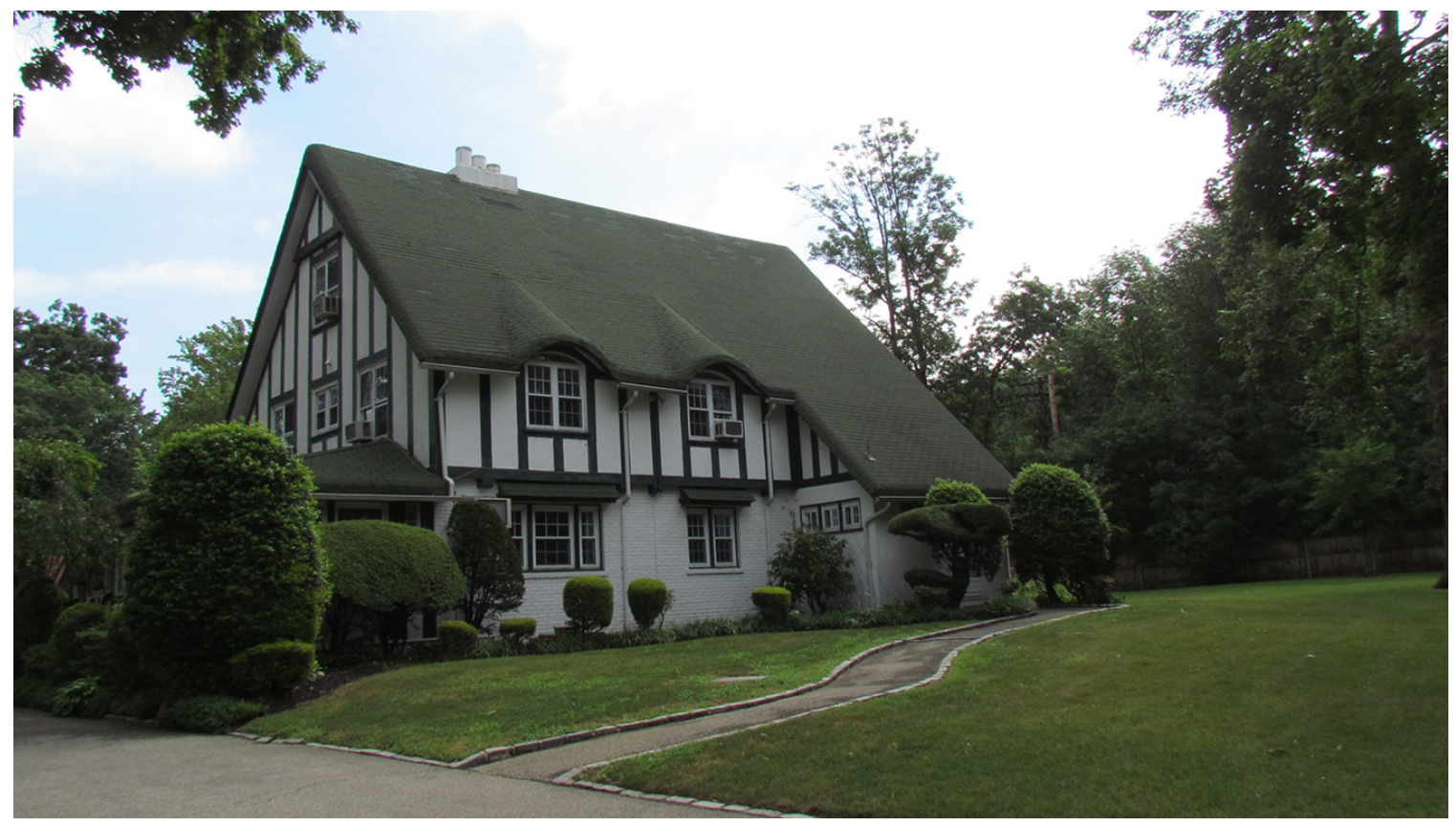


Figure 65. Northwest oblique of Quarters C (Vreeland house) (ERDC-CERL, 2013).

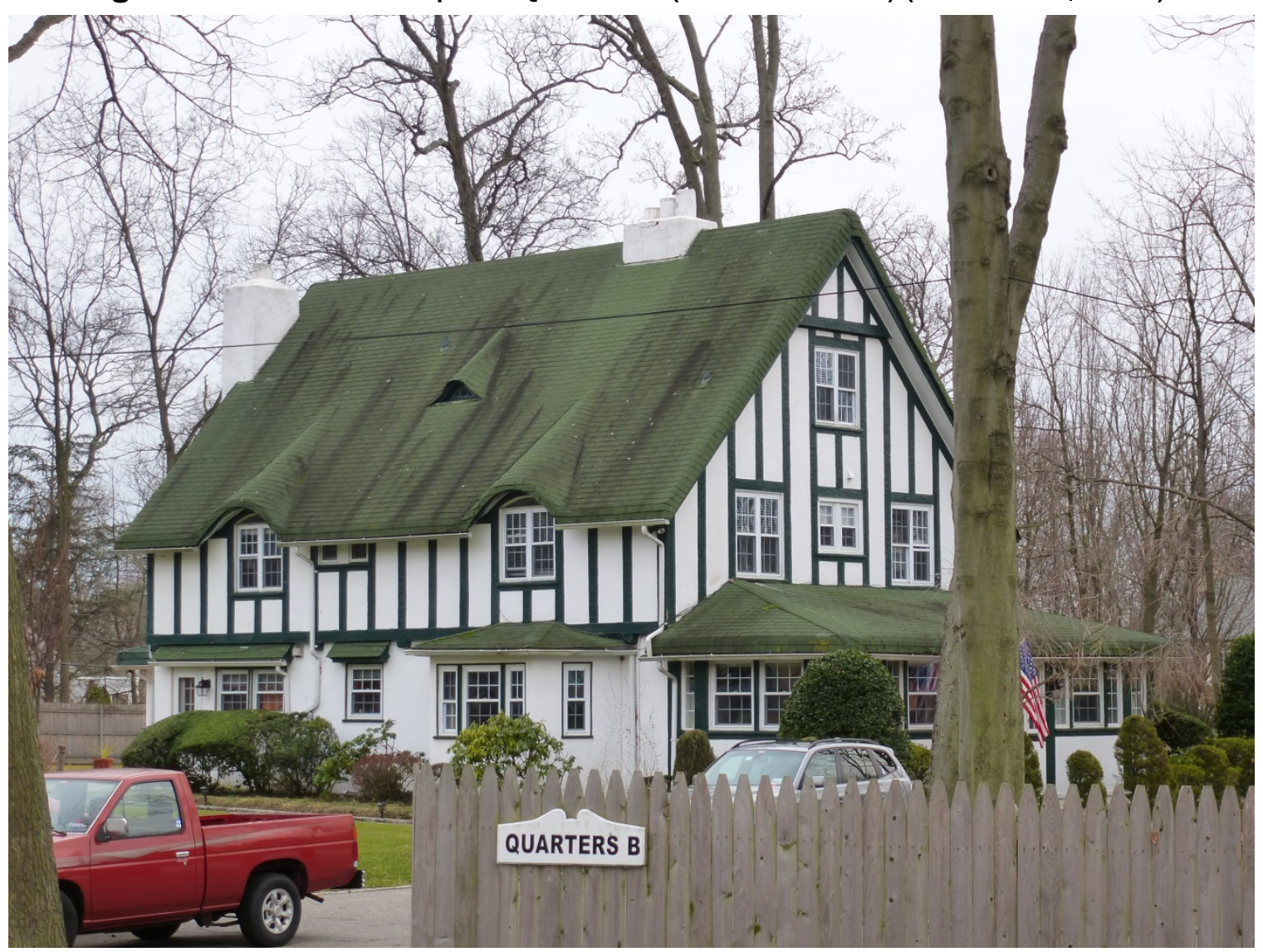

\subsubsection{Character-defining features}

Repair, renovation, and replacement of the following character-defining features of Quarters C must be coordinated with the NY SHPO.

- Overall massing

- Footprint

- Roof shape

- Roof material

- Siding

- Window placement

- Door placement

\subsubsection{Character-defining features that have been removed}

Listed below are character-defining features of Quarters $\mathrm{C}$ that have been removed or replaced over the years; as future renovations occur, these need to be replaced with elements that replicate the original character- 
defining features of the building. The historic photographs will guide this process in coordination with the NY SHPO.

- Windows

- Doors

\subsubsection{Wiley Hall (Bendel/Chrysler Mansion)}

Wiley Hall is the main administration building for the academy. The entire exterior and interior are contributing features to the historic district. It originally was constructed for Henri W. Bendel in 1916. It was designed by Henry Otis Chapman as a two-story residence with a full-height basement. The mansion features such typical design elements of Beaux Arts classicism as columns, balustrades, loggias, quoins, Palladian windows, and detailed entablatures, and it is constructed of reinforced concrete finished with stucco. The quoins were constructed with brick or terracotta block foundations that projected and were finished with stucco. The interior reflects the grandeur of the early twentieth-century Gold Coast estates with a double-height entrance hall, elaborate fireplace surrounds, and carved and painted wooden ceilings. The basement once had a large swimming pool (now offices), a smoking room, a billiard room, and a variety of mechanical rooms. The first floor had thirteen main rooms including the main entrance hall, living room, dining room, music room (with organ), conservatory, and kitchen. The open loggia was enclosed early on by the academy for use as a dining room for the cadets and now for a variety of offices. All of these rooms retain their integrity, although they all are used for different purposes (for instance the music room is now a classroom). The second floor originally had six bedrooms, a variety of sitting rooms and bathrooms, a wing for the servant bedrooms, plus the upper level of the main entrance hall. All of these rooms are now office space for academy staff. 
Figure 66. West façade of Wiley Hall (Bendel/Chrysler Mansion), showing the thennewly enclosed west-side loggia, 1942 (Bland Library, USMMA).

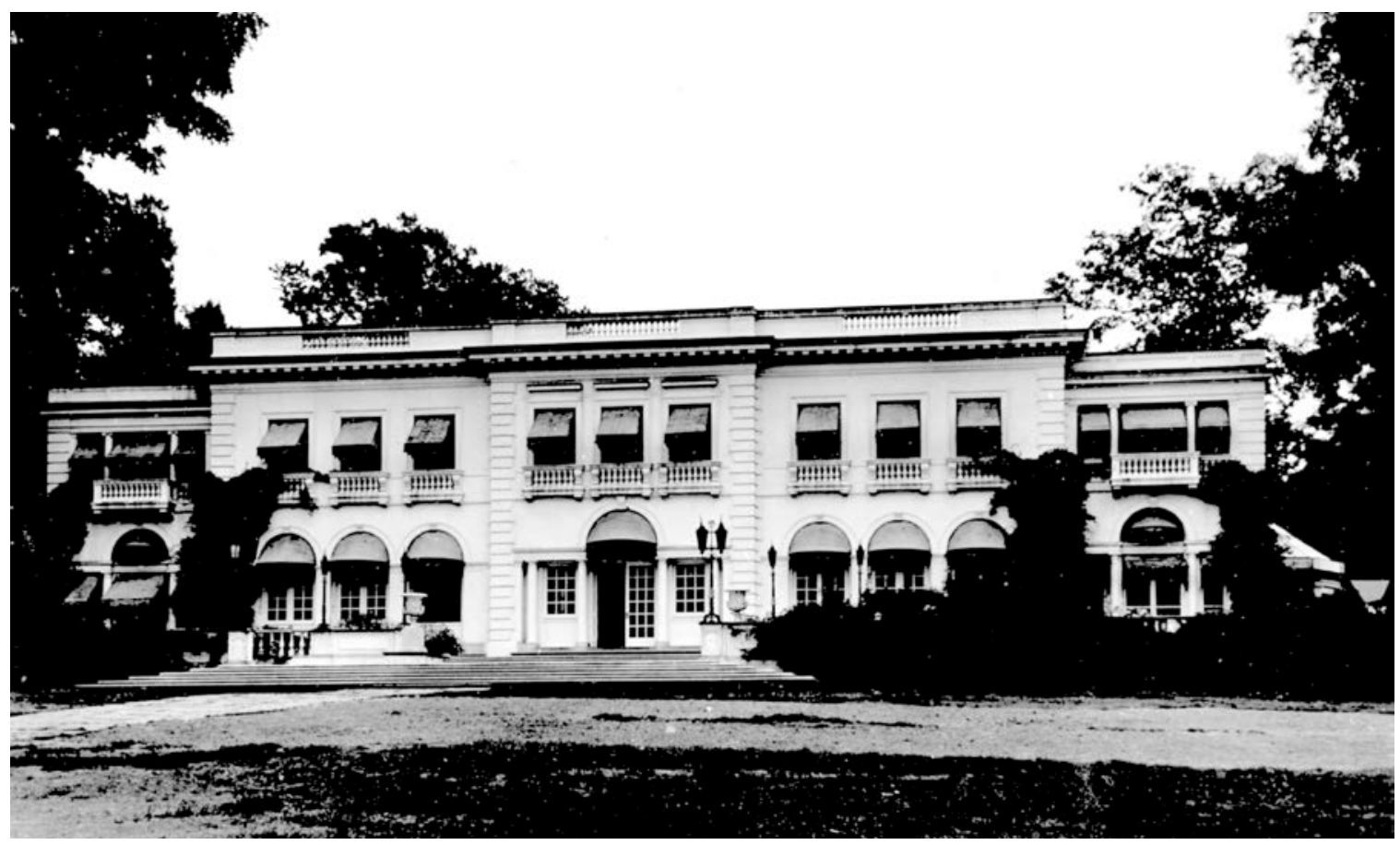

Figure 67. East façade of Wiley Hall (ERDC-CERL, 2013).

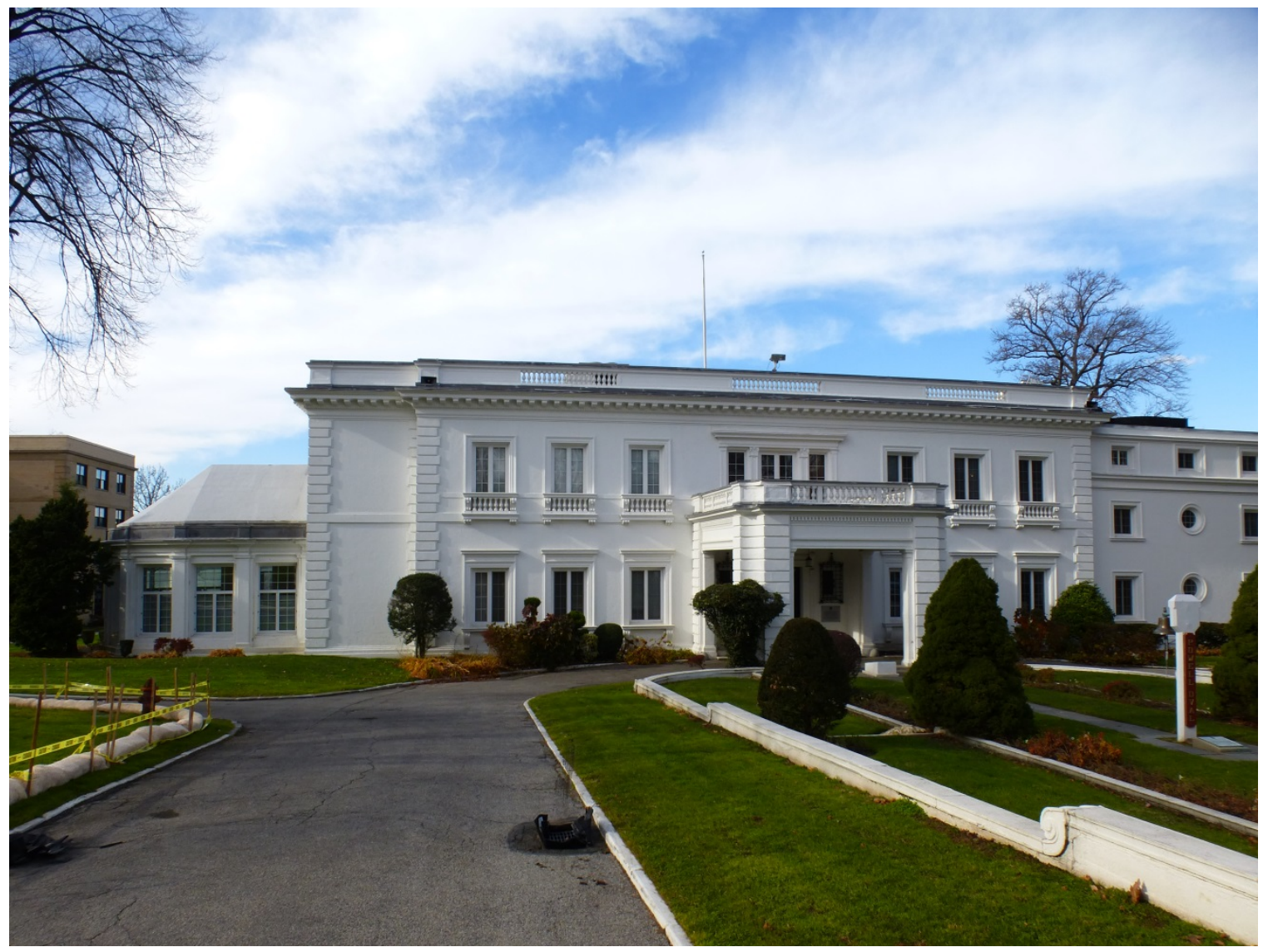


Figure 68. South façade of Wiley Hall (ERDC-CERL, 2013).

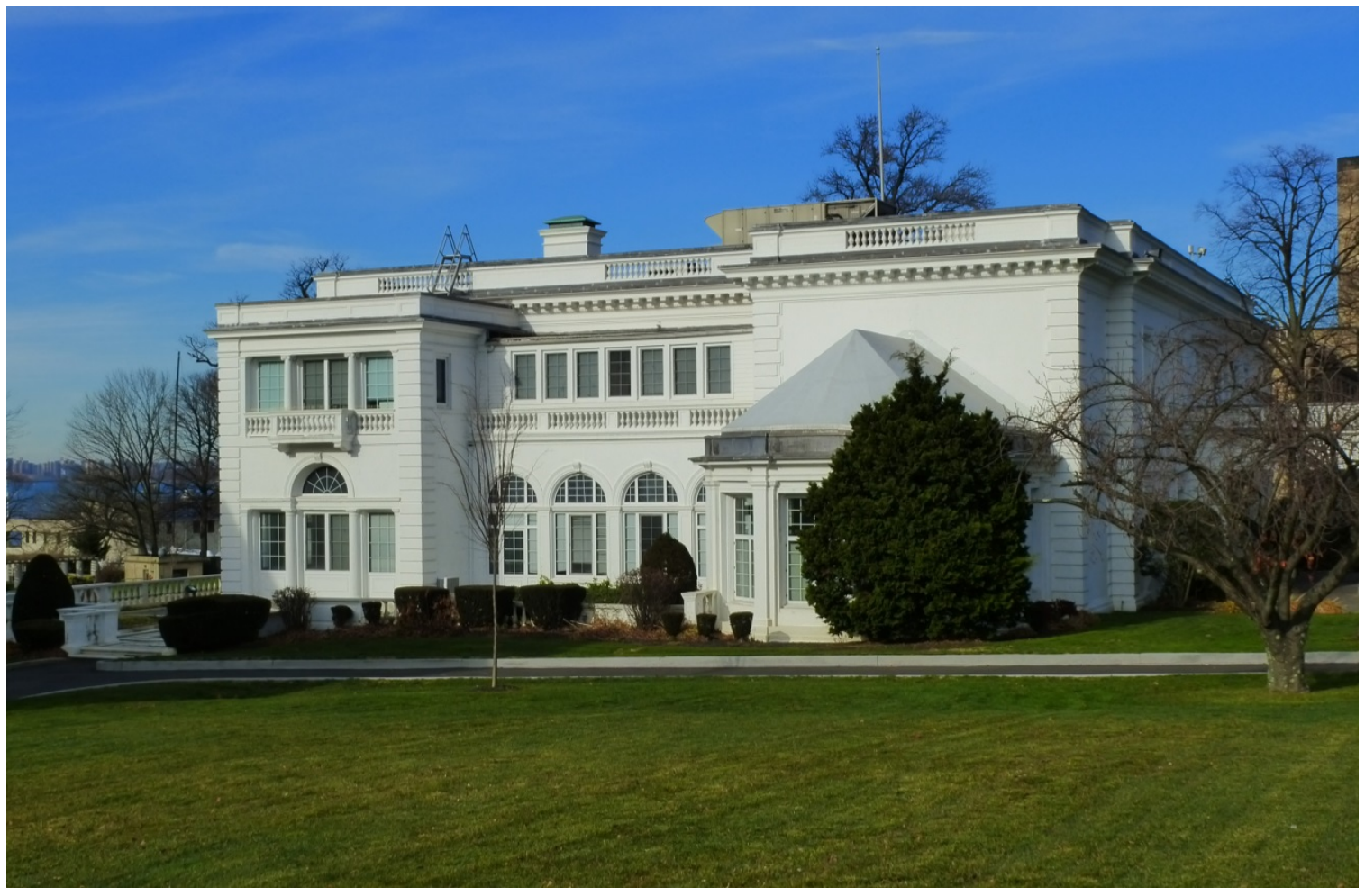

Figure 69. North façade of Wiley Hall (ERDC-CERL, 2013).

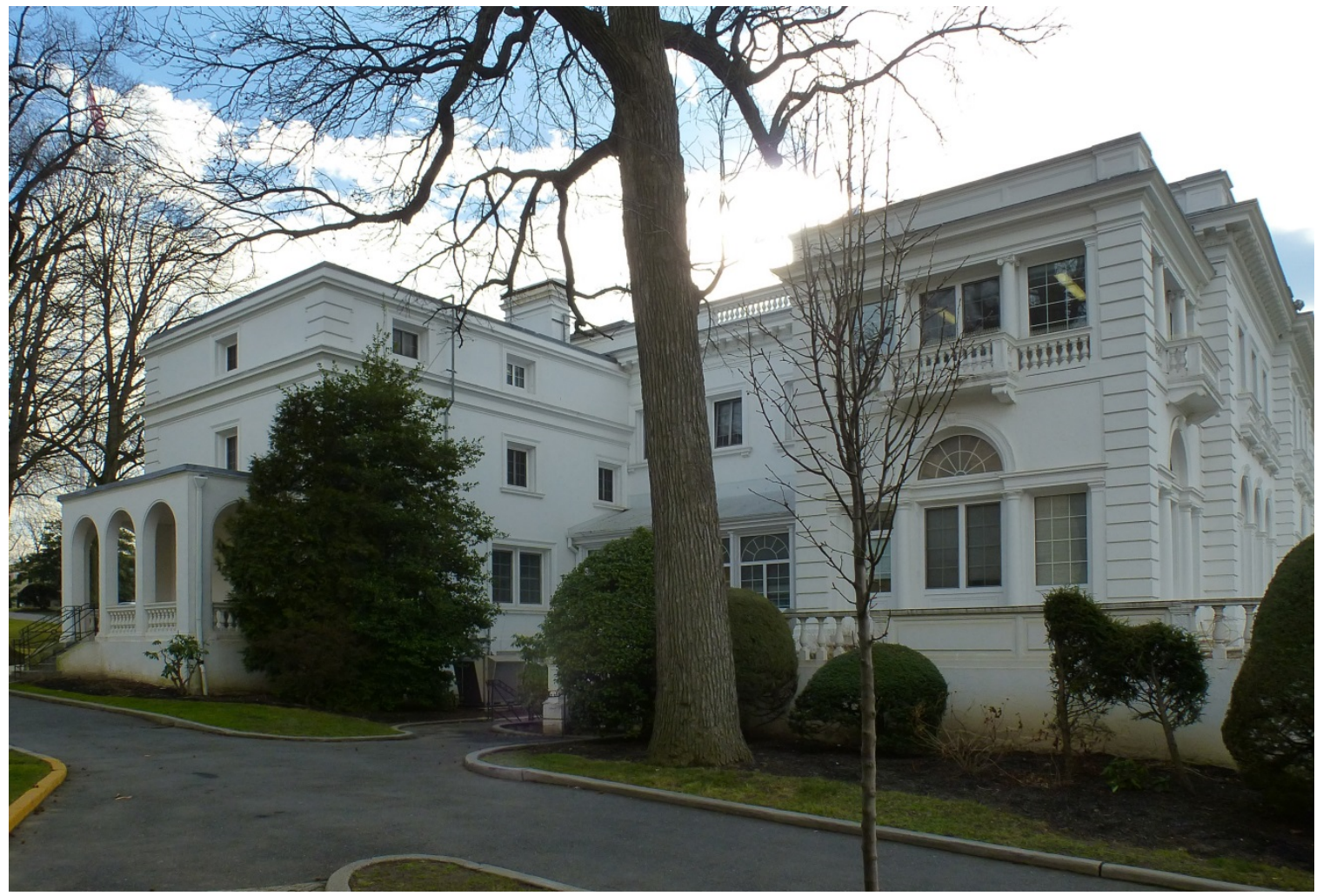


Figure 70. West façade of Wiley Hall (ERDC-CERL, 2013).

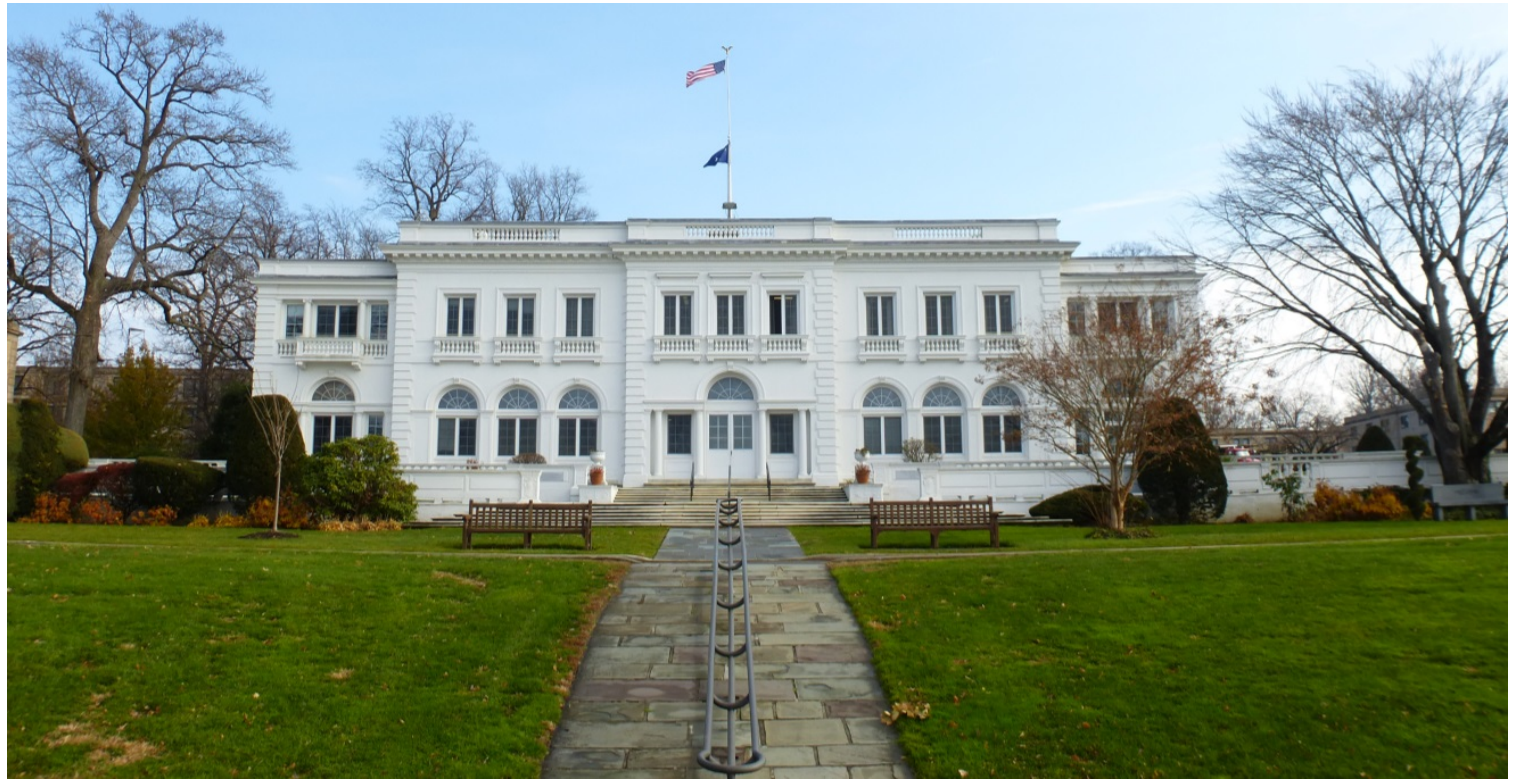

3.2.9.1 Character-defining features

All elements of Wiley Hall, both exterior and interior, are to be considered character-defining features. Several of these elements are shown in photographs below. 
Figure 71. Porte cochere on the east façade of Wiley Hall (ERDC-CERL, 2013).

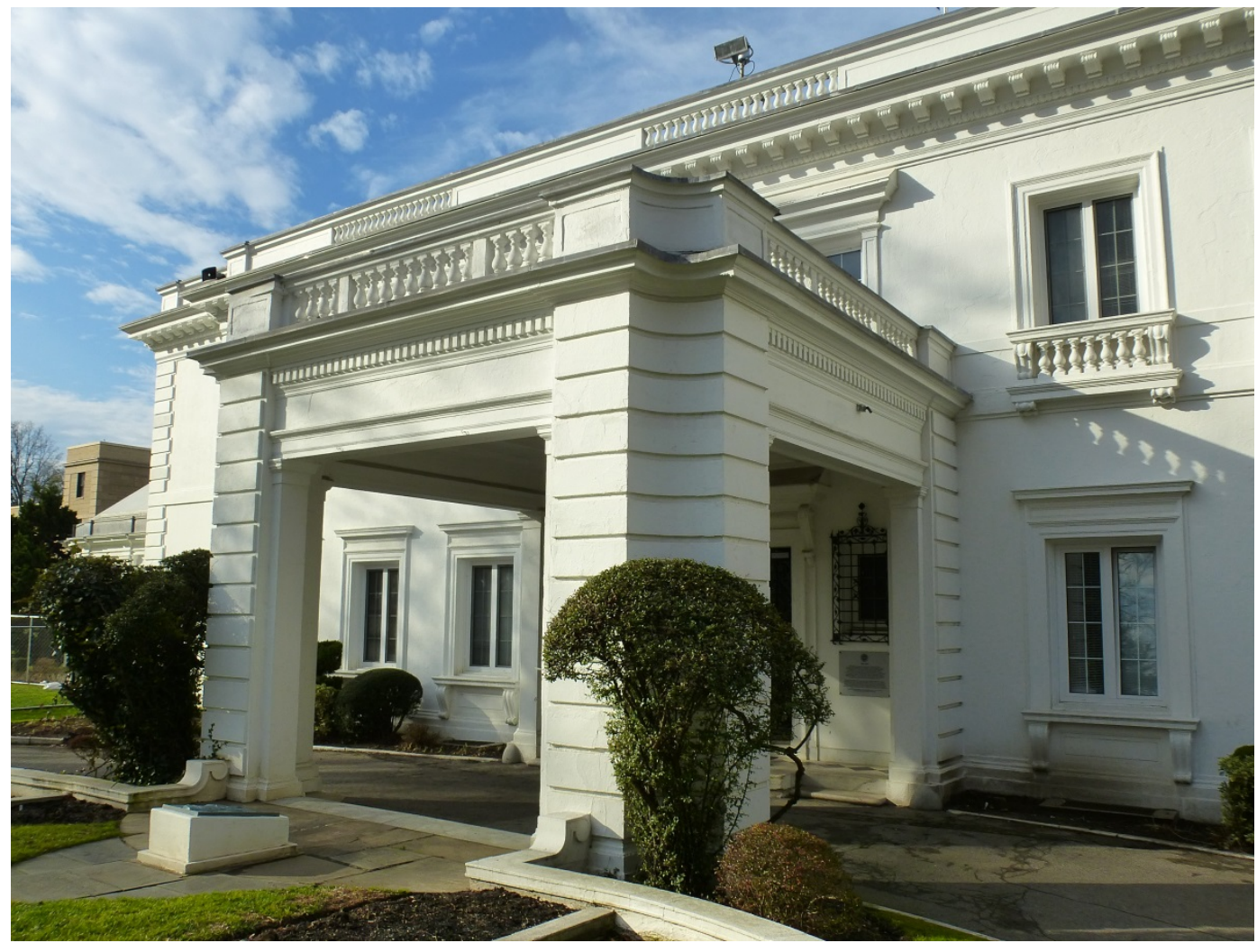

Figure 72. Balustrade beneath window on the east façade of Wiley Hall (ERDC-CERL, 2013).

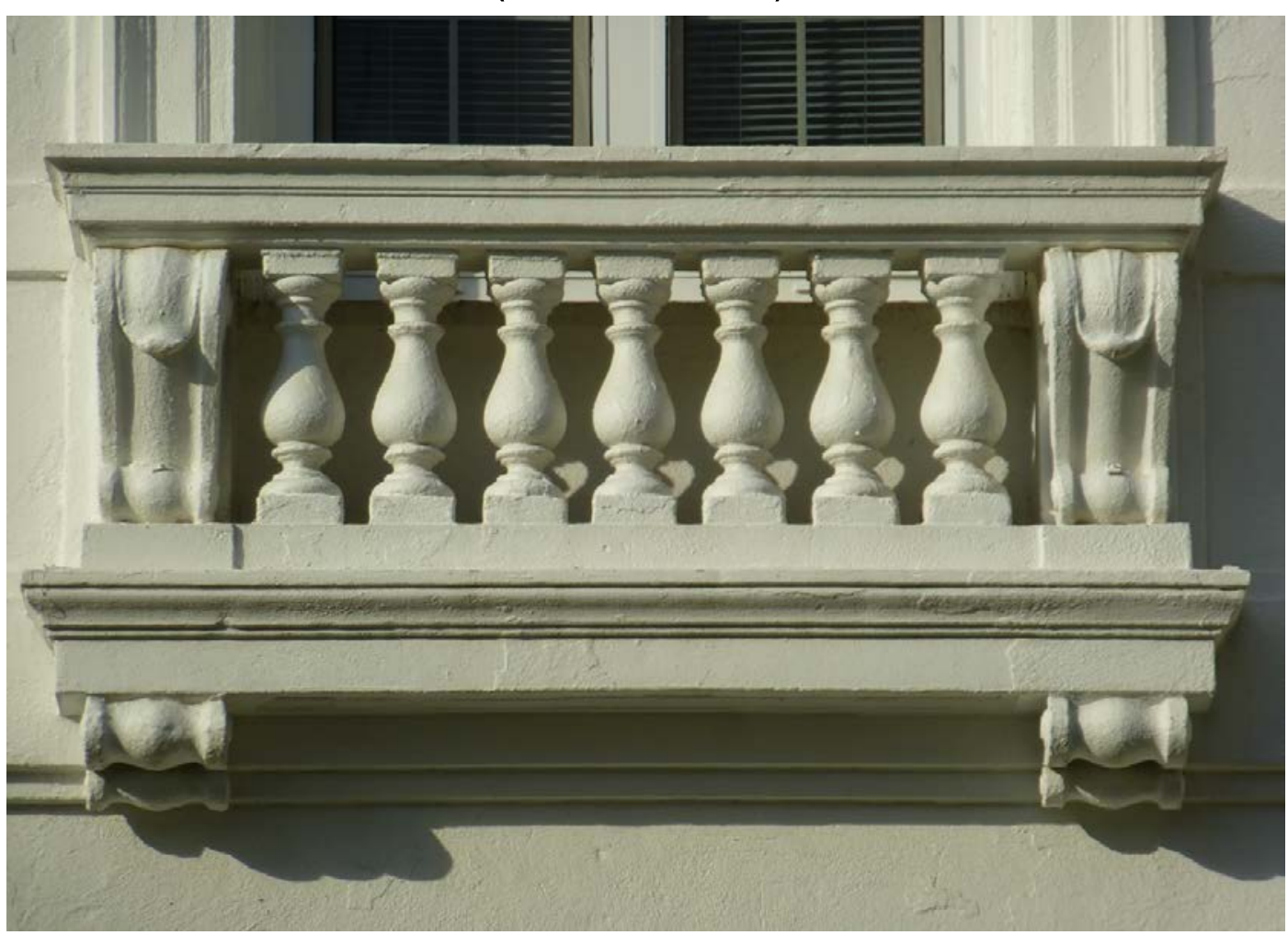


Figure 73. Round window on the east façade of Wiley Hall (ERDC-CERL, 2013).

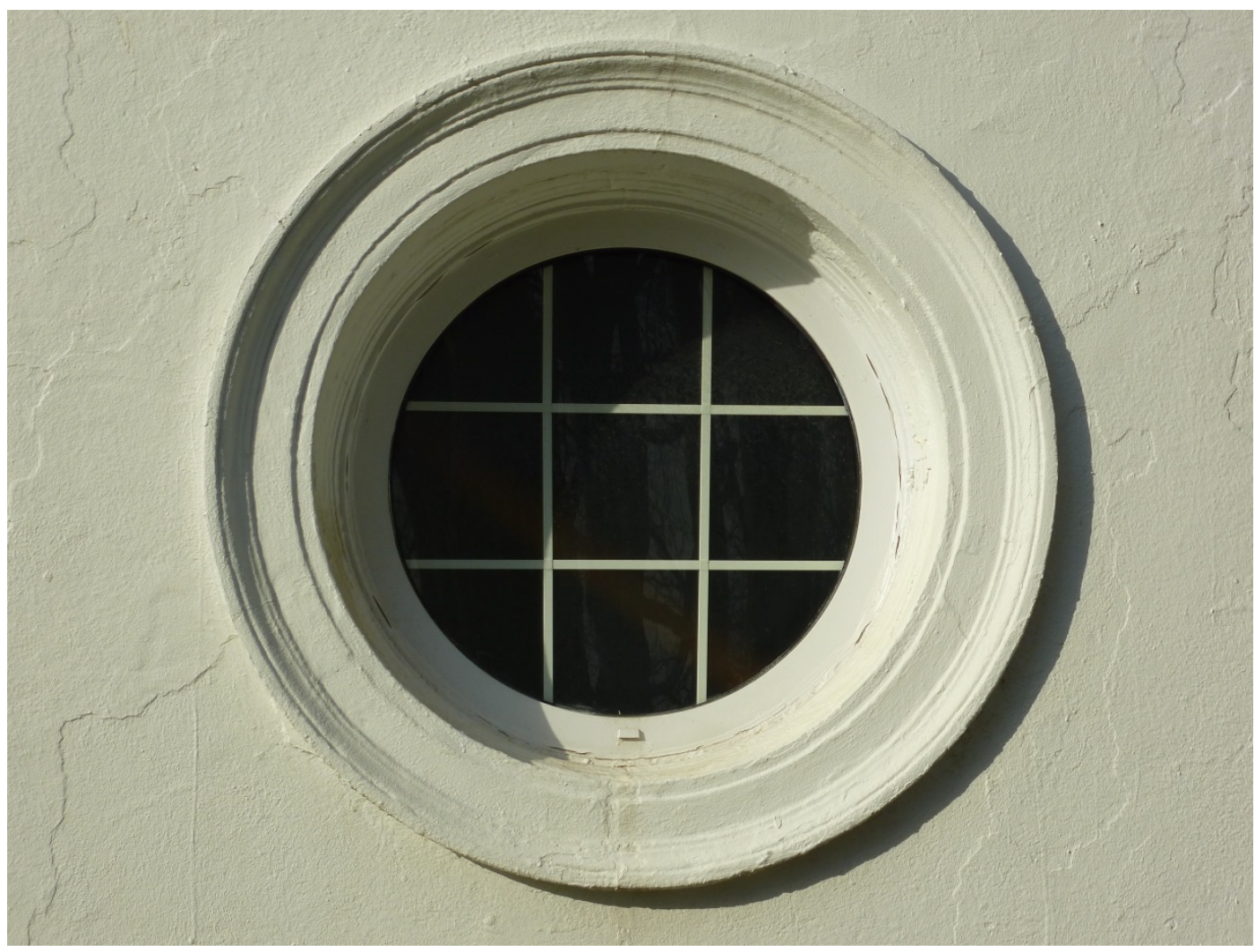


Figure 74. Light fixture underneath porte cochere on the east façade of Wiley Hall (ERDC-CERL, 2013).

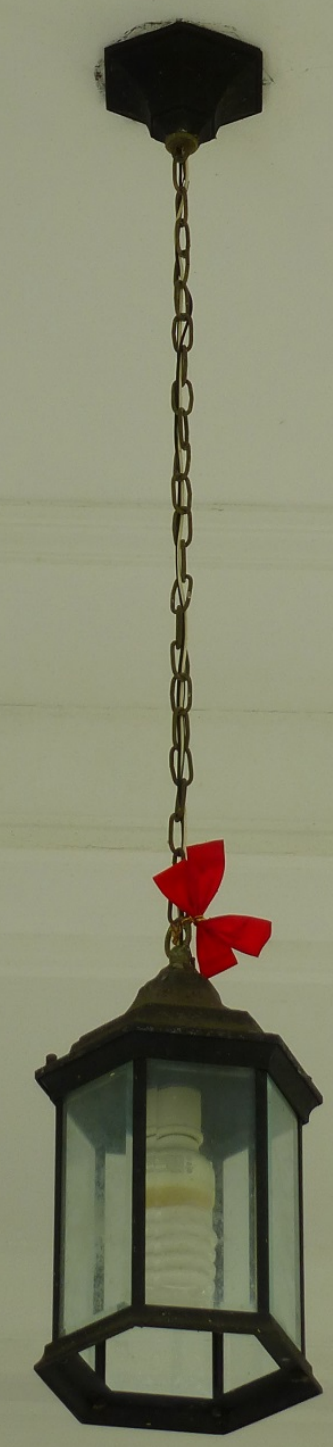


Figure 75. Corbels and egg-and-dart detail on the soffit on the west façade of Wiley Hall (ERDC-CERL, 2013).

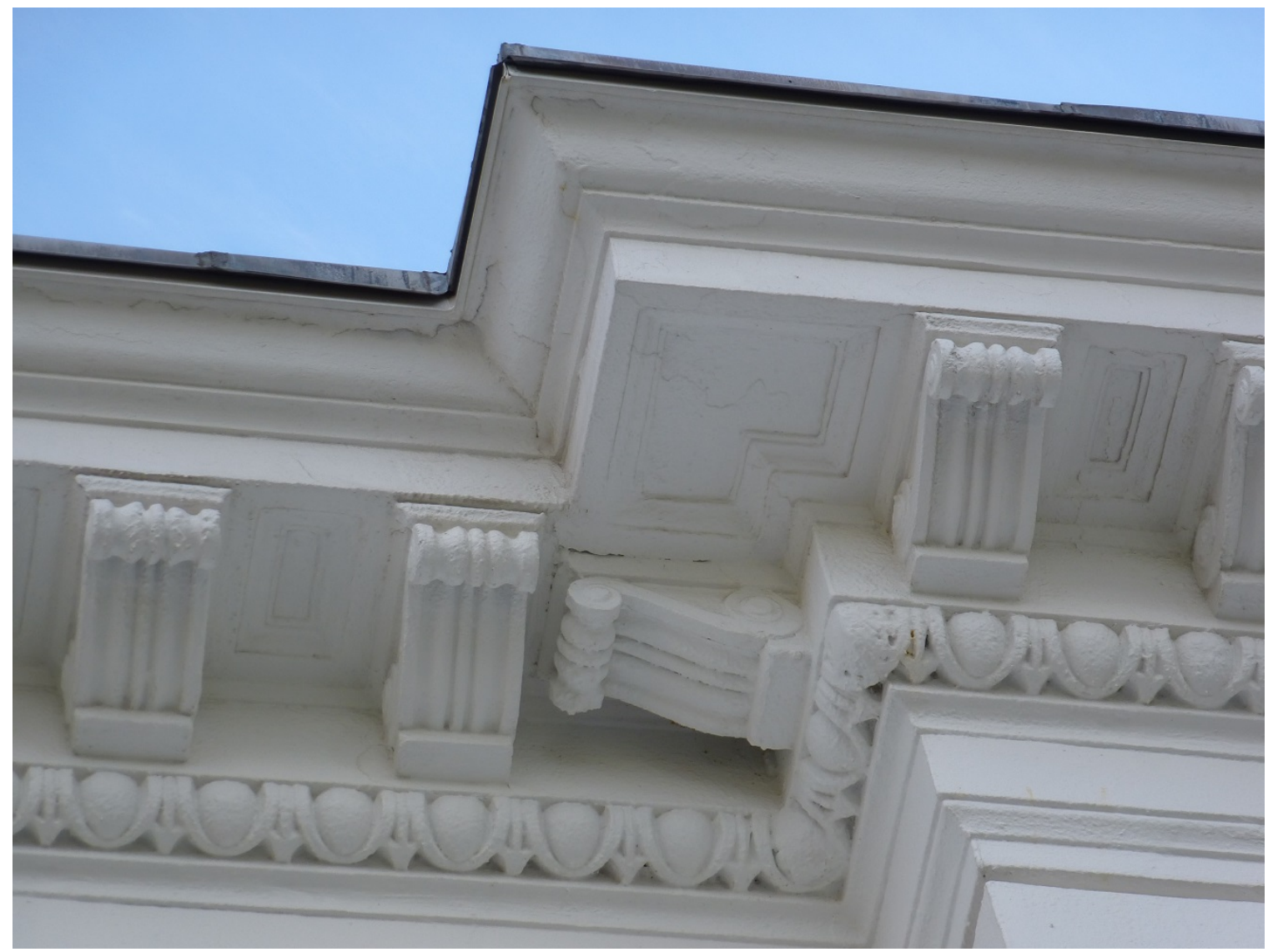

Figure 76. Terrace on the south side of Wiley Hall (ERDC-CERL, 2013).

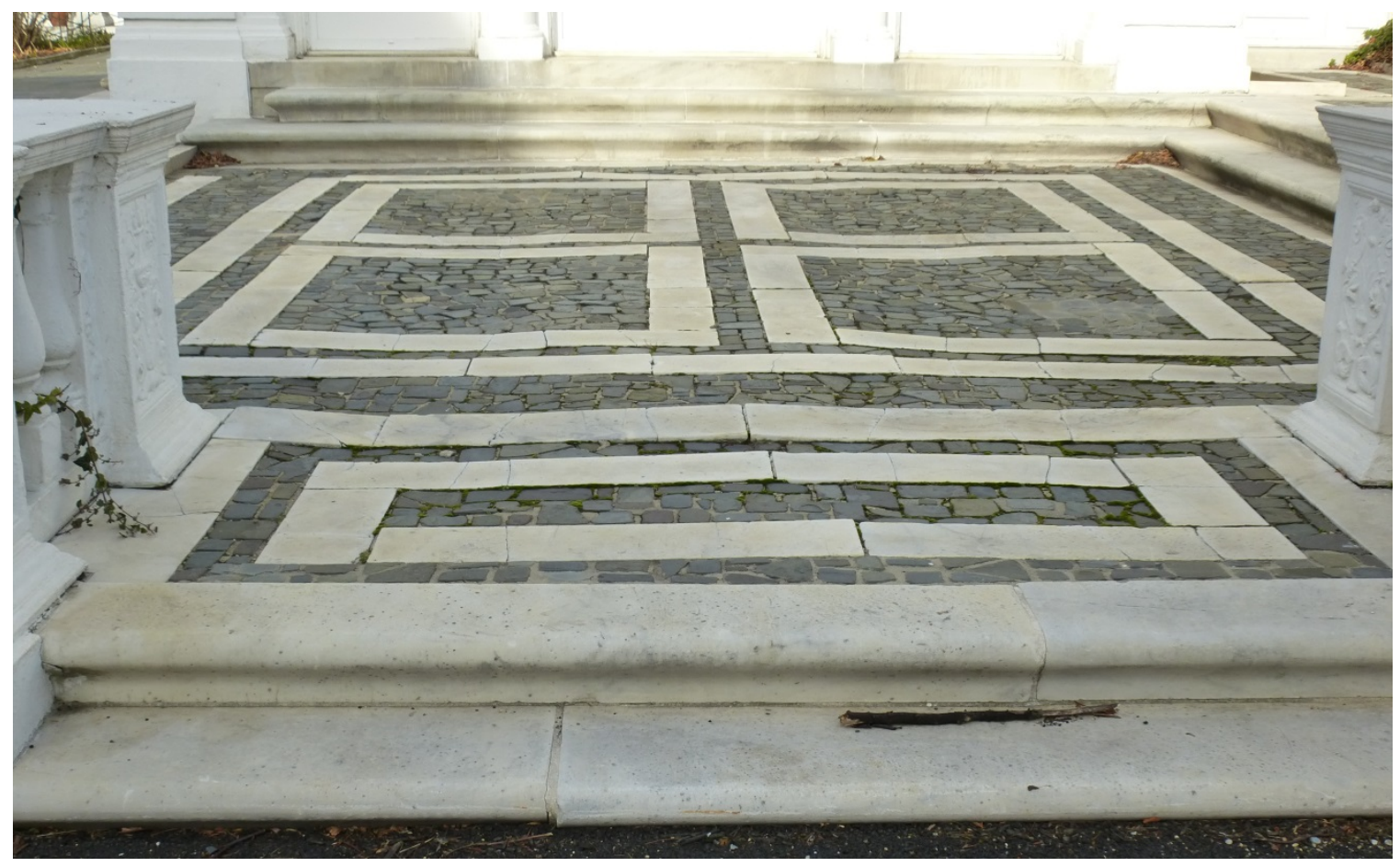


Figure 77. Main entrance hall in Wiley Hall (ERDC-CERL, 2013).

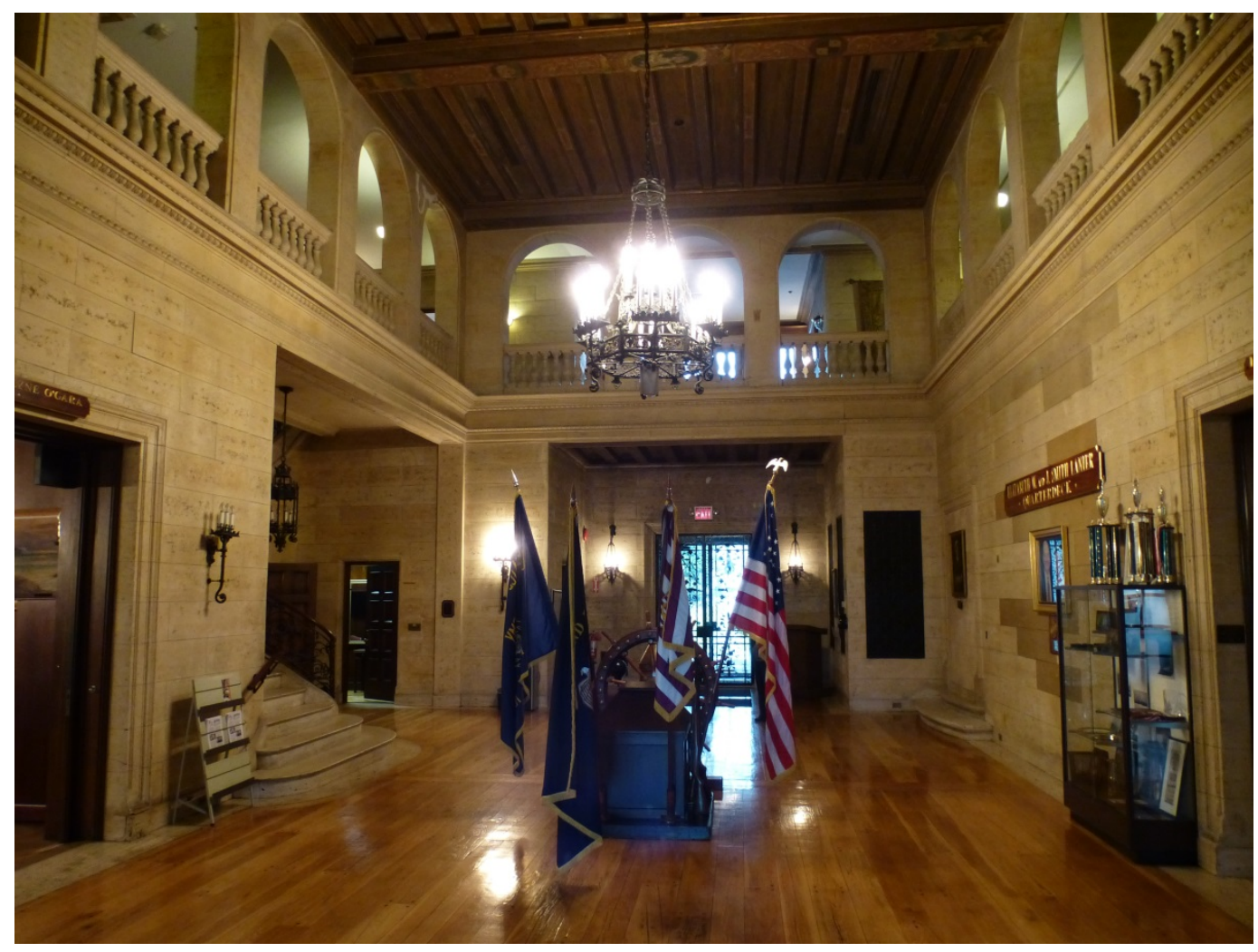

Figure 78. Main staircase in Wiley Hall (ERDC-CERL, 2013).

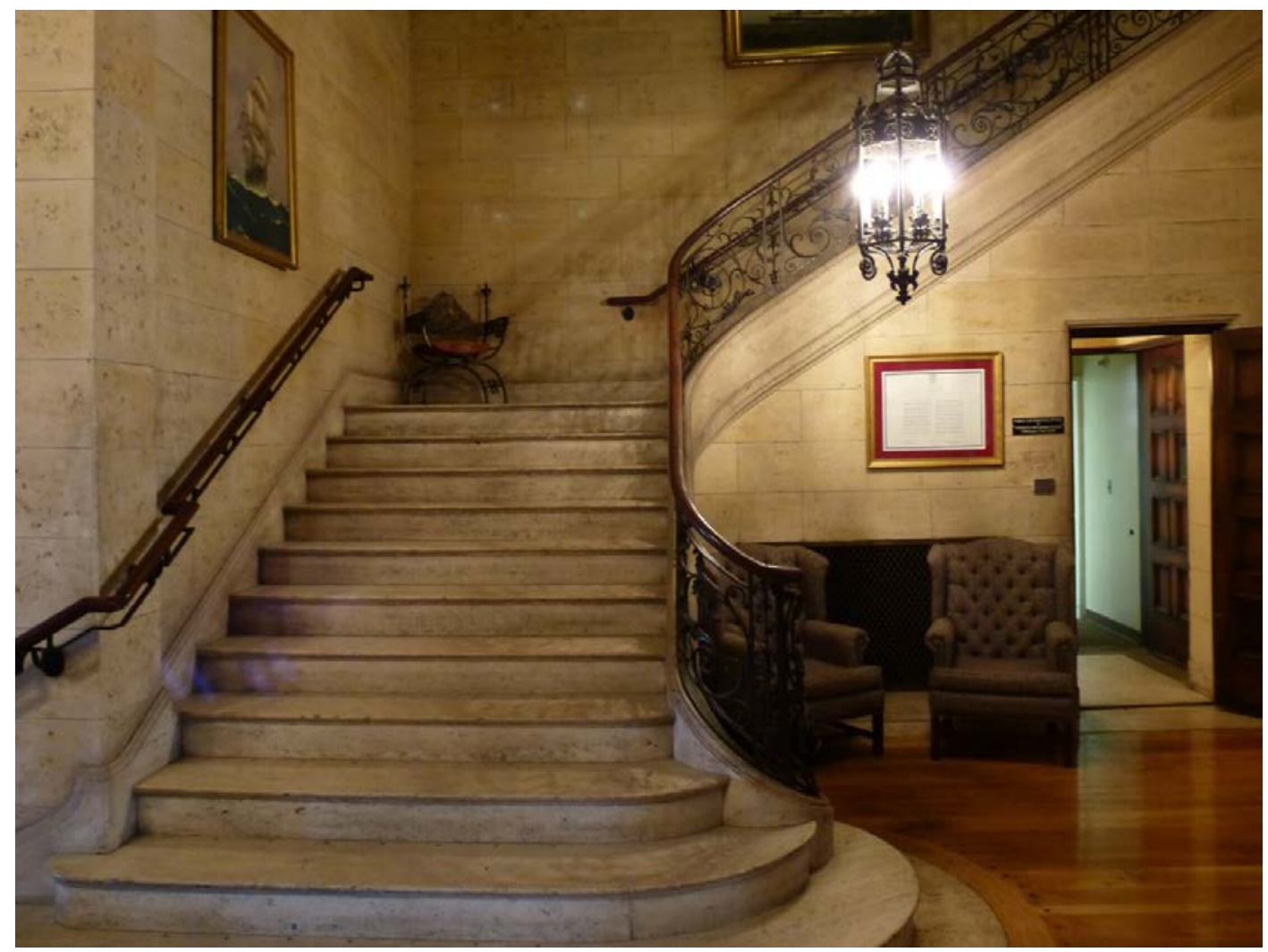


Figure 79. Former Bendel/Chrysler living room, now a lounge in Wiley Hall (ERDC-CERL, 2013).

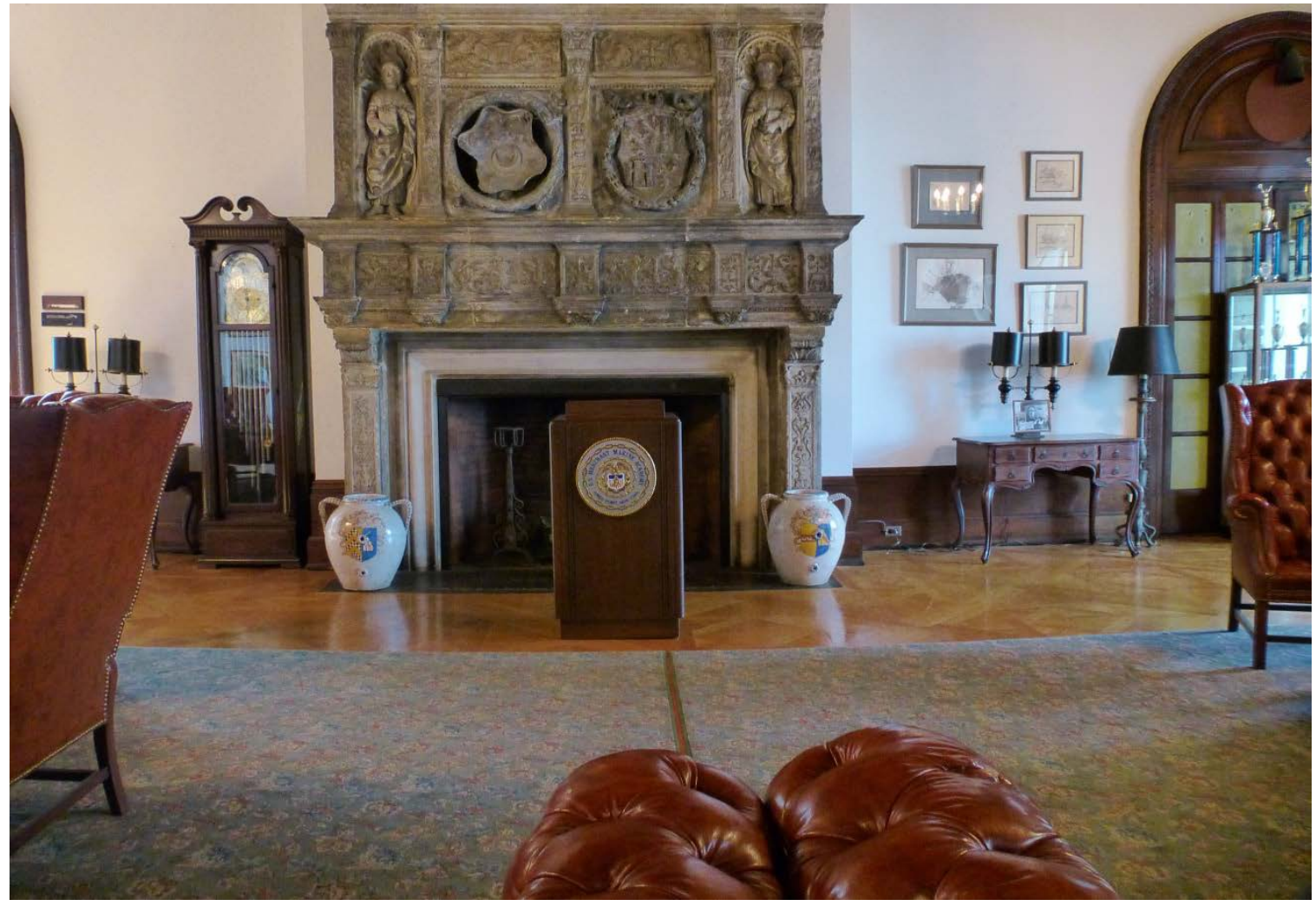

Figure 80. Painted ceiling in Wiley Hall (ERDC-CERL, 2013).

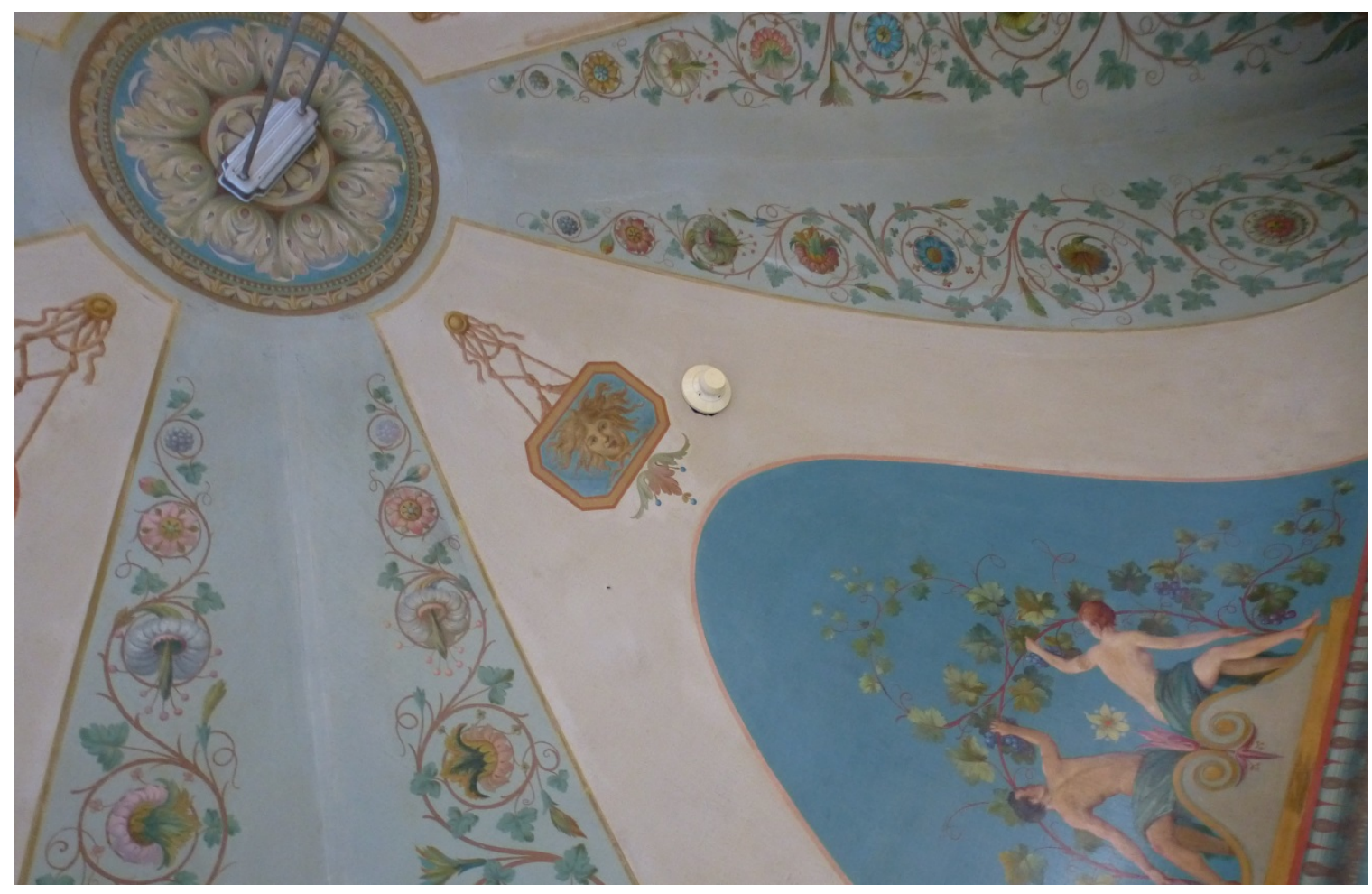


Figure 81. Tile floor in Wiley Hall (ERDC-CERL, 2013).

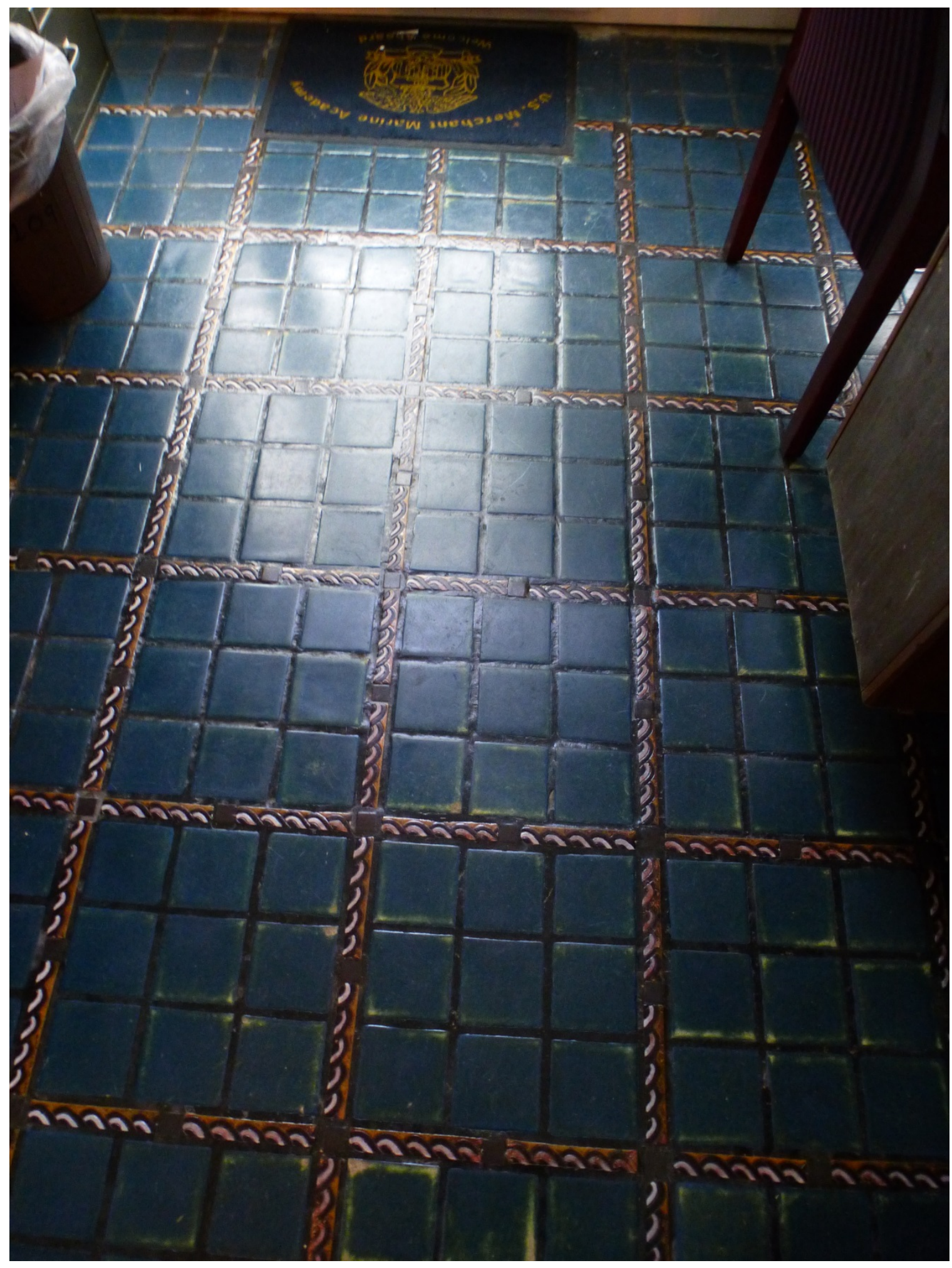


Figure 82. Door and door surround in Wiley Hall (ERDC-CERL, 2013).

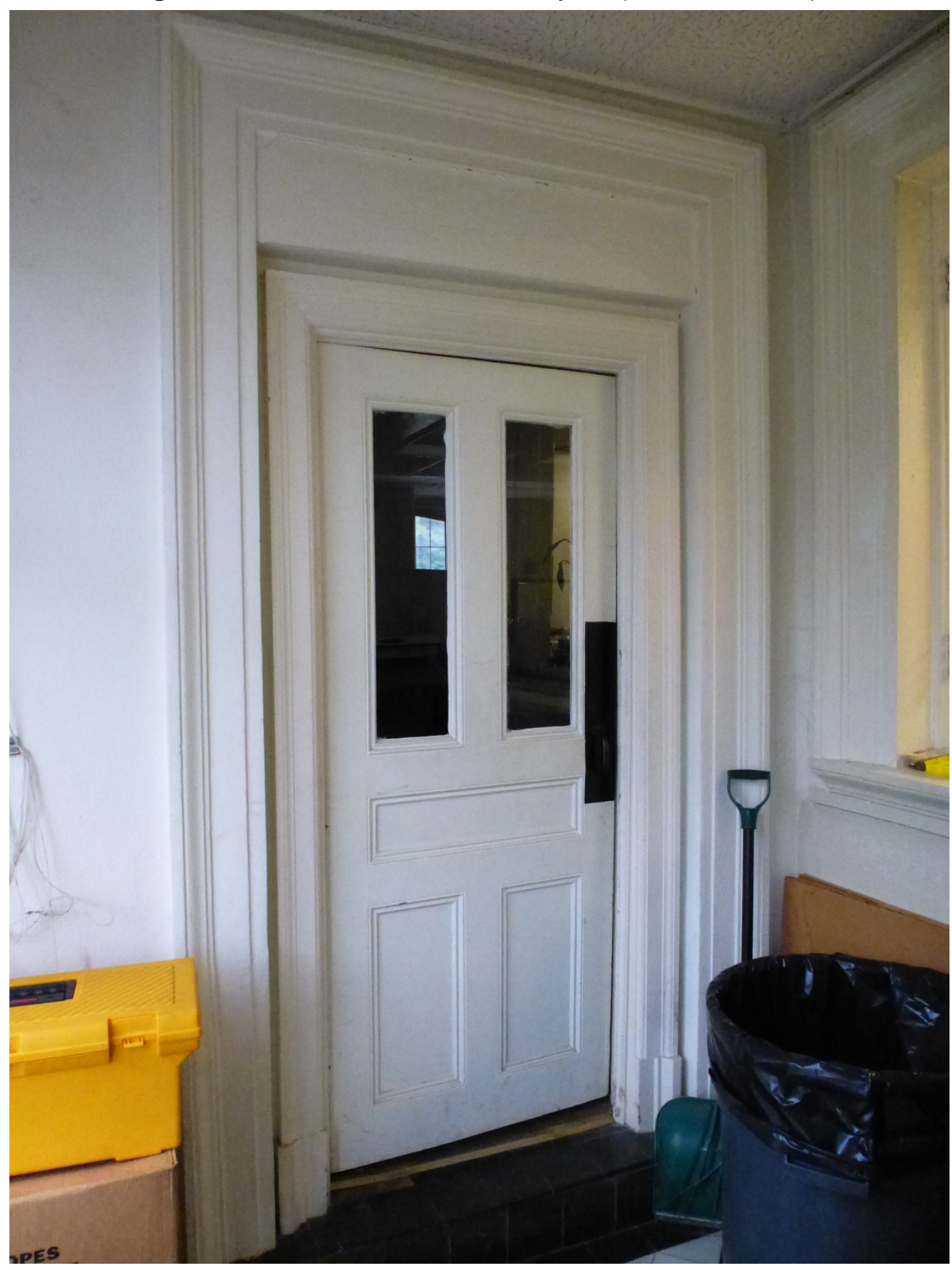


Figure 83. Fireplace in Wiley Hall (ERDC-CERL, 2013).

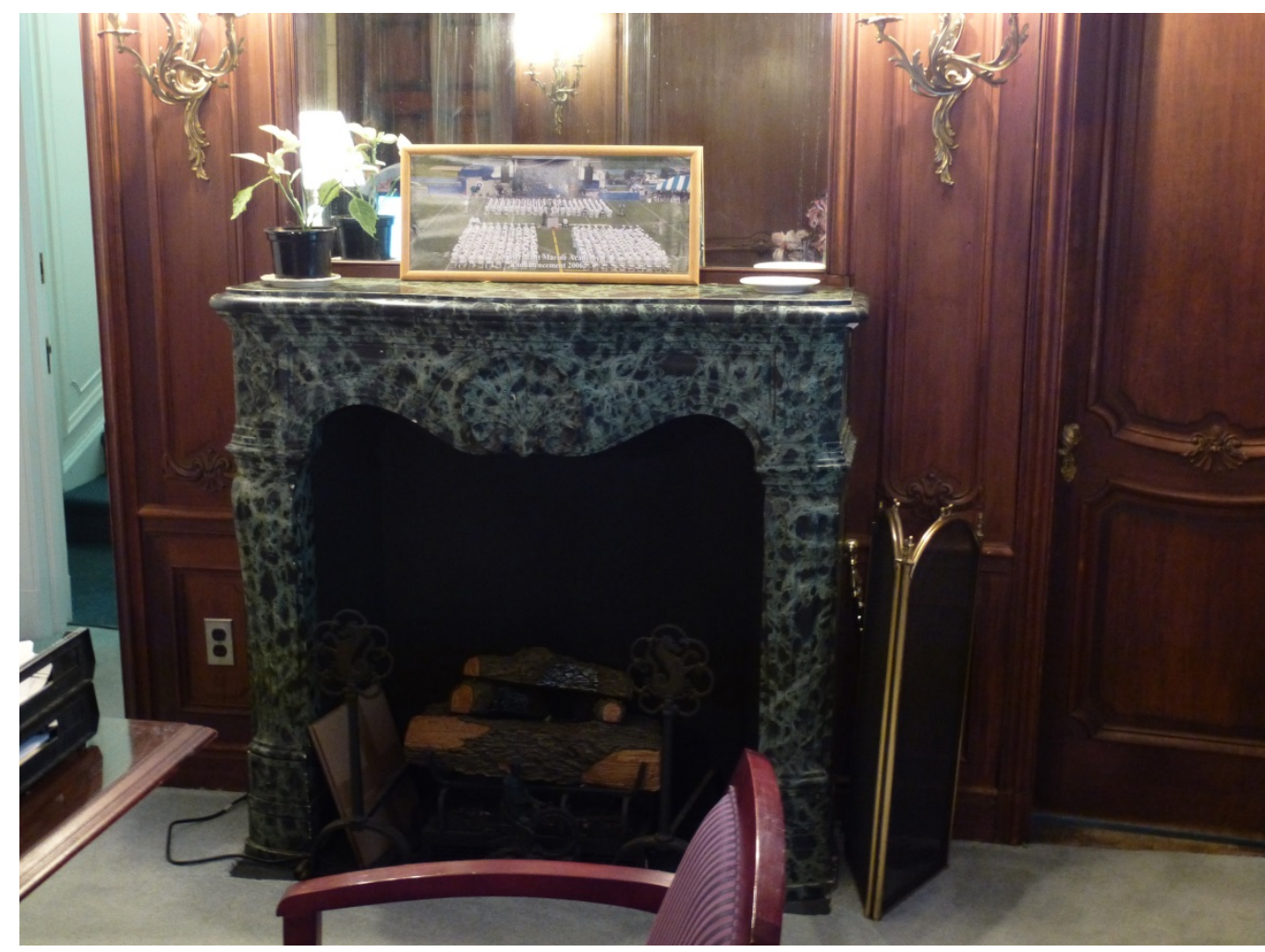

Figure 84. One of the original Bendel/Chrysler bathrooms (with a replacement sink) in Wiley Hall (ERDC-CERL, 2013).

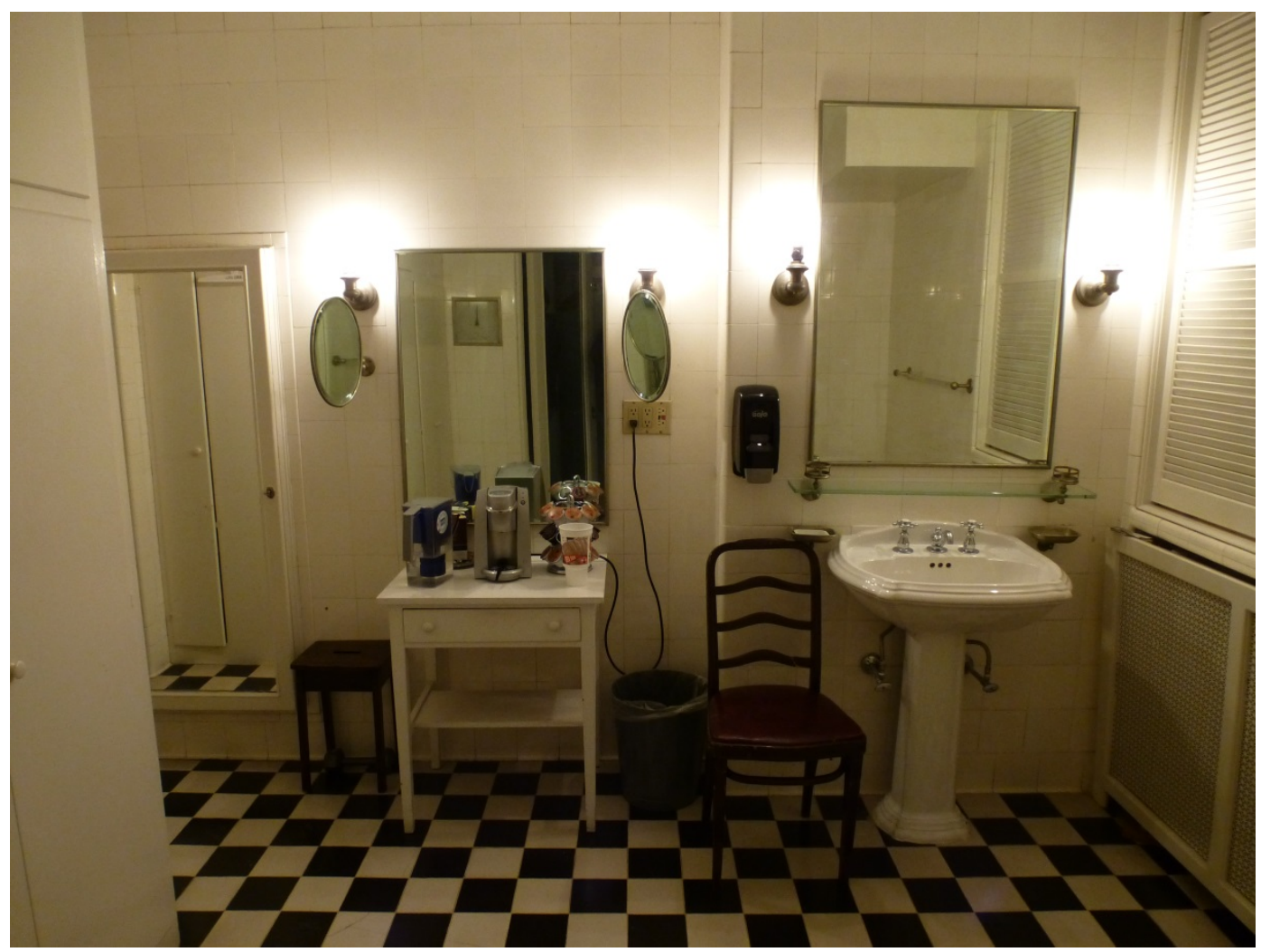




\subsubsection{Barracks (Palmer, Murphy, Cleveland, and Rogers Halls)}

Palmer, Murphy, Cleveland, and Roger Halls are contributing features of the historic district, but the interiors of these buildings are noncontributing. Rogers Hall is connected to Cleveland Hall via a "hyphen." Cleveland Hall flanks Barney Square on the east and is connected to Delano Hall on the west via a hyphen. Palmer Hall is connected to Murphy Hall via a "hyphen." Murphy Hall flanks Barney Square on the west and is connected to Delano Hall on the east via a hyphen. They were all constructed in 1943 and designed by Alfred Hopkins \& Associates. They are constructed with a cast-in-place structure and buff-colored concrete block exterior walls in a distinctive stone-like pattern. Cast stone architectural elements are placed at the lintel and sill levels on all windows. Cast stone is also utilized for all entrance door surrounds, the belt course, quoins, and the cornice. The parapet concrete block was replaced at some point. The buildings display a generally consistent cornice line which adds to the visual cohesiveness of the area. The Classical Revival-style buildings are designed with an emphasis on balance and symmetry. The roofs are layered asphalt that is hidden behind a parapet of similar buff-colored concrete masonry units. The original double-hung, six-over-six wood windows have all been replaced with anodized bronze, double-hung, six-over-one aluminum windows. The doors and light fixtures are not original. The interiors have been heavily remodeled through the years. 
Figure 85. West façades of Rogers Hall [left] and Cleveland Hall [right] (ERDC-CERL, 2013).

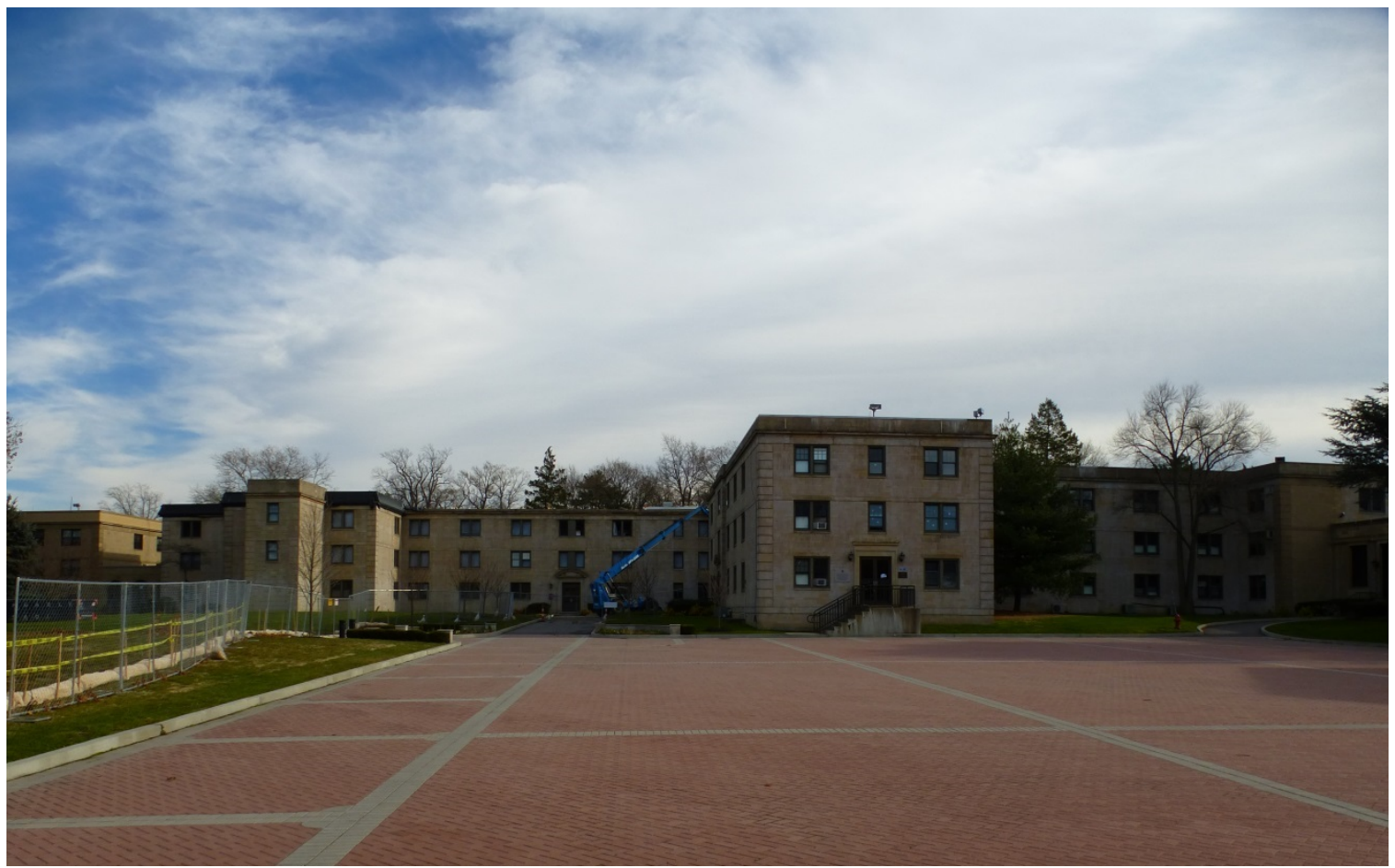

Figure 86. North façade of Murphy Hall [left] and east façade of Palmer Hall [right] (ERDC-CERL, 2013).

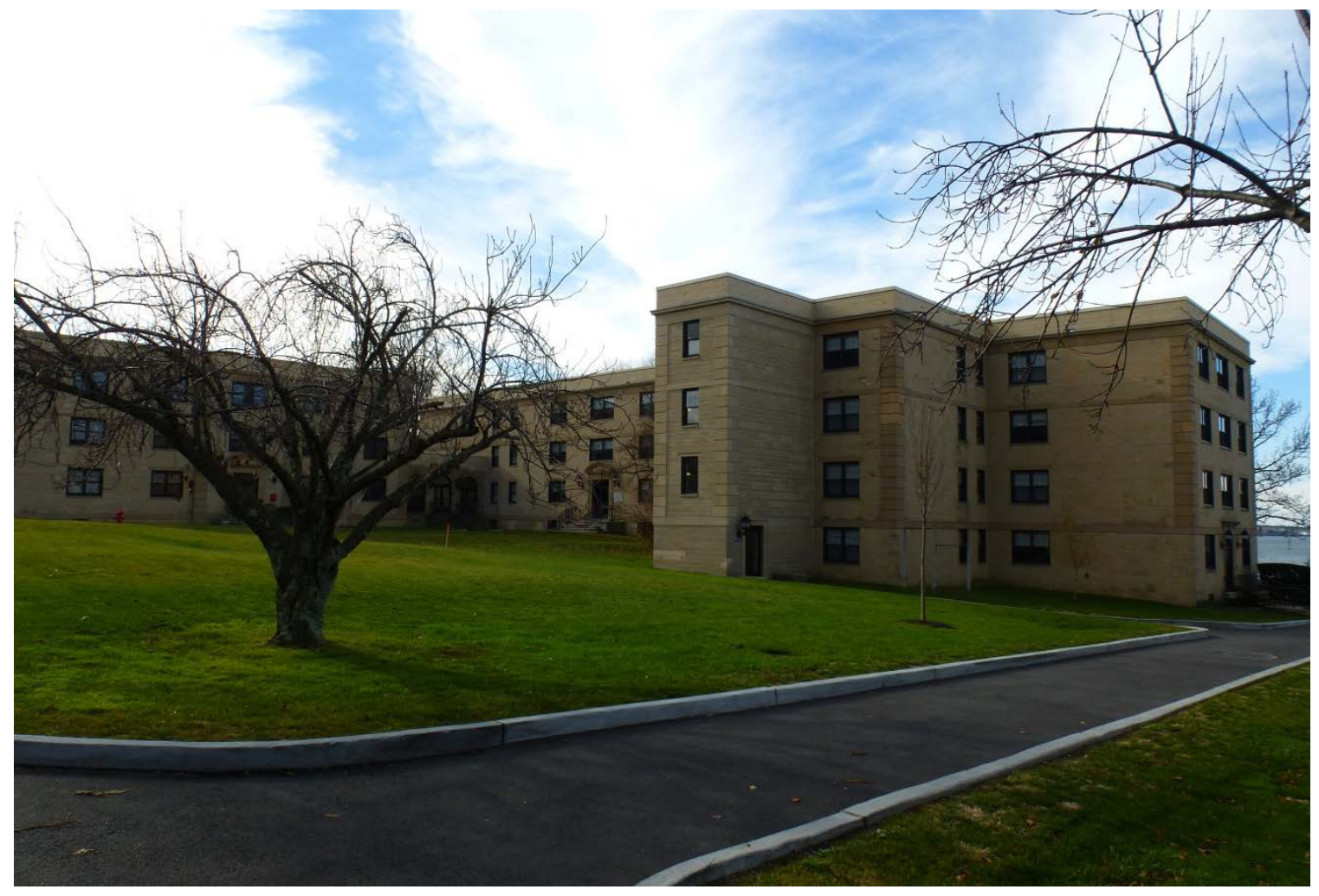


Figure 87. Close-up of the entry (center) on east façade of Palmer Hall, with entrance to Murphy Hall shown on the left (ERDC-CERL, 2013).

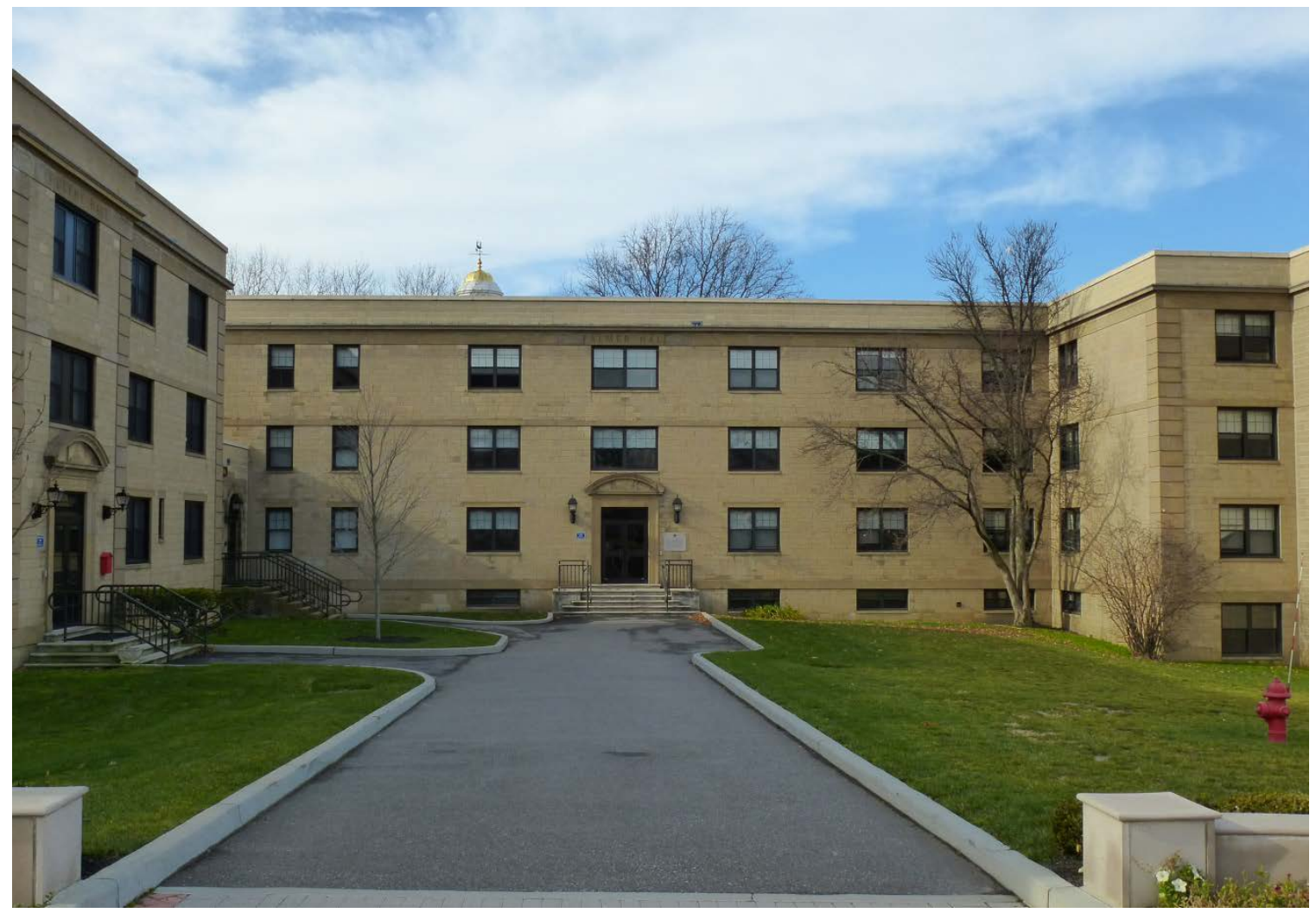

Figure 88. West entrance to Palmer Hall (ERDC-CERL, 2013).

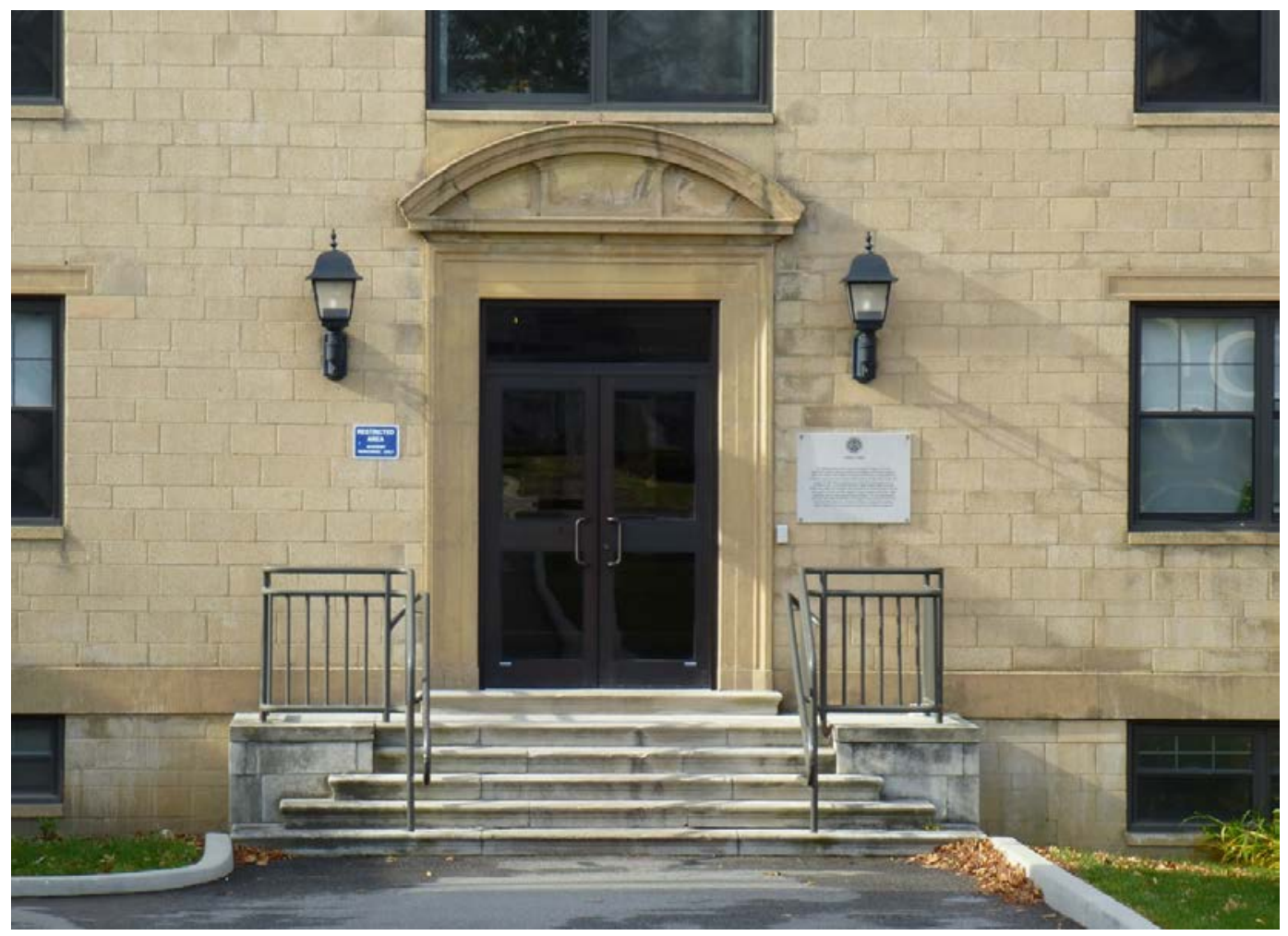


Figure 89. Cast-stone door surround and replacement light fixture on the west entrance to Palmer Hall (ERDC-CERL, 2013).

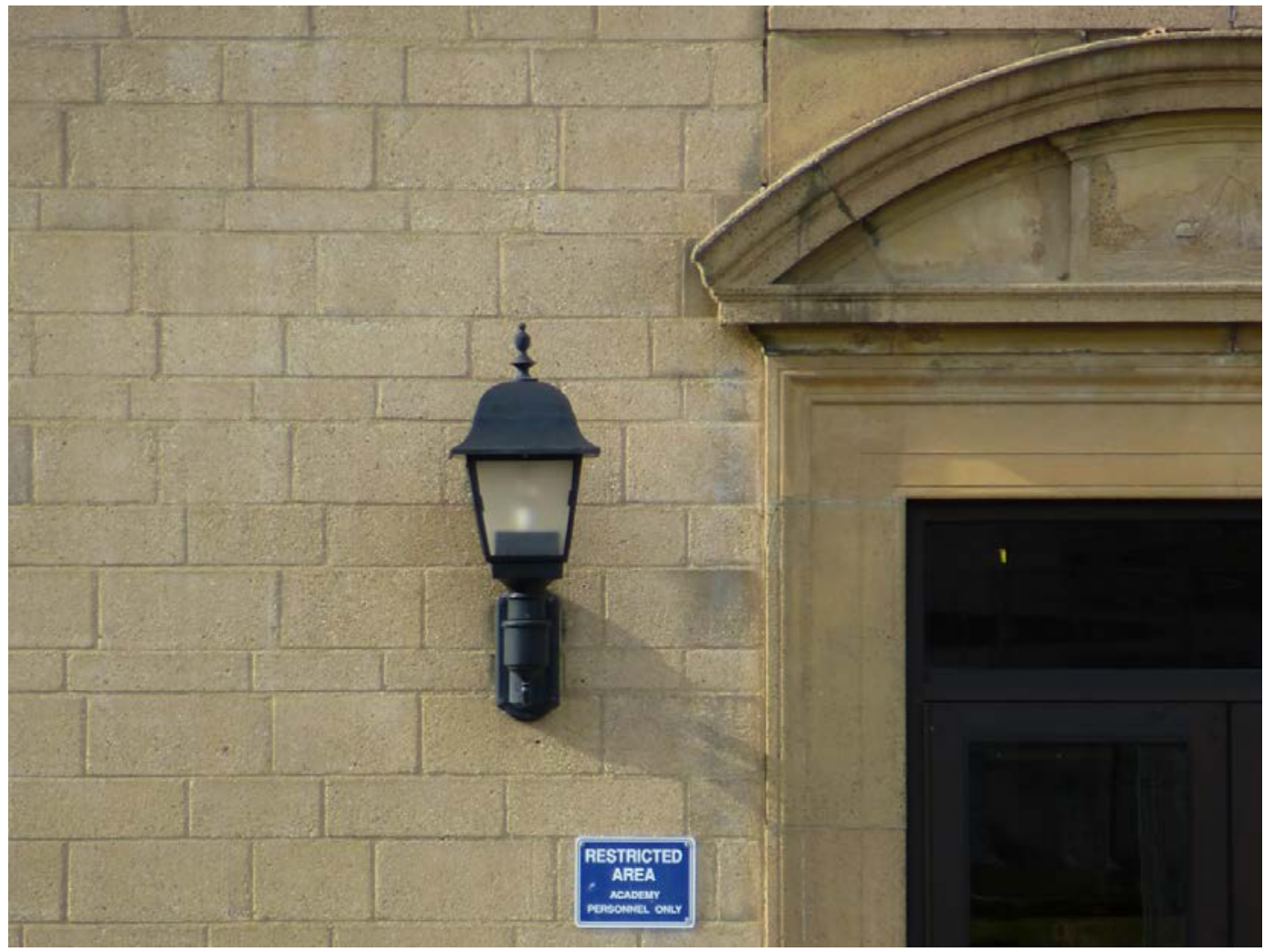

Figure 90. Detail of original architectural drawings for the barracks (USMMA, DPW).

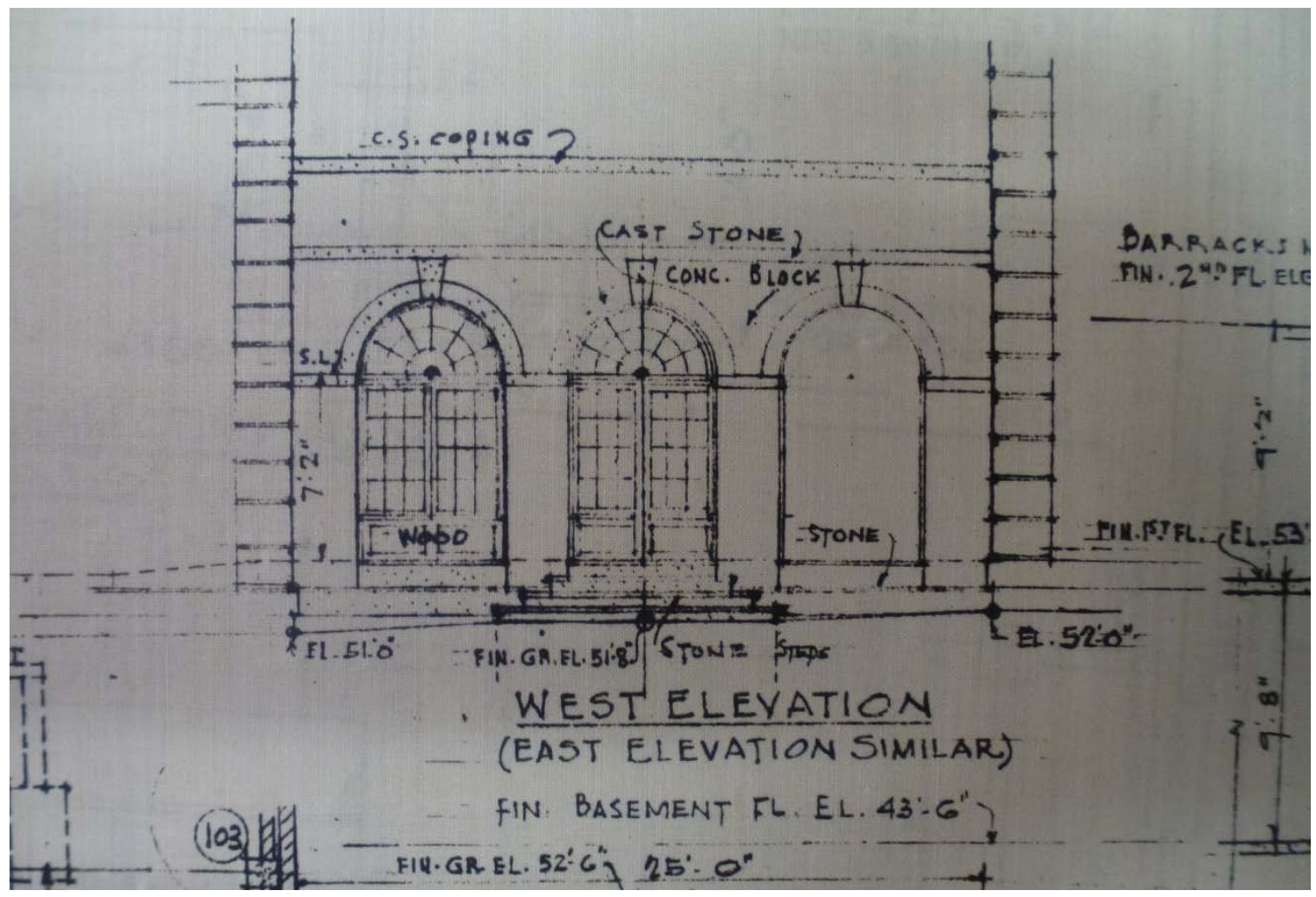


Figure 91. South façade of arcade that connects Rogers Hall to Cleveland Hall (ERDC-CERL, 2013).

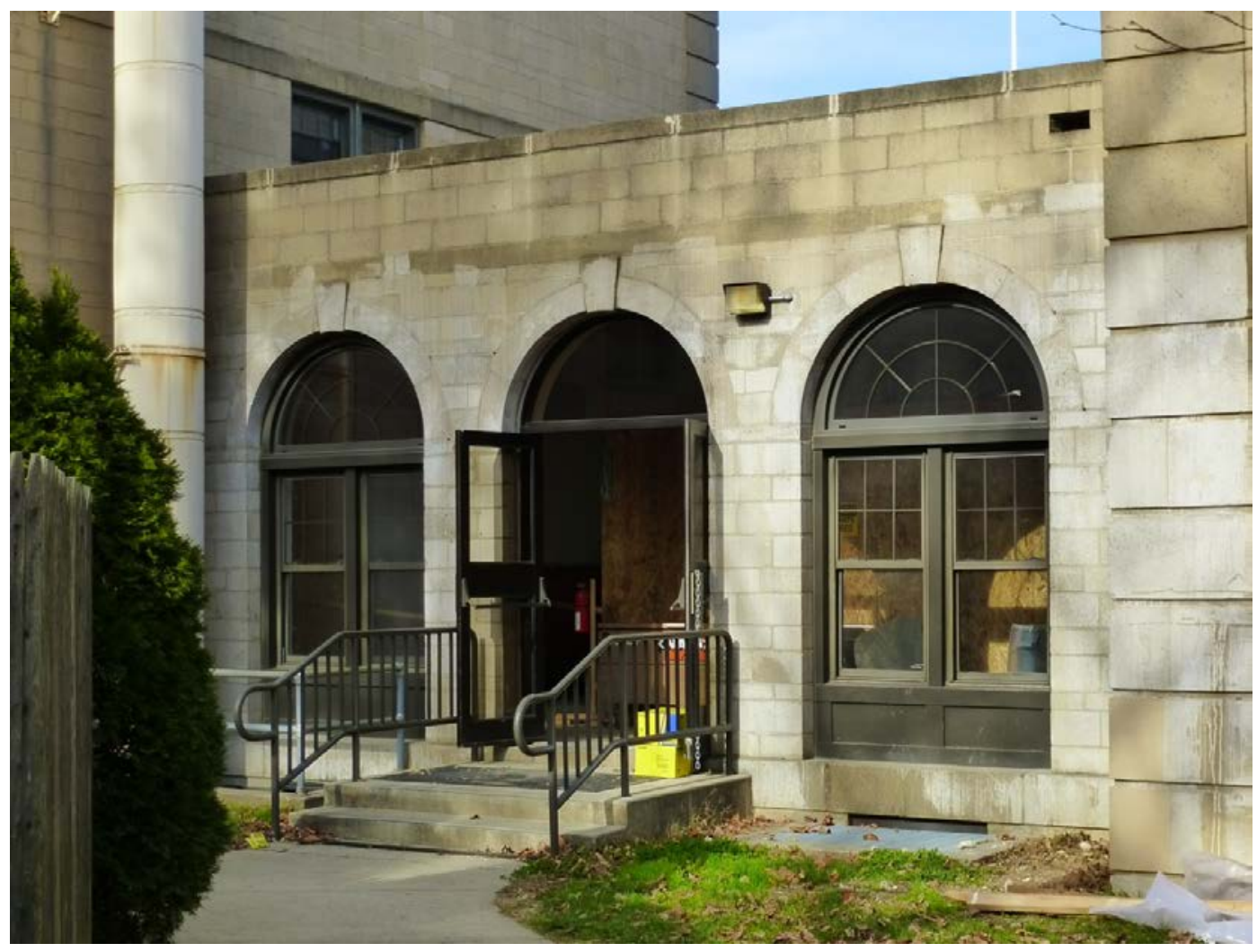


Figure 92. Detail of concrete block walls, showing distinctive stone-like pattern on these barracks (ERDC-CERL, 2013).

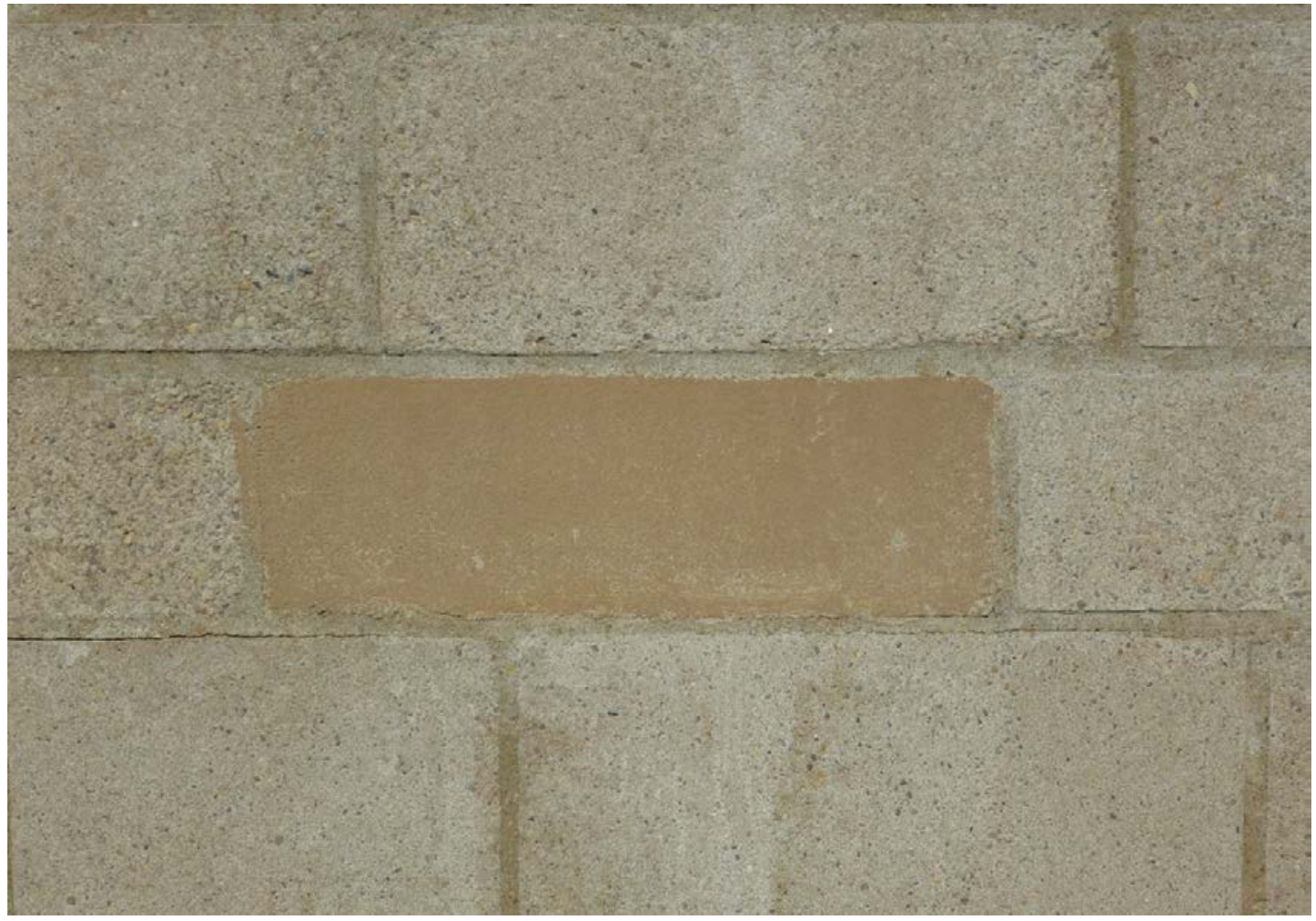

Figure 93. Detail of cornice and parapet on Cleveland Hall (ERDC-CERL, 2013).

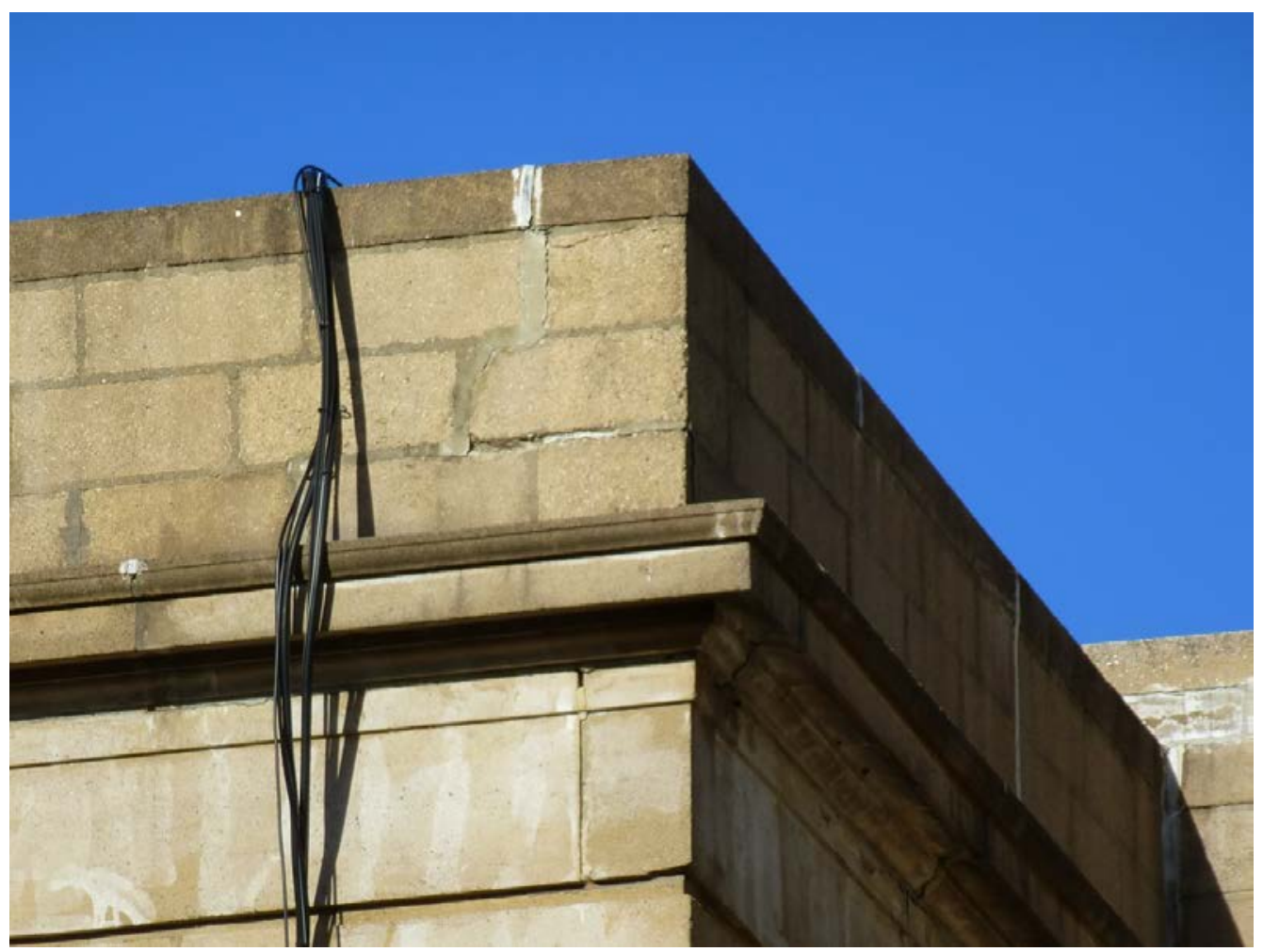


Figure 94. Original light schedule drawing for barracks entrance light fixtures (USMMA DPW).

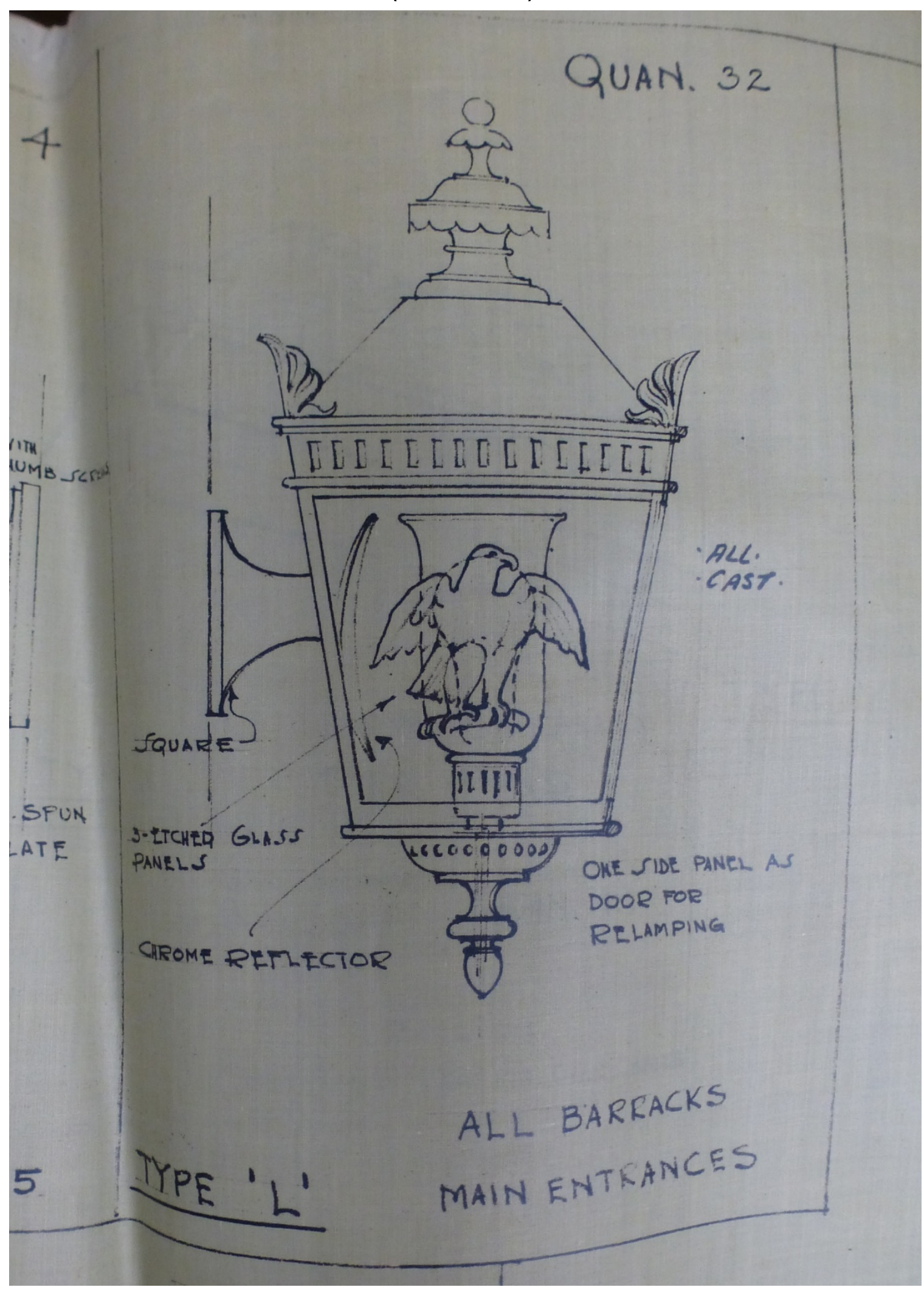


Figure 95. Typical replacement light fixture at entrance to one of the barracks (ERDC-CERL, 2013).

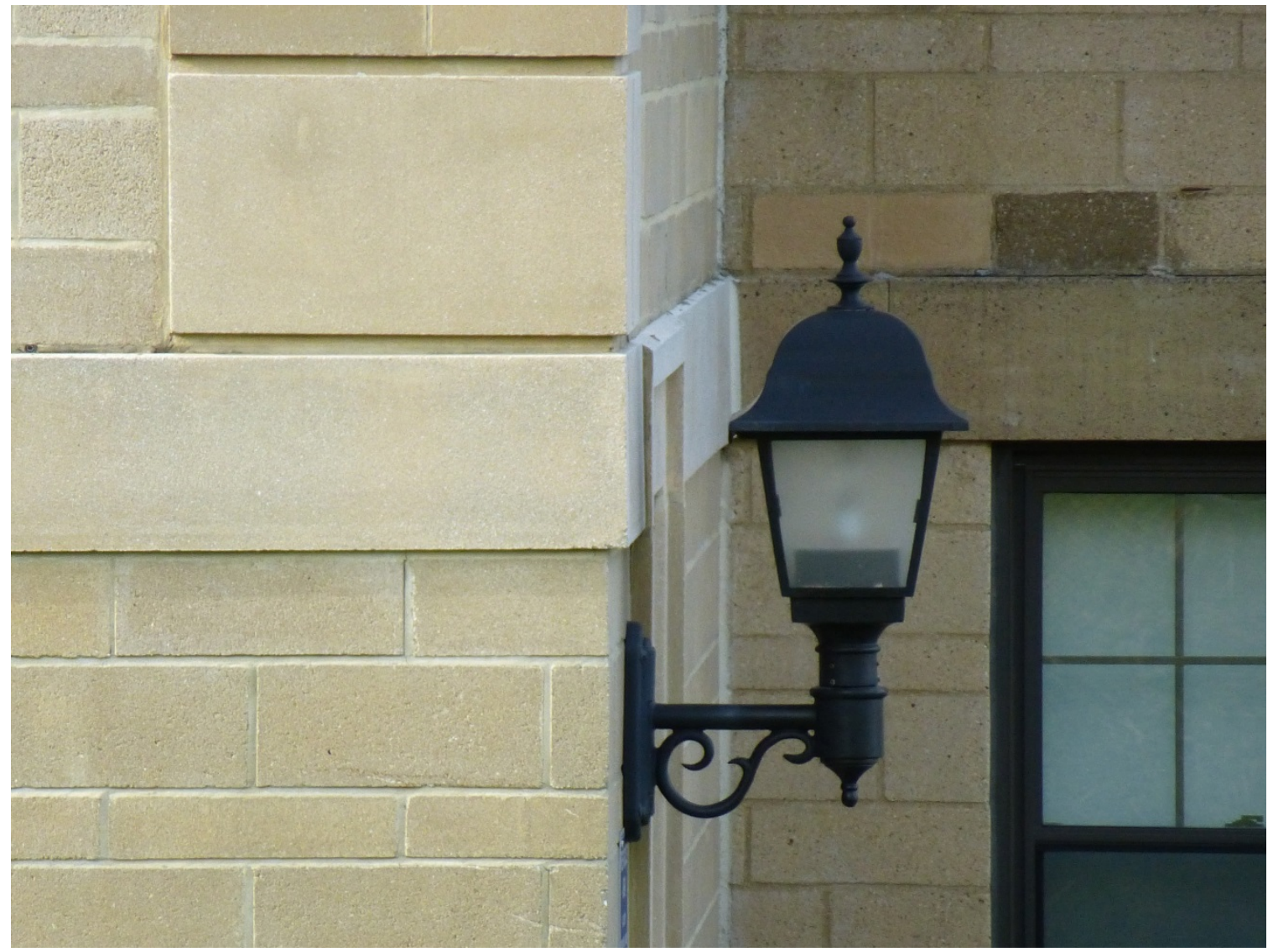

\subsubsection{Character-defining features}

Repair, renovation, and replacement of the following character-defining features of Palmer, Murphy, Cleveland, and Rogers Halls must be coordinated with the NY SHPO.

- Overall massing

- Footprint

- Exterior concrete block and its distinctive stone-like pattern

- Parapet

- All cast stone architectural elements including window sills and lintels, door surrounds, belt course, quoins, and cornices

- Window and door openings

- Multipane double-hung windows (see architectural plans ${ }^{11}$ for original window specs)

\footnotetext{
11 All architectural plans are on file with the Department of Public Works (DPW) office at USMMA.
} 


\subsubsection{Character-defining features that have been removed}

Listed below are character-defining features of Palmer, Murphy, Cleveland, and Rogers Halls that have been removed or replaced over the years; as future renovations occur, these need to be replaced with elements that replicate the original character-defining features of the building. The original architectural plans will guide this process in coordination with the NY SHPO.

- Replacement anodized-bronze windows

- Replacement entrance doors

- Replacement exterior light fixtures

\subsubsection{Nonhistoric features}

- Railings

\subsubsection{Barracks (Barry and Jones Halls) and the Truxton Arcade}

Barry and Jones Halls and the Truxton Arcade are contributing buildings to the USMMAHD, but the interiors are noncontributing. These two barracks (dorms) that are on the east side of the central campus are connected by the Truxton Arcade. The arcade allows passage to O'Hara Hall (gymnasium) to the east. Barry Hall is to the south of the arcade, while Jones Hall is to the north. They were both constructed in 1943 and designed by Alfred Hopkins \& Associates. They are constructed with a cast-in-place structure and concrete block exterior walls in a distinctive stone-like pattern. Caststone architectural elements are placed at the lintel and sill levels on all windows. Cast stone is also utilized for all entrance door surrounds, the belt course, quoins, and the cornice. The parapet concrete block was replaced at some point. An Americans with Disabilities Act (ADA)-compliant elevator was added to the interior of the Truxton Arcade, giving access to both Barry and Jones Halls. The original double-hung, six-over-six wood windows have all been replaced with anodized bronze, double-hung, sixover-one aluminum windows. The doors and light fixtures are not original. The interiors have been heavily remodeled through the years. 
Figure 96. West façade of the Truxton Arcade that connects Barry and Jones Halls (barracks), April 1943 (Bland Library, USMMA).

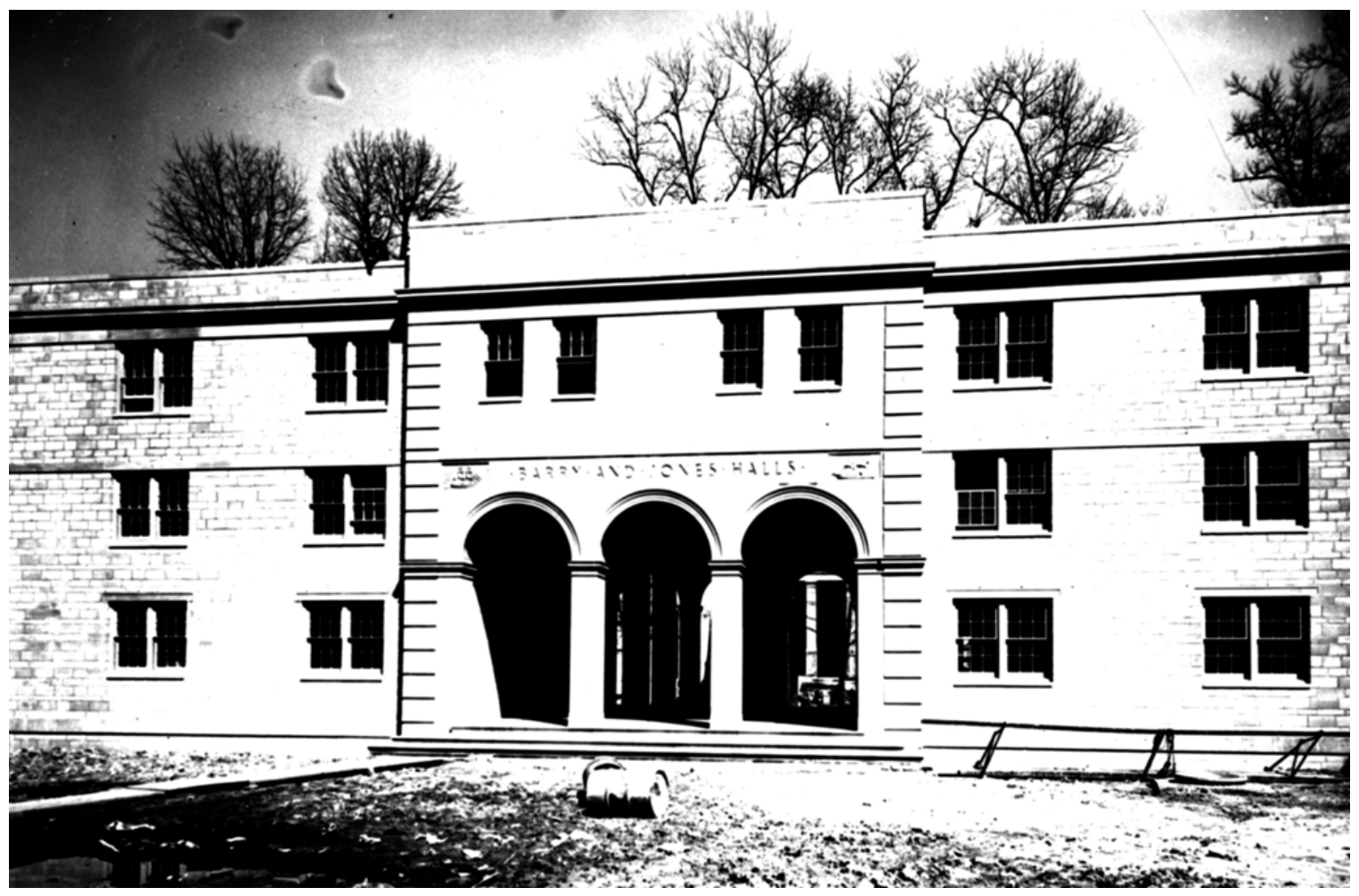

Figure 97. West façades of Jones Hall [left], Truxton Arcade [center], and Barry Hall [right] (ERDC-CERL, 2013).

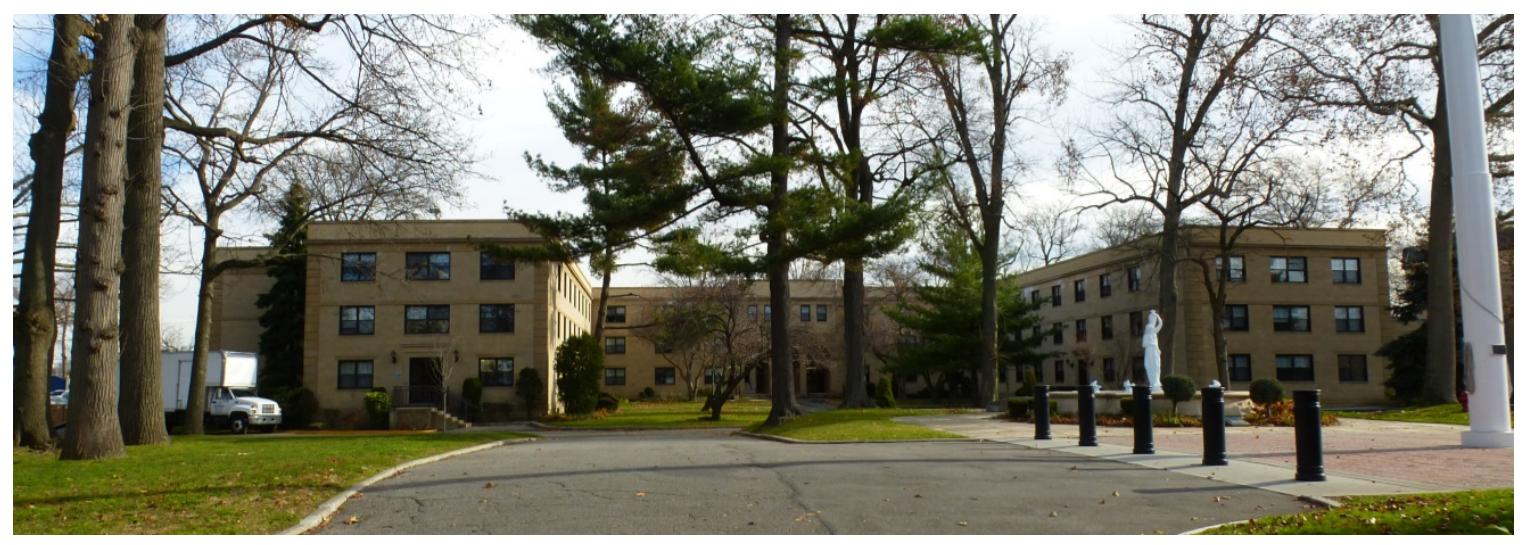


Figure 98. East façade of the Truxton Arcade (ERDC-CERL, 2013).

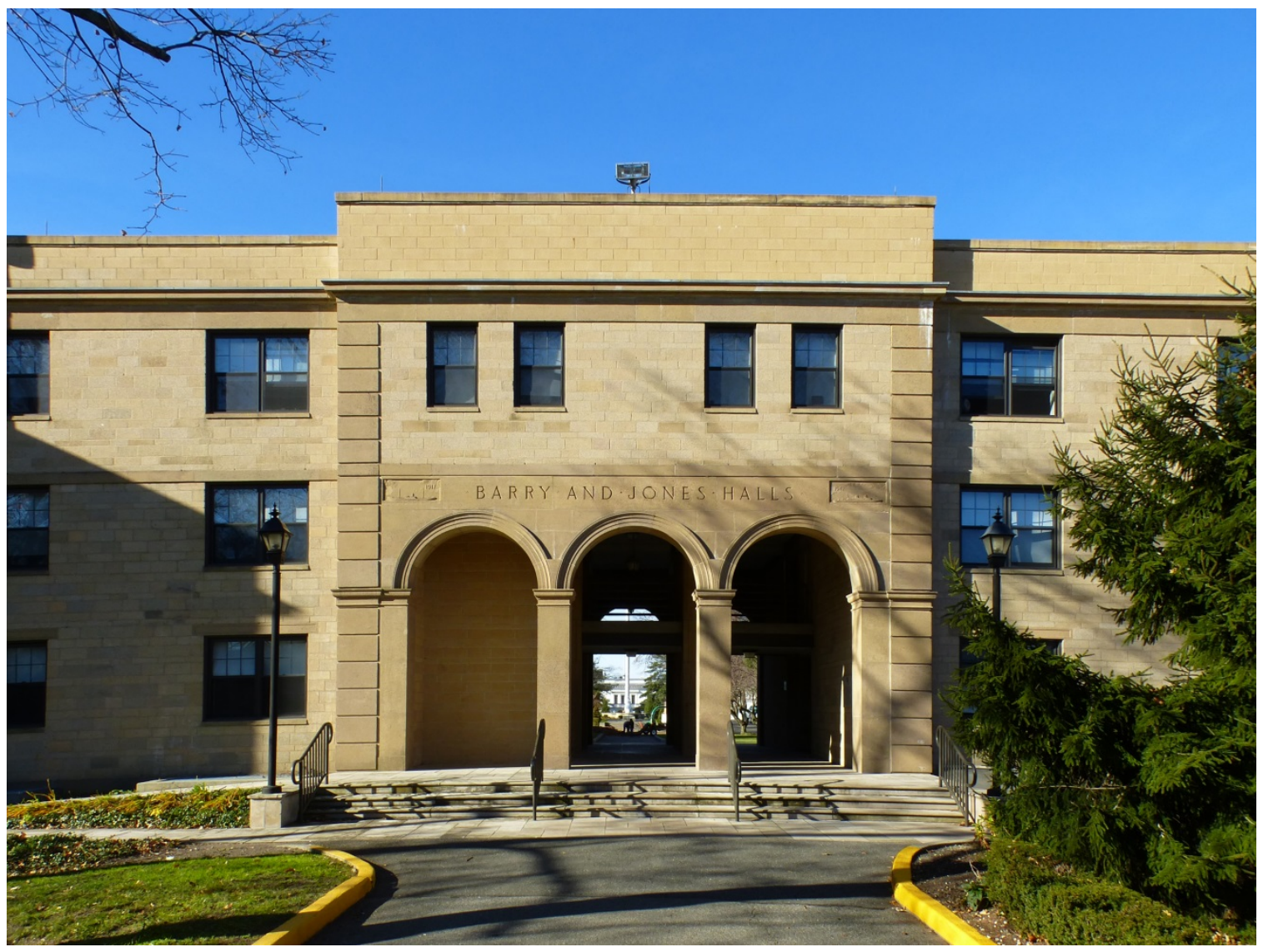

Figure 99. East façade of Barry Hall (ERDC-CERL, 2013).

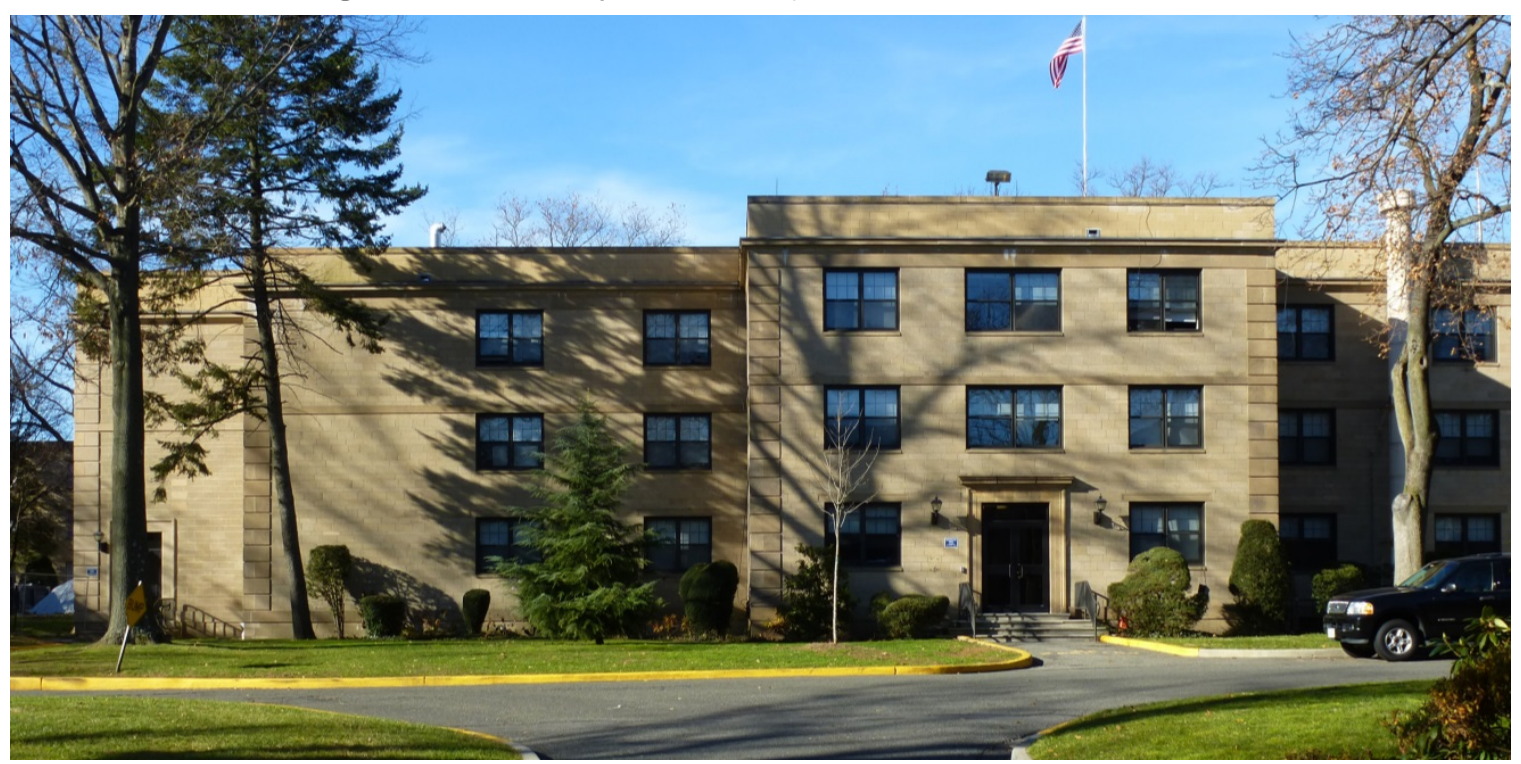


Figure 100. North façade of Jones Hall (ERDC-CERL, 2013).

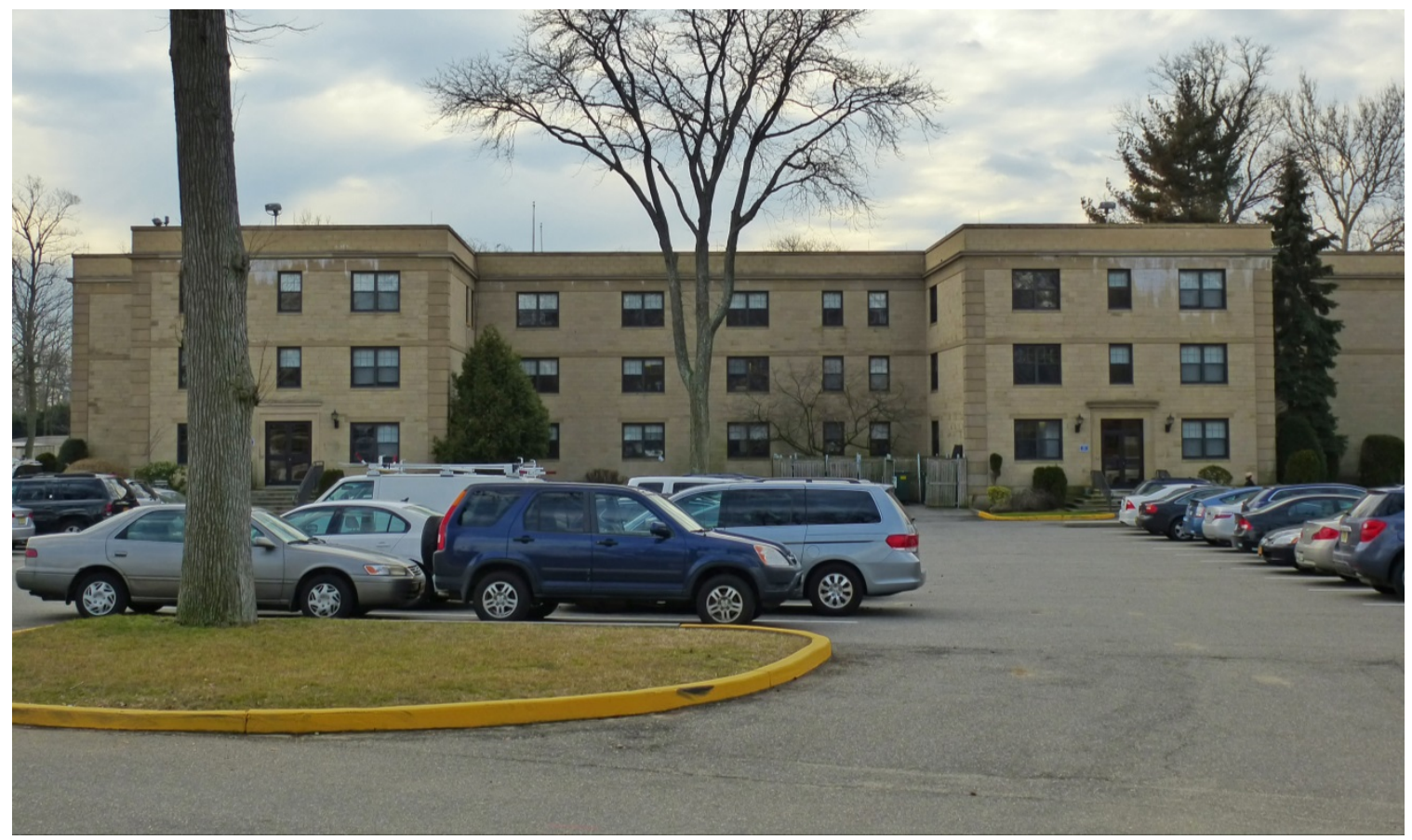

\subsubsection{Character-defining features}

Repair, renovation, and replacement of the following character-defining features of Barry and Jones Halls and the Truxton Arcade that connects them must be coordinated with the NY SHPO.

- Overall massing

- Footprint

- Exterior concrete block and its distinctive stone-like pattern

- Parapet

- All cast stone architectural elements including window sills and lintels, door surrounds, belt course, quoins, bas-reliefs, and cornices

- Window and door openings

- Multipane double-hung windows (see architectural plans for original window specs)

\subsubsection{Character-defining features that have been removed}

Listed below are character-defining features that have been removed or replaced over the years on Barry and Jones Halls; as future renovations occur, these need to be replaced with elements that replicate the original character-defining features of the buildings. The original architectural plans will guide this process in coordination with the NY SHPO. 
- Replacement anodized-bronze windows

- Replacement entrance doors

- Replacement exterior light fixtures

\subsubsection{Nonhistoric features}

- Railings

- ADA-compliant elevator in the Truxton Arcade

Figure 101. Detail of doorway on east façade of Barry Hall with nonhistoric doors (with original cast-stone surround), light fixtures, and railings (ERDC-CERL, 2013).

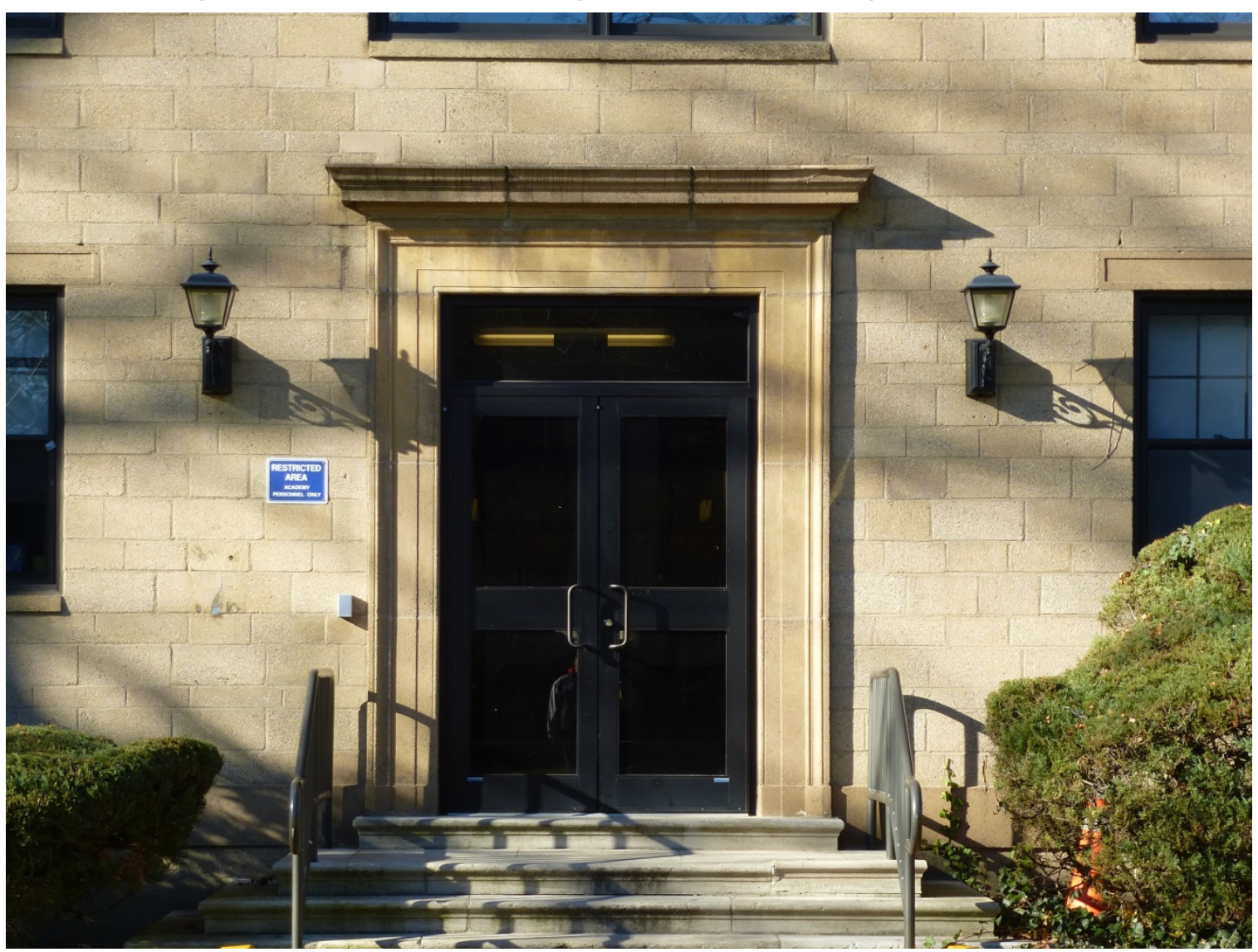


Figure 102. Detail of cast-stone door surround and nonhistoric light fixture on the east façade of Barry Hall (ERDC-CERL, 2013).

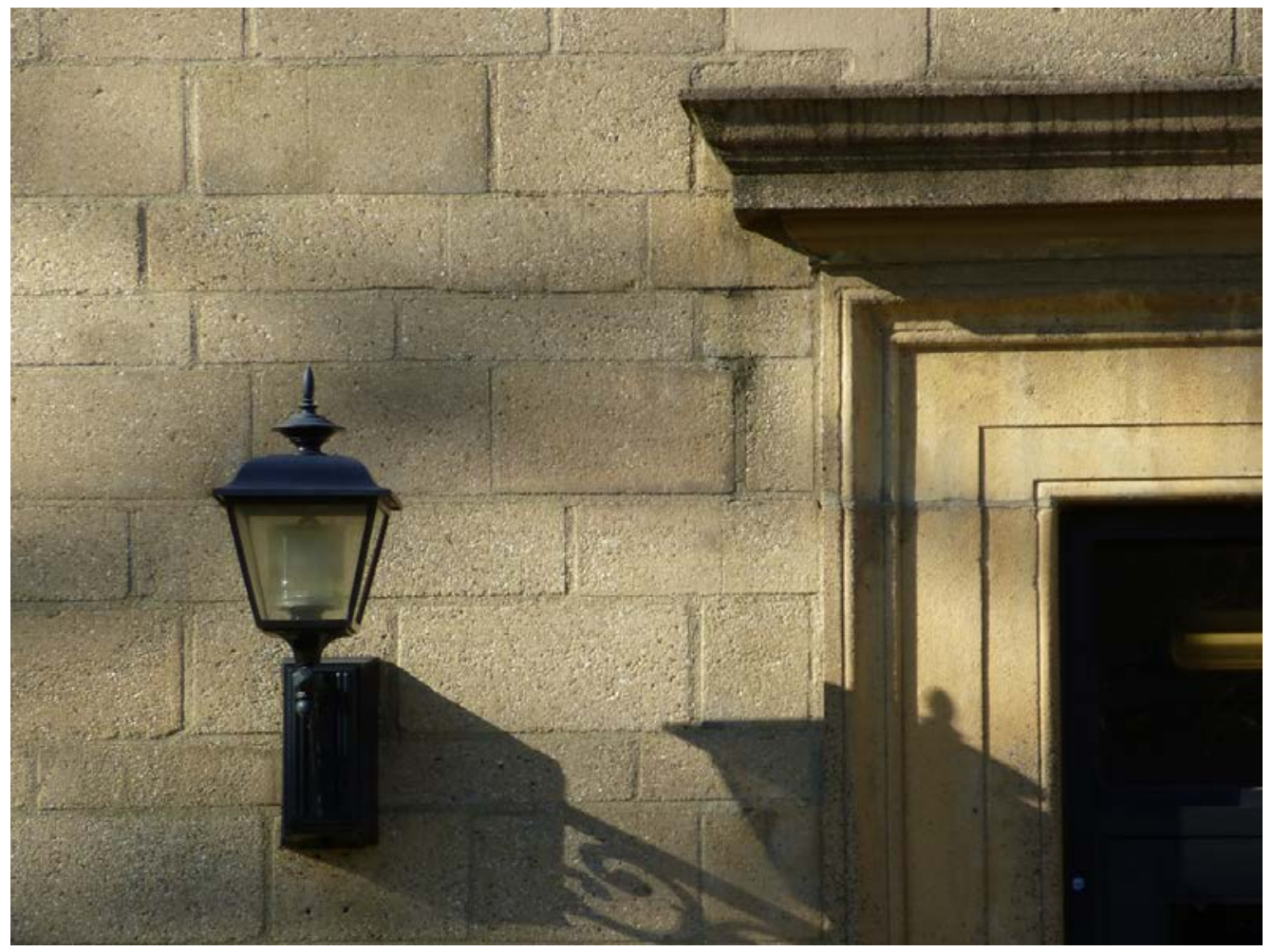

Figure 103. Detail of a cast-stone bas-relief on the east façade of the Truxton Arcade (ERDC-CERL, 2013).

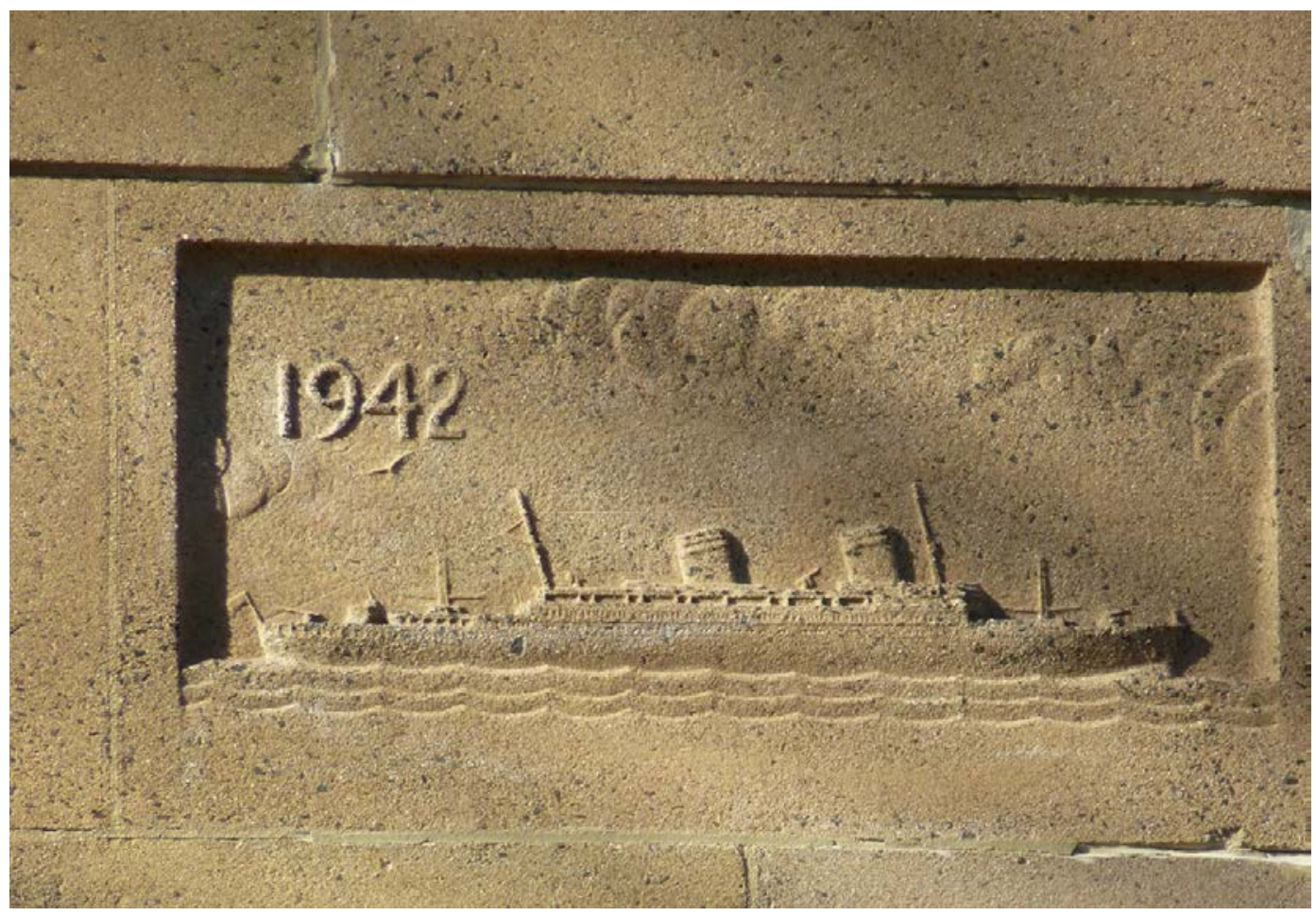


Figure 104. Detail of cast-stone elements on the arches of the Truxton Arcade (ERDC-CERL, 2013).

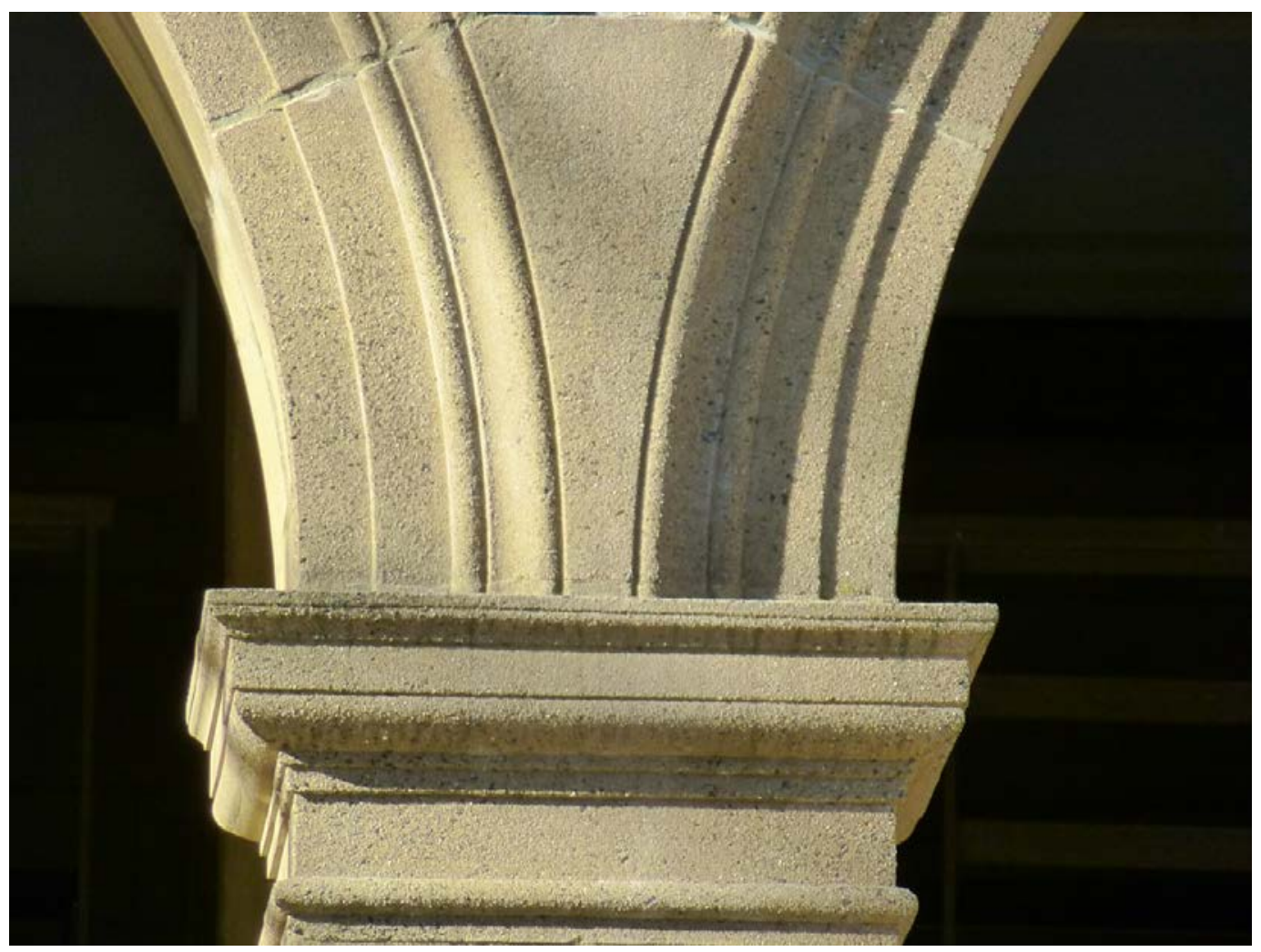

Figure 105. Detail of replacement parapet and original cast-stone quoins and cornice on the east façade of Barry Hall (ERDC-CERL, 2013).

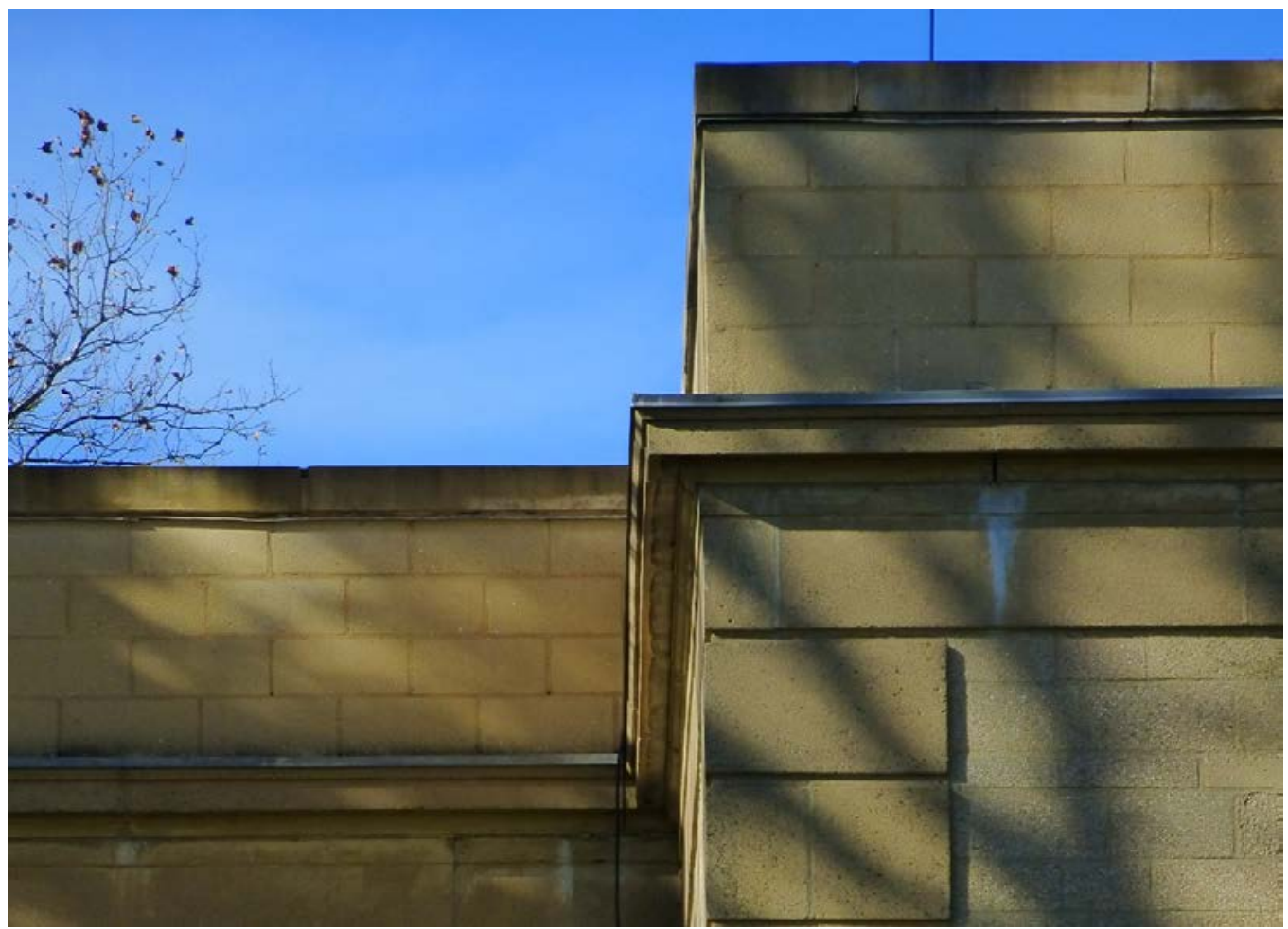


Figure 106. Original light schedule drawing for barracks entrance light fixtures (USMMA).

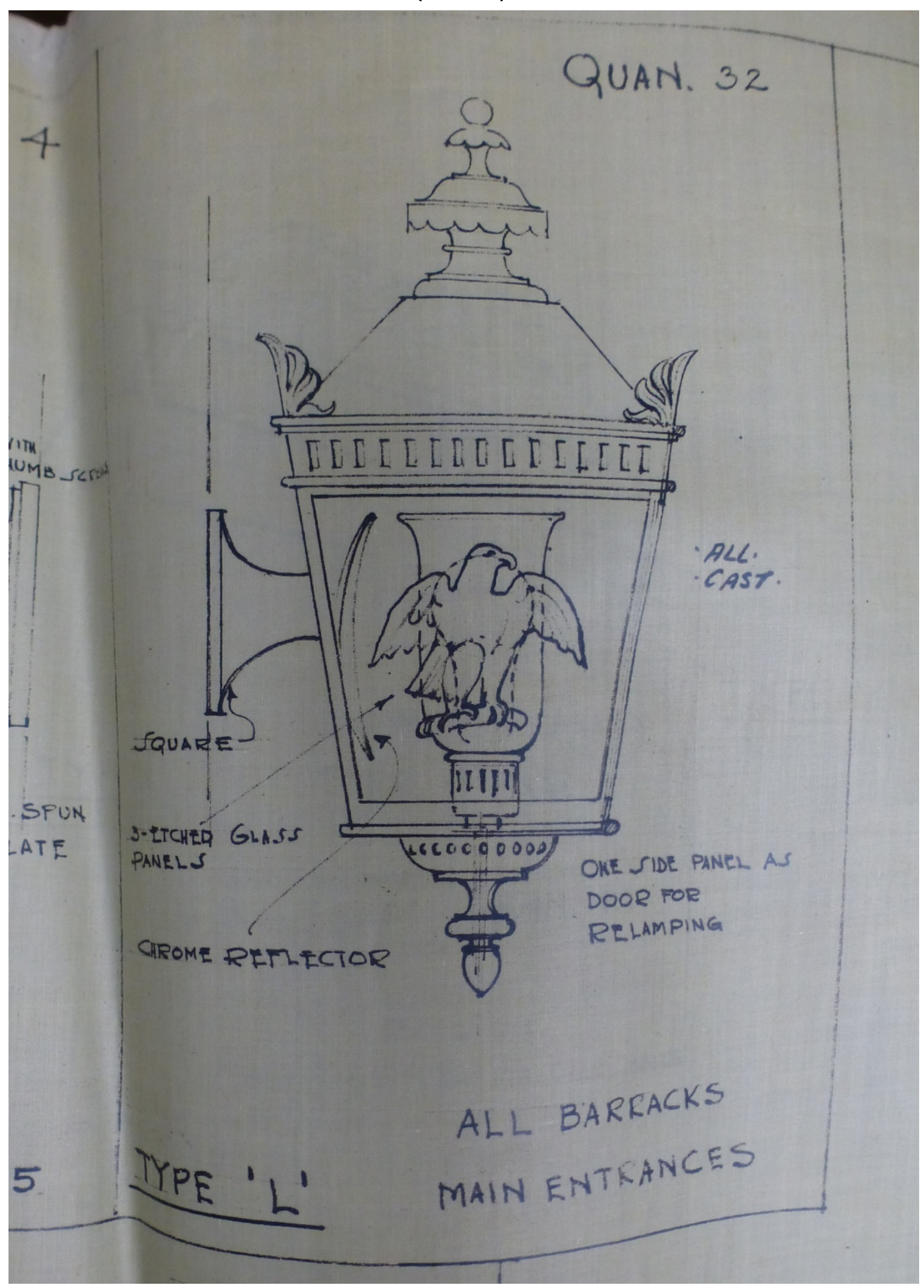




\subsubsection{Furuseth Hall}

Furuseth Hall is a contributing building to the USMMAHD, but the interior is noncontributing. It was originally constructed in 1943 as a staff barracks designed by Alfred Hopkins \& Associates. The building is located to the east of O'Hara Hall on the eastern edge of the historic district. It was converted for administrative use at an unknown date. It is of the same construction as the six other barracks discussed previously, with a cast-inplace structure and concrete block exterior walls in a distinctive stone-like pattern. Cast-stone architectural elements are placed at the lintel and sill levels on all windows. Cast stone is also utilized for all entrance door surrounds, the belt course, and the cornice. The parapet concrete block was replaced at some point. The original double-hung, six-over-six wood windows have all been replaced with anodized bronze double-hung, six-overone aluminum windows. The doors and light fixtures are not original. The interiors have been heavily remodeled through the years.

Figure 107. West façade of Furuseth Hall (ERDC-CERL, 2013).

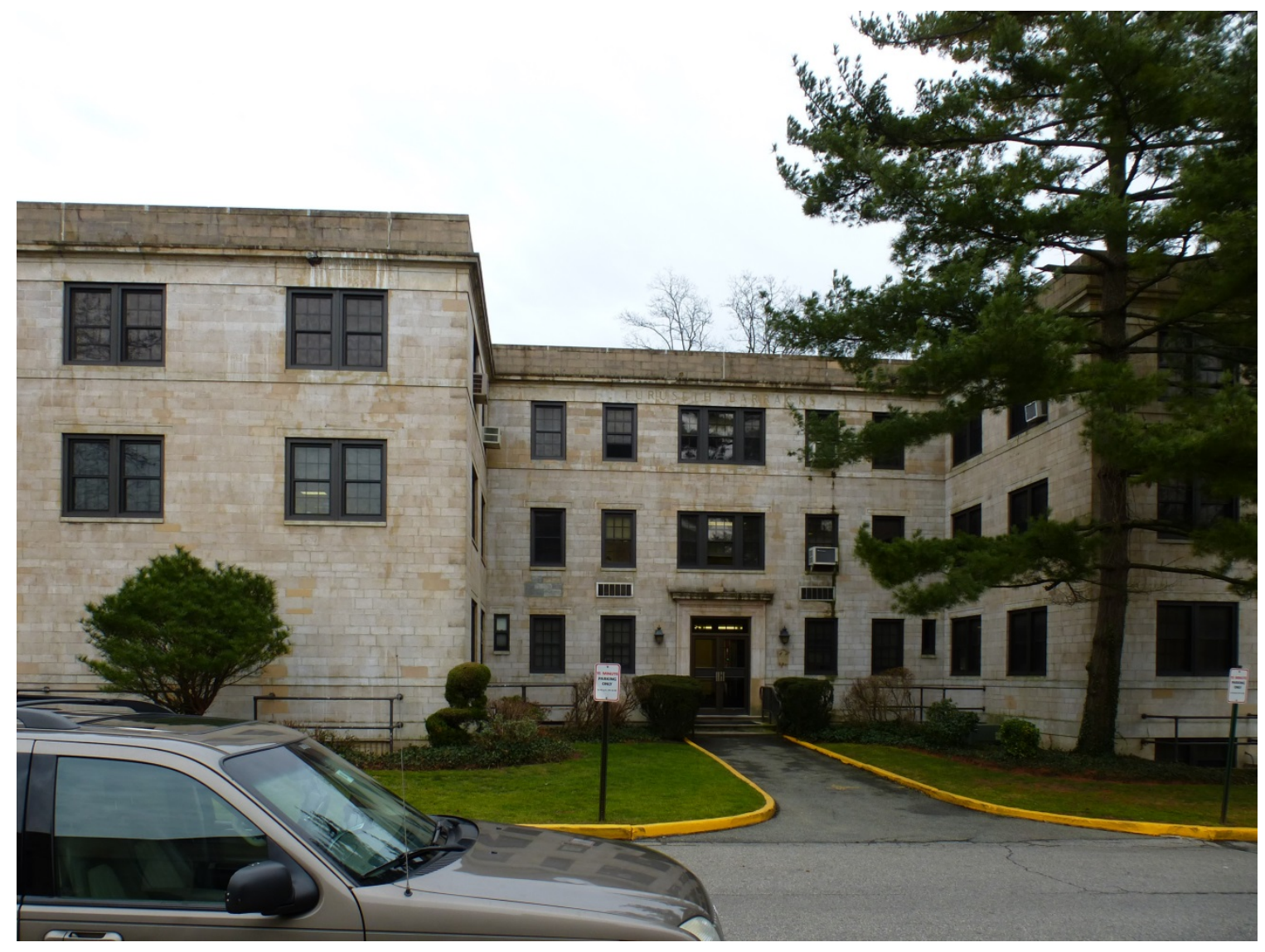




\subsubsection{Character-defining features}

Repair, renovation, and replacement of the following character-defining features of Furuseth Hall must be coordinated with the NY SHPO.

- Overall massing

- Footprint

- Exterior concrete block and its distinctive stone-like pattern

- Parapet

- All cast stone architectural elements including window sills and lintels, door surrounds, belt course, and cornice

- Window and door openings

- Metal railings at ground level

- Multipane double-hung windows (see architectural plans for original window specs)

\subsubsection{Character-defining features that have been removed}

Listed below are character-defining features that have been removed or replaced over the years on Furuseth Hall; as future renovations occur, these need to be replaced with elements that replicate the original character-defining features of the building. The original architectural plans will guide this process in coordination with the NY SHPO.

- Replacement anodized-bronze windows

- Replacement entrance doors

- Replacement exterior light fixtures 
Figure 108. Beltcourse, replacement windows, cornice, inscription, and parapet on Furuseth Hall (ERDC-CERL, 2013).

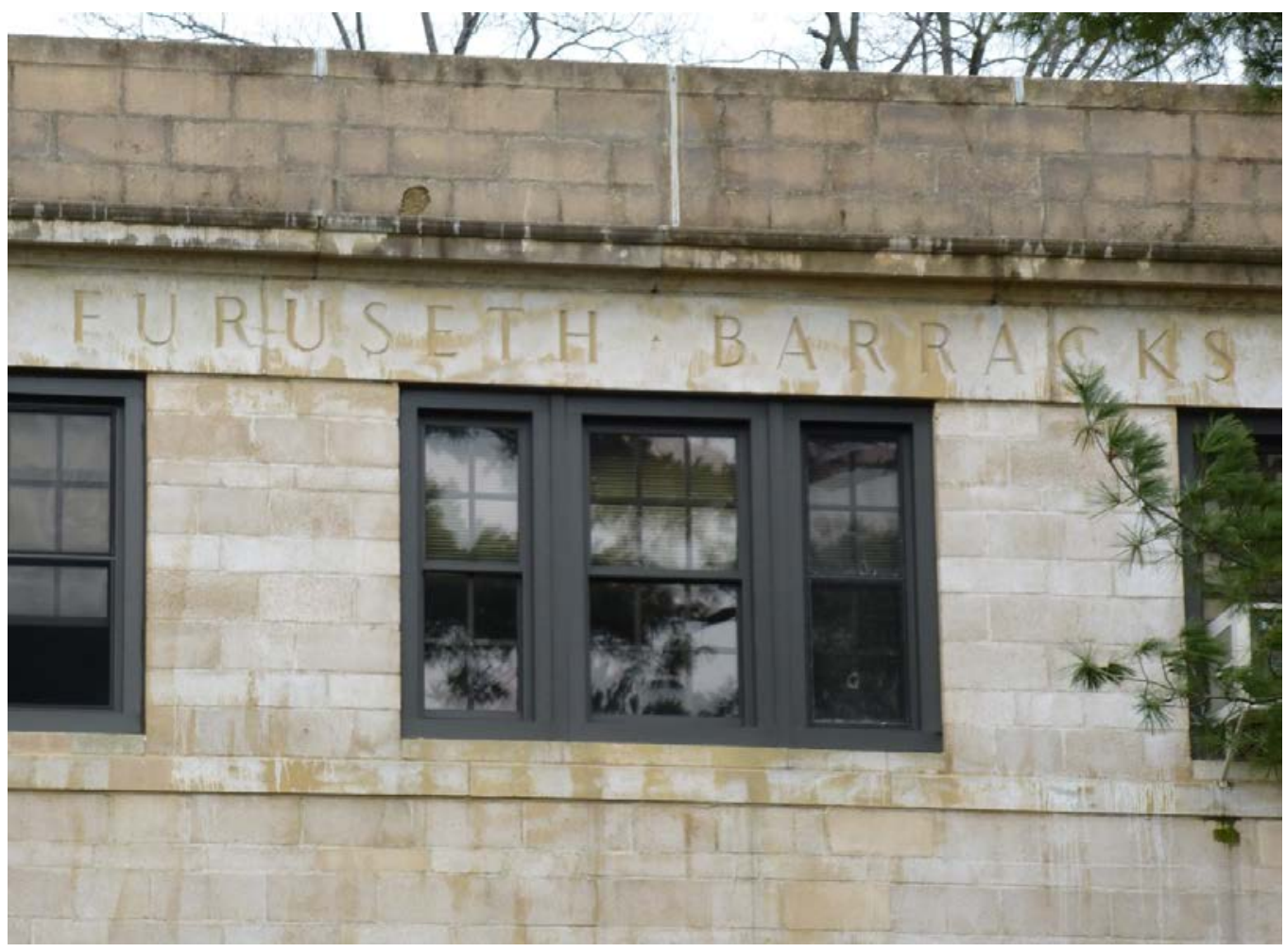

Figure 109. Detail of original architectural drawing showing cast-stone door surround, windows, and concrete block walls (USMMA).

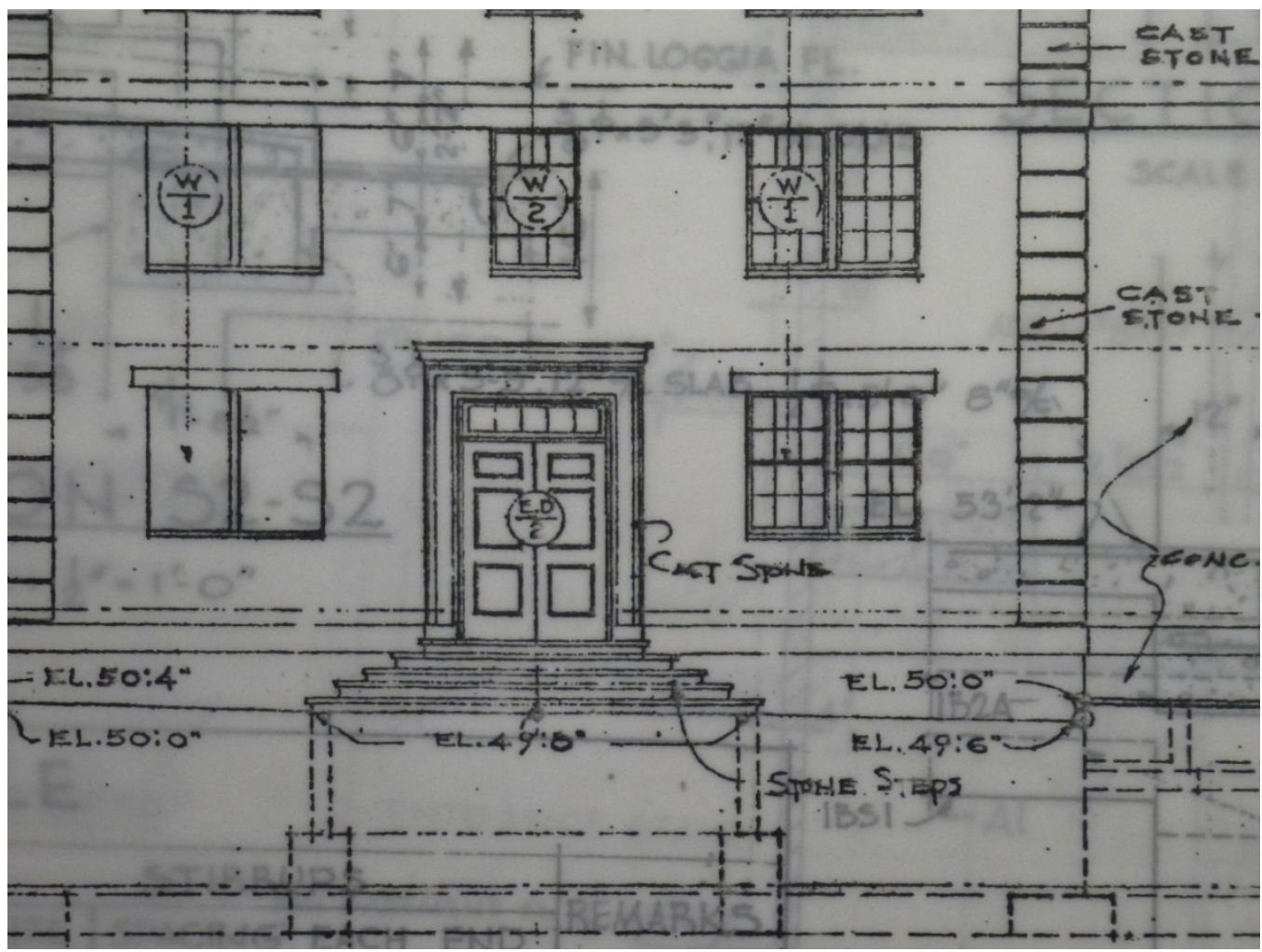


Figure 110. Windows, entrance doors, cast-stone surrounds, and exterior light fixtures on Furuseth Hall (ERDC-CERL, 2013).

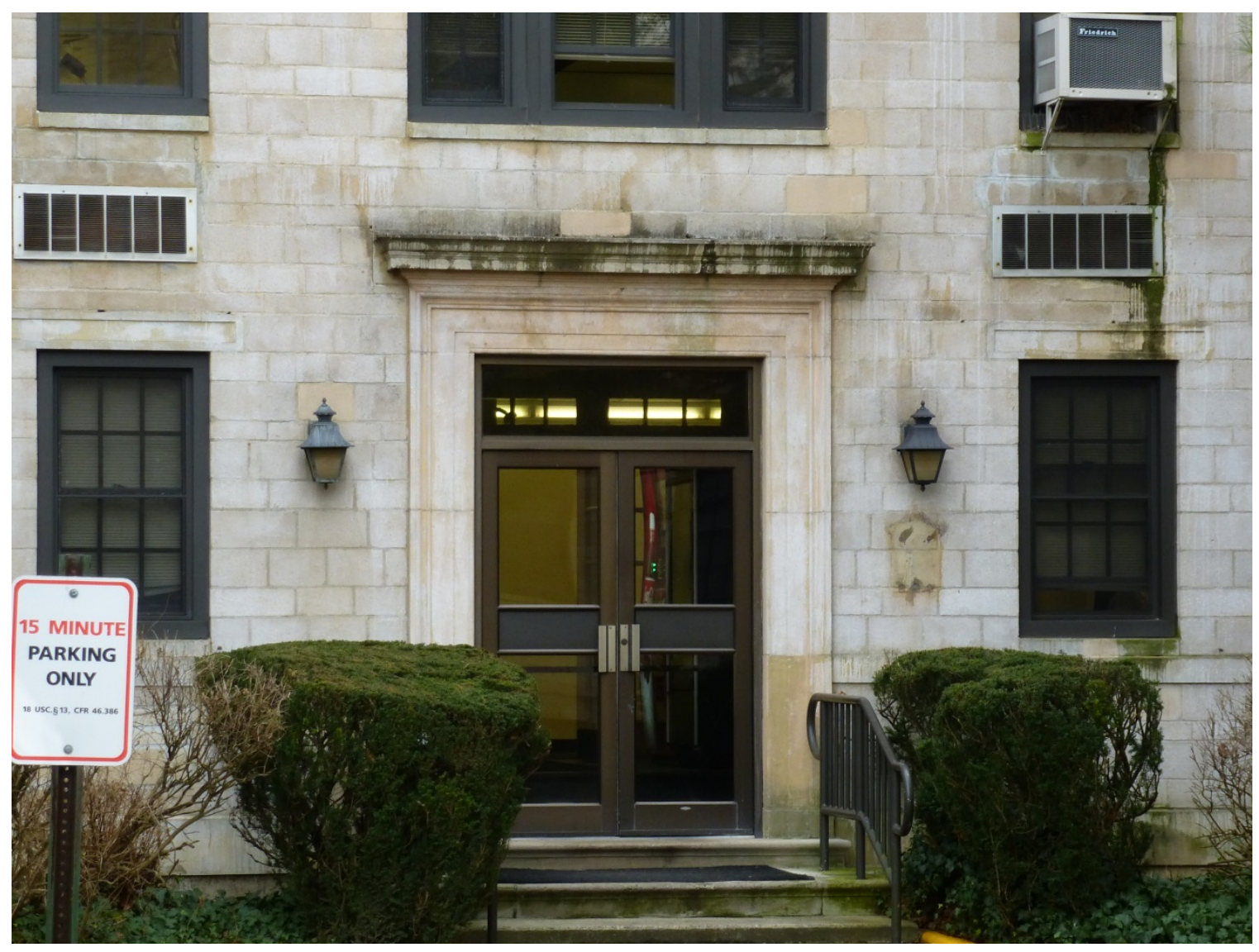


Figure 111. Original light schedule drawing for barracks entrance light fixtures (USMMA).

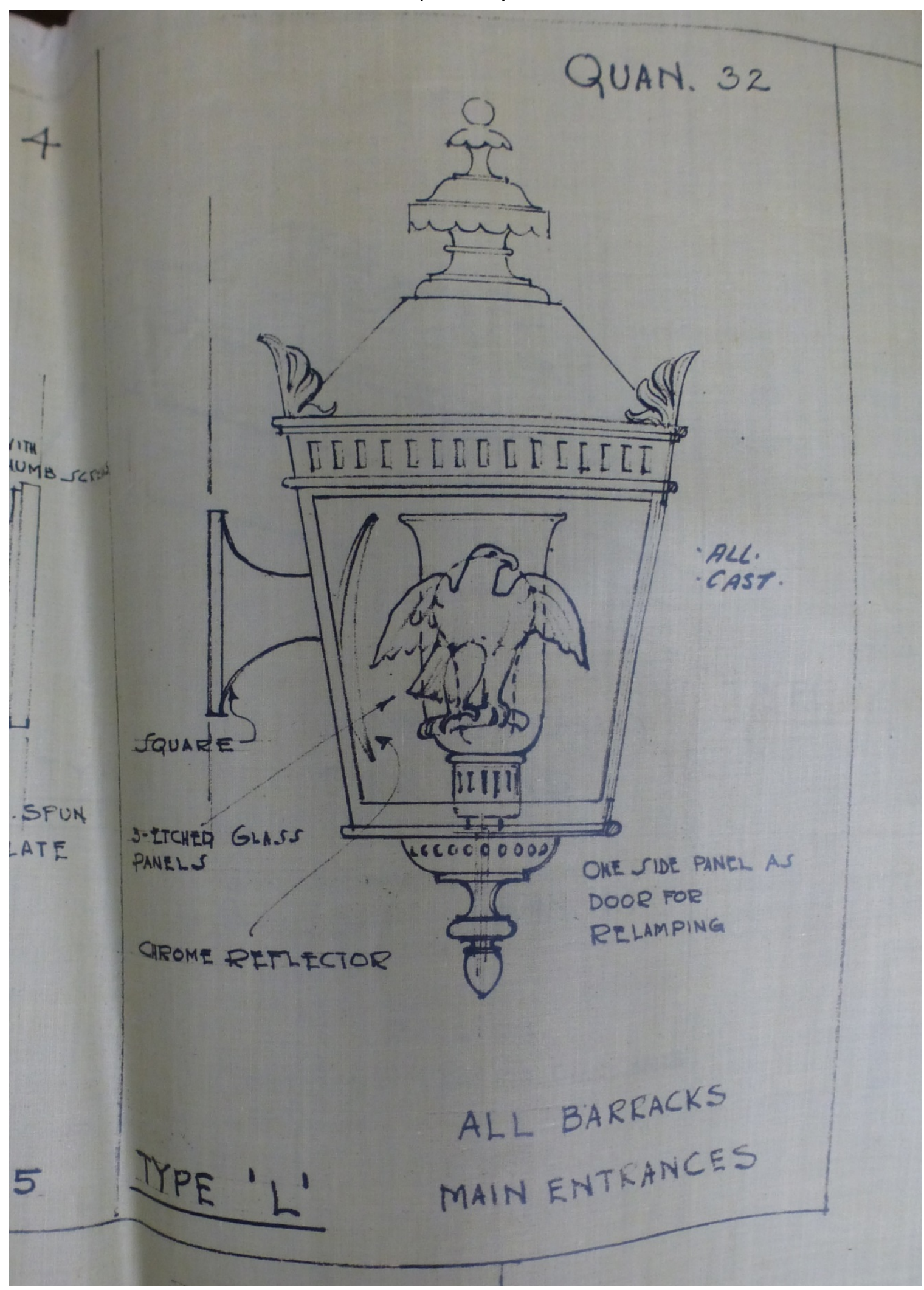


Figure 112. Replacement light fixture at entrance (ERDC-CERL, 2013).

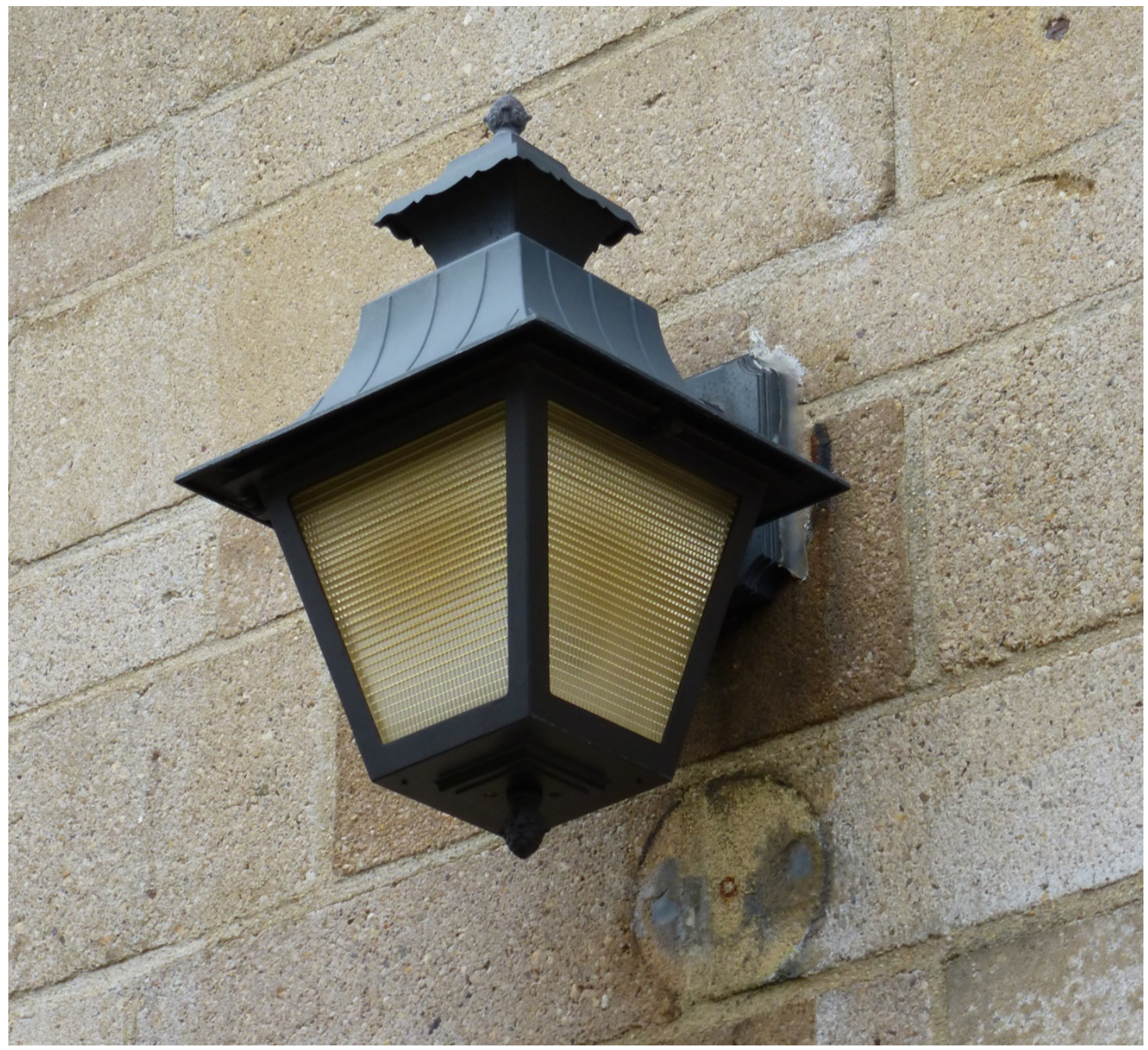

\subsubsection{Classrooms (Fulton Hall and Bowditch Hall)}

There are two large classroom buildings that flank the Bland Library on the north side of the central part of the campus. Fulton Hall is to the west of the library, while Bowditch Hall is to the east. Both of these classroom buildings' exteriors are contributing features to the historic district. Fulton Hall does not have any contributing interiors, but the auditorium and its entrance hall inside Bowditch Hall are contributing interiors. Both buildings were constructed in 1943 and were designed by Alfred Hopkins \& Associates. They are four-story concrete-framed buildings with a central hallway and classrooms off to each side. Bowditch Hall has a large auditorium on the north end. The walls of both halls are constructed of buffcolored concrete masonry units with cast-stone (concrete) window sills and lintels, belt courses, cornices, door surrounds, quoins, and bas-reliefs. 
The buildings display the same consistent cornice line as do the barracks buildings. The Classical Revival-style buildings are designed with an emphasis on balance and symmetry. The roofs are layered asphalt hidden behind a parapet of the same buff-colored concrete masonry units as the other barracks. At the north end of Fulton Hall is the heating plant for the campus, a large chimneystack, and various mechanical rooms. The original double-hung wood windows have been replaced with anodized-bronze, casement, aluminum windows. (Some windows on the north side of Bowditch Hall had been removed at some point and were closed with concrete block similar to the walls.) The doors and the light fixtures are not original, except for the light fixtures in the vestibule of the auditorium in Bowditch Hall and in the two entrance arcades that flank Bland Library. The interiors of these two classroom buildings have been heavily remodeled through the years.

Figure 113. Southeast oblique of the east entrance to Fulton Hall (classroom building), ca. 1960s (Bland Library, USMMA).

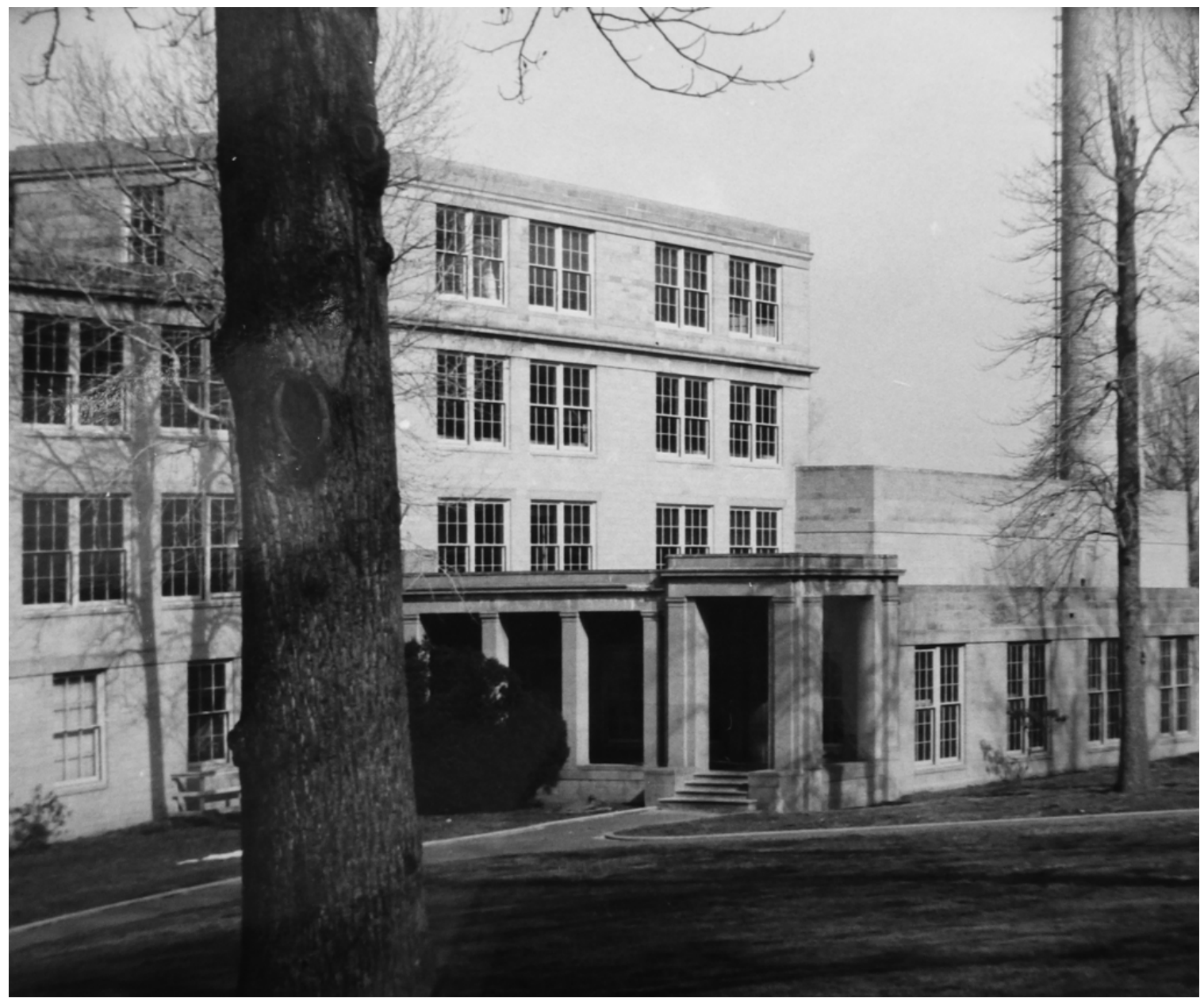


Figure 114. Southeast oblique of the east entrance to Fulton Hall (classroom building) (ERDC-CERL, 2013).

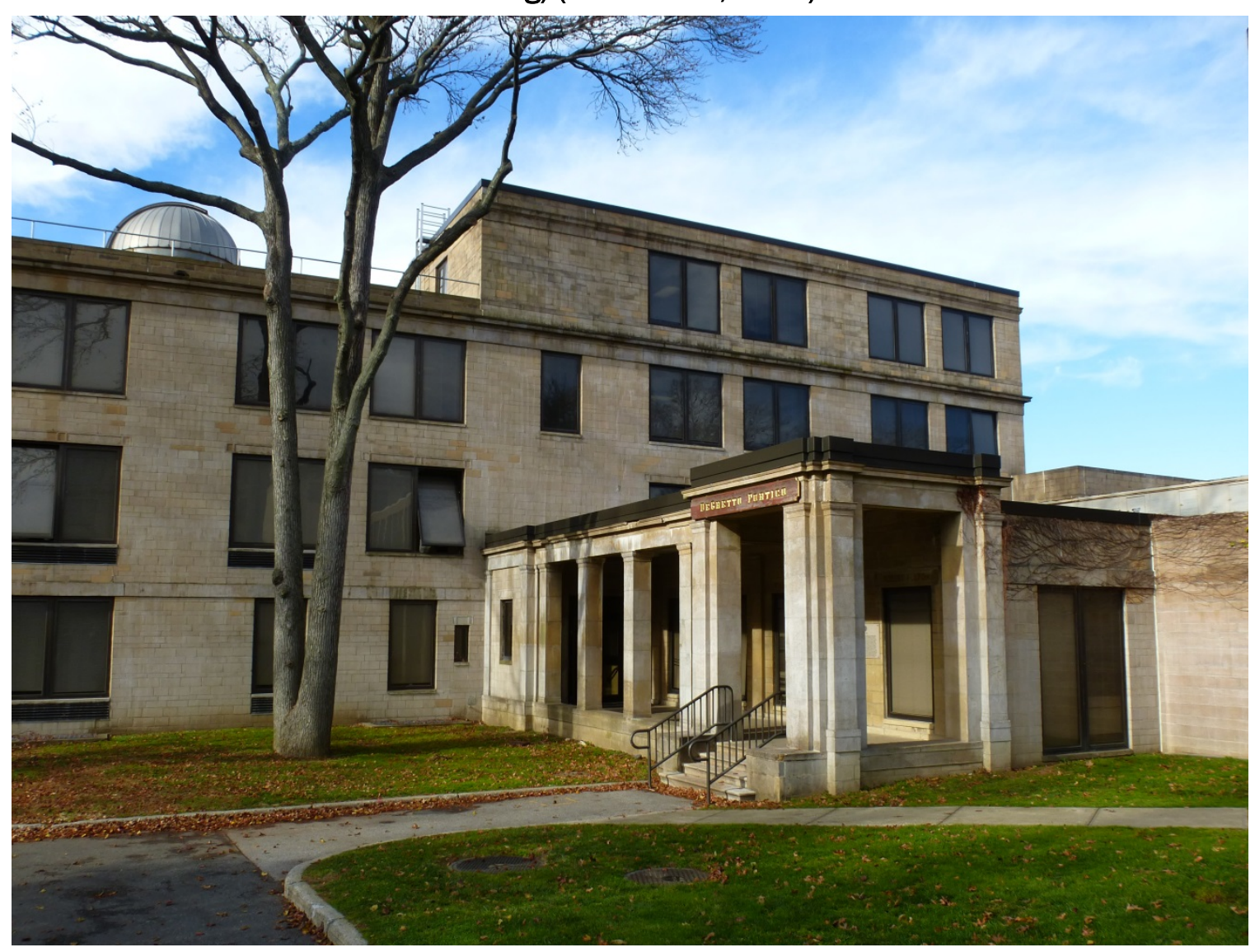


Figure 115. East entrance to Fulton Hall (ERDC-CERL, 2013).

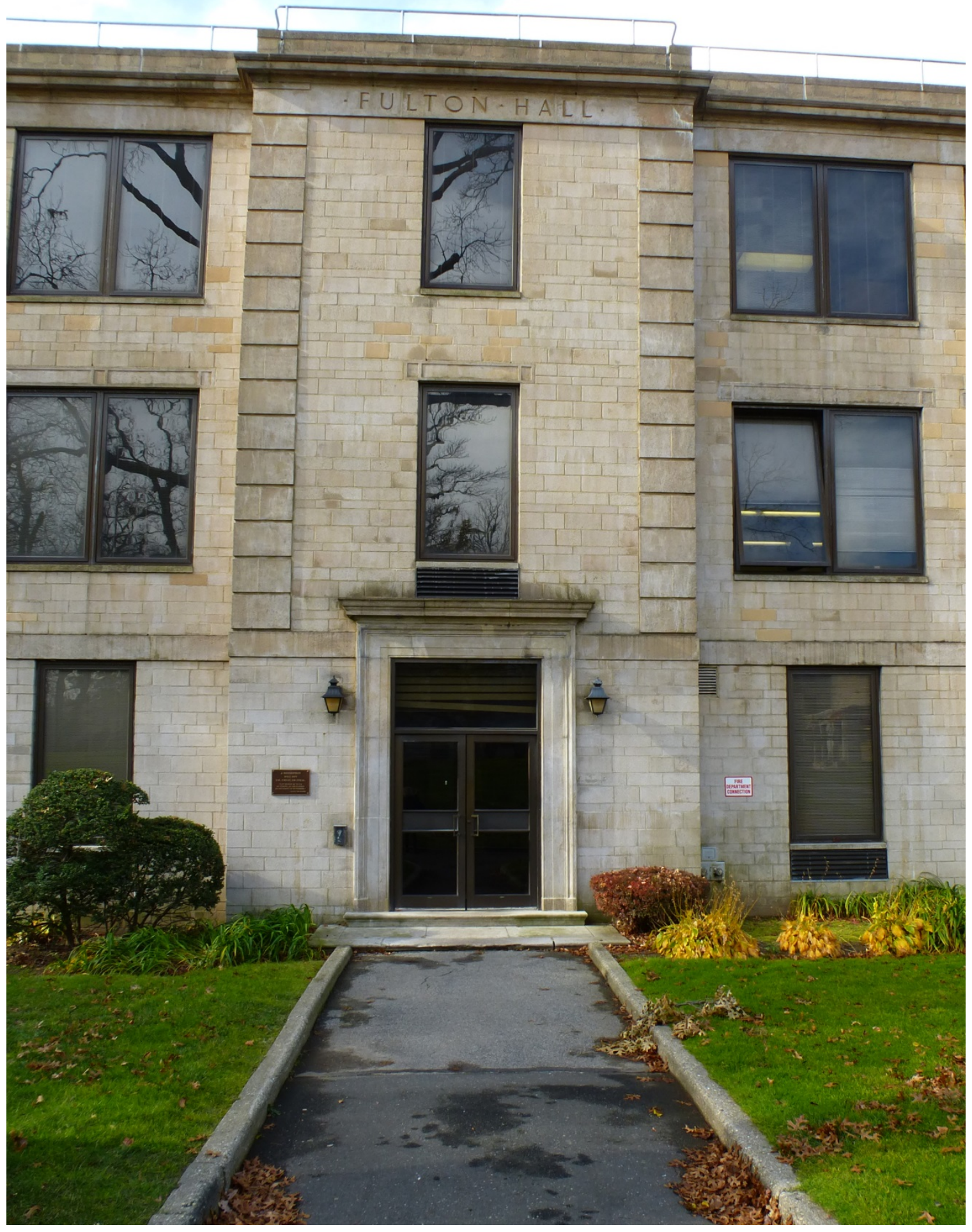


Figure 116. Mechanical room and base of chimney at the northeast corner of Fulton Hall (ERDC-CERL, 2013).

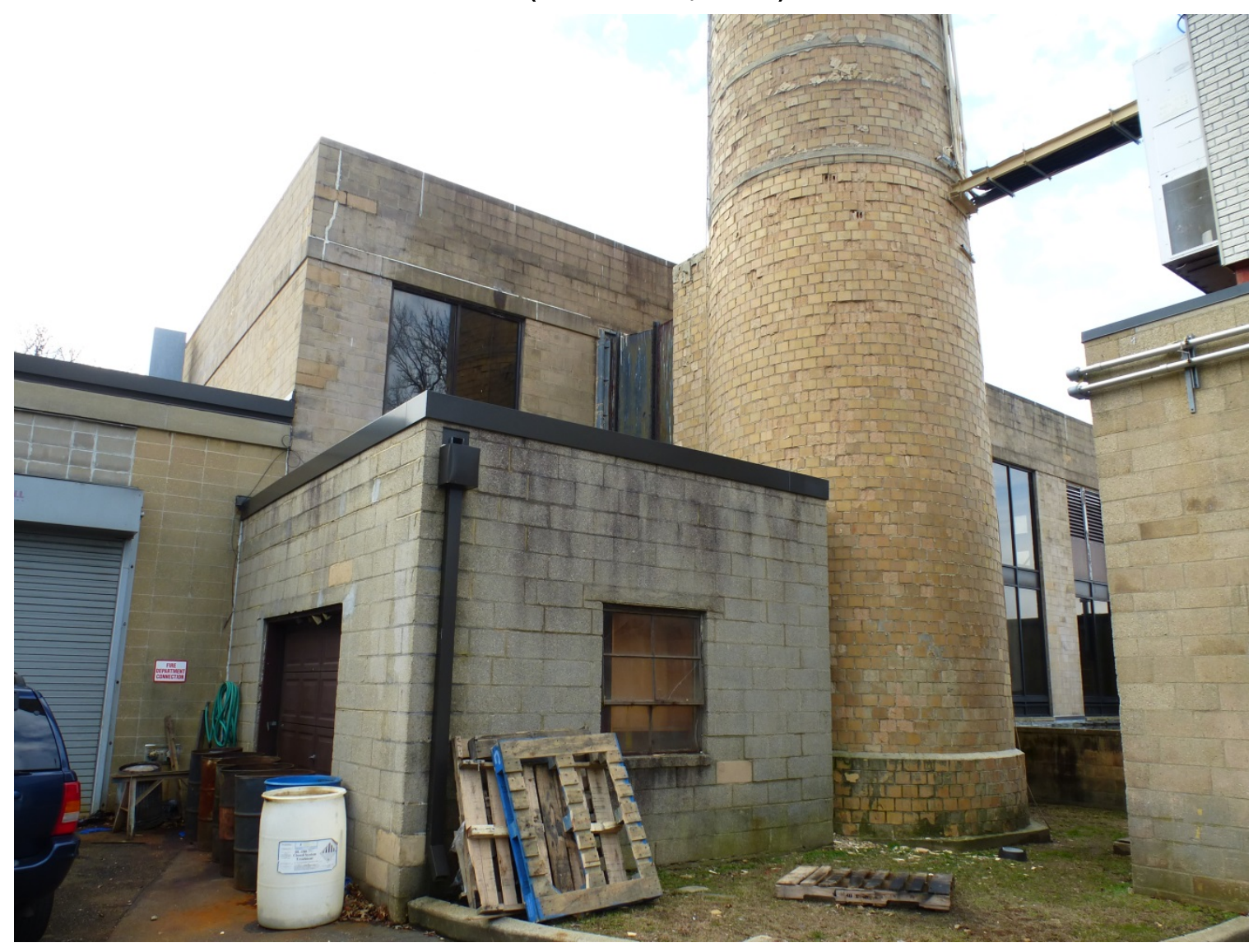


Figure 117. South façade of Gibbs Hall [left] and Fulton Hall [right], showing the transition between the two buildings (ERDC-CERL, 2013).

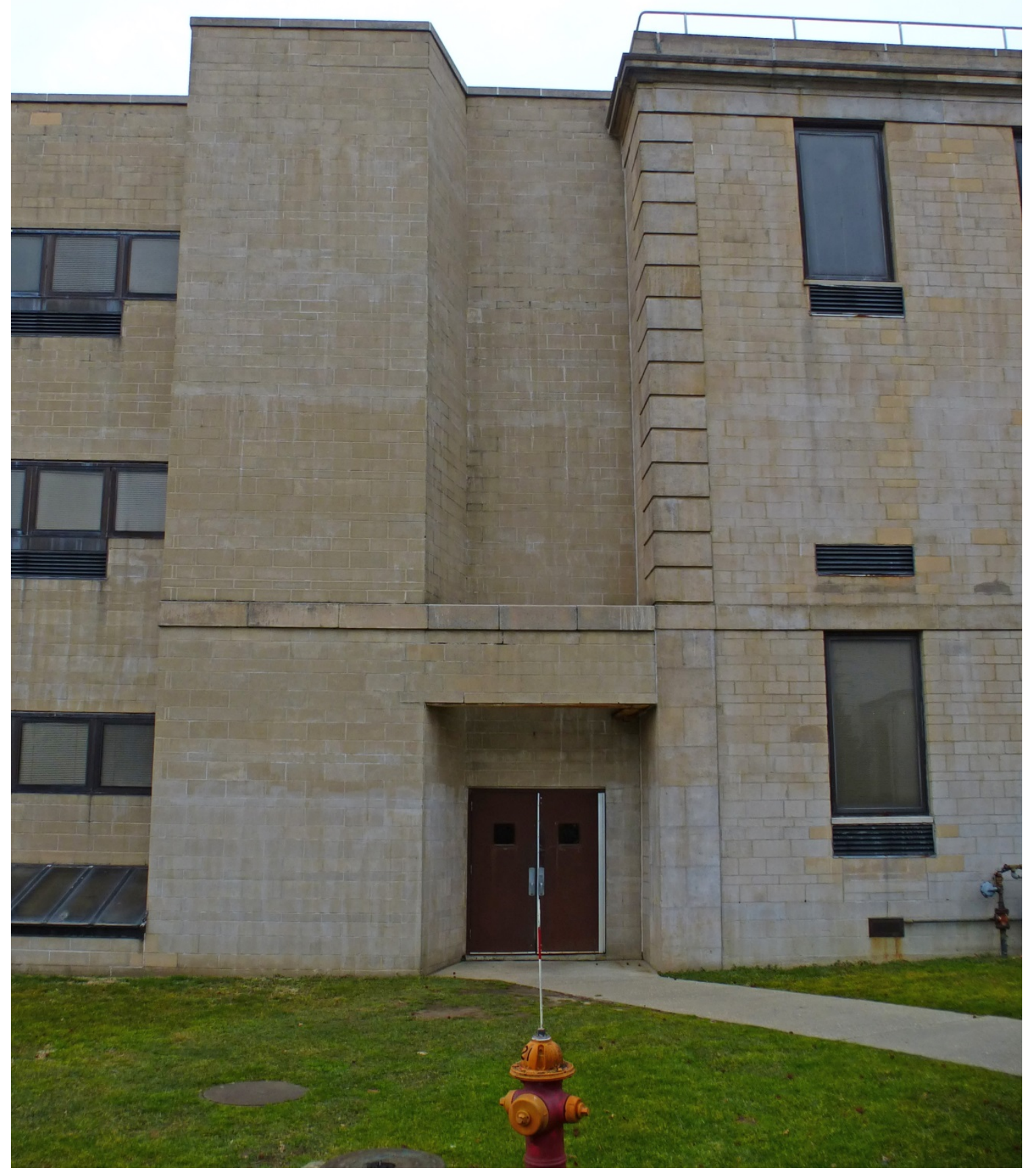


Figure 118. East façade of Bowditch Hall (ERDC-CERL, 2013).

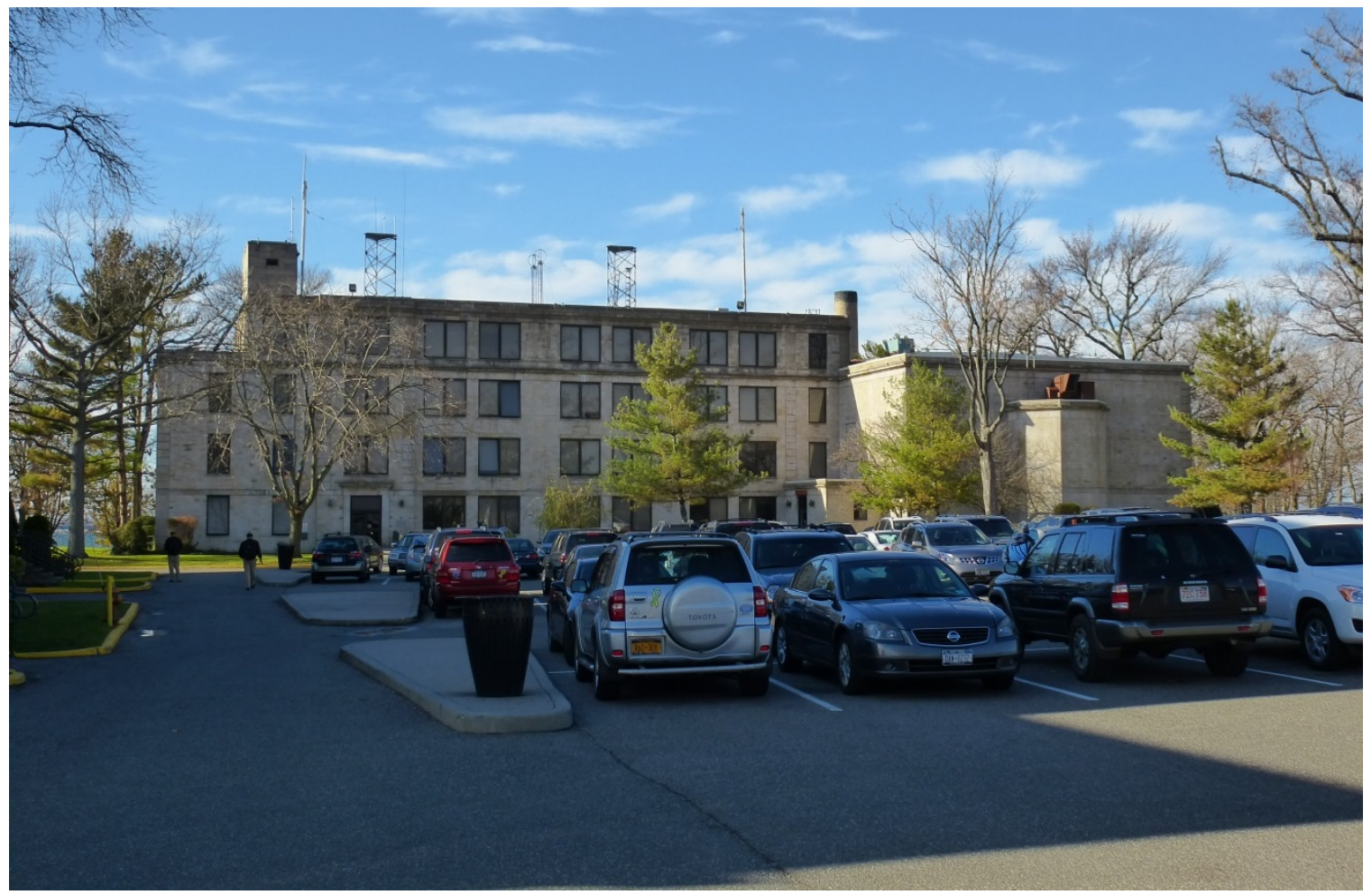

Figure 119. North façade of Bowditch Hall (ERDC-CERL, 2013).

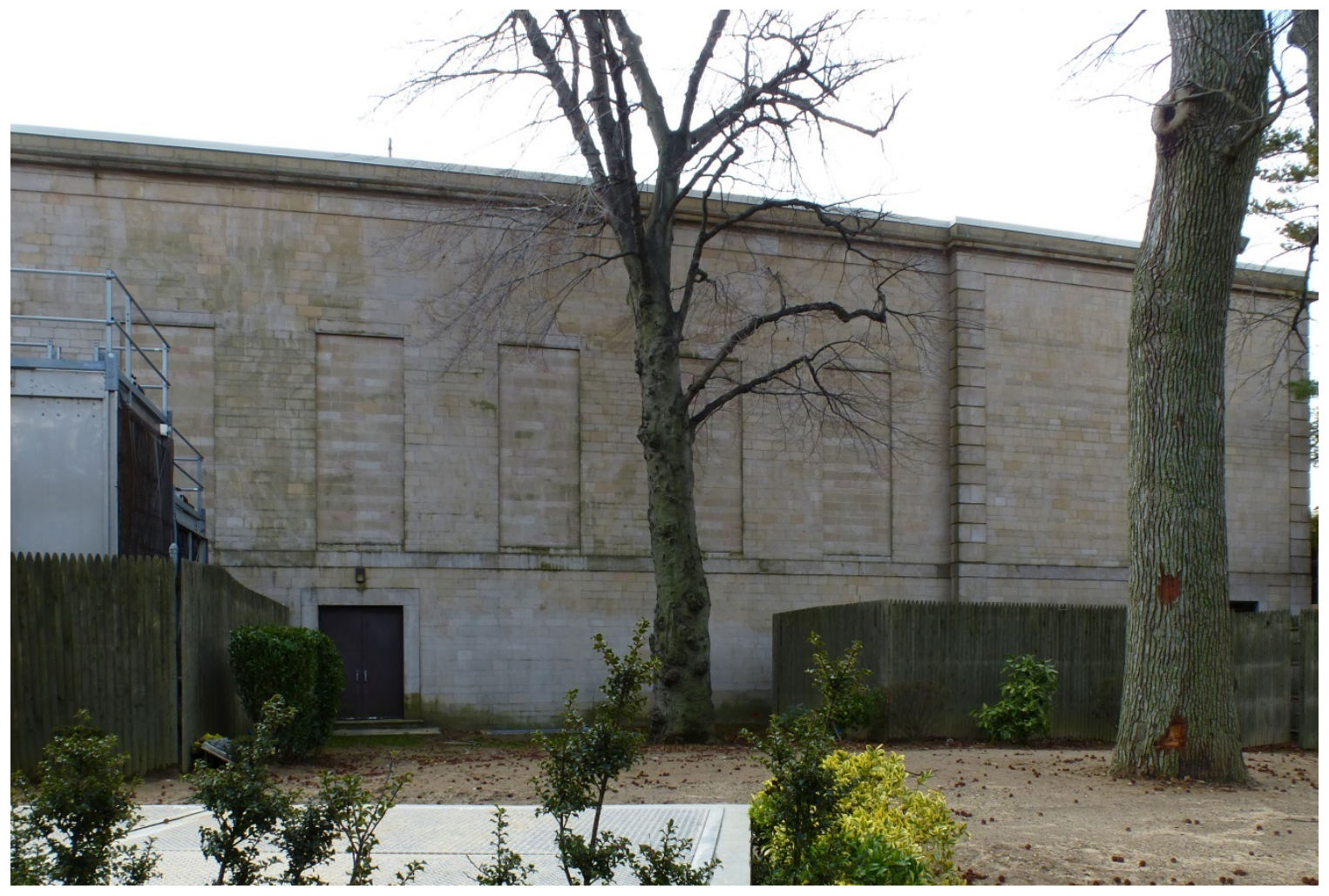


Figure 120. Auditorium vestibule in Bowditch Hall (ERDC-CERL, 2013).

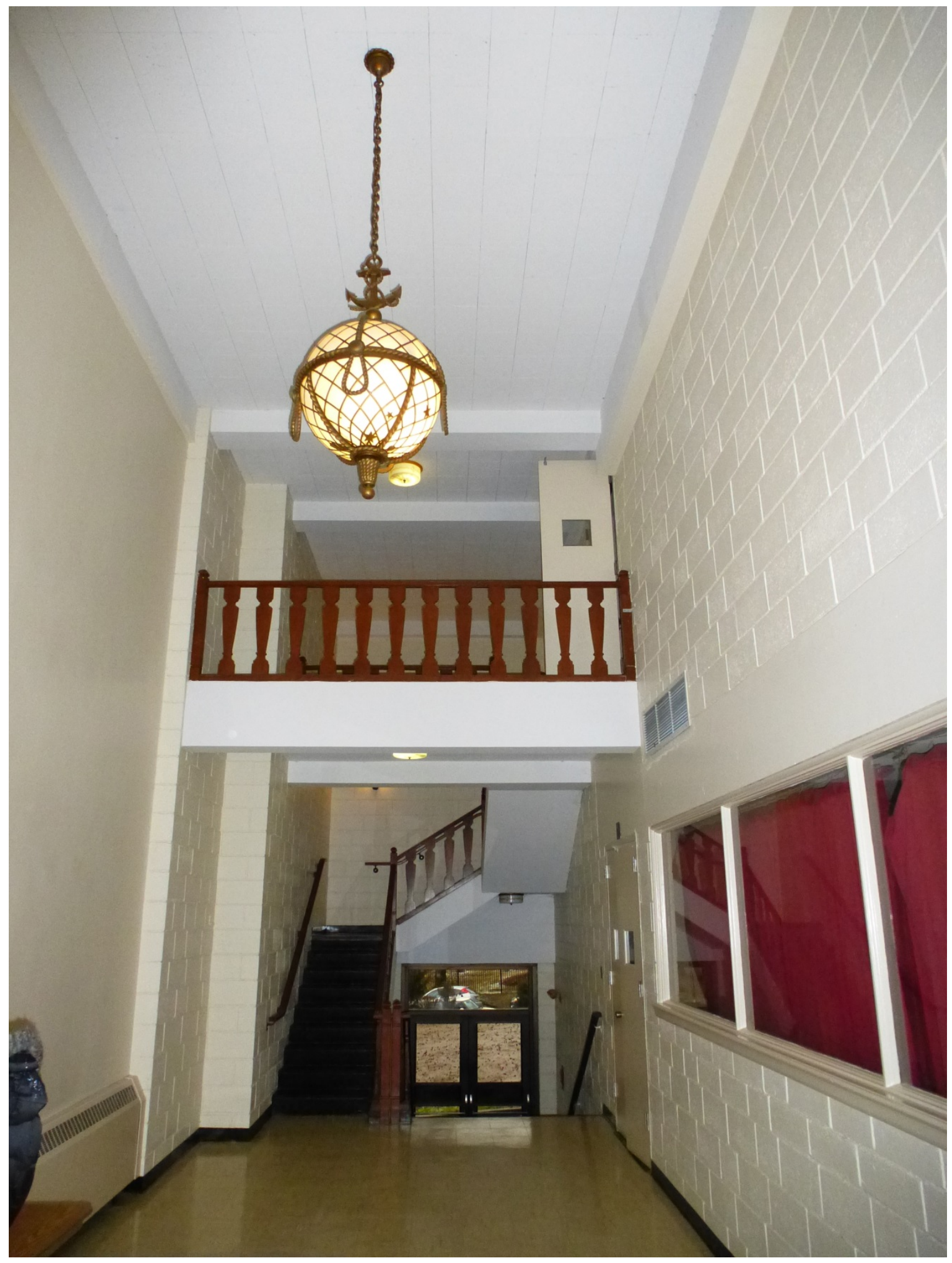




\subsubsection{Character-defining features}

Repair, renovation, and replacement of the following character-defining features of Fulton and Bowditch Halls must be coordinated with the NY SHPO.

- Overall massing

- Footprint

- Exterior concrete block and its distinctive pattern

- Parapet

- All cast stone architectural elements including window sills and lintels, door surrounds, belt course, quoins, bas-reliefs, and cornices

- Window and door openings

- Light fixtures in auditorium vestibule

\subsubsection{Character-defining features that have been removed}

Listed below are character-defining features that have been removed or replaced over the years on Fulton and Bowditch Halls; as future renovations occur, these need to be replaced with elements that replicate the original character-defining features of the building. The original architectural plans will guide this process in coordination with the NY SHPO.

- Replacement anodized-bronze windows

- Replacement entrance doors

- Replacement exterior light fixtures 
Figure 121. Detail of southwest corner of portico entrance to Fulton Hall showing cast-stone architectural elements (ERDC-CERL, 2013).

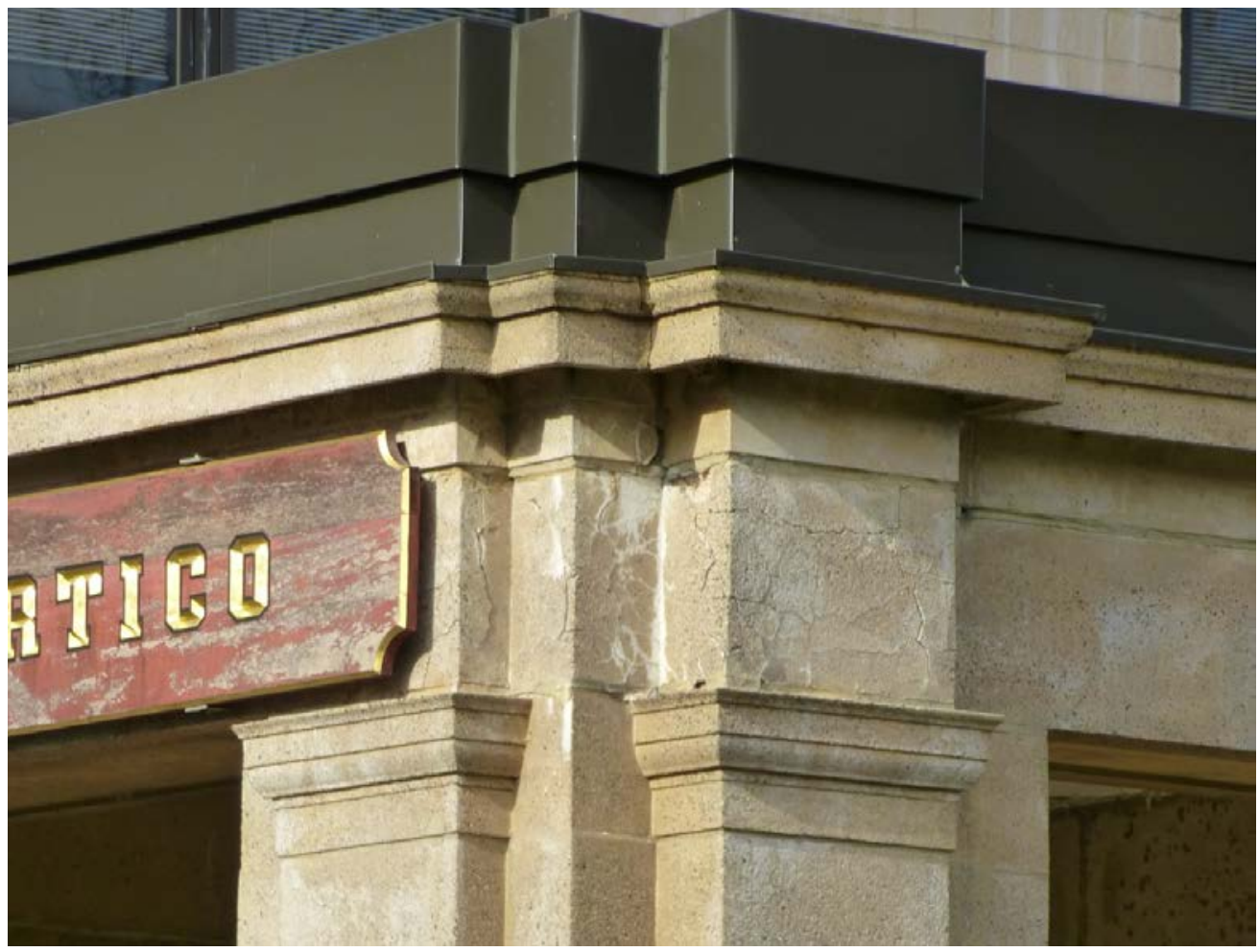

Figure 122. East entrance to Fulton Hall (ERDC-CERL, 2013).

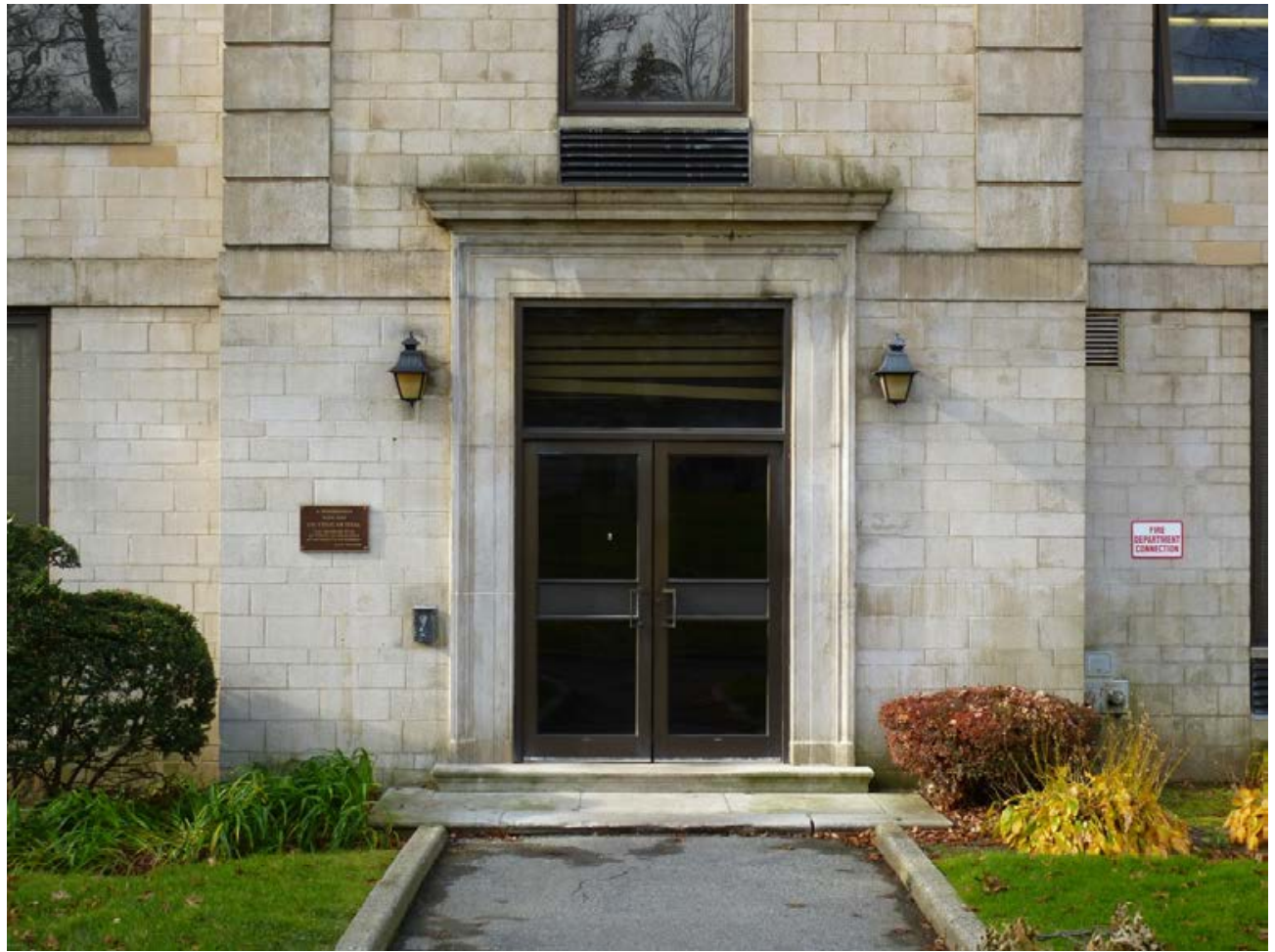


Figure 123. Replacement light fixture at east entrance to Fulton Hall (ERDC-CERL, 2013).

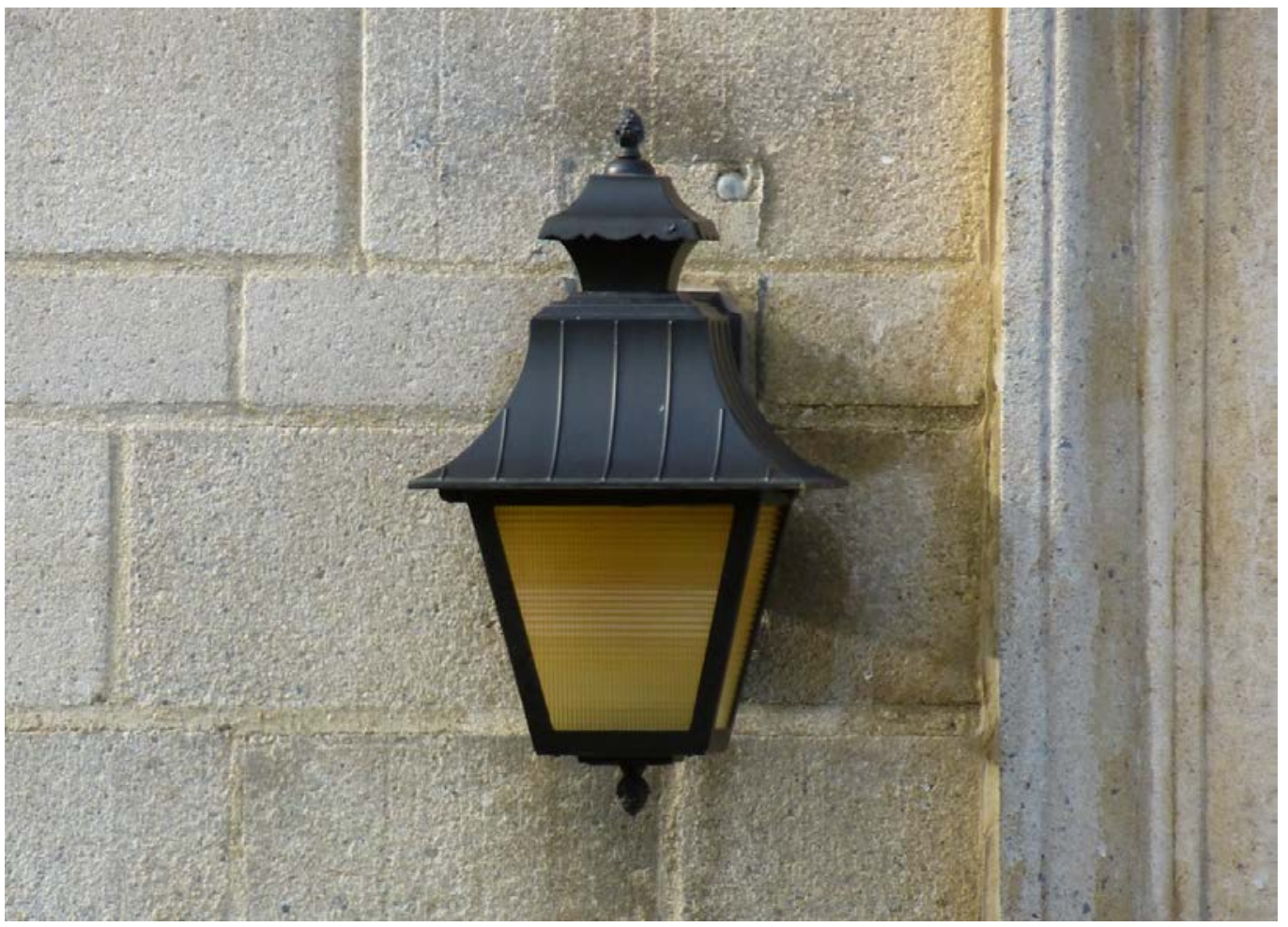

Figure 124. Inscription on cast-stone lintel at portico entrance to Fulton Hall (ERDC-CERL, 2013).

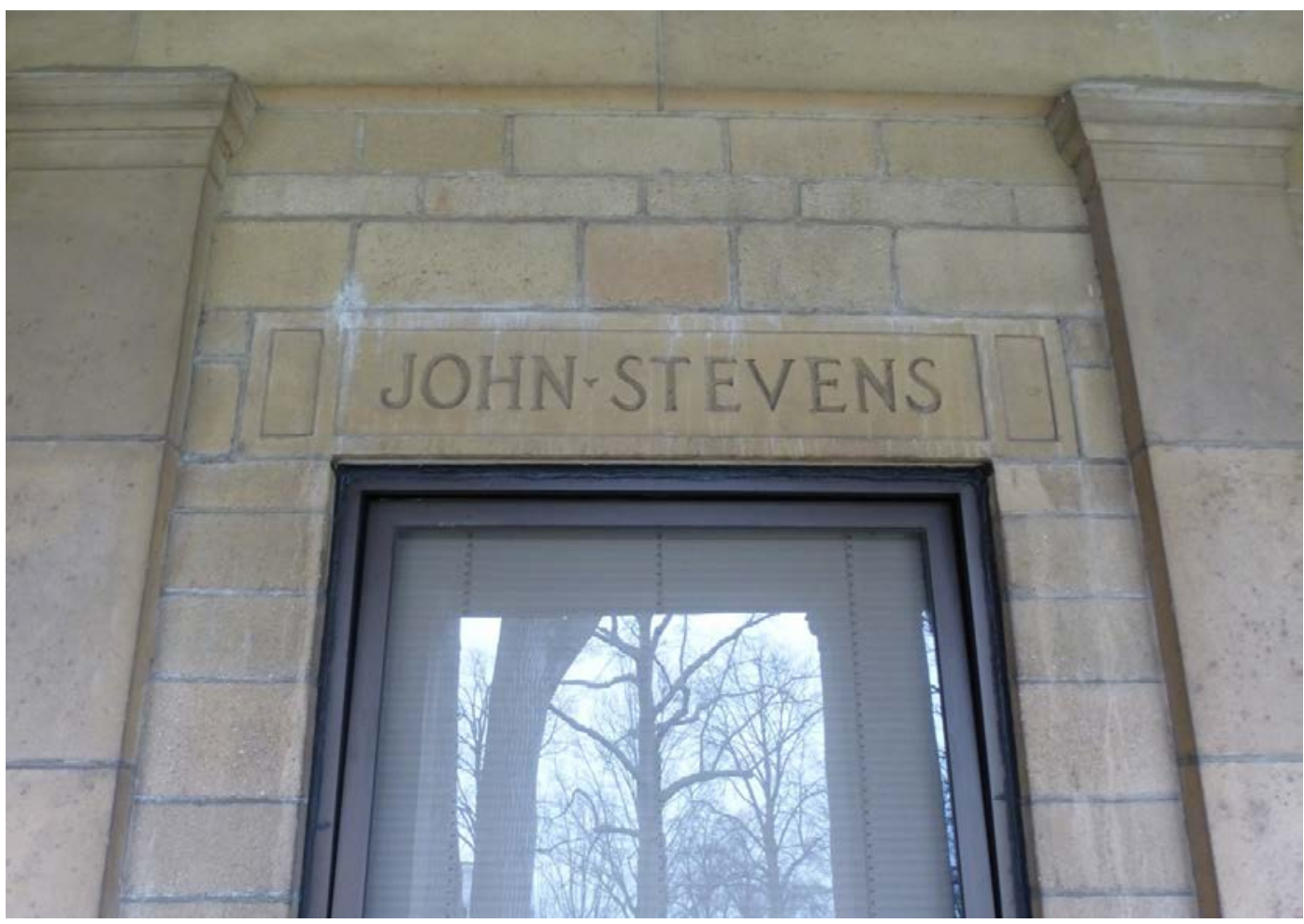


Figure 125. Bas-relief over portico entrance doors to Fulton Hall (ERDC-CERL, 2013).

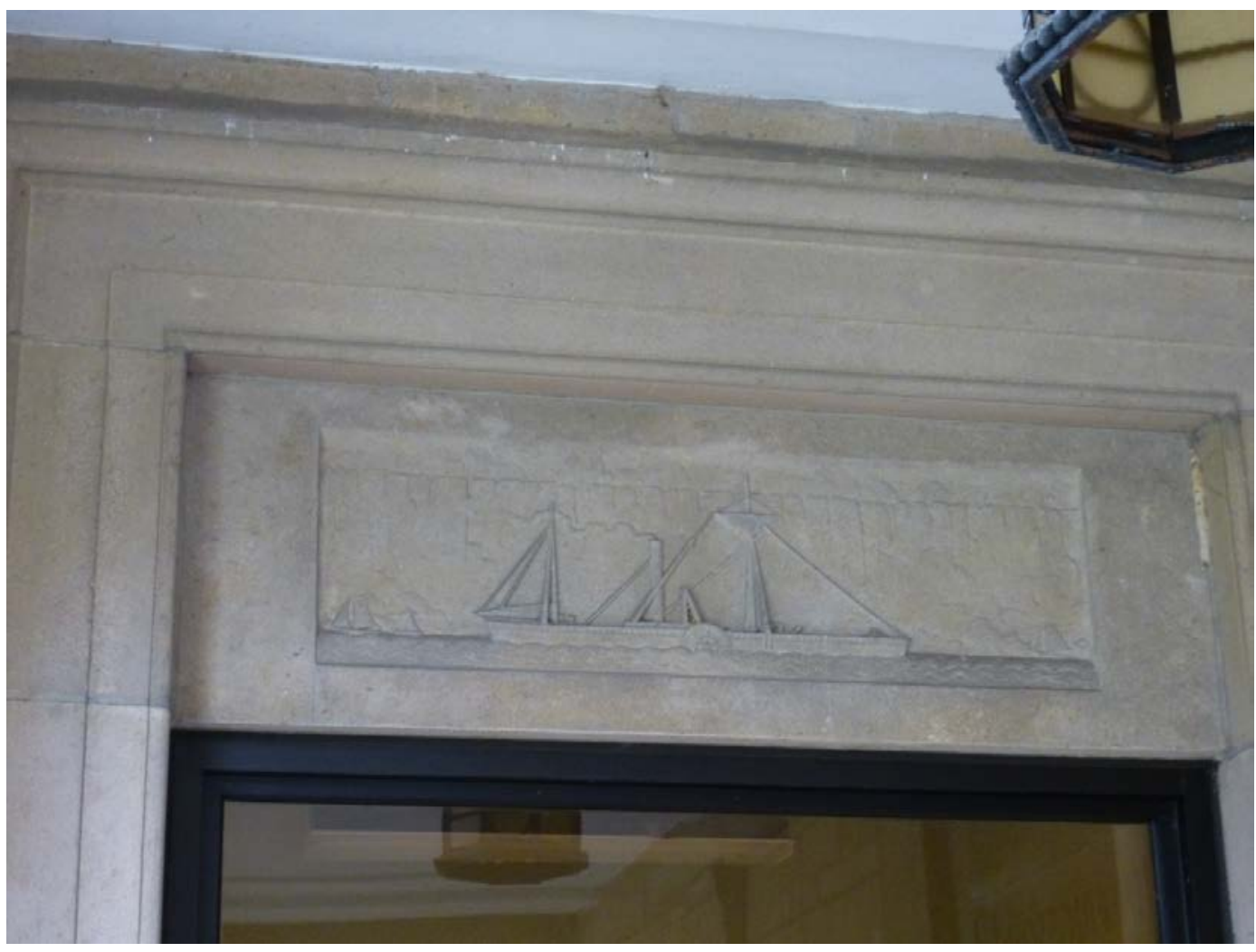

Figure 126. Original light fixture at portico entrance to Fulton Hall (ERDC-CERL, 2013).

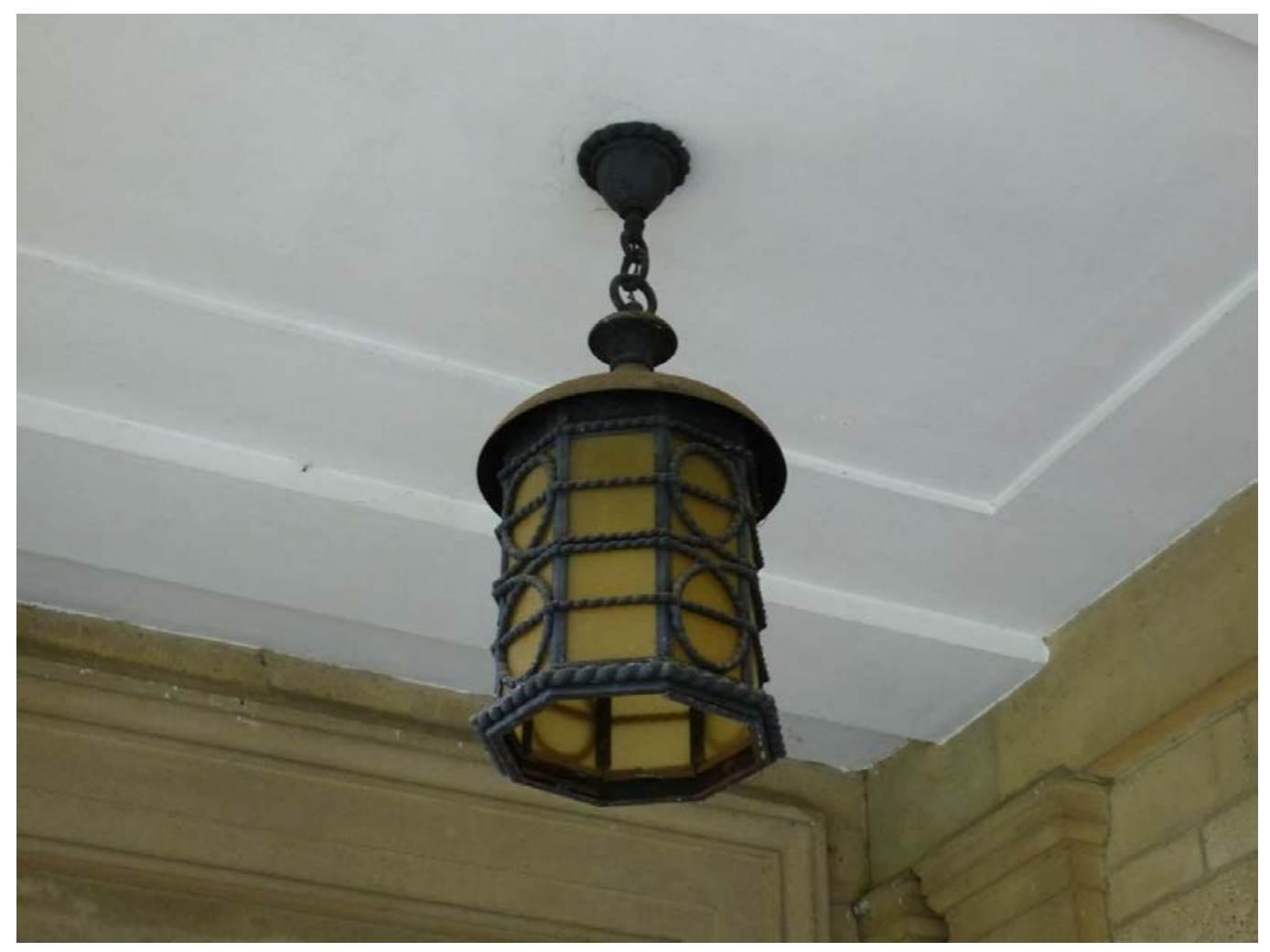


Figure 127. Replacement windows in original openings on Bowditch Hall (ERDC-CERL, 2013).

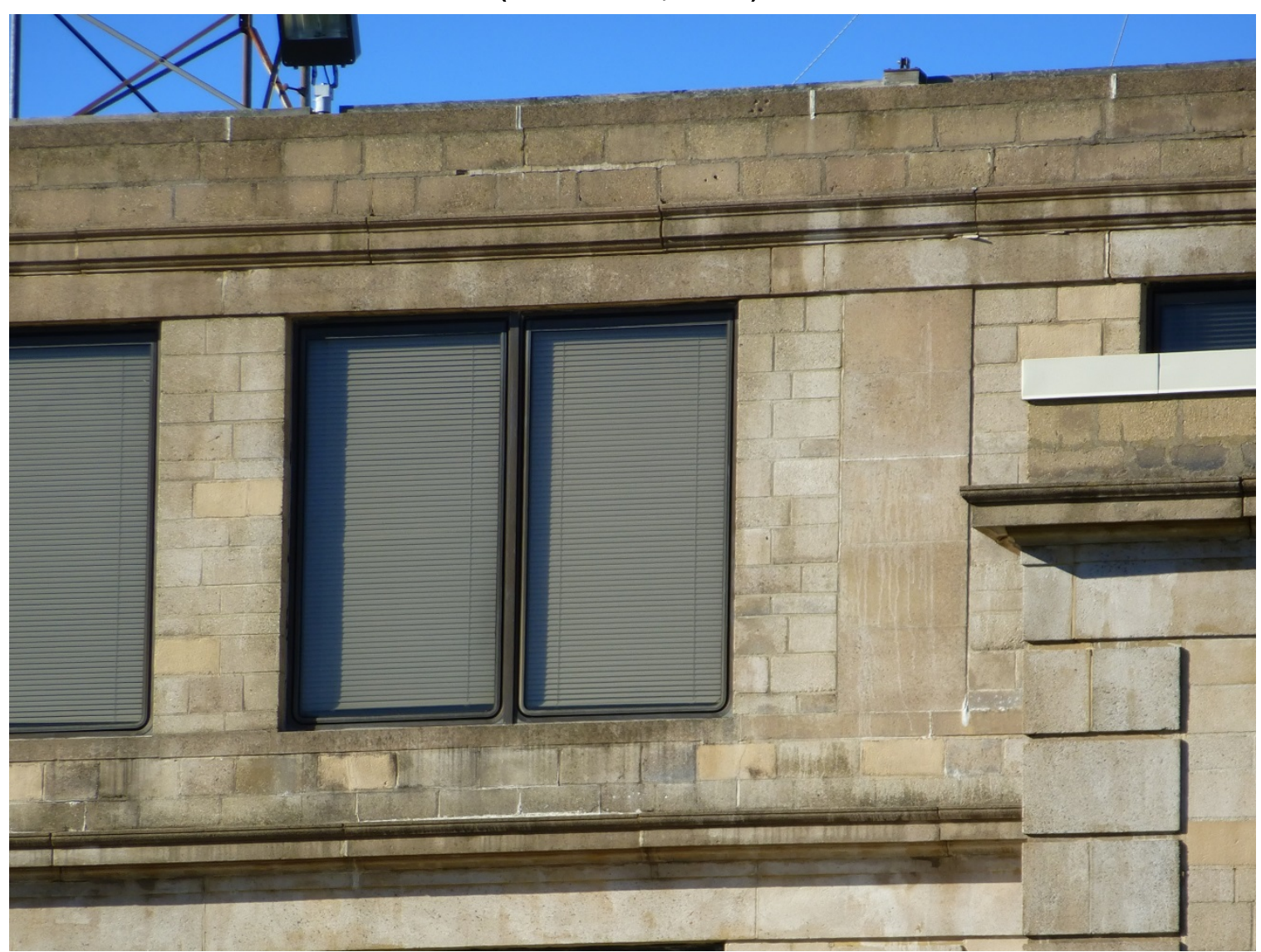


Figure 128. Original light schedule drawing for auditorium light fixtures (USMMA).

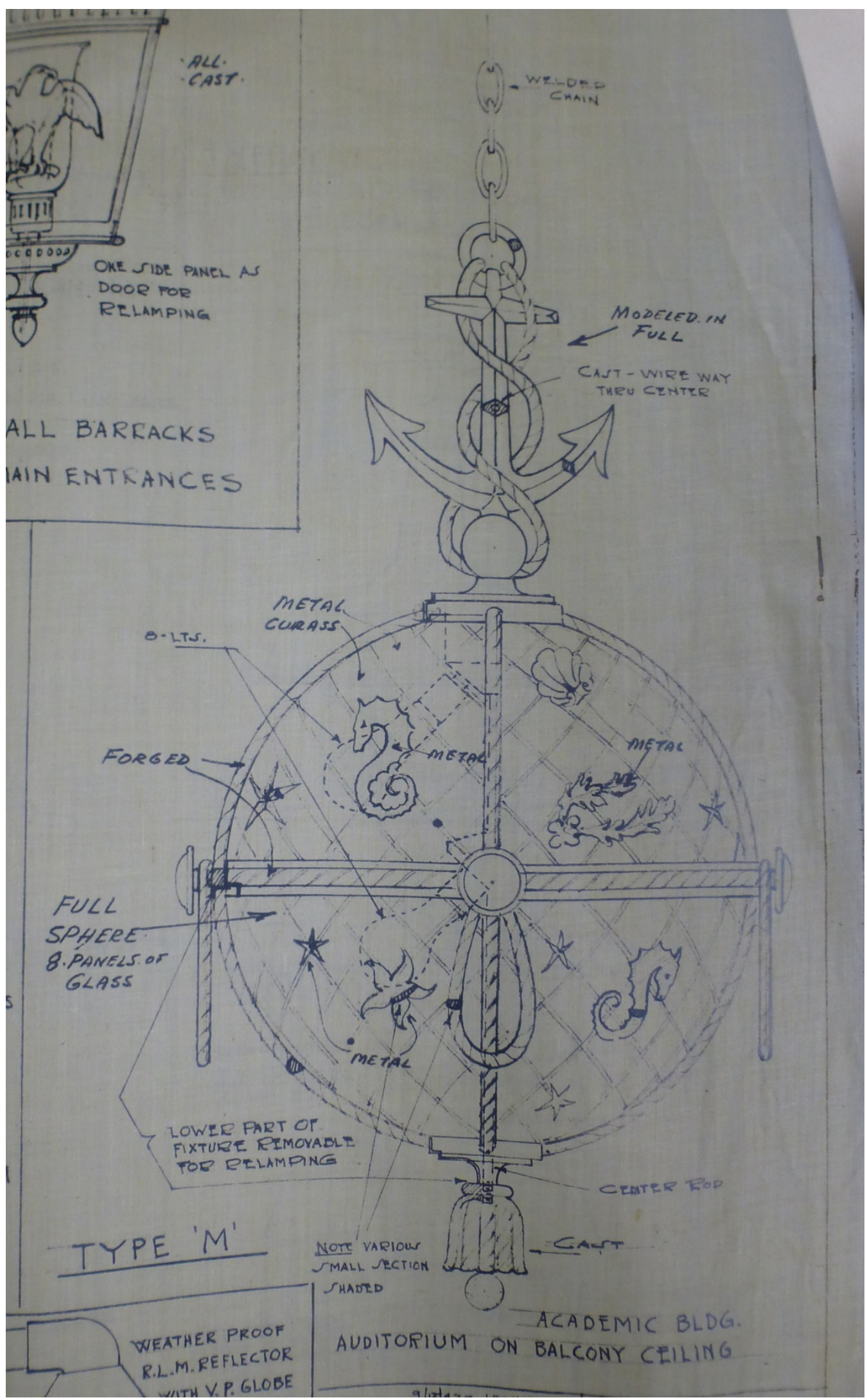


Figure 129. Original light fixture in auditorium vestibule in Bowditch Hall (ERDC-CERL, 2013).

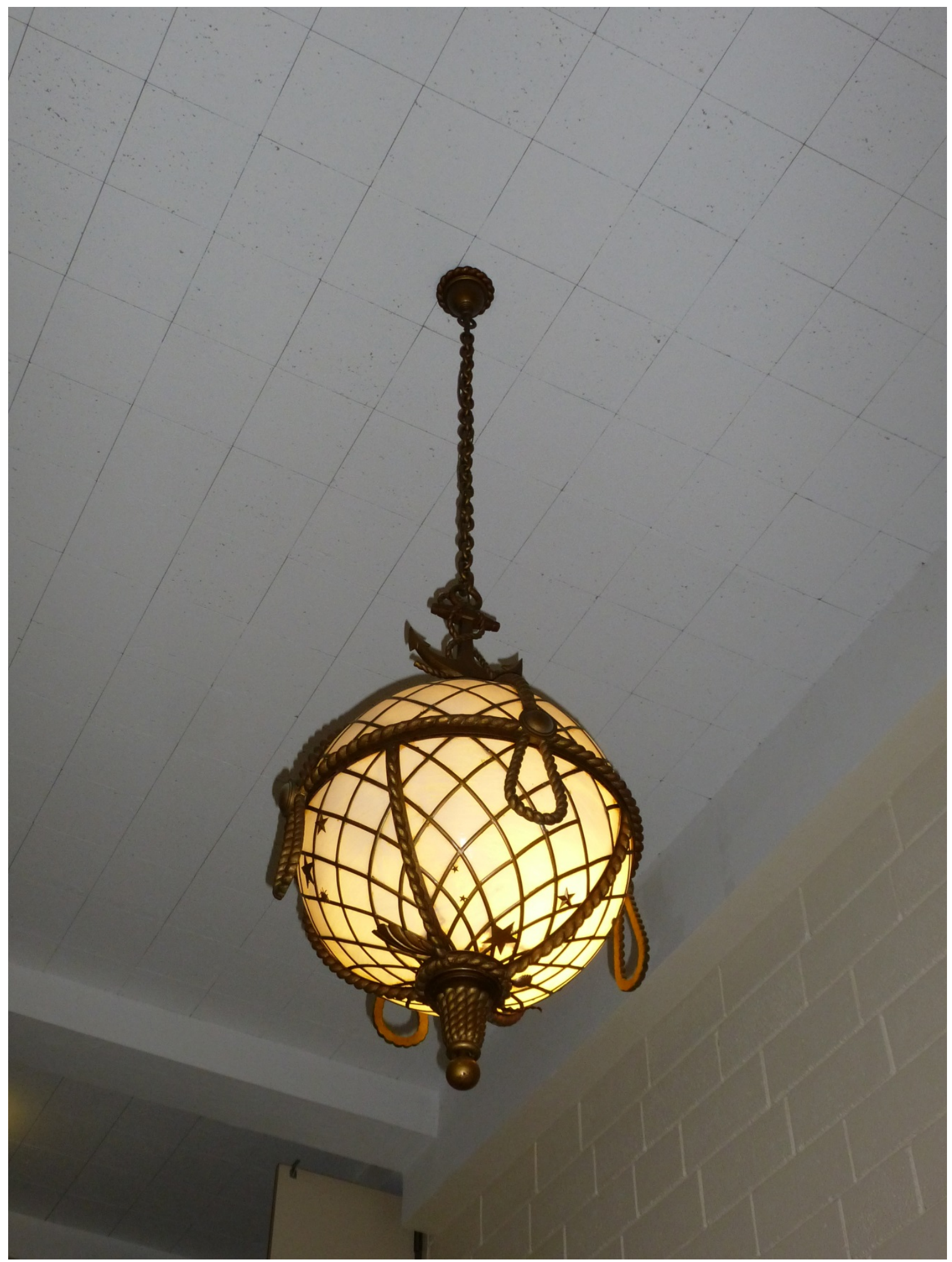


Figure 130. Original light schedule drawing for corridor ceiling light fixtures (USMMA).

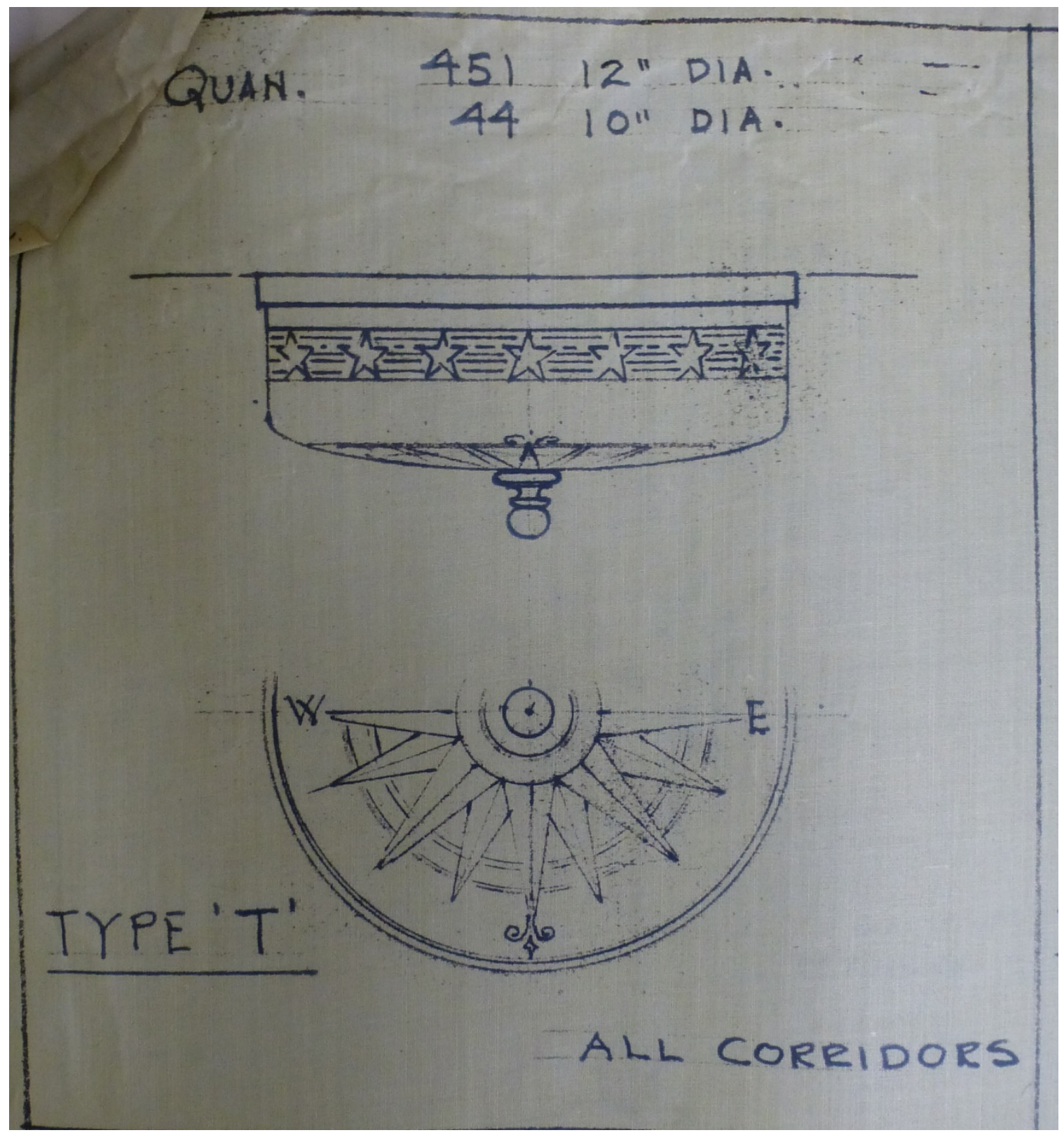


Figure 131. Original light fixture in lobby of auditorium in Bowditch Hall (ERDC-CERL, 2013).

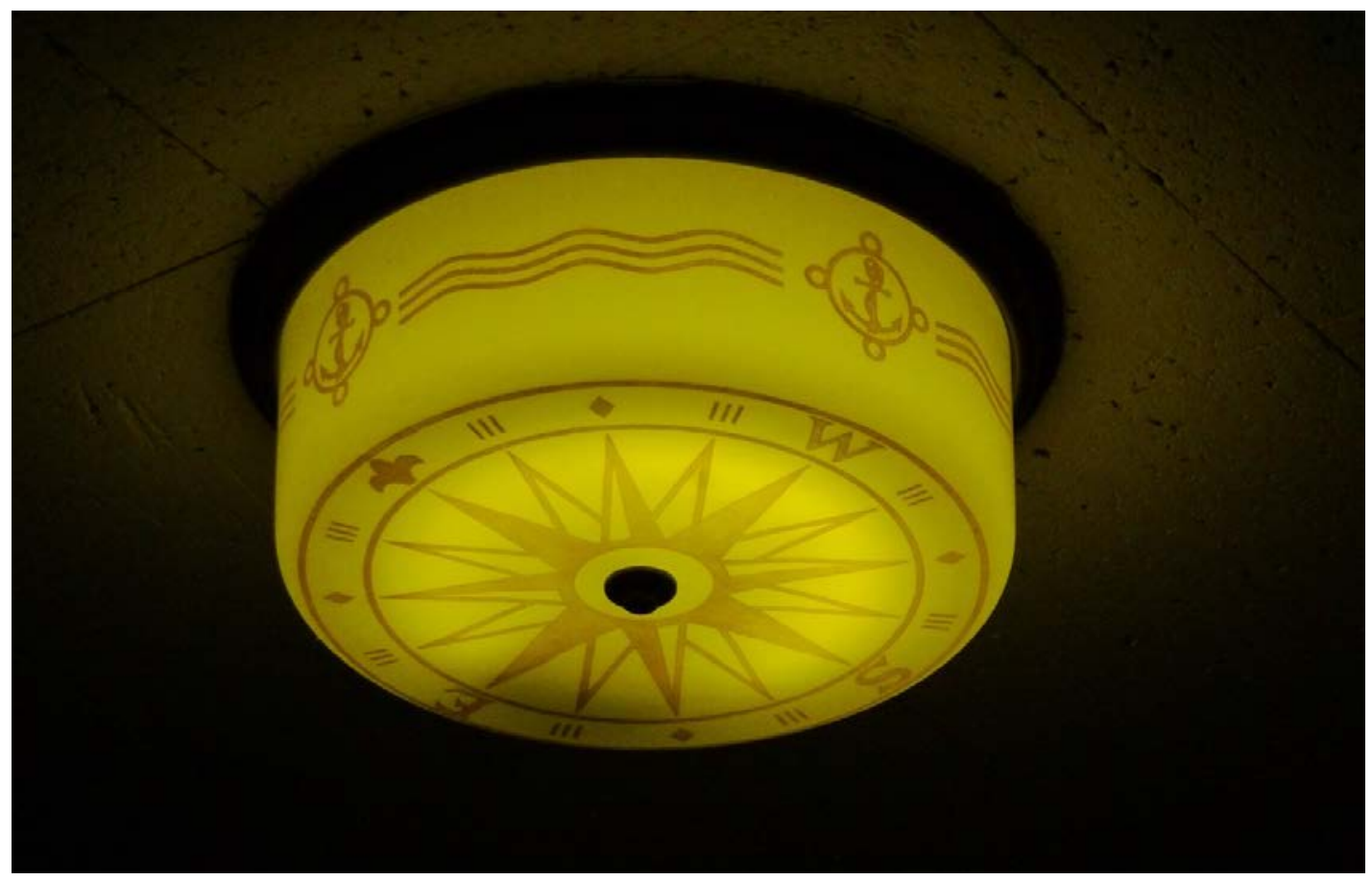

Figure 132. Original stairwell railings in auditorium vestibule in Bowditch Hall (ERDC-CERL, 2013).

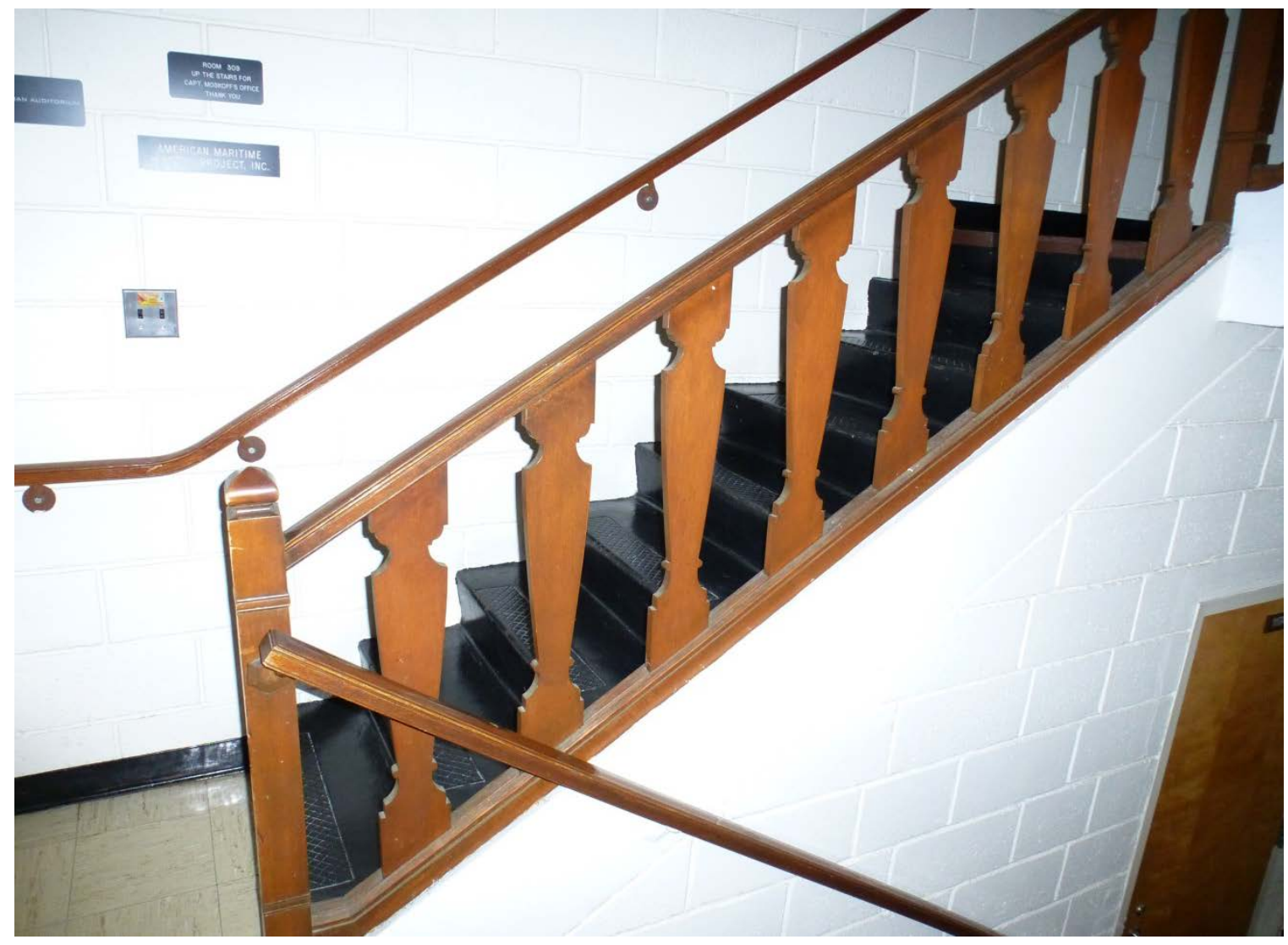




\subsubsection{Fitch Building}

The Fitch Building is a contributing feature to the USMMAHD, but the interior is noncontributing. It was originally constructed as offices and workspace for the academy's public works employees; it was constructed in 1943 and designed by Alfred Hopkins \& Associates. The building is located to the northwest of Fulton Hall and to the east of Samuels Hall. It was converted for administrative use at an unknown date. The walls are constructed of buff-colored concrete masonry units with cast-stone (concrete) accents, and the building displays the same consistent cornice line as the other buildings previously discussed. The roof is layered asphalt, hidden behind a parapet of the same buff-colored concrete masonry units, but covered by metal coping for waterproofing purposes. The original double-hung, six-over-six wood windows have all been replaced with large, anodized-bronze, casement, aluminum windows. The interior has been heavily remodeled through the years. The high-bay doors on the east side of the building are not original.

Figure 133. Northwest oblique of the Fitch Building (ERDC-CERL, 2013).

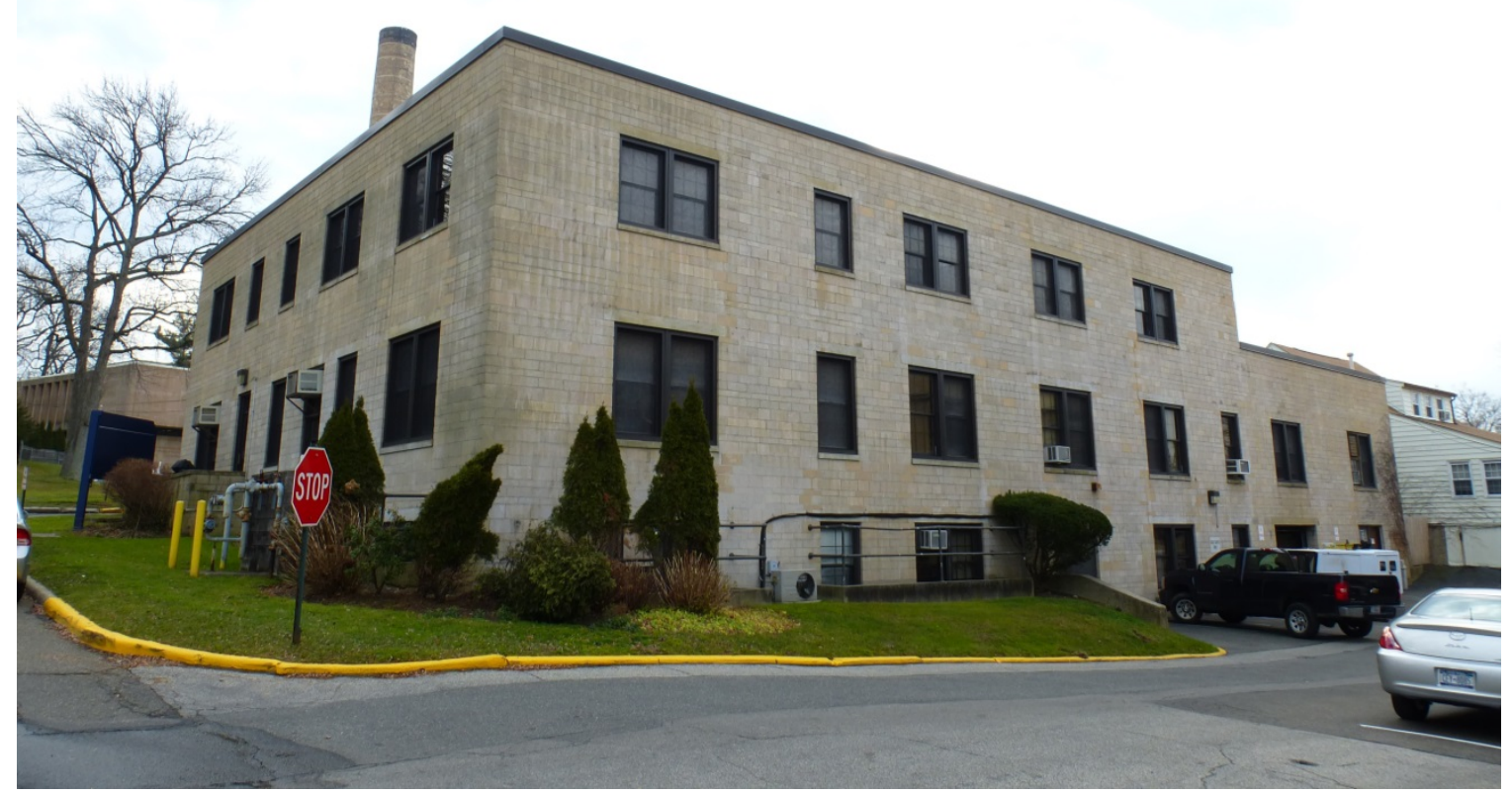


Figure 134. East façade of the Fitch Building [lens distortion caused by panorama] (ERDC-CERL, 2013).

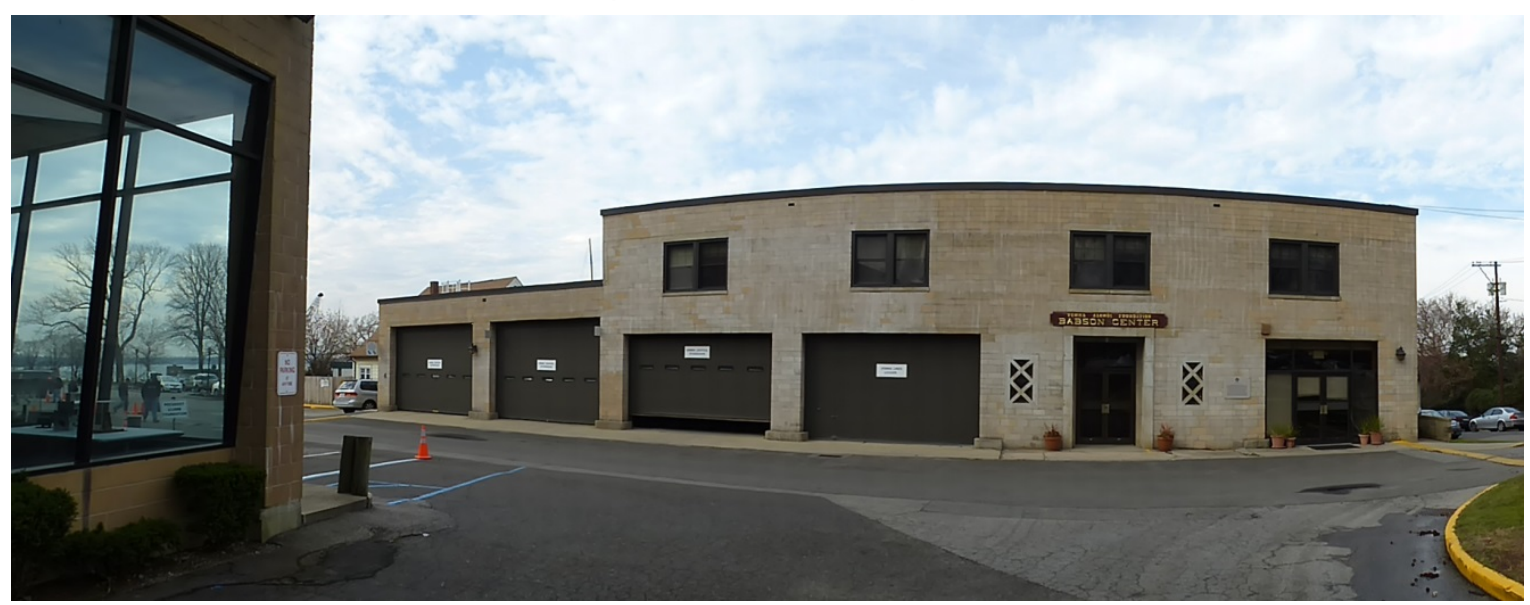

Figure 135. Entrance to the Fitch Building on the east façade (ERDC-CERL, 2013).

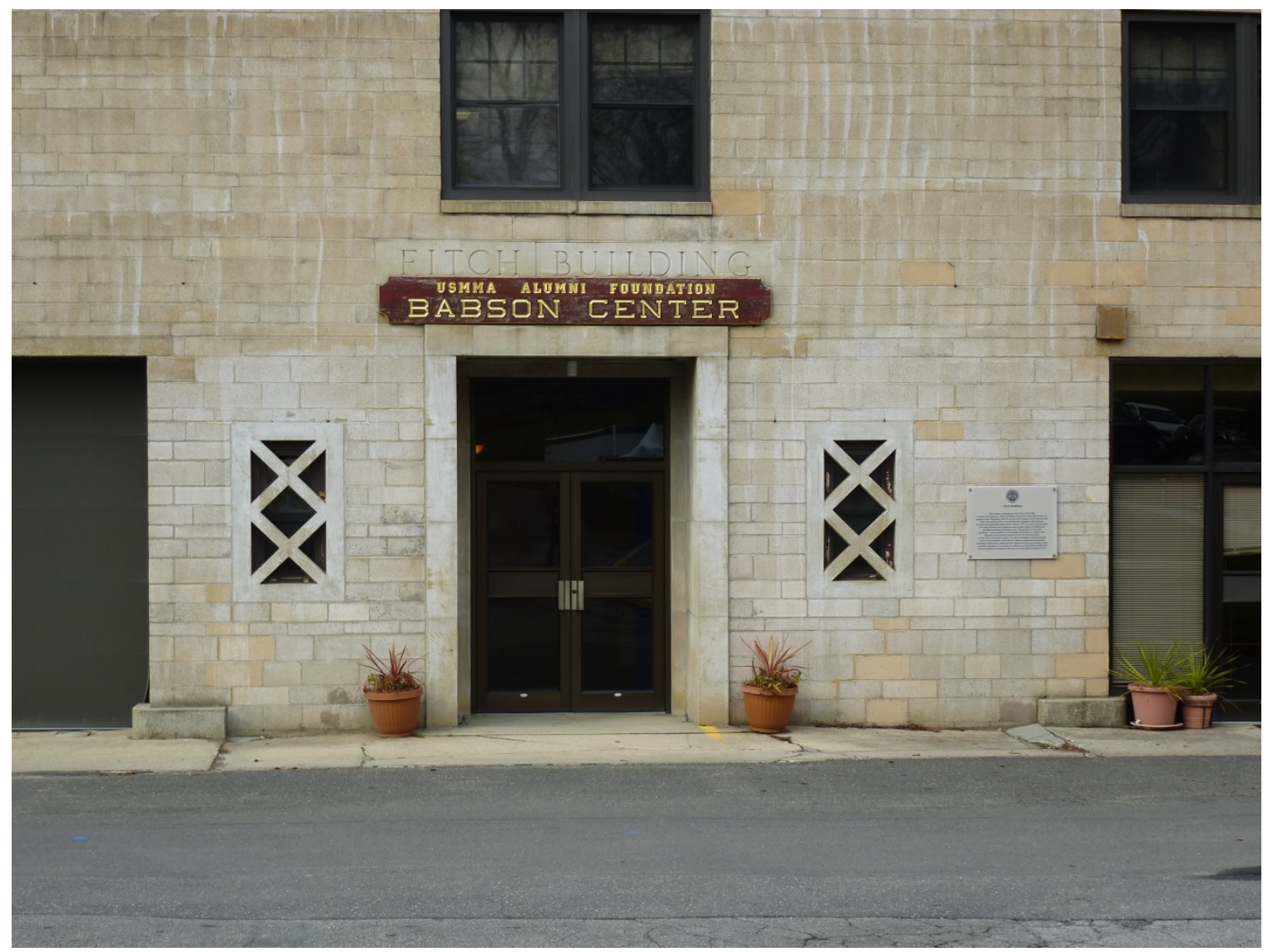




\subsubsection{Character-defining features}

Repair, renovation, and replacement of the following character-defining features of the Fitch Building must be coordinated with the NY SHPO.

- Overall massing

- Footprint

- Exterior concrete block and its distinctive stone-like pattern

- All cast-stone architectural elements including window sills and lintels, and door surrounds

- Multipane double-hung windows (see architectural plans for original window specs)

- Window and door openings

\subsubsection{Character-defining features that have been removed}

Listed below are character-defining features that have been removed or replaced on the Fitch Building over the years; as future renovations occur, these need to be replaced with elements that replicate the original character-defining features of the building. The original architectural plans will guide this process in coordination with the NY SHPO.

- Replacement anodized-bronze windows

- Replacement entrance doors

- Replacement large-bay doors

\subsubsection{Samuels Hall}

Samuels Hall is a contributing feature to the historic district, but its interior is noncontributing. It was originally constructed as academic space for seamanship and visual signaling; it was constructed in 1943 and designed by Alfred Hopkins \& Associates. The building is located to the west of the Fitch Building. The walls are constructed of buff-colored concrete masonry units with cast-stone (concrete) accents, and the building displays the same consistent cornice line as the other buildings previously discussed. The roof is layered asphalt, hidden behind a parapet of the same buffcolored concrete masonry units. The original double-hung, six-over-six wood windows have all been replaced with anodized-bronze, double-hung, six-over-one aluminum windows that can have an awning-style opening (tilt). In 1975, an addition was constructed on the building's western edge for the Computer Aided Operations Facility. The addition's structure is 
unknown, but it is covered with glazed terra cotta blocks and has no fenestration.

Figure 136. South façade of Samuels Hall, with the 1975 addition on the left (ERDC-CERL, 2013).

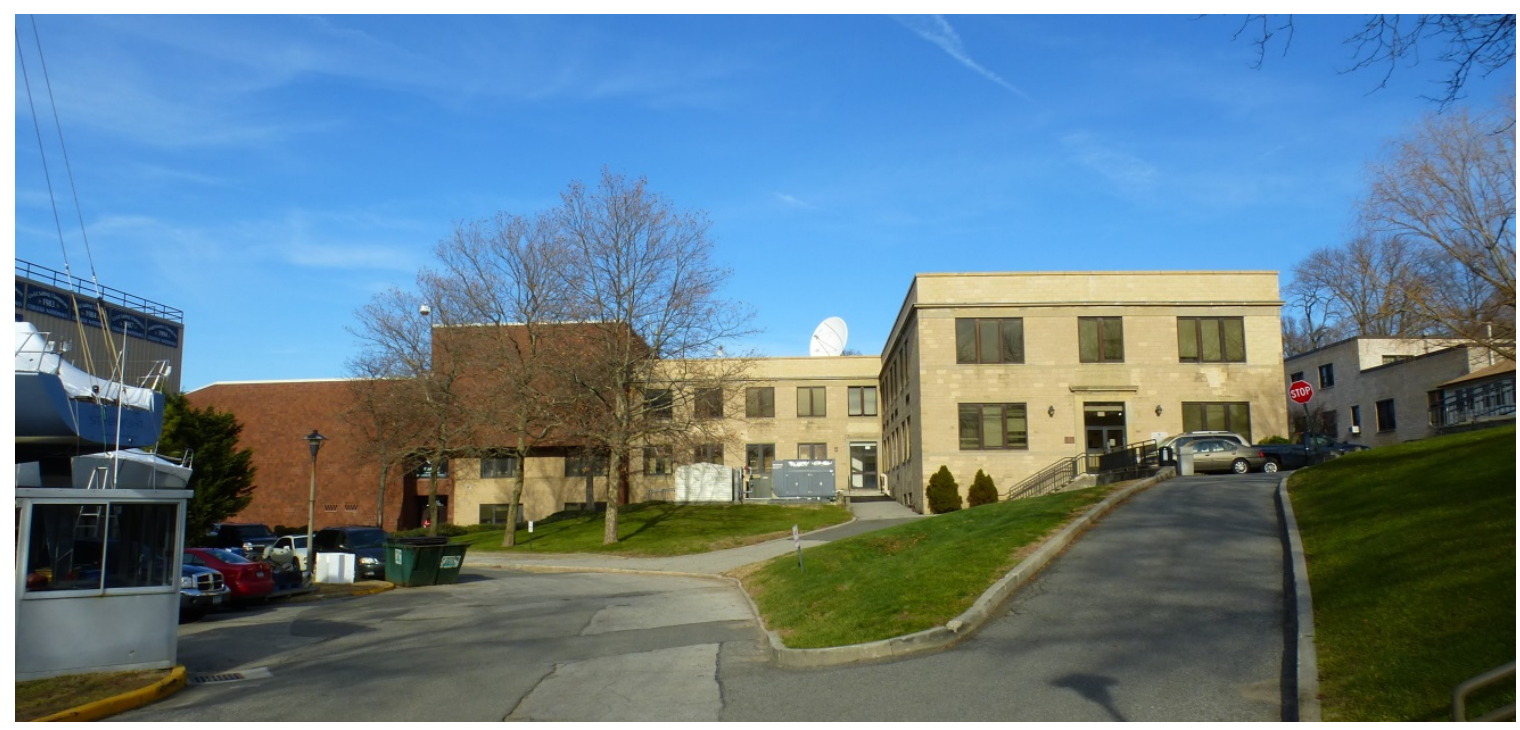

Figure 137. South façade of Samuels Hall with the 1975 addition on the left (ERDC-CERL, 2013).

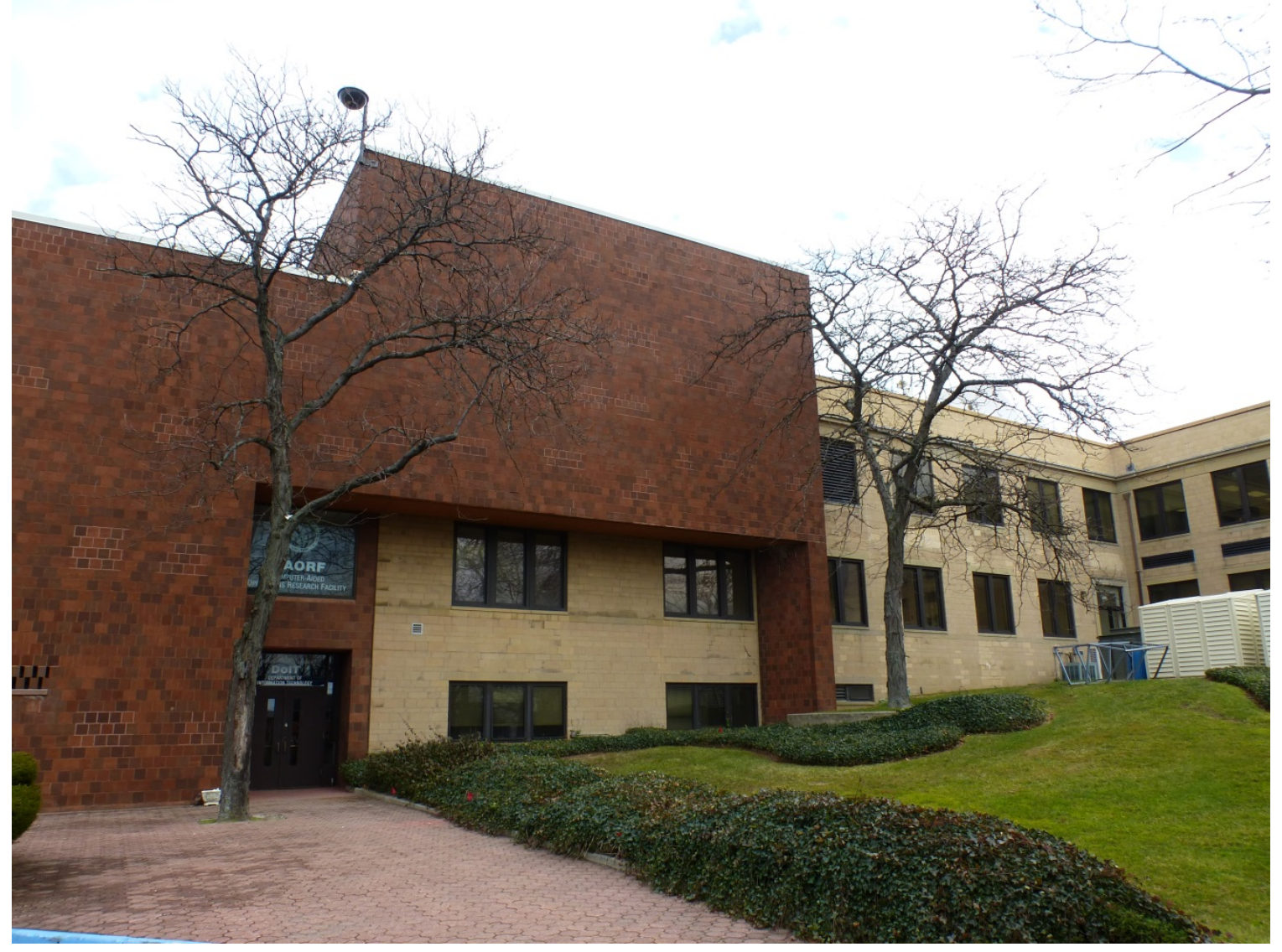


Figure 138. South entrance to Samuels Hall with cast-stone door surround, caststone with inscription, and replacement light fixtures (ERDC-CERL, 2013).

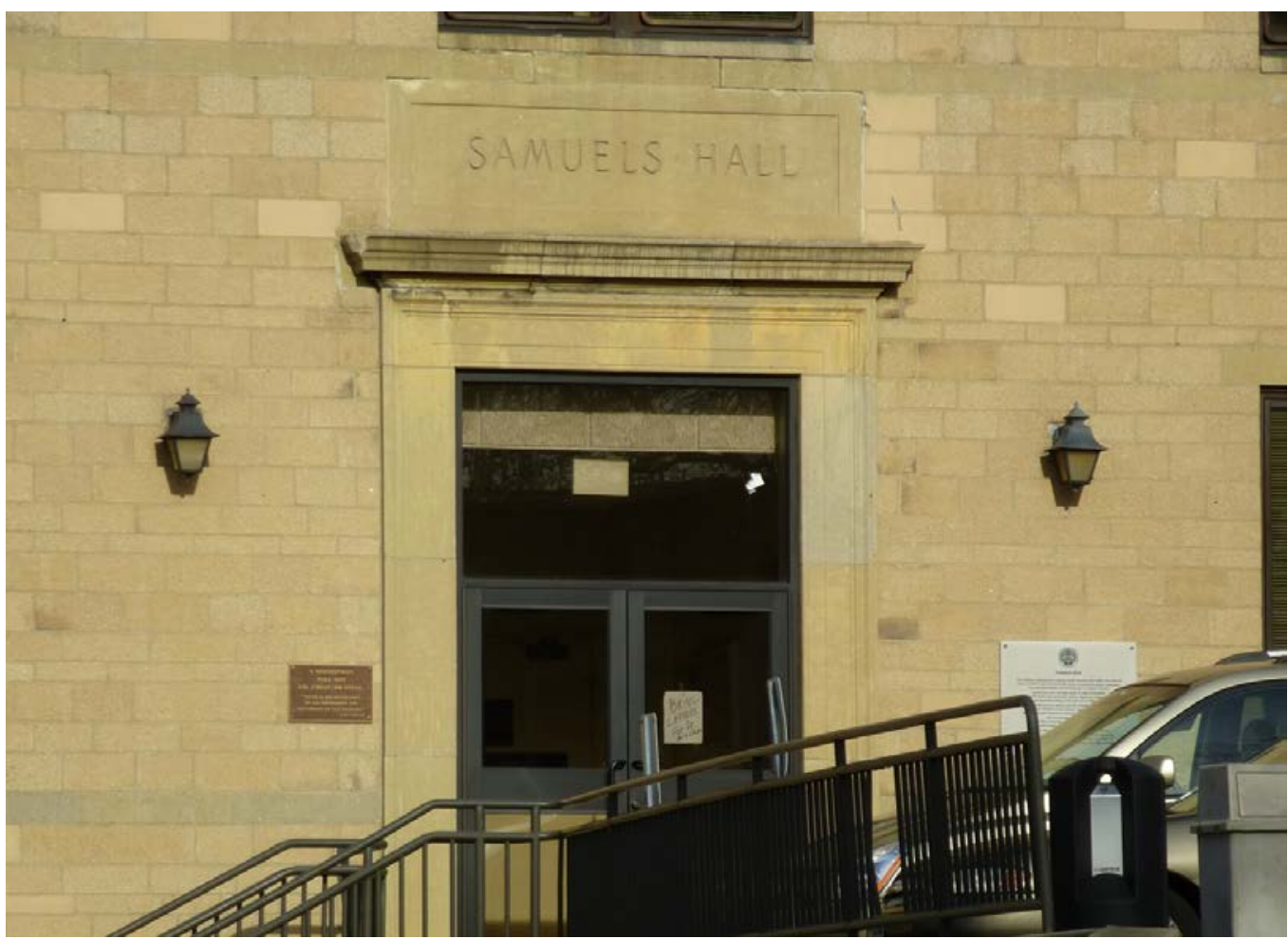

Figure 139. Replacement awning (tilt) window on Samuels Hall (ERDC-CERL, 2013).

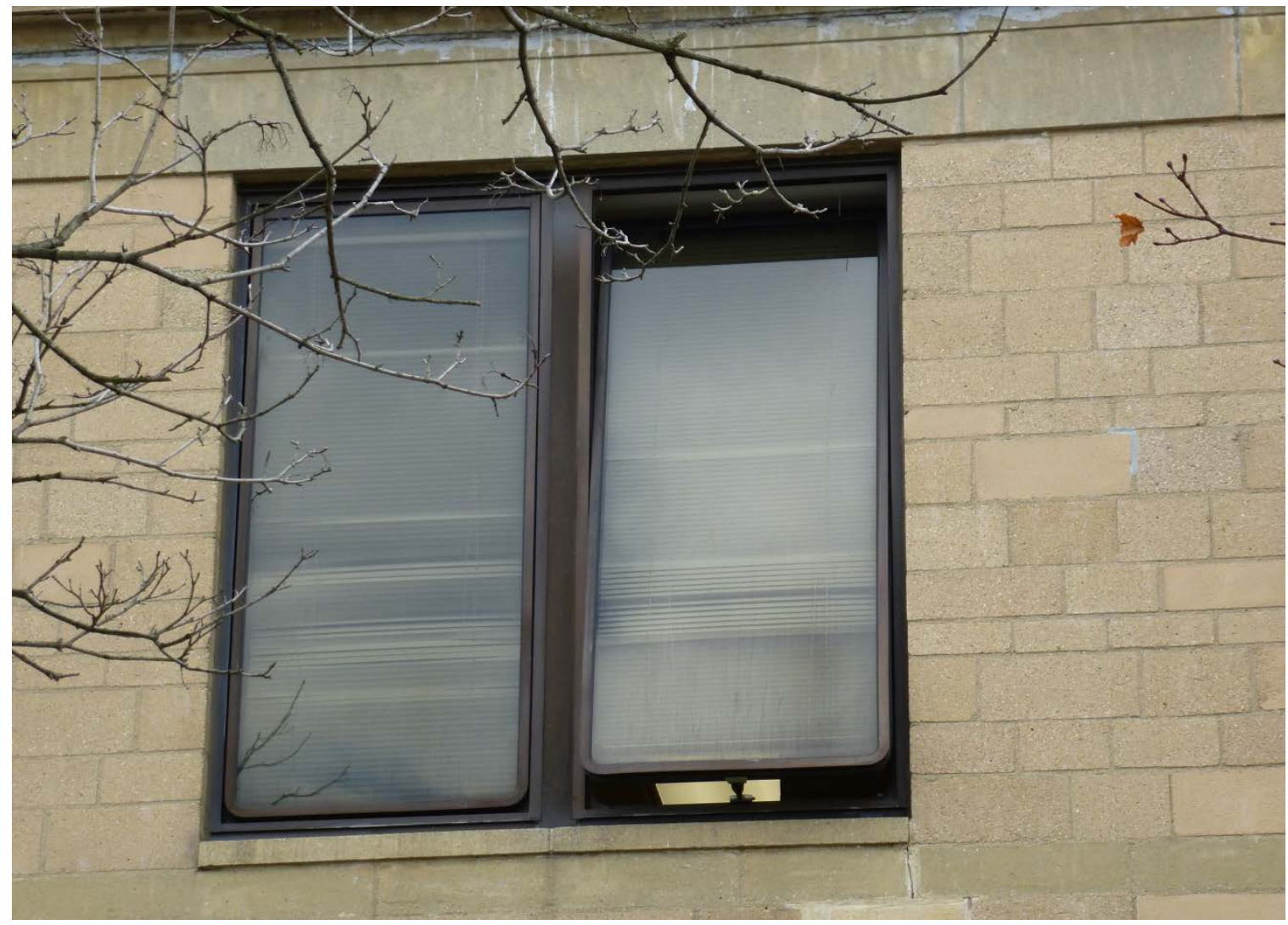




\subsubsection{Character-defining features}

Repair, renovation, and replacement of the following character-defining features of Samuels Hall must be coordinated with the NY SHPO.

- Exterior concrete block and its distinctive stone-like pattern

- Parapet

- All cast-stone architectural elements including window sills and lintels, door surrounds, belt course, quoins, bas-reliefs, and cornices

- Window and door openings

\subsubsection{Character-defining features that have been removed}

Listed below are character-defining features that have been removed or replaced over the years on Samuels Hall; as future renovations occur, these need to be replaced with elements that replicate the original character-defining features of the building. The original architectural plans will guide this process in coordination with the NY SHPO.

- Replacement anodized-bronze windows

- Replacement entrance doors

- Replacement light fixtures

\subsubsection{Nonhistoric features}

- West addition

\subsubsection{Delano Hall}

Delano Hall is a large two-story mess hall (dining facility). It is a contributing feature to the USMMAHD, as are parts of its interior. Contributing interior elements are: the main entrance vestibule, the dining hall, and the stair/entrance vestibules to the east and west. The front of Delano Hall faces Barney Square, and the building is connected by hyphens to Murphy Hall on the west and Cleveland Hall to the east. Records indicate it was constructed in 1943 and designed by Alfred Hopkins \& Associates. It is a concrete-framed building with a large dining room on the top floor and large kitchen behind that (to the south). The basement level contains several stores, a restaurant, and restrooms. It is constructed with a cast-inplace structure and concrete block exterior walls in a distinctive stone-like 
pattern. Cast-stone architectural elements are placed at the lintel and sill levels on all windows. Cast stone is also utilized for all entrance door surrounds, the belt course, quoins, inscriptions, and the cornice. There is a large, porticoed entrance that faces onto Barney Square to the north. The front-gabled portico has square, cast-concrete columns. Delano Hall is in the same Classical Revival Style as the other buildings of the central campus. Generally, the roof is layered asphalt hidden behind a parapet of the same buff-colored concrete masonry units. The original double-hung wood windows have all been replaced with anodized bronze, double-hung, aluminum windows. The doors are not original, but the light fixtures in the entrance vestibule and inside the dining facility are original and distinctive. The main-floor dining facility has not been changed and retains its integrity, while the kitchen areas and ground floor have been modified and changed throughout the years.

Figure 140. North façade of Delano Hall (mess hall) and Parade Ground, 1943 (Bland Library, USMMA).

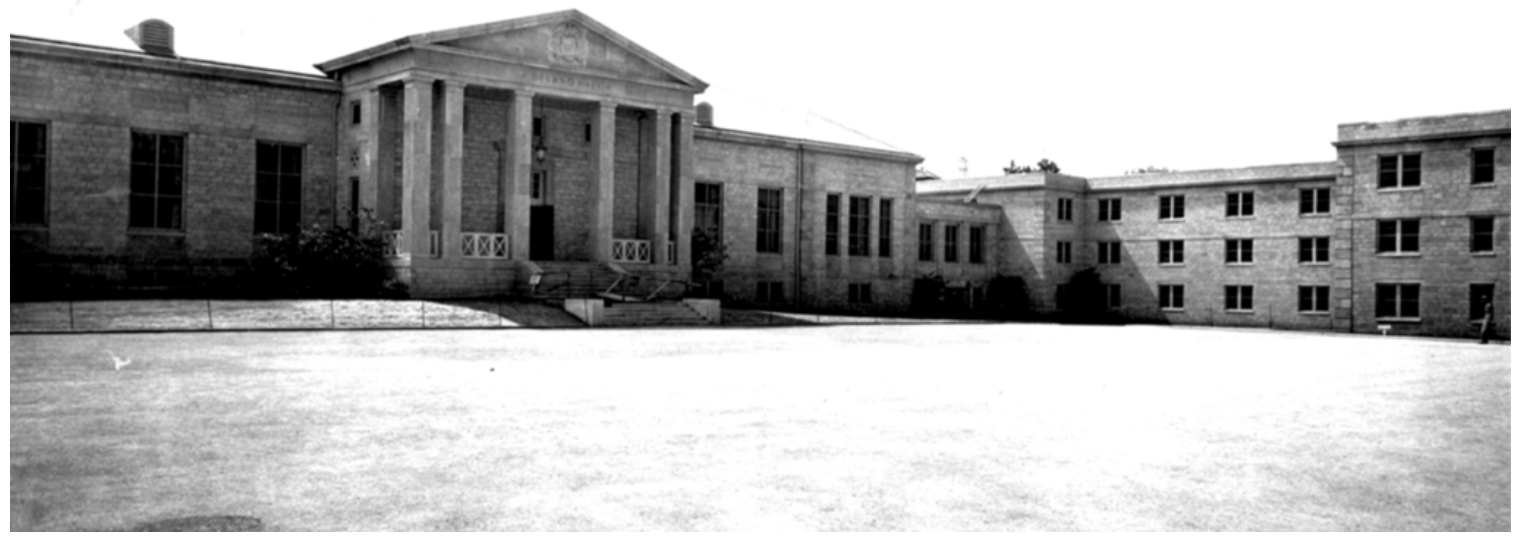


Figure 141. North façade of Delano Hall with Blarney Square in the foreground (ERDC-CERL, 2013).

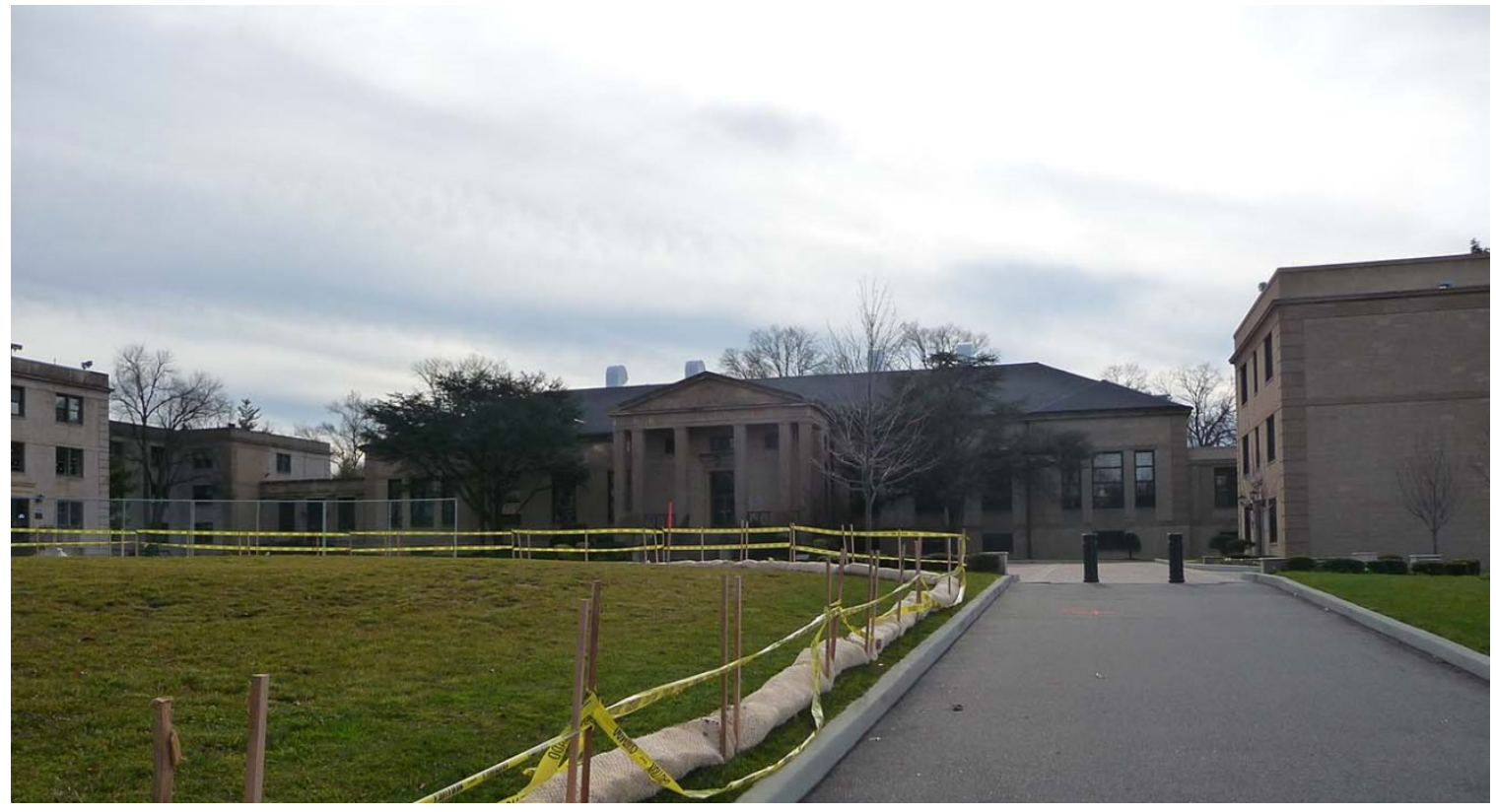

Figure 142. North façade of the Delano Hall entrance portico (ERDC-CERL, 2013).

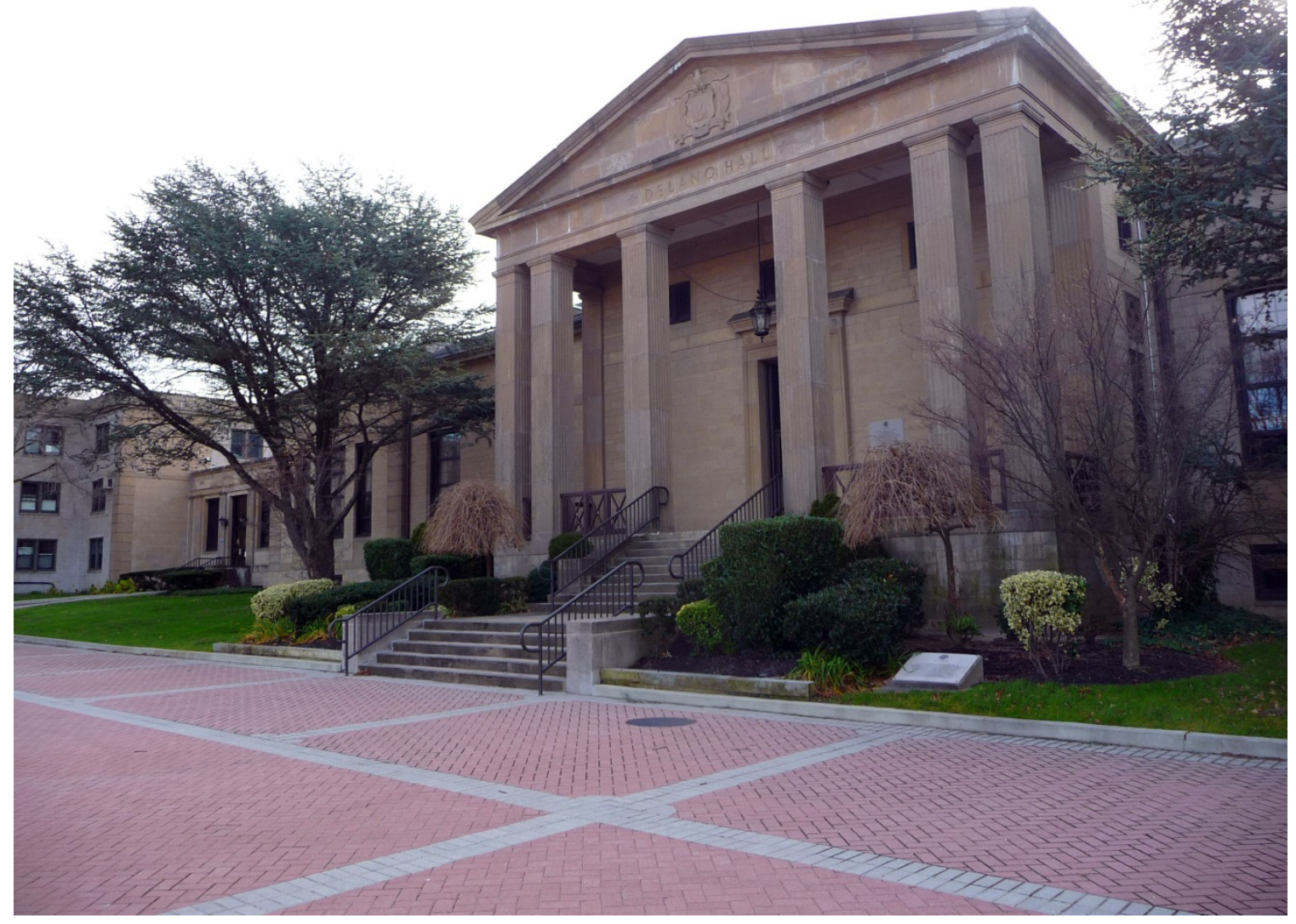


Figure 143. Southeast oblique of Delano Hall, showing the kitchen wing on the left and the dining hall on the right (ERDC-CERL, 2013).

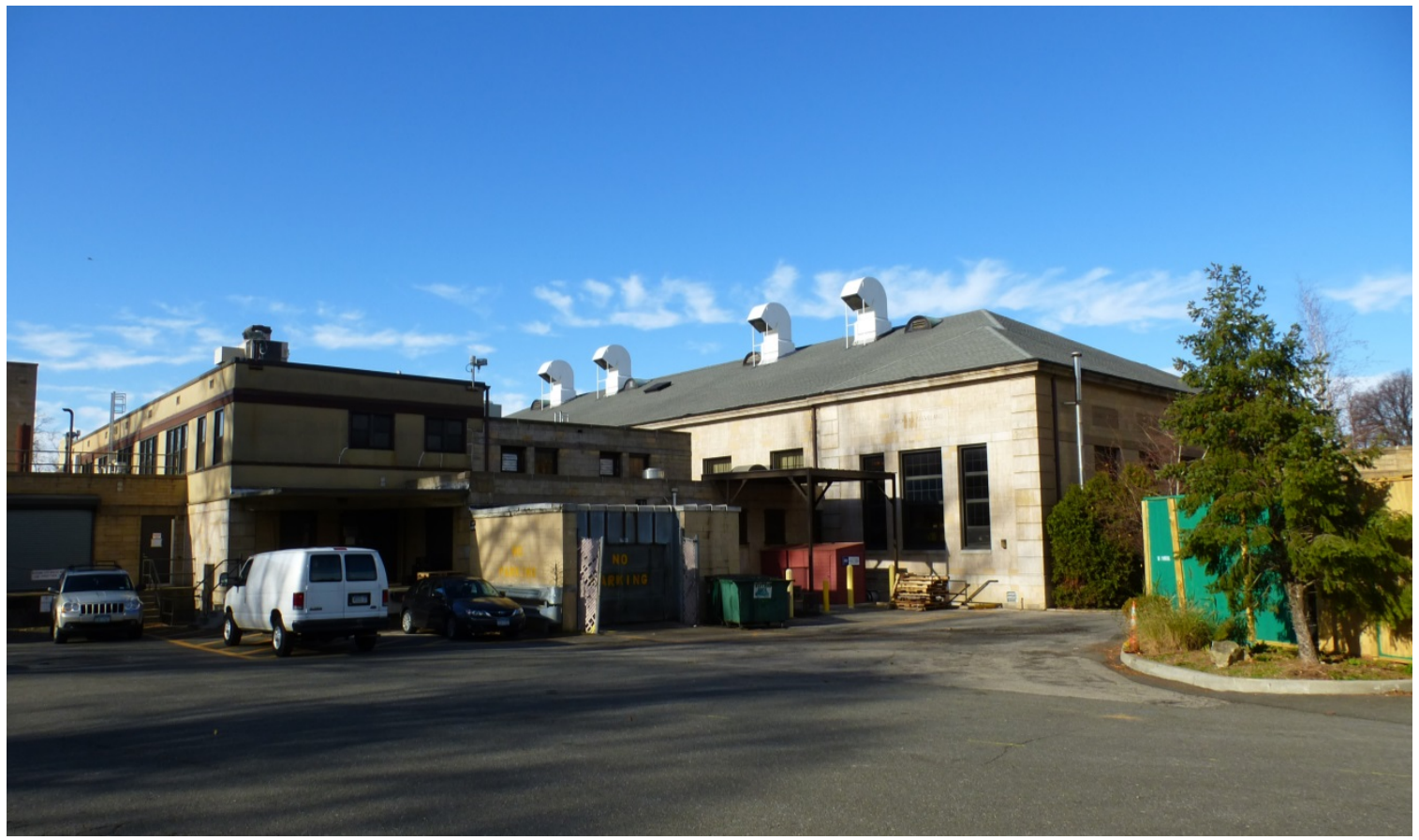

Figure 144.. Original railing on the portico on Delano Hall (ERDC-CERL, 2013).

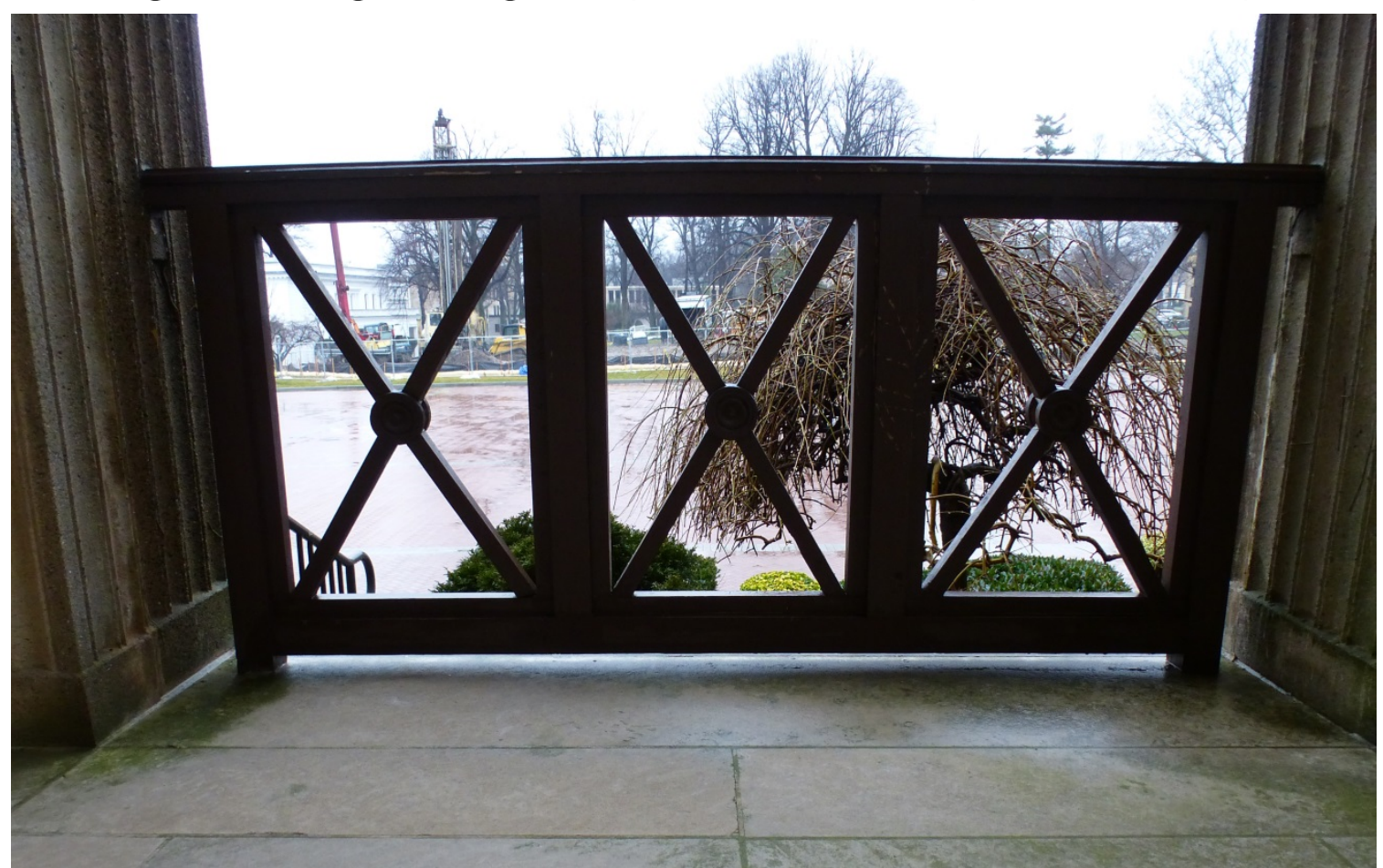


Figure 145. Original light fixture, ceiling, and cast-stone elements on the portico of Delano Hall (ERDC-CERL, 2013).

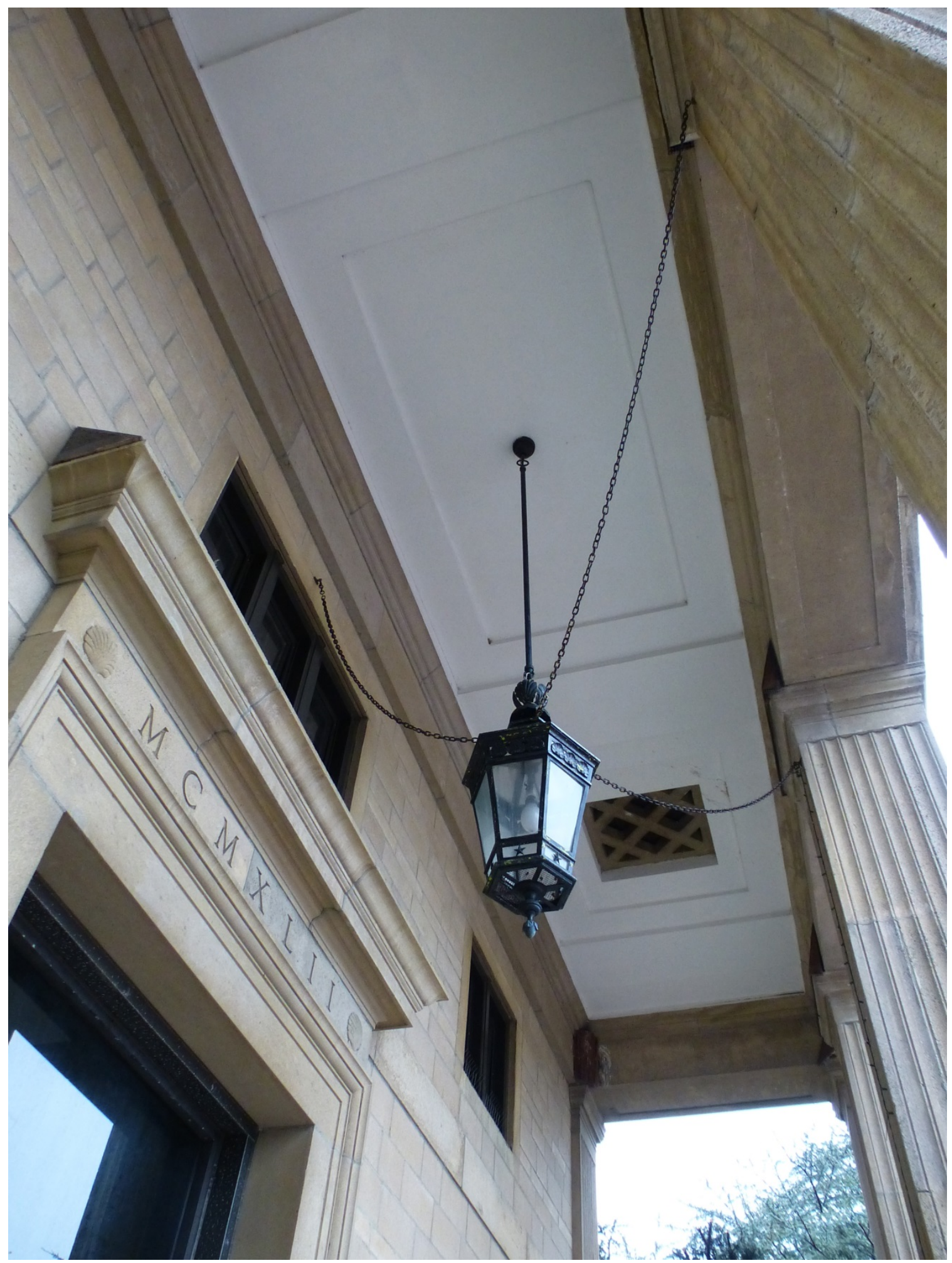


Figure 146. Original light schedule drawing for portico ceiling light fixture on Delano Hall (USMMA, DPW).

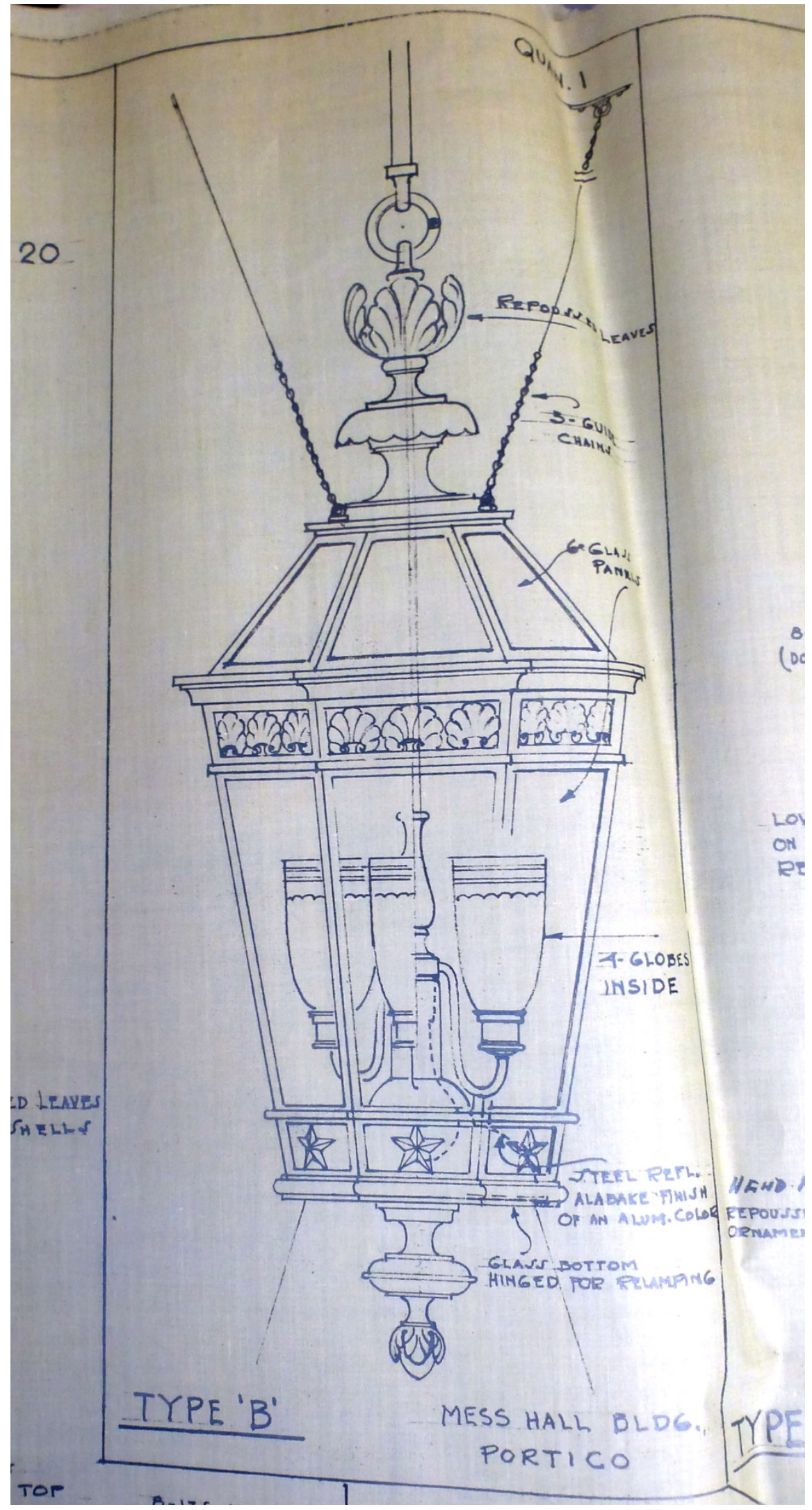


Figure 147. Detail of original light fixture on the portico (ERDC-CERL, 2013).

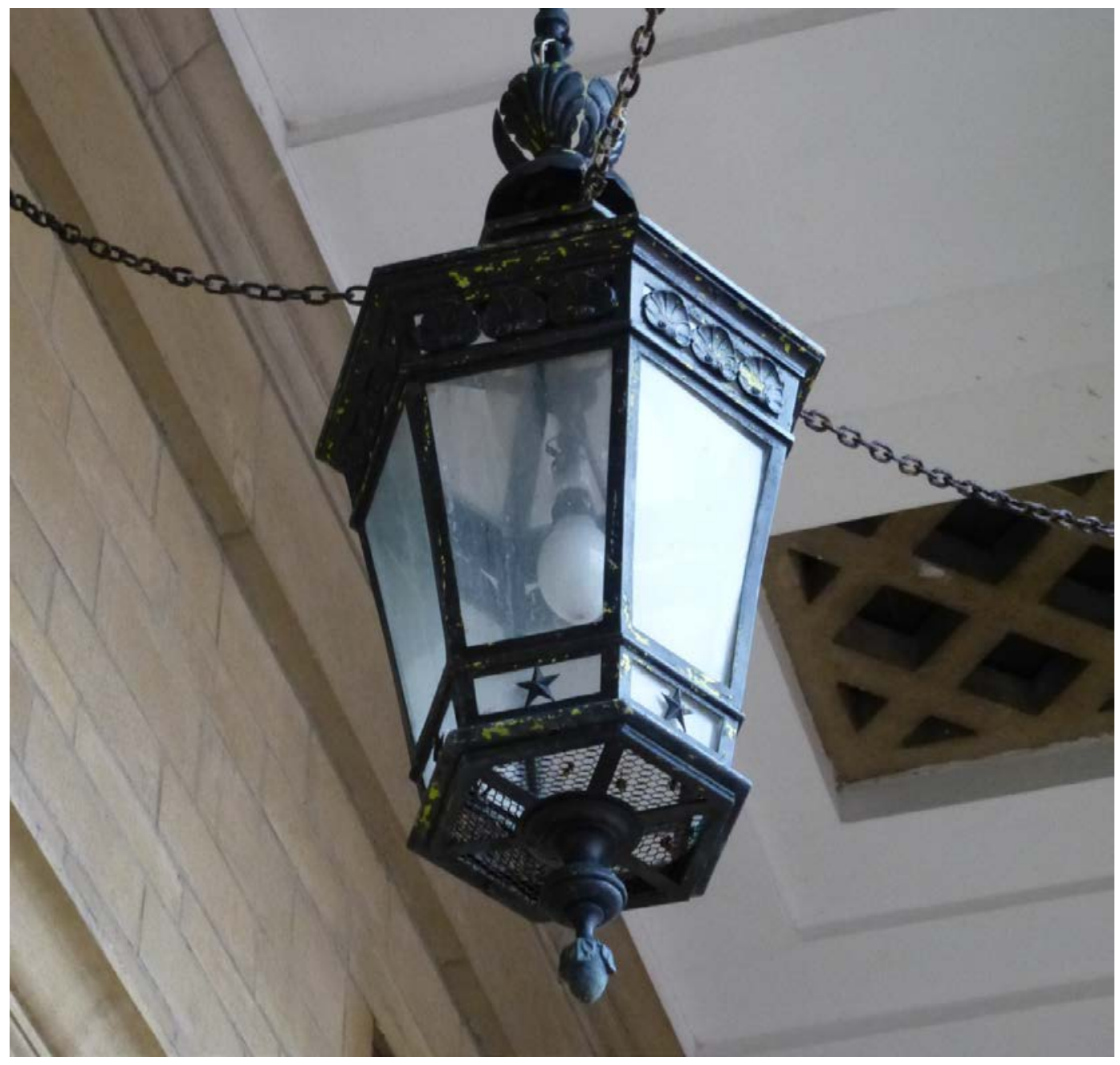


Figure 148. Original light schedule drawing for "zodiac" vestibule ceiling light fixture (USMMA, DPW).

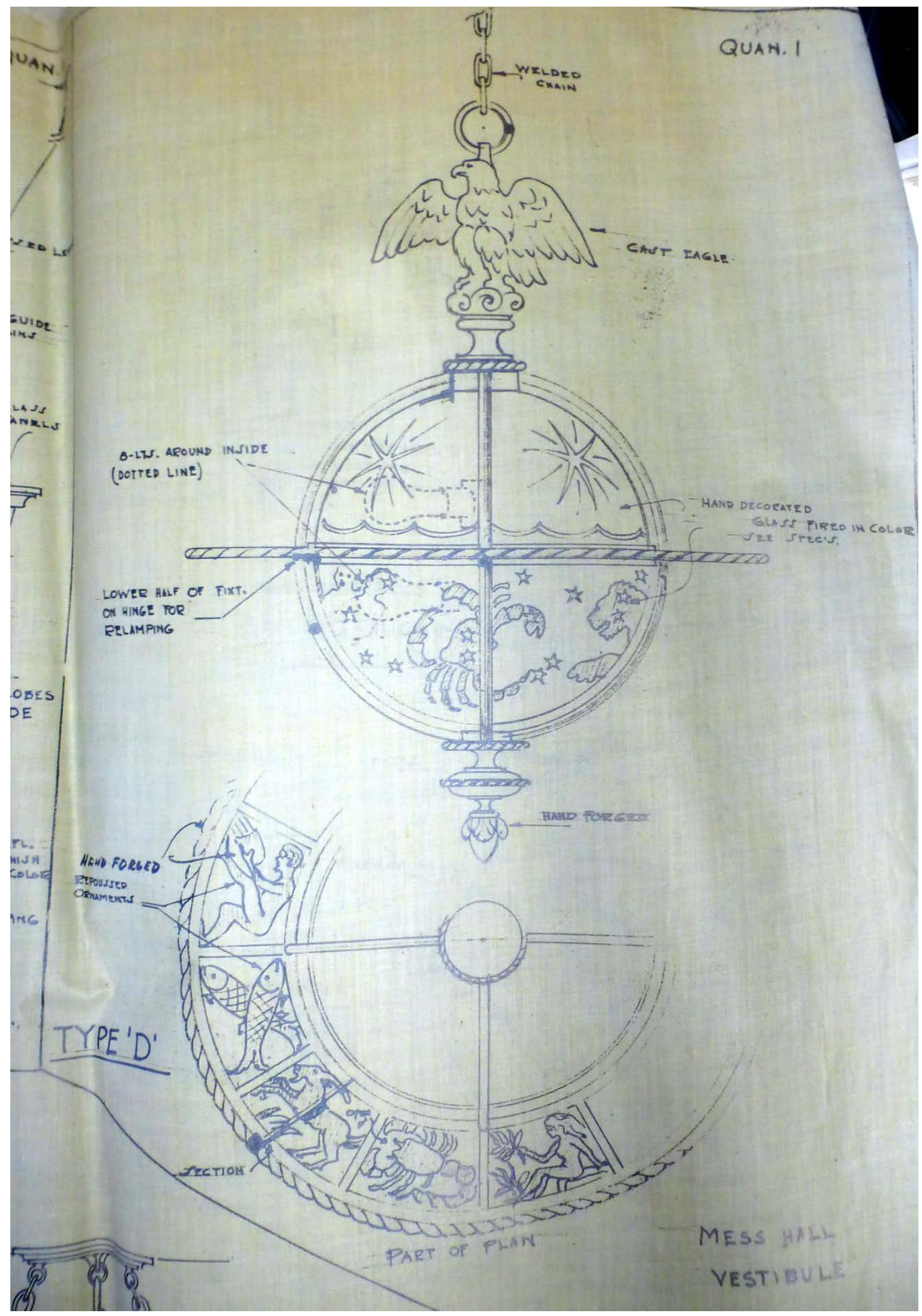


Figure 149. Looking up at the original "zodiac" light fixture in a dining hall vestibule in Delano Hall (ERDC-CERL, 2013).

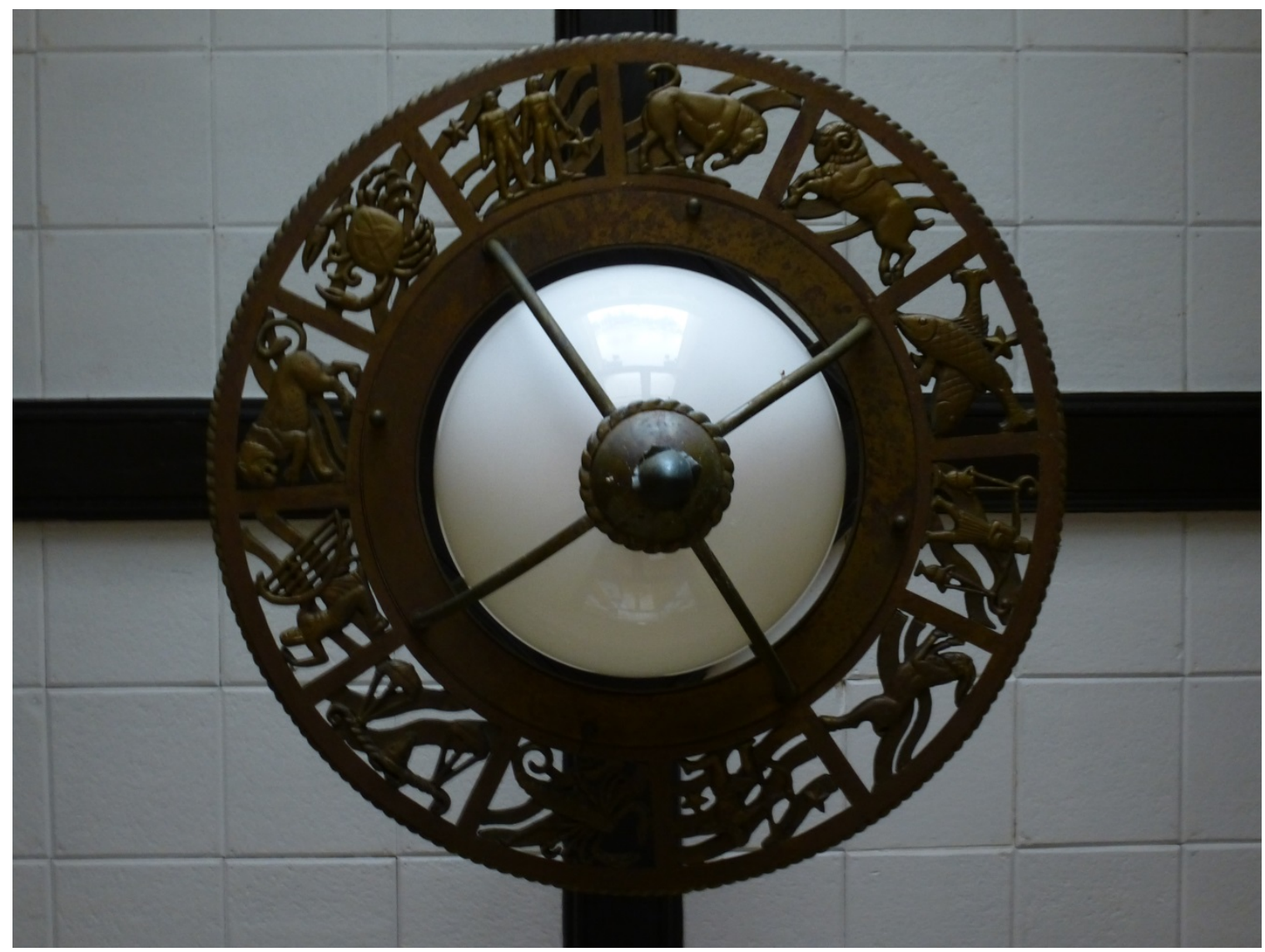


Figure 150. Main entrance from the north into the dining hall (ERDC-CERL, 2013).

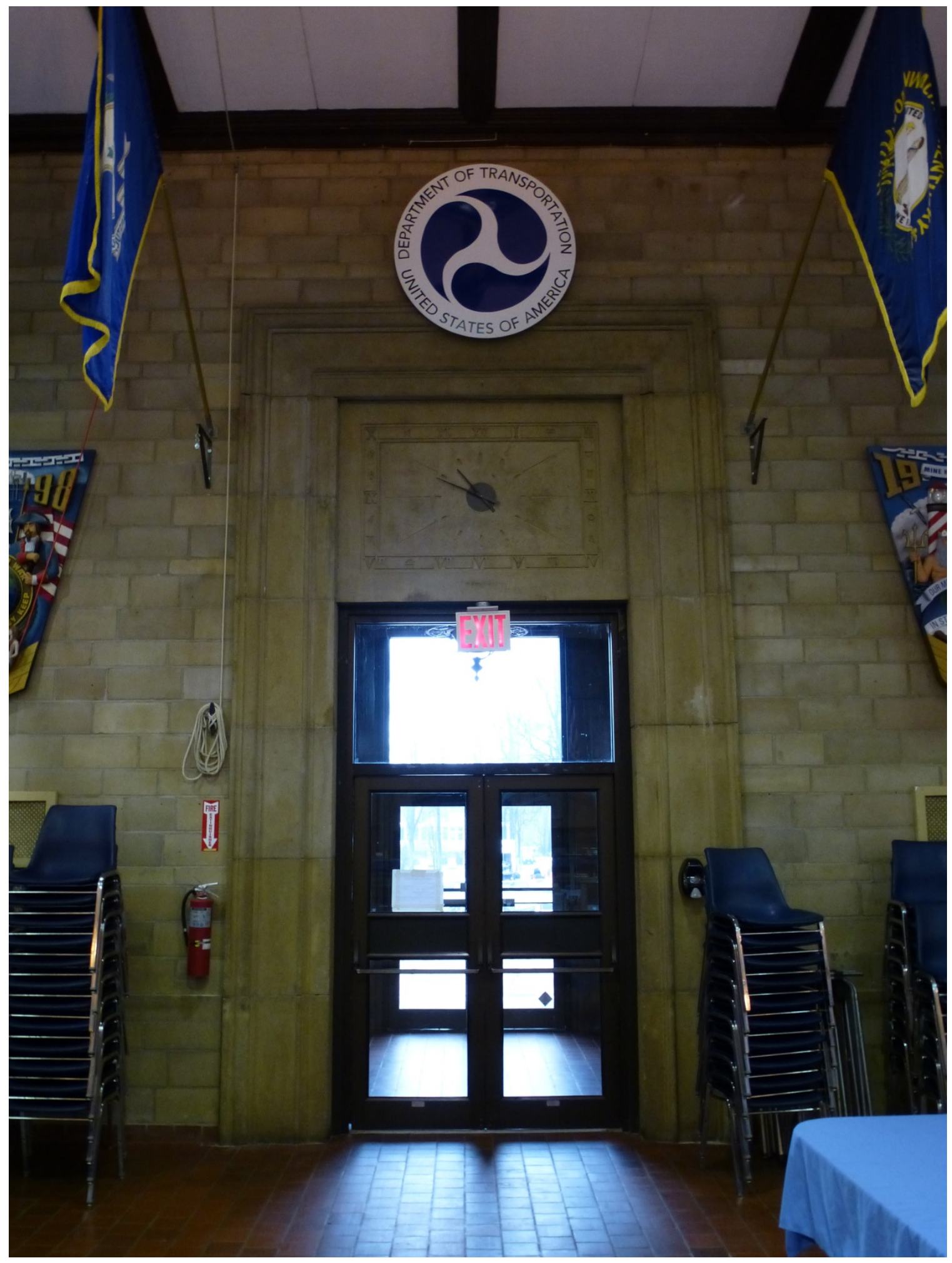


Figure 151. Cast-stone clock above doorway from dining hall to the vestibule (ERDC-CERL, 2013).

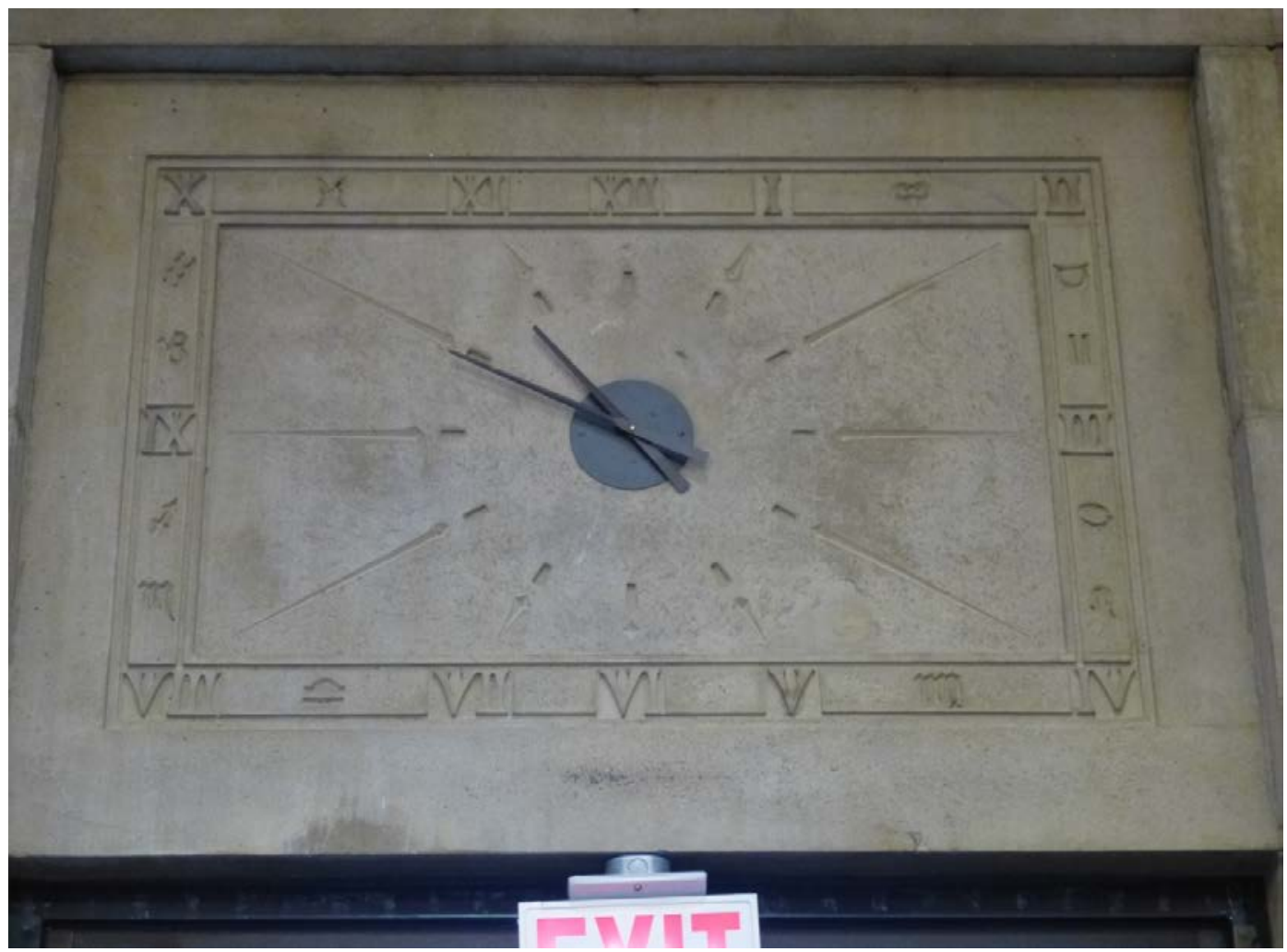

Figure 152. Interior of dining hall (ERDC-CERL, 2013).

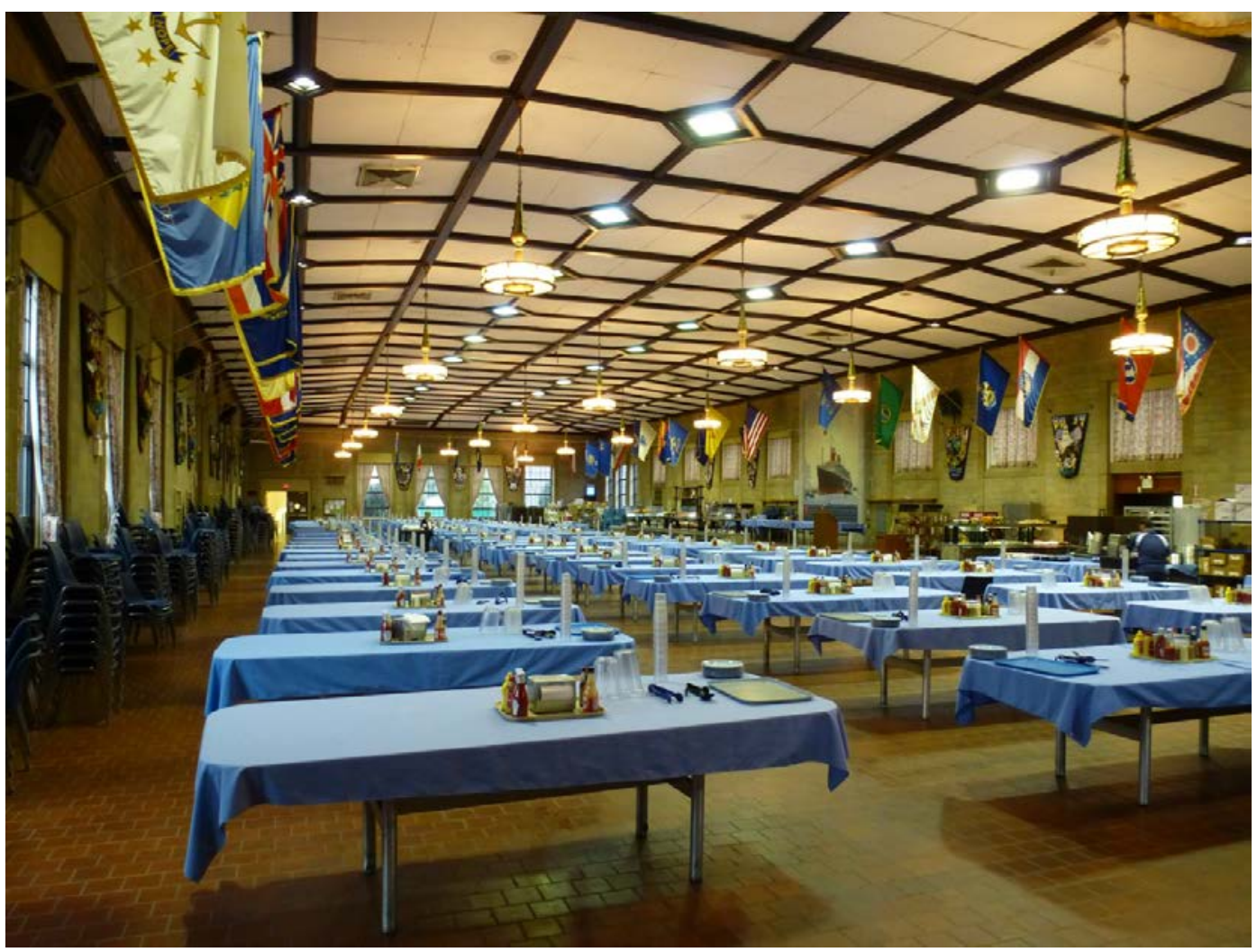


Figure 153. Original light schedule drawing for dining hall ceiling light fixtures (USMMA).

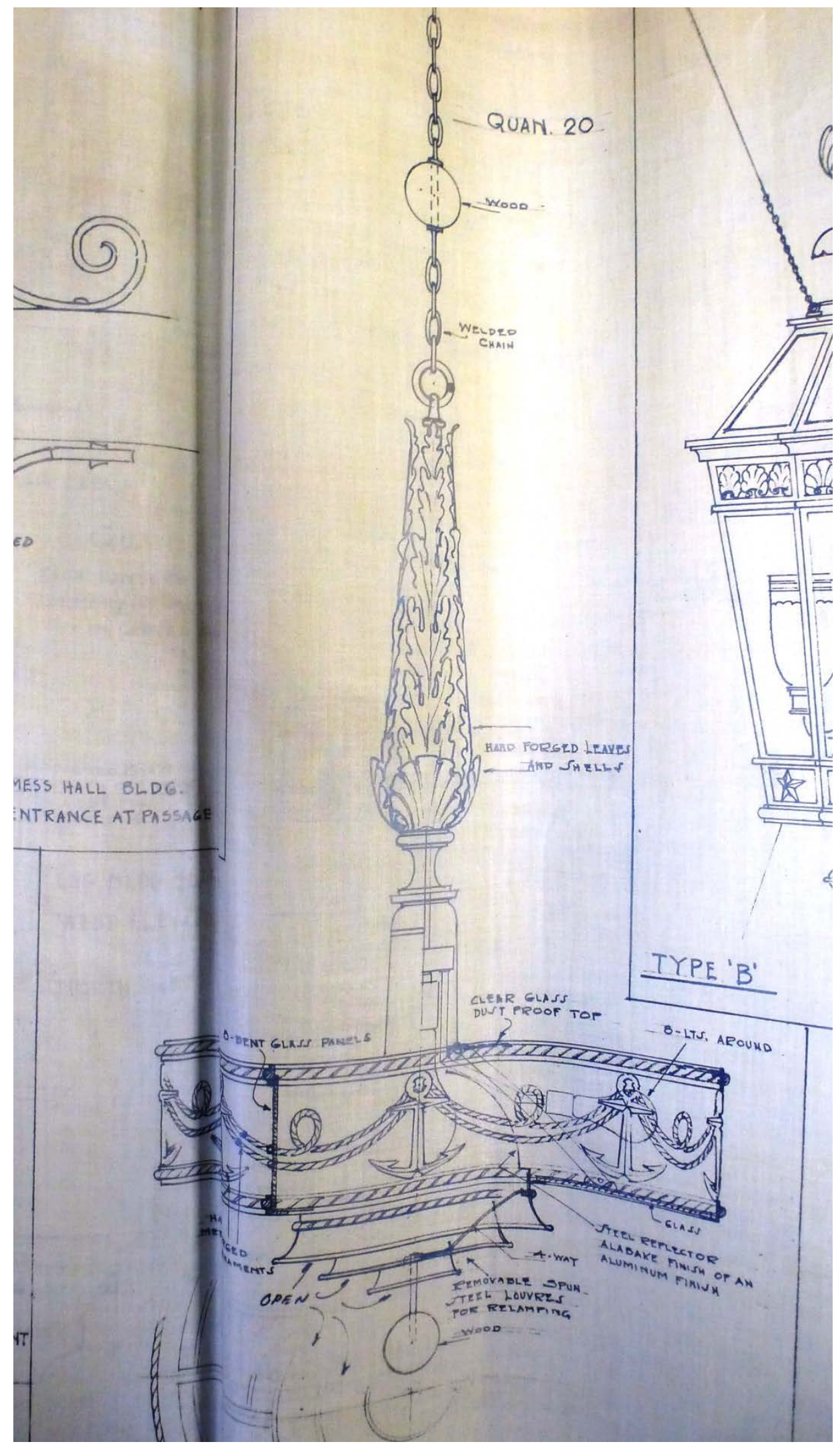


Figure 154. One of the original dining hall light fixtures in Delano Hall (ERDC-CERL, 2013).

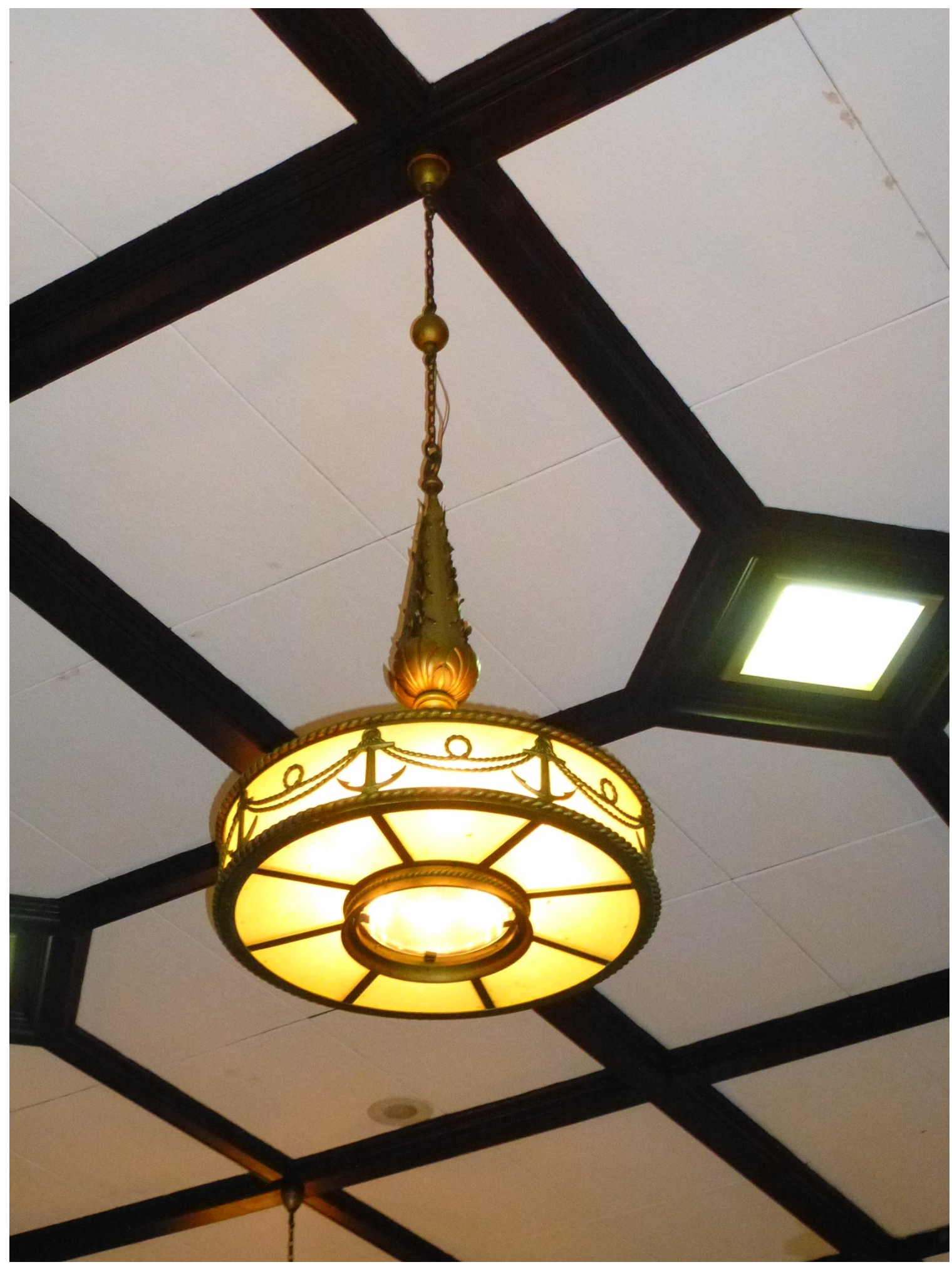


Figure 155. Mural in Delano Hall dining hall (ERDC-CERL, 2013).

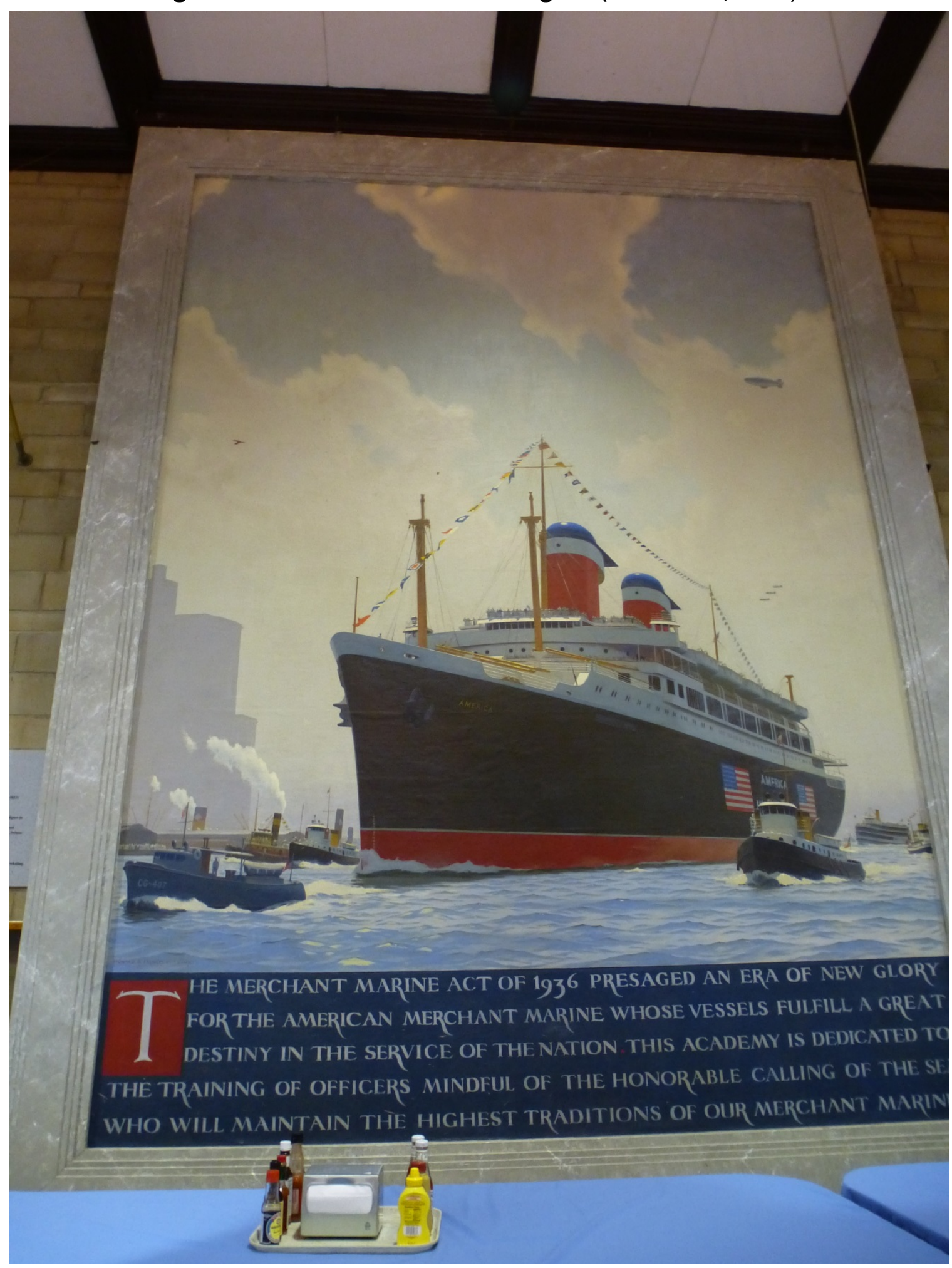


Figure 156. Replacement interior doors in Delano Hall (ERDC-CERL, 2013).

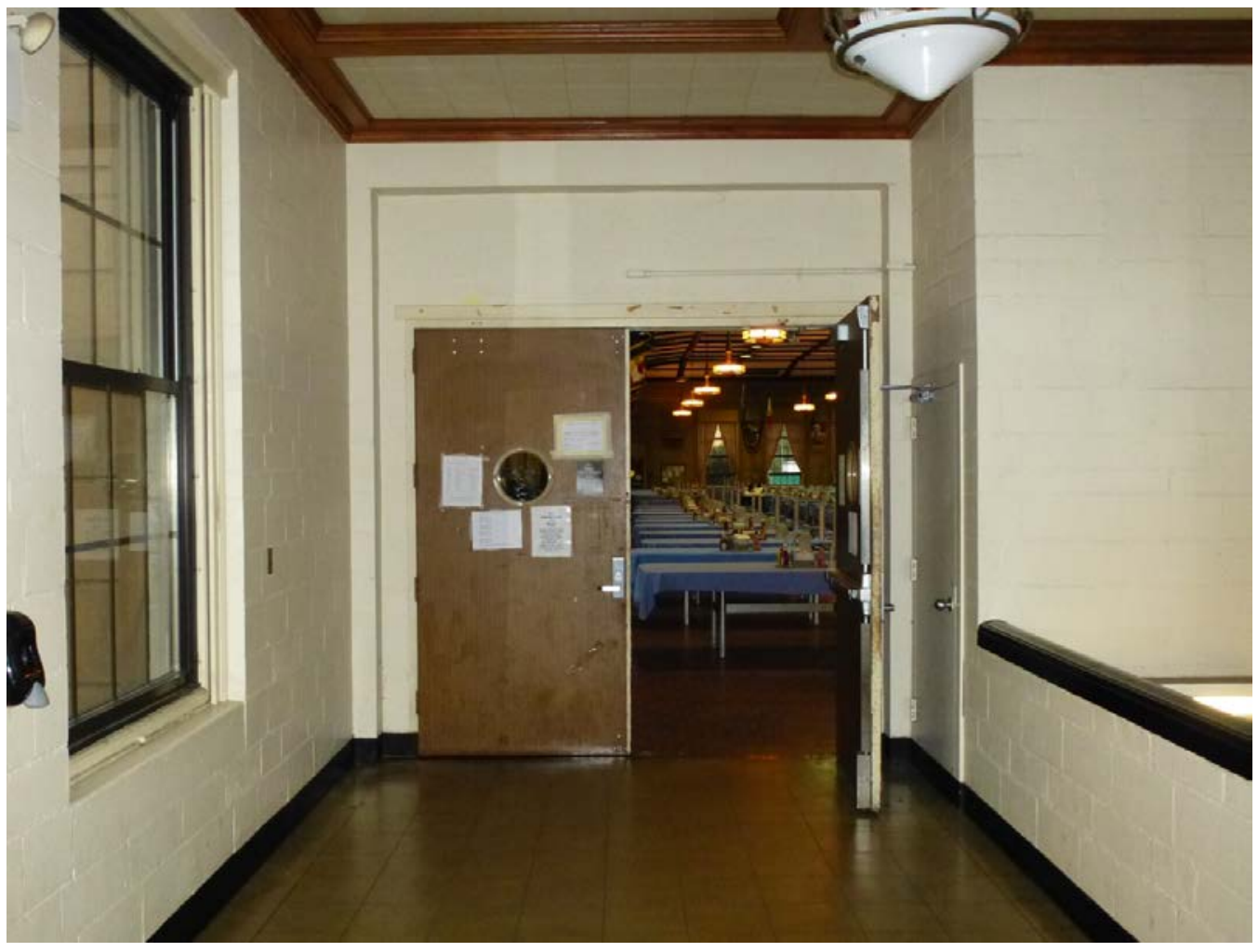

Figure 157. Detail of paint on cast-stone quoins and on concrete block wall as well as one of the replacement exterior light fixtures on Delano Hall (ERDC-CERL, 2013).

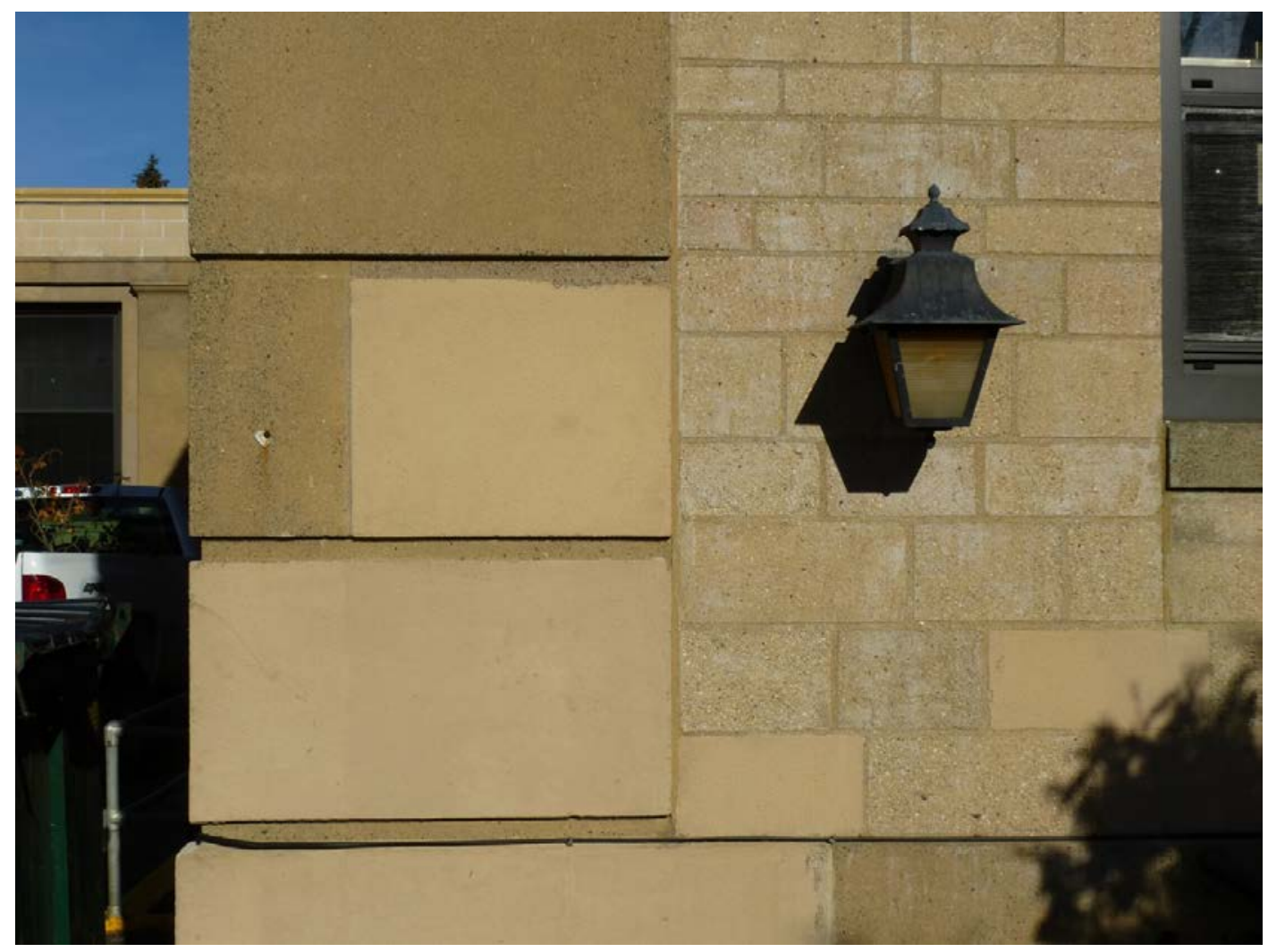


Figure 158. Non-character-defining stair railing on the portico steps (ERDC-CERL, 2013).

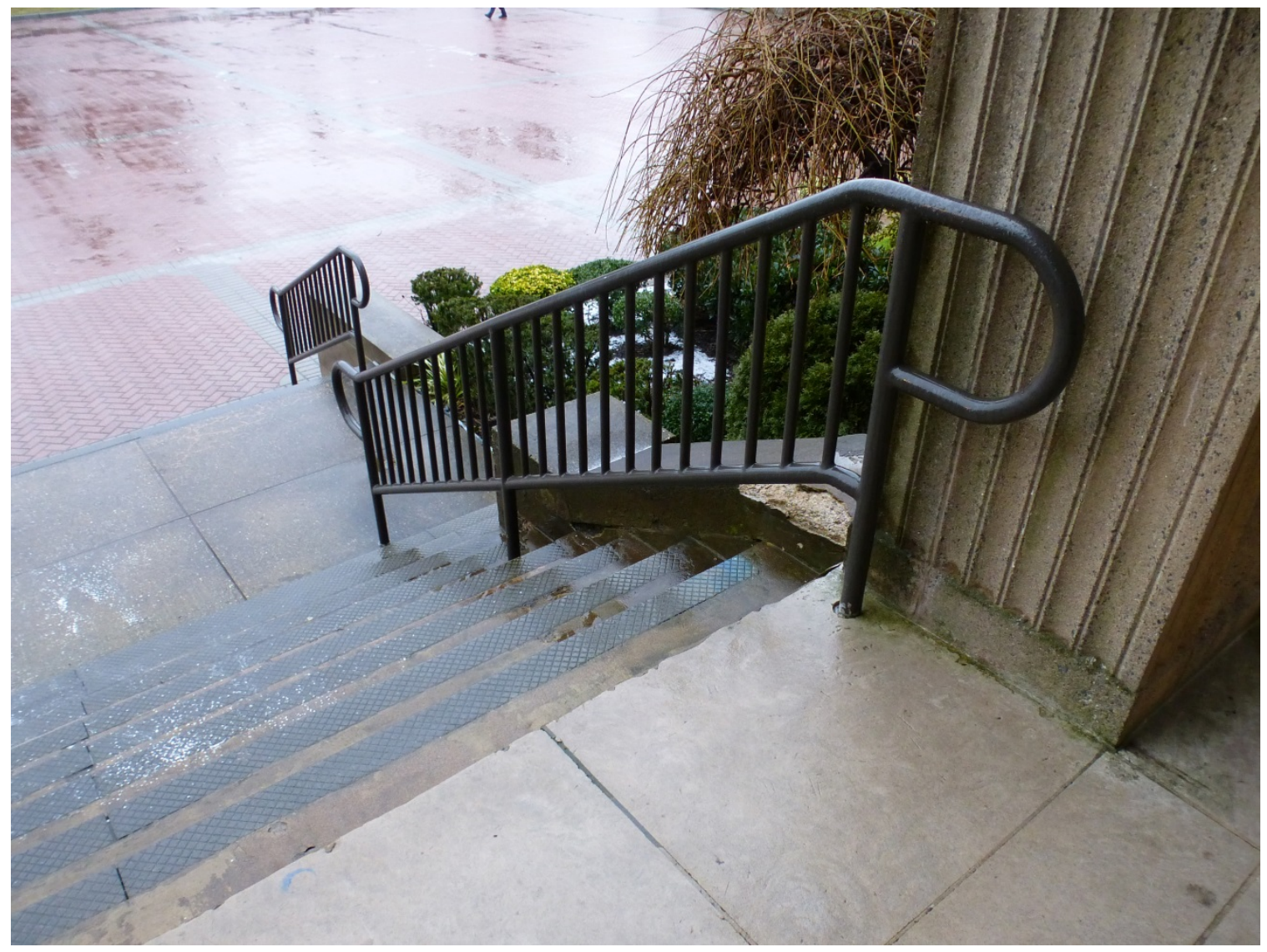

\subsubsection{Character-defining features}

Repair, renovation, and replacement of the following character-defining features for Delano Hall must be coordinated with the NY SHPO.

- Overall massing

- Footprint

- Exterior concrete block and its distinctive stone-like pattern

- All cast-stone architectural elements including window sills and lintels, door surrounds, belt course, quoins, bas-reliefs, and cornices

- Window and door openings

- Railing (main-floor portico)

- Multipane double-hung windows (see architectural plans for original window specs)

- Light fixtures on the portico, in the vestibule, and in the dining hall and its associated vestibules

- Dining hall open space

- Dining hall main floor plan 
- Interior cast-stone elements

- Interior murals

- Flooring

\subsubsection{Character-defining features that have been removed}

Listed below are character-defining features that have been removed or replaced over the years on Delano Hall; as future renovations occur, these need to be replaced with elements that replicate the original characterdefining features of the building. The original architectural plans will guide this process in coordination with the NY SHPO.

- Replacement anodized-bronze windows

- Replacement entrance doors

- Replacement exterior light fixtures (mostly wall)

- Replacement interior doors

\subsubsection{Nonhistoric features}

- Railings (exterior stair leading to the front entrance)

\subsubsection{0'Hara Hall}

O'Hara Hall is a contributing feature to the historic district. It was constructed in 1943 as the academy's drill hall and gymnasium. The drill hall interior is a contributing feature; however, the offices, restrooms, and locker rooms are not. The exterior is covered in the same buff-colored concrete masonry units and cast-stone architectural details as the other campus buildings designed by Alfred Hopkins \& Associates. The large, distinctive, bow roof was constructed with glue-laminated wood trusses. Concrete buttresses on the north and south sides structurally support the roof's weight. The front (west) façade of the building was designed in the Classical Revival Style and features a double-height, square-columned portico, while the rear (east) façade is much more utilitarian. The eagle statues positioned on either side of the west entrance are architectural elements relocated from the demolished Pennsylvania Station in New York City, and they are not contributing elements to the building or academy. The large interior is dominated by the clear-span bow roof that houses the wood-floored gymnasium. The west side of the interior has an entrance flanked by a series of offices, while the east side has an entrance flanked by restrooms and locker rooms in the basement. The former north entrance 
has been closed off. The upper walls on the west and east sides have original glass block windows. The rest of the original fenestration has been replaced with anodized bronze, double-hung, aluminum windows. Outside of the bow roof and its structural elements, the rest of the building is constructed with a cast-in-place structure and concrete block exterior walls in a distinctive stone-like pattern. Cast-stone architectural elements are placed at the lintel and sill levels on all windows all entrance door surrounds, the belt course, quoins, bas-reliefs, and cornices.

Figure 159. Northwest oblique of O'Hara Hall (drill hall/gymnasium), 1944

(Bland Library, USMMA).

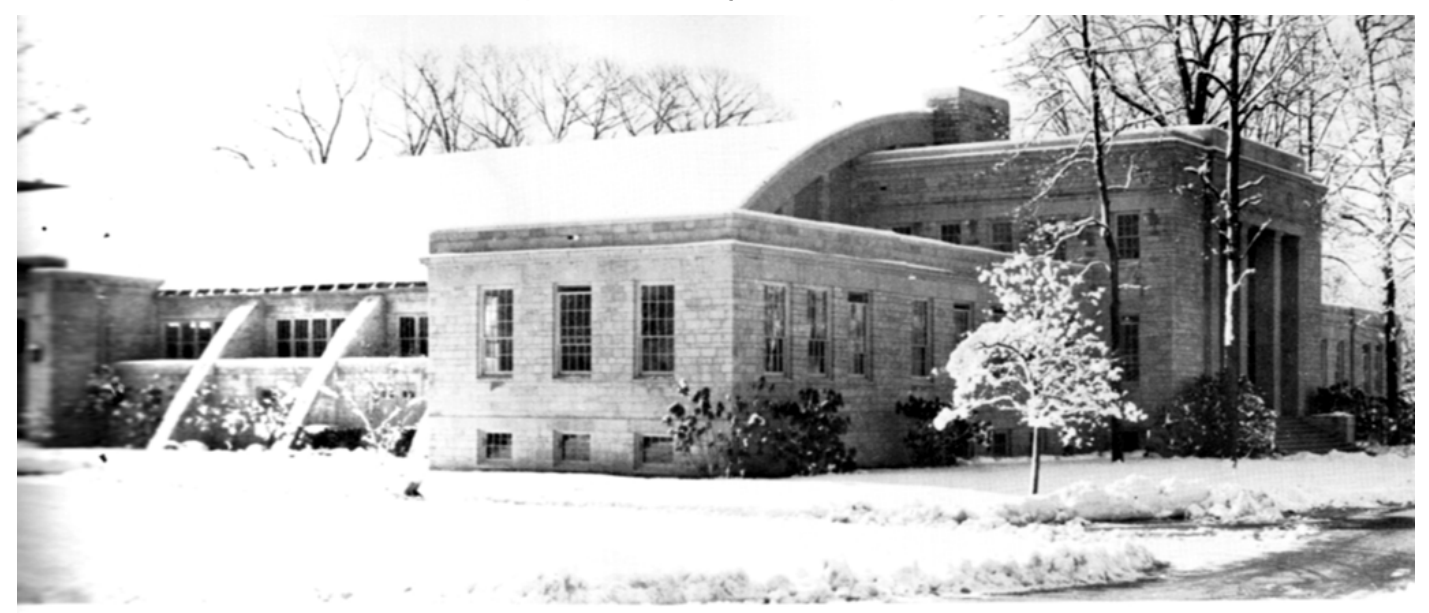

Figure 160. Northeast oblique of O'Hara Hall (ERDC-CERL, 2013).

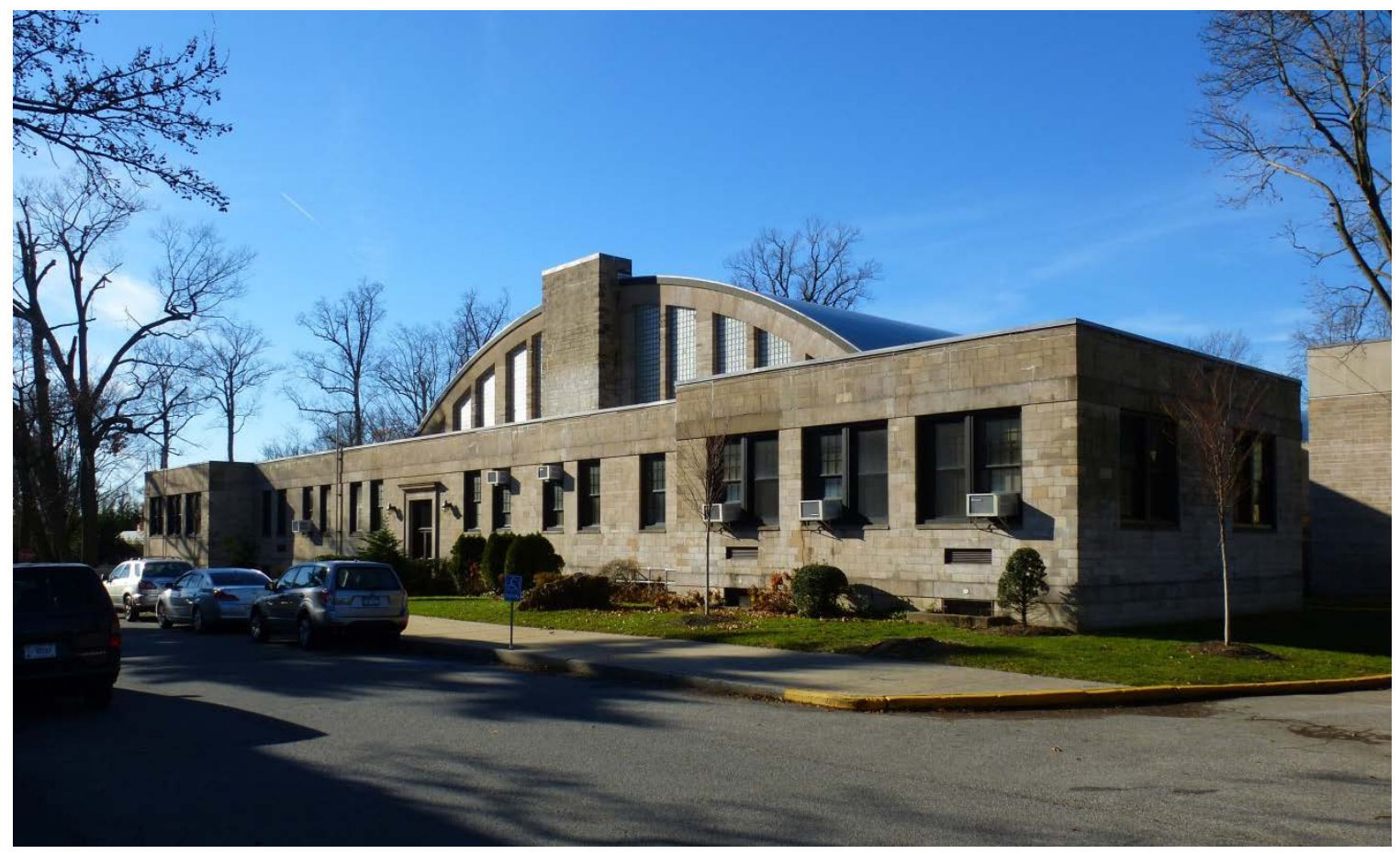


Figure 161. Interior of O'Hara Hall (drill hall/gymnasium), no date (Bland Library, USMMA).

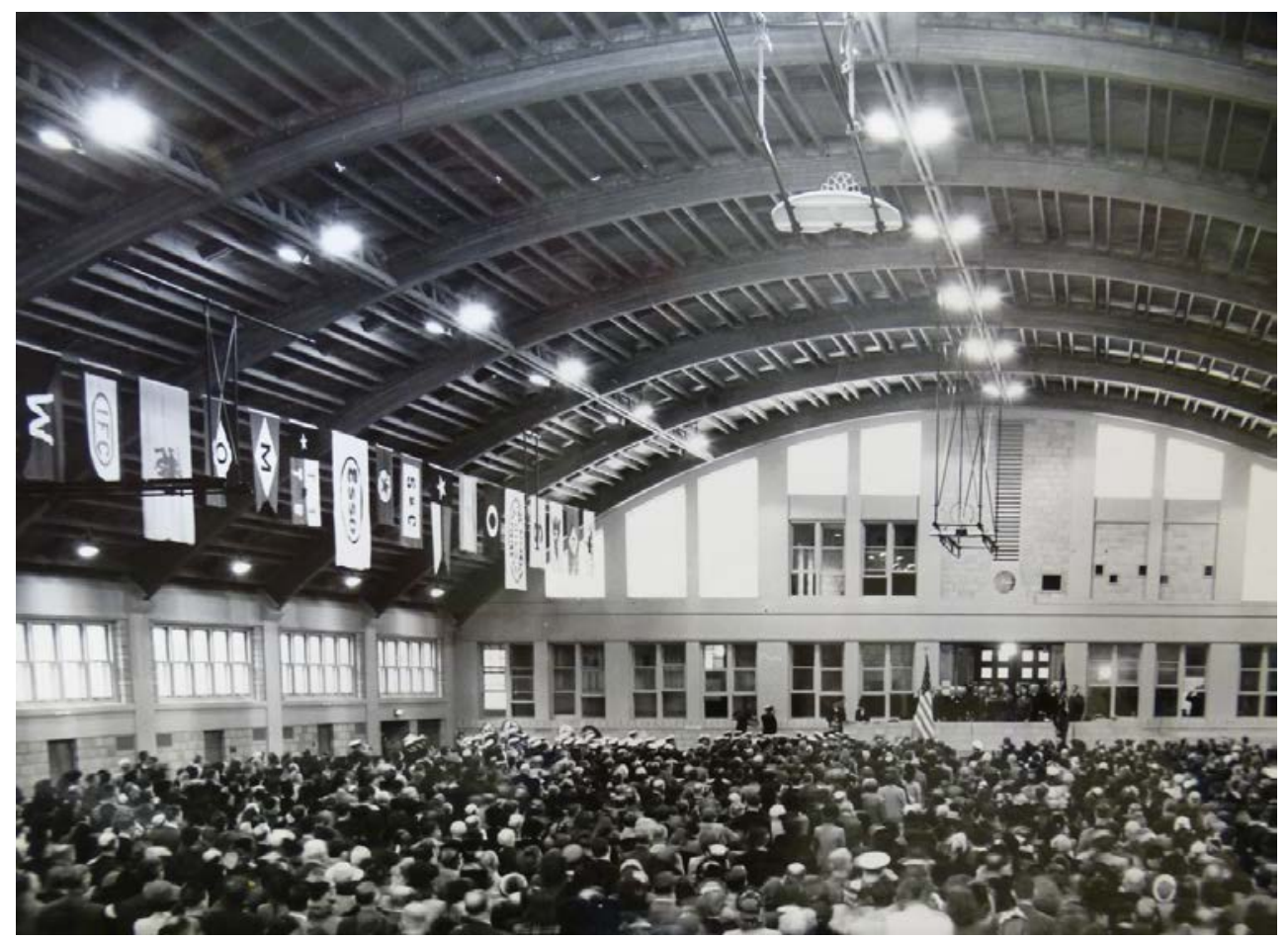

Figure 162. West façade of O'Hara Hall (ERDC-CERL, 2013).

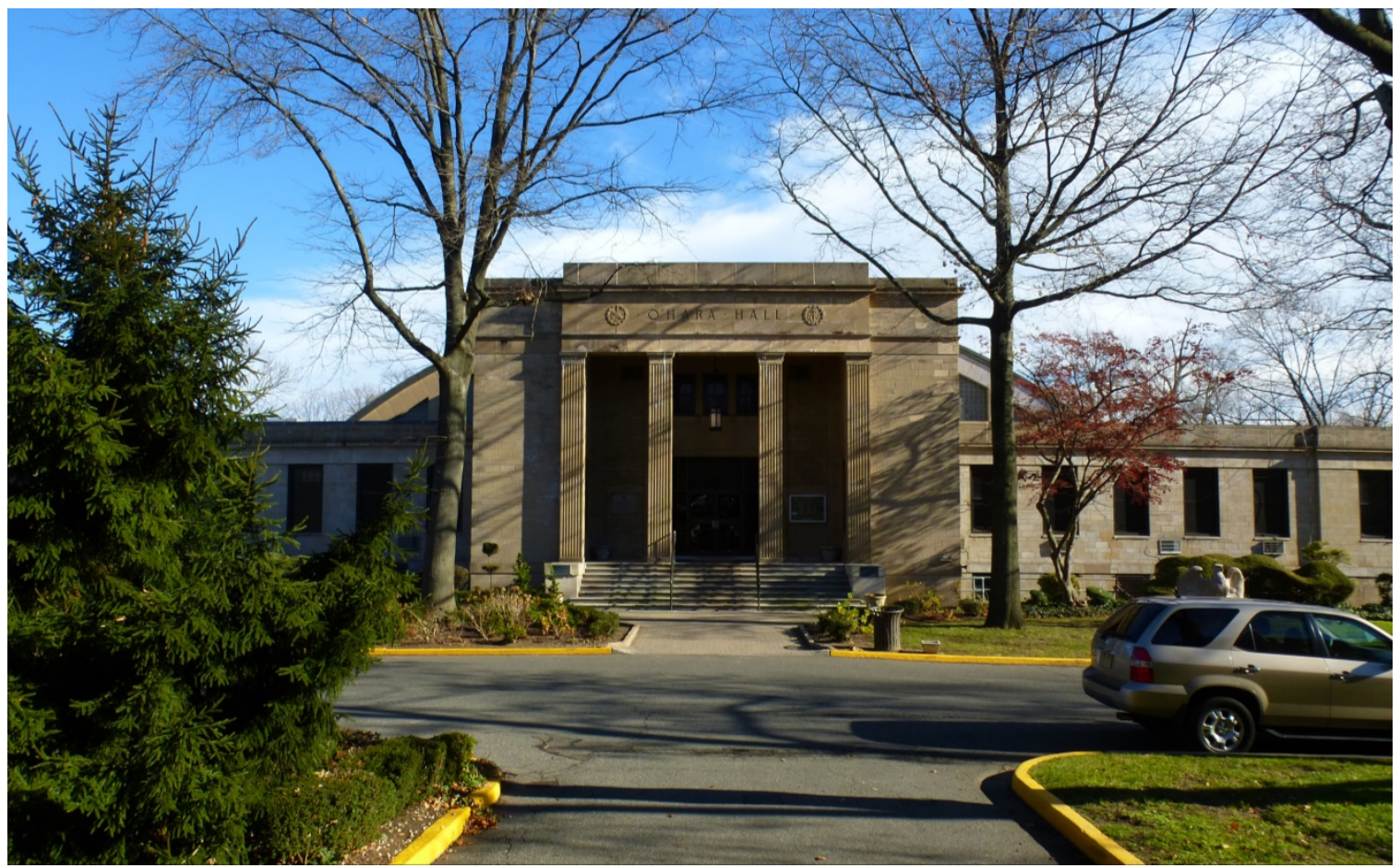


Figure 163. East façade of O’Hara Hall (ERDC-CERL, 2013).

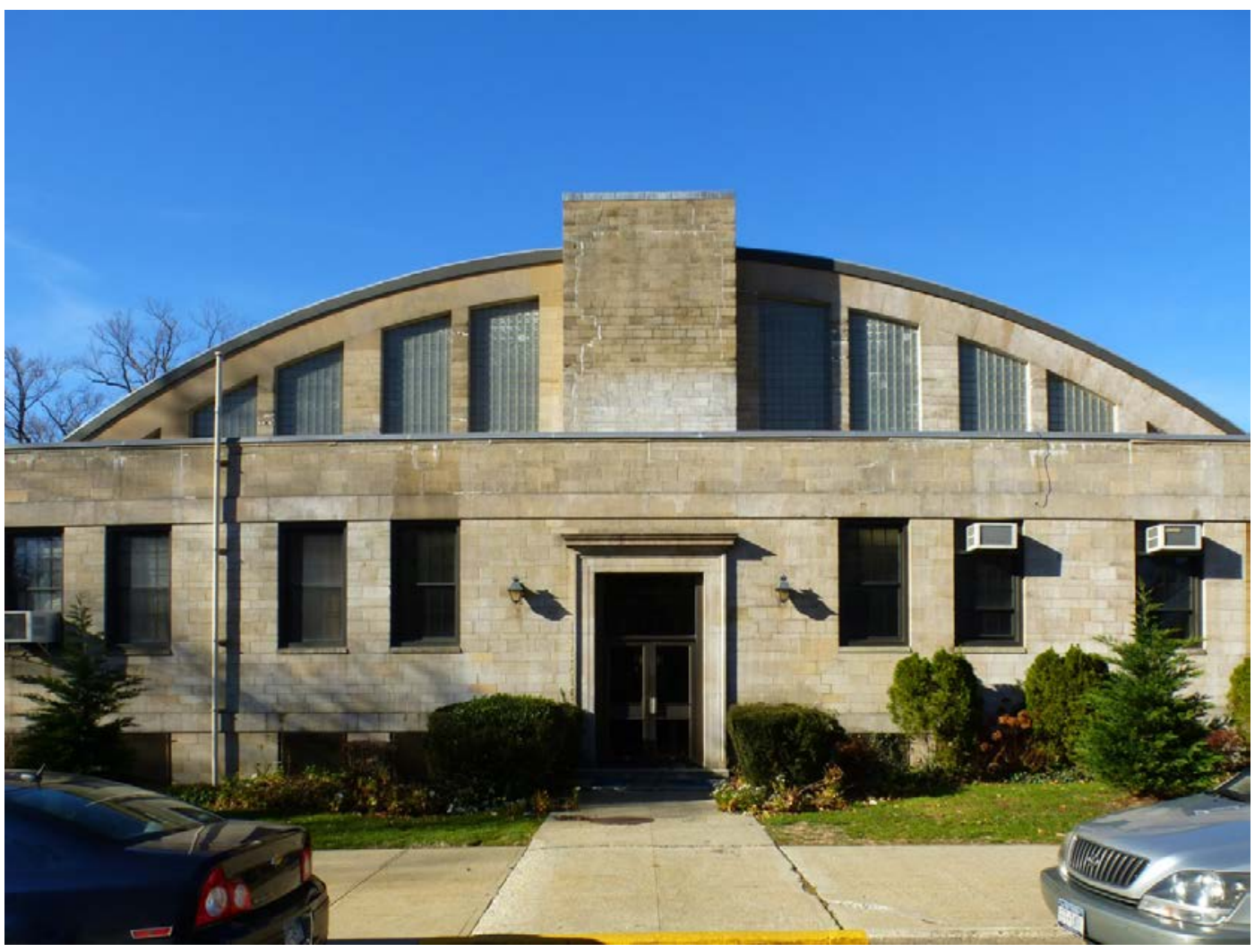

Figure 164. South side of O'Hara Hall, showing buttresses (ERDC-CERL, 2013).

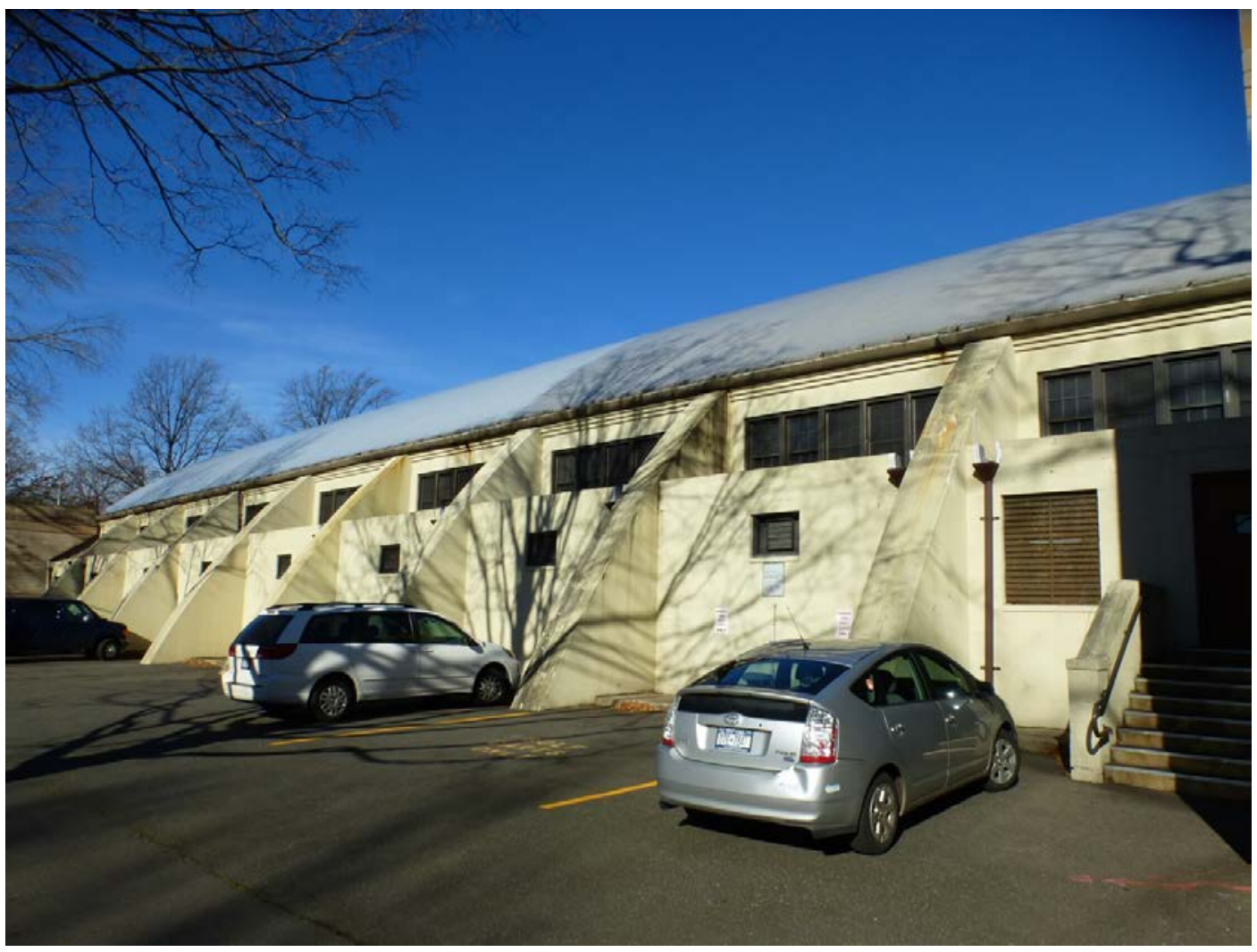


Figure 165. Interior of O'Hara Hall (ERDC-CERL, 2013).

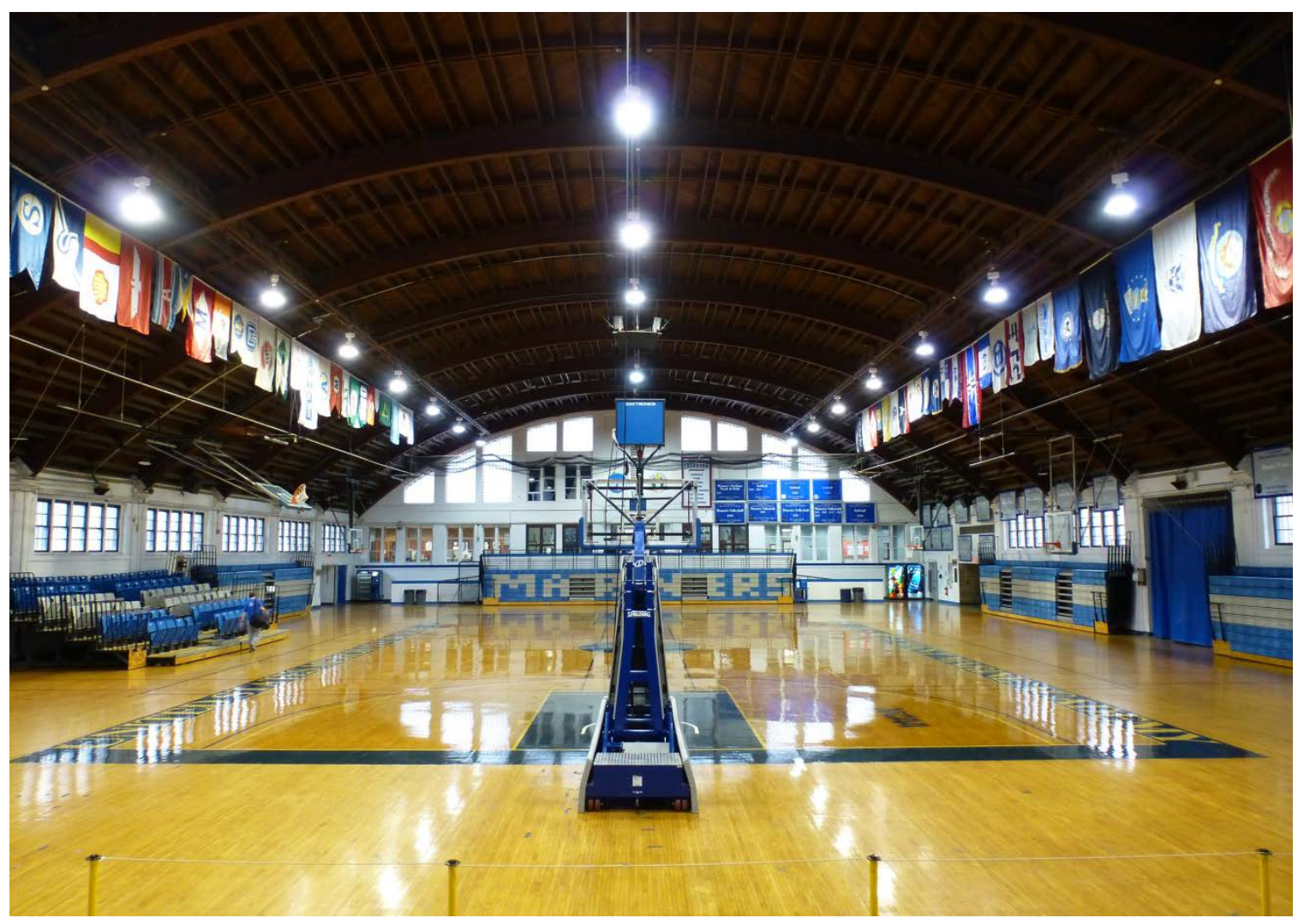

Figure 166. Replacement doors on the west façade entrance of O'Hara Hall (ERDC-CERL, 2013).
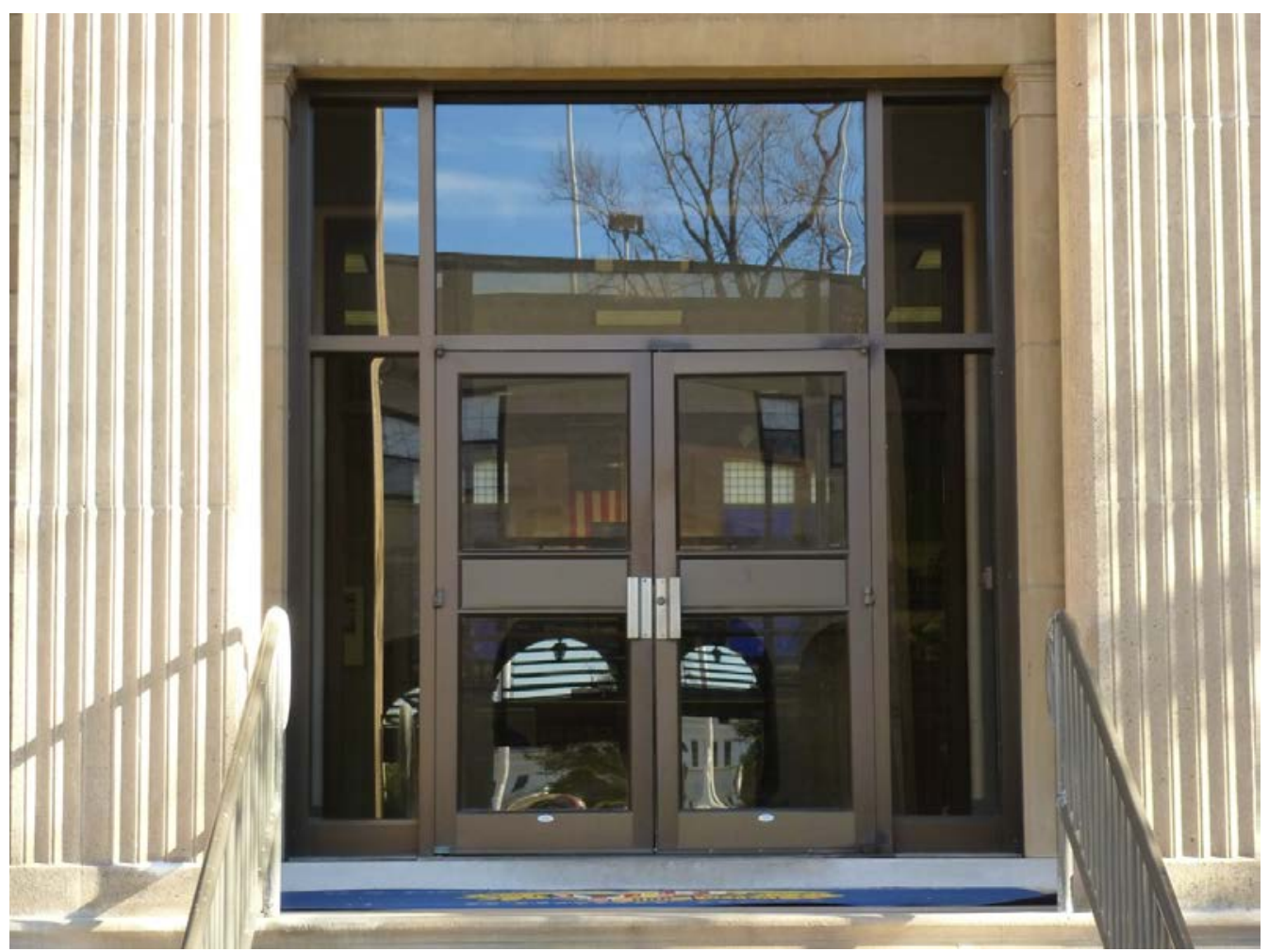
Figure 167. Detail of cast-stone elements on the portico at the west entrance of O'Hara Hall (ERDC-CERL, 2013).

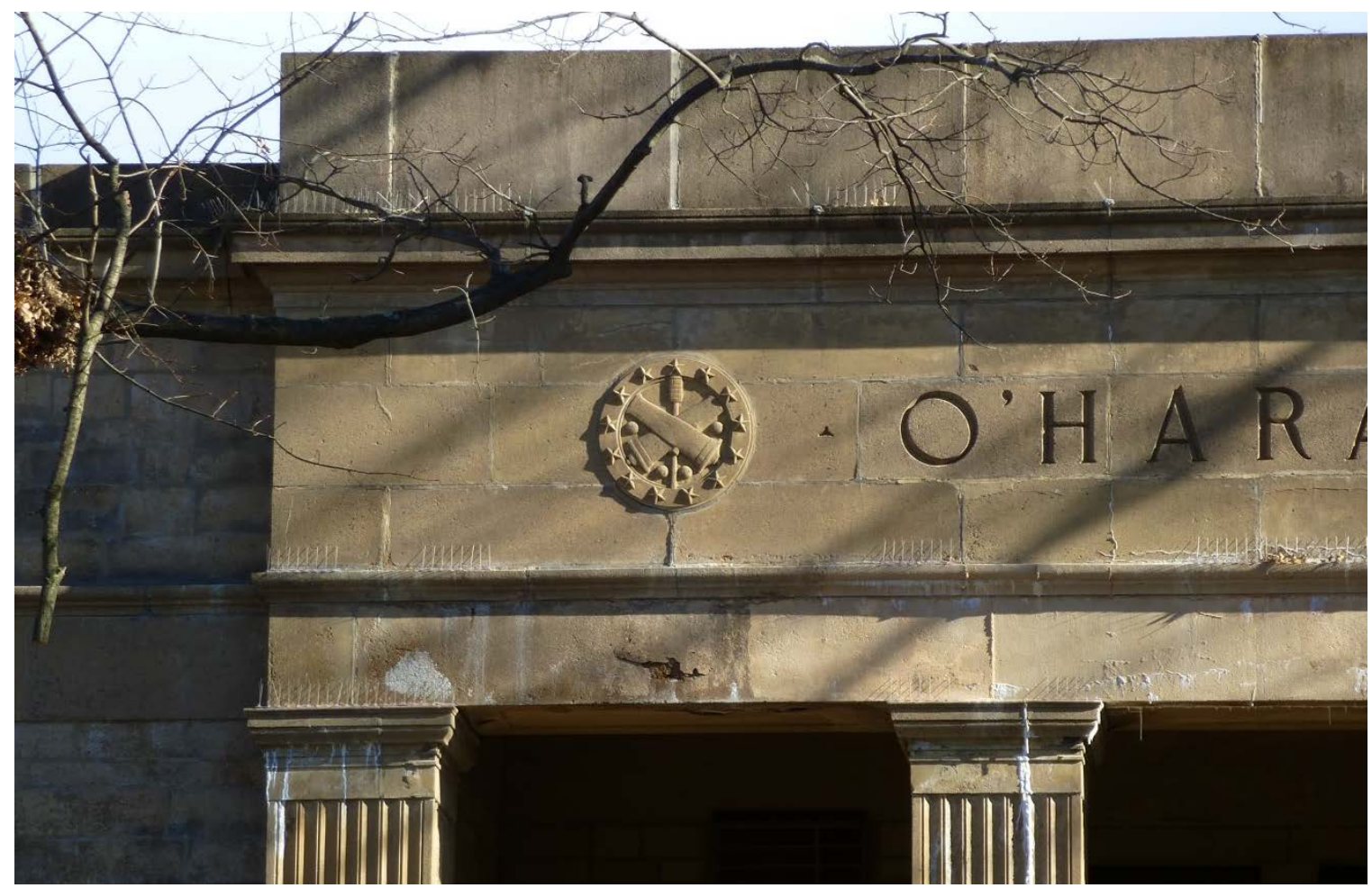

Figure 168. An eagle from the demolished New York Pennsylvania Station placed in front of the west façade of O'Hara Hall (ERDC-CERL, 2013).

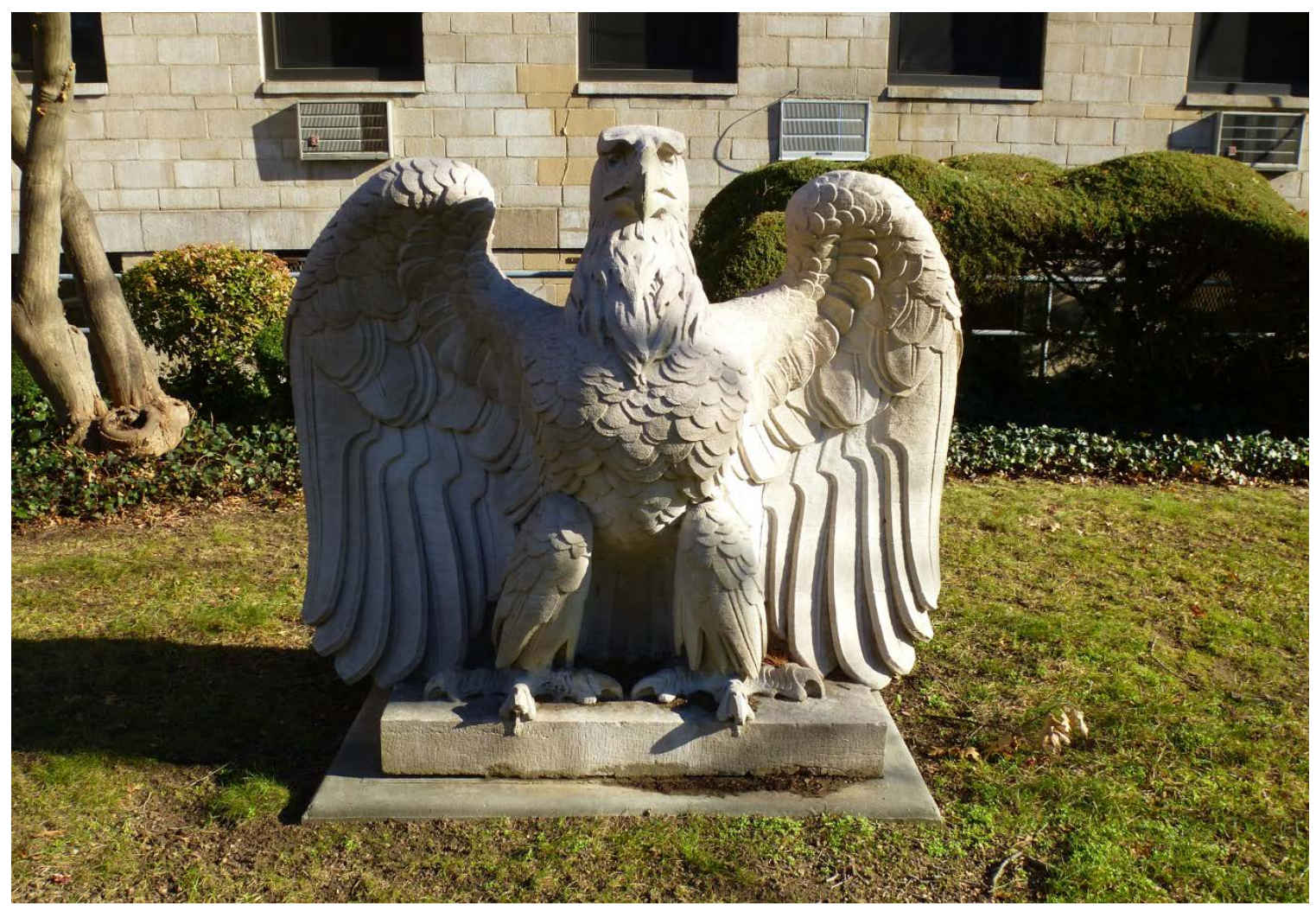


Figure 169. Original interior windows and doors between east vestibule and the drill hall at O'Hara Hall (ERDC-CERL, 2013).

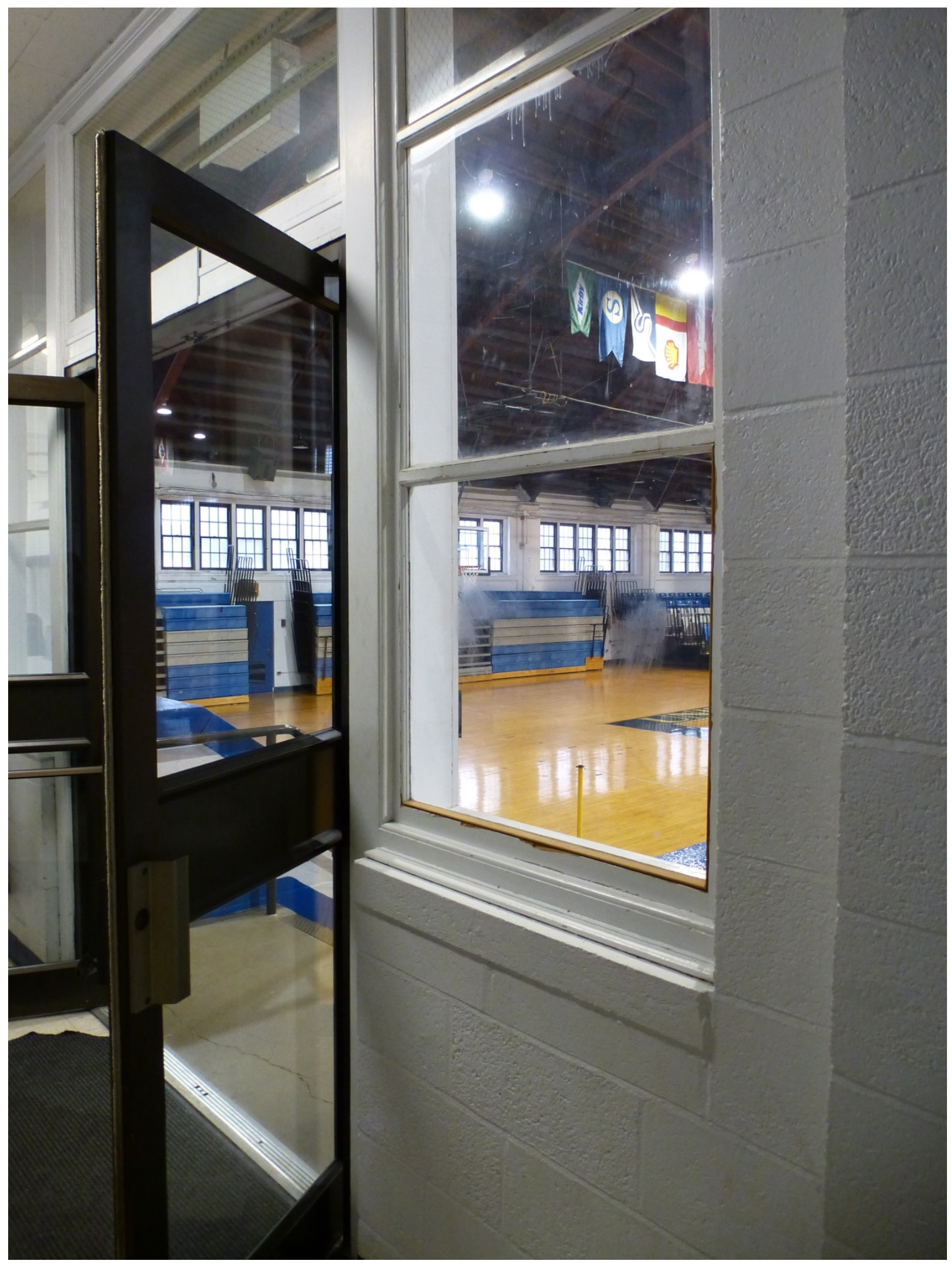


Figure 170. Original light schedule drawing for portico ceiling light fixture, O'Hara Hall (USMMA, DPW).

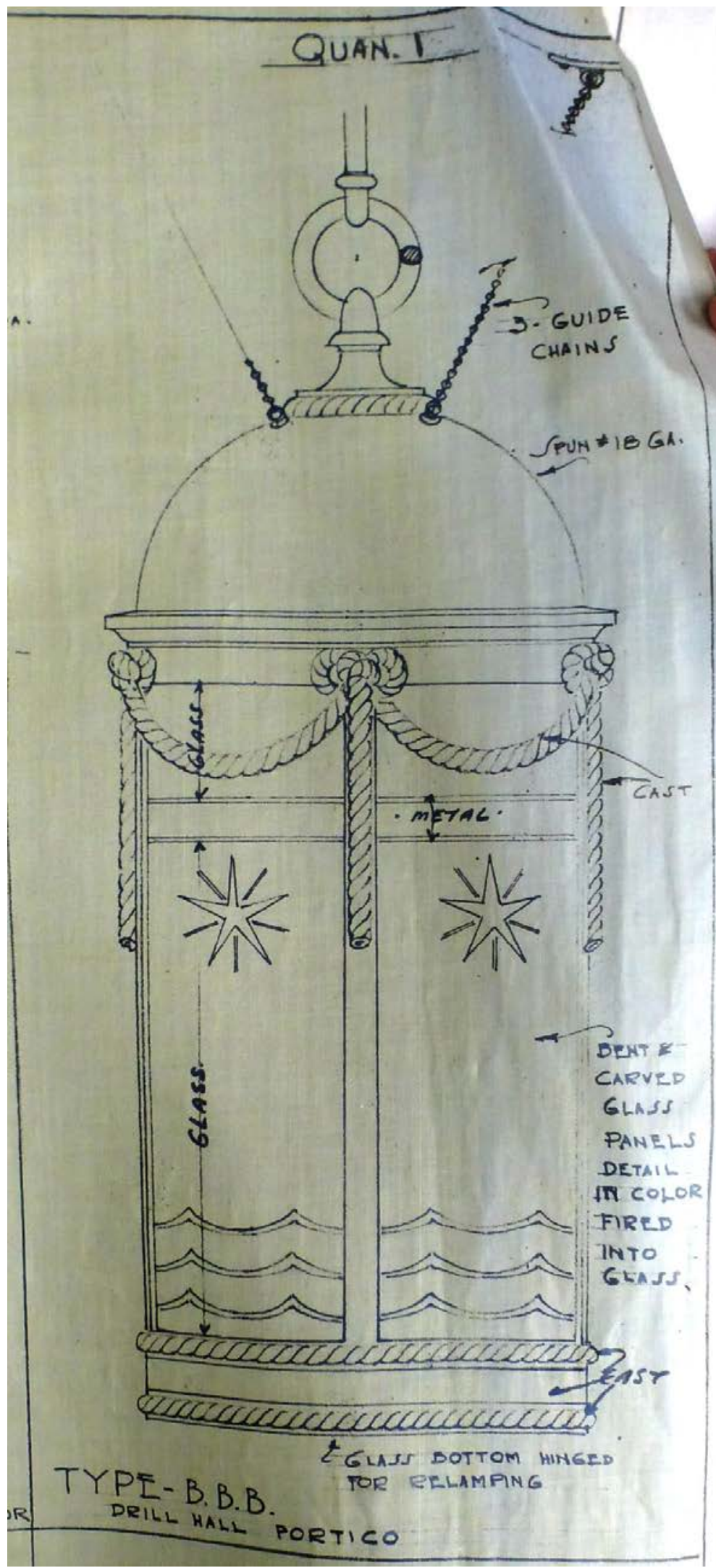



Figure 172. Replacement exterior light fixture on O'Hara Hall (ERDC-CERL, 2013).

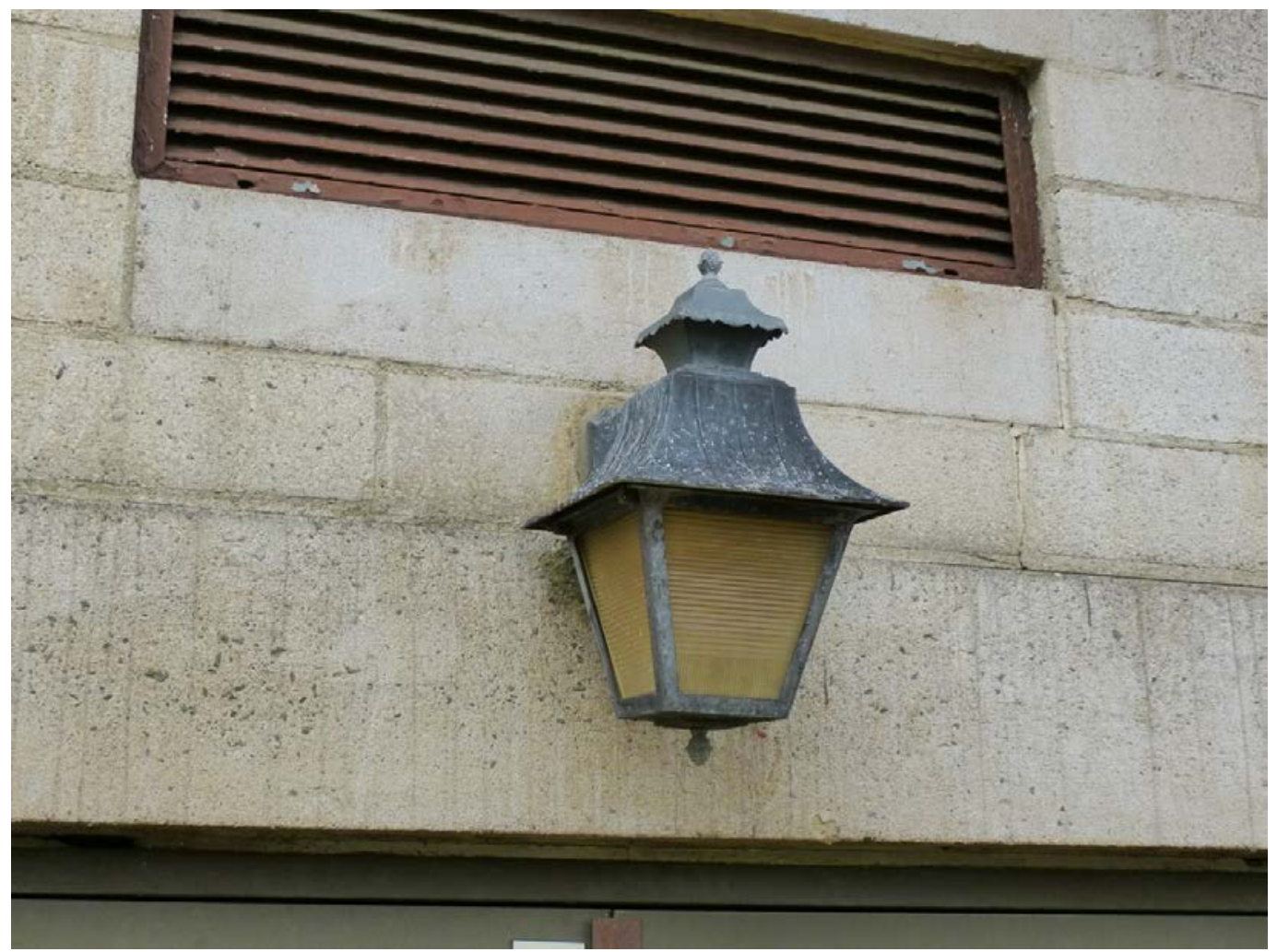

Figure 173. Hyphen (connection) between O'Hara Hall [right] and the Natatorium [left] (ERDC-CERL, 2013).

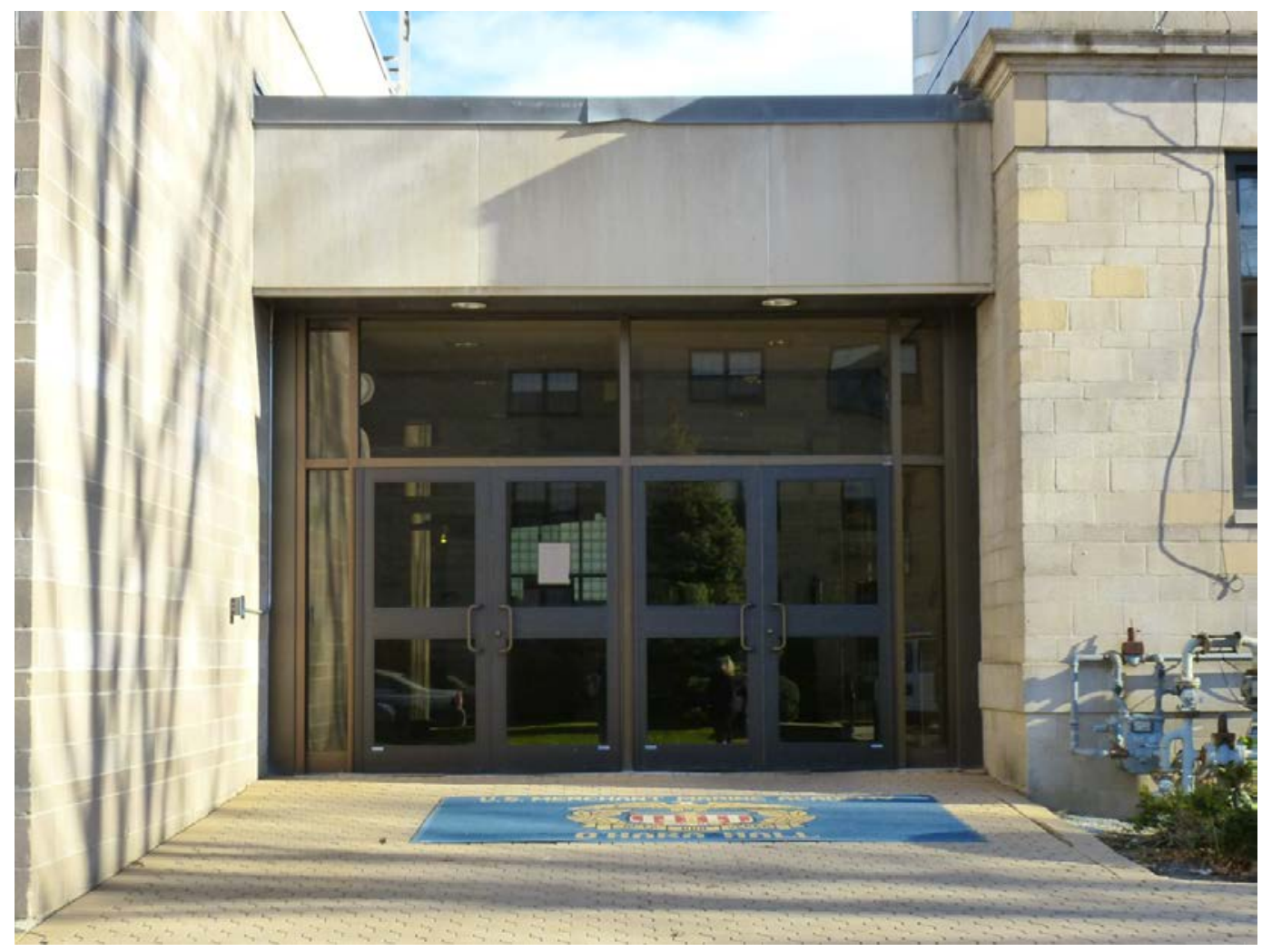




\subsubsection{Character-defining features}

Repair, renovation, and replacement of the following character-defining features of O'Hara Hall must be coordinated with the NY SHPO.

- Overall massing

- Roof forms

- Exterior concrete block and its distinctive stone-like pattern

- All cast-stone architectural elements including window sills and lintels, door surrounds, belt course, quoins, bas-reliefs, and cornices

- Window and door openings

- Glass block windows

- Multipane double-hung windows (see architectural plans for original window specs)

- Light fixtures on the portico

- Open space of the drill hall

- Floor plan of the main part of the drill hall

- Interior windows and doors from the west and east vestibules looking into the drill hall

\subsubsection{Character-defining features that have been removed}

Listed below are character-defining features of O'Hara Hall that have been removed or replaced over the years; as future renovations occur, these need to be replaced with elements that replicate the original characterdefining features of the building. The original architectural plans will guide this process in coordination with the NY SHPO.

- Interior doors

- Blocked north entrance

- Replacement anodized-bronze windows

- Replacement entrance doors

- Replacement light fixtures on the east façade

\subsubsection{Nonhistoric features}

- Hyphen (connection) to the Natatorium

- Railings

- Stone eagles from Pennsylvania Station 


\subsubsection{Admissions Center}

The Admissions Center is sited north of the Vickery Gate. The building exterior is a contributing feature to the historic district, but the interior is noncontributing. The building was first constructed in 1943 and has a large addition that was constructed circa 2000. The original building is two stories, and the east and south façades have the same buff-colored concrete masonry units as the other 1943 academy buildings. The roof is hidden by a parapet, with "U.S. Merchant Marine Academy" inscribed onto the eastern portion of the parapet. The addition to the north is a concrete masonry unit building with a barrel roof; a large portion of the original west façade of the Admissions Center was replaced with concrete masonry units similar to the addition. The original double-hung, six-oversix, wood windows have been replaced with anodized-bronze, awning, aluminum windows.

Figure 174. The east façade of the Admissions Center with addition to the right (ERDC-CERL, 2013).

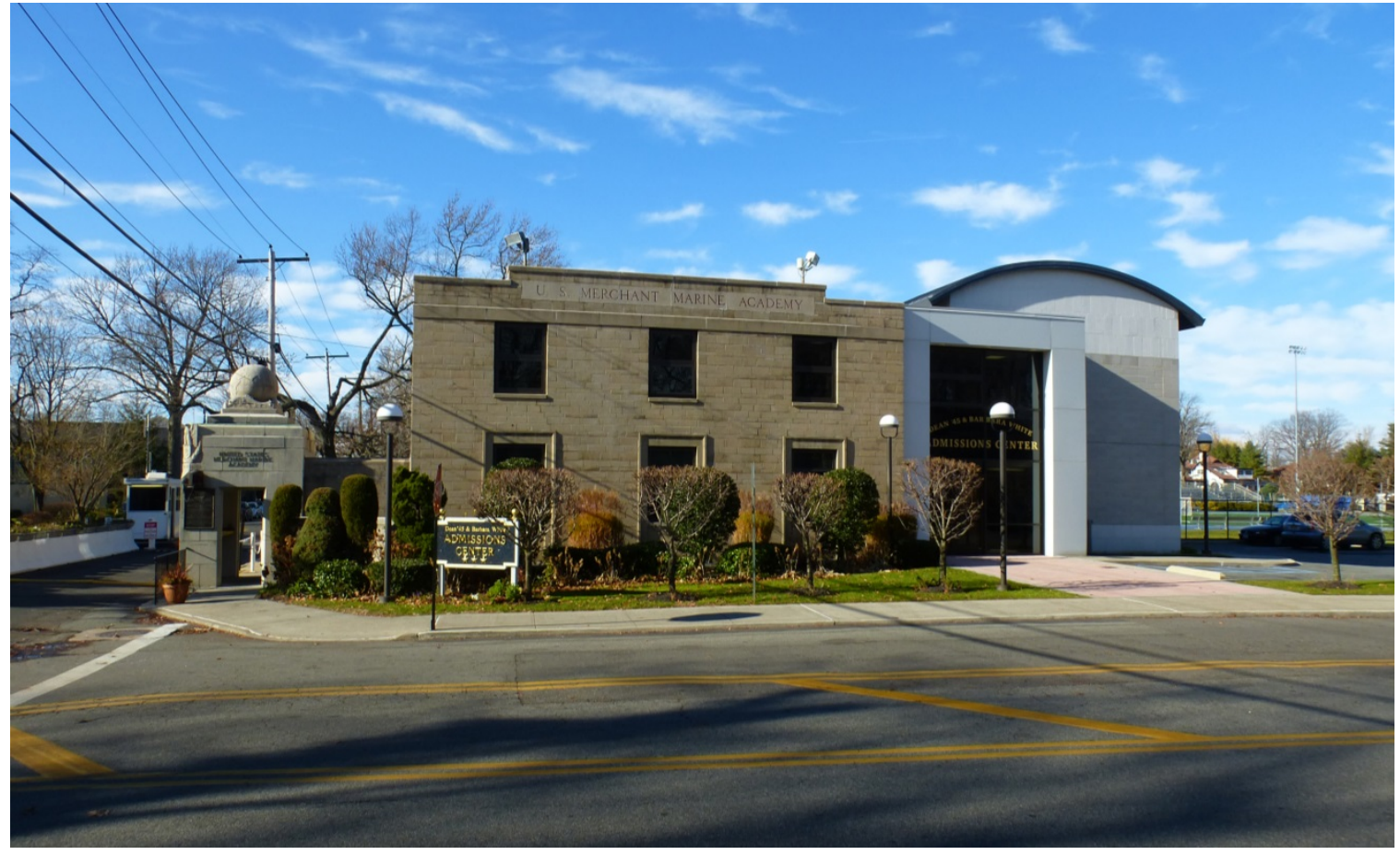


Figure 175. South façade of the Admission Center with Vickery Gate connected on the right (ERDC-CERL, 2013).

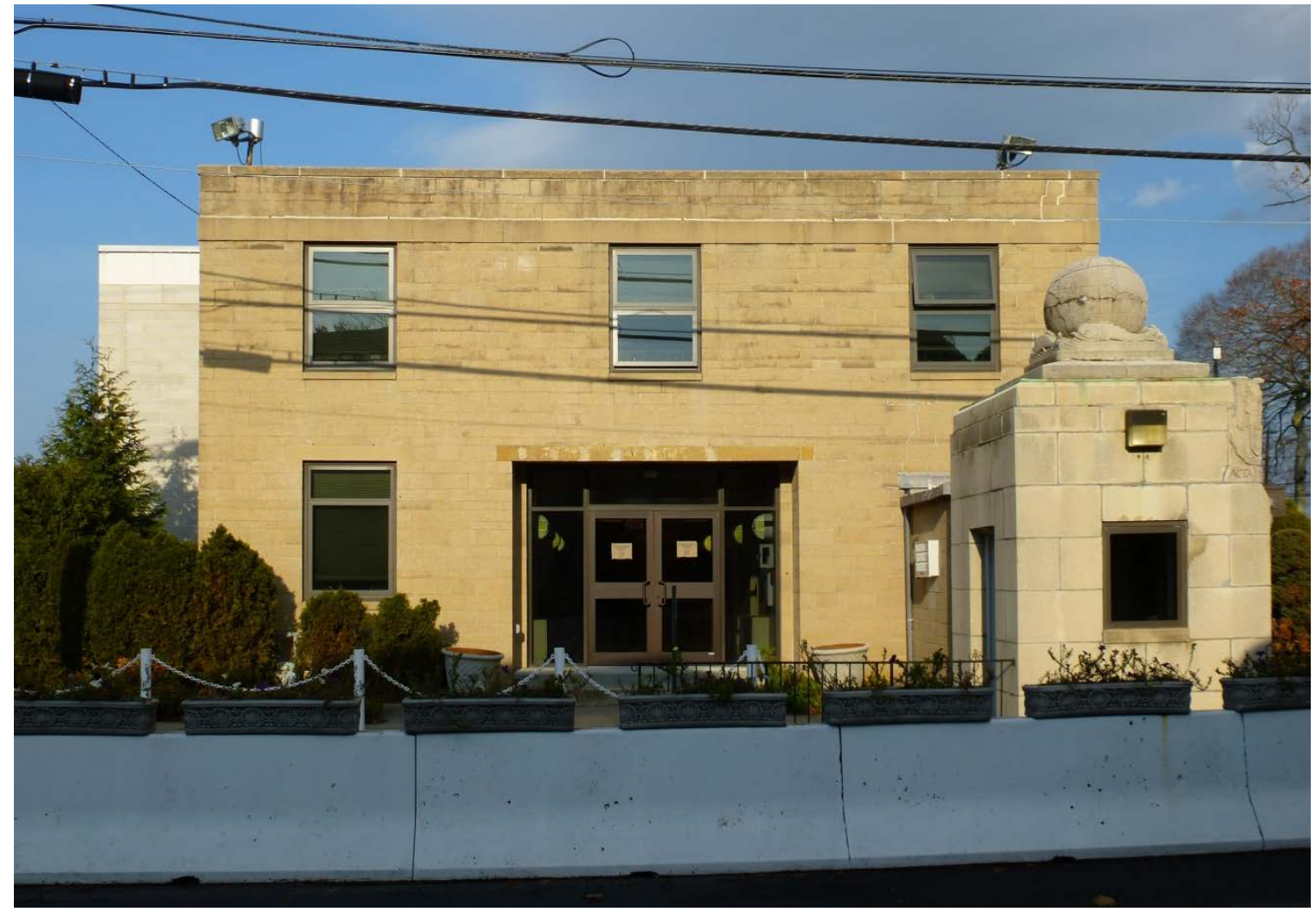

Figure 176. Northeast oblique of the Admissions Center, showing addition (ERDC-CERL, 2013).

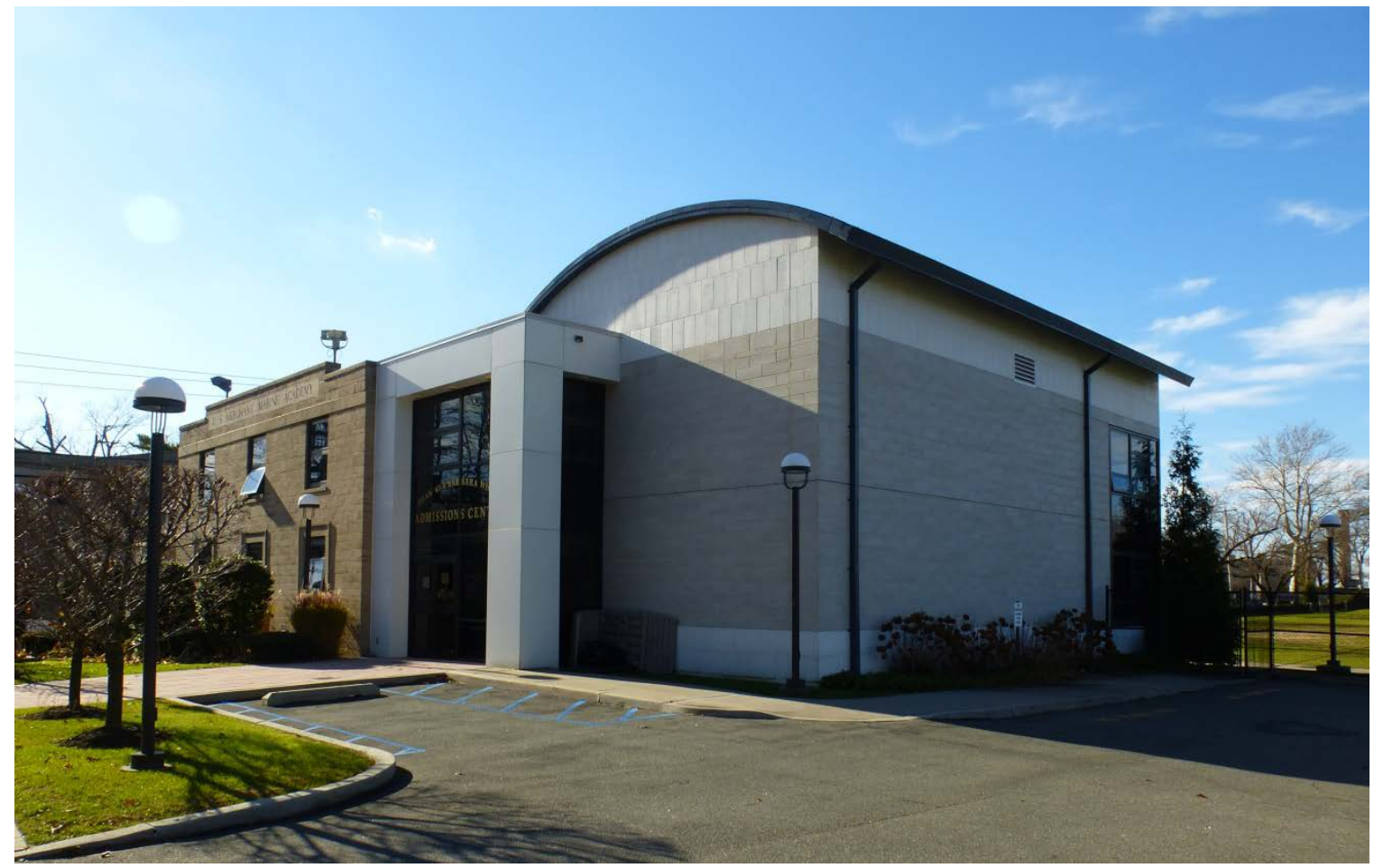


Figure 177. Detail of concrete block pattern and a cast-stone surround on Admissions Center (ERDC-CERL, 2013).

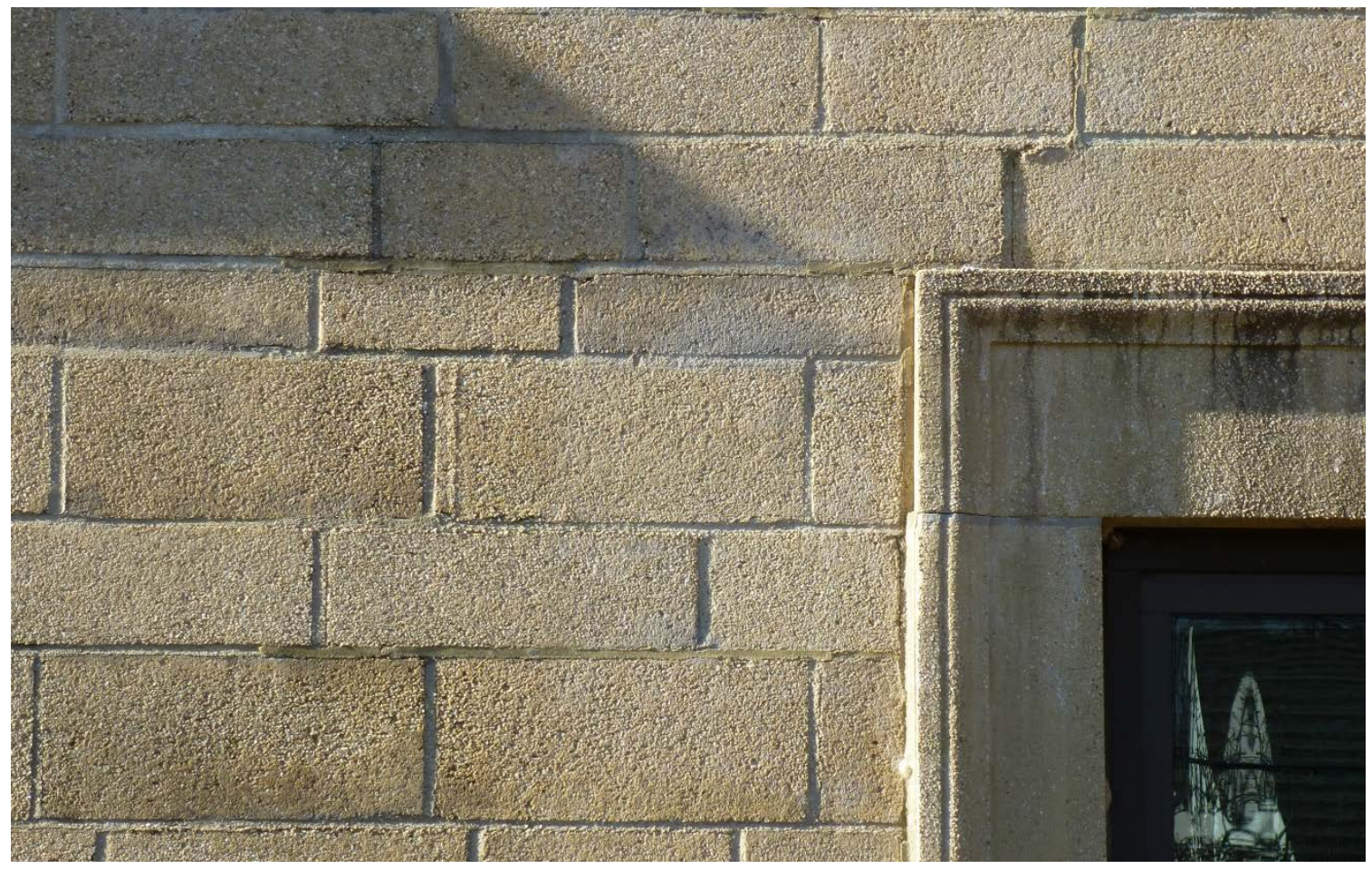

Figure 178. Replacement window with cast-stone belt course above and cast-stone lintel below at Admissions Center (ERDC-CERL, 2013).

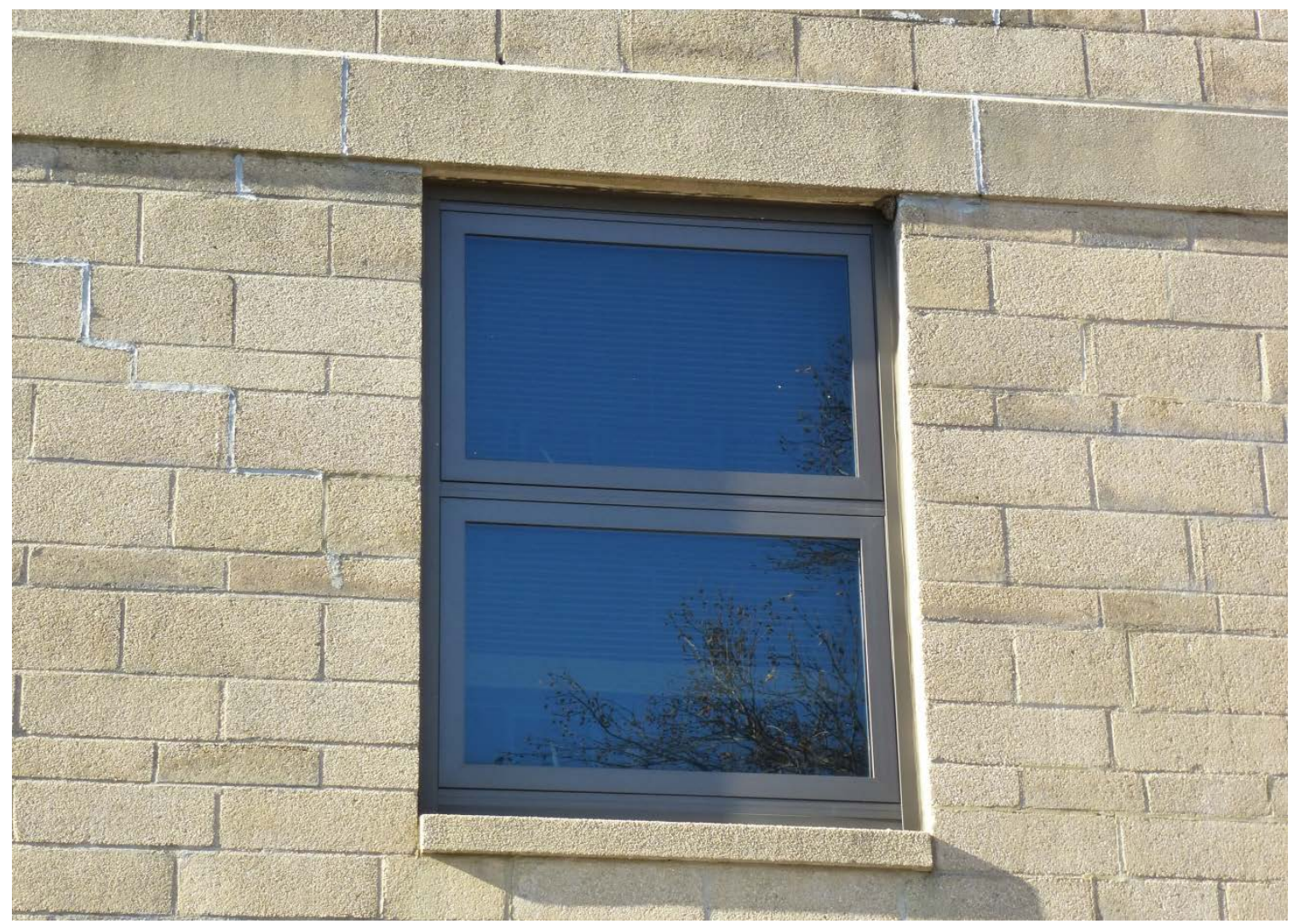




\subsubsection{Character-defining features}

Repair, renovation, and replacement of the following character-defining features of the Admissions Center must be coordinated with the NY SHPO.

- Overall massing

- Roof forms

- Exterior concrete block and its distinctive stone-like pattern

- All cast-stone architectural elements including window sills and lintels, door surrounds, belt course, quoins, inscriptions, and cornice

- Window and door openings

\subsubsection{Character-defining features that have been removed}

Listed below are character-defining features of the Admissions Center that have been removed or replaced over the years; as future renovations occur, these need to be replaced with elements that replicate the original character-defining features of the building. The original architectural plans will guide this process in coordination with the NY SHPO.

- Replacement anodized-bronze windows

- Replacement entrance doors

\subsubsection{Nonhistoric features}

- Addition to the north and west

\subsubsection{Patten Medical Clinic}

The Patten Medical Clinic is a contributing feature to the historic district, but the interior of the building is noncontributing. It is a three-story building with two-story wings utilizing the same buff-colored concrete masonry units and cast stone architectural details as the rest of the 1942-43 buildings. It was constructed in 1943 to the south of Delano Hall. A large ambulance bay is located on the north side, while the south side faces out on the old formal garden of the Neiley house. Most of the original elements of the garden are gone, but the parterre does have grass and a formal flagstone walk. The original windows were replaced at some point with one-overone (and in some cases two-over-two), anodized-bronze metal windows. The doors are replacements as well. 
Figure 179. North façade of Patten Clinic (ERDC-CERL, 2013).

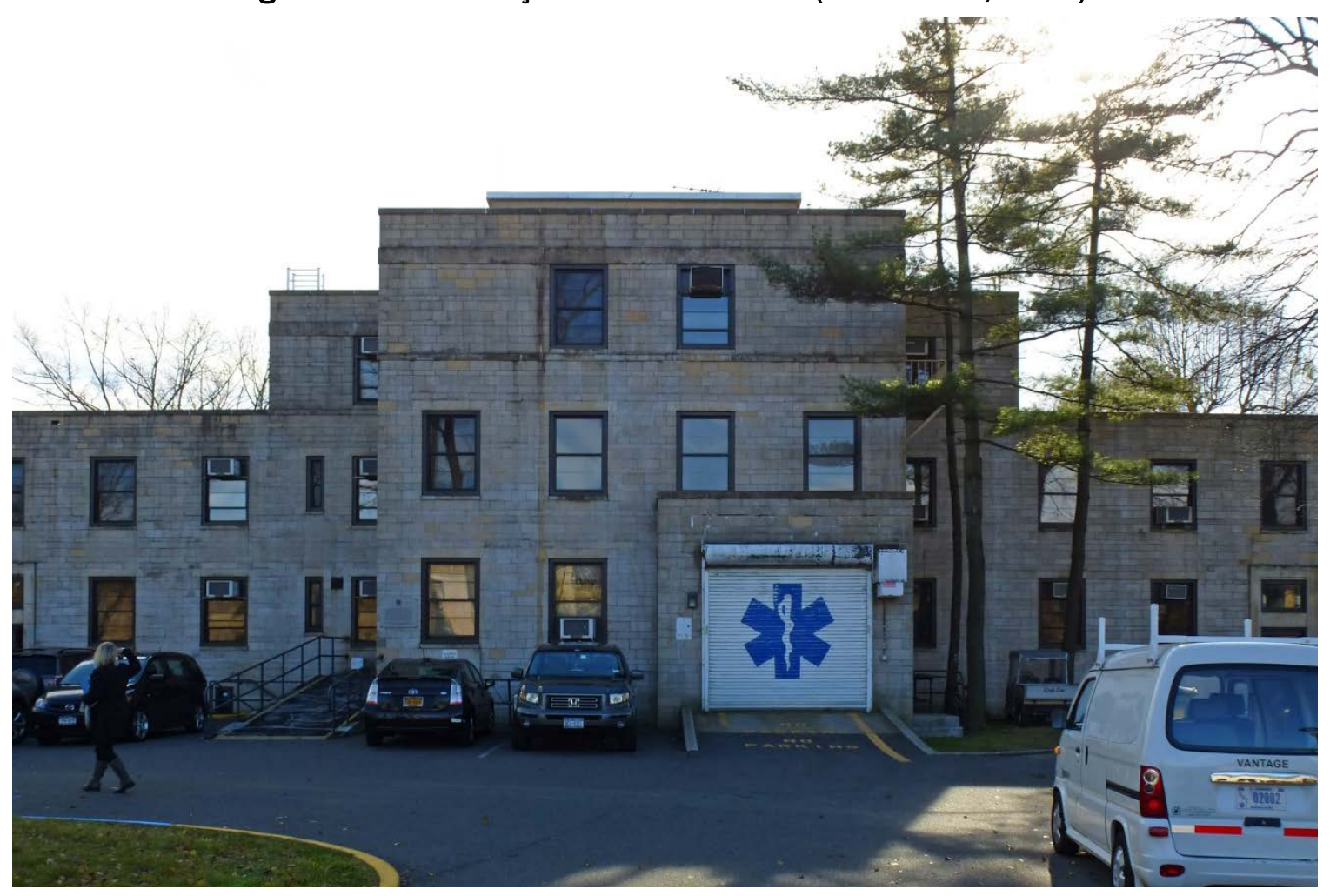

Figure 180. South façade of Patten Clinic (ERDC-CERL, 2013).

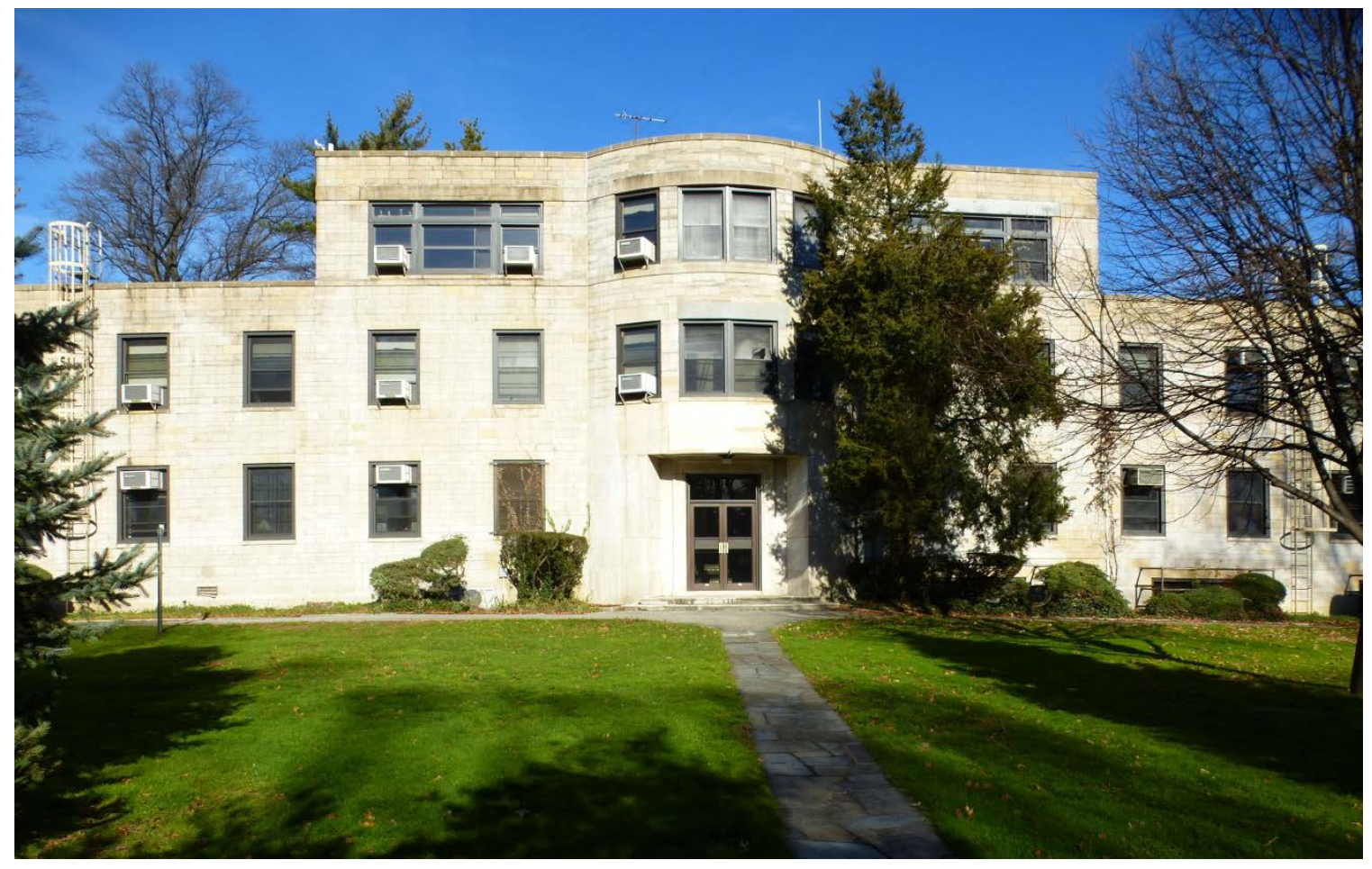


Figure 181. West façade detail of Patten Medical Clinic, showing concrete block pattern and cast-stone surrounds (ERDC-CERL, 2013).

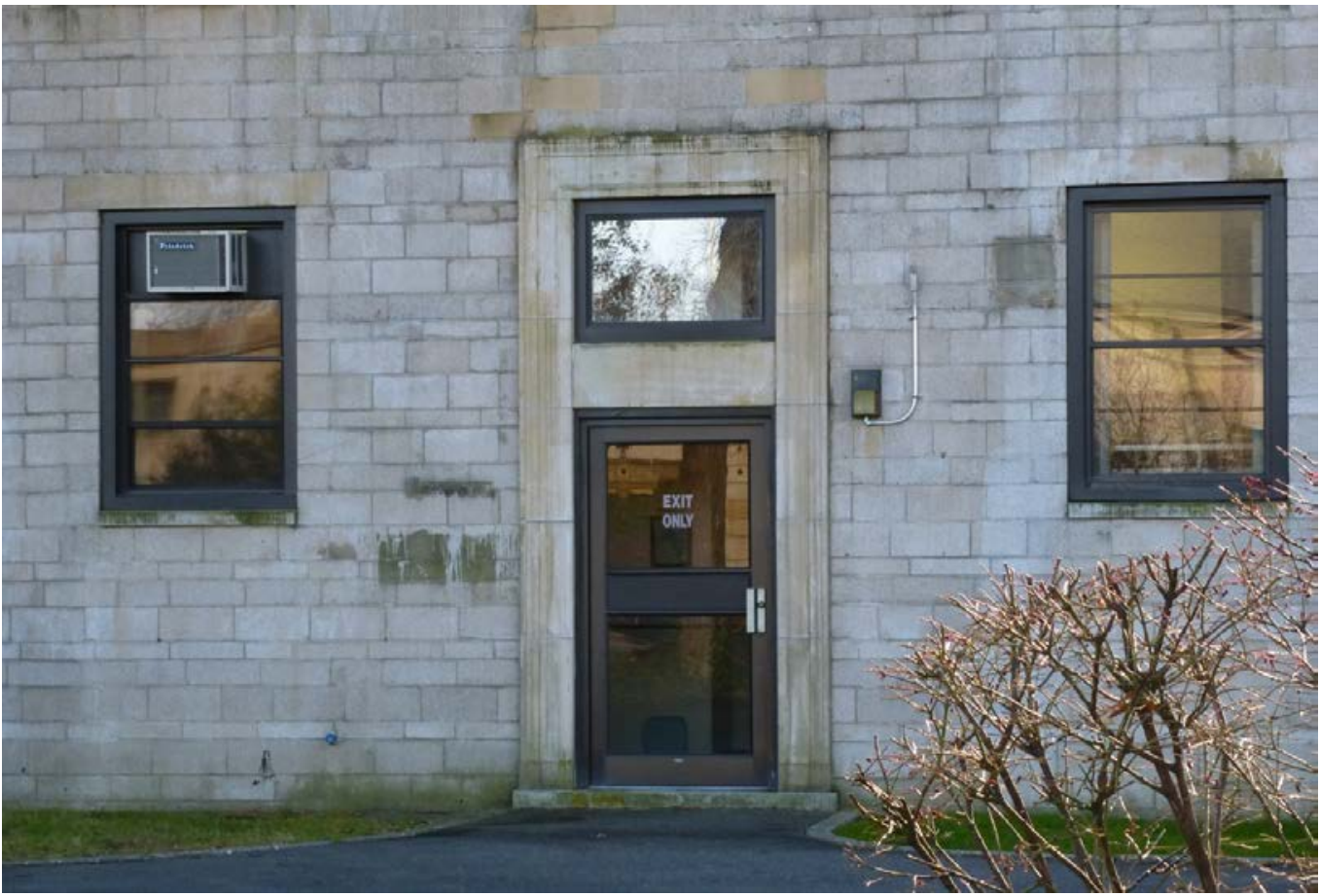

Figure 182. Detail of the south façade of Patten Medical Clinic, showing three-part window, parapet, and cast-stone belt courses (ERDC-CERL, 2013).

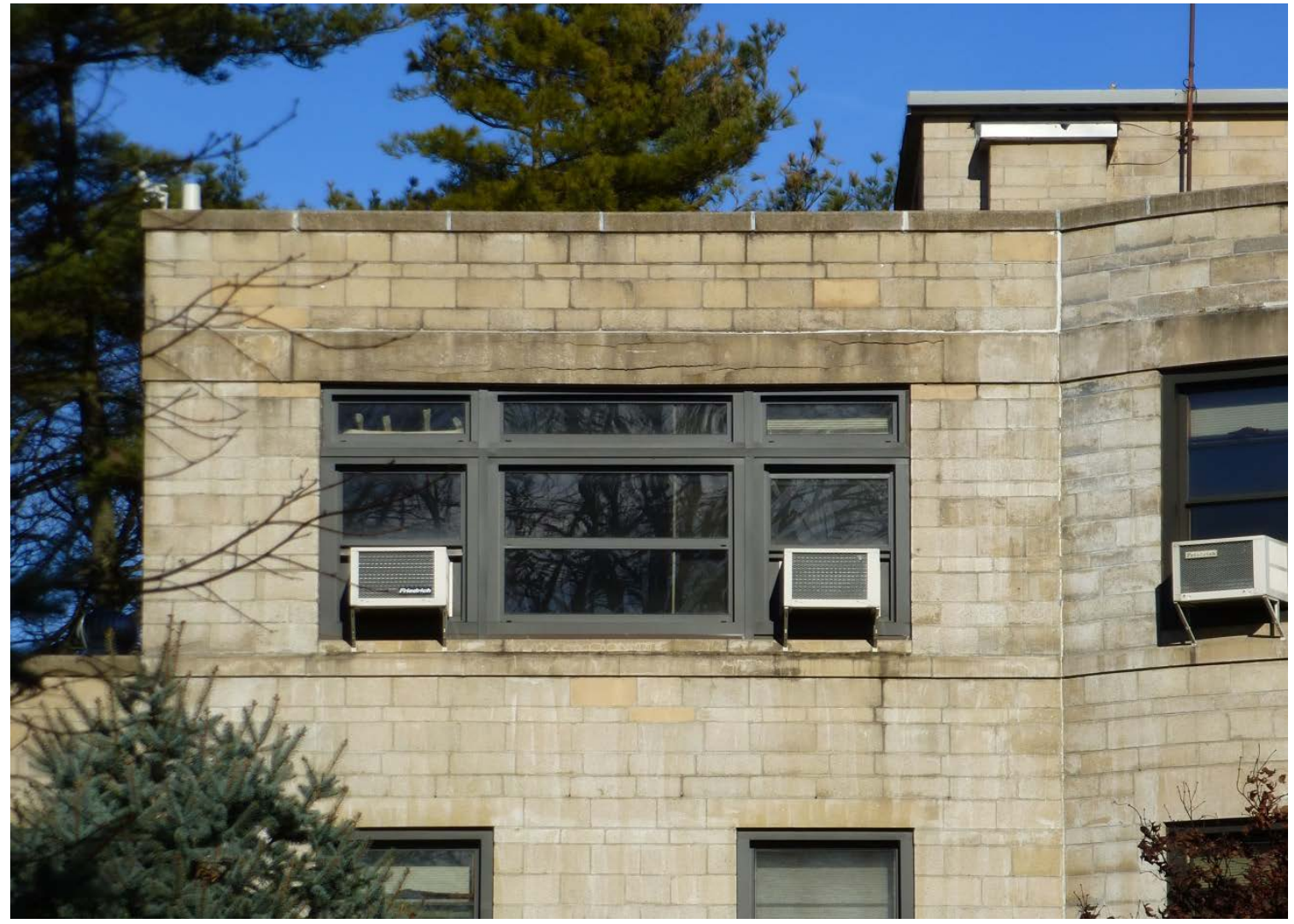




\subsubsection{Character-defining features}

Repair, renovation, and replacement of the following character-defining features of Patten Medical Clinic must be coordinated with the NY SHPO.

- Overall massing

- Footprint

- Roof forms

- Exterior concrete block and its distinctive stone-like pattern

- All cast-stone architectural elements including window sills and lintels, door surrounds, belt course, quoins, inscriptions, and cornice

- Window and door openings

\subsubsection{Character-defining features that have been removed}

Listed below are character-defining features of Patten Medical Clinic that have been removed or replaced over the years, and as future renovations occur need to be replaced with elements that replicate the original character-defining features of the building. The original architectural plans will guide this process in coordination with the NY SHPO.

- Replacement anodized-bronze windows

- Replacement entrance doors

\subsubsection{U.S. Merchant Marine Memorial Chapel}

The U.S. Merchant Marine Memorial Chapel is a contributing feature to the USMMAHD, and the interior of the chapel is also contributing. The chapel was designed by the architectural firm of Eggers \& Higgins and completed in 1962. The chapel faces north and is located to the west of Palmer Hall on the Hague Basin waterfront. The chapel contains a sanctuary and chaplain offices. The building was designed in the Classical Revival Style, similar to the earlier buildings of the academy; however, the construction is of buff-colored brick instead of concrete masonry units. The north entrance is dominated by square columns and large, double doors with smaller doors to either side. The Classical Revival steeple contains a navigational beacon, and the beacon's light sits 102 feet above sea level. The chapel's interior is a large, open nave with terrazzo flooring. The altar is dominated by a three-sided rotating altar to serve the different religions of the cadets. The large windows on the east and west are clear glass, while the smaller windows in the altar have colored glass. 
Figure 183. North façade of Memorial Chapel, with Kings Point Light navigational beacon visible in steeple, 1960 (Bland Library, USMMA).

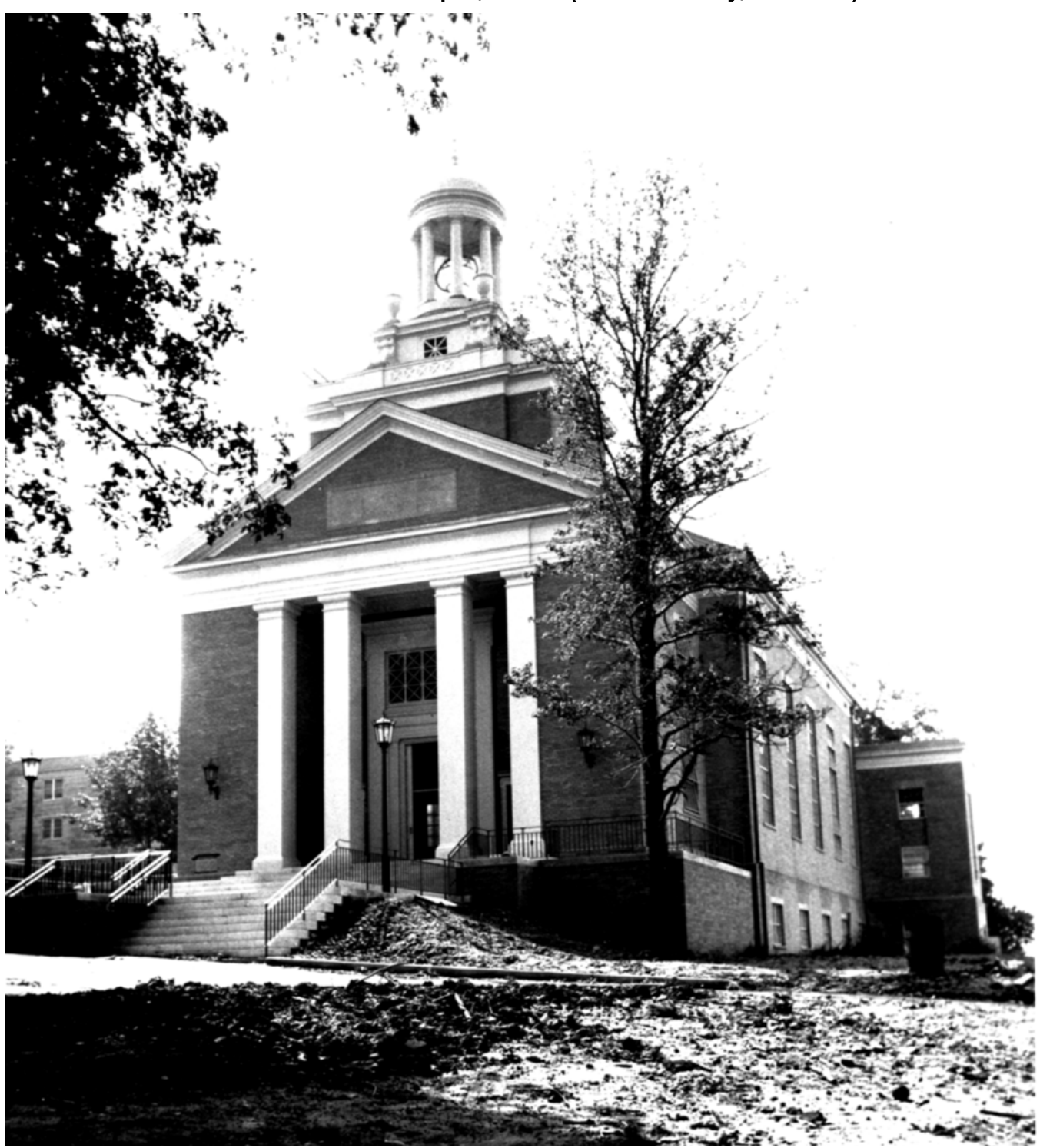


Figure 184. Rotating altar inside the Memorial Chapel, showing two of its three sides, no date (Bland Library, USMMA).

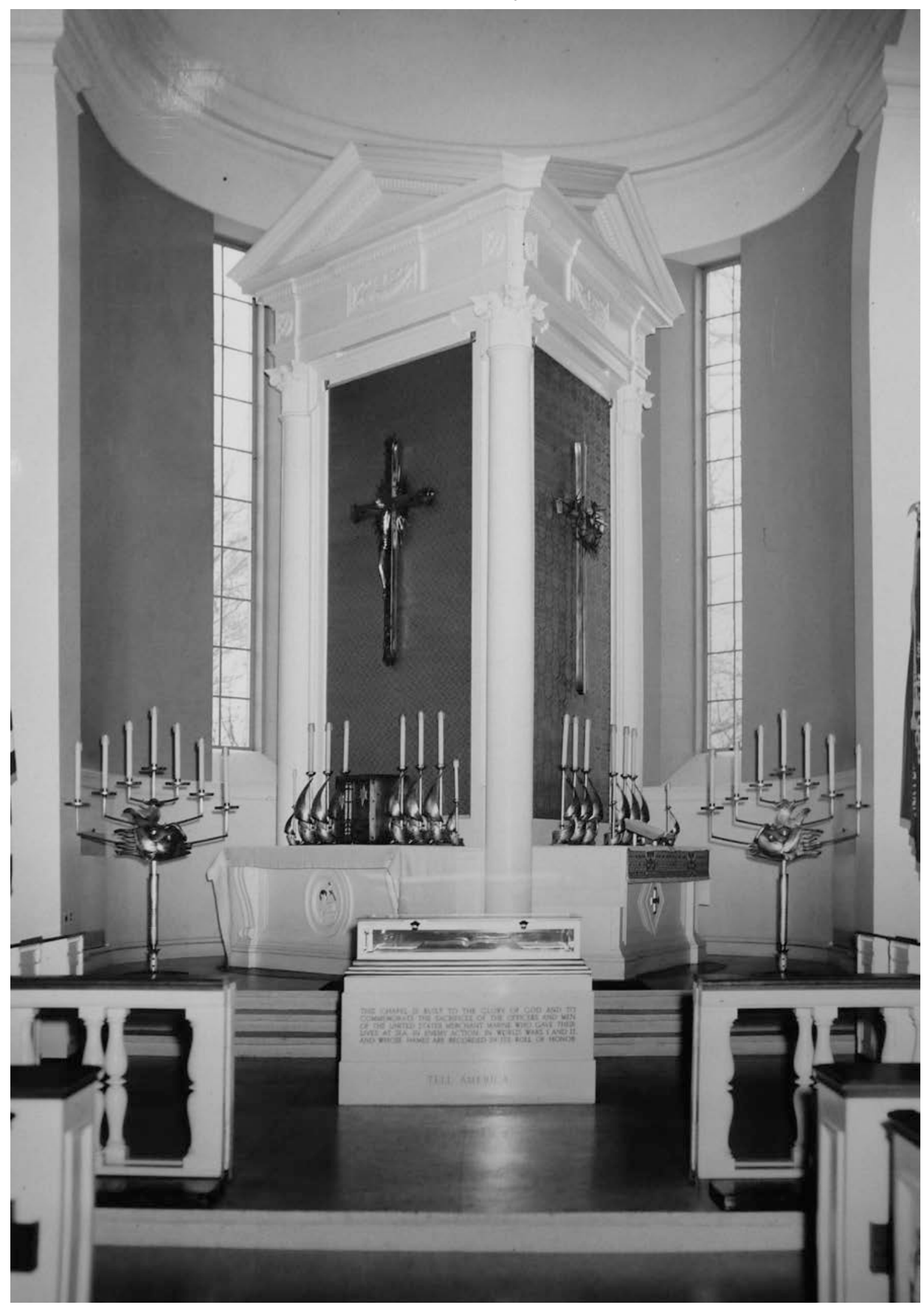


Figure 185. Northwest oblique of the chapel (ERDC-CERL, 2013).

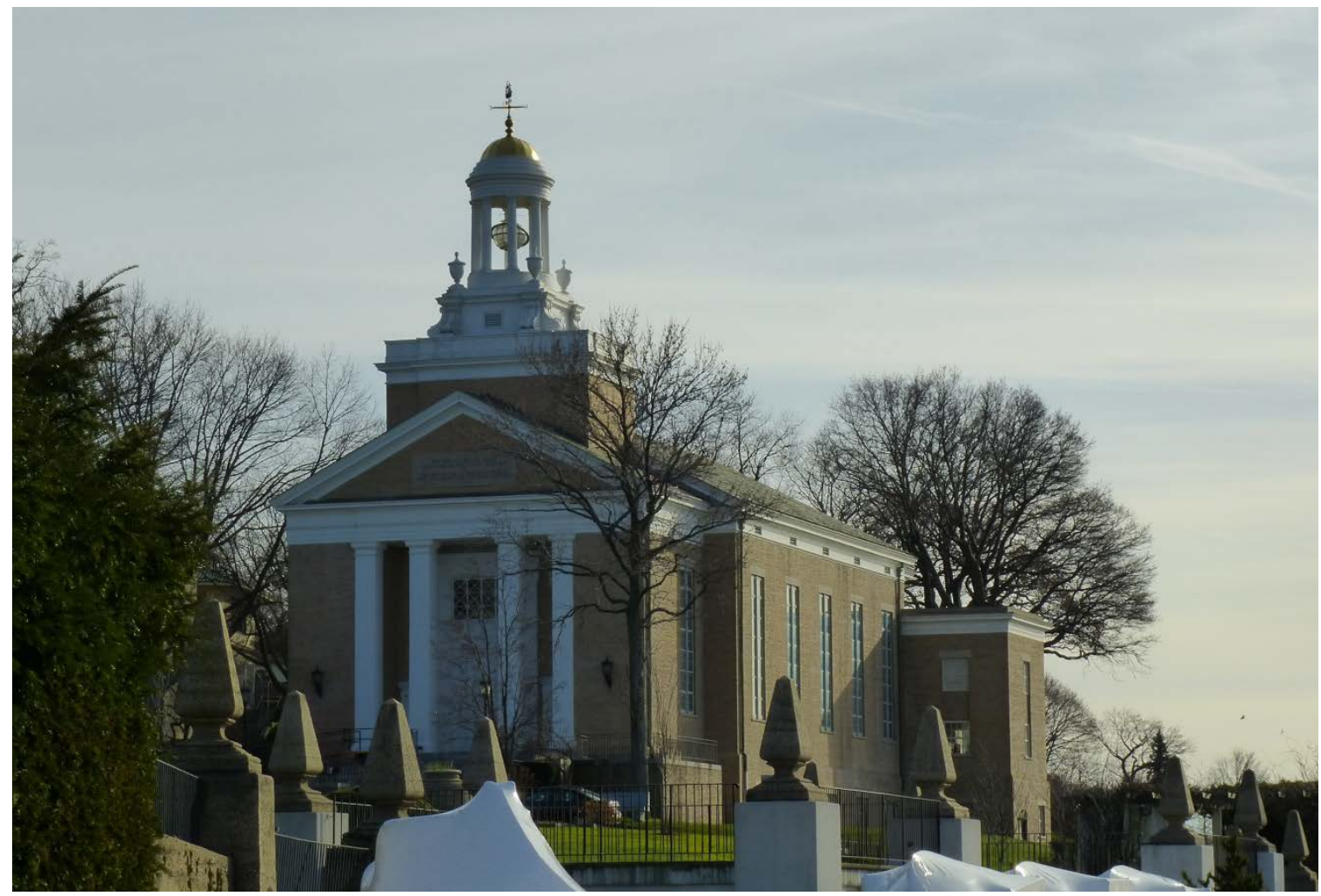

Figure 186. Chapel nave (ERDC-CERL, 2013).

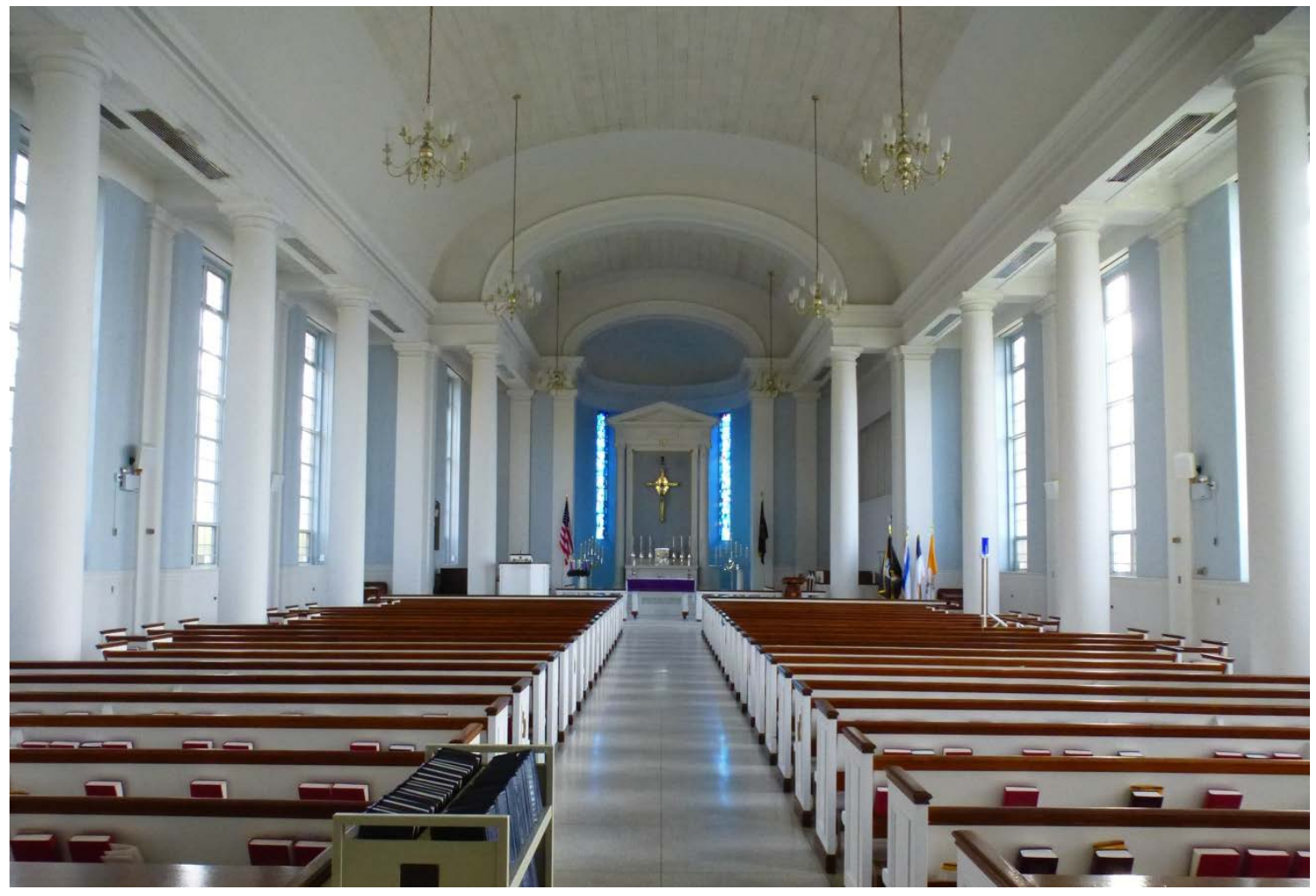


Figure 187. Altar inside the nave of the chapel, showing one side of the three-sided altar (ERDC-CERL, 2013).

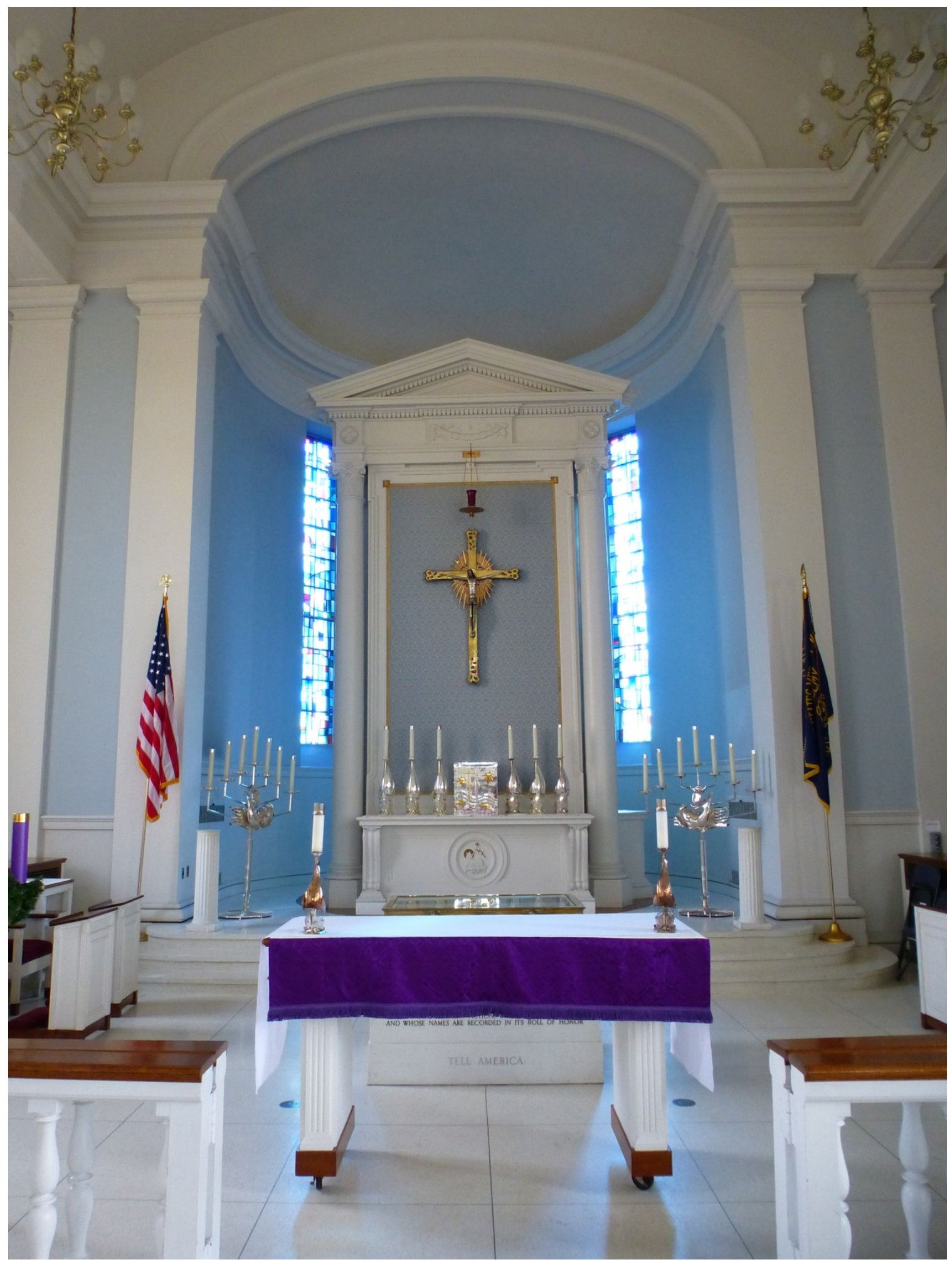


Figure 188. South side of the Memorial Chapel steeple (ERDC-CERL, 2013).

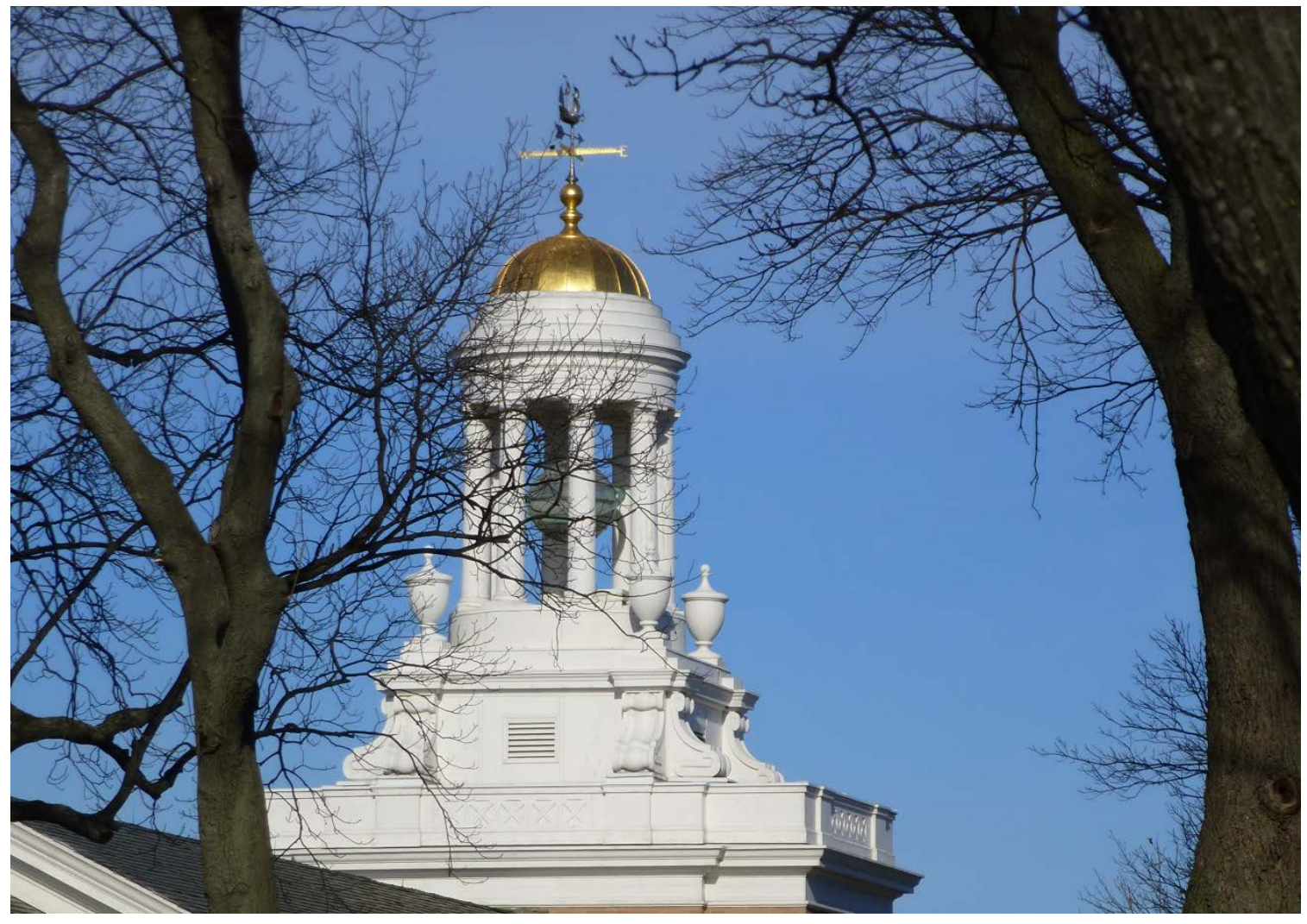

Figure 189. Weathervane detail of the Memorial Chapel steeple (ERDC-CERL, 2013).

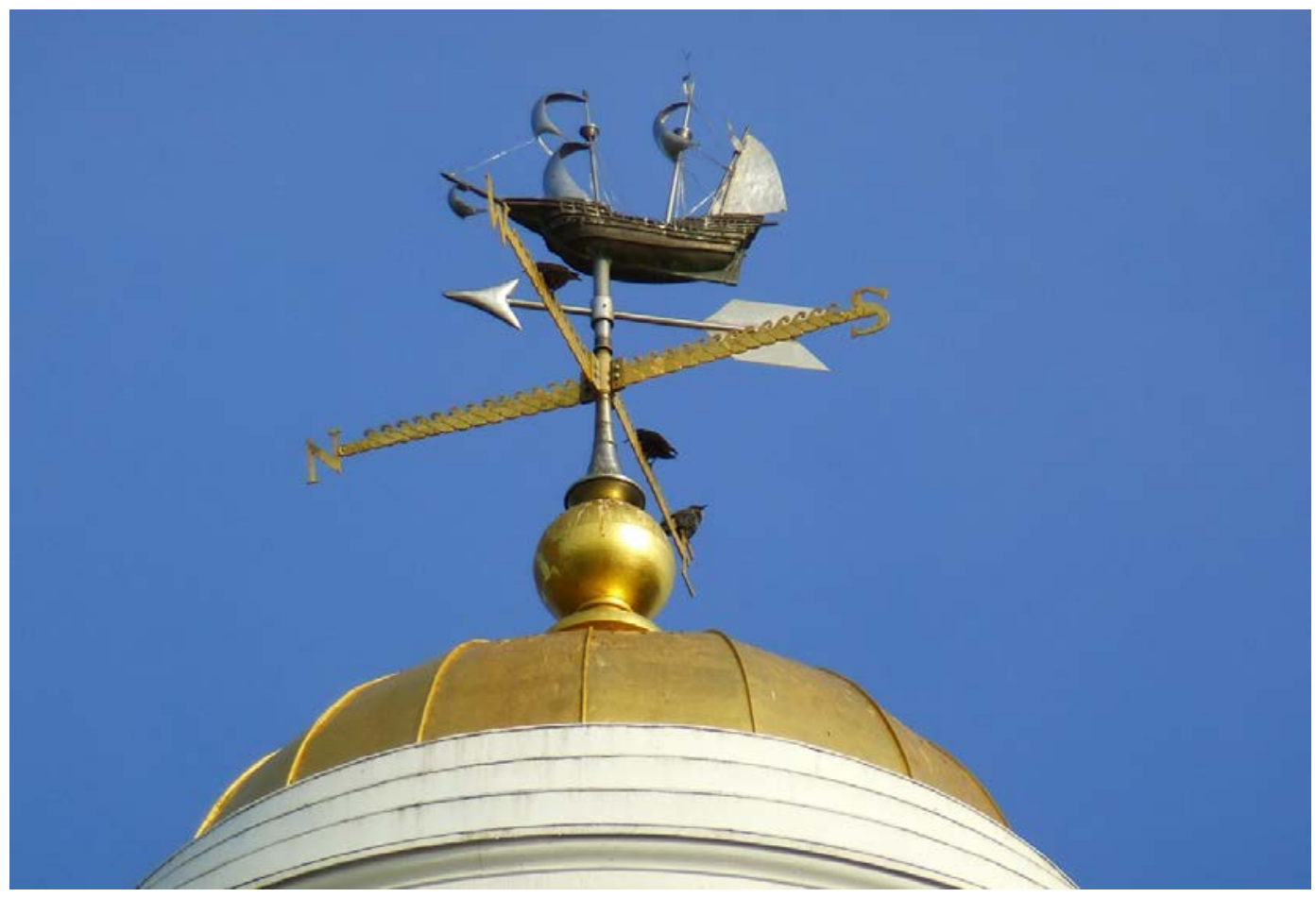


Figure 190. Wood cornice detail and downspout on Memorial Chapel (ERDC-CERL, 2013).

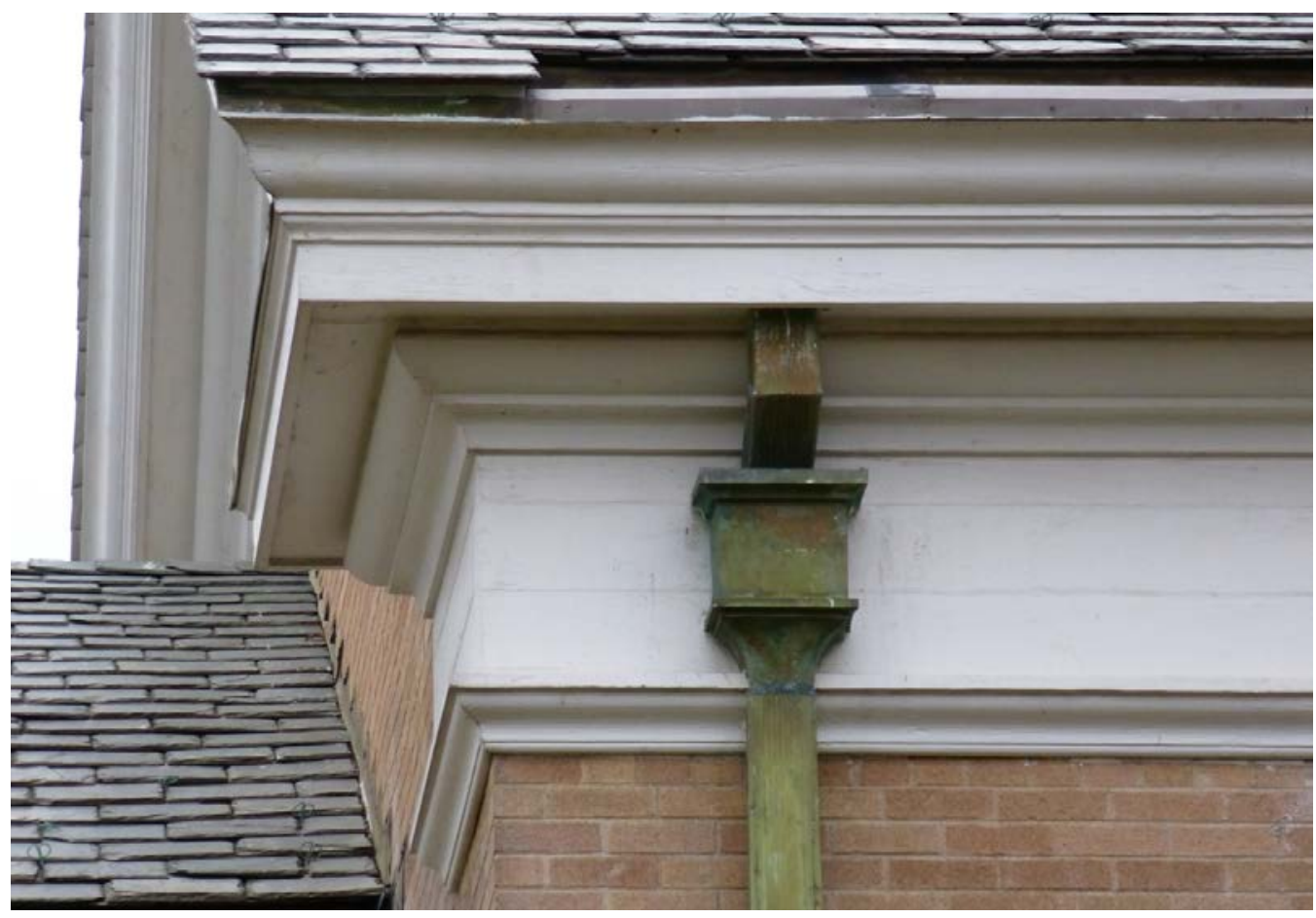

Figure 191. Detail of interior staircase, terrazzo flooring, metal railing, and wood banister in Memorial Chapel (ERDC-CERL, 2013).

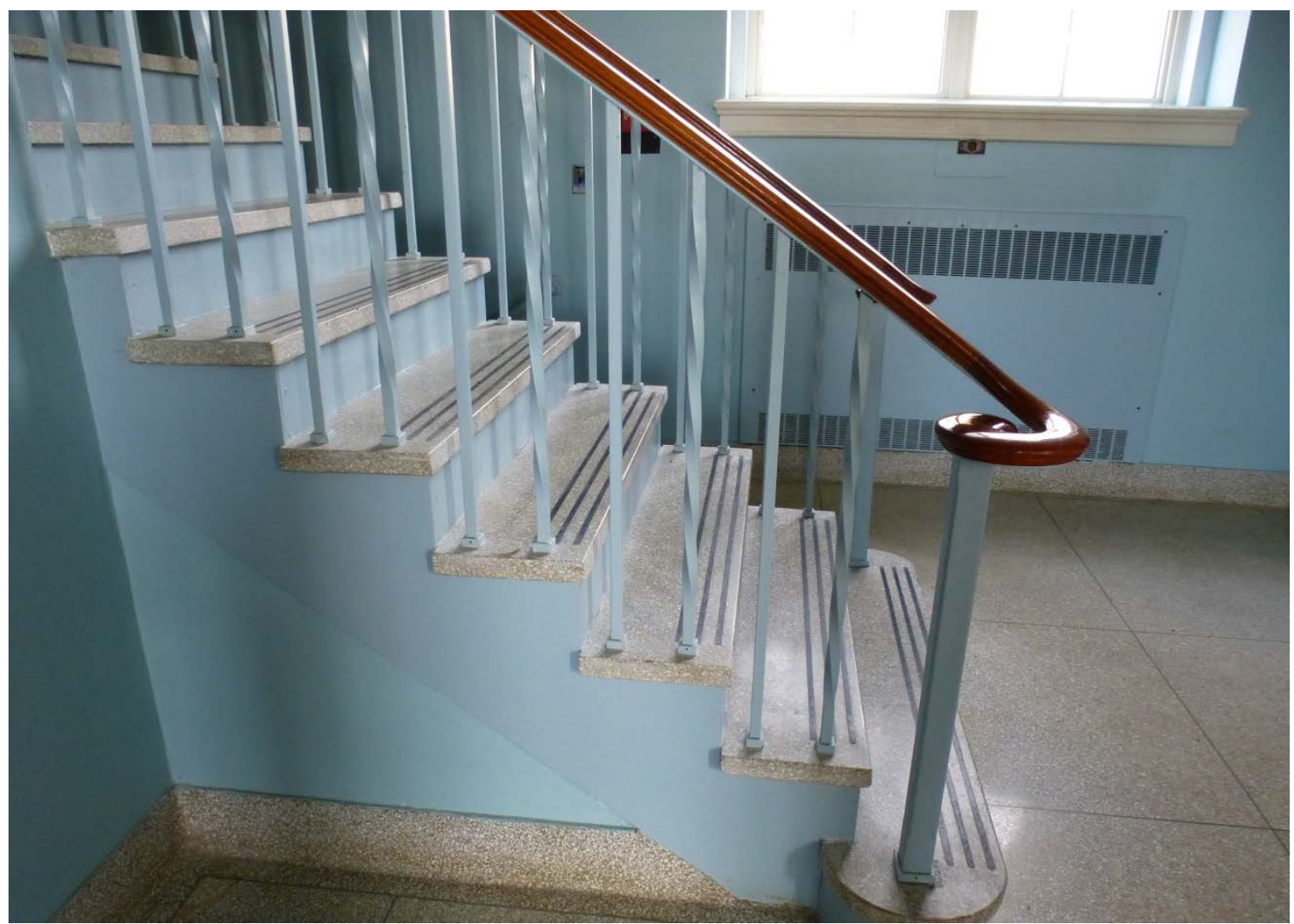




\subsubsection{Character-defining features}

Repair, renovation, and replacement of the following character-defining features of the Memorial Chapel must be coordinated with the NY SHPO.

- Overall massing

- Footprint

- Roof forms

- Exterior buff-colored brick

- All exterior wood-trim elements including columns, cornices, and rakes

- Downspouts

- Steeple and all of its architectural elements

- Beacon

- Window and door openings

- Doors

- Windows

- Pews

- Rotating altar

- Terrazzo flooring

- Staircase

- Interior wood trim

- Light fixtures 


\subsubsection{Crowninshield Pier and Boat House}

The Crowninshield Pier and Boat House were constructed in 1943 at the southern end of Hague Basin and are contributing to the historic district. All above-water elements of the pier structure and boat house building are character-defining features.

Figure 192. Looking southwest towards Crowninshield Pier and Boat House (ERDC-CERL, 2013).

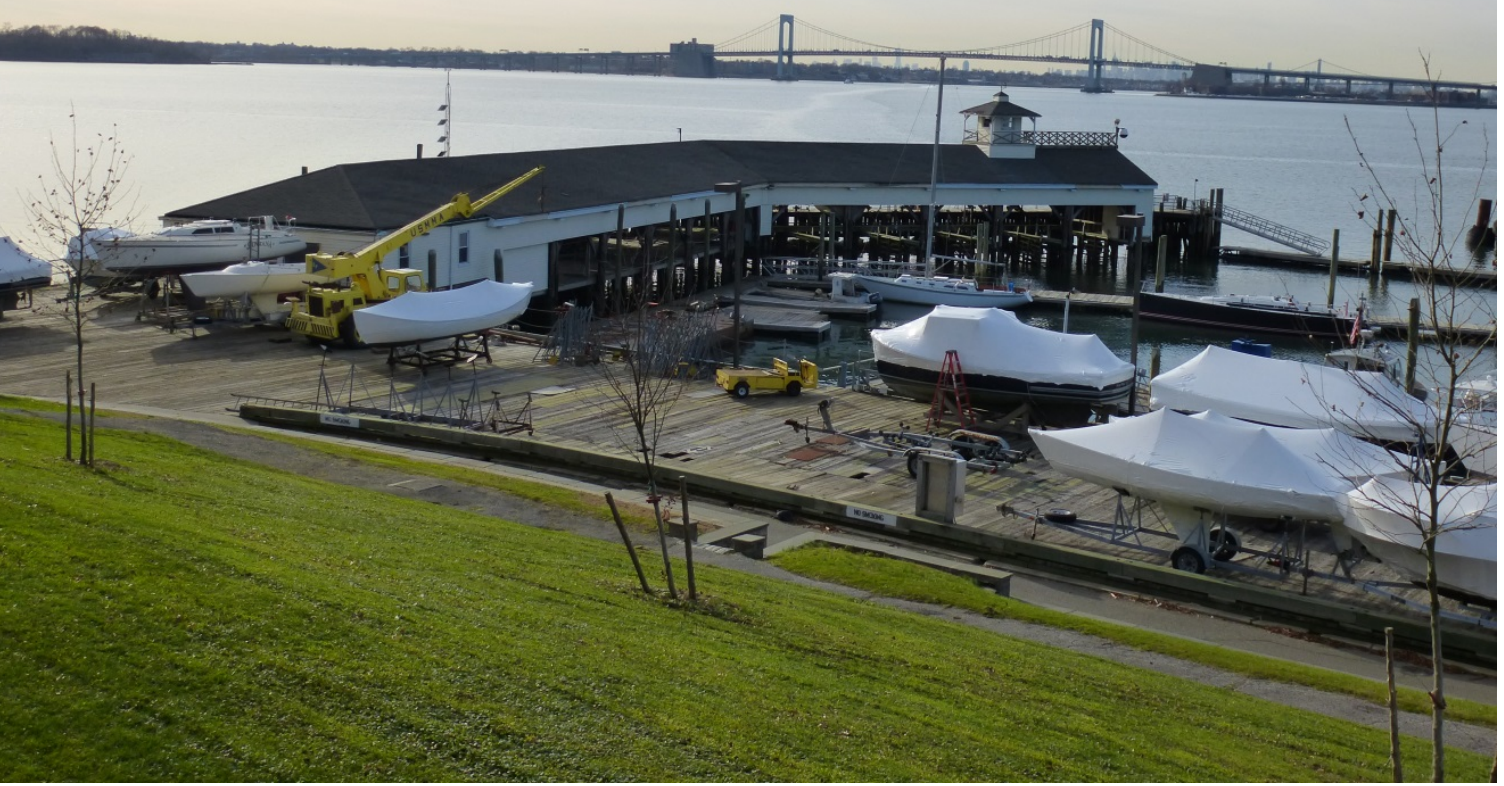




\subsubsection{Men's shower, women's shower, and paint locker}

The men's shower, women's shower, and paint locker all date to the expansion of the waterfront by Walter P. Chrysler. The buildings are located east of Eldridge Pool near Hague Basin, and all are contributing elements to the historic district; however, the interiors of the two shower rooms are not. The replacement doors and glass block windows of the shower rooms also are not character-defining features; however, the openings for them are character defining.

Figure 193. The replacement door into the men's shower at Crowninshield Pier and Boat House (ERDC-CERL, 2013).

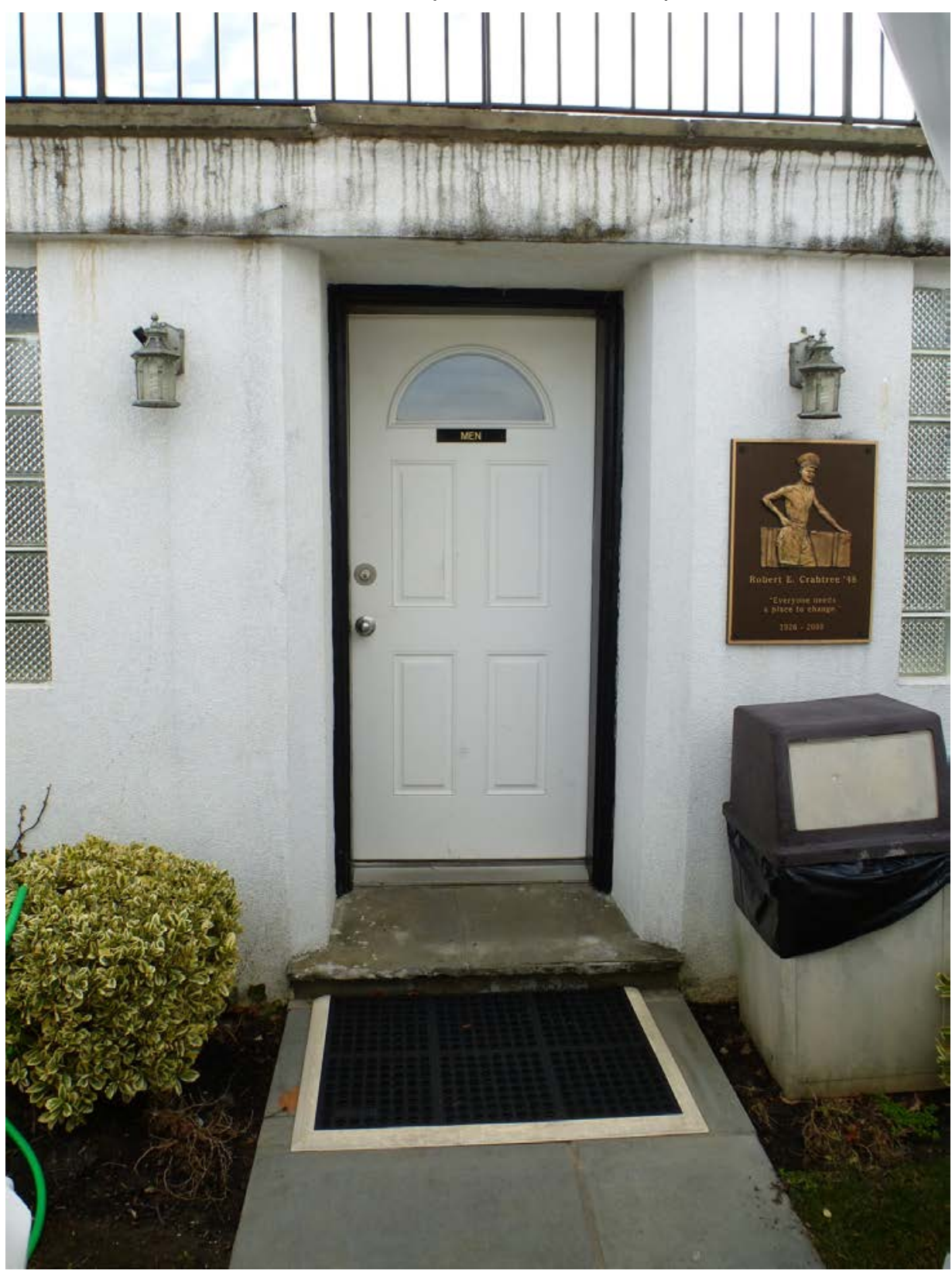


Figure 194. The replacement door into the women's shower near Eldridge Pool, shown flanked by wrapped training boats in foreground (ERDC-CERL, 2013).

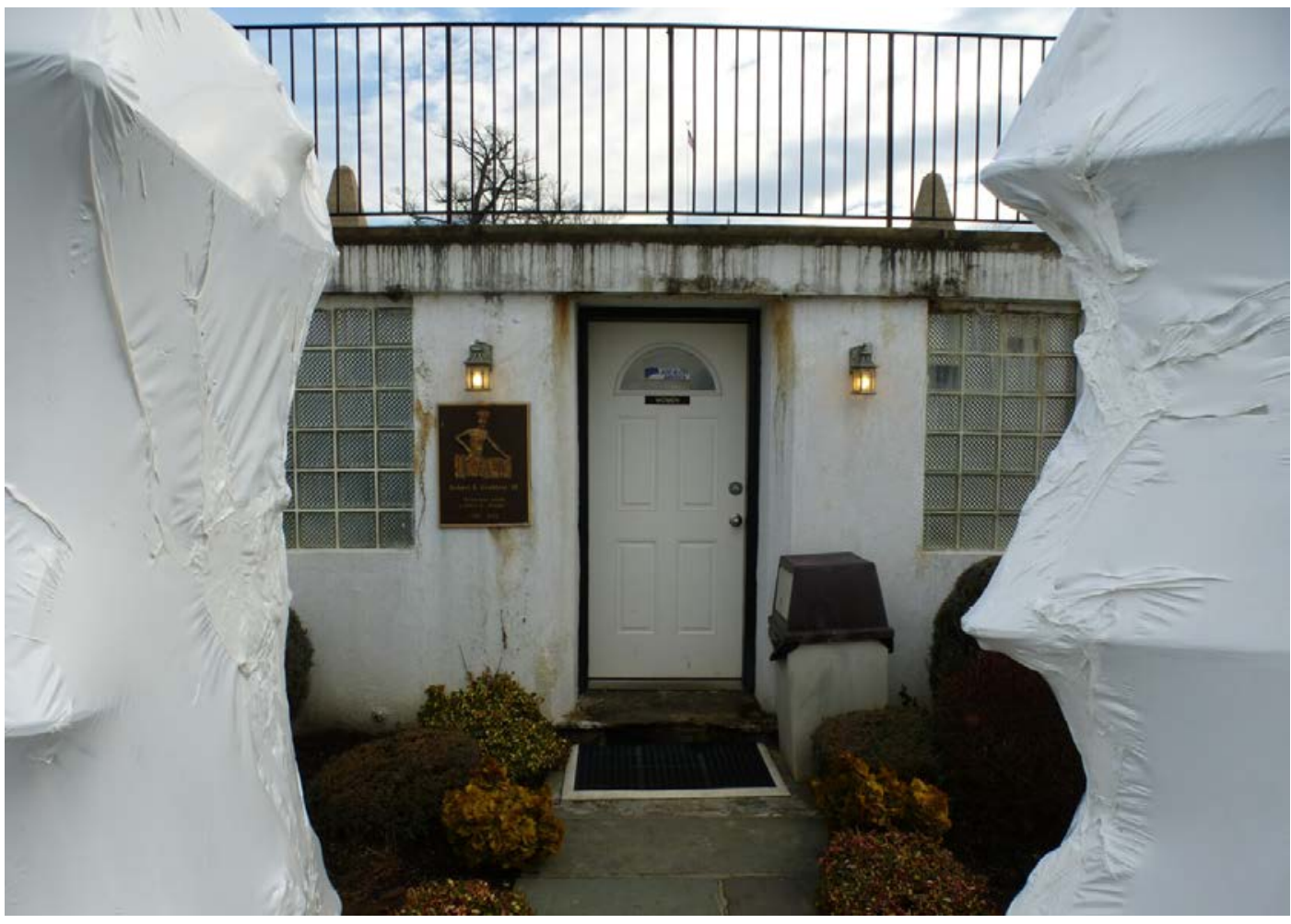

Figure 195. Noncontributing shower interior (ERDC-CERL, 2013).

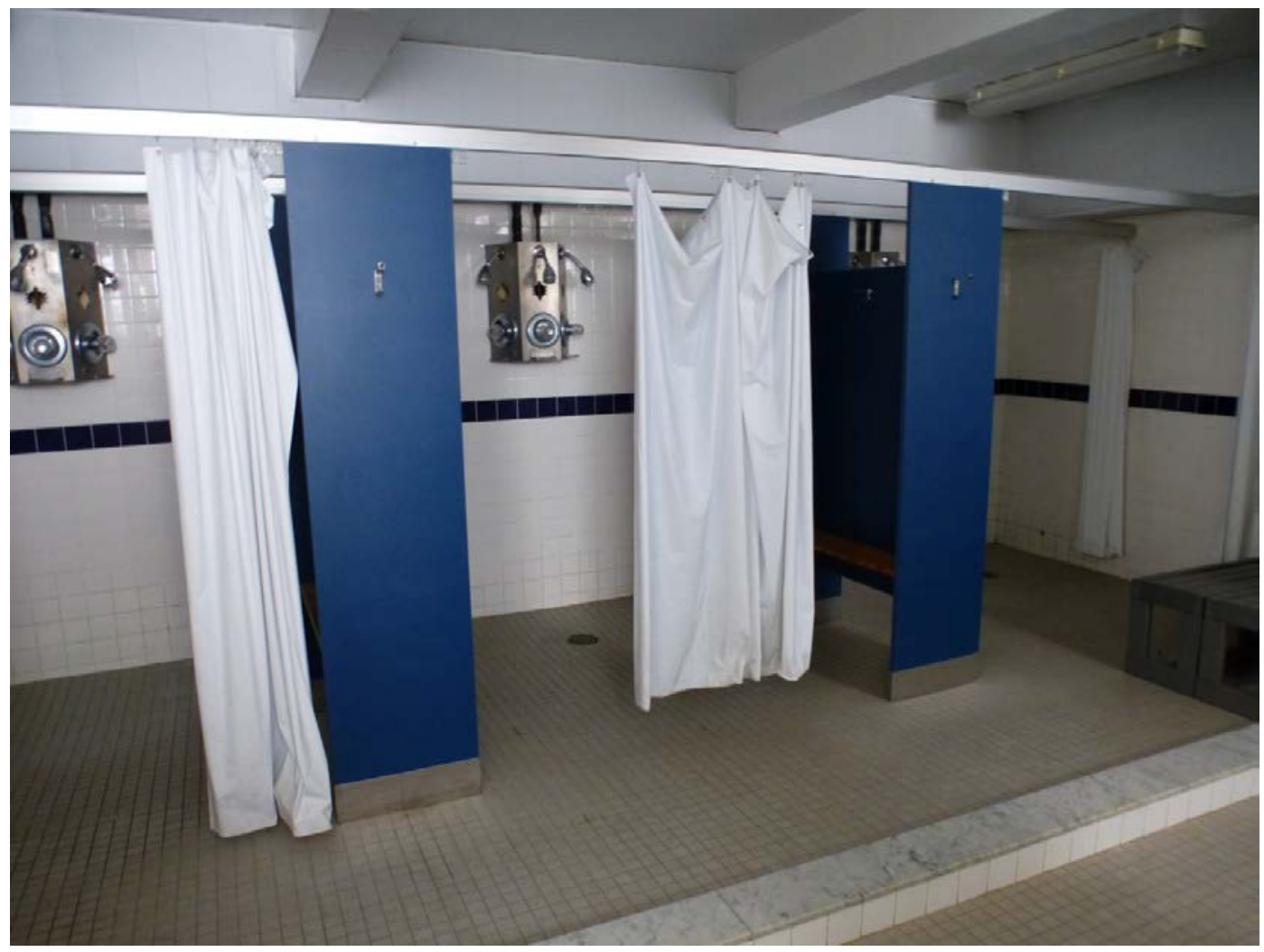


Figure 196. The paint locker north of Eldridge Pool (ERDC-CERL, 2013).

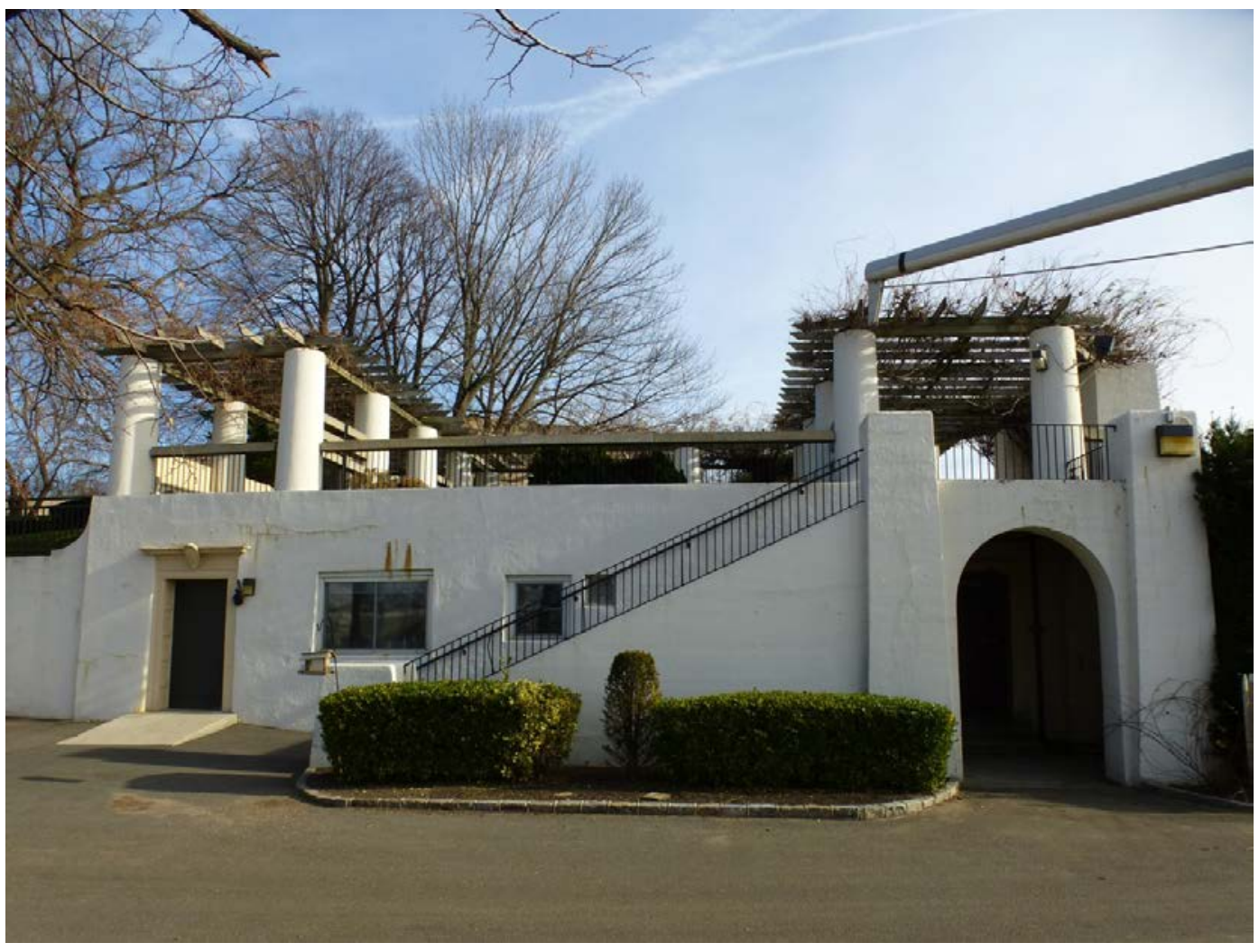

Figure 197. The interior of the paint locker (ERDC-CERL, 2013).

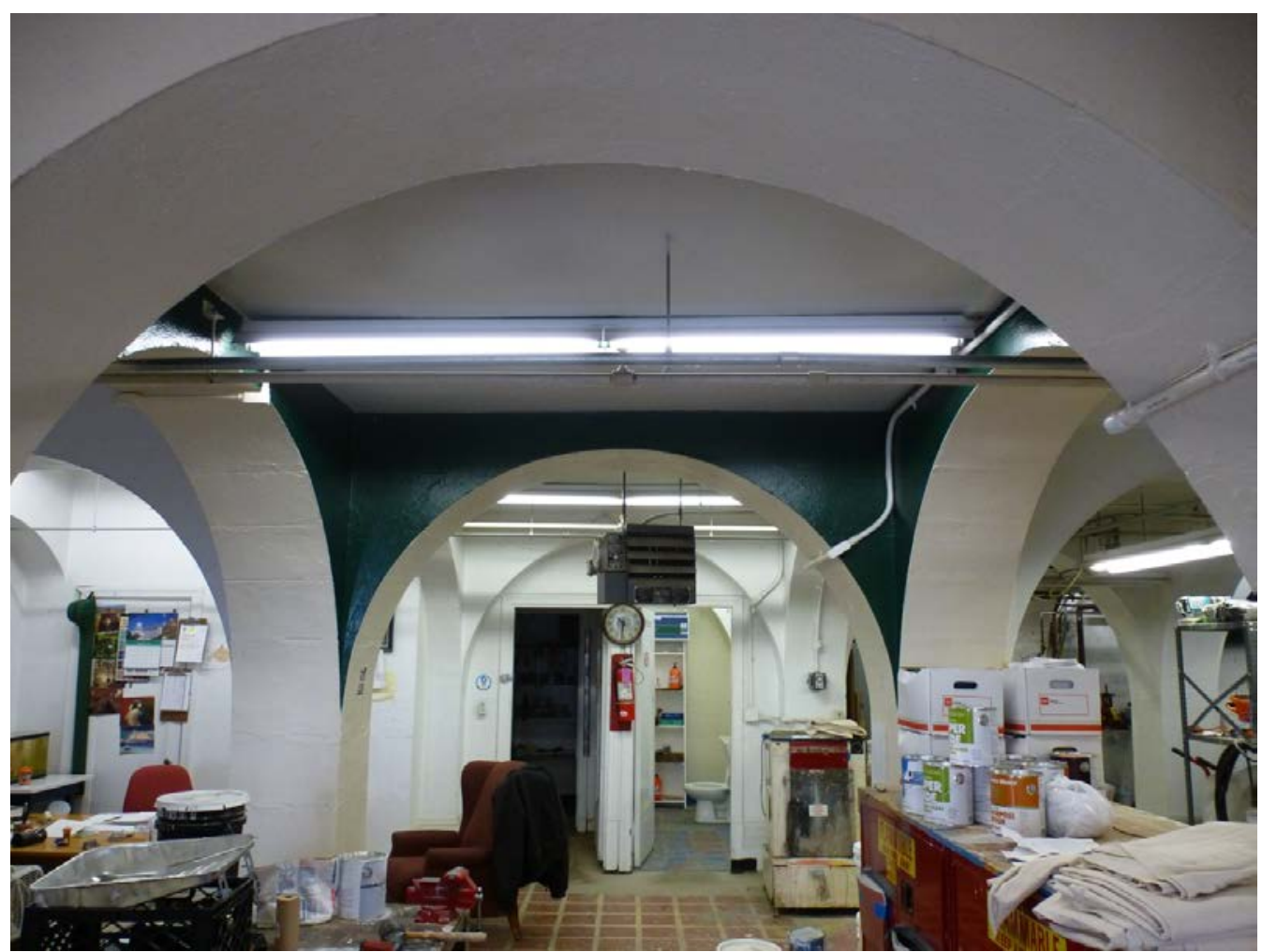




\subsubsection{Schuyler Otis Bland Library}

The Schuyler Otis Bland Library is a contributing feature of the USMMAHD, but the interior is not contributing. The Brutalist-inspired building was designed by Eggers \& Higgins and opened in 1969. It sits on the northern end of the central area of campus and is flanked by Fulton Hall on the west and Bowditch Hall on the east. It is on axis with the entrance to Delano Hall. The first-floor exterior of the library is covered in the same buff-colored concrete masonry units as the older buildings designed by Alfred Hopkins \& Associates in 1942. The second floor exterior is a concrete grid with narrow, tall windows.

Figure 198. South façade of the newly finished Schuyler Otis Bland Library, 1969 (Bland Library, USMMA).

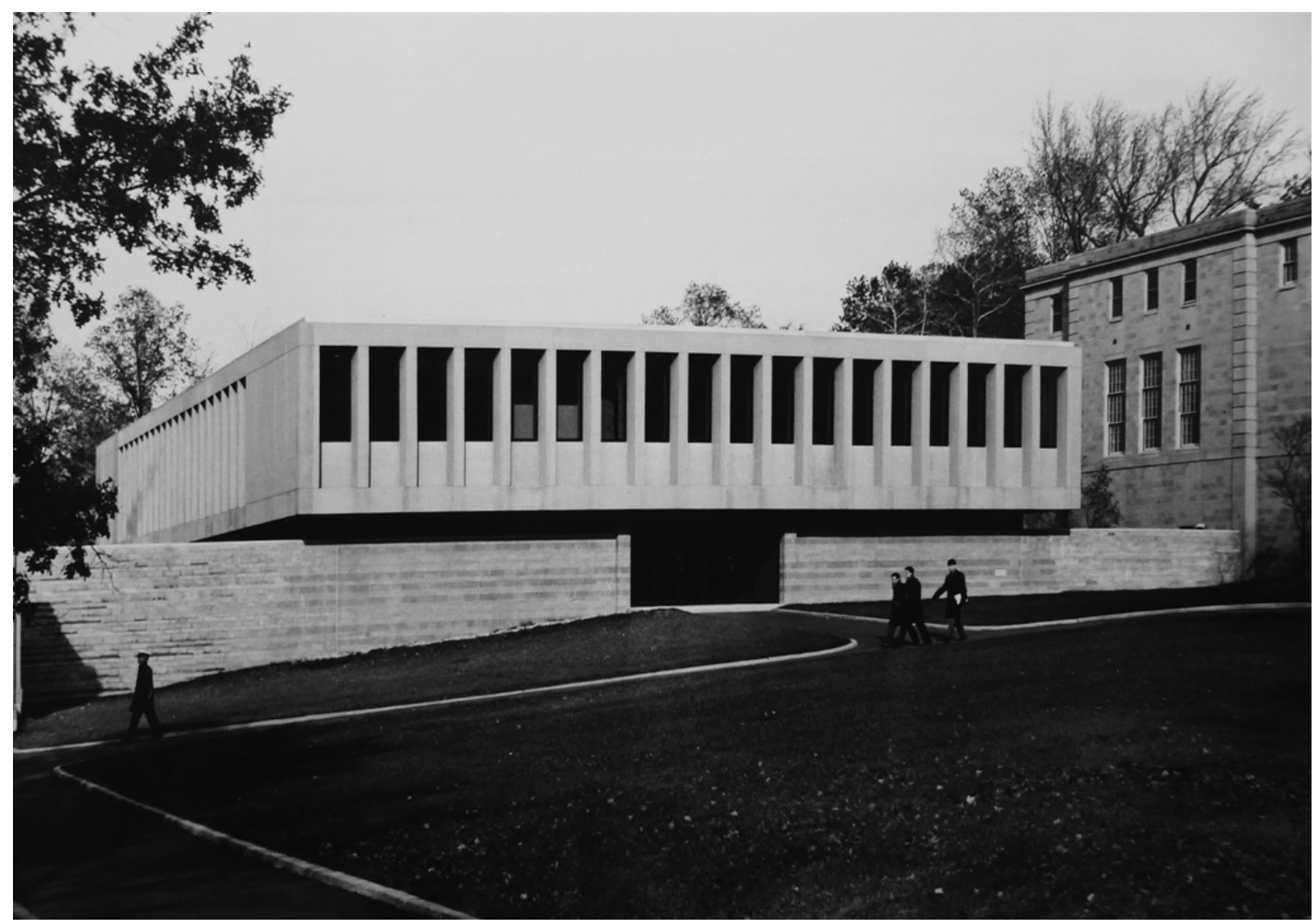


Figure 199. South façade (front) of Bland Library (ERDC-CERL, 2013).

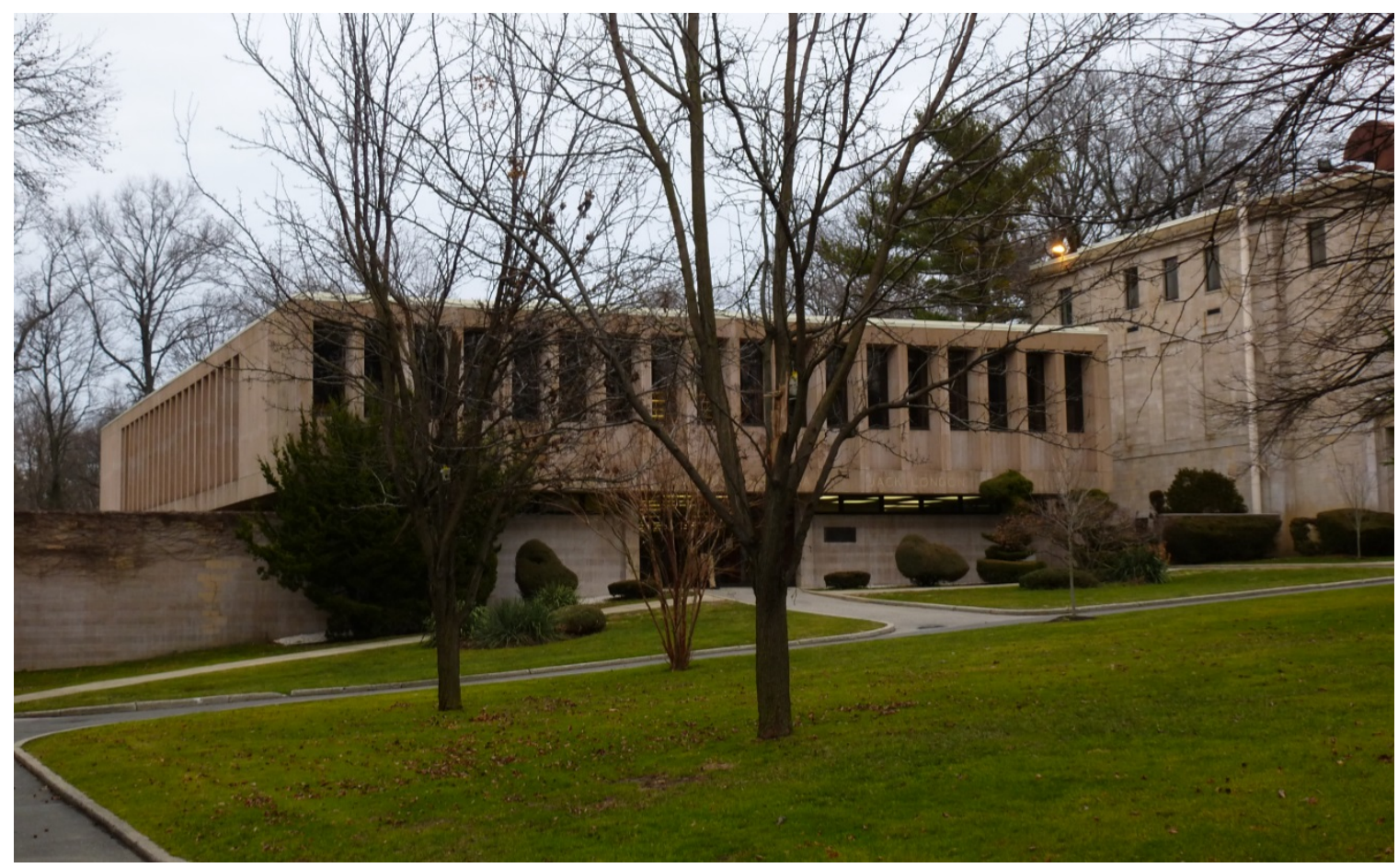

Figure 200. North façade (rear) of Bland Library (ERDC-CERL, 2013).

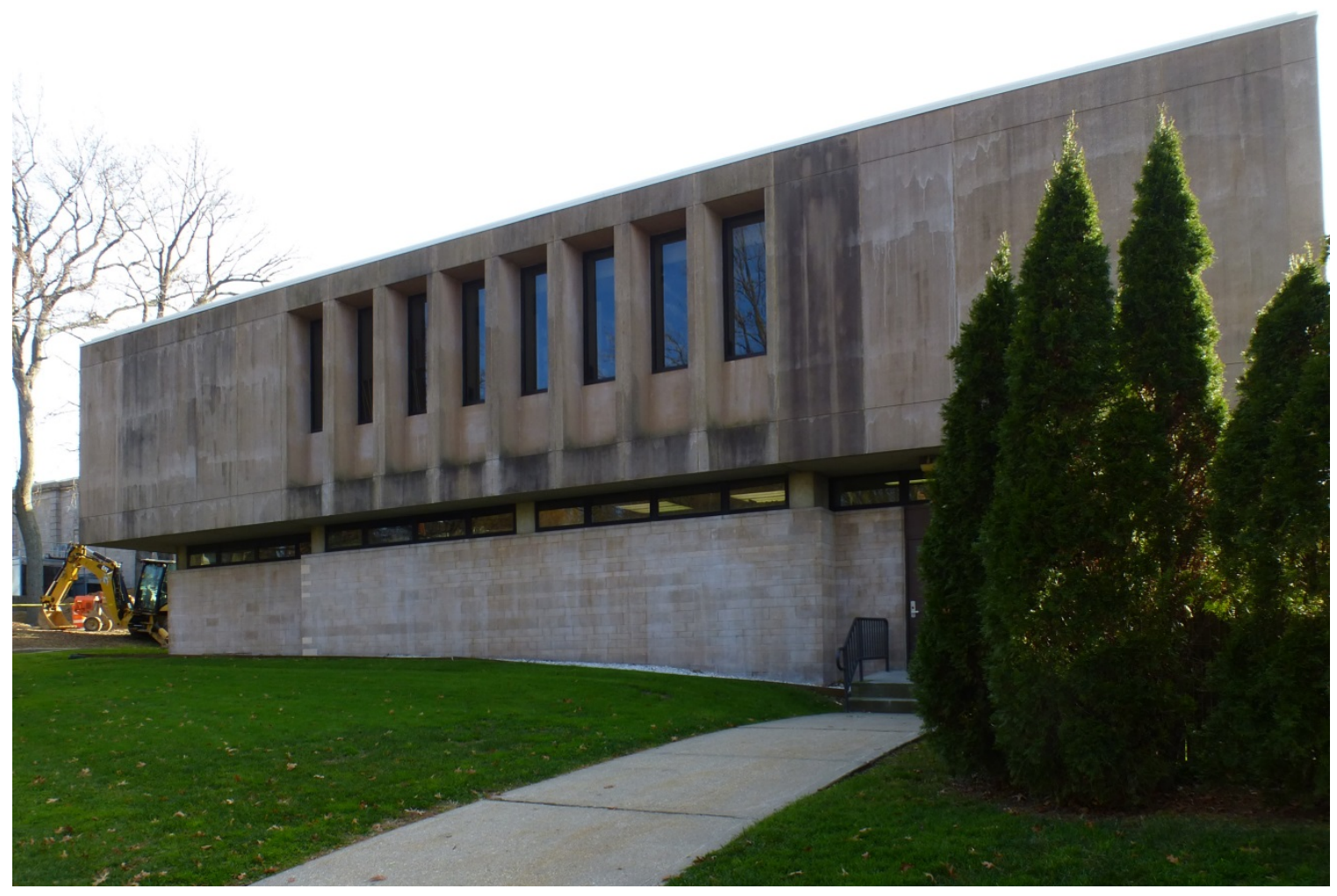




\subsubsection{Character-defining features}

Repair, renovation, and replacement of the following character-defining features of Bland Library must be coordinated with the NY SHPO.

- Overall massing

- Footprint

- Roof form

- Exterior concrete block pattern on the ground floor

- Concrete panels on second floor

- Window and door openings

- Doors

- Windows

\subsection{Structures}

\subsubsection{Vickery Gate}

Vickery Gate is now the main entrance to the academy and is situated near the corner of Steamboat Road and Stepping Stone Lane. It is a contributing feature to the historic district. The gate was constructed in 1943 and designed by Alfred Hopkins \& Associates. The gate consists of two guard rooms on either side (north and south) of Steamboat Road. The two caststone structures are square in plan and are topped by sculpted globe and dolphins atop a stepped base with Federal eagles at each building's corner. The words "United States Merchant Marine Academy" in copper lettering are on the east façade of each structure. Both structures have had their original doors removed to allow pedestrians to walk through them, and the original windows have been replaced with anodized-bronze metal windows. 
Figure 201. Original architectural drawing for the east façade of the Vickery Gate guard room on the north side of Steamboat Road (USMMA).

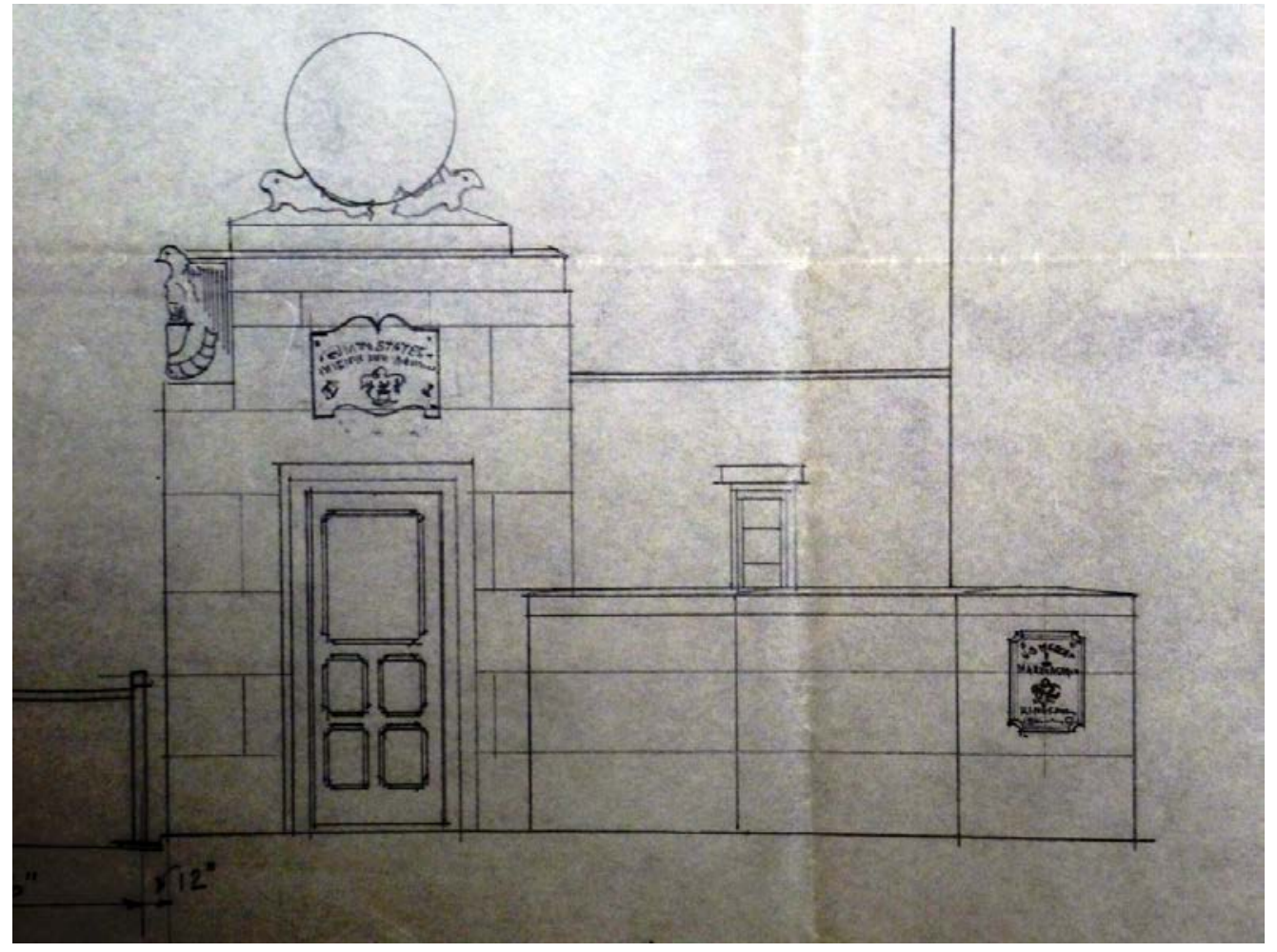

Figure 202. Original architectural drawing for the east façade of Vickery Gate guard room on the south side of Steamboat Road (USMMA).

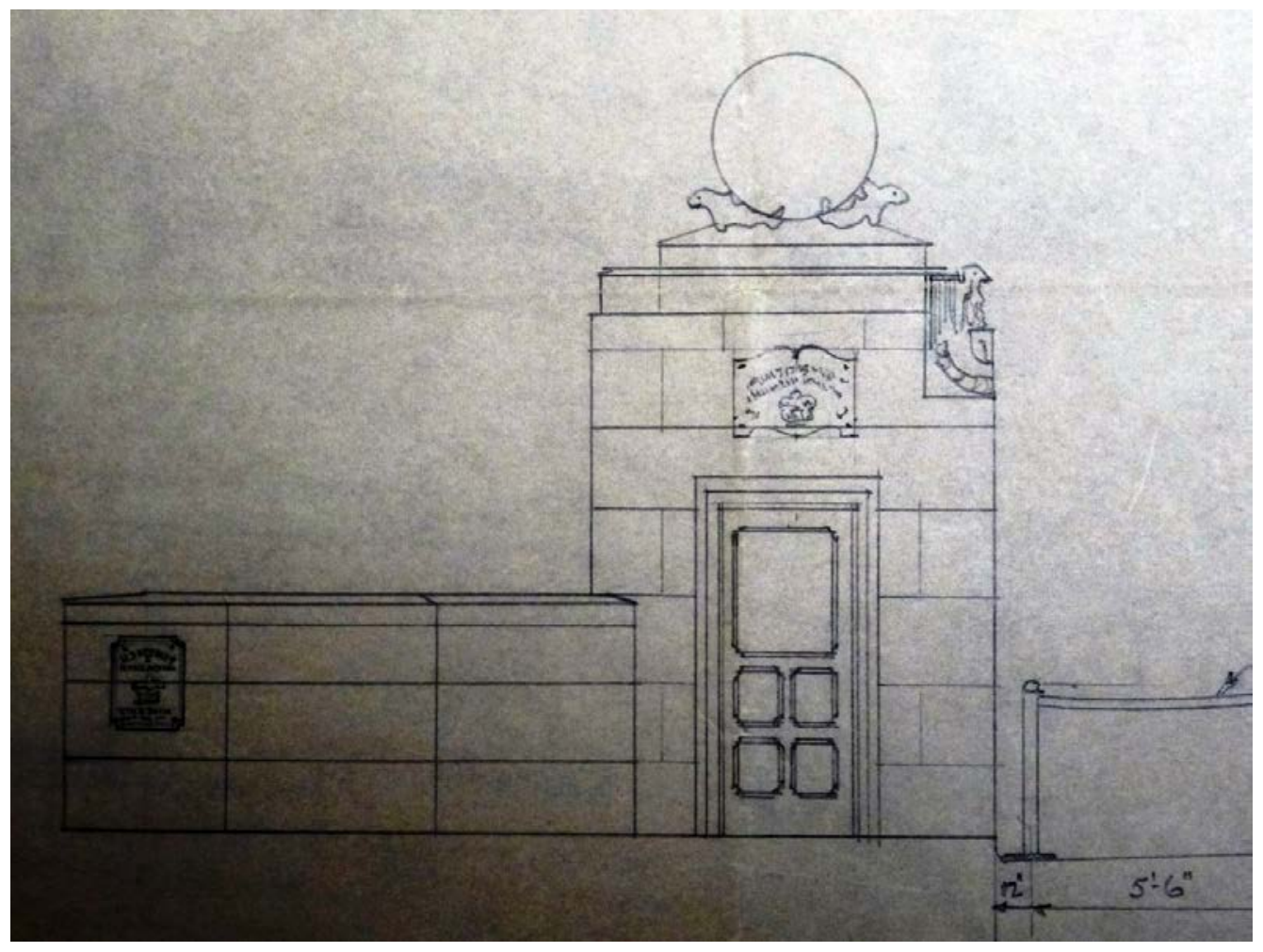


Figure 203. East façade of the Vickery Gate guard room on the north side of Steamboat Road (ERDC-CERL, 2013). Note the added top layer of wall extending from guard room that is not part of original plans.

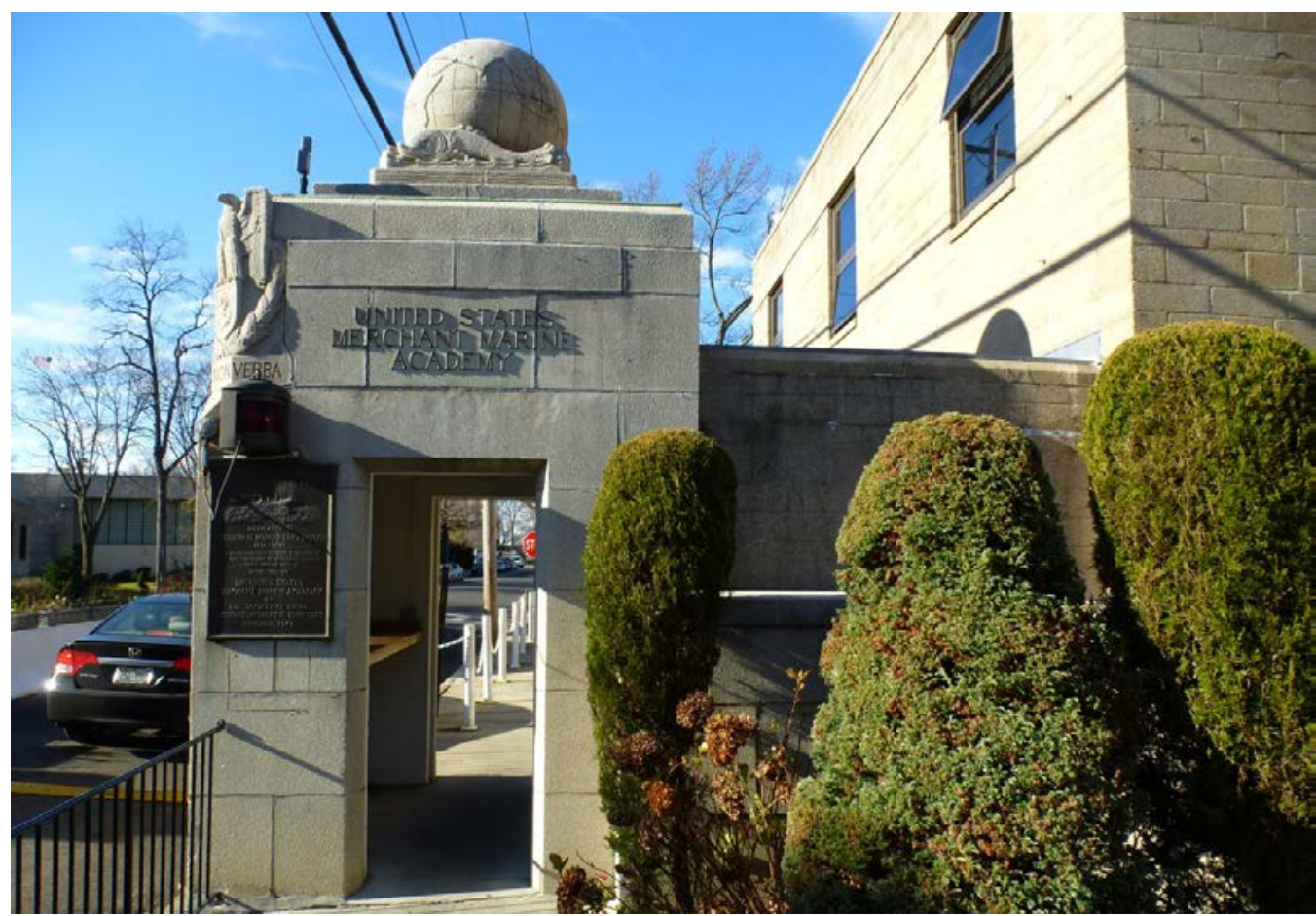

Figure 204. West façade of the Vickery Gate guard room on the south side of Steamboat Road (ERDC-CERL, 2013). (Note that this gate's wall does not have the upper layer of stone.)

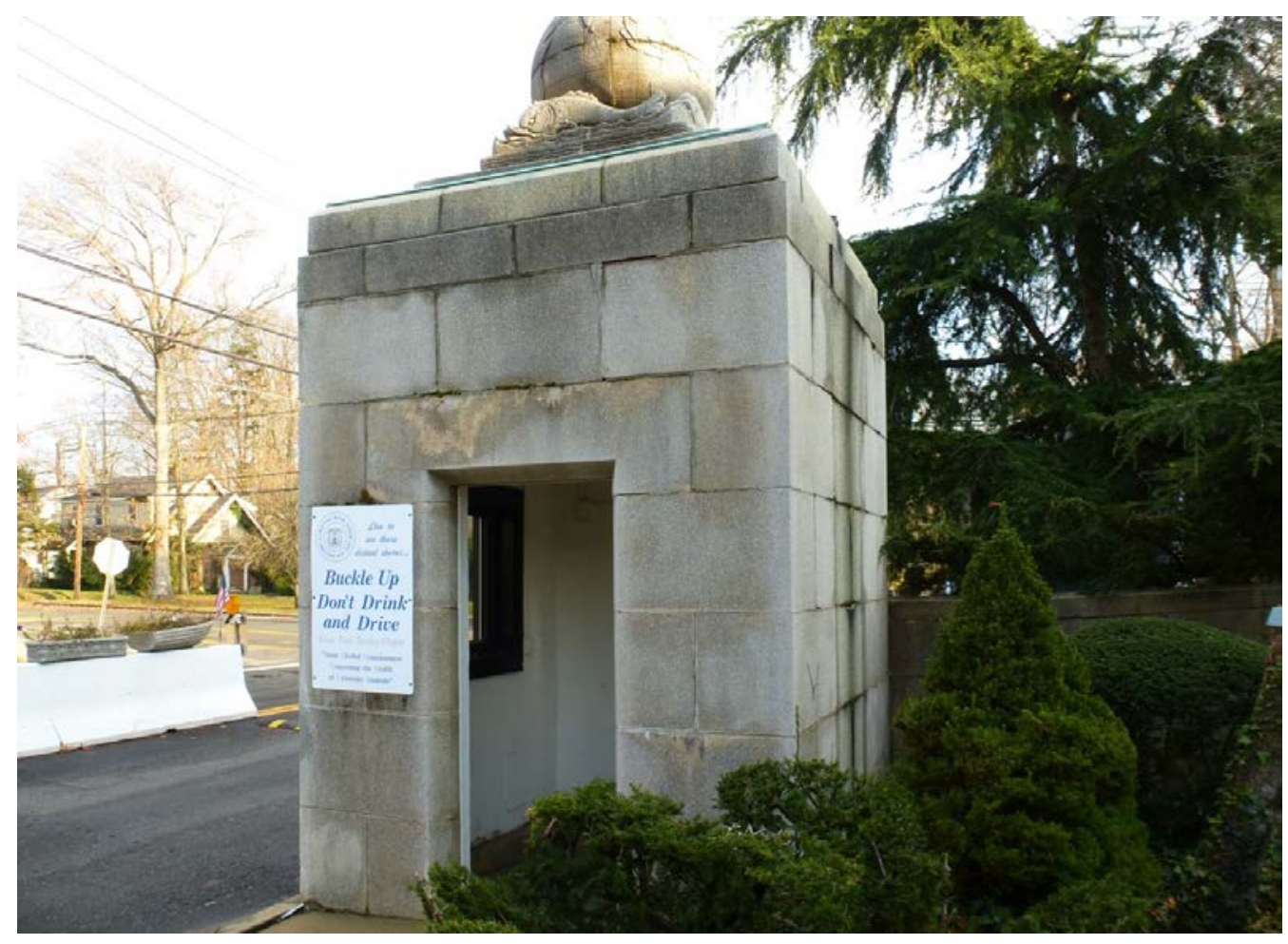


Figure 205. Globe and dolphin detail on top of Vickery Gate guardroom on the north side of Steamboat Road; the same detail is also on top of the south side guard room. (ERDC-CERL, 2013).

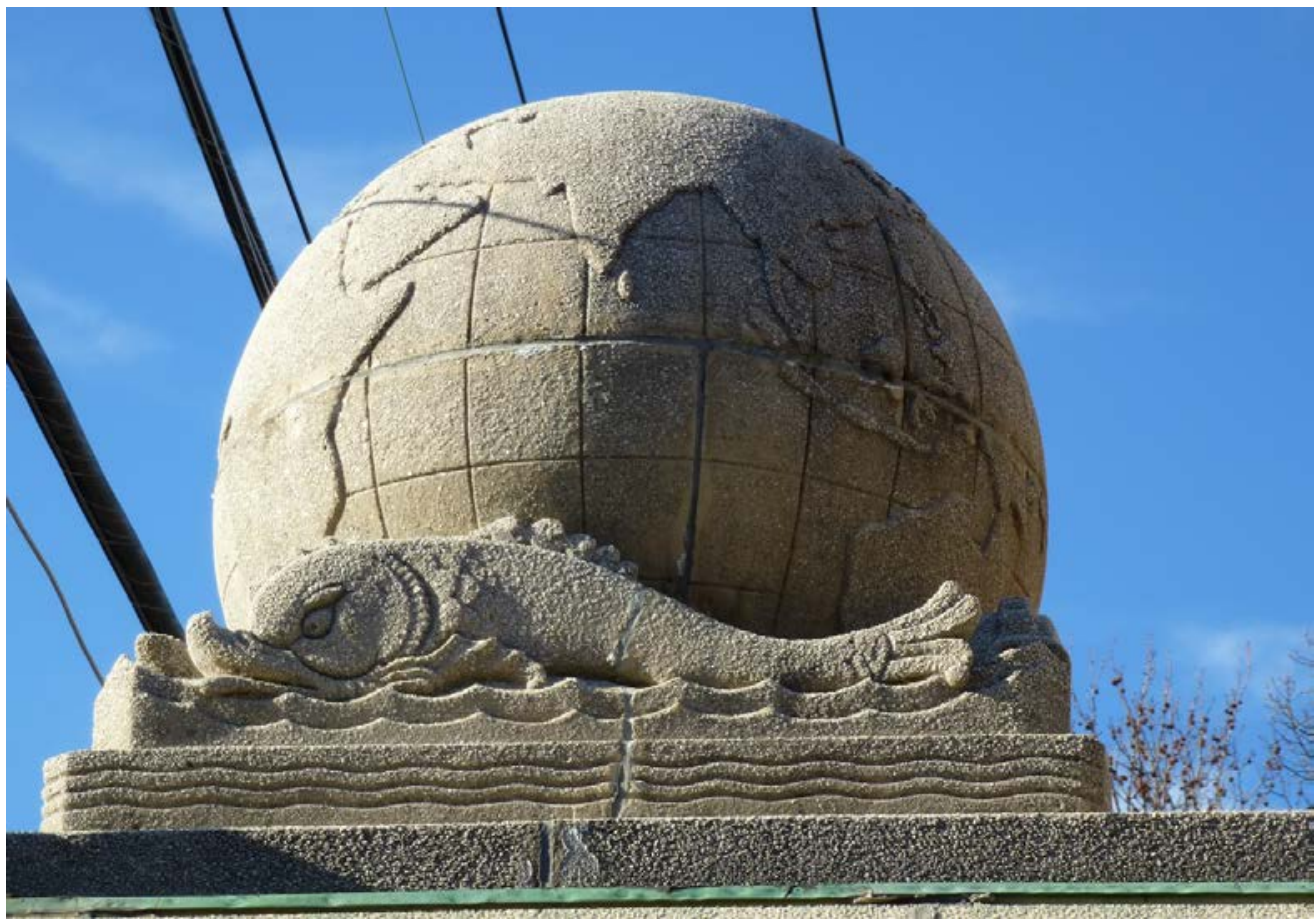

\subsubsection{Character-defining features}

Repair, renovation, and replacement of the following character-defining features of Vickery Gate must be coordinated with the NY SHPO.

- Overall massing

- Footprint

- Exterior concrete block and its distinctive stone-like pattern

- All cast-stone architectural elements including window sills and lintels, globe and dolphin sculpture, inscriptions, eagles, and cornices

- Copper lettering on east side of each structure spelling out USMMA

- Window and door openings

\subsubsection{Character-defining features that have been removed}

Listed below are character-defining features of Vickery Gate that have been removed or replaced over the years, and as future renovations occur need to be replaced with elements that replicate the original characterdefining features of the building. The original architectural plans will guide this process in coordination with the NY SHPO. 
- Replacement anodized-bronze windows

- Original doors removed

\subsubsection{Marvin Place Gate}

Marvin Place Gate (originally the main entrance) is situated near the corner of Steamboat Road and Elmridge Road. It is a contributing feature to the historic district. The gate was constructed in 1943 and was designed by Alfred Hopkins \& Associates. The gate consists of two guard rooms on the north and south sides of Steamboat Road similar to the Vickery Gate, except both structures of the Marvin Place Gate do not have the sculpted globe and dolphins atop a stepped base, but both structures do have the Federal eagles at one corner. Both structures have had their original doors replaced with steel doors; however, they both have their original windows.

Figure 206. Northeast oblique of the Marvin Place Gate guard house on the south side of Steamboat Road (ERDC-CERL, 2013).

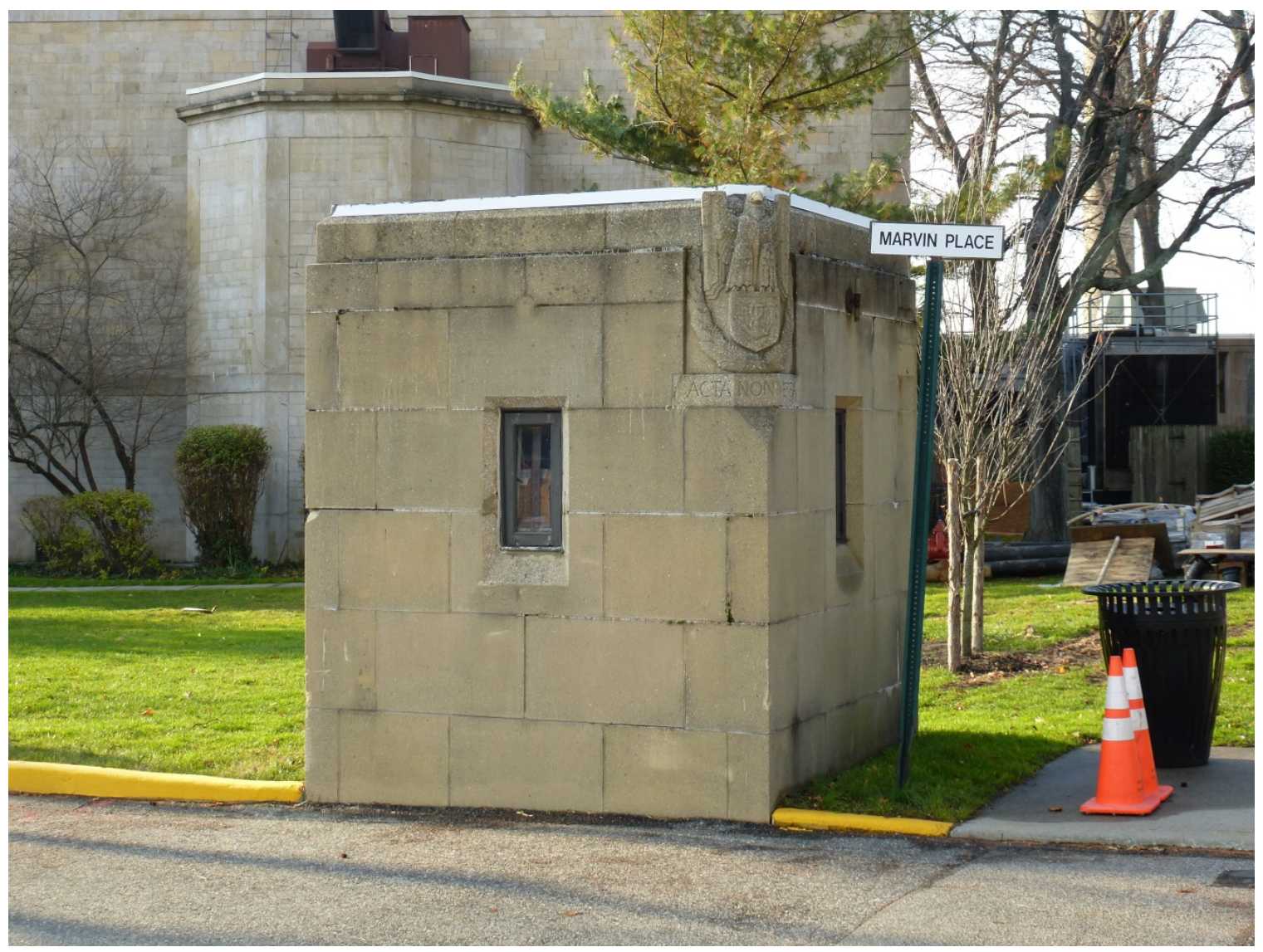


Figure 207. Southeast oblique of the Marvin Place Gate guard house on the north side of Steamboat Road (ERDC-CERL, 2013).

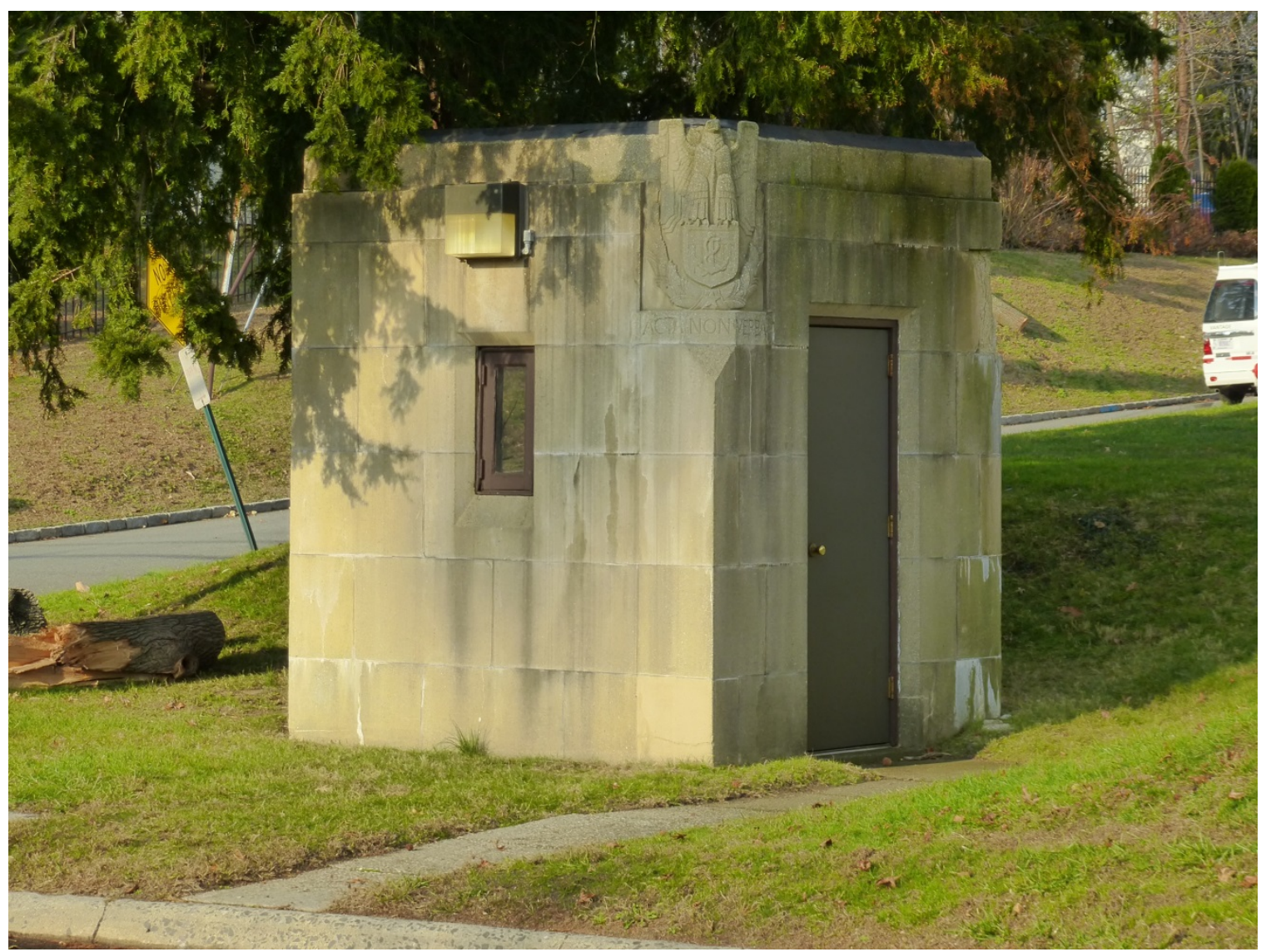


Figure 208. Cast-stone eagle on the northeast corner of the Marvin Place Gate guard house on the south side of Steamboat Road (ERDC-CERL, 2013).

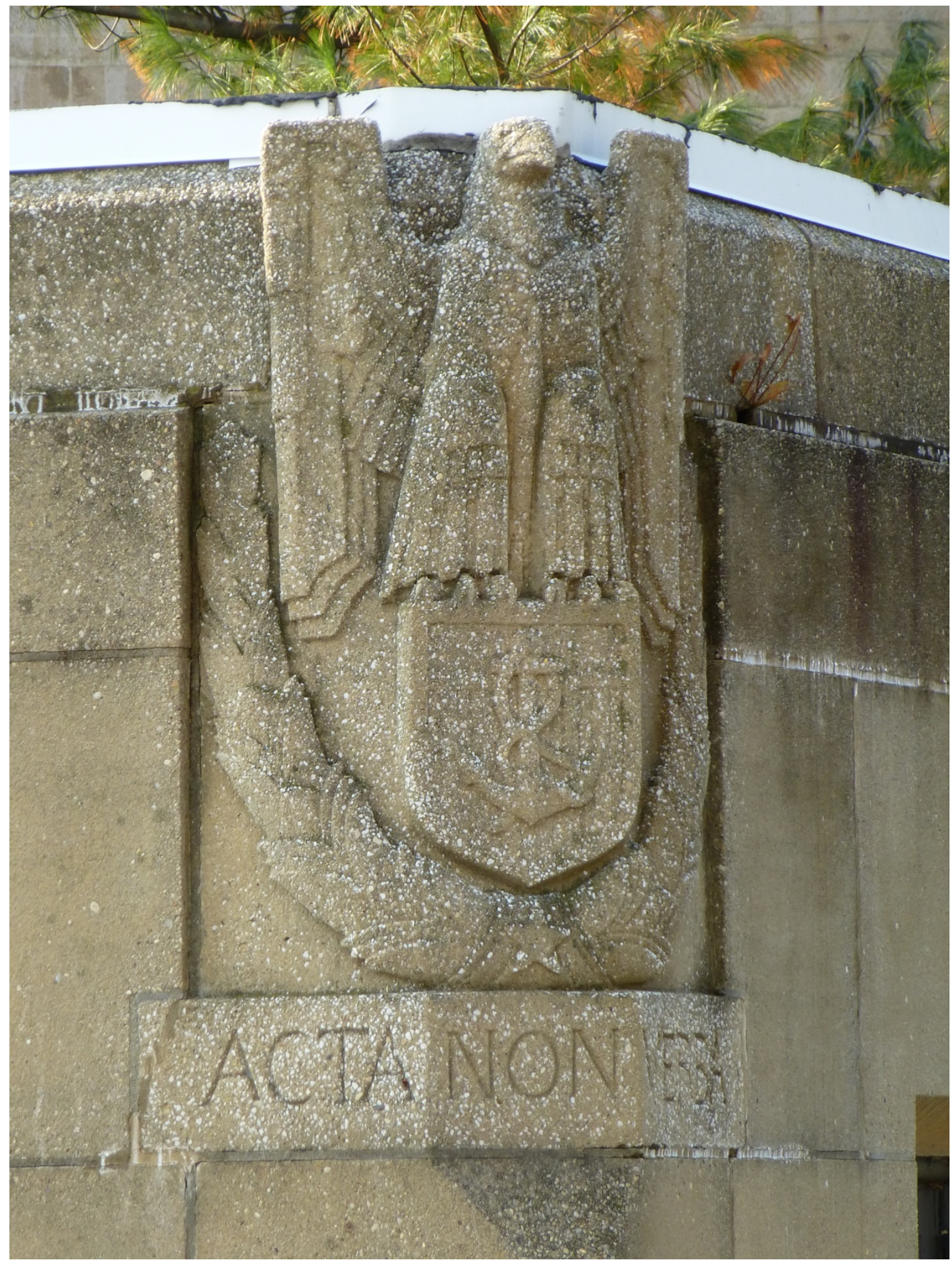


Figure 209. East façade of the Marvin Place Gate guard house on the north side of Steamboat Road, showing replacement door (ERDC-CERL, 2013).

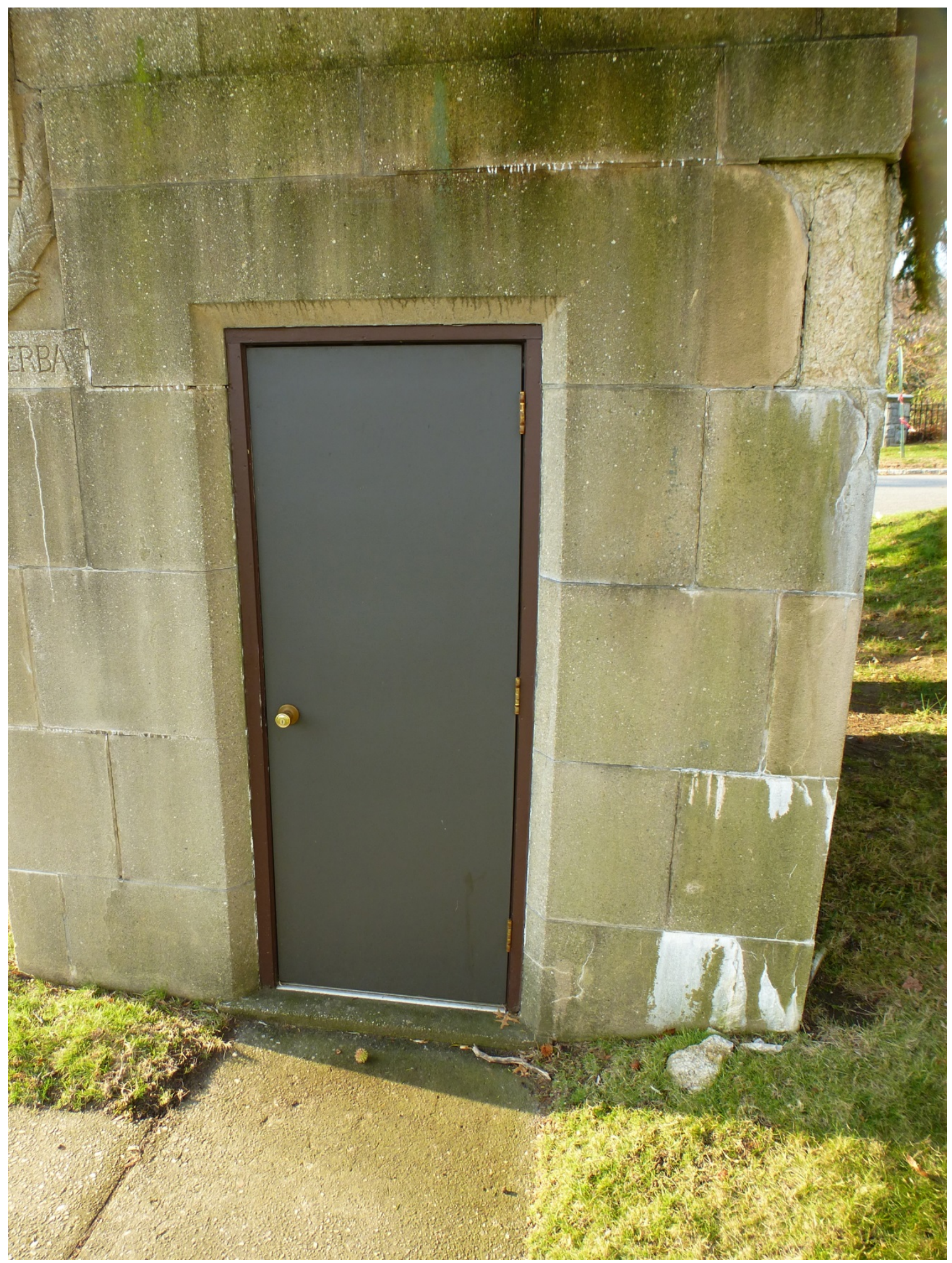




\subsubsection{Character-defining features}

Repair, renovation, and replacement of the following character-defining features of Marvin Place Gate must be coordinated with the NY SHPO.

- Overall massing

- Footprint

- Cast-stone walls in block-like pattern

- All cast-stone architectural elements including window sills and lintels, and inscriptions

- Window and door openings

\subsubsection{Character-defining features that have been removed}

Listed below are character-defining features of Marvin Place Gate that have been removed or replaced over the years; as future renovations occur, these need to be replaced with elements that replicate the original character-defining features of the building. The original architectural plans will guide this process in coordination with the NY SHPO.

- Replacement doors

\subsubsection{Mallory Pier}

Mallory Pier, a wood and concrete structure, serves as the main berthing dock at the academy. The entire pier above water level is contributing to the historic district. It provides a transition between Long Island Sound and Hague Basin. Larger training vessels dock on the outboard side of Mallory Pier, while smaller vessels, such as training dinghies, are berthed along smaller floating docks on the inboard side. The pier's shape and proportion date to the Chrysler era (circa 1930) for the northern portion of the pier closest to shore, while the portion that extends out to surround Hague Basin originally was constructed in 1943 . The southernmost portions of the pier were reconstructed in 2013 utilizing concrete on a wood substructure but with a similar plan, layout, height, and proportion to the original pier. The entire pier is a contributing element to the historic district, but the concrete materials are not character-defining features. 
Figure 210. South tip of Mallory Pier (ERDC-CERL, 2013).

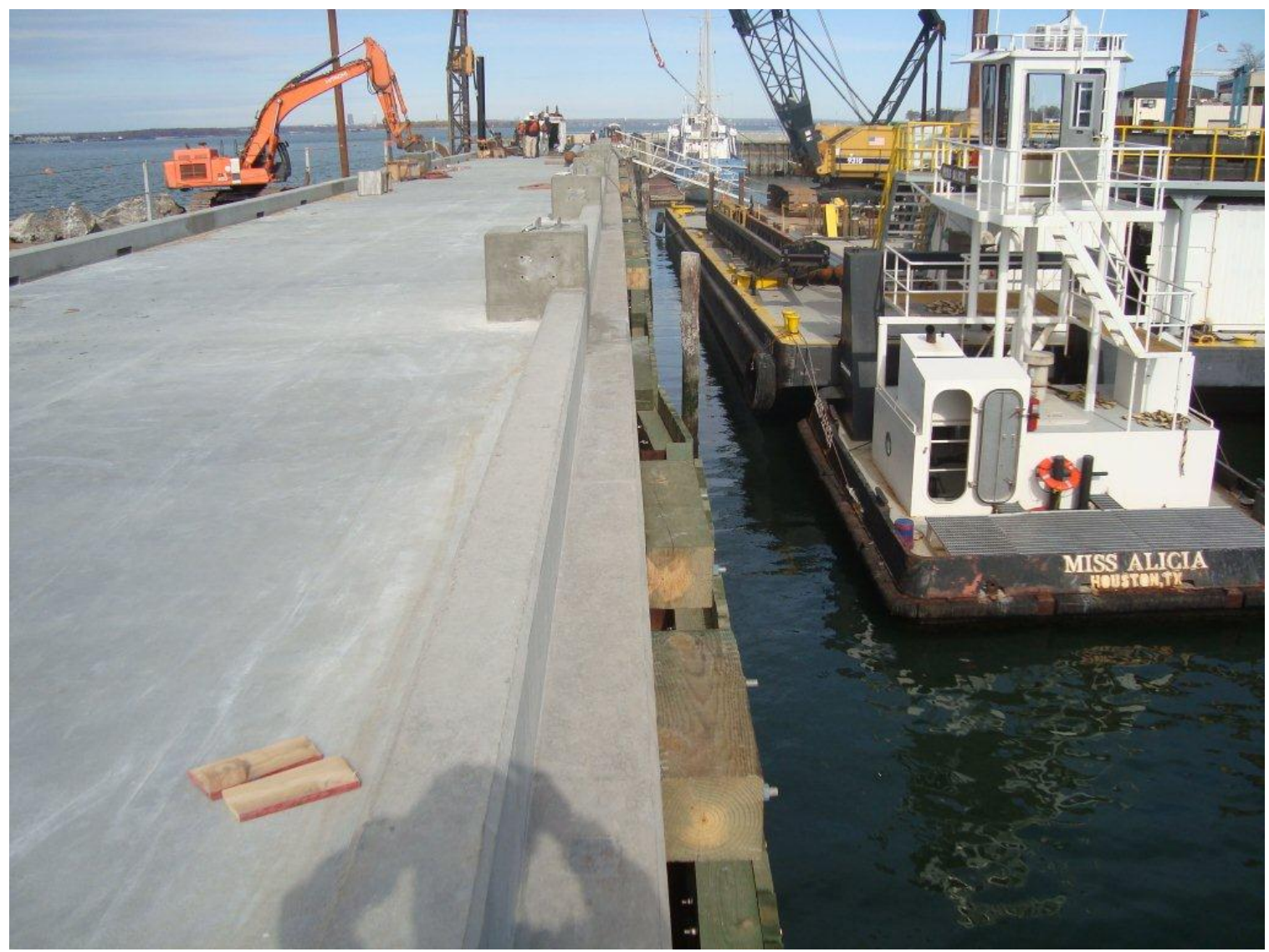




\subsubsection{Eldridge Pool}

The Eldridge Pool dates to the Chrysler era (circa 1930). The pool is concrete with a concrete surround. It has two associated bathhouses from the same era (to the east) and an associated mechanical room referred to as the paint locker (to the north) (see Section 3.2.22 for descriptions of these associated buildings). Eldridge Pool is a contributing feature to the historic district.

Figure 211. Looking to the north over Eldridge Pool (ERDC-CERL, 2013).

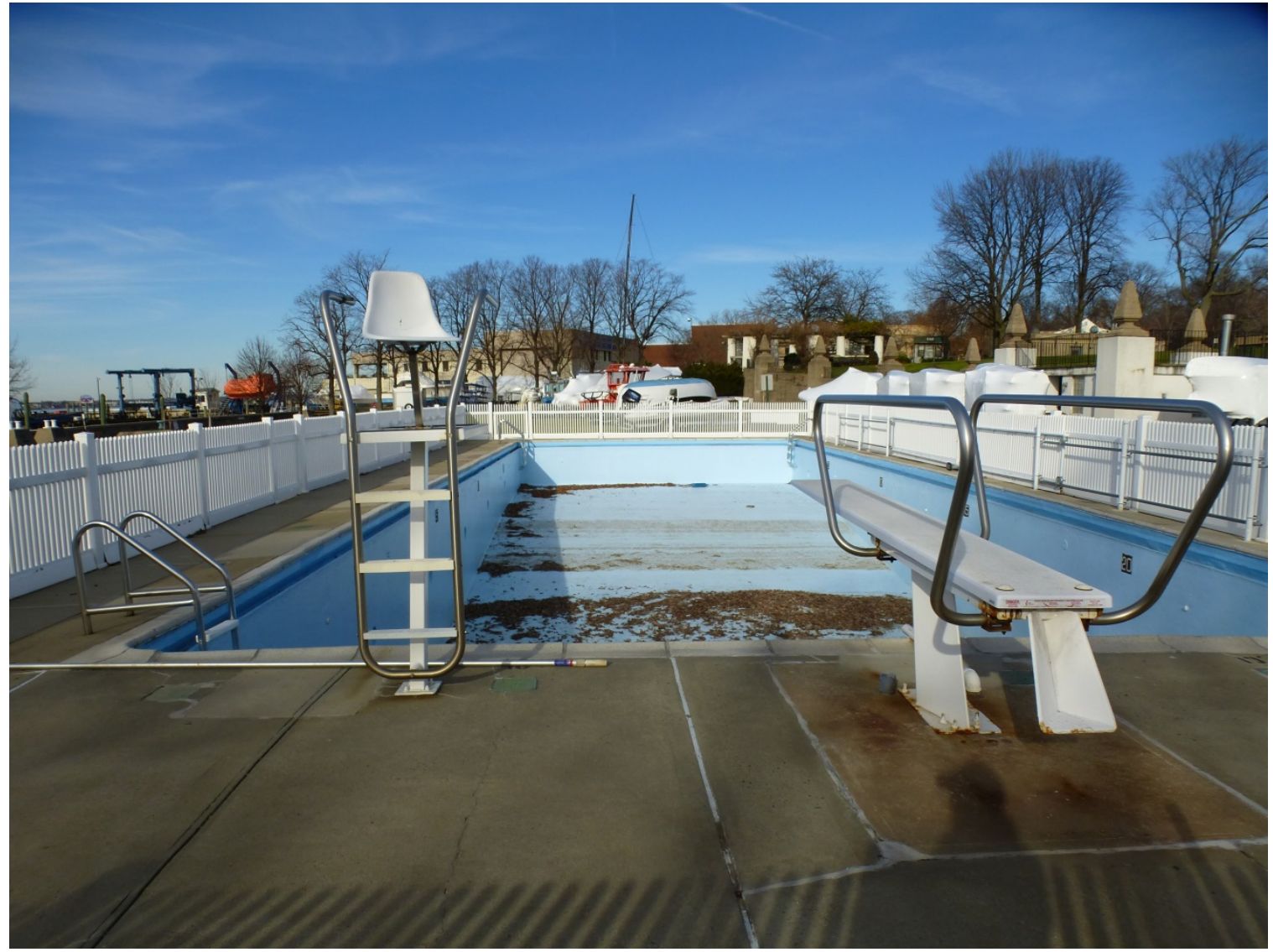




\section{References}

77th Congress, United States of America

1942a Joint Resolution 260: To Authorize the United States Maritime Commission to Acquire Certain Lands in Nassau County, New York, 9 January 1942. RG 178 U.S. Maritime Commission, Central Correspondence File and Exhibits, 1936-1950, Box 50, Folder: Legislation to Authorize the United States Maritime Commission to Acquire Certain Lands in Nassau County, New York. National Archives and Records Administration, College Park, Maryland.

1942b Committee on the Merchant Marine and Fisheries, Report on Acquisition of Certain Lands by Maritime Commission for Training School Purposes, 9 January 1942. RG 178 U.S. Maritime Commission, Central Correspondence File and Exhibits, 1936-1950, Box 50, Folder: Legislation to Authorize the United States Maritime Commission to Acquire Certain Lands in Nassau County, New York. National Archives and Records Administration, College Park, Maryland.

Alfred Hopkins \& Associates

Undated "Alfred Hopkins \& Associates, Architects-Engineers."

Promotional brochure. Collection of the American Merchant Marine Museum, Kings Point, N.Y.

Architectural Record

1914 "Suburban Houses by Caretto \& Forster." November 1914. Vol 36: No. 5 .

Architecture

1915 “House, Mrs. C.H. Smithers, Great Neck, L.I.” June 1915. Vol 31:No. 6.

Arsht, Marjorie Meyer

2006 All the Way from Yoakum: The Personal Journey of a Political Insider. College Station: Texas A\&M University Press.

Arts and Decoration

1919 “A Home at the Water's Edge." February 1919:213.

Berger (The Louis Berger Group, Inc.)

2005 Cultural Resources Survey Report, U.S. Merchant Marine Academy, Kings Point, New York. Lester, PA: Naval Facilities Engineering Command. 
Bland Library

1932 Aerial photograph of estates at Great Neck: plain and annotated. Photographic Collection, USMMA.

Bosler, Lieutenant Commander John D.

1942 Letter to Supervisor of Merchant Marine Cadet Training. 5 June 1942. RG 178 U.S. Maritime Commission, Division of Training, Maritime Training Subject File, 1938-1951, Box 2, Folder: Academy - Buildings and Acquisitions 1942. National Archives and Records Administration, College Park, Maryland.

Browning, Irving

1931 “Just an Actor's Home.” The New Movie Magazine. December 1931:44-45.

Cruikshank, Jeffrey L., and Chloe G. Kline

2008 In Peace and War: A History of the U.S. Merchant Marine Academy at Kings Point. Hoboken, NJ: John Wiley \& Sons, Inc.

Curcio, Vincent

2001 Chrysler: The Life and Times of an Automotive Genius. USA: Oxford University Press.

Dolan, Harry T.

1942 Special Assistant to the Attorney General, Lands Division, Department of Justice to Captain R.W. Dempwolf, Senior Coast Guard Officer, Third Naval District. 27 May 1942. RG 178 U.S. Maritime Commission, Division of Training, Maritime Training Subject File, 1938-1951, Box 1, Folder: Academy Expansion. National Archives and Records Administration, College Park, Maryland.

Edwards, A.J.

1942 "Map of Property Situate in the Village of Kings Point, Great Neck, Town of North Hempstead, Nassau County, N.Y.” 14 September 1942. RG 178 U.S. Maritime Commission, Division of Training, Maritime Training Subject File, 1938-1951, Box 1, Folder: Academy Plans. National Archives and Records Administration, College Park, Maryland.

Farbach, Carl F. 1942b General Counsel, United States Maritime Commission to United States Maritime Commission, 19 March 1942. RG 178 U.S. Maritime Commission, Division of Training, Maritime Training Subject File, 1938-1951, Box 1, Folder: Chrysler Estate. National Archives and Records Administration, College Park, Maryland. 
Fisher, Stan

2012 “Timeless by Design: Famed Architect's Buildings could become Museum.” The Middletown Press. 17 June 2012. http://www.middletownpress.com/generalnews/20120617/timeless-by-design-famed-architects-buildingscould-become-museum

Goldstein, Judith

2006 Inventing Great Neck: Jewish Identity and the American Dream. New Brunswick, NJ: Rutgers University Press.

Gomery, Douglas and Clara Pafort-Overduin

1991 Movie History: A Survey. Belmont, California: Wadsworth Pub. Co.

Great Neck Directory

1929http://www.greatnecklibrary.org/gnhistory/ebooks/pdfs/phone\%20 directory1929.pdf

Great Neck Public Library

ca. 1922 Map of Great Neck. Copy in Vertical File of the Great Neck Public Library, Great Neck, New York.

Hagstrom Company, Inc.

1932 Hagstrom Street and Road Atlas of Nassau County. Hagstrom Company, NY. Copy in Vertical File of the Great Neck Public Library, Great Neck, New York.

Hammersly, Lewis Randolph

1918 "Charles Leavitt, Jr." in Who's Who in New York City and State, issue 7. New York: Who's Who Publications.

Held, John, Jr.

1927 "In and Around Great Neck Pictured from the Description of a Week-end Guest: and What a Week-end." The New Yorker. 16 July 1927. Copy of map on file at the American Merchant Marine Museum, Kings Point, NY.

Holub, Rona L.

2008 "Henri Bendel.” American National Biography Online. http://www.anb.org/articles/17/17-01700.html

House and Garden 1913a “Grenwolde, Great Neck, Long Island.” February 1913:82.

1913b “Grenwolde, Great Neck, Long Island.” March 1913:160.

Houston et.al.

1926 “Agreement \#66773." Nassau County Clerk’s Office, Mineola, N.Y. 
Hyde, E. Belcher

1914 “Map of Elm Point." In Atlas of Nassau County, Long Island, New York. Published by E.B. Hyde, New York. Map Division Collection, New York Public Library, Manhattan.

Independence Seaport Museum

2012 "Steering a Course: A Short History of the Pennsylvania Nautical School and Pennsylvania Maritime Academy." http://www.phillyseaport.org/pennsylvania-nautical-school/

Kansas Historical Society

2013 “Walter P. Chrysler." http://www.kshs.org/kansapedia/walter-pchrysler/12015.

King's Point Newsletter

1975 “Improving the Plant to Improve the Product." Spring 1975, Vol 1, No 1:4.

Knight, Telfair

1941 Director, Division of Training, U.S. Maritime Commission to Commissioner John M. Carmody, 19 December 1941. RG 178 U.S. Maritime Commission, Division of Training, Maritime Training Subject File, 1938-1951, Box 1, Folder: Chrysler Estate. National Archives and Records Administration, College Park, Maryland.

1942a Director, Division of Training, U.S. Maritime Commission to Commissioner Edward Macauley. 14 January 1942. RG 178 U.S. Maritime Commission, Division of Training, Maritime Training Subject File, 1938-1951, Box 1, Folder: Academy Expansion. National Archives and Records Administration, College Park, Maryland.

1942b Director, Division of Training, U.S. Maritime Commission to Commissioner Edward Macauley. 9 February 1942. RG 178 U.S. Maritime Commission, Division of Training, Maritime Training Subject File, 1938-1951, Box 1, Folder: Academy Expansion. National Archives and Records Administration, College Park, Maryland.

1942c Director, Division of Training, U.S. Maritime Commission to D. R. McLain, 27 June 1942. RG 178 U.S. Maritime Commission, Division of Training, Maritime Training Subject File, 1938-1951, Box 1, Folder: Chrysler Estate. National Archives and Records Administration, College Park, Maryland. 
Land, E.S.

1942 Chairman of the United States Maritime Commission to Byron C. Foy and Dick R. McLain, Executors of the Last Will and Testament of Della V. Chrysler, 19 March 1942. RG 178 U.S. Maritime Commission, Division of Training, Maritime Training Subject File, 1938-1951, Box 1, Folder: Chrysler Estate. National Archives and Records Administration, College Park, Maryland.

LILRC (Long Island Library Resources)

2013 "Long Island Memories: Claralea, Grenwolde Park, Great Neck, L.I.” http://www.longislandmemories.org/cdm/singleitem/collection/p1 5281 collg/id $/ 722 / \mathrm{rec} / 2$.

Litchfield, Clarence B.

1942 Litchfield, Alfred Hopkins \& Associates to Telfair Knight, Director, Division of Training, U.S. Maritime Commission. 7 February 1942. RG 178 U.S. Maritime Commission, Division of Training, Maritime Training Subject File, 1938-1951, Box 1, Folder: Academy Expansion. National Archives and Records Administration, College Park, Maryland.

Long Island Power Authority [Uniondale, NY]

2001 Population Survey 2001: Current Population Estimates for Nassau and Suffolk Counties and the Rockaway Peninsula. Copy in collection of Great Neck Public Library, Great Neck, New York.

Los Angeles Times

1936 “Thomas Meighan.” 9 July 1936.

MacKay, Robert B.

1994 "Long Island Country Houses and Their Architects: 1860-1940." In Long Island Historical Journal, Vol. 6, No. 2:168-190.

MacKay, Robert B., Anthony K. Baker, and Carol A. Traynor

1997 Long Island Country Houses and Their Architects. W. W. Norton \& Company, New York and London.

MacRoberts, W.W.

1942 Land Division, Department of Justice to Captain Tomb, Superintendent, USMMA. 22 June 1942. RG 178 U.S. Maritime Commission, Division of Training, Maritime Training Subject File, 1938-1951, Box 1, Folder: Academy Expansion. National Archives and Records Administration, College Park, Maryland.

Maritime Administration (MARAD), Department of Transportation 2002 Maritime Administration Homepage. Accessed on August 19, 2002 at http://www.nvr.navy.mil/marad.html 
McLaren, Hugh

1942 Vice-President, Vermilya-Brown Company Inc. to Telfair Knight, Director, Division of Training, U.S. Maritime Commission. 7 February 1942. RG 178 U.S. Maritime Commission, Division of Training, Maritime Training Subject File, 1938-1951, Box 1, Folder: Academy Expansion. National Archives and Records Administration, College Park, Maryland.

McNulty, R.R.

1942a Supervisor of Merchant Marine Cadet Training to Staff of Merchant Marine Cadet Training. "Expansion of U.S. Merchant Marine Academy, Great Neck, New York.” 10 April 1942. RG 178 U.S. Maritime Commission, Division of Training, Maritime Training Subject File, 1938-1951, Box 1, Folder: Academy Expansion. National Archives and Records Administration, College Park, Maryland.

1942b Supervisor of Merchant Marine Cadet Training to Commander G. E. McCabe. 13 April 1942. RG 178 U.S. Maritime Commission, Division of Training, Maritime Training Subject File, 1938-1951, Box 1, Folder: Academy Expansion. National Archives and Records Administration, College Park, Maryland.

1942c Supervisor of Merchant Marine Cadet Training to Lieutenant Commander J. D. Bosler. 10 May 1942. RG 178 U.S. Maritime Commission, Division of Training, Maritime Training Subject File, 1938-1951, Box 1, Folder: Academy Expansion. National Archives and Records Administration, College Park, Maryland.

1942d Supervisor of Merchant Marine Cadet Training to Captain Tinkham, U.S. Coast Guard. 18 May 1942. RG 178 U.S. Maritime Commission, Division of Training, Maritime Training Subject File, 1938-1951, Box 1, Folder: Academy Expansion. National Archives and Records Administration, College Park, Maryland.

1942e Supervisor of Merchant Marine Cadet Training to Superintendent USMMA. 11 June 1942. RG 178 U.S. Maritime Commission, Division of Training, Maritime Training Subject File, 1938-1951, Box 1, Folder: Academy Expansion. National Archives and Records Administration, College Park, Maryland.

1942f Supervisor of Merchant Marine Cadet Training to Vermilya-Brown Company, Inc. 17 July 1942. RG 178 U.S. Maritime Commission, Division of Training, Maritime Training Subject File, 1938-1951, Box 2, Folder: Academy Expansion. National Archives and Records Administration, College Park, Maryland. 
1942g Supervisor of Merchant Marine Cadet Corps to Director, Division of Training, U.S. Maritime Commission. 31 August 1942. RG 178 U.S. Maritime Commission, Division of Training, Maritime Training Subject File, 1938-1951, Box 2, Folder: Academy Expansion. National Archives and Records Administration, College Park, Maryland.

Miller, Jeff

2013 "New Port Richey and Hollywood."

http://www.fivay.org/npr_hollywood.html

Mitchell, C. Bradford

1977 We'll Deliver: Early History of the United States Merchant Marine Academy, 1938-

1956. U.S. Merchant Marine Academy Alumni Association, Kings Point, New York.

Morgan Guaranty Trust Company

1975 Luxurious 8-Acre Waterfront Estate. Promotional brochure for the Barstow-Lundy House. Copy on file at Department of Engineering Resources, USMMA, Kings Point, New York.

Nassau County Board of Supervisors

1989 Nassau County: A Profile. Published by the Board of Supervisors. Copy in Vertical File of the Great Neck Public Library, Great Neck, New York.

Nassau County, Long Island, New York

2002 "The History of Nassau County." Accessed on August 12, 2002 at <http://www.co.nassau.ny.us/centen/NC-hist.html>

Nassau County Planning Commission

1997 Nassau County Comprehensive Master Plan: Inventory and Analysis. Prepared for Nassau County Planning Commission. Consultant Team: Frederick P. Clark Associates, Inc.; Dvirka and Bartilucci; Thomas Conoscenti \& Associates, Inc.; Peter Q. Eschweiler, AICP; Fleming; Ryan \& Ryan, PR; Walsh Consulting Services; Wilbur Smith Associations. Copy in the collection of the Great Neck Public Library, Great Neck, New York.

Nerney, H.V.

1941 District Cadet Training Instructor at New York to United States Maritime Commission, 29 November 1941. RG 178 U.S. Maritime Commission, Division of Training, Maritime Training Subject File, 1938-1951, Box 1, Folder: Chrysler Estate. National Archives and Records Administration, College Park, Maryland. 
1942 Acting Supervisor, U.S. Merchant Marine Cadet Corps to Superintendent, United States Merchant Marine Academy. 2 September 1942. RG 178 U.S. Maritime Commission, Division of Training, Maritime Training Subject File, 1938-1951, Box 2, Folder: Buildings and Acquisitions Jan-June 1942. National Archives and Records Administration, College Park, Maryland.

New York Herald Tribune

1942 "Chrysler Home Will be Marine Training School." 11 January 1942.

New York Times

1915a "Beauties and Transit Conveniences of Long Island Drawing Many Residents to North and South Shores.” 25 April 1915.

1915b “The Real Estate Field." 25 November 1915.

1916 "Buying at Great Neck." 2 January 1916.

1925 “Active Homebuying In The Suburbs.” 26 March 1925.

1927 "E.M. Statler, President of Hotel Chain, Weds His Secretary, Miss Alice M. Seidler.” 1 May 1927.

1929 “Mrs. Statler Sells in Great Neck.” 6 October 1929.

1942a "Chrysler Mansion to be U.S. Academy.” 11 January 1942.

1942b "Chrysler Mansion to Become U.S. Academy for Training of Merchant Marine Cadets.” 11 January 1942.

Old Long Island

2009 "When Forker House was for Sale." Old Long Island website. http://www.oldlongisland.com/2009/o7/when-forker-house-wasfor-sale.html.

Otto, F. B.

1942 Chief Engineering Officer, Division of Training to Alfred Hopkins \& Associates, 2 November 1942. RG 178 U.S. Maritime Commission, Division of Training, Maritime Training Subject File, 1938-1951, Box 2, Folder: Academy Expansion. National Archives and Records Administration, College Park, Maryland.

1943 Chief Engineering Officer, Division of Training to A.V. Lockwood, Officer-in-Charge of Construction, U.S. Merchant Marine Academy. 25 January 1943. RG 178 U.S. Maritime Commission, Division of Training, Maritime Training Subject File, 1938-1951, Box 1, no folder. National Archives and Records Administration, College Park, Maryland. 
Page, Paul D., Jr.

1942 Special Counsel, War Shipping Administration to Administrator, War Shipping Administration. 8 October 1942. RG 178 U.S.

Maritime Commission, Division of Training, Maritime Training Subject File, 1938-1951, Box 2, Folder: Academy Expansion. National Archives and Records Administration, College Park, Maryland.

Pierpont, Claudia Roth

2002 “The Silver Spire: How Two Men's Dreams Changed the Skyline of New York." The New Yorker, 18 November 2002.

Pincus, Roberta

1983 "This is Great Neck. Great Neck, NY: League of Women Voters of Great Neck."

Pittman, Trabue

1923 "Deed 31903, Trabue Pittman to Thomas Meighan.” Nassau County Clerk’s Office, Mineola, N.Y.

Plattsburgh Daily Press

1934 "Nicholas Schenck, Movie Magnate." 24 August 1934.

Polaris [Kings Point, New York]

1942a "New Barracks Near Completion." Vol. 1, No.2 September:5.

1942b "Palmer Hall Soon to be completed; Plan Five Others." Vol. 1, No.3 October:2.

1943a "Bowditch Hall: Academy Building Fitting Tribute to Great Navigator." Vol. 2, No.1 August:11.

1943b "Fulton Hall: Top Flight Marine Engineers Are Being Trained Here.” Vol. 1, No.8April:9, 28.

1943c “Samuels Hall: Home of Marlinespike Seamanship.” Vol. 1, No.9 May:13.

1944 “Barney Square.” Vol. 13, No.4 November:45.

1946a "Main Entrance to the Academy Designated Vickery Gate. Vol. 4, No.9 June:n.p.

1946b The United States Merchant Marine Cadet Corps: A Brief History of Its Establishment and Development." The Third of Five Monthly Installments. Vol. 4, No.8 March:8-10, 42.

1950a “In Memory...A Mariner’s Chapel.”Vol. 9, No.8 March:12, 32. 
1950b "O'Hara Hall: Physical Training, Naval Science, Ship's Medicine.” Vol. 10, No.2 October: 18.

1951 “Gen. J.M. Franklin Heads Chapel Fund Drive.” Vol. 10, No. 8 April:6.

1958a “After Twenty Years.” Vol. V, No. 2 Spring:4-9.

1958b “The Atom Comes to Kings Point.” Vol. V, No. 1 Winter:8-9.

1959a “Chapel Donation.” Vol. VI, No. 2 Spring:19.

1960 “Kings Point Light.” Vol. VII, No. 1 Winter:28.

1961 “The Mariner's (sic) Chapel." Vol. VIII, No. 3 Summer:14.

1963 "Facelifting for Kings Point Waterfront.” Vol. X, No. 2 Spring:27.

1965 “Our Changing Campus.” Vol. XII, No. 4 Fall:14-15,31.

Potter, Elisabeth Walton, and Beth M. Boland

1992 National Register Bulletin 41: Guidelines for Evaluating and Registering Cemeteries and Burial Places. U.S. Department of the Interior, National Park Service, Interagency Resources Division, National Register of Historic Places, Washington, D.C.

Previews Incorporated

1941 "Kings Point Estate, Steam Boat Road." Brochure. Collection of the American Merchant Marine Museum, folder: Barstow \& Barstow. USMMA, King's Point, New York.

Renick, C.M.

2001 "Quarters A.” American Merchant Marine Museum, Historical Files, Folder: Quarters “A.” Kings Point, N.Y.

Sanborn Map Company

1937 Insurance Maps of Nassau County New York, Volume Five and Six, 1936. Sanborn Map Company, New York, New York.

Schisgall, Richard

1951 "I Remember Yesterday's Great Neck." In Polaris, Vol. 10 No. 7 (March):24.

Schenck, Nicholas M.

1946 President, Loew's Incorporated to Cadet-Midshipman Charles Renick, 12 August 1946. Collection of the American Merchant Marine Museum, folder: Barstow \&Barstow. USMMA, King's Point, New York. 
Sclare, Liisa and Donald

1975 Beaux-Arts Estates: A Guide to the Architecture of Long Island. New York: The Viking Press.

Sherfy, Marcella and W. Ray Luce

1998 National Register Bulletin 22: Guidelines for Evaluating and Nominating Properties that Have Achieved Significance Within the Past Fifty Years. U.S. Department of the Interior, National Park Service, National Register of Historic Places, Washington, D.C.

Spear, Devah and Gil

1936 Book of Great Neck. Great Neck, NY.

Spinzia, Raymond E. and Judith A.

2006 Long Island's Prominent North Shore Families: Their Estates and Their Country Homes. Vol. 1. College Station, Texas:

VirtualBookworm.

Stamford Museum \& Nature Center

2013 "The Henri Bendel Mansion's Story."

http://www.stamfordmuseum.org/museum-mansion.html

Swann, Frank W., Jr.

1942 “Memorandum for Commander R. R. McNulty.” U.S. Merchant Marine Cadet Corps. 18 August 1942. RG 178 U.S. Maritime Commission, Division of Training, Maritime Training Subject File, 1938-1951, Box 2, Folder: Academy Expansion. National Archives and Records Administration, College Park, Maryland.

The Sun

1917 "Broadway Loft Building Deal.” 21 January 1917.

Tomb, J. H.

1942a Superintendent Merchant Marine Cadet Program, 23 June 1942.

RG 178 U.S. Maritime Commission, Division of Training, Maritime Training Subject File, 1938-1951, Box 2, Folder: Academy Buildings and Acquisition Jan-June 1942.National Archives and Records Administration, College Park, Maryland.

1942b Superintendent Merchant Marine Academy to Supervisor of Merchant Marine Cadet Training. 2 July 1942. RG 178 U.S. Maritime Commission, Division of Training, Maritime Training Subject File, 1938-1951, Box 2, Folder: Academy Expansion. National Archives and Records Administration, College Park, Maryland. 
1943 Superintendent Merchant Marine Academy to Supervisor of Merchant Marine Cadet Corps. 8 March 1943. RG 178 U.S. Maritime Commission, Division of Training, Maritime Training Subject File, 1938-1951, Box 1 no folder. National Archives and Records Administration, College Park, Maryland.

United States Coast Guard

1942 "Map of Property: Merchant Marine Academy, Great Neck, New York.” July 1942. RG 178 U.S. Maritime Commission, Division of Training, Maritime Training Subject File, 1938-1951, Box 2, Folder: Academy Expansion. National Archives and Records Administration, College Park, Maryland.

United States Coast Guard and United States Department of Homeland Security

2012 "Training Merchant Mariners for War: The Role of the United States Coast Guard.”

http://www.uscg.mil/history/articles/wwii training.asp.

United States Code

1920 Public Law 66-261, Merchant Marine Act. Accessed on August 19, 2002, at http://agriculture.house.gov/glossary/merchant marine act of 1 920.html

1936 Public Law 96-453, Merchant Marine Act. Accessed on June 25, 2002, at http://www.tenforward.com/bud/merchantmarineact.html.

United States Merchant Marine [USMM], U.S. Maritime Service Veterans 2002a Frequently Asked Questions about the Merchant Marine. Accessed on June 25, 2002, at http://www.usmm.org/faq.html.

2002b History of the U.S. Merchant Marine Cadet Corps. Accessed on August 20, 2002, at http://www.usmm.org/cadetcorps.html.

United States Merchant Marine Academy [USMMA] 1942a "Layout of Improvements on Property of Nicholas M. Schenck, Kings Pint, Great Neck, Long Island, N.Y.” January 1942. RG 178 U.S. Maritime Commission, Division of Training, Maritime Training Subject File, 1938-1951, Box 1, Folder: Schenck Estate-2. National Archives and Records Administration, College Park, Maryland.

1942b Map of U.S. Merchant Marine Academy. 1 August 1942.

1944 "Proposed New Construction for 1945 and Supplemental Projects." Kings Point, New York. 
2001 'Academic Catalog. Kings Point, New York.

2002a “Academics." U.S. Merchant Marine Academy Web Page. Accessed on June 25, 2002, at

<http://www.usmma.edu/chapel/history.html>

2002b “Mariners' Memorial Chapel.” U.S. Merchant Marine Academy

Web Page. Accessed on June 25, 2002, at

$<$ http://www.usmma.edu/chapel/history.html >

2013 "History of Melville Hall."

http://www.usmma.edu/facilities/melville-hall/history-melvillehall

Vermilya-Brown Company, Inc.

1942 Letter to Commander John D. Bosler, Merchant Marine Academy. 14 July 1942. RG 178 U.S. Maritime Commission, Division of Training, Maritime Training Subject File, 1938-1951, Box 2, Folder: Academy Expansion. National Archives and Records Administration, College Park, Maryland.

Village of Kings Point

1942 Village of Kings Point to Superintendent Tomb. 5 June 1942 RG 178 U.S. Maritime Commission, Division of Training, Maritime Training Subject File, 1938-1951, Box 1, Folder: Academy Expansion. National Archives and Records Administration, College Park, Maryland.

Voulgaris, Barbara

2009 "From Steamboat Inspection Service to U.S. Coast Guard: Marine Safety in the United States from 1838-1946." Washington, D.C.: United States Coast Guard Historian's Office. http://www.uscg.mil/history/articles/voulgarismarinesafety2009.p df

Walling, H.F. Company

1859 Real Estate Map, Nassau County, North Hempstead, Great Neck. Copy on file, local history room, Great Neck Public Library, Great Neck, New York.

Walter P. Chrysler Museum

2009 Heritage: Chapter One - Walter P. Chrysler. Auburn Hills, Michigan: Walter P. Chrysler Museum.

2009 Heritage: Chapter Three - Walter's Cars, Walter's Company. Auburn Hills, Michigan: Walter P. Chrysler Museum. 
Whittle, George

1936 Map Showing Property Owners in Western Kings Point Area in the 1700s. Copy on file, local history room, Great Neck Public Library, Great Neck, New York.

1940 Historical Great Neck. Prepared for Franklin National Bank. Reprinted 1961. Copy on file, local history room, Great Neck Public Library, Great Neck, New York.

Wilson, J. F.

1941 Commanding Officer, United States Maritime Commission Cadet School - New York, 9 November 1941. RG 178 U.S. Maritime Commission, Division of Training, Maritime Training Subject File, 1938-1951, Box 1, Folder: Chrysler Estate. National Archives and Records Administration, College Park, Maryland.

1942 Commanding Officer, United States Maritime Commission Cadet School. 9 March 1942. RG 178 U.S. Maritime Commission, Division of Training, Maritime Training Subject File, 1938-1951, Box 1, Folder: J.C. Marchant Estate. National Archives and Records Administration, College Park, Maryland. 


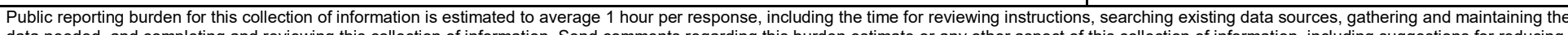

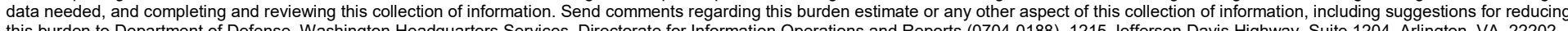

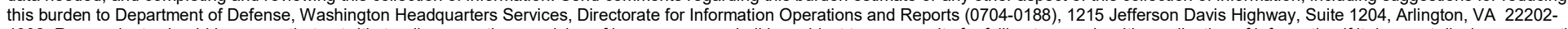

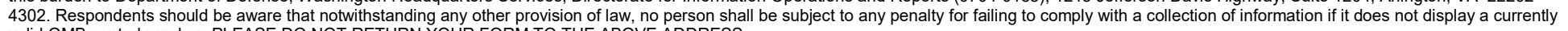
valid OMB control number. PLEASE DO NOT RETURN YOUR FORM TO THE ABOVE ADDRESS

\begin{tabular}{|l|l|l|}
\hline 1. REPORT DATE (DD-MM-YYYY) & 2. REPORT TYPE & 3. DATES COVERED (From - To)
\end{tabular}

August 2014

4. TITLE AND SUBTITLE

Final Technical Report

Character-Defining Features of Contributing Buildings and Structures in the United States

Merchant Marine Academy Historic District

5a. CONTRACT NUMBER

5b. GRANT NUMBER

5c. PROGRAM ELEMENT NUMBER

6. AUTHOR(S)

Adam D. Smith, Megan. W. Tooker, Susan I. Enscore, and Sunny E. Adams

5d. PROJECT NUMBER

400142

5e. TASK NUMBER

5f. WORK UNIT NUMBER

7. PERFORMING ORGANIZATION NAME(S) AND ADDRESS(ES)

U.S. Army Engineer Research and Development Center (ERDC)

Construction Engineering Research Laboratory (CERL)

PO Box 9005

Champaign, IL 61826-9005

\section{SPONSORING / MONITORING AGENCY NAME(S) AND ADDRESS(ES)}

U.S. Department of Transportation

Maritime Administration

MAR-612-W23-495

1200 New Jersey Ave SE

Washington, DC 20590

12. DISTRIBUTION / AVAILABILITY STATEMENT

Approved for public release. Distribution is unlimited.

\section{SUPPLEMENTARY NOTES}

Copies are available from the National Technical Information Service, 5285 Port Royal Road, Springfield, VA 22161.

\section{ABSTRACT}

This document is an architectural survey of character-defining features for the contributing features of the United States Merchant Marine Academy Historic District. This survey satisfies Section 110 of the National Historic Preservation Act of 1966 as amended, and it was used to determine which elements of the buildings and structures of the historic district are character-defining features for the elements that are eligible for the National Register of Historic Places.

\section{SUBJECT TERMS}

US Merchant Marine Academy (USMMA), historic preservation, character-defining features, historic district, historic management, National Register of Historic Places (NRHP)

\begin{tabular}{|c|c|c|c|c|c|}
\hline \multicolumn{3}{|c|}{ 16. SECURITY CLASSIFICATION OF: } & \multirow{2}{*}{$\begin{array}{l}\text { 17. LIMITATION } \\
\text { OF ABSTRACT } \\
\text { UU }\end{array}$} & \multirow{2}{*}{$\begin{array}{l}\text { 18. NUMBER } \\
\text { OF PAGES } \\
241\end{array}$} & 19a. NAME OF RESPONSIBLE PERSON \\
\hline $\begin{array}{l}\text { a. REPORT } \\
\text { Unclassified }\end{array}$ & $\begin{array}{l}\text { b. ABSTRACT } \\
\text { Unclassified }\end{array}$ & $\begin{array}{l}\text { c. THIS PAGE } \\
\text { Unclassified }\end{array}$ & & & $\begin{array}{l}\text { 19b. TELEPHONE NUMBER (in- } \\
\text { clude area code) }\end{array}$ \\
\hline
\end{tabular}

